\title{
LIFOR
}

\section{Menganalisis REDD+ Sejumlah tantangan dan pilihan}

Disunting oleh Arild Angelsen, Maria Brockhaus, William D. Sunderlin dan Louis V.Verchot

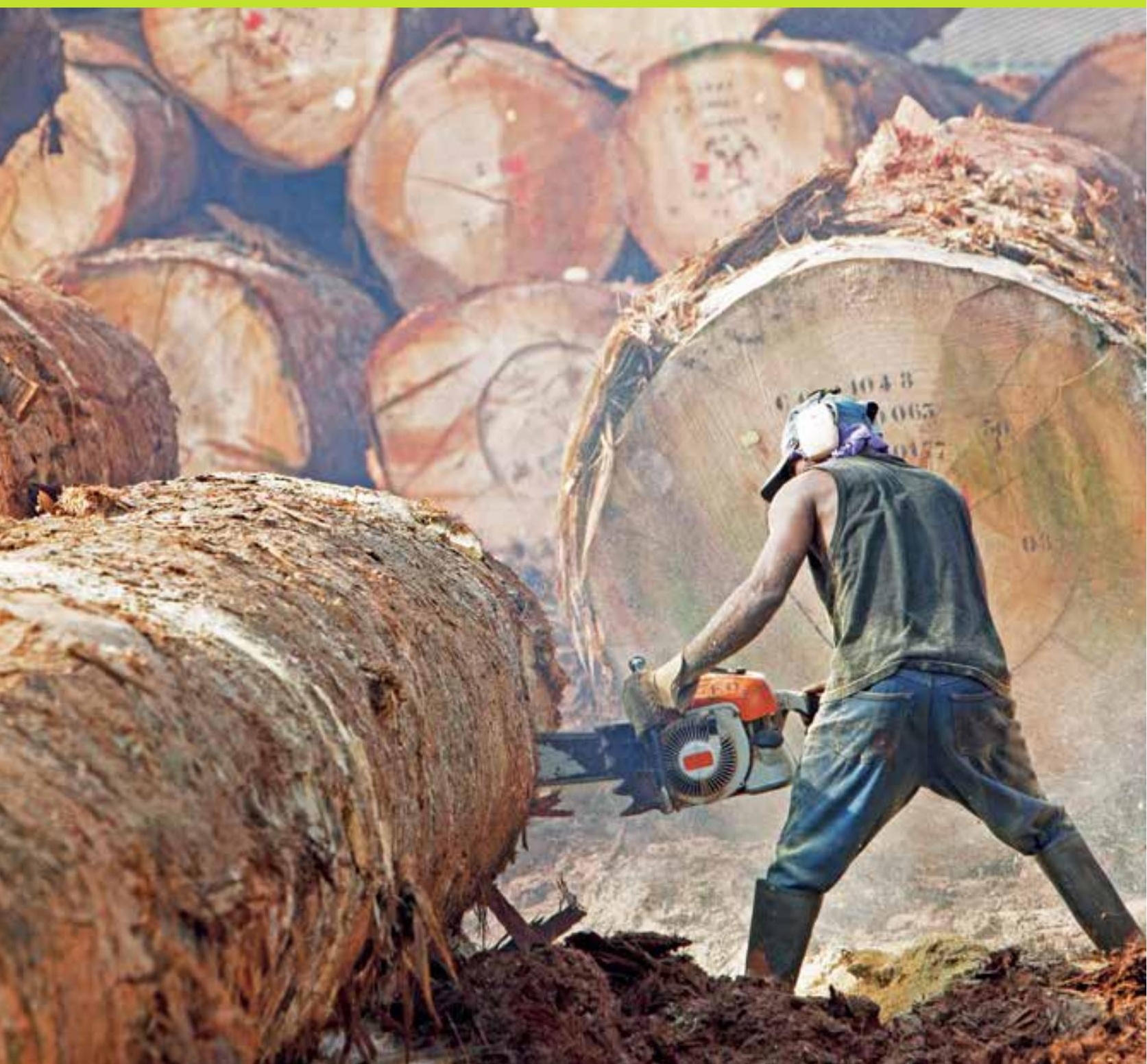





\section{Menganalisis REDD+ Sejumlah tantangan dan pilihan}

Disunting oleh

Disunting bersama oleh

Asisten redaksi
Arild Angelsen

Maria Brockhaus

William D. Sunderlin

Louis V. Verchot

Therese Dokken 
C 2013 Center for International Forestry Research.

Hak cipta dilindungi oleh Undang-Undang

Dicetak di Indonesia

ISBN: 978-602-1504-01-7

Angelsen, A., Brockhaus, M., Sunderlin, W.D. dan Verchot, L.V. (ed.) 2013 Menganalisis REDD+: Sejumlah tantangan dan pilihan. CIFOR, Bogor, Indonesia.

Terjemahan dari: Angelsen, A., Brockhaus, M., Sunderlin, W.D. and Verchot, L.V. (eds) 2012 Analysing REDD+: Challenges and choices. CIFOR, Bogor, Indonesia.

Penyumbang foto:

Sampul @ Cyril Ruoso/Minden Pictures

Bagian: 1. Habtemariam Kassa, 2. Manuel Boissière, 3. Douglas Sheil

Bab: 1 dan 10. Yayan Indriatmoko, 2. Neil Palmer/CIAT, 3. dan 12. Yves Laumonier,

4. Brian Belcher, 5. Tony Cunningham, 6. dan 16. Agung Prasetyo, 7. Michael Padmanaba,

8. Anne M. Larson, 9. Amy Duchelle, 11. Meyrisia Lidwina, 13. Jolien Schure, 14. César Sabogal, 15. Ryan Woo, 17. Edith Abilogo, 18. Ramadian Bachtiar

Desain oleh Tim Multimedia CIFOR

Kelompok pelayanan informasi

CIFOR

Jl. CIFOR, Situ Gede

Bogor Barat 16115

Indonesia

$\mathrm{T}+62(251) 8622-622$

F $+62(251) 8622-100$

E cifor@cgiar.org

\section{cifor.org}

ForestsClimateChange.org

Pandangan yang diungkapkan dalam buku ini berasal dari penulis dan bukan merupakan pandangan CIFOR, para penyunting, lembaga asal penulis atau penyandang dana maupun para peninjau buku.

\section{Center for International Forestry Research}

CIFOR memajukan kesejahteraan manusia, konservasi lingkungan dan kesetaraan melalui penelitian yang berorientasi pada kebijakan dan praktik kehutanan di negara berkembang. CIFOR merupakan salah satu Pusat Penelitian Konsorsium CGIAR. CIFOR berkantor pusat di Bogor, Indonesia dengan kantor wilayah di Asia, Afrika dan Amerika Selatan. 


\section{Daftar isi}

Kata pengantar $x$

Ucapan terima kasih $\quad$ xii

Ringkasan xiv

Daftar penulis $\quad x x i i$

1 Pendahuluan 1

Arild Angelsen, Maria Brockhaus, William D. Sunderlin dan Louis V. Verchot

Bagian 1. Memahami REDD+

2 Melihat REDD+ melalui 4I: Sebuah kerangka kerja ekonomi politis Maria Brockhaus dan Arild Angelsen

3 Evolusi REDD+

Arild Angelsen dan Desmond McNeill

4 REDD+ dan ekonomi global: Kekuatan yang bersaing dan sejumlah pilihan kebijakan

Pablo Pacheco, Louis Putzel, Krystof Obidzinski dan George Schoneveld

\section{Bagian 2. Melaksanakan REDD+}

$5 \quad$ Politik dan kekuasaan dalam proses kebijakan REDD+

Monica Di Gregorio, Maria Brockhaus, Tim Cronin dan Efrian Muharrom

6 Berbagai tataran dan tantangan REDD+

Kaisa Korhonen-Kurki, Maria Brockhaus, Amy E. Duchelle,

Stibniati Atmadja dan Pham Thu Thuy

7 Pendanaan REDD+

Charlotte Streck dan Charlie Parker

8 Siapa yang seharusnya menerima manfaat dan mengapa? Wacana tentang pembagian manfaat REDD+

Cecilia Luttrell, Lasse Loft, Maria Fernanda Gebara dan Demetrius Kweka

9 Penguasaan lahan dalam REDD+: Pembelajaran dari lapangan

Anne M. Larson, Maria Brockhaus dan William D. Sunderlin

10 Proyek-proyek REDD+ sebagai turunan berbagai pendekatan lama dan baru untuk konservasi hutan

William D. Sunderlin dan Erin O. Sills

11 Harapan dan kekhawatiran penduduk lokal mengenai proyek-proyek REDD+

Ida Aju Pradnja Resosudarmo, Amy E. Duchelle, Andini D. Ekaputri dan William D. Sunderlin

12 Pemilihan lokasi untuk proyek karbon hutan 
Bagian 3. Mengukur kinerja REDD+

13 Indikator kinerja dan penerapan REDD+

Sheila Wertz-Kanounnikoff dan Desmond McNeill

Manuel Estrada dan Shijo Joseph

15 Faktor-faktor emisi: Mengonversi perubahan tata guna lahan menjadi estimasi $\mathrm{CO}_{2}$

Louis V. Verchot, Kamalakumari Anitha, Erika Romijn, Martin Herold, dan

Kristell Hergoualc'h

16 Kerangka bertahap untuk menentukan tingkat acuan REDD+

Martin Herold, Arild Angelsen, Louis V. Verchot, Arief Wijaya, dan

John Herbert Ainembabazi

17 Pengamanan REDD+ dalam wacana kebijakan nasional dan proyek-proyek percontohan

Pamela Jagger, Kathleen Lawlor, Maria Brockhaus, Maria Fernanda Gebara,

Denis Jean Sonwa dan Ida Aju Pradnja Resosudarmo

18 Ringkasan dan kesimpulan: REDD+ tanpa penyesalan

Frances Seymour dan Arild Angelsen

Lampiran: Studi Komparatif Global (GCS) CIFOR tentang REDD+

Daftar istilah dan singkatan

Daftar istilah

Referensi 


\section{Daftar kotak, gambar dan tabel}

\section{Daftar kotak}

2.1 Moratorium Hutan Indonesia: Politik suatu kemungkinan

Frances Seymour

2.2 Alur kebergantungan kelembagaan di Daerah Aliran Sungai (DAS) Kongo

Samuel Assembe-Mvondo

3.1 Peran berbagai ideologi dalam membingkai agenda REDD+

Rocio Hiraldo dan Thomas M. Tanner

3.2 Sejumlah prasyarat bagi pasar untuk kredit REDD+

4.1 Pasar bahan bakar nabati, Standar Energi Terbarukan Uni Eropa dan hutan

Francis X. Johnson

4.2 Larangan pembalakan domestik China dan permintaan untuk kayu Afrika

4.3 Kelapa sawit, pangan dan bahan bakar nabati di Indonesia 67

4.4 Daging sapi dan kacang kedelai di Amazon Brasil 69

4.5 Bahan bakar nabati, harga-harga pangan dan investasi lahan di Afrika subSahara

5.1 REDD+ cara Brasil: Memadukan tongkat tua dengan wortel baru Jan Börner dan Sven Wunder

5.2 Mengaitkan pengetahuan dan tindakan: perumusan kebijakan REDD+ di Tanzania

Salla Rantala

5.3 Berbagai kendala dalam perumusan kebijakan REDD+ yang efektif di Nepal

Bryan R. Bushley dan Dil Bahadur Khatri

5.4 Analisis berbasis media tentang wacana REDD+ di Norwegia Laila Borge

6.1 Risiko korupsi dalam REDD+: Pengalaman dari Indonesia Ahmad Dermawan

6.2 Jejaring dan kebijakan regional di Indonesia Caleb Gallemore dan Rut Dini

6.3 Desentralisasi atau "LSM-isasi" REDD+? Lemahnya kepemimpinan nasional dalam membangun strategi REDD+ di Madagaskar

Emilia Runeberg

7.1 "Berapa besar biaya REDD+?" adalah pertanyaan yang (hampir) tidak ada artinya

Arild Angelsen

7.2 Pendanaan REDD+ di Republik Demokratik Kongo

André Aquino

8.1 Konsep-konsep utama pembagian manfaat REDD+

8.2 Perdebatan atas hak karbon di beberapa negara yang melakukan REDD+

1 Jika tidak ditentukan, kotak ini ditulis oleh penulis bab. 
8.3 Proyek REDD + di Tanzania: Menjajaki sejumlah pilihan untuk mengatasi ketegangan antara pembagian manfaat berbasiskan kinerja dan berbasiskan asupan

$\begin{array}{lll}9.1 & \text { Papua Nugini: Hak adat versus koboi karbon } & 180\end{array}$

Andrea Babon dan Daniel Mclntyre

9.2 Mitos dan kenyataan: Jaminan hak atas hutan di Vietnam 187

Thu Thuy Pham, Thu-Ba Huynh dan Moira Moeliono

9.3 Pengelolaan hutan partisipatif sebagai landasan kelembagaan untuk REDD+ di Tanzania

Therese Dokken

11.1 Apakah insentif REDD+ sejalan dengan persepsi penduduk lokal?

Pelajaran dari kawasan Transamazon di Brasil

Marina Cromberg

12.1 Katalog proyek-proyek REDD+

Mrigesh Kshatriya dan Liwei Lin

12.2 Memadukan sarana konservasi dalam program Bolsa Floresta, Amazon Brasil

Jan Börner dan Sven Wunder

13.1 Indikator kinerja dalam dana bantuan pembangunan 265

13.2 Pengukuran kinerja dalam kemitraan REDD+ Guyana-Norwegia 272

15.1 Menggunakan metode Penambahan-Pengurangan untuk meningkatkan fasilitas estimasi faktor emisi untuk lahan gambut tropis

15.2 Bukti Perkembangan antara FRA 2005 dan FRA 2010302

15.3 MRV dari global ke lokal dalam REDD+: Menghubungkan pendekatan masyarakat dan pemerintah

Finn Danielsen, Neil D. Burgess, dan Martin Enghoff

16.1 Pedoman COP17 UNFCCC dan implikasinya

16.2 Metode regresi berganda untuk analisis faktor penyebab deforestasi hutan

16.3 Tiga Tahap, Tiga Pendekatan, Tiga Tingkat, Tiga Langkah 325

16.4 Mengembangkan RL di Indonesia

17.1 Pengamanan United Nations Framework Convention on Climate Change (UNFCCC) yang diartikulasikan dalam Perjanjian Cancun

17.2 Mengaitkan Konvensi Mengenai Keanekaragaman Hayati (Convention on Biological Diversity/CBD) dan pengamanan keanekaragaman hayati oleh REDD+: Pengalaman dari Afrika subSahara

17.3 Kebijakan pengamanan REDD+ nasional di Brasil 344

A1 Sejumlah tantangan penelitian REDD+ 396

\section{Daftar gambar}

$\begin{array}{lll}1.1 & \text { Struktur buku ini } & 7\end{array}$

$\begin{array}{lll}2.1 & \text { REDD+ dan 4I } & 22\end{array}$

3.1 REDD+ sebagai gagasan yang muncul dan praktiknya 43 
4.1 Diagram yang disederhanakan tentang sejumlah kekuatan ekonomi global dan kebijakan di negara-negara konsumen dan produsen yang memengaruhi kompetisi pemanfaatan lahan yang berdampak bagi REDD+

5.1 Peristiwa/kegiatan/Peristiwa kebijakan REDD+ oleh negara 82

5.2 Kerangka kerja politik-ekonomi 84

$\begin{array}{lll}7.1 & \text { Sumber-sumber pendanaan REDD+ } & 136\end{array}$

$\begin{array}{lll}7.2 & \text { Pendanaan sektor publik dan sektor swasta untuk REDD+ } & 138\end{array}$

8.1 Berbagai struktur potensial untuk aliran dana REDD + ke tingkat subnasional

9.1 Tahapan reformasi kepemilikan lahan untuk mengurangi deforestasi dan degradasi hutan

9.2 Metatopik artikel media nasional (persentase dari total artikel surat kabar yang dianalisis per negara)

10.1 Para pemrakarsa intervensi berharap untuk memiliki dampak paling positif dalam penyerapan karbon

11.1 Pemahaman lokal mengenai sasaran-sasaran proyek REDD+ lokal

11.2 Harapan dan kekhawatiran lokal terkait proyek REDD+

12.1 Distribusi proyek REDD+

12.2 Jumlah proyek di Brasil dan Indonesia dengan kombinasi sasaran dan kegiatan yang berbeda

12.3 Perbandingan kotamadya dengan sedikitnya satu proyek REDD+ terhadap kotamadya tanpa proyek REDD+, dibagi lagi dalam kotamadya dalam Legal Amazon vs. bagian Brasil lainnya (di luar)

12.4 Perbandingan kabupaten dengan sedikitnya satu proyek REDD+ terhadap kabupaten tanpa proyek REDD+, dibagi lagi dalam kabupaten di Pulau-pulau Luar (di luar provinsi-provinsi di Jawa) vs. Jawa

13.1 Sejumlah pilihan indikator kinerja bagi semua fase REDD+

14.1 Data penginderaan jauh historis yang tersedia untuk lokasi-lokasi proyek GCS

15.1 Hubungan antara kategori utama dan tingkat tier untuk kompilasi inventarisasi dan akurasi vs pengorbanan biaya (Diadaptasi dari Maniatis dan Mollicone 2010)

15.2 Langkah-langkah yang diperlukan dalam estimasi faktor emisi (Diadaptasi dari Meridian Institute 2011a)

15.3 Perubahan kapasitas untuk 99 negara tropis nonAneks I berdasarkan perbedaan antara pelaporan FAO/FRA 2005 dan 2010 pada lima sumber karbon hutan yang berbeda

16.1 Elemen-elemen utama untuk menetapkan tingkat acuan 317

16.2 Faktor penyebab deforestasi di Brasil, Indonesia, and Vietnam 322

17.1 Motivasi proyek untuk mendapatkan FPIC: Hak, peraturan, dan keberhasilan

A1 Desain penelitian dan modul kerja Komponen 1 GCS 383

A2 Metode BACI Komponen 2 


\section{Daftar tabel}

5.1 Berbagai pemicu deforestasi, kebijakan-kebijakan yang menentang atau yang mendukung REDD+ dan otonomi para penyelenggara negara

5.2 Pelaku yang membentuk wacana kebijakan (persentase jumlah total pelaku yang mengekspresikan posisinya tentang REDD+ melalui media)

6.1 Elemen-elemen inti dalam REDD+ dan tantangan lintas tataran

6.2 Mekanisme tata kelola lintas tataran, tanggapan-tanggapan REDD+ dan beberapa contoh studi kasus

7.1 Pasokan global pengurangan emisi dari REDD+ ( $\mathrm{GtCO}_{2}$ e per tahun) (Meridian Institute 2009)

7.2 Tingkat pembiayaan REDD+ sekarang dan masa depan dalam mekanisme sektor publik dan swasta (dalam AS\$ miliar tahun)

7.3 Ringkasan kebutuhan-kebutuhan REDD+ (diadaptasi dari Meridian Institute 2009)

8.1 Ikhtisar kebijakan dan praktik pembagian keuntungan REDD+ di lima negara

8.2 Contoh-contoh penerima potensial manfaat REDD+ dan biaya serta manfaat yang mungkin akan dirasakan

8.3 Sejumlah pendekatan pembagian manfaat di tingkat proyek

8.4 Usulan model dana alokasi subnasional REDD+ di Brazil (berdasarkan Moutinho dkk (2011) [i] dan MMA (2012) [ii].)

9.1 Distribusi kepemilikan lahan hutan (data tahun 2008, dalam jutaan hektar)

9.2 Masalah dan inisiatif kepemilikan lahan tingkat nasional dan proyek

9.3 Konflik lahan, ketidakpastian dan kepatuhan peraturan hutan lokal di desa-desa sampel menurut negara (dalam angka dan persen)

9.4 Pelarangan hak dan praktik di desa-desa sampel menurut negara (dalam angka dan persen)

9.5 Masalah kepemilikan lahan, implikasi bagi REDD+ dan potensi solusinya

10.1 Rencana waktu pengenalan intervensi-intervensi di 21 lokasi proyek REDD+ dalam GCS Komponen 2

11.1 Proyek-proyek REDD+ yang dianalisis

11.2 Status proyek dan pengetahuan mengenai REDD+ dan proyek REDD+ lokal (2010)

11.3. Rekomendasi penduduk lokal untuk proyek-proyek REDD+

12.1 Jumlah proyek REDD+ di Brasil dan Indonesia berdasarkan sasaran dan kegiatan

12.2 Nilai tengah faktor-faktor yang dipertimbangkan dalam pemilihan lokasi di berbagai kotamadya atau kabupaten dengan dan tanpa proyek REDD+

12.3 Model binomial negatif dari penghitungan proyek karbon hutan di kotamadya Brasil atau kabupaten di Indonesia

12.4 Ciri-ciri desa-desa yang terletak di dalam dan di luar proyek REDD+ dalam sampel GCS 
13.1 Rantai hasil dan jenis-jenis indikator kinerja yang berbeda 263

13.2 Contoh-contoh indikator kinerja dalam inisiatif REDD+ nasional 268

14.1 Ringkasan proyek-proyek yang bekerja sama dengan GCS 278

14.2 Metodologi yang disetujui VCS untuk proyek-proyek REDD terhitung sejak Maret 2012 (VCS 2012)

14.3 Data dan tugas utama yang diperlukan untuk menetapkan kondisi awal laju deforestasi/degradasi dan /atau lokasi proyek-proyek AUDD

14.4 Persyaratan data penginderaan jauh untuk analisis perubahan tutupan hutan (historis) untuk metodologi AUDD

14.5 Sumber-sumber estimasi stok karbon yang diperlukan dalam skenario kondisi awal

15.1 Contoh Tier 1 faktor emisi untuk biomassa (atas tanah dan bawah tanah) yang terkait dengan konversi hutan menjadi padang rumput di Afrika, dihitung dengan menggunakan metode Stok-Perbedaan dan menggunakan nilai yang ditetapkan untuk sumber karbon (IPCC 2006) 298

16.1 Dimensi-dimensi pendekatan bertahap untuk mengembangkan tingkat acuan (lihat juga Kotak 16.3)

16.2 Sejumlah pilihan untuk mengatasi ketidakpastian dalam pengaturan RL (Ecofys 2012)

18.1 Tindakan prioritas berdasarkan jenis dan tingkat 366

A1 Negara-negara yang termasuk dalam penelitian GCS $\quad 374$

A2 Mitra dalam proyek GCS $\quad 375$

A3 Metode Komponen 1 untuk menganalisis strategi REDD+ nasional: $\begin{array}{ll}\text { deskripsi dan tujuan utama } & 381\end{array}$

A4 Lokasi proyek REDD+ dalam penelitian Komponen 2 GCS 385

A5 Distribusi desa-desa Komponen 2 menurut jenisnya (kontrol/intervensi) dan mode (intensif/ekstensif/nonBACI) yang datanya telah dikumpulkan

A7 Metode analisis strategi REDD+ nasional: deskripsi dan tujuan utama 393 


\section{Kata pengantar}

Saya gembira menyambut buku terbaru dari Pusat Penelitian Kehutanan Internasional (Center for International Forestry Research/CIFOR) "Menganalisis REDD+: Sejumlah Tantangan dan Pilihan". Buku ini menarik, relevan dan akan bermanfaat bagi para perunding perubahan iklim, pembuat kebijakan nasional dan lokal, berbagai lembaga pembangunan, organisasi dan lembaga kehutanan, serta para praktisi REDD+. Buku ini menyediakan informasi dan analisis yang sangat baik dan yang diluncurkan pada saat yang tepat ketika komunitas global menyiapkan putaran negosiasi perubahan iklim berikutnya, yang tentunya akan mengikutsertakan REDD+, dan mungkin akan membawanya ke tingkat yang lebih tinggi.

Buku ini mengikuti dua judul mengenai REDD+ yang diterbitkan oleh CIFOR sebelumnya, "Melangkah Maju dengan REDD: Isu, Pilihan dan Implikasi” (2008) dan "Mewujudkan REDD+: Strategi Nasional dan Sejumlah Pilihan Kebijakan" (2009), dan menyediakan analisis tentang rancangan REDD+ aktual dan implementasi awalnya. Buku ini menggunakan berbagai pengalaman REDD+ pada tingkat nasional, subnasional maupun lokal, dan mengidentifikasi berbagai tantangan dalam merancang dan menerapkan kebijakan dan proyek REDD+ yang efektif, efisien dan berkesetaraan. Sejumlah pilihan kebijakan untuk mengatasi hambatan dalam membawa REDD+ ke tingkat yang lebih tinggi juga diuraikan. 
Sebagai seorang pemimpin dalam negosiasi UNFCCC tentang REDD+ dan seorang pelaksana REDD+ di Filipina, saya menggarisbawahi pentingnya analisis para penulis tentang berbagai tantangan dan pilihan dalam REDD+. Sejalan dengan langkah maju kita untuk menjabarkan sejumlah aturan global, termasuk tentang jaringan pengaman REDD+, tingkat acuan, pengukuran, pelaporan dan verifikasi (MRV), dan keuangan, penting sekali untuk berpijak pada sejumlah pembelajaran dan memahami lebih baik hal-hal apa saja yang berjalan baik dan yang tidak. Dengan mengikuti pendekatan studi kasus nasional, para penulis buku ini membantu kita dalam merangkum berbagai pelajaran ini ke dalam arsitektur global REDD+ yang terus berkembang.

Sebagai pemenang jaringan pengaman negosiasi REDD+, dan seorang advokat untuk waktu yang lama bagi berbagai pendekatan masyarakat adat dan pengelolaan hutan berbasiskan masyarakat, saya khususnya gembira dengan penyertaan pembagian manfaat dan hak atas karbon dalam buku ini. Saya setuju dengan para penulis bahwa "dialog jaringan pengaman REDD+ perlu bergeser dari diskusi tingkat tinggi internasional menuju tindakan di lapangan."

Akhirnya, saya juga menyambut baik sorotan para penulis tentang Pembayaran untuk Jasa Lingkungan (PES) sebagai kerangka kerja yang berpotensi untuk merancang REDD+. Gagasan PES memang "menjanjikan sebuah menu menang-menang: pengguna hutan lokal akan memilih konservasi hutan jika mereka menerima kompensasi yang yang lebih tinggi daripada potensi penghasilan dari pemanfaatan hutan alternatifnya."

Kai Lee, dalam bukunya 'Between Compass and Gyroscope' tahun 1993 menulis bahwa "berbagai kebijakan adalah percobaan, belajarlah dari mereka!" Ungkapan ini khususnya berlaku untuk REDD+, mengingat wilayah yang kita masuki adalah sebuah lanskap yang belum diketahui. Analisis yang kokoh seperti yang disajikan dalam buku ini penting untuk kita pelajari, dan untuk memperbaikinya, dalam mengimplementasikan REDD+.

\section{Tony La Viña}

Fasilitator REDD+ Facilitator, Kelompok Kerja Khusus untuk Aksi Kerja Sama Jangka Panjang (Ad Hoc Working Group on Long Term Cooperative Action/LCA), UNFCCC; dan

Dekan, Ateneo School of Government, Ateneo de Manila University, Filipina 


\section{Ucapan terima kasih}

Menyelesaikan buku ini dalam rentang waktu empat bulan saja hanya mungkin terwujud karena upaya keras tim yang melibatkan lebih dari 150 orang. Sebagai penyunting, saya sangat menikmati kesempatan bekerja sama dengan semua pihak yang terlibat. Inti buku ini terdiri dari 18 bab, termasuk sejumlah kotak dengan berbagai topik, karya tulisan 66 penulis. Kualitas penulisan, dan cepatnya perputaran dan respon dalam berbagai interaksi, patut mendapatkan penghargaan yang tinggi.

Therese Dokken telah berperan sebagai poros roda dalam proses penulisan, mengelola ratusan versi bab, 508 referensi dan ribuan surat elektronik antara penyunting, penulis, pengulas dan staf produksi. Tanpa usaha-usahanya yang penuh dedikasi dan efisien buku ini tidak akan memenuhi tenggat waktu yang sangat ketat.

Di kantor pusat CIFOR, sejumlah personel dalam Kelompok Pelayanan Informasi (Information Service Group) berkontribusi pada produksi buku ini, termasuk John Colmey, Romy Serfaty, Gideon Suharyanto, Mokhamad Edliadi, Sufiet Erlita, Jacob Pratama, Vidya Fitrian, Catur Wahyu dan Eko Prianto.

Produksi buku ini, termasuk proses penyuntingan bahasa, desain grafis dan pengaturan tata letak yang seksama, dilakukan oleh Green Ink. Kami berterima kasih untuk profesionalisme dan keluwesan yang diberikan oleh tim yang terdiri dari Sophie Higman, Paul Philpot, Ruth Raymond, Tim Woods, Erin O’Connell, Sue Parrott, Christel Chater, Becky Mitchell, Anne Downes dan Jeff Walker. 
Sejumlah bab telah diulas silang oleh para penulis dari bab lainnya, demikian juga oleh 60 pengulas eksternal. Kami menghargai kontribusi penting dari pengulas yang baik dalam publikasi ilmiah ini, dan kami berterima kasih untuk saran dan kritik yang sangat bermanfaat dari: Patrick Anderson, Ken Andrasko, Odd Arnesen, Steve Ball, Tor A. Benjaminsen, JuergenBlaser, Anne Booth, Doug Boucher, Timothy Boyle, GernotBroding, Jonah Busch, Gillian Cerbu, Carol Colfer, Rane Cortez, Pham ManhCuong, Andreas Dahl-Jørgensen, Crystal Davis, Christiane Ehringhaus, Lars Ekman, Odd-HelgeFjeldstad, Tim Forsyth, Leif John Fosse, Edenise Garcia, Bronson W. Griscom, Jeffrey Hatcher, Signe Howell, Agus Djoko Ismanto, Peter AarupIversen, Tim Jessup, Ivar Jørgensen, Randi Kaarhus, David Kaimowitz, Alain Karsenty, Sjur Kasa, YemiKaterere, Thelma Krug, Rezal Kusumaatmadja, Donna Lee, Henrik Lindhjem, Peter May, MarteNordseth, IngerGerdNæss, Michael Obersteiner, Steven Panfil, Jim Penman, Leo Peskett, Francis Putz, Steve Rhee, Peter Riggs, Tom Rudel, Jeffrey Sayer, Heike Schroeder, EspenSjaastad, Margaret Skutsch, Luca Tacconi, Natalie Unterstell, Arild Vatn, Nicole R. Virgilio, Michael Wells dan Pete Wood. Selain itu, penulis Bab 7 juga berterimakasih kepada Matthew Cranford atas kontribusinya bagi bab ini.

Pendanaan untuk buku ini disediakan oleh NORAN dan Kementerian Lingkungan Hidup Norwegia, AusAID (Australia), European Commission, Departemen Energi dan Perubahan Iklim serta Departemen untuk Pembangunan Internasional (Inggris), FinAid (Finlandia), dan Fonds Français pour l'Environnement Mondial (Perancis).

Dengan tetap memberikan penghargaan yang tinggi kepada semua kontribusi tersebut, perlu diketahui para pembaca bahwa sejumlah pandangan yang disajikan dalam buku ini berasal dari para penulisnya. Mereka tidak serta merta mencerminkan padangan CIFOR, para penyunting, institusi para penulis, pendukung dana maupun para pengulas.

Sebagian besar bab dalam buku ini didasarkan pada proyek penelitian berskala besar yang dilakukan oleh CIFOR dan mitranya: Studi KomparatifGlobal untuk REDD+ (GCS). Sebuah daftar lengkap yang memuat individu, organisasi, dan pendukung yang telah berkontribusi dalam proyek ini dicantumkan dalam Lampiran. Tanpa kerja keras mitra dan koordinator di masing-masing negara, perwakilan, petugas di lapangan, ahli sandi, pengawas penelitian lapangan, responden, nara sumber, pemrakarsa proyek dan lain-lain, kami tidak akan dapat menyajikan hasil studi besar ini.

Bogor, Indonesia, dan Ås, Norwegia

31 Mei 2012

ArildAngelsen Maria Brockhaus William D. Sunderlin Louis V. Verchot 


\section{Ringkasan}

REDD+ terus bergerak maju, tetapi dengan derap yang lebih lambat dan dalam bentuk yang berbeda dari yang kami harapkan ketika diluncurkan di Bali tahun 2007. Buku ini menginventarisasi REDD+ dan mengajukan sejumlah pertanyaan. Perubahan apa saja yang telah terjadi dalam REDD+ dan mengapa? Bagaimana REDD + berkembang dalam arena kebijakan nasional? Bagaimana REDD+ diwujudkan di lapangan? Apa saja yang menjadi tantangan utama dalam merancang dan melaksanakan REDD+? Dan, apa saja pilihan yang harus diambil untuk membuat REDD+ menjadi lebih efektif, efisien dan setara? Sebagian besar analisis dalam tulisan ini didasarkan pada proyek penelitian perbandingan besar, Studi Komparatif Global REDD+ (GCS) yang diselenggarakan oleh CIFOR dan mitra-mitranya.

REDD+ - sebagai sebuah gagasan - merupakan kisah keberhasilan. REDD+ selama ini dianggap sebagai sebuah pilihan yang cepat dan murah untuk mengambil langkah dini untuk membatasi pemanasan global sampai $2^{\circ} \mathrm{C}$. REDD+ juga merupakan pendekatan baru mengenai perdebatan hutan dan iklim, dengan pendanaan besar skala besar berbasis hasil sebagai ciri utama dan harapan bahwa perubahan transformatif akan terjadi di dalam dan di luar sektor kehutanan. Pada waktu yang sama, REDD+ bersifat cukup 
umum untuk memayungi sejumlah besar pelaku sehingga masing-masing dapat mengupayakan berbagai gagasan mereka sendiri mengenai apa yang ingin dicapainya.

REDD+ terus mengalami perubahan. Tidak adanya kesepakatan internasional baru tentang perubahan iklim berarti bahwa sumber dana besar yang berpotensi dengan berdasarkan kinerja dan untuk jangka panjang belum tersedia. Saat ini, dua pertiga dari pendanaan REDD+ berasal dari anggaran bantuan pembangunan. Namun ada suatu paradoks: sementara saat ini tidak ada strategi jangka panjang yang memadai dan dapat diprediksi mengenai cara memenuhi kebutuhan finansial REDD+, dana untuk jangka pendek tersedia. Namun, pencairan dana ini lambat karena negara-negara yang membutuhkannya tidak dapat menyerap jumlah yang tersedia.

Ketersediaan dana yang lebih kecil bagi REDD+ melalui bantuan pembangunan berpengaruh besar pada kecepatan implementasi dan telah berkontribusi pada perluasan jangkauan REDD+. Lebih jauh, dalam ketiadaan mekanisme global yang kuat, negara-negara berkembang yang lebih kaya dengan kelembagaan yang lebih kuat mungkin memilih untuk membiayai sendiri sebagian proyek REDD+ mereka. Mereka mungkin juga memilih untuk terlibat dalam kesepakatan berbasiskan hasil dengan para donatur dan badan-badan internasional. Para donatur dan penerima dana mungkin memiliki kepentingan terbatas dalam mencapai standar REDD+ universal, dan praktik-praktiknya mungkin menjadi semakin beragam.

REDD+ telah memasuki arena kebijakan nasional sebagai sebuah gagasan dan dengan kemungkinan pembayaran internasional substansial untuk hasil yang dicapai. Untuk memahami bagaimana REDD+ diterima, dipahami dan disesuaikan, buku ini meninjau ekonomi politis REDD+ melalui kerangka kerja 4I: "institutions, interests, ideas and information" (kelembagaan, kepentingan, gagasan dan informasi). Untuk merealisasikan sepenuhnya potensi mitigasi REDD+ dibutuhkan perubahan transformatif dalam bentuk perubahan kerangka kerja ekonomi, peraturan dan tata kelola, penghapusan insentif yang merugikan masyarakat dan reformasi kebijakan industri hutan dan agribisnis. REDD+ juga memiliki potensi - dan telah merealisasikannya sampai taraf tertentu - untuk menjadi pengubah permainan dengan menawarkan insentif ekonomi baru (khususnya, pendanaan internasional berbasis hasil) dan juga informasi dan wacana baru, dan dengan membawa sejumlah pelaku baru ke arena, yang mungkin mengarah kepada koalisi baru untuk mewujudkan suatu perubahan.

Apakah proses REDD+ dapat menghasilkan perubahan transformatif, atau apakah kebijakan bisnis-seperti-biasa akan tetap bertahan, bergantung pada beberapa faktor. Suatu analisis di tujuh negara menyarankan bahwa faktor kunci untuk mencapai perubahan transformatif terletak pada otonomi negara 
dari sejumlah kepentingan utama yang memicu deforestasi dan degradasi hutan, dan kehadiran berbagai koalisi yang kuat yang menuntut agar terjadi perubahan. Kepemilikan nasional dari proses kebijakan REDD+ juga penting. Strategi REDD+ yang efektif kecil kemungkinannya untuk dirumuskan dan diterapkan di berbagai negara kalau proses kebijakan REDD+ didorong oleh para pelaku internasional.

Strategi REDD+ yang berhasil memerlukan koordinasi banyak tingkatan. Mekanisme REDD+ harus menautkan kebutuhan global dan 'kesediaan untuk membayar' untuk mitigasi iklim dengan lembaga-lembaga nasional dan subnasional dan kebutuhan serta aspirasi masyarakat setempat. Tantangannya terletak pada menautkan informasi, insentif dan lembaga yang efektif pada berbagai tingkat. Buku ini menyediakan analisis mendalam dari ketiga komponen ini.

Pertama, meningkatkan dan menyelaraskan aliran informasi antara tingkat lokal dan nasional sangat penting untuk pengukuran, pelaporan dan verifikasi (MRV) yang efektif dan kontrol terhadap kebocoran emisi (emisi teralihkan). Aliran informasi yang baik melintasi berbagai tingkat dapat meningkatkan daya negosiasi kelompok-kelompok yang dirugikan dan memastikan REDD+ yang lebih efektif, efisien dan setara. Keterbatasan peta umum dan pola pikir dan suatu kerangka kerja terpadu untuk mengintegrasikan berbagai sumber informasi dapat menjadi penghambat utama untuk bertindak. Para pemangku kepentingan perlu memiliki pemahaman yang sama mengenai 'di mana kita berada' sebelum mengambil keputusan mengenai 'ke mana tujuan kita' atau 'bagaimana caranya menuju ke sana'.

Kedua, penetapan mekanisme pembagian keuntungan melintasi berbagai tingkatan dan yang dapat diterima oleh semua pemangku kepentingan merupakan salah satu penghalang yang paling menantang dalam implementasi REDD+. Pembagian keuntungan penting untuk menciptakan insentif positif untuk mengurangi emisi karbon, tetapi mekanismenya harus dipandang adil; jika tidak, maka hal ini akan mengancam keabsahan dan dukungan terhadap REDD+. Berbagai wacana yang berlainan menekankan prinsip yang berbeda untuk mengalokasikan keuntungan dan biaya, dan terkait erat - secara mendasar - dengan berbagai konflik mengenai visi REDD+. Maka, sebelum merancang mekanisme pembagian keuntungan yang efektif, perlu sekali menyelesaikan sejumlah pertanyaan pada tingkat yang lebih tinggi mengenai sasaran yang ingin dicapai oleh REDD+. Dalam menegosiasikan timbal balik di antara berbagai sasaran diperlukan penilaian etis, politis dan praktis. Mengingat adanya keanekaragaman pandangan, keabsahan lembaga-lembaga pengambil keputusan dan prosesnya merupakan hal penting untuk rancangan dan implementasi pembagian keuntungan yang efektif dan berkelanjutan. 
Ketiga, struktur dan kebijakan kelembagaan nasional diperlukan untuk mendorong tindakan di lapangan. Salah satu contoh yang menonjol berhubungan dengan persoalan kepemilikan dan hak-hak atas lahan. REDD+ dapat digunakan sebagai insentif untuk mendukung reformasi di bidang kehutanan, dan sekaligus dapat merupakan strategi untuk mendukung implementasi REDD+. Reformasi di bidang ini dapat menjadi bagian penting dari perubahan transformatif yang diperlukan. Sementara REDD+ telah menarik banyak perhatian tentang kepemilikan lahan, usaha-usaha tingkat nasional untuk menangani isu-isu lahan dan karbon masih terbatas. Intervensi tingkat proyek untuk menangani masalah kepemilikan lahan menghadapi sejumlah hambatan penting bila tidak ada dukungan secara nasional.

Hak kepemilikan lahan dan hak-hal lainnya berkaitan erat dengan pengamanan untuk REDD+, suatu topik utama dalam diskusi Konvensi Kerangka Kerja tentang Perubahan Iklim PBB (UNFCCC). Para perumus kebijakan, pendukung proyek dan investor menghargai pengamanan REDD+, sebagaimana terbukti dari adopsi dini mereka terhadap standar-standar sosial dan lingkungan hidup nasional dan pada tingkat proyek. Pada waktu yang sama, dialog pengamanan REDD+ perlu untuk bergerak dari diskusi internasional tingkat tinggi ke tindakan di lapangan. Untuk mencapai 'persetujuan sukarela melalui pemberian informasi lebih dahulu' (FPIC) tetap menjadi tantangan untuk sejumlah alasan. "FPIC merupakan mimpi mustahil yang sedang kita kejar", catat seorang pendukung.

Sebagai bagian dari GCS, survei ekstensif sedang dilakukan pada proyek-proyek REDD+ di enam negara, termasuk survei pada para pendukung proyek dalam pengalaman dini mereka dalam melaksanakannya. Gagasan awal REDD+ adalah untuk menetapkan sebuah sistem atau pembayaran berbasis hasil untuk jasa lingkungan (PES) di mana pembayaran dari tingkat internasional kepada pengguna hutan secara perorangan akan dilakukan. Sebagian besar dari proyek yang diteliti bertujuan untuk mengombinasikan pendekatan PES dengan proyek terpadu konservasi dan pembangunan (ICDP) yang lebih konvensional, yang menekankan penegakan peraturan-peraturan kehutanan dan penyediaan sumber-sumber mata pencaharian alternatif. Pendekatan turunan ini memampukan para pendukung untuk meraih kemajuan awal pada penetapan proyek dan pendekatan ICDP dapat menjadi cadangan apabila PES tidak dapat terwujud, misalnya karena ketidakpastian yang terkait dengan pendanaan di masa depan. Namun pendekatan turunan ini melibatkan berbagai tantangan, karena implementasi ICDP di masa lalu sukar dan mendahulukan ICDP sambil menunda diskusi mengenai PES dengan para pemangku kepentingan lokal mungkin akan menimbulkan masalah di kemudian hari. Kapan dan apakah para pendukung akhirnya memutuskan untuk menggunakan PES, mereka harus kembali kepada semua pemangku kepentingan lokal untuk menjelaskan rencananya. 
Gagasan PES menjanjikan suatu skenario sama-sama menang: para pengguna hutan lokal akan memilih pelestarian hutan bila ganti rugi yang mereka terima lebih tinggi daripada yang akan mereka dapatkan dari penggunaan hutan alternatif. Dalam praktiknya, REDD+ mungkin, dalam menggunakan model turunan tersebut, kurang bersifat langsung dan hasilnya tidak pasti. Sebuah survei rumah tangga di beberapa lokasi proyek mengungkapkan bahwa masyarakat setempat memahami REDD+ sebagai sarana utama untuk perlindungan hutan, sementara harapan dan kekhawatiran mereka terkait dengan pendapatan dan mata pencaharian. Tantangan utama proyek-proyek REDD+ dengan demikian mencakup: i) mengomunikasikan kepada para penduduk desa mengenai cara kerja proyek, kesempatan dan risikonya, dan hak dan tanggung jawab para pemangku kepentingan; ii) melibatkan penduduk desa secara berarti dalam rancangan dan pelaksanaan proyek-proyeknya; dan iii) menyeimbangkan perlindungan hutan dengan masalah kesejahteraan penduduk desa. Survei ini juga menunjukkan bahwa para penduduk desa sangat bergantung pada pendukung proyek untuk mendapatkan informasi mengenai REDD + dan proyek lokal, dan mungkin ada kebutuhan untuk para perantara informasi independen atau penasihat hukum juga, misalnya ketika mereka menandatangani berbagai kesepakatan.

Keberhasilan REDD+ bergantung tidak hanya pada dukungan lokal, tetapi juga pada intervensi yang ditujukan pada berbagai daerah dengan deforestasi dan degradasi hutan tingkat tinggi, di mana pengurangan emisi yang nyata dapat dicapai dan dengan demikian memastikan penambahan penyerapan karbon atau pencegahan emisi karbon yang nyata, terukur dan berjangka panjang. Sebuah studi tentang lokasi-lokasi proyek di negara-negara berkembang menemukan bahwa negara yang memiliki keanekaragaman hayati tinggi dan lebih banyak wilayah yang dilindungi cenderung memiliki proyek-proyek REDD+. Hal ini sesuai dengan pernyataan para pendukung proyek yaitu bahwa mereka mempertimbangkan manfaat tambahan keanekaragaman hayati ketika memilih lokasi untuk proyek. Sebuah studi mendetail di dua negara yang paling jauh terlibat dalam kegiatan REDD+, Brasil dan Indonesia, menyarankan bahwa proyek-proyek lebih mungkin dilakukan di wilayah dengan laju deforestasi dan kerapatan karbon hutan tinggi. Ada kekhawatiran awal bahwa proyek-proyek mungkin cenderung berada di lokasi di mana hutannya sudah dilindungi dengan baik, jadi hal ini merupakan temuan yang memberi dorongan. Para pendukung proyek telah memilih wilayah yang memiliki potensi untuk memberi dampak positif.

Namun demikian, buku ini menegaskan bahwa kita mungkin memerlukan 3-5 tahun lagi sebelum kita dapat mengetahui apakah REDD+ memang berperan. Selain waktu yang diperlukan untuk mengamati perubahan di lapangan, pengukuran dampak dalam bentuk penurunan emisi bukanlah tugas ringan. Stok karbon hutan harus dipantau, dan garis dasar tingkat acuan harus dikembangkan untuk membangun skenario kontra fakta mengenai 
apa yang akan terjadi tanpa proyek atau kebijakan REDD+. Tantangan dalam mengembangkan tingkat acuan ini termasuk: keterbatasan data yang diperlukan untuk memperkirakan laju emisi di masa lalu, dan ketidakpastian yang sebenarnya dalam menentukan emisi di masa depan dan bagaimana laju ini akan mengalami penyimpangan dari laju di masa lalu. Lebih jauh lagi, tingkat acuan penting bagi para pemangku kepentingan. Ada insentif kuat untuk membuat perkiraan yang bias agar dapat membantu intervensi proyek atau agar kebijakan tertentu tampak berhasil atau untuk menghasilkan pembayaran yang lebih tinggi bila tingkat acuan digunakan sebagai dasar untuk pembayaran-berdasarkan-hasil, misalnya menjual kredit REDD+ di pasar karbon. Untuk memastikan semua hal ini diperlukan panduan internasional dan verifikasi independen dari tingkat acuan proyek/subnasional dan nasional.

Selama beberapa tahun terakhir, standar dan metode yang kuat telah dikembangkan untuk memperkirakan emisi dari deforestasi pada tingkat proyek. Namun karena metodologi dasar dan pemantauan REDD+ yang lengkap baru saja diadopsi, banyak proyek percontohan REDD+ mungkin tidak menaatinya, yang menyebabkan adanya risiko untuk kehilangan kesempatan di pasar karbon.

Proyek-proyek berikutnya harus belajar dari pengalaman ini dengan mengidentifikasi atau mengembangkan metodologi yang sesuai sebelum melakukan investasi untuk pengembangan sistem dan dasar pengukuran, pelaporan dan verifikasi (MRV).

Buku ini menyajikan pendekatan langkah demi langkah untuk mengembangkan tingkat acuan pada tingkat nasional, sejalan dengan keputusan-keputusan baru oleh UNFCCC dan membangun berdasarkan logika yang sama dengan pendekatan bertingkat untuk faktor-faktor emisi. Pendekatan langkah demi langkah ini dapat mencerminkan keadaan dan kapasitas negara yang berbeda dan akan mendorong partisipasi luas dan langkah awal. Ketersediaan dan kualitas data harus menentukan metode-metode yang digunakan untuk mengembangkan tingkat acuan, misalnya metode canggih yang diterapkan pada data yang buruk harus dihindari karena hal ini akan memperbanyak kesalahan. Ketika data yang lebih baik nantinya tersedia, mempertimbangkan faktor-faktor pemicu dan aktivitas yang menyebabkan deforestasi dan degradasi hutan akan menjadi penting untuk menyesuaikan tingkat acuan terhadap 'keadaan nasional'. Ketidakpastian tingkat acuan dapat dicerminkan dalam faktor penyesuaian konservatif dalam program pembayaran-berdasarkan-hasil. Hal ini akan memberikan insentif untuk melakukan investasi di bidang peningkatan kapasitas pengukuran dan pemantauan untuk mengurangi ketidakpastiannya. 
Faktor-faktor emisi diperlukan untuk konversi perkiraan luas hutan yang mengalami deforestasi dan degradasi menjadi perubahan emisi karbon dan stok karbon. Faktor emisi sekarang berperan sampai 60\% dari kepastian dalam inventarisasi gas rumah kaca (GRK). Faktor emisi yang spesifik untuk daerah atau negara masih sangat kurang di sebagian besar negara tropis, yang menjadikannya tidak mungkin untuk memperkirakan secara akurat dan tepat emisi dari sumber-sumber dan penghapusan oleh cadangan karbon dalam program-program REDD+ nasional dan kegiatan percontohan. Investasi yang cukup besar dan usaha-usaha terkoordinasi diperlukan sebagai bagian dari kesiapan pendanaan untuk mengatasi keterbatasan data dan kelembagaan. Kendala-kendalanya dapat diatasi bila dilakukan investasi terkoordinasi dan jelas sasarannya dan kemitraan yang produktif dibangun antara layanan teknis di negara-negara tuan rumah REDD+, lembaga-lembaga antarpemerintah dan lembaga penelitian lanjut di negara-negara berkembang.

Sementara pengukuran hasil dalam bentuk pengurangan emisi dan peningkatan pembuangan GRK dari atmosfer merupakan tujuan utama, dalam jangka waktu menengah, sebagian besar pembayaran ditujukan bagi kesiapan dan reformasi kebijakan, dan bukannya untuk perubahan emisi atau pembuangan yang sudah terbukti. Dengan demikian, indikator kinerja yang baik sangat penting untuk ketiga fase REDD+ (kesiapan, reformasi kebijakan, tindakan berbasiskan-hasil). Hal ini khususnya benar untuk Fase 2, di mana fokusnya adalah pada kinerja kebijakan. Perhatian pada pengembangan indikator semacam itu masih terbatas, tetapi buku ini menekankan bahwa pelajaran-pelajaran berharga tentang indikator tata kelola dapat dipelajari dari sektor bantuan pembangunan: hindari pencarian indikator yang sempurna dan gunakan penilaian ahli secara ekstensif.

Rancangan dan implementasi REDD+ sangat menantang: tujuannya adalah untuk mematahkan kecenderungan bersejarah panjang, membangun konsensus politik oleh para pelaku utama yang memuaskan dalam arena kebijakan, menghasilkan perubahan transformatif, mencapai koordinasi banyak tingkat (dari global sampai komunitas lokal terpencil) dan mengelola aliran-aliran informasi dan pembayaran yang kompleks, semuanya di tengah ketidakpastian besar untuk rezim mitigasi iklim di masa depan dan selera global yang kuat untuk memanfaatkan lebih banyak lahan untuk makanan, bahan bakar dan serat.

Konteksnya yang terus berubah, perjuangan politik dan ekonomi dan tantangan di lapangan menghadirkan banyak dilema. REDD+ menjanjikan untuk membawa sebuah pendekatan baru dan segar: pendanaan skala besar dan dukungan berbasis kinerja. Hal ini dimaksudkan untuk membuat REDD+ berbeda dan lebih berhasil daripada berbagai usaha konservasi sebelumnya. Namun masih belum ada pendanaan yang cukup untuk mengubah persamaan dasar dari biaya dan manfaat konversi hutan, dan 
dengan demikian menjadikan setiap orang sebagai pemenang. Dengan demikian, REDD+ harus mencapai banyak lokasi di desa, kota dan ibu kota. Secara khusus, REDD+ harus memenuhi aspirasi pembangunan. REDD+ perlu menetapkan dan memperkuat koalisi yang luas dan melayani berbagai kepentingan yang beragam untuk dapat memastikan dukungan politik yang kuat dan berlanjut. Pertanyaannya adalah: bagaimana REDD+ harus dimodifikasi untuk menghasilkan dukungan politik yang diperlukan tanpa kehilangan fokus dan menghancurkan gagasannya yang telah membuatnya menarik dari awalnya?

REDD + tidak hanya menghadirkan tantangan tetapi juga pilihan, sebagaimana ditunjukkan di seluruh buku. Ketidakpastian tidak boleh mengarah pada tiadanya tindakan. Terlepas dari apa yang terjadi pada REDD+ sebagai sebuah mekanisme global dalam proses UNFCCC, tiga set tindakan berikut harus mendapat prioritas: i) membangun dukungan politik yang luas untuk REDD+, misalnya dengan membangun koalisi dan memfokuskan pada REDD+ sebagai sasaran; ii) meletakkan fondasi yang akhirnya mengarah kepada keberhasilan REDD+, misalnya melalui investasi di bidang sistem informasi yang lebih kuat; dan iii) menerap reformasi kebijakan 'tanpa penyesalan' yang dapat mengurangi deforestasi dan degradasi hutan terlepas dari sasaran-sasaran iklim, misalnya penghapusan subsidi yang merugikan masyarakat dan mahal dan memperkuat hak kepemilikan lahan dan tata kelola. 


\section{Daftar penulis}

John Herbert Ainembabazi

Mahasiswa PhD, UMB School of Economics and Business, Norwegian

University of Life Sciences, Norway - john.ainembabazi@umb.no

Arild Angelsen

Profesor, UMB School of Economics and Business, Norwegian University of Life Sciences, Norway; Peneliti Senior Tamu, CIFOR, Indonesia arild.angelsen@umb.no

Kamalakumar Anitha

Peneliti Pascadoktoral, CIFOR, Indonesia - a.kamalakumari@cgiar.org

\section{André Aquino}

Spesialis Lingkungan, World Bank, Washington, DC adeaquino@worldbank.org

Samuel Assembe-Mvondo

Staf Peneliti, CIFOR, Cameroon - s.assembe@cgiar.org 


\section{Stibniati Atmadja}

Staf Peneliti, CIFOR, Indonesia - s.atmadja@cgiar.org

Andrea Babon

Calon Peneliti, CIFOR, Australia - a.babon@cgiar.org

\section{Laila Borge}

Mahasiswa MSc, Department of Media and Communication, University of Oslo, Norway - laila.borge@gmail.com

\section{Maria Brockhaus}

Ilmuwan, CIFOR, Indonesia-m.brockhaus@cgiar.org

\section{Neil D. Burgess}

Profesor, Centre for Macroecology, Evolution and Climate, Biology Department, University of Copenhagen, Denmark;

Scientist, World Wildlife Fund, USA - nburgess@wwf.org.uk

\section{Bryan R. Bushley}

Peneliti, University of Hawai'i and East-West Center, USA bushley@hawaii.edu

\section{Jan Börner}

Staf Peneliti, CIFOR, Brazil - j.borner@cgiar.org

\section{Marina Cromberg}

Mahasiswa MSc, Center of Human Science and Education, Santa Catarina State University, Brazil - mcromberg@gmail.com

\section{Tim Cronin}

Manajer, Sustainable Forests and Palm Oil, World Wildlife Fund-Australia;

Consultant, CIFOR - timpcronin@hotmail.com

\section{Finn Danielsen}

Ekologiwan Senior, Nordisk Fond for MiljøogUdvikling, Denmark fd@nordeco.dk

\section{Ahmad Dermawan}

Peneliti, CIFOR, Indonesia - a.dermawan@cgiar.org

\section{Monica Di Gregorio}

Dosen, School of Earth and Environment, University of Leeds, United Kingdom - M.DiGregorio@leeds.ac.uk 


\section{Rut Dini}

Mahasiswa S1, Fakultas Pertanian, Universitas Palangkaraya, Indonesia rutdini@gmail.com

\section{Therese Dokken}

Mahasiswa PhD, UMB School of Economics and Business, Norwegian

University of Life Sciences, Norway - therese.dokken@umb.no

Amy E. Duchelle

Staf Peneliti, CIFOR, Brazil - a.duchelle@cgiar.org

\section{Andini Desita Ekaputri}

Petugas Penelitian, CIFOR, Indonesia - a.desita@cgiar.org

\section{Martin Enghoff}

Sosiologiwan Pedesaan, Nordisk Fond for MiljøogUdvikling, Denmark me@nordeco.dk

\section{Manuel Estrada}

Konsultan independen Perubahan Iklim, Meksico mporruacop9@gmail.com

\section{Caleb Gallemore}

Mahasiswa PhD, Department of Geography, Ohio State University, USA gallemore.1@osu.edu

\section{Maria Fernanda Gebara}

Mahasiswa PhD, Getulio Vargas Foundation and Federal Rural University of

Rio de Janeiro, Brazil - mfgebara@gmail.com

\section{Kristell Hergoualc'h}

Ilmuwan, CIFOR, Indonesia - k.hergoualch@cgiar.org

\section{Martin Herold}

Profesor, Center of Geo-Information, Department of Environmental

Science, Wageningen University, the Netherlands - martin.herold@wur.nl

\section{Rocio Hiraldo}

Peneliti, ENDA Energy Environment and Development, Senegal r.hiraldo@alumni.ids.ac.uk

\section{Thu-Ba Huynh}

Mahasiswa PhD, University of Melbourne, Australia ttbhuynh@pgrad.unimelb.edu.au 


\section{Pamela Jagger}

Asisten Profesor, University of North Carolina at Chapel Hill, USA;

Senior Associate, CIFOR, Indonesia - pjagger@unc.edu

\section{Francis X. Johnson}

Staf Peneliti Senior, Energy and Climate Stockholm Environment Institute francis.johnson@sei-international.org

Shijo Joseph

Peneliti Pascadoktoral, CIFOR, Indonesia - s.joseph@cgiar.org

\section{Dil Bahadur Khatri}

Forestry and Ecosystem Services Specialist, ForestAction, Nepal dil@forestaction.org

\section{Kaisa Korhonen-Kurki}

Ilmuwan, CIFOR, Indonesia - k.korhonen-kurki@cgiar.org

\section{Mrigesh Kshatriya}

Staf Peneliti, CIFOR, Indonesia - m.kshatriya@cgiar.org

Demetrius Kweka

Konsultan, CIFOR, Tanzania - demetrius.kweka@gmail.com

\section{Anne M. Larson}

Peneliti Senior Tamu, CIFOR, Peru - a.larson@cgiar.org

\section{Kathleen Lawlor}

Asisten Peneliti, University of North Carolina at Chapel Hill, USA klawlor@email.unc.edu

\section{Liwei Lin}

Mahasiswa PhD, North Carolina State University, USA livia1020@gmail.com

\section{Lasse Loft}

Ilmuwan, Biodiversity and Climate Research Centre, Frankfurt am Main, Germany-lasse.loft@senckenberg.de

\section{Cecilia Luttrell}

Peneliti SeniorTamu, CIFOR, Indonesia - c.luttrell@cgiar.org

Daniel McIntyre

Calon Peneliti, CIFOR, Australia - D.McIntyre@cgiarad.org 


\section{Desmond McNeill}

Profesor, Centre for Development and the Environment (SUM), University of Oslo, Norway - desmond.mcneill@sum.uio.no

\section{Moira Moeliono}

Peneliti Senior Tamu, CIFOR, Indonesia-m.moeliono@cgiar.org

\section{Efrian Muharrom}

Petugas Penelitian, CIFOR, Indonesia - e.muharrom@cgiar.org

\section{Krystof Obidzinski}

Ilmuwan, CIFOR, Indonesia - k.obidzinski@cgiar.org

\section{Pablo Pacheco}

Ilmuwan Senior, CIFOR, Indonesia - p.pacheco@cgiar.org

\section{Charlie Parker}

Deputy Director, Forests and Climate, World Wildlife Fund, Washington, DC, USA - charlie.parker@wwfus.org

Subhrendu K. Pattanayak

ProfesorTamu, Duke University, USA - subhrendu.pattanyak@duke.edu

Pham Thu Thuy

Staf Peneliti, CIFOR, Vietnam - t.pham@cgiar.org

\section{Louis Putzel}

Ilmuwan, CIFOR, Indonesia - 1.putzel@cgiar.org

\section{Salla Rantala}

Staf Peneliti, Sustainability Science Program, Harvard Kennedy School, USA - Salla_Rantala@hks.harvard.edu

\section{Ida Aju Pradnja Resosudarmo}

Ilmuwan, CIFOR, Indonesia - d.resosudarmo@cgiar.org

\section{Erika Romijn}

Konsultan, CIFOR, Indonesia and the Netherlands erika.romijn@gmail.com

\section{Emilia Runeberg}

Mahasiswa MSc, Environmental Change and Policy, University of Helsinki, Finland - emilia.runeberg@helsinki.fi 


\section{George Schoneveld}

Mahasiswa PhD, IS Land Academy, Utrecht University, the Netherlands g.c.schoneveld@uu.nl

\section{Frances Seymour}

Direktur Jenderal, CIFOR, Indonesia - f.seymour@cgiar.org

Erin O. Sills

Profesor Tamu, North Carolina State University, USA - sills@ncsu.edu

\section{Denis Jean Sonwa}

Ilmuwan, CIFOR, Cameroon - d.sonwa@cgiar.org

\section{Charlotte Streck}

President, Climate Focus, Washington DC, USA - c.streck@climatefocus.com

William D. Sunderlin

Ilmuwan Utama, CIFOR, Indonesia - w.sunderlin@cgiar.org

\section{Thomas Tanner}

Staf Peneliti, Institute of Development Studies, UK - t.tanner@ids.ac.uk

\section{Louis V. Verchot}

Ilmuwan Utama, CIFOR, Indonesia - l.verchot@cgiar.org

\section{Sheila Wertz-Kanounnikoff}

Peneliti Senior Tamu, CIFOR, Mozambique - s.wertz-kanounnikoff@cgiar.org

\section{Arief Wijaya}

Peneliti Pascadoktoral, CIFOR, Indonesia - a.wijaya@cgiar.org

\section{Sven Wunder}

Ilmuwan Utama, CIFOR, Brazil - s.wunder@cgiar.org 



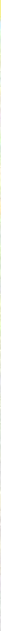

\section{Pendahuluan}

Arild Angelsen, Maria Brockhaus, William D. Sunderlin dan

Louis V. Verchot

\subsection{Menelusuri REDD+}

Sebagai sebuah gagasan, REDD+ adalah sebuah cerita keberhasilan. REDD+ telah membangkitkan semangat positif tentang kemungkinan untuk melangkah maju dalam mitigasi perubahan iklim secara cepat dan murah. REDD+ juga cukup umum untuk memayungi sejumlah besar pelaku dalam menumbuhkan pohon mereka sendiri. REDD + telah melalui proses konseptualisasi, rancangan dan implementasi yang intensif - meskipun masih jauh dari tujuan mendasarnya untuk mewujudkan pengurangan emisi berskala besar. Tidak ada ide lain untuk menyelamatkan hutan tropis dunia yang telah menimbulkan semangat dan komitmen pendanaan seperti yang dialami oleh REDD+.

Namun demikian, bagi para ilmuwan dan profesional yang berpengalaman di bidang kehutanan tropis, tidak mengejutkan bahwa REDD+ ternyata jauh lebih sulit untuk dilaksanakan daripada yang diperkirakan sebelumnya. Deforestasi dan degradasi hutan memiliki sejarah panjang dan banyak pihak yang berkepentingan dengan hutan sangat besar taruhannya pada kelanjutannya. Ranah kebijakan di banyak negara merupakan ajang 
pertempuran antara kepentingan 'bisnis seperti biasa' dan kepentingan akan perubahan transformatif. Namun ini juga merupakan pertanda baik: mereka yang diuntungkan dari bisnis seperti biasa memperhitungkan REDD+ secara serius untuk menanggapinya. Dengan demikian ada indikasi bahwa, jika dilaksanakan, REDD+ dapat memberikan dampak.

REDD+ bermaksud untuk mengatasi masalah tindakan kolektif yang mendasar: untuk mewujudkan sebuah sistem yang memberikan insentif ekonomis bagi pengguna hutan yang mencerminkan nilai karbon yang terserap dan tersimpan di dalam pohon. Membangun sistem seperti ini merupakan sebuah proyek rekayasa yang ambisius secara politis, ekonomis maupun sosial. Menetapkan mekanisme pembayaran untuk jasa lingkungan (PES) merupakan upaya untuk menciptakan keterkaitan antara 'kesediaan untuk membayar' masyarakat global dan pengguna hutan individual di desa-desa yang terpencil. Upaya ini merupakan tantangan yang dihadapi pemerintah dan para pemrakarsa proyek, yang mencoba untuk menjadikan pohon hidup lebih berharga daripada dalam kondisi mati.

REDD+ terus berkembang tanpa adanya kesepakatan internasional baru tentang perubahan iklim. Dalam perjalanan menuju COP15 di Kopenhagen tahun 2009, sebuah kesepakatan baru yang kuat diharapkan akan memberikan sejumlah besar pembiayaan untuk REDD+ berbasiskan kinerja. Saat ini, pendanaan internasional untuk REDD+ terutama bersumber dari anggaran bantuan pembangunan, yang memunculkan dinamika yang berbeda dan telah memperluas cakupan REDD+ serta menambahkan berbagai tujuan.

Perubahan konteks ini, pertempuran politis dan ekonomi serta tantangan di lapangan memunculkan sejumlah dilema. REDD+ membawa janji untuk menghadirkan pendekatan yang baru dan segar: pendanaan berskala besar dan dukungan berbasiskan kinerja. Ini seharusnya membuat REDD+ berbeda dan lebih berhasil dibandingkan berbagai upaya konservasi sebelumnya. Namun masalahnya, secara sederhana, adalah: kita tidak memiliki pendanaan yang cukup untuk mengubah isu mendasar dalam konversi hutan, yaitu biaya dan manfaat untuk melakukannya, dan karena itu menjadikan semua orang pemenang. Permintaan global yang lebih tinggi atas lahan untuk makanan, serat, bahan bakar dan jasa lingkungan telah memperbesar tantangan ini. Oleh karena itu, REDD+ harus memenuhi berbagai bidang di desa, kota dan ibukota. REDD+ harus menetapkan dan memperkuat koalisi yang luas dan mencakup beragam kepentingan untuk memastikan dukungan politis yang kuat dan berkelanjutan. Bagaimana REDD+ sebaiknya dimodifikasi untuk mendapatkan dukungan, tanpa kehilangan fokus dan melenceng dari gagasan semula yang membuatnya begitu menarik? 


\subsection{Tujuan buku ini}

\subsubsection{Tiga generasi penelitian REDD+}

Sebagaimana implementasi REDD+ memiliki tiga fase (kesiapan, reformasi kebijakan dan tindakan berbasiskan hasil), penelitian REDD+ juga mengalami kemajuan melalui tiga generasi:

Generasi pertama: merancang REDD+ dan belajar dari berbagai pengalaman yang terkait di masa lalu. Penelitian REDD + generasi pertama terkait dengan rancangan REDD+ di semua tingkat: pembentukan kelembagaan, bagaimana mengatasi sejumlah tantangan khusus seperti kebocoran, kepenambahan (additionality) dan kelanggengan (permanence) serta sejumlah kebijakan khusus yang bisa menjadi bagian dari upaya-upaya REDD+. Pertanyaan kunci yang dicoba untuk dijawab oleh berbagai upaya ini adalah: Seperti apakah seharusnya REDD+ agar dapat menjadi efektif, efisien dan berkesetaraan?

Generasi kedua: ekonomi politik dan implementasi REDD+. Penelitian generasi kedua menganalisis proses-proses perumusan kebijakan dan keputusan untuk implementasi awal, baik bagi reformasi kebijakan nasional maupun proyek-proyek lokal dan subnasional. Pertanyaan kunci yang ingin dijawab adalah: Bagaimana pengambilan keputusan mengenai REDD+ dan implementasinya, dan mengapa? Pertanyaan tambahan yang penting adalah: Apa yang merintangi atau mendorong keputusan tentang dan implementasi kebijakan dan proyek REDD+ yang efektif, efisien dan berkesetaraan?

Generasi ketiga: mengukur dampak REDD+. Penelitian generasi ketiga berupaya untuk mengukur dan menganalisis dampak REDD+, khususnya bagi karbon hutan dan mata pencaharian setempat. Dua pertanyaan dasar yang akan dijawab dalam fase ini adalah: Apakah REDD+ berlangsung baik? Bagaimana agar REDD+ dapat berfungsi lebih baik? Pertanyaan tambahan yang penting adalah: Bagaimana mengukur keluaran REDD+?

Terdapat pengurutan alami antara generasi yang berbeda tersebut, mengingat masing-masing mengikuti implementasi REDD+ aktual. Dua edisi buku REDD+ yang diterbitkan oleh CIFOR merupakan keluaran dari penelitian generasi pertama: "Melangkah Maju Bersama REDD: Isu, pilihan dan implikasi" (2008) dan "Mewujudkan REDD+: Strategi nasional dan pilihan kebijakan" (2009). Edisi ini, "Menganalisis REDD+: Sejumlah tantangan dan pilihan", membawa kita pada penelitian generasi kedua dan terutama memuat analisis atas rancangan dan implementasi awal REDD+ yang aktual. Beberapa penelitian generasi pertama tetap dipertahankan; misalnya, beberapa bab dalam Bagian 3 ('Mengukur REDD+') juga menjawab pertanyaan tentang 
bagaimana merancang dan melaksanakan REDD+. Sebenarnya, langkah maju ke penelitian generasi kedua dan ketiga tidak berarti bahwa berbagai pertanyaan generasi pertama telah sepenuhnya terjawab: masih banyak pelajaran yang dapat dijadikan pembelajaran, dan kita perlu kembali ke pertanyaan tentang rancangan optimal REDD+ sejalan dengan pengalaman yang diperoleh dari menjawab pertanyaan-pertanyaan generasi kedua dan ketiga.

Satu ciri khas penelitian generasi kedua adalah jarak yang penting. Menyadari adanya masalah yang cukup besar untuk melangkah dari ide REDD+ ke pelaksanaannya, diperlukan objektivitas yang lebih besar dalam penelitian. Ada ruang gerak yang lebih leluasa bagi para peneliti sendiri untuk menjadi lebih kritis secara konstruktif apabila mereka lebih menekankan diri sebagai pengevaluasi dan mengurangi peran mereka sebagai pemrakarsa REDD+.

Pertanyaan penelitian generasi ketiga masih belum terjawab - setidaknya pada skala yang diperlukan untuk memberikan penilaian yang adil. Sejumlah bab dalam buku ini yang membahas implementasi lokal proyek-proyek REDD+ mencakup temuan-temuan yang memberikan alasan untuk optimis (misalnya, proyek-proyek REDD+ yang berada di wilayah-wilayah yang deforestasinya tinggi, Bab 12) maupun pesimis (misalnya, REDD+ banyak dianggap sebagai pilihan 'menang-kalah', Bab 11). Namun demikian, pernyataan-pernyataan yang muncul dalam perdebatan publik REDD+ tentang apakah REDD+ berfungsi atau tidak, umumnya didasarkan pada optimisme dan harapan atau pesimisme dan kekhawatiran. Pada dasarnya kita memerlukan tiga sampai lima tahun untuk implementasi reformasi kebijakan dan proyek-proyek REDD+ sebelum kita dapat menjawab pertanyaan: Apakah REDD+ berjalan baik?

\subsubsection{Ikhtisar buku ini}

Buku ini bertujuan untuk menelusuri berbagai pengalaman REDD+ sampai saat ini di tingkat nasional, dan juga di tingkat subnasional dan lokal yang merupakan lokasi pelaksanaan proyek. Dalam proses ini, kami mengajukan beberapa pertanyaan: Apa yang terjadi di ranah kebijakan nasional dan di lapangan? Perubahan apa saja yang telah terjadi pada REDD+? Bagaimana bentuknya sekarang? Mengarah ke manakah REDD+?

Judul tambahan buku ini-“Sejumlah tantangandan pilihan"-mengindikasikan tujuan kami untuk memberikan pemahaman yang lebih baik tentang tantangan yang hadir dalam merancang dan melaksanakan kebijakan dan proyek-proyek REDD+ yang efektif, efisien dan berkesetaraan. Kami ingin menyajikan bukti komparatif tentang bentuk-bentuk tantangan dalam konteks yang berbeda dan pada skala yang berbeda, juga hambatan utama untuk mencapai keberhasilan. Kami tidak ingin berhenti di sini, kami juga bermaksud memberikan saran tentang cara untuk memecahkan kebuntuan ini. Pilihan-pilihan apa sajakah yang akan membantu kita untuk mengatasi sejumlah hambatan yang telah diidentifikasi? 
Sementara topik dalam buku ini sangat luas, kami tidak berpretensi untuk menyajikan liputan yang menyeluruh tentang semua isu REDD+. Misalnya, isu-isu seputar rancangan REDD+ global hanya mendapat perhatian terbatas, walaupun beberapa bab menyinggung hal ini, misalnya terkait keuangan (Bab 7), tingkat acuan (Bab 14 dan 16), faktor-faktor emisi (Bab 15) dan kerangka pengaman (Bab 17). Demikian pula fokus kebanyakan analisis kebijakan tingkat nasional adalah pada politik REDD+, bukan pada kesesuaian kebijakan, implementasi serta dampaknya.

Sebagian besar materi empiris yang disajikan dalam buku ini didasarkan pada upaya penelitian utama yang dilakukan oleh CIFOR dan mitra yang disebut Studi Komparatif Global REDD+ (Global Comparative Study on REDD+/GCS). Penjelasan proyek ini terdapat dalam Lampiran. Studi ini telah menghasilkan banyak informasi dari 5-12 negara (bergantung pada fokus studi), yang memungkinkan analisis komparatif dan kesimpulan yang berbobot. Buku ini merupakan sintesis pertama dari hasil-hasil penelitian dari proyek ini.

Pertanyaan yang berulang muncul dalam proyek ini adalah: Apakah REDD+ itu? (lihat juga Kotak 1 dalam Angelsen 2009). Definisi REDD+ muncul dalam dua dimensi yang penting. Pertama, dimensi vertikal yang mengacu pada gagasan keseluruhan, yang tujuannya adalah menurunkan emisi dan meningkatkan penyerapan karbon, serangkaian kebijakan atau tindakan untuk mencapai tujuan ini, dan keluaran yang dihasilkan dari proses ini atau dari proses yang melibatkan semua elemen yang telah disebutkan sebelumnya. Ke dua, REDD+ memiliki dimensi horizontal yang terkait dengan cakupannya. Definisi yang luas cakupannya, berdasarkan hasil COP13 dari UNFCCC di Bali pada tahun 2007, berpegang bahwa REDD+ terdiri dari berbagai tindakan lokal, subnasional, nasional dan global yang tujuan utamanya adalah untuk mengurangi emisi dari deforestasi dan degradasi hutan dan meningkatkan simpanan karbon hutan di sejumlah negara berkembang. Definisi yang lebih terbatas, digunakan oleh GCS untuk memilih proyek-proyek REDD+ yang ditargetkan untuk penelitian, merinci bahwa tujuan utamanya terkait dengan emisi dan penyerapan gas rumah kaca (GRK), dan bahwa tindakan yang dilakukan seharusnya mencakup pembayaran berbasiskan hasil atau bersyarat.

Para penulis buku ini bermaksud untuk menggunakan buku ini sebagai analisis kritis tentang perkembangan REDD+ sejauh ini di sejumlah arena yang berbeda. Sementara kami berusaha untuk menjaga jarak, kami juga adalah peneliti yang peduli. Kami prihatin dengan perubahan iklim, dengan perusakan hutan dan dengan kemiskinan serta kesejahteraan masyarakat yang tinggal di dalam wilayah hutan di negara-negara berkembang. Kami menyepakati tujuan keseluruhan REDD+ untuk mengurangi emisi GRK, namun kami bisa jadi memiliki pandangan yang beragam tentang apa sajakah tantangan utamanya dan bagaimana mewujudkan tujuan-tujuan REDD+. 
Sementara buku ini memuat beberapa pesan yang umum, para pembaca yang jeli juga akan mendapatkan pandangan dan penekanan yang beragam di antara bab-babnya. Memang demikianlah seharusnya.

Sejumlah bab ditulis dengan gaya yang dapat dipahami, namun didasarkan pada penelitian yang seksama. Buku ini menyediakan informasi dan penilaian kritis atas berbagai pemangku kepentingan: para praktisi dan pelaksana proyek REDD+, para pembuat kebijakan di tingkat nasional dan subnasional, juru runding internasional, donor, peneliti, jurnalis dan berbagai pihak lain yang tertarik dengan sejumlah tantangan dan pilihan yang muncul dalam upaya melaksanakan gagasan umum REDD+.

\subsection{Susunan buku ini}

Buku ini dibagi ke dalam 3 bagian. Bagian 1: Memahami REDD+ meletakkan kerangka kerja untuk analisis dan menyediakan konteks untuk sebagian besar bagian lain buku ini. Bagian 2: Melaksanakan REDD+ menyediakan sejumlah studi berbasiskan topik tentang wacana REDD+ di tingkat nasional dan lokal dan mempertimbangkan ekonomi politis dalam merancang dan melaksanakan REDD+. Bagian 3: Mengukur REDD+ mengulas tantangan dalam mengukur hasil dalam REDD+ yang berbasiskan hasil.

\subsubsection{Bagian 1: Memahami REDD+}

Banyak bab dalam buku ini menganalisis politik REDD+ dengan menggunakan kerangka kerja 4I yang disajikan dalam Bab 2. Kerangka kerja 4I ini terdiri dari: kelembagaan/institutions (aturan, alur kebergantungan atau keterlekatan), kepentingan/interest (berbagai potensi keuntungan material), gagasan/ideas (wacana kebijakan, idelogi dan kepercayaan yang mendasari) dan informasi/information (data dan pengetahuan, cara mendapatkan dan memanfaatkannya) (Gambar 1.1). Bab ini menggunakan konsep-konsep tersebut untuk membahas bagaimana perubahan transformatif dapat terjadi dan berargumen bahwa hal ini dapat terjadi karena tiga alasan: REDD+ berpotensi untuk mengubah insentif ekonomi yang mendasar; REDD+ membawa informasi dan wacana baru; dan REDD+ menghadirkan sejumlah pelaku baru ke dalam arena dan dapat mendorong terbentuknya koalisi baru ke arah perubahan.

Dengan menggunakan kerangka kerja ini, Bab 3 menelusuri perubahan utama dalam REDD+ sejak memasuki arena global tahun 2005. Pertama, bab ini mencatat bahwa sebagai sebuah gagasan REDD+ telah sangat berhasil dan mengaitkan keberhasilan ini dengan gagasan itu sendiri dan komitmennya untuk melayani pelaku dan kepentingan yang berbeda serta menjembatani agenda lingkungan hidup dan pembangunan. Para penulis berpendapat bahwa REDD+ telah mengalami banyak perubahan dalam hal utama: i) bergerak dari 

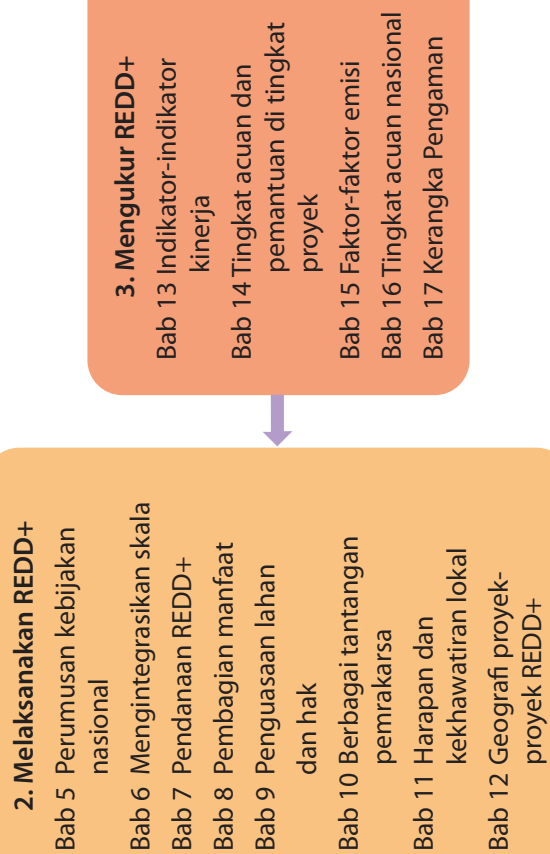

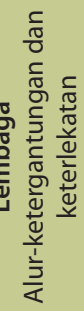

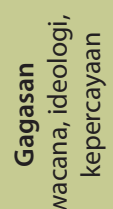

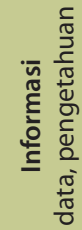

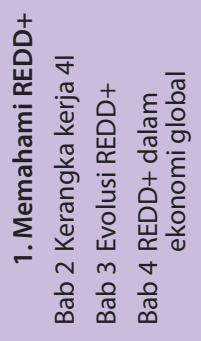

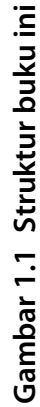


tujuan tunggal (karbon) ke multitujuan; ii) mengembangkan kebijakan dan praktik-praktik yang melangkah lebih dari sekedar pembayaran berbasiskan hasil; iii) memberikan lebih banyak perhatian dan sumberdaya di tingkat subnasional dan proyek (dibandingkan di tingkat nasional); dan iv) didanai terutama oleh anggaran bantuan internasional dan upaya-upaya negara yang melaksanakan REDD+, dibandingkan dari pasar karbon. Saat ini, ciri utama REDD+ yang membuatnya berbeda dari upaya-upaya di masa lalu di sektor kehutanan - seperti pendanaan berskala besar berbasiskan hasil - berisiko untuk terkalahkan oleh berbagai tujuan dan pendekatan lain, sehingga akan membahayakan keefektifannya.

Ekonomi global mewakili variabel kontekstual yang penting dalam pengembangan REDD+. Bab 4 menelaah empat tren utama yang telah meningkatkan tekanan bagi hutan dan menyebabkan implementasi REDD+ lebih menantang: i) meningkatnya permintaan global untuk pangan, energi dan material; ii) berkembangnya integrasi pasar untuk pangan, serat dan energi; iii) tingginya kenaikan harga yang terus menerus di pasar pangan dan pertanian global; dan iv) pengambilalihan lahan berskala besar. Bab ini mengamati bagaimana semua faktor mempengaruhi pemanfaatan lahan di Amazon Brazil, Afrika Timur dan Indonesia. Keempat tren ini meningkatkan biaya peluang (opportunity cost) REDD+, yang karena, suramnya prospek pendanaan jangka panjang menimbulkan pertanyaan tentang kelayakan skema serupa PES untuk membuat konservasi cukup menarik bagi para pemilik hutan. Bab ini menyimpulkan bahwa kebijakan yang relevan harus menangani masalah sisi pasokan dan permintaan di negara produsen dan konsumen.

\subsubsection{Bagian 2: Melaksanakan REDD+}

Bagian terbesar buku menguraikan pengalaman dalam melaksanakan REDD+, termasuk sejumlah cara yang memengaruhi banyak REDD+ di arena kebijakan dan apa yang terjadi ketika gagasan REDD+ menghadapi kenyataan di lapangan. Lima bab pertama dalam bagian ini berfokus pada isu-isu tingkat nasional dan integrasi antara tingkat nasional dan subnasional, sementara tiga bab selanjutnya khusus membahas tentang proyek-proyek REDD+ subnasional. Sebagian besar bab menggunakan penelitian yang dilakukan oleh GCS.

Ranah kebijakan nasional di negara-negara REDD+ adalah - atau bisa jadi merupakan ranah utama yang akan menentukan masa depan REDD+. Bab 5 menggunakan analisis ekonomi politis dan analisis media di tujuh negara REDD+ (Bolivia, Brasil, Kamerun, Indonesia, Peru, Nepal dan Vietnam). Dengan menggunakan kerangka kerja 4I, para penulis bermaksud untuk memahami proses-proses dan wacana kebijakan nasional dan untuk 
mengidentifikasi hambatan utama untuk menghasilkan kebijakan REDD+ yang efektif. Bab ini berargumen bahwa empat faktor yang penting untuk mengatasi rintangan ekonomi politis adalah: i) otonomi relatif suatu negara dari kepentingan utama yang memicu deforestasi dan degradasi hutan; ii) kepemilikan nasional atas proses-proses kebijakan REDD+; iii) proses-proses REDD + yang melibatkan semua pihak yang terkait; dan iv) keberadaan koalisi yang menyuarakan perubahan transformatif. Berbagai hasil dari profil negara dan analisis wacana (discourse analysis) berbasiskan media mengindikasikan bahwa semua negara bersusah payah untuk memenuhi sejumlah kriteria tersebut. Selain itu, merumuskan dan melaksanakan strategi nasional REDD+ yang efektif merupakan tantangan, khususnya bagi negara-negara yang para pelaku internasionalnya adalah pemicu tunggal proses-proses kebijakan REDD+.

Mencapai pengurangan emisi dari kehutanan merupakan teka-teki bertingkat yang melekat pada dirinya. Masyarakat lokal menghadapi tuntutan global untuk memitigasi perubahan iklim, yang harus dipenuhi melalui institusi dan struktur nasional dan subnasional yang sudah ada maupun yang mulai bermunculan. Bab 6 berargumen bahwa apabila keterkaitan antara tingkat nasional dan subnasional diabaikan, maka REDD+ dapat mengalami kegagalan. Tantangannya adalah untuk menyelaraskan institusi dan insentif yang dibutuhkan untuk melaksanakan REDD+ dan memungkinkan negosiasi oleh para pelaku dengan kepentingan yang berbeda di berbagai tingkat. Bab ini menyajikan bukti hasil penelitian yang belum diterbitkan dari tiga negara (Brasil, Indonesia dan Vietnam) tentang berbagai tantangan dan peluang dalam tata kelola multitingkat dalam dua bidang: pengukuran, pelaporan dan verifikasi (measurement, reporting and verification/MRV) serta kebocoran emisi.

Elemen kunci dalam tantangan tata kelola multitingkat adalah kebutuhan untuk memastikan aliran pendanaan kepada para pelaku yang melaksanakan tindakan-tindakan REDD+, yang dibahas dalam dua bab berikutnya. Bab 7 mengamati isu pembiayaan REDD+ secara keseluruhan dan mencakup pembahasan dan estimasi berbagai biaya REDD+. Bab ini mencatat bahwa pembiayaan REDD+ menghadapi sebuah titik balik: sementara pembiayaan berjangka pendek tersedia, penyaluran pembayarannya berjalan lambat dan peluang investasinya langka. Pada saat yang sama, tidak ada strategi jangka panjang yang tepat dan dapat diprediksi tentang cara memenuhi kebutuhan pembiayaan REDD+. Tanpa adanya kesepakatan iklim internasional dan lambatnya perkembangan pendanaan REDD+ dari pasar karbon, sekitar dua pertiga dari pembiayaan internasional sejauh ini bersumber dari anggaran bantuan pembangunan. Pembiayaan sektor publik dari berbagai donor internasional dan pemerintah negara pelaksana REDD+ tampaknya mendominasi pembiayaan REDD+ dalam jangka pendek sampai menengah. 
Distribusi dana REDD+ untuk berbagai pelaku yang berbeda adalah salah satu aspek rancangan yang terpenting. Bab 8 menyajikan ikhtisar tentang perdebatan utama terkait rancangan dan implementasi mekanisme pembagian manfaat REDD+. Pembagian manfaat ini penting untuk menciptakan insentif positif bagi para pelaku untuk mengurangi emisi karbon, namun juga memiliki implikasi dalam penyalurannya. Karena itu mekanismenya harus adil agar dapat meningkatkan legitimasi dan dukungan yang lebih besar bagi REDD+. Sementara perdebatan tentang keefektifan versus kesetaraan merupakan wacana utama, ada beberapa nuansa di kedua kriteria ini. Bab ini juga menyajikan sejumlah contoh dari mekanisme pembagian manfaat yang direncanakan atau baru-baru ini ditetapkan di negara-negara REDD+ dan di proyek-proyek subnasional.

Pembagian manfaat berkaitan dengan hak karbon, yang di sebagian besar negara terkait sangat erat dengan hak penguasaan dan kepemilikan lahan. Bab 9 mencatat bahwa REDD+ dapat digunakan sebagai insentif untuk mendukung reformasi penguasaan lahan hutan, dan pada saat yang sama, reformasi penguasaan lahan merupakan sebuah strategi untuk mendukung REDD+. Reformasi penguasaan lahan dapat menjadi bagian penting dalam perubahan transformatif yang tampaknya diawali oleh REDD+ sekaligus menjadi penentu keberhasilan REDD+. Bab ini menyajikan kajian umum tentang isu-isu penguasaan lahan yang penting di enam negara REDD+ (Brasil, Kamerun, Indonesia, Peru, Tanzania dan Vietnam) dan menggambarkan kemajuan yang dicapai sejauh ini dalam menghadapi isu-isu tersebut. Sementara REDD+ telah menarik perhatian kepada penguasaan lahan, upaya-upaya di tingkat nasional untuk menindaklanjuti isu-isu lahan dan hak atas karbon masih terbatas. Pada saat yang sama, intervensi tingkat proyek untuk menindaklanjuti penguasaan lahan menghadapi hambatan penting jika tidak mendapat dukungan nasional.

Fokus tiga bab selanjutnya adalah proyek-proyek REDD+ tingkat lokal dan subnasional. Bab 10 membahas proyek-proyek dari sudut pandang para pemrakarsanya dan Bab 11 dari perspektif para penduduk desa, sementara Bab 12 menggunakan pandangan sekilas dan berfokus pada lokasi suatu proyek.

Pada awalnya, gagasan utama REDD+ adalah untuk menetapkan sistem pembayaran atas jasa lingkungan (PES) dari tingkat internasional kepada para pengguna hutan perorangan. Bab 10 menunjukkan, berdasarkan survei terhadap para pemrakarsa proyek, sebagian besar proyek-proyek REDD+ yang dianalisis menggabungkan pendekatan PES dengan suatu pendekatan proyek konservasi dan pembangunan terpadu (Integrated Conservation and Development Project/ICDP) yang sudah banyak berlaku, dengan menekankan penegakan peraturan kehutanan dan menyediakan sumber mata pencaharian alternatif. Pendekatan turunan ini bermanfaat, sebagian karena ketidakpastian 
mengenai masa depan REDD+, khususnya dalam hal aliran pembiayaan. Dalam kondisi ketidakpastian kebijakan dan pasar, struktur turunan ini memungkinkan pemrakarsa untuk melangkah awal dalam pembentukan proyek dan pendekatan ICDP dapat menjadi pilihan yang dicadangkan apabila PES tidak terwujud. Namun demikian, pendekatan turunan ini juga bisa jadi melemahkan satu keutamaan terkuat REDD+, dengan potensi konsekuensi negatif dalam hal keefektifan dan kesetaraan.

Gagasan PES menjanjikan menu menang-menang (win-win): pengguna hutan lokal akan memilih konservasi hutan apabila kompensasi yang mereka terima lebih besar daripada penerimaan potensial dari pemanfaatan hutan alternatifnya. Dalam pelaksanaannya, model turunan dalam REDD+ bisa jadi tidak sesederhana yang dibayangkan dan hasilnya menjadi tidak pasti. Bab 11 menyajikan survei rumah tangga terperinci di daerah-daerah proyek REDD+ tentang persepsi, harapan dan kekhawatiran lokal. Hasilnya jelas: masyarakat setempat berpandangan bahwa REDD+ terutama menyangkut perlindungan hutan, sementara harapan dan kekhawatiran utama mereka terkait dengan pendapatan dan mata pencaharian. Studi ini menyoroti pentingnya mempertimbangkan kekhawatiran lokal tentang REDD+ ketika mengembangkan strategi komunikasi dan intervensi yang direncanakan atau dilaksanakan oleh para pemrakarsa proyek.

Keberhasilan REDD+ tidak hanya bersandar pada dukungan lokal, namun juga pada intervensi yang ditujukan ke daerah-dearah yang tingkat deforestasi dan degradasi hutannya tinggi, yaitu, daerah yang dapat menghasilkan pengurangan emisi yang sebenarnya. Bab 12 mengamati lokasi sejumlah proyek dengan menggunakan berbagai sumber informasi, termasuk suatu pusat data global tentang proyek-proyek REDD+ yang dikembangkan oleh GCS. Di tingkat internasional, analisis yang dilakukan menemukan bahwa negara-negara yang keanekaragaman hayatinya tinggi dan yang memiliki lebih banyak kawasan yang dilindungi akan lebih mungkin memiliki proyek-proyek REDD+. Hal ini cocok dengan pernyataan para pemrakarsa bahwa mereka menganggap keanekaragaman hayati sebagai manfaat tambahan ketika memilih lokasi proyek. Sebuah studi mendalam di dua negara utama REDD+ - Brasil dan Indonesia - menunjukkan bahwa sejumlah proyek lebih mungkin dikembangkan di daerah yang laju deforestasi dan kepadatan karbon hutannya tinggi: kesimpulan yang menggembirakan dari perspektif REDD+ dan konsisten dengan fokus pada kepenambahan.

\subsubsection{Bagian 3: Mengukur REDD+}

Ciri utama REDD+ adalah keberhasilannya diukur berbasiskan kinerja atau hasil, yang tentu saja menuntut hasilnya harus dapat diukur. Keluaran akhirnya diukur dalam bentuk emisi yang menurun (atau penyerapan karbon yang meningkat), yang pada dasarnya membutuhkan tiga jenis informasi: 
i) informasi kegiatan (misalnya, daerah yang dikonversi dari hutan primer menjadi lahan budidaya); ii) faktor-faktor emisi (misalnya, pengurangan karbon per hektar ketika terjadi konversi hutan primer menjadi lahan budidaya); dan iii) tingkat acuan emisi, atau acuan bisnis seperti biasa (yaitu emisi tanpa REDD+). Ketiga jenis informasi ini terkait satu sama lain sebagai berikut:

\section{Pengurangan emisi $=\left(\right.$ kegiatan ${ }^{*}$ faktor-faktor emisi $)-$ emisi acuan}

Tiga bab di Bagian 3 membahas semua elemen ini. Bab 14 mengulas pengukuran atas berbagai kegiatan dan acuan di tingkat lokal, Bab 15 membahas faktor-faktor emisi, sementara Bab 16 membahas tingkat acuan di tingkat nasional.

Namun demikian, kurangnya data yang handal tentang emisi dan penyerapan di banyak negara menandakan bahwa, sebuah sistem berbasiskan kinerja dengan menggunakan perubahan karbon hutan sebagai suatu kriteria akan sulit diimplementasikan selama beberapa waktu. Karena itu Bab 13 berargumen bahwa, dalam jangka menengah, kebanyakan pembayaran adalah untuk kesiapan dan reformasi kebijakan, dan bukan untuk pengurangan emisi yang dapat dibuktikan. Dengan demikian, indikator kinerja yang baik sangat penting untuk ketiga fase REDD+, khususnya untuk fase yang berfokus pada kinerja kebijakan. Sayangnya, fokus kepada indikator kinerja semacam itu sangat terbatas dalam perdebatan REDD+. Bab ini berargumen bahwa pelajaran berharga tentang berbagai indikator tata kelola dapat dipelajari dari sektor bantuan pembangunan: hindari mencari indikator yang sempurna dan gunakan penilaian para ahli secara ekstensif.

Bab 14 mencatat bahwa selama beberapa tahun terakhir, standar dan metode yang berbobot telah dikembangkan untuk memperkirakan emisi dari deforestasi di tingkat proyek. Bab ini menyajikan dan membahas salah satu dari standar ini secara khusus, yaitu standar karbon terverifikasi (verified carbon standard/VCS). Bab ini juga mengamati pemakaian standar pemantauan dan acuan di antara para pemrakarsa proyek dalam GCS, mengulas bahwa sebagian besar dari proyek-proyek ini mungkin menghadapi masalah dalam memenuhi beberapa persyaratan standar VCS. Hal ini kebanyakan terkait dengan metode yang digunakan untuk memperkirakan deforestasi di masa mendatang, kurangnya data untuk menyusuri laju deforestasi historis dan penggunaan petak sampel cadangan karbon nonpermanen. Proyek-proyek generasi berikutnya seharusnya belajar dari pengalaman ini dan mengidentifikasi atau mengembangkan metode yang sesuai sebelum berinvestasi dalam pengembangan tingkat sistem acuan dan MRV mereka.

Faktor-faktor emisi dibutuhkan untuk mengonversi estimasi luas deforestasi dan degradasi hutan menjadi perubahan emisi dan cadangan karbon, baik 
pada proyek-proyek REDD+ lokal dan di tingkat nasional. Bab 15 mencatat bahwa kontribusi faktor-faktor emisi mencapai $60 \%$ dari ketidakpastian dalam inventarisasi GRK. Faktor-faktor emisi yang spesifik untuk suatu negara atau kawasan tertentu sangat kurang di sebagian besar negara tropis, sehingga mustahil untuk memperkirakan emisi secara akurat dan teliti dari sumber-sumber dan penyerapan karbon dalam program-program REDD+ dan berbagai kegiatan uji cobanya. Karena itu diperlukan investasi besar dan usaha-usaha terkoordinasi sebagai bagian dari kesiapan pembiayaan untuk mengatasi keterbatasan data dan ketidaklayakan kelembagaan. Berbagai hambatan dapat diatasi jika ada investasi yang ditargetkan dan terkoordinasi, serta dikembangkan kemitraan yang produktif antara layanan teknis di negara tuan rumah $\mathrm{REDD+}$, lembaga-lembaga antarpemerintahan dan sejumlah lembaga penelitian terkemuka di berbagai negara maju.

Isu terkait pengembangan tingkat acuan nasional dan tingkat acuan emisi dibahas dalam Bab 16. Berbagai tantangannya terkait dengan kurangnya kualitas data di banyak negara, ketidakpastian yang nyata tentang laju deforestasi dan degradasi hutan di masa depan, serta insentif yang potensial untuk menggunakan perkiraan yang berat sebelah. Bab ini menyarankan untuk menghadapi tantangan ini melalui sebuah pendekatan bertahap dalam mengembangkan tingkat acuan hutan dan tingkat acuan emisi, yang mencerminkan situasi dan kapasitas di negara yang berbeda. Cara ini dapat memfasilitasi partisipasi yang luas, inisiasi awal dan motivasi untuk memperbaiki dari waktu ke waktu. Ketidakpastian prediksi tentang apa saja juga mendapat perhatian dan berbagai pilihan untuk menghadapinya juga dibahas.

Akhirnya, REDD + tidak hanya dinilai dari pengurangan emisi yang dicapai, namun juga sampai sejauh mana REDD+ sesuai dengan kerangka pengaman yang diterima secara luas. Bab 17 mengamati bahwa pemakaian standar sosial dan lingkungan hidup awal di tingkat nasional maupun proyek menunjukkan bahwa para perumus kebijakan REDD+, pemrakarsa proyek dan investor menghargai kerangka pengaman REDD+. Bersumber dari penelitian GCS, bab ini membahas kerangka pengaman, wacana dan sejumlah tindakan di tingkat internasional, nasional dan proyek. Dialog kerangka pengaman REDD+ perlu bergeser dari diskusi tingkat tinggi internasional menuju tindakan di lapangan. Untuk mencapai 'Persetujuan bebas sukarela setelah menerima informasi sebelumnya (FPIC)' tetap merupakan tantangan karena berbagai alasan. "FPIC merupakan sebuah mimpi yang tidak mungkin terwujud," demikian dicatat oleh salah satu pemrakarsa proyek.

Bab 18 merangkum buku ini dan melihat ke depan. Perubahan dalam REDD+ selama lima tahun sebelumnya telah membawa pergeseran penting dalam hal kemungkinan ukuran dan komposisi pembiayaan, kecepatan dan biaya implementasi dan keragaman kepentingan antarpelaku dan tingkat-tingkat 
yang berbeda. Berbagai tantangan yang disebabkan oleh perubahan ini adalah 'bantuan-isasi' REDD+, masalah-masalah berurutan yang dihadapi oleh para pemrakarsa proyek dan kurangnya penghargaan yang jelas untuk upaya-upaya REDD+ oleh negara-negara berhutan dan masyarakatnya. Untuk mengatasi ketidakpastian mengenai ukuran dan bentuk pembiayaan REDD+, bab ini mengajukan reformasi kebijakan 'tanpa penyesalan' dan investasi. Di dalamnya termasuk membangun dukungan politik yang luas untuk REDD+ dengan membingkai ulang tujuannya daripada programnya, membangun landasan untuk implementasi REDD+ yang berhasil, dan melaksanakan reformasi kebijakan yang harusnya tetap dijalankan tanpa ada tujuan-tujuan mitigasi iklim. Reformasi semacam ini mencakup memperjelas penguasaan lahan, meningkatkan tata kelola dan menghilangkan subsidi merugikan yang mendorong deforestasi dan degradasi hutan. 


\section{Nor}

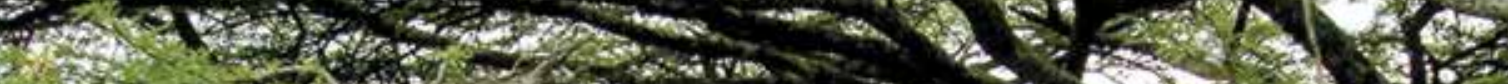

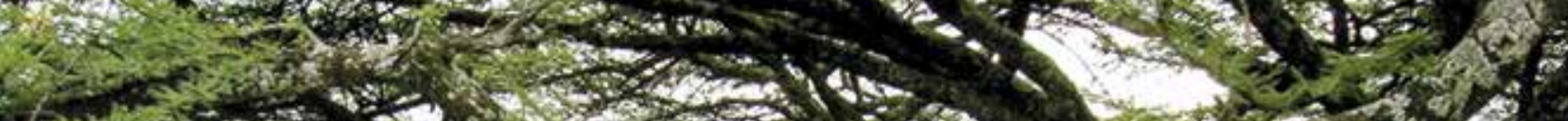

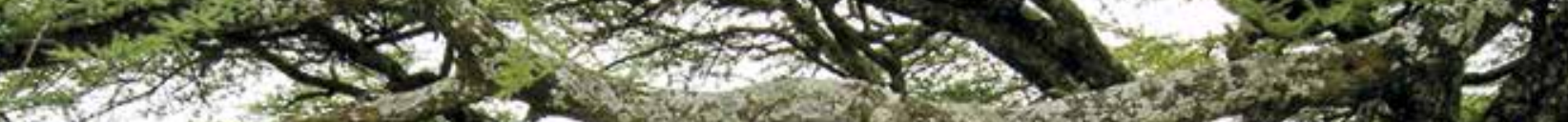

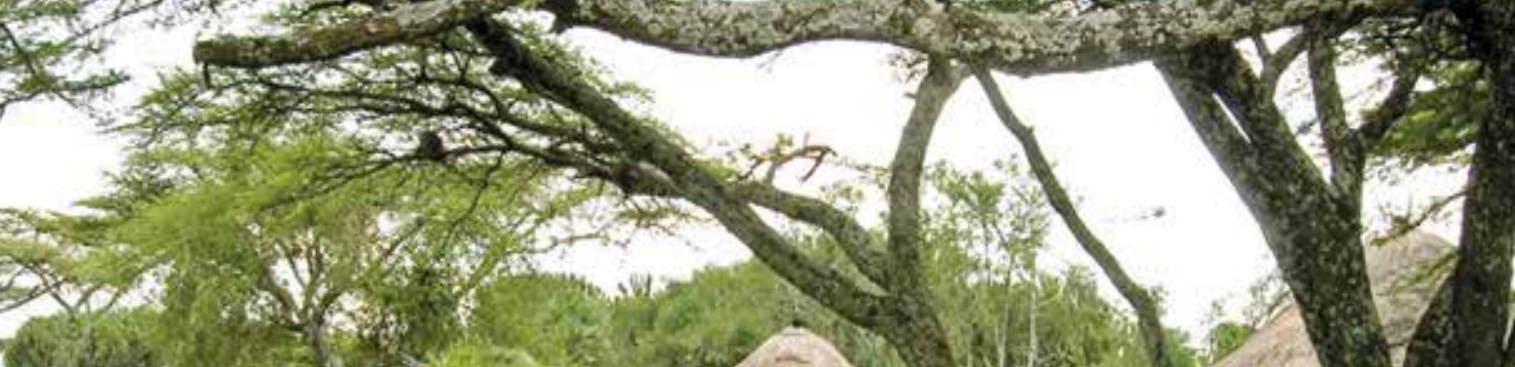
3.8.

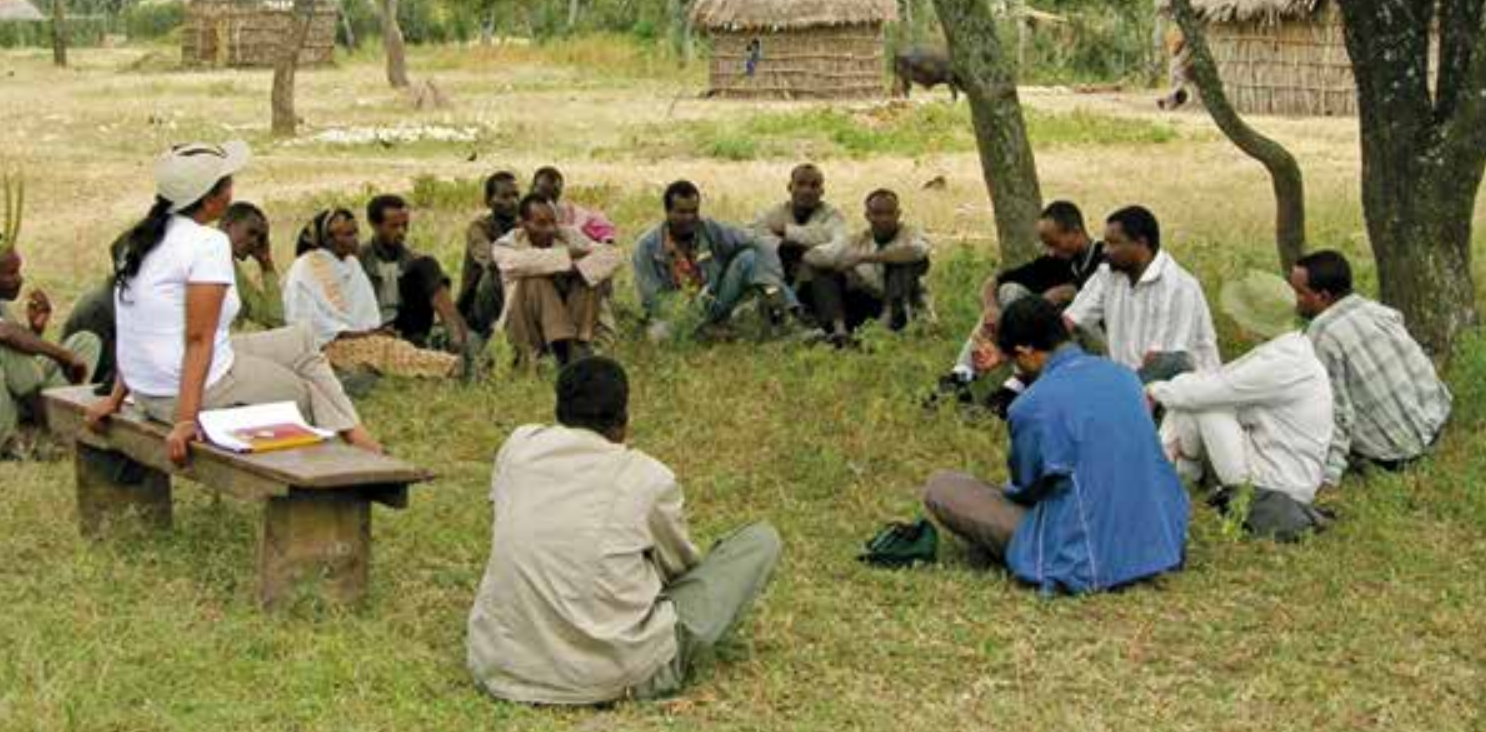





\section{Bab}

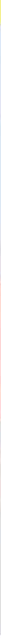

\section{Melihat REDD+ melalui 4I \\ Sebuah kerangka kerja ekonomi politis}

Maria Brockhaus dan Arild Angelsen

- Menganalisis REDD+ dengan 4I - kelembagaan (institutions) dan alur kebergantungan serta 'keterlekatan', para pelaku dan kepentingan, gagasan serta informasi (interests, ideas and information) mereka - dapat membantu untuk memahami sejumlah kendala dan faktor-faktor yang mendukung ke arah perubahan.

- Perubahan transformatif di luar sektor kehutanan dibutuhkan untuk mewujudkan potensi penuh mitigasi REDD+, namun berbagai kepentingan ekonomi dan struktur kekuasaan menghadirkan berbagai tantangan untuk perubahan yang diinginkan.

- REDD+ juga dapat berperan - dan sampai tingkat tertentu telah berperan - sebagai pengubah permainan. Sejumlah insentif ekonomi baru, informasi baru, berkembangnya kekhawatiran publik tentang perubahan iklim, koalisi sejumlah pelaku baru dan kebijakan baru, semuanya berpotensi untuk memunculkan perubahan transformatif.

\subsection{Pengantar}

Bab ini mengenalkan sebuah kerangka kerja konseptual untuk menganalisis politik REDD+, sebuah kerangka kerja yang kemudian diterapkan dalam bab-bab selanjutnya. Melalui lensa ekonomi politis, kami berfokus pada 
lembaga, kepentingan dan gagasan (Hall 1997). ${ }^{1}$ Selain itu kami juga mengenalkan informasi sebagai elemen keempat yang mendukung perubahan kebijakan yang efektif (Angelsen 2010a). Kami menyebutnya sebagai 'kerangka kerja 4I': Kelembagaan/ institutions (aturan, alur kebergantungan atau keterlekatan), Kepentingan/interest (berbagai potensi keuntungan material), Gagasan/ideas (wacana kebijakan, ideologi dan kepercayaan yang mendasari) dan Informasi/information (data dan pengetahuan, pembentukan dan pemanfaatannya). Tanpa melupakan saling kebergantungan antara semua elemen dalam 4I, kami akan mengupas setiap elemen ini pada bagian-bagian selanjutnya. Kerangka kerja $4 \mathrm{I}$ ini memungkinkan kita untuk mengidentifikasi dan mendeskripsikan berbagai kendala, tantangan dan peluang di antara berbagai topik relevan dalam arena kebijakan REDD+.

Kerangka kerja ini juga menunjukkan beberapa cara yang mungkin untuk memecahkan kebuntuan politis dan mengatasi masalah 'ayam dan telur' yang terkait dengan perubahan transformatif. Gagasan REDD+ dan insentif ekonomi yang menyertainya seharusnya memunculkan pergeseran dari bisnis seperti biasa. Namun agar REDD+ dapat mencapai tujuan utamanya yaitu mengurangi emisi secara keseluruhan, maka dibutuhkan perubahan langsung dalam ranah kebijakan REDD+ di semua tingkat. Walaupun dilema ini bukan unik untuk REDD+, kebutuhan akan perubahan ini hanya mendapat perhatian terbatas dalam berbagai perdebatan dan kepustakaan. Kami berusaha mengatasi hal ini dengan menanyakan, apa saja yang memotivasi atau menghambat para pelaku di ranah kebijakan REDD+ untuk melaksanakan proses-proses perubahan transformatif?

Bagian 2.2 mendefinisikan pemahaman kami tentang perubahan transformatif dan mengapa ini diperlukan untuk mewujudkan potensi REDD+. Pada bagian 2.3 kami membahas berbagai kendala atau pendorong perubahan bagi REDD+, dengan mengenalkan kerangka kerja 4I dan menggambarkan masing-masing elemennya. Bagian 2.4 membahas beberapa cara yang mungkin untuk mengatasi masalah 'ayam dan telur' dalam REDD+ dan perubahan transformatif. Kami mengakhiri bab ini dengan sebuah analisis tentang apakah REDD+ diluncurkan sebagai sebuah langkah baru ke depan atau REDD+ sendiri yang dibentuk dan diperlemah oleh bisnis seperti biasa yang mengelilinginya.

1 Sejumlah kerangka kerja telah digunakan dalam berbagai disiplin ilmiah untuk menganalisis secara lebih baik isitlah-istilah yang kami sebut sebagai kelembagaan, kepentingan, gagasan dan informasi. Walaupun terdapat variasi istilah dan perspektif, sebenarnya tidak terlalu berbeda, misalnya ketika para sosiolog menggunakan konsep budaya, pengetahuan, kekuasaan, dan sejarah. Hall (1997) dan Grindle (1999) menerapkan istilah-istilah ini dalam disiplin ekonomi politik. Dalam kaitannya dengan perubahan strategi ke arah tindakan selama periode jelas dan tidak jelas, Swidler (1986) memberikan masukan yang mendalam tentang peran kausal budaya dalam memengaruhi tindakan dan berlaku sebagai alat bantu yang dapat digunakan oleh para pelaku untuk mewujudkan strategi baru. 


\subsection{Perubahan transformatif dan ranah kebijakan REDD+}

Dalam konteks REDD+, kami mendefinisikan perubahan transformatif sebagai sebuah pergeseran wacana ${ }^{2}$, sikap, hubungan kekuasaan, dan kebijakan serta aksi protesyang sengaja dilakukanyang mendorong perumusan kebijakan dan implementasi yang menjauh dari pendekatan kebijakan bisnis seperti biasa, yang secara langsung dan tidak langsung mendukung deforestasi dan degradasi hutan (lihat juga Bab 5). Pergeseran seperti ini tertanam di dalam dan diterjemahkan sebagai berbagai perubahan dalam lembaga ${ }^{3}$ formal dan informal utama yang relevan dalam implementasi REDD+, termasuk perubahan koordinasi dan transparansi di berbagai tingkat tata kelola.

Berbagai contoh perubahan transformatif dalam konteks hasil kebijakan REDD+ adalah: i) perubahan kerangka kerja ekonomi, peraturan dan tata kelola, termasuk devolusi hak para pengguna lokal; ii) penghapusan insentif yang merugikan, seperti subsidi dan konsesi yang mendukung kepentingan ekonomi tertentu dan merangsang deforestasi dan degradasi hutan; dan iii) reformasi kebijakan dan peraturan industri kehutanan yang secara efektif mengurangi pemanenan hasil hutan yang tidak lestari (Kanninen dkk. 2007). Perubahan semacam ini khususnya dibutuhkan ketika perusakan hutan dikaitkan dengan pemburuan dan penciptaan rente (Ross 2001) - yaitu, situasi ketika kelompok-kelompok yang berkuasa memperoleh akses ke lahan hutan, kayu atau sumberdaya lain yang bernilai tinggi, dan menggunakan kekuasaan mereka untuk meraup dan/atau memperbesar rente hutan. Karena itu, perubahan transformatif di tingkat nasional mencerminkan perubahan kerangka kerja kebijakan dari yang merangsang eksploitasi hutan menjadi yang mendorong konservasi hutan dan pemanfaatan yang berkelanjutan.

Ranah REDD+, yang seharusnya menjadi tempat terjadinya perubahan ini, dapat dibagi menjadi beberapa bagian: negosiasi iklim, bantuan pembangunan, kebijakan nasional dan realitas lokal (Bab 3). Di sini kami

2 Dryzek mendefinisikan wacana sebagai "sebuah cara bersama untuk memahami dunia". Wacana melekat dalam bahasa, dan memungkinkan mereka yang terlibat di dalamnya untuk menafsirkan bagian dari informasi dan meletakkannya pada suatu studi atau catatan yang bersangkutan. Masing-masing wacana bersandar pada "asumsi, penilaian, dan ketidaksetujuan" (Dryzek 1997:8). Khususnya dalam bidang lingkungan hidup, wacana dapat bersifat sangat berbeda dan bertentangan.

3 Menurut Douglass North, kami memahami lembaga sebagai "rangkaian aturan permainan dalam suatu masyarakat yang memengaruhi insentif dalam hubungan timbal balik manusia, baik politis, sosial atau ekonomi ... Tujuan peraturan adalah untuk menetapkan cara suatu permainan dimainkan. Namun tujuan para pelaku atau tim dalam rangkaian peraturan itu adalah untuk memenangkan permainan" (North 1990:3-5). Secara konsep aturan-aturan ini dibedakan dari pemain dalam definisi oleh North ini. 
mengamati ranah REDD+ teragregasi, namun dengan acuan khusus pada ranah kebijakan nasional. ${ }^{4}$

Ranah REDD+ memiliki banyak kesamaan dengan ranah kebijakan (iklim) lainnya. Namun, ada ciri-ciri pembeda pada ranah kebijakan REDD+ yang perlu dijadikan faktor dalam analisis ketika menerapkan 4I dan membuat tugas perubahan transformatif lebih menantang:

Lembaga bertingkat dan proses berlapis yang terikat dengannya, yang bersifat kronologis dan hirarkis, yang merupakan ciri-ciri utama REDD+ (Bab 6). Banyaknya lapisan di dalam berbagai lembaga menciptakan tantangan sekaligus peluang, khususnya ketika desentralisasi atau resentralisasi juga sedang berlangsung. Misalnya, kerangka kerja dan kesepakatan global dapat menyediakan pendanaan untuk implementasi lokal, hasil lokal dapat menyediakan penerimaan untuk penjualan kredit karbon bagi pemerintah nasional, dan hukum nasional dapat memungkinkan atau meniadakan tindakan lokal. Koordinasi bertingkat yang lebih baik dibutuhkan untuk keberhasilan REDD+ dan ini tengah berlangsung di banyak bidang REDD+ yang relevan, termasuk pembagian manfaat (Bab 8) dan pemantauan, pelaporan dan verifikasi (MRV) serta kebocoran (Bab 6).

Berbagai pelaku dengan otoritas dan kepentingan berbeda, yang mengikuti wacana, kepercayaan dan model mental yang beragam dan kontradiktif, juga mencirikan ranah REDD+. Ini terlihat dari dinamika kekuasaan dalam negosiasi UNFCCC. Dalam ranah kebijakan nasional, kepentingan pembangunan dan penciptaan keuntungan dalam bentuk industri kehutanan, bisnis pertanian, dan bahkan produsen pertanian berskala kecil mengalami pertentangan dengan para pendukung konservasi, yang ingin melihat hutan dalam keadaan utuh. Di tingkat lokal, prospek untuk pekerjaan di perkebunan besar atau keterlibatan dalam skema petani plasma kelapa sawit sering menutupi manfaat yang dinikmati dari hasil-hasil hutan dan jasa nonkayu yang bervariasi, yang tersedia di hutan. Selain itu, pelaku yang memperoleh manfaat, baik dari eksploitasi hutan maupun dari hutan yang tidak terganggu, tidak serta merta adalah mereka yang tinggal di dalam atau berdekatan dengan suatu hutan.

Struktur tata kelola berada dalam suatu spektrum antara pasar dan negara, dan dapat berbentuk hirarki, koalisi atau jaringan kerja. Negara-negara REDD+ memiliki cakupan rezim politis yang berkisar dari negara demokratis sampai otoriter, dengan implikasi negosiasi timbal balik yang harus diperhitungkan

4 Namun demikian, penting diperhatikan bahwa proses dan keputusan dalam satu bidang kebijakan nasional tertentu dapat juga memengaruhi yang lainnya dan dapat membentuk efek tumpahan (spillover), khususnya pada tingkat regional (misalnya, Amazon, DAS Kongo dan di wilayah Asia Tenggara). 
dalam implementasi REDD+ yang berkesetaraan, efektif dan efisien (Bab 5). Perdebatan lain dalam REDD+ adalah mengenai tingkat keterkaitan pasar dalam REED+ (Böhm dan Dhabi 2011; Michaelowa 2011; Newell 2011), dan pembobotan relatif pada tingkat tata kelola yang berbeda.

Kebergantungan pada konteks mencerminkan bahwa perubahan kebijakan yang lebih luas dari sektor kehutanan dibutuhkan untuk mencapai tujuan-tujuan REDD+. Hal ini juga mengacu pada rintangan bagi perubahan transformatif, mengingat sektor kehutanan di negara-negara REDD+ yang penting selama beberapa dekade ini terkait dengan kekuasaan politis dan ekonomi. Misalnya, dengan mengalokasikan sumberdaya hutan (rente) kepada sejumlah individu dan kelompok dalam rangka membangun dukungan dan koalisi politik.

Sementara sejumlah ciri tersebut tidak hanya unik untuk REDD+, besarnya tantangan ini membuat REDD+ berbeda dari kesepakatan lainnya. Misalnya, proyek-proyek mitigasi di bawah Mekanisme Pembangunan Bersih, seperti pembangkit listrik tenaga air atau tempat penimbunan sampah atau bahkan aforestasi/reforestasi (A/R) relatif sederhana dibandingkan dengan REDD+. Dalam ranah yang sangat kompleks ini, perubahan transformatif harus terjadi kalau deforestasi dan degradasi hutan ingin diatasi secara efektif.

\subsection{Kerangka Kerja $4 \mathrm{I}$}

\subsubsection{Sekilas tentang elemen-elemen utamanya}

Gambar 2.1 menyajikan diagram skematis ranah kebijakan REDD+. Ranah ini dicirikan oleh sejumlah besar pelaku internasional, nasional dan subnasional, termasuk kementerian, lembaga dan beberapa badan pemerintah, LSM pembangunan dan lingkungan hidup; organisasi hak masyarakat adat; kelompok bisnis; partai-partai politik; organisasi penelitian dan kelompok pemikir; dan berbagai ajang partisipatif seperti forum meja bundar dan masyarakat madani. Berbagai kelompok seperti 'masyarakat yang bergantung pada hutan' mungkin diwakili oleh kelompok-kelompok di atas atau memiliki perwakilan yang menyatakan dirinya bertindak atas nama mereka dalam ranah kebijakan.

Semua pelaku tersebut beroperasi dalam 'aturan permainan' atau lembaga yang ada. Norma, peraturan dan pengaturan kelembagaan formal dan informal lainnya dibentuk oleh sejarah yang telah mendorong dan sering merangsang deforestasi dan degradasi hutan - dan yang sebagian dibentuk untuk memenuhi kepentingan beberapa pelaku dalam ranah kebijakan REDD+. Akibatnya, para pelaku yang memiliki kepentingan seperti ini mungkin tidak terlalu bersemangat untuk berubah, meskipun situasi saat ini kemungkinan tidak mendorong ke hasil yang optimal secara sosial dan bagi 


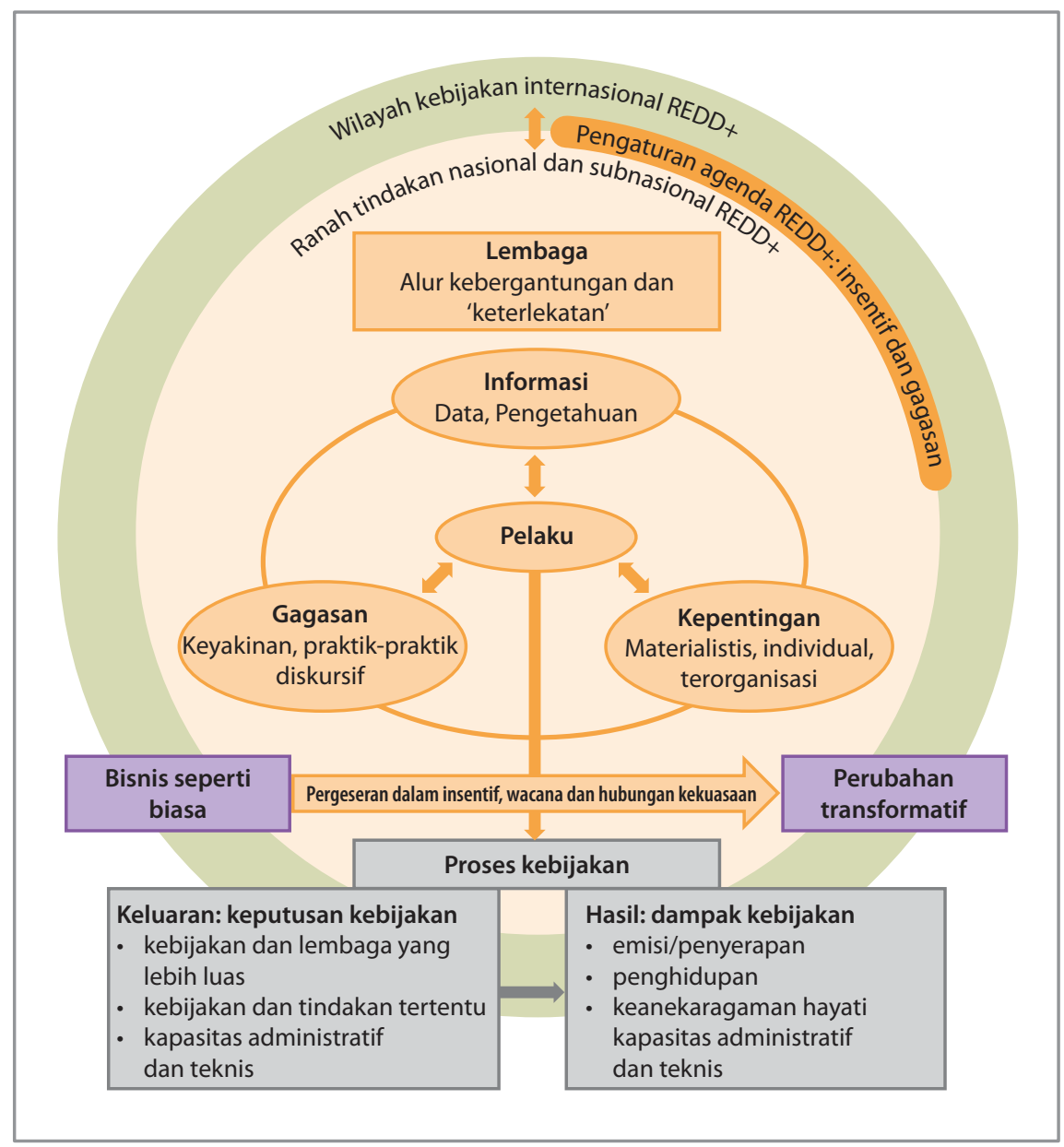

\section{Gambar 2.1 REDD+ dan 4I}

lingkungan hidup. Namun kepentingan dan kekuasaan untuk mewujudkan perubahan dapat juga berubah sejalan dengan waktu sebagai respon atas perubahan lembaga, peluang ekonomi dan insentif yang baru, serta gagasan dan informasi baru.

Para pelaku dalam ranah kebijakan REDD+ mengikuti suatu gagasan khusus (termasuk ideologi) dan sering didasari keyakinan kuat tentang bagaimana mengelola hutan negara. Mereka menggunakan berbagai wacana untuk melegitimasi pemenuhan kepentingan mereka. Memang benar, ranah REDD+ dipenuhi oleh berbagai ideologi yang berbeda tentang apa hakikat REDD+ itu dan apa tindakan prioritasnya (berikut strateginya) (lihat kotak 3.2). 
Di semua tingkat dan skala dalam ranah kebijakan REDD+, berbagai wacana terungkap melalui informasi yang beragam dan sering bertentangan. Pengetahuan digunakan dan disalahgunakan dalam negosiasi politis untuk membenarkan bagaimana dan mengapa - atau mengapa tidak - menerapkan REDD+. Sejalan dengan dimensi politis ini adalah dimensi teknis, yang para pelakunya memiliki kapasitas berbeda dalam mengakses, memroses dan menyediakan informasi.

Secara keseluruhan, 4I membentuk berbagai pilihan dari apa yang seharusnya dan yang dapat menjadi kontribusi hutan dan lahan berhutan bagi kesejahteraan sosial (dan individual), dan kemungkinan bentuk dari sejumlah kontribusi ini.

Pada Gambar 2.1, skenario yang ideal adalah ketika gagasan REDD+ memasuki ranah, mendorong terjadinya revisi atas struktur insentif dan lembaga. Sampai sejauh mana gagasan baru ini dipakai dan mendorong perubahan kebijakan yang diinginkan dalam jangka pendek dan menengah bergantung pada: i) dinamika yang terjadi di dalam ranah keseluruhan; dan ii) sifat saling memengaruhi antara elemen dalam 4I yang memungkinkan pergeseran insentif, wacana dan hubungan kekuasaan dalam ranah kebijakan nasional dan subnasional. Skenarionya bergantung pada konteks kelembagaan dan hubungan kekuasaan yang ada di suatu negara, dan juga tahapan proses REDD+ yang terkait (Bab 5). Misalnya, perubahan politik di sekitar Moratorium Hutan Indonesia jelas menggambarkan kondisi saling memengaruhi, terkait faktor-faktor yang membatasi dan yang memungkinkan perubahan jangka panjang (Kotak 2.1).

Kami membahas bagaimana mencapai perubahan jangka panjang pada bagian 2.4. Namun pertama kami mengamati secara rinci bagaimana 4I menghambat atau memungkinkan negosiasi hasil dan keluaran kebijakan yang akhirnya akan mendorong ke perubahan transformatif dan pengurangan emisi hutan.

\subsubsection{Lembaga: alur kebergantungan dan 'keterlekatan'}

Untuk memahami perubahan historis, North (1990) mengamati peran utama sejumlah lembaga dan bagaimana mereka membentuk dan dibentuk oleh masyarakat dari waktu ke waktu. Dalam kerangka kerja North, suatu lembaga terkadang dikembangkan untuk menangkap peluang ekonomi bagi masyarakat luas, namun sejumlah kelompok juga bisa jadi memiliki kekuasaan untuk membentuk berbagai lembaga untuk memenuhi kepentingan tertentu mereka. Selain itu, lembaga dapat dilihat sebagai barang publik, dan karena itu dapat dipandang sebagai masalah tindakan kolektif yang harus diselesaikan untuk menyediakan lembaga yang efektif. 


\section{Kotak 2.1 Moratorium Hutan Indonesia: Politik suatu kemungkinan}

Frances Seymour

Berbagai kebijakan REDD+ tingkat nasional diprakarsai dan dibentuk oleh gabungan para pelaku kebijakan yang kompleks, baik domestik dan internasional, di dalam maupun di luar pemerintah. Bentuk moratorium atas ijin baru konsesi hutan selama dua tahun di Indonesia, dan proses yang mendorong kemunculannya, memberikan contoh yang jelas tentang 'politik suatu kemungkinan' ketika para konstituen untuk perubahan transformatif menghadapi kepentingan yang telah tertanam dalam bisnis seperti biasa.

Komitmen untuk mengeluarkan "penundaan dua tahun untuk semua konsesi baru bagi konversi hutan alam dan lahan gambut" merupakan salah satu elemen kunci dalam 'Surat Pernyataan Kehendak' (Lol) yang ditandatangani pada Mei 2010 antara pemerintah Indonesia dan Norwegia. Walaupun tanggal target awal yang ditetapkan adalah 1 Januari 2011, Instruksi Presiden (Inpres) yang menetapkan moratorium tersebut tidak diterbitkan sampai seminggu sebelum satu tahun perayaan Lol pada bulan Mei 2011. Keterlambatan ini, yang disertai dengan beredarnya rumor tentang berbagai versi yang dipertimbangkan, menunjukkan perjuangan yang berlarut-larut di antara sejumlah kepentingan yang berusaha untuk memengaruhi cakupannya. Termasuk dalam kepentingan ini adalah Satuan Tugas REDD+ (yang berlokasi di Kantor Kepresidenan) dan pendukungnya dalam masyarakat madani, Kementerian Kehutanan, dan perusahaan dengan model-model usaha yang bergantung pada keberlanjutan konversi hutan, termasuk agribisnis dan pertambangan. Karena Inpres ini tidak berlaku surut dan tidak berlaku pada ijin yang 'pada prinsipnya telah disetujui' oleh Kementerian Kehutanan, penundaan 5 bulan juga memberi peluang kepada pihak swasta untuk mendapatkan ijin baru. Di antara provinsi lainnya, hal ini terjadi di Kalimantan Tengah, yang terpilih menjadi provinsi uji coba REDD+ berdasarkan Lol tersebut.

Sebuah analisis spasial tentang Peta Moratorium Indikatif yang menyertai Inpres menghasilkan perkiraan bahwa 22,5 juta hektar hutan telah diberikan perlindungan sementara yang baru oleh instrumen kebijakan REDD+ ini. Luas ini jauh lebih kecil dibandingkan yang diharapkan oleh para konstituen REDD+, terutama karena penafsiran 'hutan alam' dalam Lol tersebut diartikan sebagai 'hutan primer' dalam Inpres, sehingga tidak memasukkan sekitar 46,7 juta hektar areal bekas tebangan dan hutan sekunder lain, yang masih kaya akan karbon dan keanekaragaman hayati. Selanjutnya, bahkan wilayah yang tercakup dalam Inpres tersebut tunduk pada perkecualian untuk kegiatan yang 'penting' bagi pembangunan nasional, termasuk untuk ketahanan pangan dan energi. Perkecualian semacam itu, ditambah dengan hutan sekunder yang masih ada dan 'lahan kosong' yang telah berijin yang dilaporkan dimiliki oleh perusahaan kelapa sawit dan lainnya, menunjukkan bahwa potensi moratorium sangat terbatas untuk membatasi konversi hutan dengan bisnis seperti biasa. 
Namun demikian, cakupan moratorium yang luas untuk hutan lahan gambut dapat menghasilkan pengurangan emisi yang penting jika pelaksanaannya benar-benar mengurangi laju perusakan, drainase dan konversi dari ekosistem yang kaya karbon ini. Selain itu, komitmen Inpres untuk meninjau dan merevisi Peta Moratorium Indikatif secara berkala dan transparan menunjukkan sebuah langkah maju yang penting dalam tata kelola hutan Indonesia. Proses ini memicu penerbitan data tutupan lahan oleh Kementerian Kehutanan tahun 2009, yang membuka sebuah jendela yang sebelumnya tertutup bagi pemeriksaan publik, sementara revisi berkala atas Peta Moratorium Indikatif menyediakan sebuah media baru untuk pelibatan masyarakat madani dalam perumusan kebijakan hutan.

Menurut Murdiyarso dkk. (2011).

Peraturan yang telah ditetapkan dan batasan hubungan kekuasaan membatasi pilihan ke arah perubahan kelembagaan melalui apa yang disebut alur kebergantungan (path-dependency) dan 'keterlekatan' (stickiness) (lihat Baumgartner dkk. 2011). Alur kebergantungan merupakan realitas bagi REDD+: apa yang telah dan sedang membentuk apa yang akan terjadi. Misalnya, tipe rezim yang berlaku saat ini, struktur tata kelola tersentralisasi atau terdesentralisasi, serta norma kolonial atau pascakolonial sering termasuk dalam pola-pola deforestasi yang melekat dengannya (lihat Kotak 2.2).

'Keterlekatan' dicirikan oleh resistensi untuk berubah yang sering terlihat dalam organisasi pemerintah yang bertanggung jawab atas pengelolaan sumberdaya alam. Kementerian kehutanan di negara kaya hutan bisa jadi takut kehilangan bagian dari pengaruh wewenang mereka, atau kementerian pertanian mengkhawatirkan REDD+ akan membatasi peluang untuk membuka lahan pertanian baru. Salah satu cara untuk mengatasi keterlekatan kelembagaan ini adalah dengan menciptakan lembaga baru dan memperkenalkan pelaku baru, yang juga ada negosiasi timbal baliknya tersendiri. Kekuasaan formal umumnya tetap berada pada organisasi yang 'paling melekat' - yaitu organisasi yang memiliki pengaruh cukup untuk menolak perubahan - sementara lembaga dan pelaku yang baru diabaikan atau tetap dipinggirkan.

\subsubsection{Kepentingan: Materi, individu dan terorganisasi}

'Kepentingan' merupakan sebuah kepentingan sejumlah pelaku dan kelompok pelaku atas materi dalam ranah kebijakan REDD+. Berbagai pelaku dan kelompok yang berbeda dalam ranah kebijakan REDD+ memiliki kepentingan dan potensi berbeda untuk mewujudkan keuntungan materi bersama REDD+, tanpa REDD+ dan melalui REDD+.

Berbagai kepentingan, misalnya yang terkait dengan manfaat ekonomi, memengaruhi pemosisian para pelaku dalam ranah REDD+ (Peskett dan 


\section{Kotak 2.2 Alur kebergantungan kelembagaan di Daerah Aliran Sungai (DAS) Kongo}

Samuel Assembe-Mvondo

Negara-negara Daerah Aliran Sungai (DAS) Kongo sedang menetapkan sejumlah strategi untuk implementasi mekanisme REDD+. Reformasi untuk mengadaptasi sistem penguasaan lahan sesuai agenda internasional tengah berlangsung, namun menghadapi sejumlah tantangan yang dicirikan oleh koeksistensi yang bertentangan antara hukum perundang-undangan yang menonjol dan hukum adat yang terpinggirkan.

Misalnya, selama periode administrasi Jerman, sejumlah besar areal lahan di wilayah suku Bakweri di Kamerun telah dialokasikan bagi perusahaanperusahaan Jerman dan individu untuk tujuan pengembangan coklat, pisang, karet dan kelapa sawit. Model ini diikuti oleh pemerintah kolonial Inggris yang membentuk Perusahaan Pembangunan Kamerun (Cameroon Development Corporation), yang merupakan industri pertanian pertama dan terbesar di Kamerun, di bawah kepemilikan negara. Setelah kemerdekaan, reformasi legislatif atas administrasi pascakolonial bermaksud untuk mengadaptasi hukum kolonial dengan status baru Negara merdeka. Namun hal ini menyebabkan dominasi hukum tertulis yang terus berlanjut atas hukumadat.Secara perlahan-lahan kondisi inimenghilangkan praktik-praktik adat untuk mengambil manfaat dari sistem hukum yang ditegakkan oleh otoritas kolonial Eropa. Karena itu, sistem penguasaan lahan pascakolonial menutupi sistem penguasaan lahan adat dan memasukkan lahan adat, yang dianggap kosong dan tidak berpenghuni, menjadi lahan Negara. Masyarakat lokal hampir sepenuhnya terusir dari lahan mereka. Kepemilikan adat atau hak penguasaan lahan diganti dengan hak pemanfaatan yang diberikan kepada petani dan masyarakat lokal dan kemungkinan kepada operator manapun yang memilih melakukan pendaftaran. Monopoli negara atas lahan dikuatkan dalam hukum lahan dan registrasi sistematis. Memang, adanya suatu hukum lahan yang baru melibatkan penghilangan atas konsep adat tentang pengelolaan ruang. Dalam konteks ini, satu-satunya hak pemanfaatan adat yang dikenali atau ditoleransi oleh hukum perundangundangan adalah Droit de hache/wood cutting or axe rights (penebangan kayu atau hak menebang). Istilah ini digunakan untuk menggambarkan hak yang timbul dari membuka atau menebang hutan dengan persetujuan dari penghuni sebelumnya. Hak-hak ini diturunkan dari dan didasarkan pada pemanfaatan yang berlanjut.

Republik Demokratik Kongo (RDK) merupakan sebuah ilustrasi yang tepat untuk situasi semacam ini. Memang, hukum penguasaan lahan lahan RDK yang dikeluarkan tahun 1973 dan dimodifikasi tahun 1980, menyatakan bahwa semua lahan dan sumberdaya alam merupakan milik Negara. Karena itu, Negara pada saat itu tidak mengenali peraturan apa pun yang terkait dengan akses dan kendali atas lahan dan sumberdaya alam yang berakar dari masyarakat lokal. Situasi pascakolonial yang dicirikan oleh kepemilikan eksklusif oleh Negara 
atas lahan dan sumberdaya hutan berkurang dengan adanya Konferensi Rio serta sejumlah tuntutan sosial dan demokratis oleh organisasi akar rumput di awal tahun 1990-an. Sejak saat itu, undang-undang hutan saat ini (2002) telah mengakui bahwa pemangku kepentingan lokal harus menikmati hak dasar untuk mengelola lahan dan sumberdaya alam (hutan masyarakat).

Namun demikian, tren lain baru dimulai melalui pemakaian Panduan tentang Partisipasi Masyarakat Lokal dan Masyarakat Adat oleh Komisi Hutan Afrika Tengah (Guidelines on the Participation of Local Communities and Indigenous People by Central Africa Forest Commission/COMIFAC). Panduan ini mewakili pemisahan dengan sistem hukum kolonial di masa lalu - sebuah inovasi sejalan dengan penyediaan instrumen ini melibatkan mekanisme-mekanisme yang bermunculan seperti REDD+, Penegakan Hukum, Tata Kelola dan Perdagangan bidang Kehutanan - Perjanjian Kemitraan Sukarela (Forest Law Enforcement, Governance and Trade - Voluntary Partnership Agreements - FLEGT/VPA), PES dan kepemilikan adat atas lahan dan sumberdaya hutan. Selain itu, beberapa negara di DAS Kongo baru-baru ini juga mengadopsi perundangundangan nasional tentang hak masyarakat adat (misalnya, Pygmies), berdasarkan Konvensi ILO No. 169 tentang Masyarakat Hukum Adat dan Deklarasi PBB tahun 2007 tentang Hak-Hak Masyarakat Adat (khususnya, Republik Kongo dan Republik Afrika Tengah).

Tren saat ini dalam evolusi hak masyarakat lokal dan masyarakat adat menyajikan perbaikan yang dipicu oleh agenda subregional (komitmen COMIFAC) maupun internasional (CBD, FLEGT, REDD dll), namun dibangun atas dan berhadapan dengan alur kebergantungan kolonial dan pascakolonial.

Brockhaus 2009). Para pelaku menegosiasikan kepentingan mereka dalam kebijakan dan proses REDD+ secara horizontal, vertikal, dan antartahapan dalam proses perumusan kebijakan. Negosiasi horizontal terjadi, misalnya, di antara kementerian kehutanan, pertanian, pertambangan, pertanian dan keuangan. Secara vertikal, negosiasi dapat terjadi, misalnya, di antara pelaksana proyek, pelaku dari masyarakat madani dan para perunding. Koalisi yang terbangun di antara pelaku yang berbeda memengaruhi kekuasaan politik untuk mewujudkan kepentingan. Kepentingan mana yang menang sering merupakan hasil dari kombinasi kekuasaan ekonomi dan politis. Namun pembentukan koalisi juga terhambat karena sejumlah kepentingannya sering bertentangan atau mengharuskan negosiasi timbal balik, bahkan di dalam kelompok-kelompok pelaku.

Kepentingan bisnis dapat diarahkan untuk mendukung atau menentang REDD+, bergantung pada kegiatan ekonomi industri atau bisnis yang terlibat, 
misalnya perwakilan industri bubur kayu dan kertas (yang melihat REDD+ sebagai suatu ancaman) versus investor karbon (yang melihat REDD+ sebagai sebuah peluang). Demikian juga, lembaga-lembaga pemerintah dan lingkup kepentingan dan pengaruhnya dapat bertentangan dengan REDD+, misalnya lembaga perlindungan lingkungan hidup versus kementerian pertanian. Masing-masing sisi membenarkan posisinya dengan mengaitkan kepentingan negara dalam hal kesejahteraan ekonomi dan sosial. Namun REDD+ terbentuk dalam negara yang pemerintah negara dan sistem birokrasinya sering terkait sangat erat dengan sektor bisnis, dan kurangnya otonomi kepentingan bisnis yang mendorong deforestasi dan degradasi akan membatasi pilihan negara untuk mengubah praktik-praktik saat ini. Hal ini berlaku khususnya ketika pencarian rente, penipuan, kolusi dan korupsi merupakan praktik di dalam sistem birokrasi yang melayani kepentingan individu daripada kepentingan masyarakat (Karsenty dan Ongolo 2012). Konflik atau jalan buntu dapat timbul apabila tidak ada koalisi ke arah perubahan atau apabila hanya sedikit partisipasi dari para pelaku utama yang merupakan bagian dari skenario bisnis seperti biasa saat ini dan yang berkontribusi secara langsung atau tidak langsung bagi deforestasi dan degradasi hutan, seperti negara dan para pelaku bisnis (Bab 5).

\subsubsection{Gagasan, ideologi dan kepercayaan: Wacana untuk bisnis seperti biasa atau ke arah perubahan}

Tindakan para pelaku tidak hanya dibentuk oleh pengejaran kepentingan materi secara rasional saja, namun juga oleh gagasan dan cita-cita. Pelaku yang berbeda memiliki gagasan spesifik (konsep atau konstruksi mental) atau ideologi (serangkaian norma atas gagasan) selain kepentingan materi mereka. Namun gagasan dan ideologi bukanlah tujuan akhir. Seperti dibahas oleh Swidler (1986) dalam uraiannya tentang pengaruh budaya, gagasan mereka membentuk alat bantu yang secara tidak langsung menyediakan sumberdaya untuk, atau secara langsung mengatur, cara pelaku menyusun strategi tindakan mereka.

Dalam ranah kebijakan multitingkat dan multipelaku, beragam strategi dinegosiasikan oleh pelaku yang berbeda, dan perubahan kebijakan dapat merupakan hasil dari negosiasi ini. Sistem kepercayaan para pelaku dalam subsistem politis memiliki tingkat resistensi untuk berubah yang berbeda-beda (Sabatier dan Jenkins-Smith 1999). Tingkat resistensi ini bervariasi menurut ruang negosiasi: i) 'keyakinan mendasar' atau kepercayaan normatif fundamental; ii) 'poros kebijakan' atau posisi politik dasar; iii) 'aspek-aspek sekunder' atau evaluasi dari dan persengketaan tentang berbagai program dan lembaga dan preferensi atas kebijakan tertentu. Aspek sekunder lebih dapat dinegosiasikan antara koalisi advokasi, dan banyak tindakan REDD+ terletak di sini. Namun demikian, peran Bolivia dalam UNFCCC - yaitu ketika para perunding Bolivia menolak gagasan REDD+ karena keterkaitannya 
dengan pembiayaan berbasiskan pasar - menunjukkan bahwa aspek-aspek REDD+ bersinggungan dengan kepercayaan 'poros mendalam' dan sejumlah posisi politik.

Kebijakan publik dan tata kelola lingkungan hidup pada hakikatnya merupakan sebuah proses politis, yang dipengaruhi oleh berbagai kepentingan, kepercayaan dan praktik-praktik wacana yang digunakan untuk membingkai wacana kebijakan (Hajer 1995; Forsyth 2003; Jasanoff 2009). REDD+ juga bukan merupakan perkecualian. Ciri-ciri wacana memengaruhi pembuatan kebijakan, karena mereka membingkai masalah dan menyajikan sejumlah pilihan yang terbatas atas apa yang 'beralasan' atau yang diajukan sebagai 'hal yang mungkin' (Hajer dan Versteeg 2005) - atau dalam konteks REDD+, apakah yang dimaksud dengan 'efektif, efisien dan berkesetaraan'. Bab 8 yang membahas tentang pembagian manfaat REDD+ menyajikan sebuah contoh yang tepat untuk proses ini.

Wacana dan koalisi wacana yang muncul dibingkai oleh dukungan individu atau kepentingan yang terorganisasi. Berbagai wacana ini dapat melegitimasi dan mendominasi tindakan dan kebijakan yang mendukung deforestasi dan degradasi hutan dan dapat membatasi penjabaran gagasan baru seperti REDD+. Lanskap REDD+ sendiri juga didominasi oleh berbagai wacana yang sebagian saling bertentangan: i) 'kejelasan penguasaan lahan dulu kemudian baru REDD+' atau 'Tidak ada hak tidak ada REDD+'; ii) sentralisasi REDD+ versus desentralisasi REDD+; dan iii) manfaat REDD + bagi mereka yang berkontribusi bagi efisiensi dan keefektifan, versus manfaat bagi mereka yang memiliki hak moral berbasiskan pertimbangan kesetaraan (Bab 8). Pada tingkat nasional dan global, kami melihat adanya persepsi dan wacana terkait kedaulatan sumberdaya alam; posisi pasar dan antipasar; serta kesetaraan global (misalnya, terkait pemanfaatan kredit REDD+ sebagai pengganti kerugian). Demikian pula paradigma pembangunan nasional yang juga memengaruhi gagasan REDD+ melalui fokusnya pada eksploitasi sumberdaya alam dan perwujudan keuntungan ekonomi dalam jangka pendek.

Sebuah aspek REDD+ yang penting, yang dibahas lebih lanjut dalam Bab 3, adalah bahwa konsep ini cukup ditentukan secara terbuka untuk ditafsirkan secara berbeda, sehingga pada dasarnya sesuai untuk berbagai kepercayaan normatif, seperti keyakinan yang dipegang oleh pasar lingkungan hidup liberal dan 'kelompok hijau sosial' (Kotak 3.1, Hiraldo dan Tanner 2011a). Koalisi baru dalam ranah kebijakan REDD+ adalah hasilnya. Namun ketidaksepakatan yang kuat dapat terlihat ketika rincian REDD+ harus dibuat spesifik, seperti berapa banyak yang harus disandarkan pada pendanaan pasar karbon di masa depan, dan sampai sejauh mana penguasaan lahan dan hak harus ditindaklanjuti sebelum tindakan REDD+ akan dilaksanakan. 


\subsubsection{Informasi: Mata uang global saat ini}

Informasi adalah elemen keempat dalam perubahan transformatif, namun merupakan bagian yang tidak terpisahkan dari kelembagaan, kepentingan dan gagasan. Fakta tidak muncul dengan sendirinya, mereka dipilih, ditafsirkan, dan dibentuk dalam konteks yang mencerminkan kepentingan penyedia informasi. Foucault dan sejumlah ilmuwan lain telah memberikan wawasan tentang kaitan yang kuat antara pengetahuan, wacana dan kekuasaan (lihat Foucault 1980; Arts dan Buizer 2009; Winkel 2012). Di atas kami menyebutkan beberapa wacana yang sering bertentangan. Informasi baru muncul menggantikan 'alat bantu untuk bertindak' yang sudah ada dengan yang baru, khususnya apa yang disebut Swidler (1986) sebagai 'situasi yang tidak jelas'. Masalah global perubahan iklim dapat dianggap sebagai suatu situasi yang tidak jelas. Namun apa yang membuat para pengambil keputusan menggantikan paradigma pembangunan berbasiskan eksploitasi dengan wacana baru yang memihak pada tegakan hutan? Menggunakan gagasan-gagasan baru sebagai sebuah kekuatan ke arah perubahan berjangka panjang bergantung pada sejumlah kondisi struktural.

Selain itu, berbagai faktor seperti penyingkapan, ketersediaan, dan kredibilitas data dalam REDD+ semuanya memengaruhi apakah informasi menjadi penghambat atau pendukung ke arah perubahan. Para pelaku memiliki akses yang tidak sama untuk mendapatkan informasi, serta kapasitas teknis yang bervariasi untuk menghasilkan, menyediakan, dan mengubah pengetahuan menjadi manfaat ekonomi langsung atau mendukung pembuatan keputusan publik. Dalam dunia REDD+, informasi merupakan mata uang dan sumber kekuasaan.

Pengumpulan dan penyebaran data dan informasi adalah mur dan baut dalam mekanisme REDD+, yang sedang dalam pengembangan. Lebih dari intervensi kebijakan umumnya, REDD+ memiliki target spesifik - pengurangan emisi - yang harus dikuantifikasi. Namun angka memiliki sifat ekonomi politis sendiri dan selalu bisa dimodifikasi dan ditafsirkan secara berbeda (Espeland dan Stevens 2008:411). Misalnya, pengurangan emisi dibandingkan dengan suatu tingkat acuan, namun tidak ada cara yang mudah untuk menetapkannya (Bab 16).

Walaupun secara teoritis pengambilan keputusan seharusnya berbasiskan bukti dan berorientasi pada solusi, kenyataan politis jarang memenuhi harapan ini. Hal ini mungkin karena minat terhadap tindakan berbasiskan bukti dan berorientasi solusi hanya sedikit, atau karena buktinya tidak dihasilkan atau tidak tersedia. Proses pembelajaran REDD+ untuk rancangan kebijakan REDD+ yang lebih baik, yang terkait panduan UNFCCC global dan proyek-proyek lokal, akan memerlukan perantara atau broker bukti dan pengetahuan. Perantara untuk pembelajaran kebijakan, seperti agen-agen 
konsultan, LSM internasional yang besar dan berbagai organisasi penelitian, juga dapat menjadi bagian dari proses-proses politis dan menentukan perumusan kebijakan. Salah satu contohnya adalah publikasi kurva biaya pengurangan marjinal (Marginal Abatement Cost/MAC) oleh McKinsey (McKinsey and Company 2009) dan perannya sebagai penasihat kebijakan di negara-negara REDD+.

\subsection{Bagaimana mencapai perubahan tranformatif}

Untuk mendapatkan respon yang dipandang efektif, efisien dan berkesetaraan atas tantangan mitigasi global, dibutuhkan perubahan transformatif. Keluaran terpenting dari proses kebijakan harus berupa perubahan dalam kerangka kerja ekonomi, peraturan dan tata kelola yang lain, juga reformasi kebijakan di dalam dan di luar sektor kehutanan. Kami membahas tiga cara yang dapat mendasari perubahan transformatif dalam REDD+: perubahan insentif ekonomi, gagasan dan informasi baru, serta para pelaku dan sejumlah koalisi baru.

\subsubsection{Perubahan insentif ekonomi}

Penyediaan sumberdaya pembiayaan internasional untuk tiga tahap REDD+: kesiapan, reformasi kebijakan dan emisi yang dikurangi (Bab 7) berada di luar sistem-sistem nasional dan subnasional yang seharusnya menjadi tempat perubahan berlangsung. Hal ini merupakan inti gagasan awal REDD+: REDD+ harus mengubah persamaan biaya-manfaat dasar sehingga nilai tegakan hutan menjadi lebih tinggi dibandingkan hutan yang ditebang. Smith dkk. (2004) menyebutnya sebagai 'transisi yang disengaja' - suatu perubahan yang memang dimaksudkan yang didorong oleh berbagai pelaku dari luar.

Logikanya menarik, dan bukti menunjukkan bahwa prospek pendanaan REDD+ yang signifikan telah menjadi pengubah permainan di beberapa negara (Bab 5). Namun potensi pendanaan eksternal untuk menjadi pencetus perubahan transformatif menghadapi beberapa pertanyaan: siapa yang sepenuhnya merugi; siapa yang menerima kompensasi lebih sedikit dibandingkan biaya yang ditanggung; siapa yang akan merasakan manfaat bersihnya; dan bagaimana menghadapi ketidakpastian tentang pembayaran aktual di masa depan.

Pertama, walaupun sekelompok negara bisa jadi mendapatkan manfaat ekonomis setelah implementasi REDD+ melalui pendanaan internasional, tidak semua yang berada dalam ranah REDD+ akan merasakan manfaatnya. Khususnya para pelaku besar yang akan tetap memperoleh keuntungan dari praktik-praktik bisnis seperti biasa yang tetap berlanjut, kemungkinan besar akan merugi. Kompensasi penuh bagi kelompok-kelompok yang kaya dan 
berkuasa secara politis tidak dapat diterima, khususnya dalam ranah REDD+ internasional, dan akan merusak kredibilitasnya serta membahayakan peluang-peluang pendanaan jangka panjang. Selain itu, sebagian besar pendanaan REDD+ saat ini adalah dari bantuan pembangunan, yang tujuan utamanya adalah untuk pengentasan kemiskinan. Namun dukungan yang lebih luas untuk REDD+ dibutuhkan, dan hal ini dapat dicapai dengan memastikan bahwa semua pihak yang relevan merasakan manfaatnya. Namun dilema utamanya adalah bahwa ini bisa menyebabkan kebijakan REDD+ melemah dan tidak efektif dalam mengurangi emisi. Moratorium Hutan Indonesia dapat dijadikan contoh: Tindakan ini menjadi bagian dari kesepakatan AS \$1 miliar antara Indonesia dan Norwegia dan memperoleh dukungan yang cukup untuk mewujudkannya sebagai kenyataan, namun di sepanjang perjalanannya begitu banyak kompromi yang terlibat sehingga dampak potensialnya diragukan.

Kedua, kompensasi internasional penuh untuk biaya-biaya REDD+ tidak realistis untuk kebanyakan negara karena beberapa alasan. Pendanaan internasional yang cukup tidak tersedia dan negara-negara REDD+ berpenghasilan menengah diharapkan untuk menanggung sendiri sebagian biaya ini sebagai bagian dari prinsip UNFCCC yaitu "bersama namun dengan tanggung jawab yang dibedakan dan sesuai dengan kemampuan masing-masing" ("common but differentiated responsibilities and respective capabilities"). Artinya, sejumlah negara harus bersedia untuk menerima negosiasi timbal balik jangka pendek dan menengah untuk visi jangka panjang yang lebih luas atas dampak pembangunan hijau dan penghindaran perubahan iklim.

Ketiga, insentif REDD+ selama tahap-tahap awal belum merupakan kenyataan, namun lebih merupakan janji-janji tentang pembayaran berbasiskan hasil di masa depan. Memang demikianlah sifat dari pembayaran berbasiskan hasil; pembayaran hanya dapat dilakukan setelah hasil (misalnya, pengurangan emisi) dicapai dan diverifikasi. Karena itu, harus dibangun kepercayaan dalam insentif yang dijanjikan ini. Tanpa ada prediksi tentang besarnya pembayaran yang akan diterima negara-negara REDD+ untuk perubahan yang mereka capai, REDD+ tampaknya kurang mampu merangsang perubahan transformatif yang ingin dicapainya.

\subsubsection{Sejumlah gagasan dan informasi baru}

REDD+ telah menyediakan wacana baru tentang nilai tegakan hutan dan perannya dalam menyerap dan menyimpan karbon (Cronin dan Santoso 2010; Kengoum 2011; May dkk. 2011a; Pham 2011). Sementara pemahaman tentang peran ini bukan merupakan hal baru, REDD+ telah meningkatkan kesadaran tentang fakta bahwa emisi gas rumah kaca (GRK) dari deforestasi hutan tropis menyumbangkan 17\% dari emisi 
global (IPCC 2007a), dan mengurangi emisi ini penting untuk mencapai target dalam membatasi kenaikan suhu sampai dengan $2^{\circ} \mathrm{C}$ di atas tingkat praindustri. Dalam pelaksanaannya, REDD+ juga telah memberi andil dalam peningkatan kesadaran tentang sejumlah risiko tinggi pemanasan global.

REDD+ juga telah memfokuskan perhatian pada sejumlah isu lama dan baru yang kesemuanya menunjuk pada perlunya perubahan dalam kebijakan-kebijakan dan praktik-praktik bisnis seperti biasa untuk dapat mewujudkan potensi REDD+. Contoh-contohnya adalah: i) hak adat dan masyarakat, serta konflik tentang penggunaan hutan oleh kelompok-kelompok lokal dan perusahaan kehutanan komersial berskala besar, ii) tata kelola, korupsi dan ekonomi politis dalam pemanfaatan hutan; iii) biaya yang tidak efisien dan beranggaran tinggi atas berbagai kebijakan dan praktik yang mendukung kegiatan yang menghancurkan hutan. ${ }^{5}$ Karena itu sejumlah koalisi wacana baru yang melibatkan sejumlah pelaku nasional dan lokal dalam konteks pemikiran REDD+ tentang hak, konservasi hutan dan ketidaksetaraan dalam eksploitasi hutan dapat berpengaruh penting ke arah perubahan.

Akhirnya, sebuah aspek yang tidak banyak dibahas dalam kepustakaan REDD+ adalah potensinya untuk meninjau kembali peran antara negara maju dan berkembang. Negara berkembang yang kaya hutan berpeluang untuk menyediakan jasa bagi negara maju, dan untuk ini mereka dibayar. Hal ini membalikkan posisi peran negara berkembang selama ini sebagai penerima yang bergantung pada bantuan pembangunan dari negara maju. REDD+ dapat ditafsirkan sebagai mekanisme untuk mengubah posisi, dengan meninjau ulang peran negara berkembang yang kaya hutan bergeser dari kebergantungan pada bantuan menuju dukungan bagi negara maju dalam menyediakan barang publik global (mitigasi iklim). Karena itu, beberapa pelaku dalam negara memandang REDD+ sebagai kontributor bagi kedaulatan nasional yang dapat mendorong pelaku-pelaku domestik untuk terlibat dalam REDD+.

\subsubsection{Sejumlah pelaku dan koalisi baru}

Perubahan insentif ekonomi serta gagasan dan wacana baru dapat menyebabkan pergeseran dalam hubungan kekuasaan di antara para pelaku utama (Knight dan Sened 1995; March dan Olsen 1998; Marsh dan Smith 2000; Cleaver 2002). Diperkenalkannya REDD+ dan janji insentif yang melekat padanya dalam ranah kebijakan nasional dan subnasional mendorong terjadinya perubahan de facto. Ketika (atau jika) hak karbon hutan telah ditetapkan, mereka yang berhak atas karbon memperoleh kekuasaan. Demikian pula kepemilikan

5 Tentu saja, tidak satupun dari isu ini adalah baru. Repetto dan Gillis (1998) menulis sebuah studi yang menonjol tentang peran aspek yang kedua dan ketiga; aspek yang pertama telah dimunculkan oleh berbagai LSM dan sejumlah peneliti selama beberapa dekade. 
informasi tentang konsep REDD+, peluang potensial yang dapat disediakan oleh REDD+, atau data yang dibutuhkan untuk melaksanakan REDD+ dapat menjadi sumber kekuasaan yang baru. Pergeseran dan perubahan dalam kekuatan tawar ini dapat berpotensi membawa perubahan tambahan - dan mengindikasikan perubahan transformatif (Gambar 2.1).

Selain itu, sejumlah pelaku baru memasuki ranah REDD+ dan mendapatkan kekuasaan dan pengaruh yang baru dalam pengambilan keputusan (Schroeder dan Lovell 2011). Akibatnya, mereka dapat menggunakan lembaga mereka untuk mengubah perwakilan politis atas kepentingan tertentu dan dapat memperbaiki ketidakseimbangan informasi yang ada. Pergeseran ini bisa jadi akhirnya mengubah hubungan kekuasaan. Dengan demikian, ambang pintu yang pertama telah terlewati: sebuah gagasan eksogen mengubah hubungan kekuasaan endogen, dan proses-proses perumusan dan implementasi kebijakan seharusnya memperkuat dinamika ini ke arah perubahan transformatif.

REDD + telah menarik banyak pelaku dengan agenda dan ideologi yang berbeda, yang masing-masing mencoba untuk memperoleh bagian dari kue REDD + yang mereka amati. Hal ini menyebabkan agenda REDD+ beragam dan kurang fokus, yang berisiko kehilangan ciri awal REDD+ yang semula membuatnya menarik (Bab 3). Namun, koalisi yang luas atas kepentingan yang berbeda dan pelaku dengan ideologi yang berbeda seperti itu (lihat Kotak 3.1) juga dapat menjadi landasan ke arah perubahan transformatif. Sebuah penanda utama untuk skenario mana yang akan terwujud adalah apakah fokus akan tetap berada pada REDD+ sebagai tujuan (Bab 18) atau apakah REDD+ hanya menjadi rangkaian kegiatan yang gagal untuk mencapai pengurangan emisi secara signifikan.

REDD + berpotensi untuk mendorong perubahan transformatif, namun pada akhirnya: "uang tunai adalah raja" dan "wacana adalah ratu". Pergeseran dalam insentif keuangan dan dalam praktik-praktik yang mewujudkan wacana tertentu menyediakan alat yang kuat untuk menjaga fokus tetap pada target utama: meningkatkan nilai relatif tegakan pohon sehingga jumlah yang akan ditebang menjadi lebih sedikit.

\subsection{Kesimpulan}

Mengurangi emisi melalui deforestasi dan degradasi hutan yang dihindari membutuhkan perubahan kelembagaan dan kebijakan yang mendasar. Kami menyediakan lensa 4I untuk memahami politik dan kekuasaan dalam REDD+. Analisis lembaga serta alur kebergantungan dan keterlekatan, serta para pelaku berikut kepentingan, gagasan dan informasi mereka dapat bermanfaat untuk memahami faktor-faktor yang mendorong pergeseran hubungan kekuasaan, insentif dan praktik-praktik yang berbeda. 
Meskipun terdapat sejumlah hambatan seperti diuraikan di atas, banyak kemajuan telah dicapai dalam ranah kebijakan global dan nasional, serta sejumlah proses politik untuk mengembangkan kerangka REDD+ telah berlangsung sejak gagasannya muncul pada COP11 di Montreal tahun 2005. REDD+ berpotensi untuk menjadi pengubah permainan dengan membentuk sejumlah koalisi baru seputar nilai tegakan hutan (Bab 5). Namun perubahan transformatif akan bergantung pada kekuatan dari koalisi baru ini, sejauh mana pergeseran dalam praktik-praktik yang berbeda, dan pembentukan insentif ekonomi, baik internasional maupun domestik, yang menghargai tegakan hutan lebih dari hutan yang ditebang.

Dalam bab ini kami telah memusatkan pembahasan tentang dua keluaran yang terbentuk dari permainan REDD+: bisnis seperti biasa atau perubahan transformatif. Di kebanyakan negara, kenyataannya akan berupa sesuatu di antara keduanya, dan ambang batas atau titik kritisnya harus diatasi, misalnya pembentukan konstituen yang baru dan berkuasa ke arah perubahan.

Bab-bab berikutnya menguraikan pilihan-pilihan penting untuk meningkatkan peluang perubahan transformatif, termasuk cara mengatasi hambatan yang diuraikan di sini dan mengambil manfaat dari peluang-peluang yang bermunculan. Sejauh mana perubahan akan dicapai sangat bergantung pada kemampuan sejumlah agen dalam ranah kebijakan REDD+ untuk: i) mengelola kepentingan yang beragam antartingkat dan koalisi pelaku yang berkuasa; ii) menyediakan informasi dan kapasitas untuk mengubah data menjadi pengetahuan yang mendorong perubahan perilaku di antara agen-agen pemerintah dan nonpemerintah; dan iii) mengomunikasikan visi yang lebih luas tentang REDD+ dan mitigasi perubahan iklim yang dapat menggantikan paradigma pembangunan yang ada saat ini. 



\section{Bab 3}

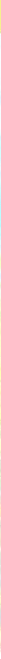

\section{Evolusi REDD+}

Arild Angelsen dan Desmond McNeill

- Sebagai sebuah gagasan, REDD+ terbukti sangat populer, sebagian karena gagasan ini cukup luas untuk menampung berbagai kepentingan yang berbeda. Namun konsepnya telah berkembang, dipicu oleh tidak adanya kesepakatan iklim internasional yang baru, kepentingan bisnis seperti biasa yang kuat, sejumlah pelaku dengan agenda yang beragam dan pengalaman di lapangan.

- Perubahan utama dalam REDD+ termasuk hal-hal berikut: i) fokusnya telah bergeser dari hanya karbon menjadi berbagai sasaran; ii) kebijakan yang dipakai sejauh ini tidak hanya, atau bahkan terutama, diarahkan untuk mencapai pembayaran berbasiskan hasil; iii) kegiatan di tingkat subnasional dan proyek - bukan di tingkat nasional - menerima bagian besar dari sumberdaya; dan iv) sampai saat ini pendanaan terutama berasal dari bantuan internasional dan anggaran nasional negara-negara REDD+, dan bukan berasal dari pasar karbon.

- Kekhasan REDD+ yang membuatnya berbeda dari upaya-upaya sebelumnya dalam sektor kehutanan - pendanaan yang signifikan berbasiskan hasil - berisiko tertutupi oleh berbagai sasaran dan pendekatan lainnya, sehingga membahayakan keefektifan REDD+. 


\subsection{Pengantar}

REDD+ telah mengalami perubahan drastis sejak gagasan ini diluncurkan dalam COP11 di Montreal tahun 2005, baik dalam hal persepsi tentang gagasan ini maupun bagaimana gagasan ini telah diterapkan. Sementara beberapa dari perubahan ini timbul dari pematangan gagasan ini secara alami, sejalan dengan pembelajaran dan pengalaman yang kita peroleh, sejumlah perubahan yang terjadi juga merupakan akibat dari REDD+ diterjunkan ke arena politik dan dipengaruhi oleh sejumlah kepentingan dan ideologi yang beragam (Bab 2). Pemahaman tentang apa yang membentuk REDD+ telah dimodifikasi, dengan beberapa pelaku menggunakan 'kekuasaan secara skematis' yang kuat. Selain itu, lambatnya kemajuan dalam negosiasi iklim global dan kekaburan prospek pendanaan REDD+ jangka panjang, demikian juga kepentingan domestik yang kuat untuk tetap melakukan bisnis seperti biasa (Bab 5), memiliki implikasi kuat bagi kecepatan dan bentuk pengembangan REDD+.

Terdapat beragam interpretasi mengenai REDD+. Definisi umum, berdasarkan keputusan COP13 di Bali tahun 2007, menyatakan bahwa REDD+ tersusun atas sejumlah tindakan lokal, nasional dan global yang tujuan utamanya adalah untuk mengurangi emisi dari deforestasi dan degradasi hutan dan memperkuat cadangan karbon di negara-negara berkembang (Angelsen 2009a). Sedangkan definisi yang lebih sempit, yang digunakan untuk memilih sejumlah proyek untuk Studi Komparatif Global (GCS) CIFOR tentang REDD+ (lihat Lampiran), merinci bahwa tujuan utamanya terkait dengan pengurangan emisi dan penyerapan gas rumah kaca (GRK), dan tindakan yang melibatkan pembayaran berbasiskan hasil atau bersyarat (Wertz-Kanounnikoff dan Angelsen 2009).

Bab ini akan menguraikan aspek-aspek utama evolusi REDD+ sebagai sebuah gagasan dan praktik dan meninjau sejumlah kekuatan pendorong di balik perubahan yang telah terjadi. REDD+ - sebagai sebuah gagasan - adalah kisah sukses dan alasan keberhasilan ini diulas dalam Bagian 3.2. Bagian 3.3 menyediakan sebuah kerangka kerja untuk mengamati bagaimana dan mengapa REDD+ telah berubah dalam empat arena: negosiasi iklim, bantuan internasional, kebijakan nasional dan realitas lokal. Bagian 3.4 membahas perubahan REDD+ dalam empat hal utama: tujuan, kebijakan, skala implementasi dan pendanaan. Terakhir, kami membahas implikasi perubahan ini bagi REDD+.

\subsection{Sebagai suatu gagasan, REDD+ adalah sebuah kisah sukses}

REDD+ telah menjadi sebuah gagasan yang sangat berhasil. Sejak RED diluncurkan pada COP11 dan REDD+ diintegrasikan sepenuhnya dalam 
agenda iklim global pada COP13 2007, gagasan ini dinilai berpotensi menjadi strategi mitigasi yang paling efektif dan efisien yang tersedia saat ini. Sejumlah negara berkembang telah menyiapkan - dan beberapa telah mulai menerapkan - strategi-strategi kebijakan REDD+. Ratusan proyek lokal REDD+ telah dimulai dan para peneliti dan berbagai pihak lain telah termotivasi untuk menulis ribuan publikasi. ${ }^{1}$ Sejumlah donor menjanjikan miliaran dolar bagi REDD+ (Bab 7) dan program-program internasional yang baru telah dibentuk, seperti Fasilitas Kemitraan Karbon Hutan (Forest Carbon Partnership Facility/FPCF) dari Bank Dunia, Program UN-REDD dan Program Investasi Hutan (Forest Investment Program/FIP) dari Bank Dunia. Kita mungkin perlu kembali ke wacana 'pembangunan berkelanjutan' yang dipromosikan oleh World Commission on Environment and Development (WCED 1987), untuk memperoleh gagasan yang lebih berhasil dalam bidang lingkungan hidup dan pembangunan. Walaupun pembangunan berkelanjutan lebih merupakan sebuah aspirasi dibandingkan suatu rangkaian tindakan spesifik, aspirasi ini memiliki daya tarik yang sama dengan REDD+, yaitu bisa dipahami sebagai hal berbeda bagi orang yang berbeda. Ketidakjelasan - atau keluasan - gagasan ini, menurut kami, adalah sebagian dari alasan keberhasilannya. ${ }^{2}$ Selain itu, seperti halnya pembangunan berkelanjutan, daya tarik REDD+ awalnya berasal dari janjinya untuk menjadi kebijakan menang-menang-menang (win-win-win): kombinasi pengurangan emisi GRK dengan pengentasan kemiskinan dan perlindungan keanekaragaman hayati.

\subsubsection{REDD+ terlihat besar, murah dan cepat}

Emisi GRK dari deforestasi hutan menyebabkan 17\% emisi global (IPCC 2007b), meskipun studi yang lebih baru menunjukkan bahwa kontribusi ini mungkin hanya sekitar $12 \%$, sebagian karena pertumbuhan pesat dalam emisi bahan bakar fosil (van der Werf dkk. 2009). Mengurangi emisi dari hutan tropis tidak hanya berpotensi besar untuk mengurangi emisi global, namun laporan oleh Stern (2006) dan lain-lain telah meyakinkan para perumus kebijakan bahwa pendekatan semacam itu tidak akan membutuhkan biaya besar. Menurut laporan Stern, menghilangkan deforestasi yang paling besar hanya akan membutuhkan biaya rata-rata AS $\$ 1-2$ per $\mathrm{tCO}_{2}$, yang sangat murah dibandingkan dengan hampir semua pilihan mitigasi lainnya. Walaupun estimasi ini telah dikritik dan beberapa estimasi lain adalah lebih tinggi (misalnya, Kindermann dkk. 2008), ada kesan umum yang terbentuk bahwa REDD+ akan menjadi murah.

1 Sebuah penelusuran Google Scholar mengutip sekitar 18.000 publikasi tentang REDD+ (diakses 6 Maret 2012).

2 "Gagasan yang paling berhasil dalam arena kebijakan bukan berupa analisis yang paling mendalam, namun yang paling dapat ditempa, yaitu yang dapat ditafsirkan untuk menyesuaikan dengan perspektif yang beragam, mencapai konsensus dengan mengantarkan arti yang berbeda bagi pihak-pihak sasaran yang berbeda" (McNeill 2006). 
Diasumsikan juga bahwa REDD+ adalah mudah dan dapat dilakukan dengan cepat, yang membuatnya menarik bagi berbagai konstituen yang berbeda. Dalam pidatonya pada COP13, yaitu pada saat peluncuran Inisiatif Iklim dan Hutan Internasional Norwegia (International Climate and Forest Initiative of Norway), Perdana Menteri Norwegia Jens Stoltenberg menyampaikan bahwa, "Melalui langkah-langkah yang efektif dalam melawan deforestasi, kita dapat mencapai penurunan besar emisi GRK - dengan cepat dan biaya murah. Teknologinya sudah diketahui dengan baik dan telah tersedia selama ribuan tahun. Semua orang tahu bagaimana untuk tidak menebang pohon." ${ }^{3}$

\subsubsection{REDD+ mewakili sebuah pendekatan baru}

Pada awalnya, satu ciri pembeda REDD+ adalah penggunaan insentif keuangan untuk mengubah perilaku pengguna hutan: konservasi hutan agar menjadi lebih menguntungkan daripada penebangan hutan melalui pembayaran untuk berbagai jasa lingkungan (PES). Logikanya menarik. Penyerapan dan penyimpanan karbon adalah barang publik yang disediakan oleh hutan dan pemilik hutan. Saat ini tidak ada pasar atau mekanisme seperti pasar untuk memberikan insentif bagi pemilik dan pengguna hutan untuk memperhitungkan nilai jasa ini ke dalam keputusan pengelolaan mereka. Melalui sistem PES, pemilik lahan akan menjaga hutan karena mereka dapat menghasilkan uang dengan melindungi hutan. Aspek ini membuat REDD+ berbeda sekali dengan upaya-upaya konservasi hutan sebelumnya (Sunderlin dan Atmadja 2009). Sebuah pendekatan berbasiskan kinerja, dengan pembayaran yang dilakukan hanya jika hasilnya telah dapat ditunjukkan, juga sangat menarik bagi kebanyakan sumber-sumber pembiayaan.

Ciri pembeda kedua REDD+ adalah besarnya pendanaan yang tersedia, yang membuat upaya-upaya konservasi sebelumnya terlihat kecil, misalnya Rencana Aksi Hutan Tropis (Tropical Forest Action Plan) pada tahun 1980-an. Transfer tahunan untuk negara-negara REDD+ diperkirakan berpotensi membawa puluhan miliar dolar, demikian menurut laporan-laporan yang berwenang (misalnya, Stern 2006; Eliasch 2008).

Terakhir, REDD+ menargetkan reformasi dan perubahan transformatif di luar sektor kehutanan (Bab 2). Suatu pendekatan nasional yang luas telah dipilih ${ }^{4}$ untuk memungkinkan penggunaan kebijakan ekstrasektoral, yang dapat berdampak lebih besar dibandingkan pendekatan sektoral (Kanninen dkk. 2007). Suatu pendekatan nasional juga akan menindaklanjuti tantangan kebocoran, alasan utama mengapa deforestasi yang dihindari tidak dimasukkan ke dalam Mekanisme Pembangunan Bersih (Clean Development Mechanism/CDM) pada tahun 2001.

3 http://www.regjeringen.no/nb/dep/smk/aktuelt/taler_og_artikler/statsministeren/ statsminister_jens_stoltenberg/2007-4/Tale-til-FNs-klimakonferanse-pa-Bali.html?id=493899.

4 Sementara fokusnya bersifat nasional, suatu pendekatan dalam satu sarang (Pedroni dkk. 2007) yang dimulai pada tingkat subnasional, pada situasi tertentu, dapat diterima sebagai suatu langkah sementara. 


\subsubsection{REDD+ menarik bagi banyak pelaku di berbagai tingkat}

Karena diharapkan akan menyediakan kompensasi untuk pengurangan emisi, REDD+ mewakili solusi menang-menang untuk kebanyakan pelaku hutan, termasuk pemilik hutan dan pemerintah negara REDD+. REDD+ dipandang berkontribusi bagi lingkungan hidup dan tujuan pembangunan, sehingga menghindari 'hukum besi kebijakan iklim': ketika tujuan lingkungan hidup dan ekonomi berbenturan, maka tujuan ekonomi yang akan menang (Pielke 2010).

Suatu konsep utama dalam Rencana Aksi Bali (UNFCCC 2007) adalah bahwa REDD+ seharusnya mengikutsertakan 'insentif positif', yang oleh banyak pihak ditafsirkan sebagai kompensasi oleh negara-negara Annex I kepada negara-negara nonAnnex I untuk mencapai pengurangan emisi kehutanan yang terukur. Karena itu REDD+ sangat sesuai dengan bagian yang ditetapkan dalam Protokol Kyoto: negara-negara Annex I akan melaksanakan komitmen untuk pengurangan emisi, sementara negara-negara nonAnnex I akan melaksanakannya secara sukarela (baru-baru ini dinyatakan sebagai NAMAs - Nationally Appropriate Mitigation Actions/Aksi Mitigasi yang Disesuaikan secara Nasional: sejumlah kebijakan dan tindakan yang disepakati untuk dilaksanakan oleh negara-negara berkembang untuk mengurangi emisi GRK mereka). Dengan beberapa negara Annex I (khususnya Norwegia) bersedia untuk memberikan dana dalam jumlah relatif besar, REDD+ dapat menjembatani kesenjangan antara Utara dan Selatan dalam negosiasi iklim, meletakkan beberapa langkah ke depan yang terkait isu-isu dalam agenda UNFCCC. Apabila negosiasi gagal dalam bidang lain (dan ini sering terjadi), REDD+ dapat menjadi kelinci dalam topi untuk menunjukkan kemajuan yang dapat dicapai.

Sampai saat ini, kredit REDD+ belum memungkinkan untuk digunakan sebagai pengganti kerugian, yaitu untuk memenuhi kewajiban pengurangan emisi bagi negara-negara Annex I. Namun prospek bahwa hal ini dapat berubah merupakan faktor yang memotivasi - baik bagi negara-negara nonAnnex I yang berhutan yang mengantisipasi potensi aliran pendapatan yang besar maupun untuk negara-negara Annex I yang berharap untuk memenuhi komitmennya dalam pengurangan emisi dengan biaya yang lebih murah. ${ }^{5}$

Dukungan bagi REDD+ tetap tinggi, sebagian karena belum didefinisikan dengan jelas. Banyak isu sulit yang belum terselesaikan, misalnya apakah pendanaan diarahkan untuk pelaku deforestasi komersial berskala besar atau pada kelompok-kelompok adat yang melestarikan hutan. Selama

5 Brazil merupakan kekecualian, karena sejak awal bersifat skeptis terhadap gagasan ini, sebagian karena kekhawatiran kedaulatan dan setelah itu juga karena kekhawatiran bahwa kredit REDD+ akan menghilangkan upaya-upaya mitigasi negara-negara REDD+ (Angelsen dkk. 2012b). 
REDD+ masih belum jelas, kepentingan dan pandangan yang berbeda tampaknya dapat diakomodasi. Sebagai contoh, tingkat acuan disetujui harus didasarkan pada 'kondisi nasional', walaupun tidak ada yang tahu persis apa maksud istilah ini (Bab 16). Sama halnya, definisi REDD+ dari COP13 (UNFCCC 2007) memasukkan 'peningkatan cadangan karbon hutan'; beberapa Pihak menafsirkan hal ini untuk mengikutsertakan hutan tanaman (yang juga merupakan hutan, sesuai dengan definisi standar FAO), sementara beberapa pihak lain berpendapat lain.

Singkatnya, bagi banyak pelaku dalam arena iklim, REDD + terlihat seperti sebuah solusi ideal. REDD+ dapat menyediakan pengurangan emisi secara cepat dan murah serta peluang menang-menang-menang bagi semua orang: transfer dana besar ke Selatan, pengganti kerugian yang murah bagi Utara dan pendanaan untuk proyek-proyek konservasi dan pembangunan. Namun ketika REDD+ mulai diuji dan didefinisikan secara lebih rinci, permasalahan mulai timbul. Selama REDD+ tetap tidak jelas, suatu koalisi yang luas dapat mendukung gagasan ini. Namun suatu gagasan tidak akan efektif sampai benar-benar dilaksanakan, dan kemudian kepentingan yang berkuasa dapat menguatkan atau melemahkannya.

\subsection{REDD+ di arena yang berbeda}

Seperti diuraikan sebelumnya, REDD+ telah mengalami perubahan penting sejak pertama diluncurkan, baiksebagai suatu gagasan maupun sebagai praktik. Gambar 3.1 menyediakan kerangka kerja sederhana untuk menganalisis perubahan dalam REDD+ dengan menggunakan kerangka kerja 4I yang diuraikan dalam Bab 2. Bagian kiri gambar ini mengidentifikasi empat arena relevansi REDD+: arena negosiasi iklim UNFCCC, arena bantuan pembangunan (termasuk arena konservasi dan memiliki donor bilateral yang besar, organisasi multinasional dan NGO atau BINGO internasional yang besar), serta arena nasional dan lokal. Dua yang terakhir - arena nasional dan lokal - masing-masing merupakan subyek pembahasan yang lebih detail dalam Bab 5 dan 11.

Kita akan mulai dengan menganalisis bagian kiri gambar dan akan mengaitkannya dengan bagian kanannya - perubahan tujuan, kebijakan, skala, dan pendanaan dari waktu ke waktu - dalam Bagian 3.4. Sejumlah lembaga formal yang menghubungkan tingkat global dan lokal dari kebijakan dan tindakan REDD+ hanya sedikit dan lemah, namun keempat arena tersebut terkait dengan beberapa cara yang berbeda. Banyak pelaku yang beroperasi pada lebih dari satu arena dan beberapa, seperti halnya BINGO, beroperasi di semua arena. Karena itu, kepentingan dan gagasan berbagai pelaku hutan ada di semua arena dan di semua tingkat. Informasi merupakan mata uang dalam arena ini: tidak hanya informasi teknis namun 


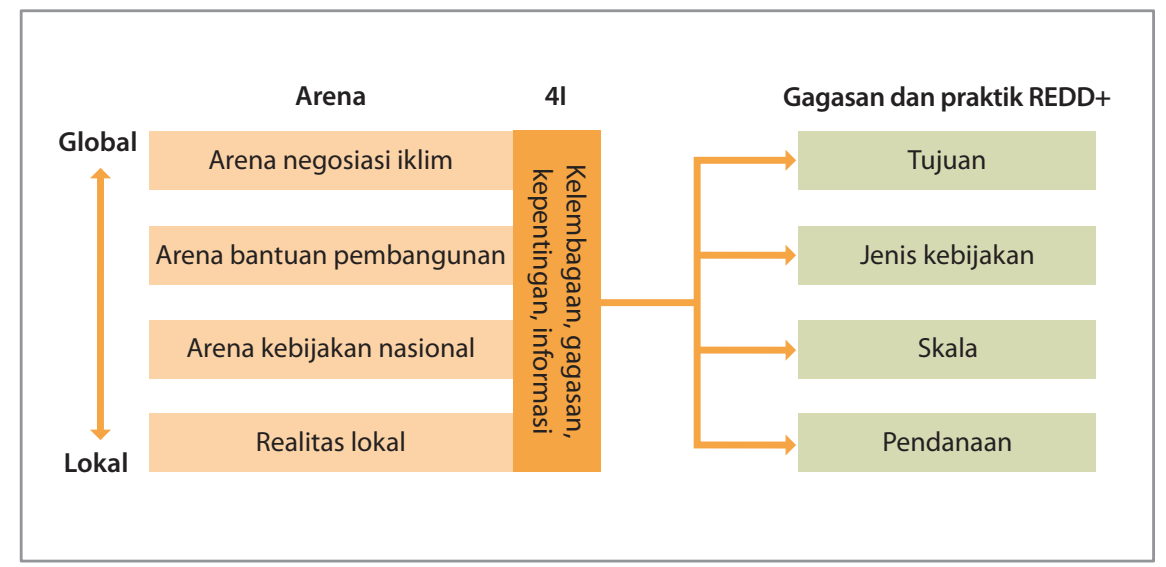

Gambar 3.1 REDD+ sebagai gagasan yang muncul dan praktiknya

juga pengetahuan yang terpilih dan ditafsirkan oleh para pelaku untuk mendukung kepentingan mereka. Dan berbagai keputusan pada satu tingkat dapat membingkai dan membatasi wacana, kebijakan dan aksi pada tingkat lainnya. Misalnya, wacana di tingkat global tercermin dengan jelas dalam perdebatan REDD+ nasional (lihat Bab 5).

Berbagai perdebatan ini dapat dianalisis dalam hal ideologi yang saling bertentangan, seperti dirangkum dalam Kotak 3.1. Di sini, narasi ideologi membingkai posisi REDD + dan berbagai usulan dikaitkan dengan pandangan dunia tentang lingkungan hidup dari empat kelompok utama (menurut Clapp dan Dauvergne 2005): pelaku pasar liberal, institutionalis, para pendukung lingkungan hidup dan kalangan sosial hijau. REDD+ dapat ditafsirkan dalam konteks masing-masing ideologi ini dan ketidaksepakatan dalam perincian $\mathrm{REDD}+$ sering dipahami sebagai pertentangan di antara mereka.

\subsubsection{Sejumlah negosiasi iklim}

RED - dengan satu D - memasuki arena global dalam COP11 tahun 2005, ketika Para Pihak diundang untuk menyampaikan "pandangan mereka tentang isu terkait pengurangan emisi dari deforestasi di negara-negara berkembang (UNFCCC 2005). Badan Pendukung untuk Nasihat Ilmiah dan Teknologi (SBSTA) dari UNFCCC, khususnya, diminta untuk melaporkannya pada pertemuan bulan Desember 2007 (COP13 di Bali, Indonesia). Selama periode intervensi, beberapa pertemuan diselenggarakan untuk membahas kekhawatiran tentang kebocoran yang sudah ada sejak lama, kepenambahan dan tingkat acuan, skala serta pemantauan, pelaporan dan verifikasi (pengumpulan informasi tentang semua hal ini dan isu-isu lain dapat dilihat dalam Angelsen 2008b dan Parker dkk. 2009b). 


\section{Kotak 3.1 Peran berbagai ideologi dalam membingkai agenda REDD+ \\ Rocio Hiraldo dan Thomas M. Tanner}

Menegosiasikan dan mengembangkan program-program REDD+ membutuhkan keterlibatan banyak pelaku. Sementara agenda politik dan finansial memainkan peran dalam mengembangkan kerangka REDD+, narasi ideologi yang berbeda mendasari posisi para pelaku yang berbeda. Bagaimana perdebatan REDD+ dibingkai dapat membenarkan satu atau serangkaian tindakan lainnya (Leach dkk. 2010). Narasi ideologi yang dominan dalam membingkai posisi dan usulan REDD+ dapat dikaitkan dengan cara pandang tentang lingkungan hidup (menurut Clapp dan Dauvergne 2005).

\section{Hutan dan pertumbuhan ekonomi: pasar liberal}

Pasar liberal mendukung mekanisme pasar dan memandang produk hutan sebagai sumber utama pertumbuhan ekonomi dan pengurangan kemiskinan bagi negara-negara berkembang: "Tanpa konsesi hutan sebagian besar dari pulau-pulau di luar Jawa akan tetap tertinggal" (Kementerian Kehutanan Indonesia, dikutip dalam Gellert 2005:1351). Pandangan ini mendukung sikap yang sering dikaitkan - baik secara benar atau tidak - dengan Bank Dunia: bahwa meningkatnya keterlibatan pihak swasta dan penggunaan pasar karbon penting untuk keberlanjutan mekanisme REDD+ di masa depan.

\section{Hutan dan tata kelola: institusionalis}

Ideologi institusionalis berakar pada kebutuhan akan institusi yang kuat, tata kelola yang baik dan hukum yang efektif untuk lingkungan hidup dan kesejahteraan manusia. Penghambat utama untuk tata kelola yang baik mencakup kebijakan dan kerangka kerja hukum yang lemah, kapasitas penegakan yang terbatas, keterbatasan data, korupsi dan kondisi pasar yang buruk untuk berbagai produk kayu. Ideologi ini tercermin dalam beberapa program untuk meningkatkan 'kesiapan' negara untuk REDD+ dan menetapkan partisipasi terhadap program sebagai prasyarat untuk pemenuhan standar tata kelola yang baik. Contohnya adalah yang dilakukan oleh FCPF dan Program UN-REDD, dukungan bilateral Australia untuk Indonesia dan dukungan Norwegia untuk Brasil, Republik Demokratik Kongo, Guyana, Indonesia dan Tanzania.

\section{Nilai ekologis hutan: 'bio-environmentalist'}

Cara pandang bio-environmentalist dicirikan oleh sejumlah kendala ekologis dan kebutuhan untuk memodifikasi tingkah laku manusia dalam menyelesaikan masalah lingkungan. Cara pandang ini mendorong target pengurangan emisi dan laju deforestasi yang ambisius, yang terlihat dalam berbagai kampanye WWF dan Fauna and Flora International. Sementara bio-environmentalist berhadapan dengan model bisnis seperti biasa, visi 
mereka tidak selalu sejalan dengan pendekatan pasar liberal; mereka melihat pasar karbon sebagai sarana untuk mencapai kelestarian lingkungan hidup. Contoh inisiatif yang dimotivasi oleh ideologi bio-environmentalist adalah dukungan Greenpeace untuk Mekanisme Pengurangan Emisi Deforestasi Tropis (Tropical Deforestation Emissions Reduction Mechanism/ TDERM), yang merupakan turunan model dana terkait pasar bagi REDD+ (Parker dkk. 2009b).

\section{Hutan dan hak azasi: sosial hijau}

Ideologi sosial hijau terutama didasarkan pada pemikiran sosial dan ekonomi; argumennya adalah masyarakat dan lingkungan tidak dapat dianggap sebagai bagian yang terpisah. Karena itu, menurut ideologi ini REED+ harus menyeimbangkan tujuan pengurangan emisi dengan kesejahteraan masyarakat hutan, termasuk partisipasi, hak dan pengetahuan mereka. Laporan yang disampaikan Friends of the Earth International kepada UNFCCC merangkum pemikiran ini, yang menyatakan bahwa "memastikan hak dan kepentingan masyarakat adat dan masyarakat lokal dalam rancangan REDD adalah lebih dari sekedar suatu kebijakan negara. Pendekatan berbasiskan hak juga akan berkontribusi bagi keefektifan dan kelanggengan program-program REDD" (FOEI 2009).

Diambil dari: Hirado dan Tanner (2011b)

Cakupan REDD+ merupakan isu yang diperdebatkan. Degradasi hutan - D yang kedua - dimasukkan dalam definisi UNFCC untuk REDD+ pada tahun 2007, mengingat fakta bahwa bagian besar dari emisi hutan merupakan akibat degradasi. Namun pengikutsertaan tersebut hanya terjadi setelah banyak tekanan, termasuk dari negara-negara Komisi Hutan Afrika Tengah (Central African Forests Commission). Selain itu, tiga elemen pelengkap ditambahkan ke dalam definisi REDD+ untuk menampung kepentingan yang berbeda: i) konservasi, untuk menampung kepentingan negara-negara yang deforestasinya rendah dan hutannya luas serta sejumlah LSM lingkungan hidup; ii) pengelolaan hutan lestari, untuk menampung kepentingan negara-negara yang memiliki pendekatan pemanfaatan hutan yang aktif; dan iii) peningkatan cadangan karbon hutan, untuk menampung kepentingan negara yang cadangan karbonnya sedang berkembang, seperti India dan China. Cakupan perdebatan kebanyakan mencerminkan situasi hutan yang berbeda di masing-masing negara dan bagaimana mereka dapat mengambil manfaat dari rezim REDD+ internasional.

Selain melibatkan Para Pihak dalam UNFCCC, negosiasi REDD+ juga dicirikan oleh kehadiran kuat berbagai LSM dan kelompok adat mengenai isu terkait hak-hak lokal dan adat serta jaringan pengaman (Bab 17). Berbagai LSM menuntut, dan pada banyak kasus telah memperoleh tempat di meja 
diskusi tingkat global maupun negara. Hal ini memengaruhi definisi dan fokus REDD+, misalnya penetapan jaringan pengaman sebagai isu utama, dan juga telah memperluas tujuan dan cakupan REDD+ (lihat di bawah).

Dampak terpenting negosiasi iklim yang sejauh ini bagi REDD+ mungkin adalah karena apa yang tidak mereka capai, yaitu kesepakatan iklim global yang menjanjikan pendanaan jangka panjang dalam jumlah besar, misalnya melalui sistem pembatasan dan perdagangan (cap and trade system) dengan kredit REDD+ sebagai pengganti kerugian. Karena itu, sampai saat ini pendanaannya masih kurang dari yang dibayangkan dan telah didominasi oleh sumber-sumber nonpasar, yang menyebabkan REDD+ lebih jauh lagi memperluas tujuan dan cakupannya.

\subsubsection{Arena bantuan pembangunan}

Bersamaan dengan negosiasi UNFCCC, para pelaku di arena bantuan pembangunan telah kuat pengaruhnya dalam pengembangan REDD+. Kebanyakan aliran uang diputuskan dalam arena ini melalui kesepakatan bilateral, melalui berbagai lembaga multilateral dan kegiatan berbagai LSM besar, yang juga mendominasi proyek-proyek uji coba REDD+ (lihat Bab 12).

Beberapa inisiatif juga telah muncul di layar multilateral. FCPF, yang mulai beroperasi bulan Juni 2008, telah membentuk sebuah kerangka kerja dan proses kebijakan untuk negara-negara yang berpartisipasi yang membantu mereka menyiapkan diri untuk fase ketiga REDD+ dengan insentif keuangan berbasiskan hasil. Saat ini, 37 negara menerima dukungan dari FCPF. ${ }^{6}$ Program UN-REDD diluncurkan pada September 2008. Sebagai sebuah kolaborasi antara FAO, UNEP dan UNDP, program ini bermaksud untuk membantu negara-negara berkembang dalam menyiapkan dan menerapkan strategi-strategi REDD+. Saat ini, sebanyak 14 negara telah menerima dukungan dari program UN-REDD untuk program-program nasional ${ }^{7}$ mereka. FIP menyediakan pendanaan untuk peningkatan pembiayaan proyek dan investasi yang diidentifikasi melalui strategi nasional REDD+.

Selain pendanaan dari sejumlah lembaga multilateral, ada juga beberapa inisiatif bilateral. Norwegia sejauh ini merupakan pendukung pembiayaan terbesar untuk inisiatif-inisiatif seperti itu, melalui kesepakatan AS \$1 miliar dengan Brasil (2009) dan Indonesia (2010). Meskipun ada komitmen yang dinyatakan terkait hubungan donor, seperti halnya dari Busan, ${ }^{8}$ para donor yang mendanai REDD+ sering menggunakan prosedur-prosedur dan praktik mereka sendiri.

6 http://www.forestcarbonpartnership.org, diakses pada 3 April 2012.

7 www.un-redd.org, diakses pada 3 April 2012.

8 Konferensi keempat mengenai Keefektifan Bantuan Pembangunan, Busan. Desember 2011, lihat http://www.aideffectiveness.org/busanhlf4/. 
Kemitraan multilateral REDD+ dibentuk pada bulan Mei 2010, setelah COP15 di Kopenhagen yang mengecewakan, untuk menjadi "suatu landasan sementara bagi negara-negara mitra untuk meningkatkan tindakan dan pembiayaan untuk inisiatif-inisiatif [REDD+]." Tujuannya adalah untuk menyediakan suatu forum informal untuk diskusi, meningkatkan koordinasi donor, dan mempertahankan momentum REDD+ serta mungkin menyelesaikan sejumlah isu yang masih belum terselesaikan. Namun demikian, konflik-konflik tradisional telah terbawa ke dalam forum ini.

Setelah bergeser ke arah bantuan pembangunan, REDD+ dipengaruhi oleh keragaman pelaku, berbagai tujuan dan bentuk bantuan pembangunan yang mencirikan arena ini; isu ini yang akan kami bahas kembali dalam bagian 3.4.1.

\subsubsection{Arena kebijakan nasional}

REDD+ telah memunculkan perdebatan aktif dan ketidaksepakatan di antara beberapa negara penerimanya (Bab 5). Kebanyakan pemerintah terlihat positif, namun sejumlah kecil tidak demikian, terutama Bolivia setelah tahun 2009. ${ }^{10}$ Negara-negara REDD+ telah menerima dukungan eksternal yang kuat, dan sebagai akibatnya, diakui atau tidak, sejumlah lembaga multilateral dan negara-negara donor telah menjadi para pelaku politik pada ajang nasional.

Dengan mengasumsikan bahwa peluang dan biaya-biaya lain akan mendapat kompensasi penuh, berbagai tindakan REDD+ akan - pada prinsipnya - hanya memunculkan pemenang. Namun tidak demikian dalam praktiknya: berbagai mekanisme pembagian manfaat yang dibayangkan (Bab 8) tidak dapat menjamin bahwa tidak satupun pihak akan dirugikan. Tentunya, di tingkat nasional maupun lokal, REDD+ dianggap menghambat pertumbuhan ekonomi (Bab 11). Para pelaku ekonomi dan politik yang berkuasa dan terlibat di bidang pertanian, kehutanan dan pertambangan komersial memandang REDD+ sebagai ancaman bagi kepentingan mereka (Brockhaus dkk. 2012). Saat ini masih terlalu awal untuk menilai bagaimana kepentingan bisnis seperti biasa akan memengaruhi rancangan dan implementasi kebijakan REDD+ nasional. Namun kontroversi baru-baru ini tentang moratorium konversi hutan di Indonesia dan Forest Code di Brasil menunjukkan bahwa gagasan inti REDD+ (yang akan mendorong perubahan transformatif dalam bentuk reformasi kebijakan nasional secara luas yang akan memengaruhi insentif yang mendasarinya) mungkin telah diperlemah. Kemudian REDD+ mungkin akan dipaksa untuk mundur agar tidak terlalu mengancam kebijakan sektor kehutanan dan proyek-proyek lokal.

9 http://reddpluspartnership.org/en/.

10 Walaupun ada resistensi terhadap REED, Bolivia telah mengambil langkah untuk mengurangi emisi dari deforestasi, dan dengan demikian telah melaksanakan REDD+, namun dengan nama lain. 


\subsubsection{Realitas lokal}

Sementara pembahasan tentang REDD+ global telah berlangsung intensif, kemajuan di tingkat lokal berlangsung lambat. Bahkan proyek-proyek uji coba, yang dimulai dalam skala kecil dan biasanya dengan keterlibatan LSM, biasanya membutuhkan waktu yang lebih banyak untuk menerapkannya daripada yang direncanakan, seperti yang ditunjukkan oleh GCS CIFOR (Bab 10). Hal ini sebagian terjadi karena tugas yang menantang untuk klarifikasi batas dan status lahan (Bab 9). Perumusan hukum yang baru, dan jika dibutuhkan, institusi yang baru memerlukan waktu. Akibatnya, tahapan yang dimaksudkan berikutnya - peningkatan skala - menjadi terlambat.

Masyarakat lokal sering berpandangan positif tentang REDD+, karena harapan mereka untuk mendapatkan pemasukan darinya. Namun demikian, temuan yang disajikan dalam Bab 11 menunjukkan bahwa para penduduk desa sebagian besar memandang REDD+ sebagai upaya konservasi hutan. Ketidakpastian tentang seberapa besar dan bentuk manfaat yang akan diberikan oleh REDD+ terlihat jelas: secara umum tidak ada kebijakan nasional yang disepakati tentang kapan, berapa besar dan bagaimana masyarakat lokal akan dibayar. Berbagai proyek uji coba dapat melakukan pembayaran ini, namun tidak ada jaminan bahwa preseden ini akan berlanjut di masa depan. Sementara verifikasi pihak ketiga sering menuntut Persetujuan sukarela setelah menerima Informasi sebelumnya (FPIC) oleh masyarakat lokal (lihat Bab 17), dalam banyak kasus pertanyaan mendasarnya - 'persetujuan untuk apa?' - masih belum terjawab. Sampai pemerintah nasional dapat menetapkan apakah pembayaran atau manfaat lain yang, jika ada, akan diterima oleh masyarakat lokal, FPIC tampaknya akan merupakan prasyarat yang tidak mungkin dipenuhi. Karena itu ada risiko besar bahwa harapan tinggi masyarakat di tingkat lokal tidak akan terpenuhi, yang menjurus ke kekecewaan dan bahkan mungkin penolakan terhadap program ini.

Singkatnya, manfaat yang akan diberikan oleh REDD+ di tingkat lokal, yang secara langsung berdampak pada mata pencaharian masyarakat, masih tidak jelas. Pada satu sisi dari berbagai kemungkinan, masyarakat lokal akan mendapatkan manfaat, baik melalui kepastian hak mereka atas hutan dan melalui menerima kompensasi keuangan yang besar atas usaha mereka untuk mengurangi deforestasi dan degradasi hutan. Pada sisi yang lain, sebuah skenario 'terburuk', hal yang dikhawatirkan oleh sejumlah kelompok masyarakat desa dan hak adat, tidak hanya bahwa mereka menerima sedikit pembayaran atau tidak sama sekali, bahkan mereka akan kehilangan hak tradisional mereka atas sumberdaya hutan. 


\subsection{Evolusi REDD+: Empat tren utama}

Setelah konsensus besar awal tentang gagasan REDD+, konsep ini telah disesuaikan dan dikonfigurasi ulang sebagai akibat sejumlah konflik kepentingan yang bermunculan dan tidak adanya kesepakatan iklim internasional yang baru. Fokus bagian ini adalah empat tren utama dalam evolusi gagasan REDD+ dan bagaimana perubahannya, dalam hal tujuan, kebijakan, skala dan pendanaan, sejak REDD+ memasuki diskusi iklim global tahun 2005.

\subsubsection{Dari satu tujuan menjadi multitujuan}

Tujuan akhir UNFCCC, seperti dinyatakan dalam Pasal 2, adalah "stabilisasi konsentrasi GRK di atmosfer pada tingkat yang akan mencegah intervensi antropogenis yang membahayakan sistem iklim" (UNFCCC 1992). Pada awalnya, ini juga merupakan tujuan utama dari REDD+. Setelah 2005, tujuan lain ditambahkan, seperti perlindungan keanekaragaman hayati dan penurunan kemiskinan/meningkatkan mata pencaharian lokal. Selanjutnya lebih banyak lagi manfaat tambahan yang ditambahkan: memperkuat hak-hak adat, tata kelola yang lebih baik, dan kapasitas yang lebih tinggi untuk adaptasi iklim. REDD+ juga semakin banyak dikaitkan dengan agenda pertanian-iklim. Karena itu, REDD+ telah bergerak dari satu tujuan menjadi multitujuan; ilustrasi ironis dari hal ini adalah judul sebuah acara tambahan REDD+ dalam COP17 di Durban bulan Desember 2011: 'Karbon sebagai manfaat tambahan' (Carbon as a co-benefit)!

Tekanan untuk memasukkan keanekaragaman hayati ke dalam REDD+ sebagian besar berasal dari LSM konservasi internasional berskala besar. Sementara tujuan iklim dan keanekaragaman hayati bersifat tumpang tindih (Strassburg dkk. 2010), aliran pendanaan baru untuk proyek-proyek REDD+ juga menyediakan peluang untuk mendanai kegiatan-kegiatan konservasi yang sedang berjalan (dimodifikasi jika perlu). Dorongan untuk memasukkan tujuan-tujuan pembangunan dalam REDD+ berasal dari beberapa sumber. Berbagai LSM pembangunan telah memainkan peran yang sama dalam arena REDD+ seperti yang dimainkan oleh berbagai LSM lingkungan hidup dalam negosiasi keanekaragaman hayati. Selain itu, kebanyakan pendanaan internasional untuk REDD+ berasal dari anggaran bantuan pembangunan, yang tujuan utamanya adalah pembangunan dan penurunan kemiskinan.

Banyak pihak mengkhawatirkan bahwa REDD+ menjadi terlalu terbebani oleh berbagai tujuan yang baik sehingga akan mengurangi keefektifannya. Kami juga mengkhawatirkan hal ini, namun juga berargumen bahwa kunci keberhasilan utama REDD+ terletak pada kombinasi antara tujuan konservasi dan pembangunan bagi pembangunan berkelanjutan. Baik dalam arena kebijakan nasional maupun implementasi lokal, REDD+ harus terwujud agar tujuannya tercapai (Bab 2, 5, dan 11). 


\subsubsection{Dari PES menuju kebijakan yang lebih luas sampai ke kebijakan hutan dan proyek?}

Pada awalnya REDD+ digambarkan sebagai sistem PES multitingkat (Angelsen dan Wertz-Kanounnikoff 2008), yang memiliki sejumlah keunggulan penting. Berbagai insentifnya kuat dan langsung (Wunder 2005). Mengingat PES bersifat sukarela, pengguna hutan akan memilih konservasi hanya jika manfaat bersihnya lebih tinggi dari manfaat eksploitasi hutan lainnya. Dengan demikian hasil yang bersifat menang-menang akan bisa dipastikan, setidaknya secara teoritis.

Pembentukan pasar untuk jasa lingkungan mengandalkan empat unsur penting: ketersediaan komoditas atau jasa yang dapat dikuantifikasi, pembeli, penjual dan pasar berikut aturan dan peraturan yang terkait (lihat Kotak 3.2). Sejumlah unsur ini belum tersedia di kebanyakan negara REDD+: komoditasnya sulit untuk dikuantifikasi, penjualnya belum diketahui dengan baik, tidak ada pembeli besar dan aturan permainan belum ditetapkan dengan baik. Karena itu, merancang dan menerapkan suatu sistem yang secara langsung menguntungkan pengurangan emisi (dan penyerapan karbon) oleh individu, rumah tangga, maupun kelompok-kelompok tetap menjadi rintangan utama.

Selain berbagai isu praktis terkait penerapan suatu sistem PES, pertentangan ideologis juga harus dihadapi. Berangkat dari tradisi lama seperti dalam Polanyi (1994), REDD+ telah dikritik sebagai contoh meningkatnya privatisasi dan pemasaran alam (Lohmann 2012:85). Bagi pihak tertentu, PES mencerminkan sebuah sistem dari "kapitalisme di dalam hutan," 11 yang memberikan potensi bagi para elite untuk menetapkan hak karbon dan pembagian manfaatnya.

Sementara kekhawatiran tersebut mungkin tidak sepenuhnya dapat dibenarkan, REDD+ memang merupakan suatu paradoks. Sementara berupaya menurunkan kemiskinan dan meningkatkan kehidupan masyarakat miskin dengan memberikan kompensasi kepada mereka untuk mengurangi emisi karbon, dalam kenyataannya, para pelaku komersial berskala besar, bukan pelaku miskin, yang bertanggung jawab untuk bagian terbesar deforestasi yang terjadi (Rudel 2007). Karena itu, bagian terbesar dari pendanaan seharusnya - sesuai dengan prinsip ini REDD+ - ditujukan bagi para perusahaan dan masyarakat yang tidak miskin. Namun demikian, pengamatan awal mengenai kebijakan REDD+ menunjukkan bahwa para pelaku komersial besar ini tidak akan mendapatkan kompensasi penuh untuk biaya peluang mereka; pembelajaran awal dari program-program PES menunjukkan bahwa REDD+ memiliki bias yang berpihak kepada kaum miskin (Bond dkk. 2009).

11 Slogan pada tombol-tombol yang terlihat dalam sejumlah pertemuan iklim. 


\section{Kotak 3.2 Sejumlah prasyarat bagi pasar untuk kredit REDD+}

Pasar untuk kredit REDD+ (atau sistem PES untuk mengurangi deforestasi dan degradasi hutan) bersandar pada empat pilar:

Komoditas yang terkuantifikasi: komoditas atau jasa yang diperdagangkan dalam pasar karbon adalah pengurangan emisi. Pengurangan emisi didefinisikan sebagai perbedaan antara emisi yang sebenarnya dengan acuan bisnis seperti biasa. Karena itu, komoditas memiliki dua aspek: i) emisi yang sebenarnya harus terukur, dilaporkan dan terverifikasi; dan ii) titik acuan harus ditetapkan melalui suatu acuan bisnis seperti biasa untuk memungkinkan pengukuran dampak emisi atau penyerapan karbon sebagai hasil dari tindakan-tindakan REDD+ oleh penyedia jasa. Lebih rumit lagi, para pihak mungkin sepakat untuk menetapkan landasan untuk pembayaran secara berbeda dari acuan bisnis seperti biasa, berdasarkan pertimbangan pemanfaatan dana REDD+ yang terbatas, secara efektif dan efisien atau tanggung jawab yang dibedakan (Bab 16).

Sejumlah penjual (penyedia jasa): Siapakah para penyedia jasa, dan - khususnya - siapakah yang berhak untuk menjual pengurangan emisi dari hutan? Dalam skema yang ideal, pemilik karbon hutan adalah para penjual, yang akan ditetapkan sesuai hukum nasional. Sementara hal ini menimbulkan pertanyaan besar yang terkait dengan pembagian keuntungan (Bab 8), setidaknya secara konseptual hal ini sederhana. Sejumlah isu yang lebih rumit muncul ketika REDD+ diterapkan di tingkat nasional melalui sejumlah kebijakan yang luas, misalnya pembentukan kawasan konservasi atau moratorium konversi pemanfaatan lahan Indonesia (Kotak 2.1). Siapa yang berhak menerima pembayaran internasional apapun untuk pengurangan emisi: petani kecil dan perusahaan kelapa sawit yang kehilangan pendapatan, sejumlah lembaga yang menerapkan kebijakan atau masyarakat luas?

Sekelompok pembeli: Para pembeli kredit REDD+ akan berasal dari tiga sumber utama: i) pendanaan publik, termasuk bantuan pembangunan, dalam suatu sistem berbasiskan kinerja; ii) pendanaan sukarela swasta, seperti dalam pasar sukarela; dan iii) entitas publik atau swasta yang membeli kredit REDD+ untuk mematuhi pembatasan emisi dengan menggunakan REDD+ sebagai skema ganti rugi. Pendanaan REDD+ sejauh ini termasuk ke dalam kategori i), sementara potensi untuk pendanaan berskala besar sebagian besar ditemukan dalam kategori iii) (Bab 7).

Institusi pasar yang telah terbentuk: Aturan dan peraturan memberikan landasan hukum bagi pasar karbon atau PES. Sejumlah lembaga dibutuhkan untuk mengatur aliran informasi mengenai perubahan cadangan karbon hutan 


\section{Kotak 3.2 Lanjutan}

dan aliran uang untuk memberikan penghargaan atas perubahan ini. Dua lembaga dibutuhkan untuk membuat sistem ini berfungsi: sebuah badan mandiri yang melakukan verifikasi atau mengeluarkan sertifikat pengurangan emisi dan suatu mekanisme serta otoritas untuk mengatur aliran uang REDD+ yang memberikan insentif dan kompensasi untuk perubahan ini. Sejumlah lembaga ini harus memiliki otonomi dari pemerintah untuk memastikan keobjektifan dan transparansi mereka. Membangun suatu jalur yang dapat dipercaya untuk pendanaan internasional memerlukan banyak waktu dan bersifat sensitif secara politis, yang dapat menjelaskan kesenjangan yang ada terus dalam pendanaan maupun penyaluran dana dalam REDD+ (Bab 7).

Banyak pemrakarsa proyek yang mengadopsi suatu model turunan (Bab 10), di mana pembayaran kepada masyarakat setempat hanya merupakan salah satu dari beberapa elemen strategi mereka. Di tingkat nasional, REDD+ telah lama diakui harus bergerak lebih jauh dari PES untuk memasukkan rangkaian kebijakan yang luas. Inilah pesan utama dalam buku CIFOR sebelumnya, 'Mewujudkan REDD+' (Angelsen dkk. 2009), yang membedakan tiga rangkaian kebijakan yang luas, yang berupaya untuk menciptakan insentif bagi konservasi hutan:

1. Kebijakan yang berdampak pada rente pertanian, yaitu keuntungan dari konversi hutan, seperti halnya subsidi dan pajak pertanian, perubahan teknologi dan infrastruktur

2. Kebijakan yang mengatur rente hutan dan peraupan rente tersebut oleh pengguna hutan melalui berbagai skema seperti PES dan pengelolaan hutan oleh masyarakat

3. Peraturan langsung, dalam bentuk penetapan dan penegakan kawasan yang dilindungi, perencanaan tata guna lahan dan kebijakan konsesi.

Beberapa kebijakan tersebut bertentangan dengan tujuan lainnya, termasuk tujuan untuk meningkatkan produksi pertanian dan keamanan pangan, sehingga secara politis sulit untuk diimplementasikan (Angelsen 2010b). Lebih lanjut lagi, bahkan jika keuntungan bersih bagi masyarakat adalah positif, reformasi kebijakan semacam itu akan menciptakan pemenang dan pihak yang kalah, dengan pihak yang kalah sering berpotensi memiliki kekuasaan yang cukup untuk menghambat reformasi (Bab 5).

Di tingkat nasional, tampaknya terlalu awal untuk memperkirakan kebijakan REDD+ yang manakah yang akan ditempuh oleh suatu negara. Pengamatan awal kami menunjukkan penekanan untuk memperkuat institusi tingkat lokal, mendorong partisipasi dan memastikan hak, intensifikasi pertanian dan 
perencanaan penggunaan lahan, termasuk kebijakan konsesi dan kawasan konservasi. Berbagai skema PES terutama berada pada tahap uji coba, dan pada skala lokal, dengan beberapa pengecualian yang jelas terlihat di beberapa negara Amerika Latin sebelum ada REDD+ (misalnya, Kaimowitz 2008).

Secara singkat, REDD+ seharusnya terutama didorong oleh PES. Walaupun kebanyakan pendukung di tingkat lokal bermaksud untuk menerapkan PES atau sistem serupa PES, bentuknya mungkin berupa skema pembayaran yang umum, dan bukan insentif khusus bagi individu pengguna untuk mengurangi deforestasi dan degradasi hutan. Reformasi kebijakan nasional juga diserukan, namun bersifat kontroversial; para pihak berkuasa yang berpotensi kalah dapat menghambatnya. Namun ada juga tren yang menggembirakan, termasuk integrasi agenda pertanian dan kehutanan dan integrasi REDD+ dalam perencanaan pembangunan rendah karbon. Risikonya, hasil akhirnya akan berupa sejumlah kecil kebijakan yang terbatas dalam situasi menang-menang dan fokusnya sempit pada kebijakan sektor kehutanan dan proyek-proyek lokal saja.

\subsubsection{Dari fokus nasional menuju ke proyek - dan kembali lagi?}

Prinsip utama ketika RED(D) diluncurkan adalah fokus nasional yang kuat, dan bukan subnasional. Prinsip ini didukung oleh sebagian besar kesediaan negara awal untuk mendukung UNFCCC (Guizol dan Atmadja 2008), bukan hanya atas dasar kedaulatan, tetapi juga karena pendekatan nasional dianggap lebih efektif (Bagian 2.2). REDD+ dianggap sebagai pergeseran penting dari proyek berbasiskan konservasi sebelumnya: sekarang pemerintah nasional akan menjadi pelaku utama dalam konservasi hutan.

Sejauh ini (walaupun ini masih dalam tahap awal), REDD+ belum membawa pergeseran tersebut. Kebanyakan pendanaan REDD+ telah diberikan kepada berbagai inisiatif lokal dan subnasional. Beberapa faktor dapat menjelaskan perkembangan ini. Pertama, seperti dijelaskan di atas dan dalam Bab 5, reformasi tingkat nasional sering memunculkan situasi menang-kalah, dengan kelompok berkuasa menghadapi kekalahan. Kedua, ketersediaan komitmen donor yang besar menciptakan tekanan untuk menghabiskannya dengan cepat, yang disambut dengan kesiapan LSM konservasi dan pembangunan untuk menerapkan berbagai proyek (pendanaan yang masih menjadi sumber dana utama bagi sejumlah LSM, walaupun mereka terlibat kuat dalam perdebatan kebijakan). Ketiga, donor lebih memilih mendanai proyek atau program yang konkret, dibandingkan reformasi kebijakan yang lebih sulit untuk memantau uang dan untuk meyakini penggunaan akhirnya (lihat Bab 13).

Namun demikian, temuan awal dari proyek GCS CIFOR menunjukkan bahwa pergeseran fokus dari nasional menuju ke proyek mungkin tidak akan 
berlanjut. Proyek-proyek REDD+ - seperti yang telah banyak dilakukan sebelumnya - menemukan bahwa tindakan yang efektif di lapangan terhambat atau terkendala oleh kebijakan dan institusi nasional. Hal ini digambarkan oleh kasus penguasaan lahan, yang dibahas secara rinci dalam Bab 9. Karena itu, tekanan untuk reformasi tingkat nasional akan berlanjut, dan lebih banyak tindakan diperlukan untuk memungkinkan keterkaitan antara kegiatan subnasional dan rancangan kebijakan tingkat nasional (Bab 6).

\subsubsection{Pendanaan: Dari pasar menuju ke sumber-sumber publik internasional dan kontribusi nasional}

Dalam laporan mereka kepada UNFCCC selama 2007-2008, kebanyakan negara menginginkan pendekatan pendanaan ganda: sumber-sumber publik akan menyediakan pendanaan berjangka pendek untuk peningkatan kapasitas, sementara pendanaan jangka panjang untuk pembayaran berbasiskan hasil akan berasal dari pasar (Guizol dan Atmadja 2008). Rencana Aksi Bali 2007, di mata para pelaku utama, adalah rencana untuk menjadikan REDD+ bagian dari kesepakatan iklim global, dengan kredit REDD+ digunakan sebagai kompensasi dalam sistem pembatasan dan perdagangan (cap and trade) global. COP15 di Kopenhagen tahun 2009 gagal menghasilkan kesepakatan ini. Pada bulan April 2009, atas undangan Pangeran Charles, 21 pemimpin dunia bertemu untuk membentuk Kelompok Kerja Informal - Pembiayaan Sementara untuk REDD+ (IWG-IFR 2009). Inisiatif ini merupakan respon langsung atas kebutuhan pendanaan REDD+ "sampai pasar karbon dapat mengambil alih", seperti disampaikan oleh seorang peserta dalam proses tersebut kepada salah satu penulis bab ini. Sementara pada waktu itu pengambilalihan diharapkan akan terjadi tahun 2013, Landasan Durban/ Durban Platform (COP17) menunjukkan bahwa hal ini tidak akan terjadi sebelum 2020.

Alasan utama keterlambatan pendanaan pasar bagi REDD+ terkait dengan tidak adanya kesepakatan iklim global yang memasukkan kredit REDD+, baik sebagai mekanisme pengganti kerugian maupun secara tidak langsung, seperti melalui pelelangan perolehan emisi untuk menghasilkan penerimaan bagi dana REDD+ global. Dari dua pasar karbon regional yang berpotensi besar, Layanan Perdagangan Emisi Uni Eropa (EU Emission Trading Service) tidak memasukkan REDD+, sementara pasar karbon Amerika Serikat masih belum terwujud. Namun demikian, pasar karbon regional yang lebih kecil bisa jadi secara bertahap menyediakan pendanaan bagi REDD+ (Bab 7).

Pendanaan pasar bersifat kontroversial, khususnya ketika kredit REDD+ digunakan sebagai pengganti kerugian (yaitu untuk memungkinkan suatu negara atau perusahaan untuk diperhitungkan sebagai bagian dari kewajiban pengurangan emisi mereka). Sebagian pertentangan ini bersifat ideologis, dengan alasan bahwa merupakan hal yang tidak bermoral untuk membayar 
pihak lain agar dirinya sendiri dapat terus melakukan polusi. Kekhawatiran lainnya berkaitan dengan banjir pasar, yaitu kredit REDD+ murah yang dapat menurunkan harga pasar karbon dan menghilangkan mitigasi dalam sektor bahan bakar fosil. Tantangan utamanya adalah untuk mengatur laju pengenalan kredit REDD+ ke dalam pasar karbon dengan menyesuaikan pembatasan secara keseluruhan ketika sistem kredit ini diperkenalkan (Angelsen dkk. 2012).

Harapan pendanaan dari sektor swasta juga tinggi; namun sekali lagi, ini berlandaskan pada asumsi yang kurang berdasar. Pendanaan swasta dapat dibagi ke dalam tiga kategori: i) tanggung jawab sosial perusahaan; ii) investasi yang menghasilkan keuntungan; dan iii) pengganti kerugian untuk mematuhi peraturan pemerintah. Besarnya pendanaan dari tanggung jawab sosial perusahaan untuk REDD+ hanya terbatas, dan jauh lebih sedikit daripada yang diperkirakan oleh hubungan masyarakat (humas) dan liputan media. Pasar sukarela relatif sehat, namun volume keseluruhannya kecil dan tampaknya akan tetap demikian (Diaz dkk. 2011). Peluang bisnis yang menguntungkan dalam penghindaran deforestasi dan degradasi hutan mungkin terdapat dalam bentuk pemanfaatan hutan secara nonkonsumtif (misalnya, kopi yang tumbuh di bawah tegakan), namun bukan merupakan 'buah yang menggantung rendah'. Sumber potensi pendanaan swasta yang utama adalah dari pengganti kerugian. Namun, seperti diketahui, hal ini mengandalkan keberadaan pembatasan emisi yang ketat dan pembukaan untuk pengganti kerugian dalam REDD+.

Karena itu, pendanaan internasional utama untuk REDD+ dalam jangka pendek sampai menengah harus berasal dari sumber-sumber publik di negara-negara Annex I. Sejauh ini duapertiga dari pendanaan publik internasional berasal dari bantuan pembangunan melalui jalur-jalur bilateral dan multilateral (lihat Bab 7 untuk gambaran umum tentang sumber-sumber pendanaan).

Selain pergeseran fokus dari pasar menjadi sektor publik, perkembangan utama kedua dalam pemikiran tentang pendanaan REDD+ adalah pergeseran dari Utara ke Selatan, dari negara-negara Annex I ke nonAnnex I. Rencana Aksi Bali (UNFCCC 2007) menekankan bahwa REDD+ berkenaan dengan "pendekatan kebijakan dan insentif positif ..."; insentif positif ditafsirkan oleh banyak pihak sebagai kompensasi penuh bagi negara-negara berkembang. Hal ini berbeda nyata dengan Landasan Durban/Durban Platform (UNFCCC 2011d), yaitu “...memutuskan untuk meluncurkan proses untuk mengembangkan suatu protokol, instrumen hukum yang lain atau hasil yang disepakati dengan kekuatan hukum di bawah UNFCCC yang berlaku bagi semua Pihak..."(penekanan ditambahkan). Keputusan ini dapat berakhir menjadi ajang yang penting dalam negosiasi iklim, termasuk bagi REDD+. Pergeseran dari REDD+ yang didominasi oleh sistem pembayaran dari Utara 
ke Selatan untuk pengurangan emisi hutan menjadi sesuatu yang dipandang sebagai suatu tanggung jawab bersama, disebabkan oleh beberapa faktor.

Pertama, perbedaan antara negara Annex I dan nonAnnex I sudah tidak berlaku lagi. Sejumlah negara nonAnnex I saat ini memiliki pendapatan per kapita yang lebih tinggi daripada negara termiskin dalam Annex I. Misalnya, China, sebuah negara nonAnnex I, sekarang menduduki posisi pertama dalam emisi GRK dan banyak negara nonAnnex I lain emisi per kapitanya lebih tinggi daripada negara dengan emisi terendah dalam Annex I (IFA 2011). Kebanyakan perkembangan emisi di masa depan akan berasal dari negara-negara nonAnnex I dengan penghasilan menengah dan pertumbuhan yang cepat dan tampaknya sulit untuk memenuhi target membatasi kenaikan suhu global sampai dua derajat tanpa adanya komitmen yang kuat dari negara-negara ini. Kedua, banyak negara berpenghasilan menengah yang telah memberi komitmen dan mengembangkan strategi untuk mengurangi emisi dibandingkan dengan skenario bisnis seperti biasa. ${ }^{12}$ REDD + diikutsertakan ke dalam berbagai strategi pembangunan rendah karbon nasional ini. Ketiga, mekanisme internasional tampaknya tidak mampu untuk mengompensasi sepenuhnya negara berkembang untuk biaya REDD+. Bukan hanya pendanaan yang tidak cukup, namun juga kurangnya kemauan - baik di tingkat nasional maupun internasional - untuk sepenuhnya mengompensasi industri pertanian atas kehilangan pendapatan dari menghentikan bisnis seperti biasa atas konversi hutan. Karena itu, sebagian besar dari biaya peluang untuk REDD+ yang sukses tampaknya akan ditanggung oleh, misalnya penghasil kelapa sawit dan kedelai. Keempat, REDD+ tidak akan berhasil tanpa komitmen kuat dari negara-negara REDD+.

Singkatnya, banyak biaya REDD+ yang akan ditanggung oleh pelaku domestik, termasuk pemerintah di berbagai tingkatan, yang bertanggung jawab untuk perencanaan dan pelaksanaan REDD+ dan mungkin juga untuk membayar kompensasi atas kesempatan yang hilang. Selain itu, ada kemungkinan bahwa sejumlah pelaku domestik - seperti industri pertanian dan perusahaan tambang - tidak akan mendapatkan kompensasi untuk biaya kesempatan mereka.

\subsection{Mengapa perubahan REDD+ penting?}

REDD+ telah mengalami sejumlah perubahan penting karena tiga alasan utama. Pertama, suatu proses pembelajaran dan pendewasaan telah berlangsung. Beberapa gagasan awalnya terbukti tidak realistis, misalnya pembentukan sistem PES yang cepat dan dapat sepenuhnya memberikan insentif dan kompensasi bagi para pengguna hutan untuk pengurangan

12 http://www.unep.org/climatepledges/. 
emisi. Namun demikian gagasan ini telah memicu semangat awal REDD+, dan optimisme ini - yang bersebelahan dengan kenaifan - mungkin telah mendorong pembentukan koalisi baru dan solusi inovatif bagi sejumlah permasalahan iklim yang hangat.

Kedua, REDD+ secara optimis diharapkan untuk menjadi bagian dari kesepakatan iklim internasional yang akan memunculkan sumber-sumber utama pendanaan melalui pasar karbon. Perwujudannya telah tertunda setidaknya sampai 2020, yang berarti bahwa pendanaan REDD+ mungkin tidak akan pernah mencapai skala seperti yang dibayangkan sebelumnya. Akibatnya, kebijakan REDD+ akan perlu mencerminkan fakta bahwa kompensasi akan menjadi terlalu mahal dan kebanyakan pendanaan internasional untuk jangka pendek dan menengah akan berasal dari anggaran bantuan pembangunan, dengan tujuan dan logika mereka sendiri, dan dari sumber-sumber domestik.

Ketiga, dua kekuatan telah memodifikasi gagasan REDD+: kepentingan bisnis seperti biasa telah membentuk suatu oposisi kuat bagi reformasi kebijakan dan memiliki ruang aksi politik yang terbatas. Pada saat yang sama, para pendukung REDD+ memiliki kepentingan yang sangat berbeda, sehingga tujuan akhir maupun makna REDD+ telah mengalami konfigurasi ulang: misalnya, beberapa LSM telah mendorongnya sebagai alat untuk memastikan hak-hak adat atas lahan.

REDD+ bukan merupakan gagasan konsisten yang didefinisikan dengan jelas. Jika REDD+ benar-benar berbasiskan pasar, maka akan diperlukan definisi yang disepakati: setiap orang yang menjual atau membeli harus memiliki pemahaman yang sama dan komoditas berstandar untuk diperdagangkan. Karena hal ini tidak terjadi, makna REDD+ dapat ditafsirkan secara berbeda sehingga terus dinegosiasikan oleh kepentingan yang berbeda di tingkat internasional, nasional dan lokal. Negara-negara kaya bisa jadi berkepentingan untuk mencoba mencapai kesepakatan tentang apa yang seharusnya dilakukan REDD+, namun proses untuk mencapai kesepakatan semacam ini tidak jelas. Negara-negara yang dibayar karena mengurangi emisi mereka bisa jadi berkepentingan untuk tidak memerlukan pemahaman yang sama dan mereka tentunya memiliki tingkat kekuasaan yang berbeda untuk menentukan bagaimana REDD+ dilaksanakan. Selama satu atau beberapa negara kaya (atau yayasan atau perusahaan) bersedia untuk membayar mereka untuk mengurangi emisi, mengapa mereka perlu menyepakati suatu praktik umum yang berlaku untuk semua?

Di mana kita berada sekarang? REDD+ tampaknya telah kehilangan beberapa ciri khas awalnya yang membuatnya menjadi suatu hal baru dan membangkitkan suatu harapan yang tinggi. Sekarang REDD+ berisiko kehilangan ciri khas pentingnya yaitu pembayaran berbasiskan hasil 
dan reformasi tingkat nasional dan hanya menjadi suatu bentuk lain dari bantuan pembangunan untuk mendukung proyek-proyek pengelolaan hutan konvensional dengan tujuan yang cakupannya luas. Pertanyaan mendasarnya: apakah REDD+ dapat mengurangi emisi dari deforestasi dan degradasi hutan secara signifikan dan apa yang diperlukan untuk membuatnya berbeda dari upaya-upaya yang telah dilakukan sebelumnya? 


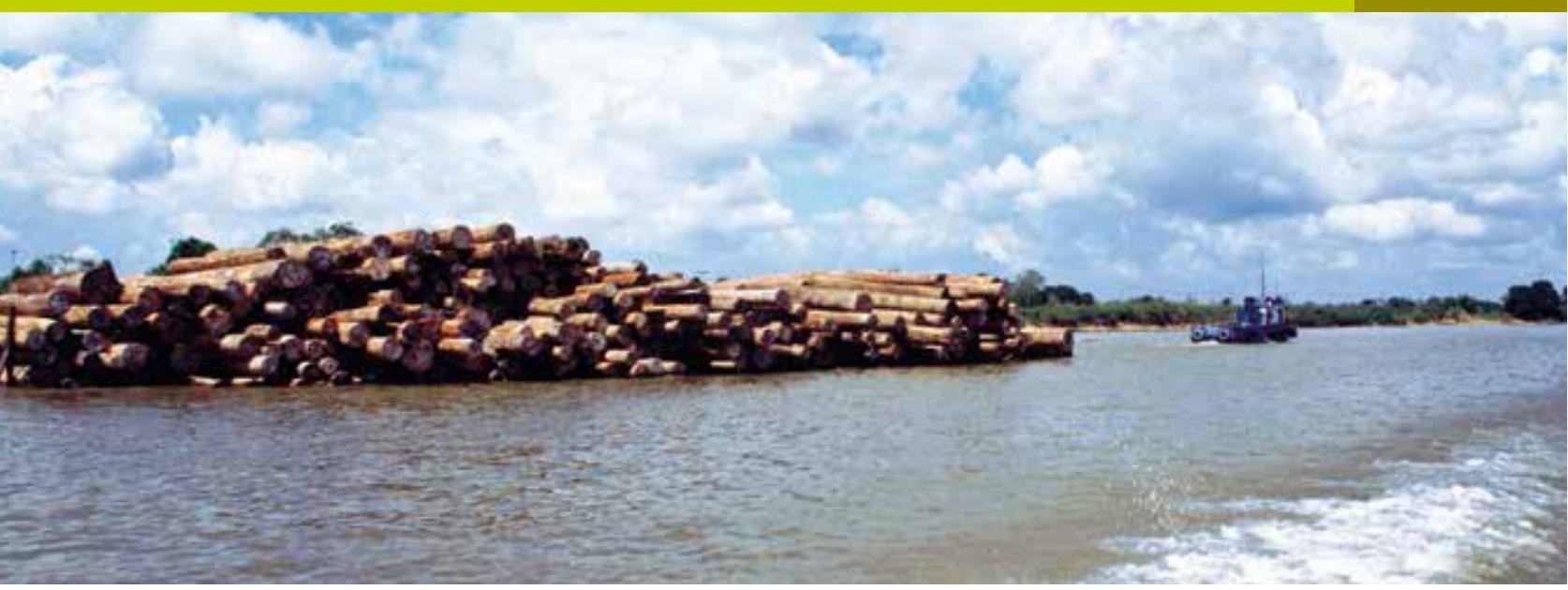

\section{REDD+ dan ekonomi global}

\section{Kekuatan yang bersaing dan sejumlah pilihan kebijakan}

Pablo Pacheco, Louis Putzel, Krystof Obidzinski dan

George Schoneveld

- Globalisasi dan pasar serta liberalisasi keuangan telah mendorong kawasan hutan menjadi semakin terbuka terhadap perdagangan dan investasi global, yang memperburuk tren historis deforestasi dan degradasi hutan.

- Kekuatan utama yang menyaingi REDD+ termasuk integrasi yang berkembang atas pasar pangan, energi dan keuangan, kenaikan dan volatilitas harga-harga komoditas, dan suatu gelombang baru investasi berskala besar di bidang pertanian.

- Agar REDD+ dapat mengurangi tekanan pada hutan sekaligus mendorong transisi menuju pembangunan yang lebih berkesetaraan dan berkelanjutan, dibutuhkan sejumlah tindakan baik dari sisi penawaran maupun permintaan untuk mendorong pelaksanaan pemanfaatan lahan yang melestarikan hutan, mengurangi insentif bagi konversi lahan hutan, dan memberikan insentif bagi peningkatan produksi lahan bukan hutan.

\subsection{Pengantar}

Tantangan untuk mengurangi emisi gas rumah kaca (GRK), sekaligus menyediakan pangan bagi penduduk yang terus bertambah dan memenuhi 
permintaan global untuk serat dan energi, telah menarik perhatian yang semakin besar (Kissinger 2011; Wollenberg dkk. 2011). Bab ini menyajikan ikthisar tentang perdagangan dan investasi terkait pemicu deforestasi dan degradasi hutan di kawasan tropis saat ini, serta bagaimana mereka menjadi penghambat implementasi REDD+, dengan mengamati tiga aspek secara lebih mendalam. Selain itu, kami menyodorkan sejumlah pilihan kebijakan yang dapat membantu mengatasi berbagai pemicu global ini dengan menempatkan pertumbuhan ekonomi yang lebih bersahabat dengan konservasi hutan.

Pembahasan dikelompokkan seputar tiga pertanyaan:

1. Apa sajakah pemicu ekonomi dan tren utama yang memengaruhi deforestasi dan degradasi hutan tropis yang mewakili hambatan utama bagi REDD+?

2. Aspek apa saja dari sejumlah pemicu ekonomi tersebut yang mewakili tantangan terbesar dalam mengurangi deforestasi dan degradasi hutan di Indonesia, Amazon Brasil dan Afrika Timur?

3. Pendekatan kebijakan apakah yang akan menjadi paling efektif dalam mengurangi pengaruh kekuatan ini atas hutan dan apakah implikasinya bagi REDD+?

Sejarah deforestasi terkait dengan pembangunan ekonomi, pertumbuhan penduduk dan permintaan akan pangan, serat dan energi. Menurut kami terdapat sejumlah pemicu kontemporer, yang terkait erat dengan pasar dan investasi global, yang menyebabkan meningkatnya persaingan lahan, termasuk lahan hutan tropis. Berbagai pemicunya termasuk meningkatnya integrasi pasar untuk pangan, serat, energi dan keuangan; volatilitas harga yang tinggi dan harga-harga komoditas yang meningkat; dan gelombang perolehan lahan transnasional. Hal-hal ini menyebabkan usaha untuk mengurangi emisi karbon melalui REDD+ menjadi lebih menantang, karena secara langsung maupun tidak langsung, berbagai pemicu ini mendorong konversi lahan hutan menjadi penggunaan untuk pertanian dan meningkatkan kegiatan pembalakan yang sering menyebabkan degradasi hutan. Namun demikian, terdapat variasi regional yang penting mengenai pengaruh berbagai pemicu tersebut pada hutan, seperti ditunjukkan oleh pengamatan kami di Indonesia, Amazon Brasil dan Afrika Timur.

Kami menggunakan definisi REDD+ yang luas, yaitu seperangkat kebijakan yang bertujuan utama untuk mengurangi emisi karbon dari deforestasi dan degradasi hutan dan dapat mencakup insentif dan kompensasi berbasiskan hasil (lihat Bab 1). Terdapat banyak faktor yang memengaruhi implementasi REDD+. Dalam bab ini, fokus kami adalah pemicu ekonomi global dan tren yang dibentuk oleh pasar dan kebijakan publik - di negara konsumen dan produsen - yang menyebabkan perubahan tata guna lahan, yang berdampak pada tutupan dan kualitas hutan. Untuk merumuskan kebijakan REDD+ 
yang lebih efektif, kita harus memperhitungkan dinamika ekonomi global dan interaksinya dengan kondisi politik dan kelembagaan di tingkat nasional. Dari sisi penawaran, dibutuhkan suatu penataan kembali insentif pasar dan peraturan untuk mengarahkan kembali pembangunan ekonomi di negara-negara berkembang tropis untuk menyelaraskan penyediaan pangan dan energi dengan konservasi hutan, sejalan dengan tindakan kebijakan di sisi permintaan.

\subsection{Sejumlah pemicu ekonomi dan tren yang bersaing dengan REDD+}

Sejumlah faktor dan kondisi pada skala yang berbeda memengaruhi dinamika deforestasi dan degradasi hutan. Gambar 4.1 menunjukkan kekuatan ekonomi global utama dan kebijakan ekonomi dan lingkungan di negara-negara konsumen dan produsen yang memengaruhi kompetisi penggunaan lahan dan berbagai implikasinya bagi REDD+. Kekuatan ini mewakili kepentingan ekonomi berbeda yang berkontribusi pada konfigurasi pengaturan kelembagaan dan politik yang memengaruhi penggunaan lahan dan hutan sehingga berimplikasi langsung bagi pemanfaatan lahan dan biaya peluang. Berbagai kebijakan REDD+ harus menindaklanjuti kekuatan ini agar dapat secara efektif mengurangi deforestasi dan degradasi dan juga emisi karbon.

Seiring waktu, tekanan manusia pada hutan telah meningkat juga untuk memenuhi kebutuhan pangan dan serat yang terkait dengan kemajuan ekonomi dan masyarakat (Lambin dkk. 2003). Sekitar 8000 tahun yang lalu hutan menutupi sekitar $50 \%$ wilayah daratan bumi, namun saat ini hanya $30 \%$ lahan yang berhutan (Ball 2001). Selama tiga dekade terakhir, globalisasi dan liberalisasi pasar telah mendorong keterkaitan yang lebih kuat antara pasar dan perdagangan serta arus modal yang intensif, tidak hanya antara Utara dan Selatan, tetapi juga di antara negara-negara selatan (Khor 2000). Liberalisasi pasar di berbagai negara berkembang terjadi dalam konteks peningkatan yang terus-menerus atas permintaan global untuk pangan, energi dan materi yang terkait dengan meningkatnya permintaan konsumen (Tilman dkk. 2011), kebanyakan dipengaruhi oleh ekonomi-ekonomi yang berkembang seperti Brasil, Rusia, India dan China (BRIC). Selain itu, migrasi produksi industri ke ekonomi yang berkembang (khususnya di Asia) telah meningkatkan multipolaritas sistem ekonomi global, memutar kembali rantai penawaran sumberdaya alam global (World Bank 2011), yang berimplikasi bagi pemanfaatan lahan global (Rudel dkk. 2009)

Berbagai dampak proses ekonomi global pada perubahan pemanfaatan lahan, dan konversi hutan, bersifat langsung dan tidak langsung dan semakin dipengaruhi oleh ketergantungan regional yang dijembatani oleh perdagangan internasional (Meyfroidt dkk. 2010, Pfaff dan Walker 2010). 


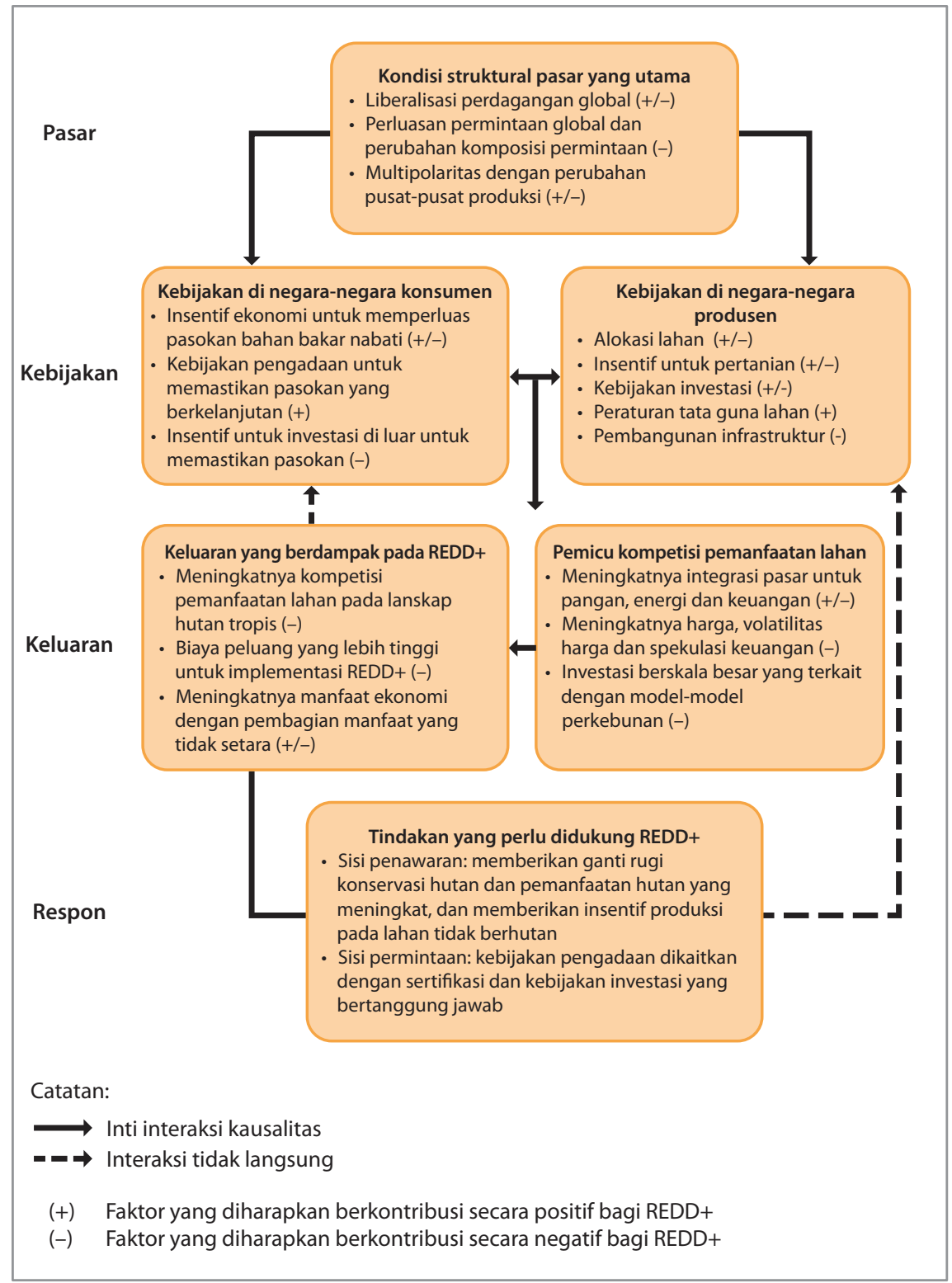

\section{Gambar 4.1 Diagram yang disederhanakan tentang sejumlah kekuatan ekonomi global dan kebijakan di negara-negara konsumen dan produsen yang memengaruhi kompetisi pemanfaatan lahan yang berdampak bagi REDD+}

Meningkatnya konsumsi di beberapa negara dapat menyebabkan perubahan pemanfaatan lahan yang lebih besar di negara lain. Dinamika pemanfaatan lahan dipengaruhi oleh keputusan kebijakan di negara-negara konsumen dan produsen. Kotak 4.1 dan 4.2 menyajikan contoh pengaruh keputusan kebijakan di negara konsumen, seperti kebijakan energi terbarukan di Uni Eropa, dan larangan pembalakan domestik di China. Beberapa contoh kebijakan yang 


\section{Kotak 4.1 Pasar bahan bakar nabati, Standar Energi Terbarukan Uni Eropa dan hutan}

Francis $\mathrm{X}$. Johnson

Target yang ditetapkan oleh Standar Energi Terbarukan Uni Eropa (EU Renewable Energy Directive/EU-RED) untuk tahun 2020 mencakup 10\% target energi terbarukan pada sektor transportasi di semua Negara Anggota (EC 2009). Bahan bakar nabati yang digunakan untuk mencapai target ini harus memenuhi kriteria kelestarian tertentu. Termasuk di dalamnya adalah batasan tentang jenis lahan yang digunakan untuk produksi, tingkat pengurangan GRK minimum dan larangan pembukaan hutan atau pemanfaatan lahan dengan cadangan karbon yang tinggi atau keanekaragaman hayati yang tinggi untuk produksi bahan bakar nabati. Skema sertifikasi bahan bakar nabati yang diakui oleh EC memasukkan syarat untuk mencegah konversi lahan seperti itu menjadi bahan mentah untuk bahan bakar nabati.

EU-RED ini menindaklanjuti deforestasi yang terkait dengan perubahan tata guna lahan langsung. Namun demikian, perubahan tata guna lahan yang tidak langsung (iLUC) tidak secara eksplisit ikut diperhitungkan. ILUC merupakan akibat pengaruh fisik dan ekonomi atas kenaikan permintaan untuk lahan yang terkait produksi bahan bakar nabati. Misalnya, ketika bahan mentah untuk bahan bakar nabati dibudidayakan pada lahan pertanian, maka produksi pangan mungkin dipindahkan pada bagian lain dunia. Berbagai dampak iLUC pada emisi GRK karena penerapan standar EU-RED tampaknya akan menjadi aspek paling diperdebatkan dalam insentif pengembangan bahan bakar nabati sebagai bagian dari kebijakan energi terbarukan. Pada tahun 2011, Komisi Eropa menunda keputusan tentang perlunya menindaklanjuti faktor-faktor iLUC.

Sebagian besar studi menunjukkan bahwa pengembangan bahan bakar nabati memberikan tekanan yang lebih besar pada lahan sebagai akibat iLUC (misalnya, Edwards dkk. 2010). Sebuah estimasi baru-baru ini mengindikasikan bahwa tambahan seluas 5,2 juta hektar lahan penanaman akan dibutuhkan sampai tahun 2020 secara global, dibandingkan dengan skenario dasar tanpa standar EU-RED. Sekitar $11 \%$ dari tambahan perluasan ini diperkirakan berlangsung pada hutan terbuka dan $30 \%$ pada lahan hutan tertutup (Fonseca dkk. 2010).

Memperluas pasar bahan bakar nabati menawarkan peluang ekonomi bagi negara-negara berkembang untuk mengekspor ke negara Uni Eropa dan untuk mengembangkan pasar domestik mereka. Produktivitas biomassa yang tinggi di kawasan tropis dan subtropis dapat menyebabkan dampak tata guna lahan yang lebih rendah dan emisi GRK yang lebih rendah dibandingkan bahan bakar nabati yang diproduksi di Uni Eropa. Insentif bahan bakar nabati di negara berkembang dapat dikaitkan dengan REDD+, menyediakan penghidupan bagi masyarakat pedesaan yang miskin dan mengokohkan kawasan perbatasan pertanian, sementara juga mengurangi perubahan tata guna lahan dan emisi GRK (Killeen dkk. 2011). Namun demikian, negara-negara berkembang bisa jadi menghadapi biaya yang lebih tinggi dalam memenuhi kriteria kelestarian, karena kurangnya sumberdaya teknis, keuangan dan manusia untuk mendukung sertifikasi (Johnson dkk. 2012). 


\section{Kotak 4.2 Larangan pembalakan domestik China dan permintaan untuk kayu Afrika}

Pada tahun 1998, China mengeluarkan larangan pembalakan domestik untuk melindungi hutan alamnya (Liu dan Diamond 2005; Wang dkk. 2007; Laurance 2008). Sekitar saat yang sama, krisis keuangan di Asia menyebabkan kekurangan uang tunai di Jepang dan di tempat lain, dan China dengan cepat menjadi konsumen terbesar di dunia untuk kayu bulat dan kayu semiolahan tropis. Rantai penawaran yang baru dibentuk untuk menghubungkan China dengan pemasok kayu di Asia Tenggara, Afrika dan Amerika Selatan. Pungutan yang lebih rendah untuk kayu impor dan pembatalan persyaratan ijin impor memfasilitasi tren ini dan menarik penanaman modal asing, yang mendorong kenaikan permintaan untuk kayu (Lang dan Chan 2006).

Sementara larangan pembalakan China telah mengurangi produksi domestik sampai dengan 30\% antara tahun 1995 dan 2003 (Lang dan Chan 2006), kebijakan ini memindahkan deforestasi dan gangguan hutan terkait pembalakan ke negara-negara lain (Mayer dkk. 2005). Kenaikan permintaan China untuk kayu bulat dan kayu gergajian khususnya sangat terlihat di Afrika, yang saat ini jumlahnya melebihi kombinasi dari semua negara maju. Permintaan kayu Afrika tidak hanya mendorong tingginya volume ekspor, namun juga dalam perubahan lain yang tampaknya menyebabkan intensifikasi pembalakan. Sejumlah angka yang digabungkan mengindikasikan pergeseran ke arah impor oleh negara-negara maju untuk kayu olahan, dan berlanjutnya preferensi untuk kayu yang kurang diolah oleh pasar China, walaupun impor kayu olahan juga meningkat.

Antara tahun 1991 dan 2006, ekspor kayu dari Gabon ke China meningkat sampai lebih dari $8000 \%$, sementara ekspor ke Perancis, pasar terbesar sebelumnya, turun sampai lebih dari separuh. Produksi kayu bulat Gabon meningkat tinggi sampai 2,5 juta meter kubik setiap tahun (Terheggen 2010). Pada saat yang sama, pasar China meminta jumlah jenis yang lebih banyak dibandingkan pasar lain (Putzel 2010; Terheggen 2010; Cerutti dkk. 2011). Kombinasi kenaikan volume dan intensitas pemanenan yang lebih besar memiliki beberapa konsekuensi. Pertama, sementara pemilihan yang lebih sedikit saja mungkin berarti perluasan pembalakan yang lebih lambat, digabungkan dengan permintaan yang lebih tinggi, hal ini tampaknya akan mengakibatkan degradasi hutan yang lebih besar. Kedua, sampai negara-negara pengekspor dan pengimpor dapat mengendalikan pembalakan liar dan ekspor kayu, permintaan yang lebih tinggi untuk sejumlah besar jenis kayu dapat menambah tekanan pada hutan yang tidak dialokasikan untuk pembalakan, yang memperumit implementasi REDD+. 
diterapkan oleh negara produsen (misalnya, penguasaan lahan, insentif untuk pertanian, kebijakan investasi dan peraturan pemanfaatan lahan) dibahas secara mendalam di Bagian 4.3.

Tren pasar struktural seperti dijelaskan di atas, sejalan dengan interaksinya dengan kebijakan di negara-negara konsumen maupun produsen, telah berkontribusi pada munculnya tiga tren global yang membentuk pemicu ekonomi utama dalam perubahan pemanfaatan lahan kontemporer:

- Meningkatnya integrasi pasar untuk pangan, serat dan energi yang menyebabkan perubahan penawaran dan permintaan dalam satu pasar berdampak pada pasar lainnya (Roberts 2008; Naylor 2011)

- Volatilitas harga dalam pasar pangan dan pertanian global yang terjadi dalam tren umum meningkatnya harga, yang sebagian terkait dengan 'finansialisasi' pasar-pasar komoditas (UNCTAD 2009; Falkowski 2011)

- Suatu tren pengambilalihan lahan berskala besar, yang terkait erat dengan dua tren sebelumnya (HLPE 2011; Anseeuw dkk. 2012).

Ketiga tren tersebut mendatangkan tekanan pada lahan, yang berdampak pada hutan melalui interaksi yang kompleks. Perkiraan tentang seberapa besar kontribusi deforestasi dari perluasan pertanian bagi persediaan pangan dan energi global masih bersifat kontroversial. Misalnya, Gibbs dkk. (2010), menggunakan analisis penginderaan jauh di sepanjang kawasan tropis utama, menunjukkan bahwa sekitar 55\% dari 100 juta hektar lahan yang dikonversi menjadi pertanian pada tahun 1980-an dan 1990-an terjadi dengan mengorbankan hutan yang 'utuh'. Selanjutnya, Angelsen (2010b), berdasarkan data dari Badan PBB untuk Pangan dan Pertanian (FAO) menyarankan bahwa, di tingkat global kurang dari $10 \%$ dari produksi panen dan ternak total antara tahun 1985 dan 2004 berada pada lahan yang baru terdeforestasi. Secara keseluruhan, estimasi ini menunjukkan bahwa walaupun sejarah pembukaan hutan mungkin hanya bertanggung jawab untuk bagian yang relatif kecil dari penyediaan pangan global, banyak lahan pertanian baru yang cenderung dibuka dengan mengorbankan hutan. Permintaan global untuk pangan dan energi diperkirakan akan terus meningkat dengan bertambahnya populasi dunia dari tingkat saat ini, yaitu 7 miliar pada tahun 2011 menjadi 9 miliar pada tahun 2050 (Royal Society 2012).

\subsection{Sebuah pandangan regional mengenai berbagai kekuatan yang memengaruhi dinamika penggunaan lahan}

Bagian ini mengamati tren yang telah digambarkan pada bagian 4.2 dan sejumlah implikasinya bagi deforestasi dan degradasi serta implementasi REDD+ di tiga kawasan: Indonesia di Asia Tenggara, Amazon Brasil dan 
Afrika Timur. Kami menekankan pengaruh interaksi antara faktor-faktor ekonomi dan kebijakan serta pasar dan investasi global pada meningkatnya atau menurunnya tekanan pada lahan hutan. Kami juga menilai biaya peluang pemanfaatan lahan alternatif di tiga kawasan ini untuk mengindikasikan biaya potensial sistem kompensasi berbasiskan biaya (seperti PES) di bawah kerangka kerja kebijakan REDD+. Terakhir, kami mengamati beberapa tanggapan kebijakan utama yang digunakan oleh negara-negara tersebut untuk mengatasi deforestasi.

\subsubsection{Sejumlah kekuatan yang memengaruhi dinamika penggunaan lahan di Indonesia}

Di Indonesia, proyek-proyek berskala besar di kehutanan, minyak kelapa sawit dan produksi pangan diperkirakan akan meningkat sampai sekitar 17 juta hektar untuk memenuhi target pemerintah. Selain itu akan diperlukan lahan tambahan seluas 3 juta hektar apabila produksi batubara menjadi dua kali lipat, seperti diprediksikan pada tahun 2025 (Bahroeny 2009; Suparno dan Afrida 2009; Tragistina 2011). Keuntungan ekonomis yang diharapkan dari investasi ini adalah signifikan. Misalnya, pada tahun 2011, ekspor bubur kayu dan kertas, minyak kelapa sawit mentah dan batu bara mewakili sekitar AS \$35 miliar (AS \$4 miliar, AS \$9 miliar, dan AS \$22 miliar secara berturut-turut), atau sekitar 20\% dari total nilai ekspor (COMTRADE 2012). Meningkatnya permintaan untuk minyak kelapa sawit (baik untuk pangan maupun bahan bakar nabati) merupakan pemicu utama deforestasi di Indonesia (Kotak 4.3), namun investasi lahan berskala besar juga menargetkan komoditas lain, seperti kayu atau batu bara, di bawah tren kenaikan harga di pasar internasional (Inamura dkk. 2011). Dalam beberapa tahun terakhir, pertambangan batu bara merupakan pemicu utama pengambilalihan lahan berskala besar di Indonesia. Produksi batu bara meningkat hampir empat kali lipat dalam sepuluh tahun terakhir dan luas lahan yang digunakan oleh konsesi pertambangan telah bertambah pesat (Ministry of Energy and Mineral Resources 2010; Tragistina 2011). Saat ini, konsesi pertambangan mencakup sekitar 5 juta hektar di Kalimantan dan Sumatra; sekitar separuhnya berlokasi di lahan hutan. Sementara menurut undang-undang hanya sekitar 20\% dari total wilayah konsesi, atau 1 juta hektar yang boleh dibuka untuk memungkinkan ekstraksi batu bara, batasan ini jarang dipatuhi.

Hutan tanaman kayu juga telah mengalami peningkatan pesat. Pada tahun 2006, pemerintah meluncurkan kebijakan baru yang berupaya untuk membangun 9 juta hektar hutan tanaman baru sampai tahun 2016. Walaupun implementasi berjalan lambat, karena masalah alokasi lahan dan terbatasnya minat petani kecil (Obidzinski dan Dermawan 2010), harapan akan pasar yang positif untuk bubur kayu telah mendorong investasi yang lebih besar. Pada April 2011, Kementerian Kehutanan Indonesia mengumumkan investasi baru yang besar pada sektor hutan tanaman bubur kayu dan kayu. Investasi yang diproyeksikan ini mencakup tujuh industri bubur kayu yang baru, dengan kapasitas hampir 5 juta ton dan hampir 2 juta hektar hutan 


\section{Kotak 4.3 Kelapa sawit, pangan dan bahan bakar nabati di Indonesia}

Selama dekade terakhir, sektor kelapa sawit Indonesia telah mengalami pertumbuhan besar-besaran. Antara tahun 1990 dan 2010, kawasan yang digunakan untuk perkebunan meningkat tujuh kali lipat dari 1,1 juta hektar menjadi 7,8 juta hektar (Sheil dkk. 2009; Direktorat Jenderal Perkebunan 2011). Pada akhir tahun 2011, produksi minyak sawit mentah (crude palm oil/CPO) Indonesia mencapai 23,6 juta ton, atau sekitar $45 \%$ keluaran global (Slette dan Wiyono 2011). Setiap tahunnya, ekspor CPO dan turunannya menghasilkan lebih dari AS \$12 miliar pendapatan devisa (Bahroeny 2009; World Bank 2010). Sektor kelapa sawit juga dianggap sebagai kunci potensial untuk mengamankan kebutuhan energi Indonesia melalui produksi bahan bakar nabati berbasiskan CPO dan sebagai sumber lapangan kerja yang penting di pedalaman Indonesia.

Dalam rangka mengantisipasi berlipatnya permintaan global untuk kelapa sawit sampai tahun 2025, pemerintah Indonesia merencanakan untuk melipatgandakan produksi CPO sebanyak 23 juta ton pada dekade mendatang, melalui intensifikasi dan dengan mengembangkan 4 juta hektar tambahan perkebunan kelapa sawit (Bahroeny 2009; Suparno dan Afrida 2009; Kongsager dan Reenberg 2012). Ada kekhawatiran bahwa perluasan yang baru akan menargetkan zona hutan sekunder, yang dikecualikan dari moratorium konversi hutan yang berlaku sejak 2011 (Boucher dkk. 2011; Colchester dan Chao 2011). Sementara investasi baru diharapkan akan berjalan dengan kemitraan bersama masyarakat lokal melalui program petani plasma, pertanyaan tentang nilai dan keefektifannya tetap tersisa (McCarthy 2010).

Spekulasi tentang perluasan perkebunan kelapa sawit maupun hutan tanaman kayu telah memunculkan kekhawatiran tentang keamanan pangan nasional (Rusastra dkk. 2008; Basuno dan Weinberger 2011). Perencana pemerintah memperkirakan bahwa selama dua dekade berikutnya setidaknya 2 juta hektar lahan baru akan dibutuhkan untuk menanam tanaman pangan bagi penduduk Indonesia yang terus bertambah (Jakarta Post 2010). Indikasi awal menunjukkan bahwa investasi perkebunan pangan menargetkan wilayah lahan berhutan yang signifikan (Colchester dan Chao 2011). Hal ini tampaknya akan memperlemah penerimaan dan keamanan pangan dari masyarakat yang bergantung pada hutan, yang menyebabkan resistensi dan konflik dan berkontribusi pada kenaikan tingkat emisi GRK di Indonesia.

Keluaran negatif dari perluasan kelapa sawit dapat diminimalisasi. Para perencana pemerintah perlu menegakkan moratorium konversi hutan dan memastikan bahwa perkebunan kelapa sawit yang baru dikembangkan pada lahan tidak berhutan. Konsesi yang telah dialokasikan dan diketahui mencakup tutupan hutan yang signifikan harusnya dapat dikenai tinjauan hukum. Jika kedudukan hukum dari konsesi-konsesi ini valid, maka pemerintah harus menawarkan tukar guling lahan dan insentif pajak untuk mengecualikan lahan berhutan dari mereka. Insentif yang sama harus digunakan untuk mendukung intensifikasi produksi CPO di perkebunan yang sudah ada, daripada mendorong perluasannya. Penerapan sertifikasi Forum Meja Bundar untuk Kelapa Sawit (Roundtable on Sustainable Palm Oil/RSPO) yang lebih luas oleh berbagai perusahaan khususnya akan membantu, mengingat ini mencakup batasan stok karbon dan kalau melebihi batas ini pembukaan hutan tidak diijinkan. 
tanaman kayu baru, dengan biaya keseluruhan sebesar AS \$14 miliar. Investasi ini tampaknya akan menyebabkan emisi karbon dalam skala besar (Koran Kaltim 2011). Sementara target ini mungkin ambisius, industri bubur kayu dan kertas yang ada terus meningkatkan kapasitasnya, dan sampai dengan tahun 2010, separuh dari kebutuhan bahan mentah mereka bergantung pada hutan alam (IWGFF 2010).

Sejumlah kesulitan yang membuat REDD+ kompetitif secara ekonomis dapat diilustrasikan dengan membandingkannya dengan perkebunan kelapa sawit.

Kelapa sawit termasuk dalam komoditas yang paling cepat berkembang di kawasan tropis; di Indonesia, perkebunan kelapa sawit bertambah sekitar 400.000 hektar per tahun (Slette dan Wiyono 2011). Estimasi nilai bersih sekarang (net present value) dari perkebunan kelapa sawit bervariasi dari AS \$4000 dolar sampai dengan AS \$29000 dolar per hektar (Persson dan Azar 2009; World Bank 2010), walaupun sebagian besar estimasi berada pada kisaran AS $\$ 6000$ dolar- $\$ 9000$ dolar per hektar (Butler dkk. 2009). Kalau luas lahan yang sama tetap dipertahankan berhutan akan menghasilkan AS \$614 dolar- \$994 dolar dalam kredit karbon (Butler dkk. 2009). Perbedaan ini secara kasar menjadi dua kali lipat jika nilai kayu yang dikeluarkan dalam proses pembangunan hutan tanaman ikut dipertimbangkan dalam perhitungan manfaat yang hilang (Fiser dkk. 2011). Dengan berbasiskan sebuah proyek, pembayaran karbon tampaknya tidak mungkin dapat bersaing dengan keuntungan dari kayu dan kelapa sawit dengan harga mereka saat ini. Namun demikian, mungkin terdapat ruang untuk sinergi dengan REDD+, khususnya jika sektor perkebunan terutama diwujudkan melalui intensifikasi lahan perkebunan yang sudah ada, jika tukar guling lahan digunakan untuk menggeser beberapa konsesi ke lahan tidak berhutan, dan jika batasan pembukaan hutan bagi konsesi pertambangan benar-benar dipatuhi.

\subsubsection{Sejumlah kekuatan yang memengaruhi dinamika penggunaan lahan di Amazon Brasil}

Pada tahun 2010, Amazon Brasil telah mengalami deforestasi sebanyak hampir 75 juta hektar, atau sekitar 18\% dari tutupan hutan aslinya (INPE 2011). Saat ini, 44,6 juta hektar merupakan daerah padang rumput (62\% dari total wilayah yang terdeforestasi), sementara 3,5 juta hektar merupakan tanaman tahunan (5\% dari total wilayah yang terdeforestasi), kebanyakan untuk produksi kedelai (EMBRAPA/INPE 2011). Sejak awal tahun 1970-an, pembukaan hutan terkait erat dengan perluasan ternak berskala besar dan ekstensif (Margulis 2004). Selain itu, sejak awal tahun 2000, terdapat perluasan pertanian berskala besar dan dengan modal intensif, terutama untuk produksi kacang kedelai (Nepstad dkk. 2006). Tebang pilih sering mengawali kegiatan pertanian di suatu wilayah hutan primer yang luas (Chomitz dkk. 2007). Deforestasi mencapai puncaknya pada 2,7 juta hektar 
per tahun pada tahun 2004, menurun terus sampai mencapai 700.000 hektar pada tahun 2010 (INPE 2011). Deforestasi di Amazon Brasil juga terkait dengan integrasi wilayah ke dalam ekonomi nasional, berhubungan lebih erat dengan permintaan dan investasi dari negara-negara selatan, dan juga dari pasar global (Nepstad dkk. 2006; Walker dkk. 2009).

Kenaikan harga-harga internasional juga telah mendorong produksi daging sapi dan kacang kedelai (Kotak 4.4). Variabel lain, seperti perubahan nilai tukar uang juga berpengaruh penting dalam dinamika ekspor. Richards dkk. (2012) berpendapat bahwa sekitar sepertiga dari produksi kacang kedelai di Amerika Selatan saat ini, termasuk di Brasil, merupakan akibat devaluasi mata uang lokal pada akhir tahun 1990-an. Sebaliknya, depresiasi yang baru terjadi pada dolar dan apresiasi pada real Brasil mungkin menetralkan kenaikan harga kacang kedelai global. Karena itu, deforestasi cenderung naik atau turun sejalan dengan gejolak harga internasional dan nilai tukar uang (Macedo dkk. 2012). Insentif pemerintah untuk perluasan pasokan bahan bakar nabati juga telah berkontribusi bagi meningkatnya pasar untuk kacang kedelai yang diproduksi di Brasil, walaupun masih dalam tingkat proporsi yang lebih kecil (de Andrade dan Miccolis 2011). Misalnya, suatu estimasi menunjukkan bahwa $13-18 \%$ deforestasi total di Mato Grosso disebabkan oleh produksi kacang kedelai, walaupun kurang dari 6 persennya dapat dikaitkan dengan bahan bakar nabati (biodiesel), karena kebanyakan kacang kedelai digunakan untuk produk-produk lain (Lima dkk. 2011).

\section{Kotak 4.4 Daging sapi dan kacang kedelai di Amazon Brasil}

Pengembangan padang rumput untuk menggembalakan ternak untuk produksi daging sapi di Amazon, di masa lalu, terkait erat dengan dinamika pasar lokal. Namun demikian, produksi ini sekarang memasok pasar yang lebih jauh, menjangkau wilayah lain seperti Brasil dan pasar global (da Veiga dkk. 2004). Peningkatan produksi daging sapi sejalan dengan pertambahan penduduk dan peningkatan konsumsi daging sapi per kapita. Selain itu, ekspor daging sapi Brasil telah meningkat dari 123.000 ton pada tahun 1990 menjadi 1,4 juta ton pada tahun 2008 (FAO Statistics 2012). Pada tahun 2011, dua pertiga dari ekspor ditujukan ke Rusia, Iran, Mesir dan China. Walaupun wilayah Amazon hanya berkontribusi sebanyak 15,4\% dari total ekspor daging sapi pada tahun 2006, andil ini meningkat pesat (Pacheco dan Poccard-Chapuis 2012). Sementara sebagian besar ekspor daging sapi berasal dari Brasil bagian tenggara dan tengah-barat, pertumbuhan ekspor telah menimbulkan kesenjangan di pasar domestik, yang dipenuhi oleh daging sapi dari Amazon (Kaimowitz dkk. 2004). Pada beberapa tahun terakhir, terjadi perluasan rumah penjagalan di wilayah 


\section{Kotak 4.4 Lanjutan}

Amazon, karena kehadiran pelaku pengusaha utama di sektor daging sapi Brasil (Smeraldi dan May 2009; Pacheco dan Poccard-Chapuis 2012).

Produksi kacang kedelai di Brasil meningkat dari 11,5 juta sampai 23,3 juta hektar antara tahun 1990 dan 2010. Pertumbuhan ini berpusat di Mato Grosso di perbatasan barat daya Amazon, yang memiliki 10,4 juta hektar wilayah budidaya kedelai pada tahun 2010, suatu bagian besar dari cerrado (IBGE 2011). Peningkatan ini didorong oleh ketersediaan lahan murah, perluasan jalan, dan akses terhadap teknologi budidaya yang baru (Kaimowitz dan Smith 2001). Kehadiran pedagang perusahaan (misalnya, Archer Daniels Midland dan Louis Dreyfus) dan sebuah perusahaan Brasil berskala besar (Gruppo Maggi) telah berkontribusi dalam mengintegrasikan kawasan ini ke dalam pasar global (Baker 2004). Sementara pasar domestik penting di Brasil, bagian produksi yang penting dan terus meningkat ditujukan pada pasar ekspor. Sekitar $70 \%$ dari biji kacang kedelai diproses di dalam negeri dan sisanya diekspor, $47 \%$ dari tempe dan $60 \%$ dari minyak kedelai dikonsumsi di dalam Brasil. Pada tahun 2011,67\% dari ekspor kacang kedelai Brasil ditujukan ke China dan 69\% dari tempe ke Uni Eropa (COMTRADE 2012). Sekitar 23\% dari perluasan kacang kedelai selama periode 2001-2004 dilakukan di hutan yang dibuka, sementara sisanya berada di padang rumput yang sudah ada (Morton dkk. 2006). Meskipun demikian, perluasan kedelai telah mendesak ternak jauh ke pinggiran hutan (Barona dkk. 2010, Arima dkk. 2011) dan peningkatan permintaan untuk bahan bakar nabati dapat memperbesar pengaruh ini (Lapola dkk. 2010).

Pacheco dan Poccard-Chapuis (2012) menyarankan beberapa mekanisme kebijakan dapat membatasi perluasan peternakan yang ekstensif dan membantu menutup perbatasan: i) menetapkan lahan publik sebagai kawasan konservasi dan hutan produksi. Tindakan ini telah menghentikan perluasan peternakan ekstensif ke lahan berhutan publik secara efektif; ii) batasan tata guna lahan didefinisikan melalui pembuatan zona ekonomi dan ekologis. Tindakan ini terbukti merupakan sebuah pembatasan yang efektif bagi perluasan dalam beberapa tahun terakhir; iii) intensifikasi kegiatan peternakan yang sudah ada, dengan berbagai insentif ekonomi yang memadai; dan iv) mendorong peternakan di luar bioma Amazon. Namun demikian, tindakan ini akan memindahkan masalah ke ekosistem cerrado, yang juga mengalami tekanan kuat deforestasi. Kebijakan-kebijakan tersebut dapat dikombinasikan dengan sertifikasi sistem produksi daging sapi yang sesuai dengan peraturan lingkungan dan menerapkan praktik-praktik produksi yang berkelanjutan. Pilihan kebijakan i) dan ii) juga berlaku pada perluasan kacang kedelai. Selain itu, moratorium produksi kacang kedelai yang dimulai pada tahun 2006 telah berperan dalam menghambat perluasan perbatasan kacang kedelai ke lahan berhutan (Rudorff dkk. 2011). 
Pada akhir tahun 1990 dan awal tahun 2000, integrasi Amazon Brasil dengan pasar nasional dan global, pada saat harga-harga lebih tinggi untuk komoditas pertanian, telah meningkatkan tekanan dari sektor peternakan dan kedelai pada hutan. Kehilangan hutan ini diperparah dengan kebijakan ekonomi yang mendorong modernisasi pertanian dan pengembangan bisnis pertanian (Chomitz dkk. 2007). Selain itu, perluasan peternakan dan pertanian komersial tidak hanya mendorong fragmentasi pemilikan lahan berskala besar, namun juga berkontribusi pada penyerobotan lahan publik oleh pemilik lahan pribadi, yang menguasai lahan melalui jalan semilegal, sebagian dipicu oleh tujuan-tujuan spekulatif (Pacheco dan Poccard-Chapuis 2012). Pemerintah menanggapinya dengan memperluas kawasan hutan publik yang dimasukkan ke dalam berbagai kategori konservasi, termasuk cagar alam pembangunan berkelanjutan dan kawasan konservasi (May dkk. 2011b).

Laju deforestasi telah menurun sejak pertengahan 2000-an. Beberapa faktor menjelaskan kecenderungan ini, termasuk meningkatnya penegakan hukum-hukum lingkungan, fluktuasi harga-harga komoditas pertanian, implementasi inisiatif-inisiatif swasta untuk mengurangi deforestasi (misalnya, moratorium di Mato Grosso dan sebuah larangan oleh pasar-pasar swalayan di Brasil bagian selatan untuk menjual daging sapi yang berasal dari lahan yang dibuka secara ilegal) dan berbagai tekanan dari pergerakan sosial (Hecht 2012). Penegakan hukum lingkungan yang lebih ketat di Brasil sepanjang tahun 2005 dan 2009 seharusnya dapat melindungi lebih dari setengah kawasan hutan yang jika tidak akan dibuka (Assunção dan Gandour 2012).

Analisis prospek implementasi REDD+ di kawasan Amazon memperlihatkan bahwa beberapa konversi hutan di Amazon Brasil - seperti halnya lahan di bawah peternakan ekstensif - memberikan hasil yang rendah per hektar, yang dapat dikompensasikan dengan ganti rugi karbon. Börner dkk. (2010) menyarankan bahwa sekitar setengah dari kehilangan hutan yang diproyeksikan selama periode 2009-2018 (55\% atau 12,5 juta hektar) memberikan hasil bersih yang setara dengan ganti rugi pembayaran yang mencerminkan harga kredit karbon sementara dalam pasar sukarela sekarang. Ganti rugi ini tidak memperhitungkan fakta bahwa produktivitas dan keuntungan dari produksi daging telah berkembang seiring waktu, sehingga meningkatkan biaya peluang untuk pemanfaatan lahan yang menyebabkan deforestasi (Pacheco dan Poccard-Chapuis 2012). Hal yang sama juga terjadi dalam deforestasi yang dipicu oleh perluasan kedelai, yang jauh lebih menguntungkan daripada peternakan ekstensif. Walaupun tekanan langsung perluasan kacang kedelai pada hutan primer rendah, hal ini secara tidak langsung menyebabkan konversi hutan (Lapola dkk. 2010; Arima dkk. 2011). 
Kombinasi penegakan hukum dan berbagai insentif ekonomi dibutuhkan untuk 'menutup perbatasan' di Amazon Brasil agar secara efektif memengaruhi kebutuhan dan kepentingan beragam pelaku, termasuk masyarakat yang melakukan kegiatan pertanian ekstraktif, petani kecil dan pemilik lahan berskala besar. Tidak satu pun pendekatan REDD+ 'satu ukuran cocok untuk semua' dapat mencapai keefektifan biaya dan kesetaraan ketika pelaku yang berlainan dengan kebutuhan berbeda memengaruhi lahan dengan cara yang berbeda (Pacheco dkk. 2011).

\subsubsection{Sejumlah kekuatan yang memengaruhi dinamika penggunaan lahan di Afrika Timur}

Afrika Timur saat ini menghadapi salah satu laju deforestasi tertinggi di benua ini, melebihi $1 \%$ per tahun (FAO 2010). Deforestasi khususnya sangat kuat di Etiopia, Kenya dan Madagaskar. Perluasan pertanian, pembalakan, produksi arang, dan penggembalaan berlebihan di kawasan lahan kering dianggap berkontribusi bagi kehilangan hutan (Bishaw 2001; FAO 2003; Olson dkk. 2004; Tabor dkk. 2010). Di Afrika subSahara, kenaikan produksi sering dikaitkan dengan perluasan luas lahan budidaya daripada efisiensi pemanfaatan lahan (FAO 2003). Menurut Chomitz dkk. (2007), konversi langsung lahan hutan menjadi pertanian permanen berskala kecil terkait dengan kenaikan jumlah penduduk dan menyebabkan sekitar $60 \%$ dari perubahan pemanfaatan lahan di Afrika. Selain itu, produksi arang, yang merupakan lebih dari $80 \%$ konsumsi energi rumah tangga, juga berdampak pada degradasi hutan (UN DESA 2004).

Kekuatan pasar global bisa jadi meningkatkan intensitas kompetisi pemanfaatan lahan. Misalnya, meskipun cadangan kayu berkurang, Tanzania - negara Afrika Timur yang hutannya paling luas - melaporkan peningkatan pesat dalam ekspor kayu sampai hampir 1300\% dalam dekade 2000-2010, sebagian besar untuk pasar India dan China (COMTRADE 2012). Milledge dkk. (2007) memperkirakan bahwa, di kawasan pembalakan utama di Pesisir Tanzania, antara 77-96\% dari jenis-jenis kayu bernilai tinggi dipanen secara ilegal, terutama akibat korupsi dan rendahnya kapasitas pemerintah untuk menegakkan hukum kehutanan. Selain meningkatnya permintaan internasional, akses yang semakin mudah akibat pembangunan infrastruktur juga diyakini menjadi faktor pendukung yang penting untuk pembalakan ilegal (Tabor dkk. 2010). Tren yang sama juga dijumpai di Mozambik, negara tetangganya (MacKenzie 2006).

Selain itu, akibat gelombang kebutuhan lahan baru-baru ini di Afrika (Kotak 4.5), sejumlah besar lahan berhutan dan pertanian berisiko untuk dikonversi menjadi perkebunan multikultur. Karena ketersediaan lahan murah dan sesuai secara agro-ekologis, Afrika subSahara menjadi tujuan utama untuk investasi lahan pertanian berskala besar - yang menurut beberapa pihak - bertanggung jawab untuk dua pertiga dari total lahan global 


\section{Kotak 4.5 Bahan bakar nabati, harga-harga pangan dan investasi lahan di Afrika subSahara}

Sebuah proses pengambilalihan lahan pertanian berskala besar yang signifikan tengah berlangsung di Afrika subSahara (SSA). Bukti empiris yang dapat dipercaya terkait kekuatan, distribusi dan pemicu yang mendasar masih jarang. Untuk mengatasi kesenjangan pemahaman ini, Schoneveld (2011) memverifikasi 353 proyek lahan pertanian berskala besar yang ukurannya melebihi 2000 hektar dan diselenggarakan antara tahun 2005 dan 2011. Analisis ini mendokumentasikan pertanian perkebunan dan proyek-proyek kehutanan di 32 negara di SSA, yang mencakup kawasan seluas 18,1 juta hektar. Suatu konsentrasi geografi tingkat tinggi dapat diamati, dengan hanya tujuh negara yang membentuk hampir dua pertiga dari kawasan yang diambil alih (Zambia, Ghana, Madagaskar, Mozambik, Etiopia, Sudan Selatan dan Liberia). Di Etiopia dan Ghana, terdapat ancaman yang khususnya tinggi bahwa pengambilalihan ini akan bersaing dengan pemanfaatan lahan yang bernilai sosial dan lingkungan hidup, mengingat 43\% (Etiopia) dan 62\% (Ghana) dari lahan yang sesuai dan 'tersedia' telah dipindahtangankan kepada para investor sejak 2005. Ancaman-ancaman ini difasilitasi oleh lemahnya penegakan peraturan investasi domestik dan fakta bahwa sebagian besar lahan yang diambil alih berasal dari kawasan lahan adat.

Afrika subSahara merupakan tujuan investasi yang menarik, karena lahan yang sesuai secara agro-ekologis berlimpah dan kemungkinan untuk menyewa lahan dengan nilai sewa yang rendah (biasanya $<5 \%$ dari nilai di negara lain dengan sektor pertanian perkebunan yang kuat, seperti Malaysia dan Indonesia). Desakan yang belum pernah terjadi sebelumnya pada lahan pertanian Afrika ini juga dipicu oleh faktor-faktor eksogen. Pertama, mandat gabungan di negara-negara industri telah menjamin pasar yang stabil untuk bahan bakar nabati. Peluang ekonomi yang dimunculkannya telah mendorong para investor untuk mendapat akses ke sejumlah besar lahan untuk membudidayakan bahan mentah bahan bakar nabati, seperti Jatropha curcas $L$. dan tebu. Para pendukung dari Eropa dan Amerika Utara bertanggung jawab atas lebih dari $53 \%$ total kawasan yang diambil alih di SSA dan 71\% dari kawasan ini digunakan untuk budidaya bahan mentah bahan bakar nabati.

Pemicu utama yang kedua adalah kenaikan harga pangan internasional selama 2007-2008. Pemicu ini memunculkan dua jenis investor: mereka yang dimotivasi oleh keuntungan potensial dari tingginya harga pangan dan batasan pasokan serta pelaku, seperti perusahaan semi otonom (parastatal) dan dana kekayaan kedaulatan (sovereign wealth funds), yang lebih terkait erat dengan tujuan kebijakan pemerintah mereka untuk mengurangi pengaruh fluktuasi harga pangan. Proyek-proyek pangan yang mereka pimpin ini cenderung diinisiasi oleh negara-negara selatan, yang kapasitas perluasan domestiknya khususnya dibatasi oleh terbatasnya ketersediaan lahan yang sesuai. Karena itu produsen kelapa sawit di Asia Tenggara dan produsen bahan makanan pokok di Asia Selatan sangat penting. Kelompok investor terbesar yang kedua, Asia, merupakan $21 \%$ dari total kawasan yang diambil alih, yang $78 \%$ di antaranya adalah untuk budidaya tanaman pangan. Pengamatan ini menyoroti kekuatan aliran investasi lintas batas yang dipengaruhi oleh kebijakan domestik dan kondisi pasar. Oleh karenanya, dibutuhkan peraturan baik dari sisi penawaran maupun permintaan. 
yang diambilalih untuk kepentingan ini sejak awal 2000-an (Deininger dan Byerlee 2011; HLPE 2011; Anseeuw dkk. 2012). Investasi ini diikuti oleh peningkatan 'finansialisasi' pasar komoditas global dan peningkatan dana investasi khusus lahan pertanian, yang menggambarkan peran lembaga keuangan dalam berspekulasi untuk mendapatkan keuntungan tinggi pada sektor-sektor ini di masa mendatang (Merian Research dan CRBM 2010; Knopfel 2011). Walaupun ada potensi keuntungan ekonomi bagi negara tuan rumah, aliran investasi ini berkompetisi langsung dengan konservasi. Terdapat indikasi bahwa perkebunan komersial pada lahan yang diperoleh para investor di Etiopia, Kenya, Tanzania dan Uganda akan diperluas, yang berakibat merugikan bagi hutan (WWF 2009; Mortimer 2011).

Sejumlah jenis investasi tersebut dimungkinkan oleh kondisi ekonomi politik domestik yang mendukung penanaman modal asing/PMA. Biaya peluang REDD+ adalah tinggi, mengingat nilai bersih sekarang (NPV) bagi tanaman seperti tebu dan kelapa sawit (Butler dkk. 2009; Persson dan Azar 2010). Selanjutnya, sementara aliran PMA di sektor pertanian mengancam keberlangsungan REDD+, ketergantungan ekonomi yang tinggi pada tanaman keras domestik yang cepat menghasilkan uang, seperti kopi, teh, kapas dan cengkeh, akan terus mengganggu usaha-usaha untuk menghambat deforestasi. Misalnya, di Etiopia, Madagaskar dan Tanzania, sektor pertanian menyediakan lebih dari $80 \%$ pendapatan ekspor. Dengan permintaan yang meningkat cepat untuk tanaman keras Afrika Timur dari negara-negara berkembang yang besar dan harapan bahwa aliran PMA baru untuk pertanian akan menambah nilai dengan memperkuat kapasitas pemrosesan domestik, alih teknologi dan meningkatkan akses petani kecil pada saluran pemasaran global, maka mungkin hanya sedikit daya tarik politik jangka panjang untuk program yang membatasi pilihan-pilihan perluasan lahan.

\subsection{Menelusuri sejumlah pilihan kebijakan: Apa implikasinya bagi REDD+?}

Dua bagian sebelumnya menunjukkan bahwa tren jangka panjang dalam pertumbuhan penduduk, kenaikan permintaan konsumen, dan baru-baru ini, pergeseran besar dalam produksi, perdagangan dan teknologi global merupakan kunci untuk memahami dinamika deforestasi dan degradasi hutan saat ini di negara-negara tropis. Agar berfungsi efektif, REDD+ perlu mengatasi pengaruh terkait hutan dari berbagai tren ini dan menindaklanjuti pemicu ekonomi dan kebijakan di negara-negara konsumen maupun produsen, dengan memahami bahwa perwujudan dampaknya berbeda di kawasan yang berbeda. Secara umum, sejumlah kekuatan ekonomi tersebut telah meningkatkan tekanan pada lahan untuk memenuhi kenaikan permintaan untuk pangan, serat dan energi. Hal ini secara langsung maupun tidak langsung memberikan tekanan di pinggiran kawasan hutan, khususnya 
di daerah tropis. Karena itu, agar kebijakan REDD+ dapat mencapai tujuannya, koridor yang digunakan haruslah yang mengurangi tekanan pada hutan, namun mendukung pertumbuhan ekonomi.

Karena besarnya skala keuangan dan sifat volatilitas kekuatan yang ada, kami tetap skeptis mengenai kelayakan dalam mengatasi biaya peluang REDD+ melalui ganti rugi keuangan, seperti PES atau pasar karbon saja. Pentingnya peraturan dan lembaga untuk penegakan hukum, klarifikasi hak penguasaan, perencanaan tata guna lahan dan pembangunan infrastruktur yang efektif di negara-nagara produsen semakin diakui.

Sementara berbagai pendekatan berbasiskan pasar mungkin berjalan baik dalam kasus tertentu, yaitu ketika kegiatan ekonomi yang membutuhkan deforestasi memberikan keuntungan terbatas, berbagai pendekatan peraturan tingkat nasional di negara produsen tetap akan dibutuhkan untuk menyeimbangkan kembali keuntungan ekonomi yang terkait dengan berbagai pemanfaatan lahan. Peraturan yang lebih baik di negara konsumen juga dapat melengkapi insiatif para pelaku nonpemerintah, seperti sertifikasi sukarela, dan mendorong konsumsi komoditas dari sumber-sumber yang lestari sebagai cara untuk mengurangi tekanan pada hutan. Implikasi kesetaraan pada inisiatif berbasiskan pasar dan peraturan hukum harus diperhatikan secara seksama, baik di negara produsen maupun konsumen.

Berbagai kebijakan REDD+ bertujuan untuk mendorong transisi menuju pembangunan yang menyatukan pertumbuhan ekonomi dan konservasi hutan, namun mereka menghadapi tantangan besar. Untuk mengatasi hal ini, kami berpendapat bahwa kombinasi peraturan negara dan inisiatif oleh para pelaku nonpemerintah dibutuhkan pada tingkat global maupun nasional. Berbagai tindakan kebijakan ini perlu diterapkan di sisi penawaran dan permintaan, untuk mengurangi deforestasi dan degradasi hutan secara lebih efektif. Sementara tindakan-tindakan ini dapat dianggap sebagai bagian dari implementasi REDD+, akan dibutuhkan suatu paradigma pembangunan yang berbeda, yang memprioritaskan tujuan karbon rendah berdasarkan model-model bisnis dan kebijakan yang lebih berkelanjutan dan inklusif.

Dari sisi penawaran, tindakan kebijakan dapat mengikutsertakan dukungan bagi optimalisasi pemanfaatan lain dari segi ekonomi, sosial dan teknologi, dengan: i) menyediakan kompensasi yang cukup untuk pemanfaatan dalam bentuk melestarikan hutan dan memperluas hutan; ii) mengurangi insentif untuk membuka lahan hutan di kawasan bernilai ekologis tinggi; dan iii) memberikan insentif bagi produksi pada lahan yang tidak berhutan, termasuk lahan terdegradasi, sebagai bagian dari proses yang lebih luas dalam intensifikasi pertanian dan dukungan bagi pertanian pemilik lahan kecil. Kombinasi kebijakan yang berbeda dapat digunakan untuk mencapai tujuan ini (Angelsen 2010b). Di sisi lain, rente pertanian berskala besar dan 
ekstensif dapat diturunkan misalnya, dengan mereformasi penguasaan lahan atau menghindari pembangunan infrastruktur pada lahan perbatasan yang baru. Pada sisi lain, rente yang diperoleh dari kegiatan hutan ekstraktif atau protektif dapat ditingkatkan, baik dengan mendukung upaya-upaya pengguna hutan lokal untuk mengelola hutan mereka yang sudah ada maupun dengan mendorong pasar melalui sistem imbalan seperti PES.

Meskipun demikian, berbagai langkah pada sisi penawaran tidak akan cukup untuk mengatasi tekanan pada hutan. Menindaklanjuti isu ini dari sisi permintaan juga perlu dilakukan. Sejumlah tindakan kebijakan dapat digunakan secara meluas di negara-negara konsumen utama, yang seharusnya juga melibatkan negara-negara berkembang, mengingat peran mereka yang semakin meningkat dalam memengaruhi perdagangan dan konsumsi global. Tindakan ini mencakup penerapan peraturan yang mendukung kebijakan pengadaan yang berkelanjutan, kemungkinan dikaitkan dengan sertifikasi sukarela, dan disertai dengan penghilangan hambatan yang menyimpangkan perdagangan global. Pemerintah dan pelaku swasta juga perlu mendorong lembaga keuangan swasta dan publik untuk menerapkan kebijakan investasi yang bertanggung jawab agar meningkatkan akuntabilitas para investor.

Sejumlah pilihan kebijakan yang dibahas di sini menunjukkan bahwa REDD+ harus dipandang sebagai bagian dari sebuah arsitektur kelembagaan yang lebih luas. REDD+ bukan hanya untuk mengurangi tekanan pada hutan namun juga untuk mendorong pembangunan ekonomi yang lebih berkelanjutan dan berkesetaraan, yang dapat menggabungkan tujuan pengurangan emisi GRK dan penyediaan pangan dan energi yang cukup. Tindakan kebijakan untuk meningkatkan tata kelola dan mengurangi dampak perdagangan dan investasi harus menindaklanjuti sisi penawaran maupun permintaan dan melibatkan upaya-upaya negara produsen maupun konsumen, dan juga mengombinasikan inisiatif para pelaku pemerintah maupun nonpemerintah. Upaya-upaya ini harus dipandang sebagai bagian dari proses transformasi ekonomi yang lebih luas, yang bersama-sama mengusung tujuan pertumbuhan ekonomi, pengentasan kemiskinan dan konservasi hutan dalam konteks perubahan iklim. 


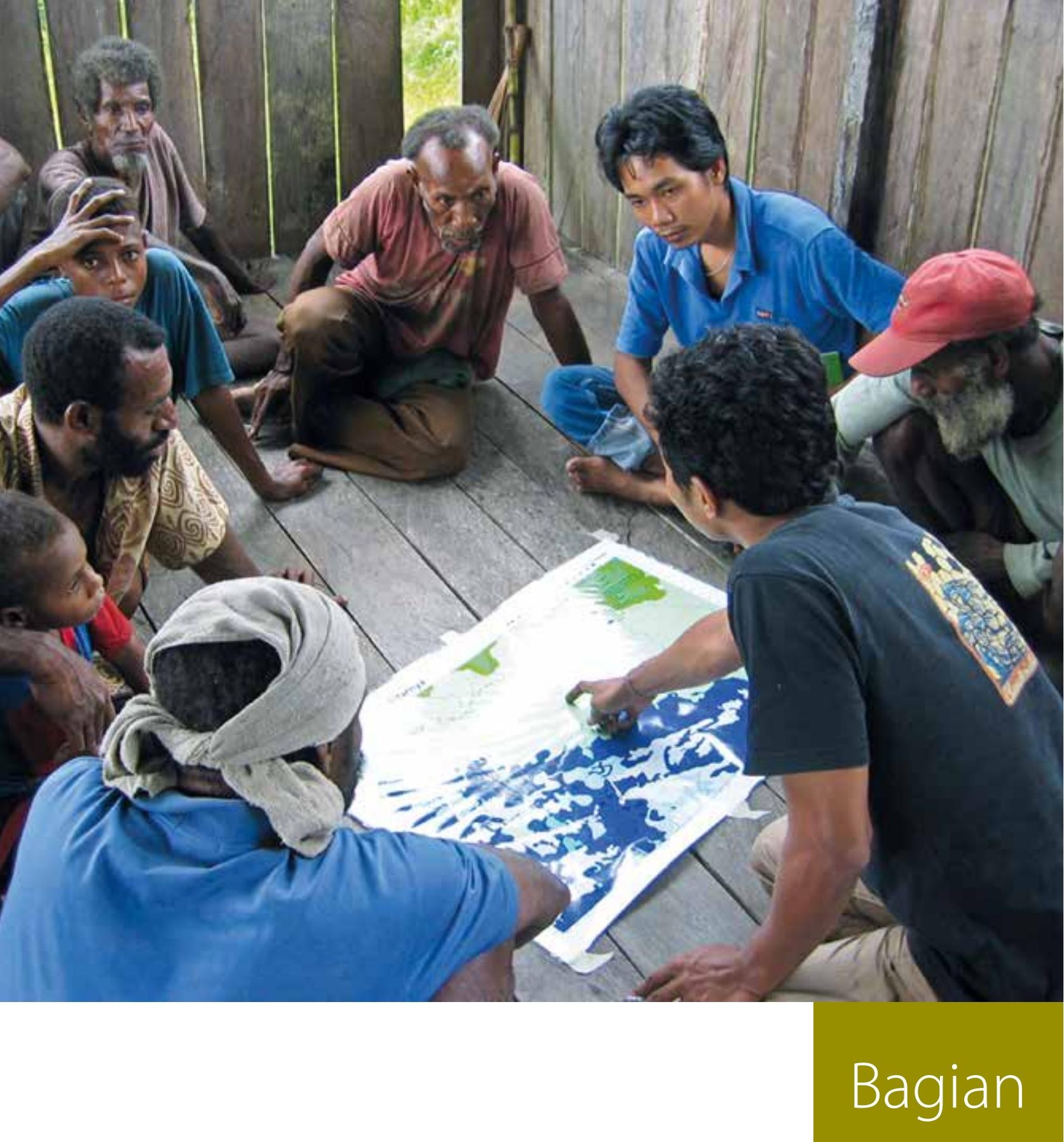

\section{Melaksanakan REDD+}





\section{Bab}

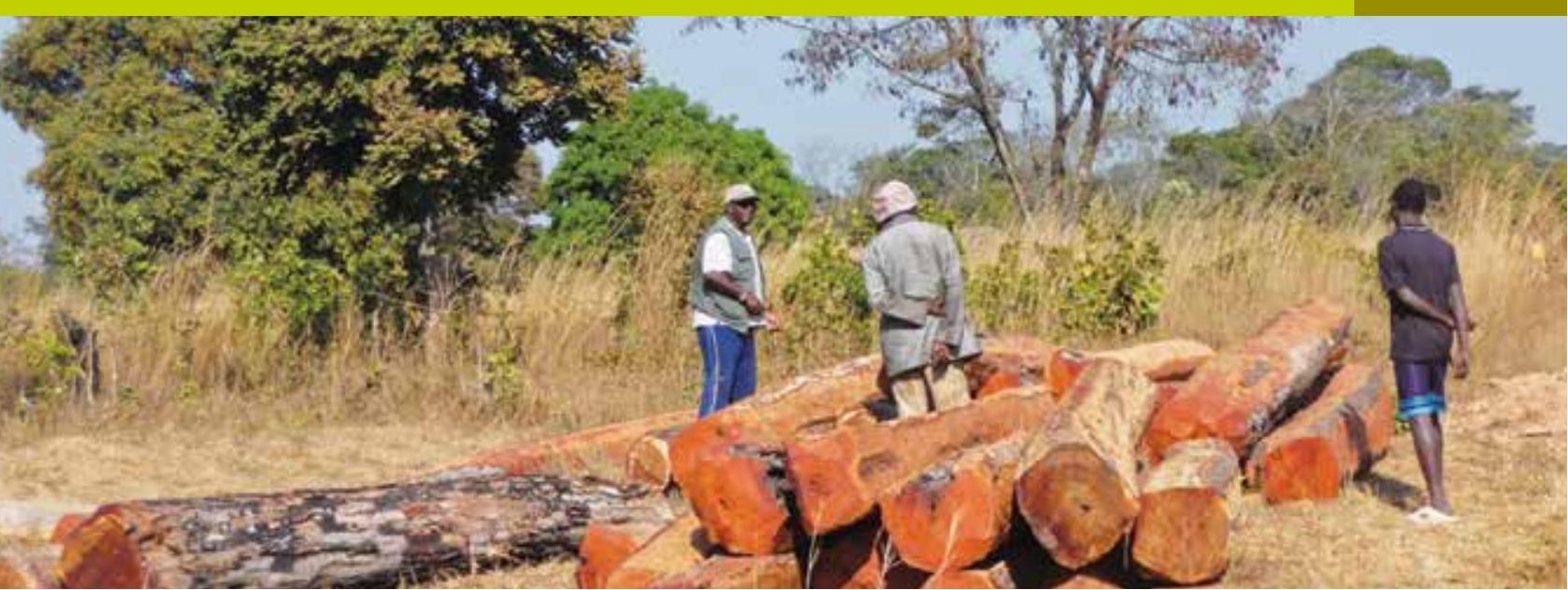

\section{Politik dan kekuasaan dalam proses kebijakan REDD+}

Monica Di Gregorio, Maria Brockhaus, Tim Cronin dan

Efrian Muharrom

- Diperlukan empat prasyarat untuk mengatasi berbagai rintangan politik-ekonomi dalam usaha mencapai pengurangan emisi melalui REDD+: i) otonomi relatif negara/bangsa terhadap kepentingan yang mendorong deforestasi dan degradasi hutan, ii) pengakuan atau rasa memiliki nasional atas proses-proses kebijakan REDD+, iii) proses kebijakan REDD+ yang inklusif, dan iv) adanya koalisi yang menyerukan perubahan transformatif.

- Merumuskan dan melaksanakan strategi nasional REDD+ adalah hal yang sangat menantang bagi negara-negara di mana para pelaku internasional merupakan kekuatan pemicu satu-satunya bagi proses kebijakan REDD+.

- Koalisi baru yang mampu memutuskan ketergantungan kelembagaan dan langkah politik membutuhkan partisipasi kalangan elite di masing-masing negara dan keterlibatan para pelaku bisnis untuk memengaruhi agenda politik secara signifikan.

\subsection{Pengantar}

Bab ini menyajikan analisis proses kebijakan perumusan dan usulan implementasi strategi REDD+ di tingkat nasional (dan federal) di tujuh negara: Bolivia, Brasil, Kamerun, Indonesia, Nepal, Peru dan Vietnam. Dengan 
menggunakan lensa ekonomi-politik, kami mengidentifikasi kendala-kendala utama dalam perumusan kebijakan yang efektif. Mulai dari pemicu utama deforestasi dan konteks khusus masing-masing negara, pertama kami mengidentifikasi ciri-ciri utama dalam proses kebijakan nasional, termasuk kondisi struktural, pelaku-pelaku kebijakan yang memegang peran dominan dan berbagai proses yang membantu atau menghambat pengembangan kebijakan-kebijakan REDD+ yang efektif, efisien dan berkesetaraan. Tentunya iklim negosiasi internasional memengaruhi proses kebijakan nasional tentang REDD+, namun dalam bab ini kami tidak membahas hubungan antara keduanya, tetapi memfokuskan pembahasan pada tingkat nasional.

Negara-negara yang terlibat dalam pengembangan kebijakan REDD+ mengalami kemajuan dengan kecepatan yang berbeda dan terlibat dengan derajat yang berbeda dalam kerja sama multilateral maupun bilateral untuk desain kebijakan REDD+, dengan penekanan khusus pada pengembangan kapasitas (Bab 3). Rezim politik negara-negara ini beragam, mulai dari pemerintahan demokrasi sampai ke pemerintahan otoriter. Seperti bisa diduga rezim demokratis menghadirkan proses kebijakan yang lebih terbuka dan inklusif (Johannsen dan Pedersen 2008). Di semua negara, ada banyak pelaku, baik di tingkat subnasional, nasional dan internasional yang terlibat dalam proses kebijakan nasional REDD+ (Hiraldo dan Tanner 2011a). Pertentangan politik selalu berada di jantung setiap proses kebijakan, dan arena kebijakan REDD+ tidak terkecuali.

Masing-masing dari tujuh negara yang diteliti tersebut telah mengalami berbagai peristiwa di mana kebijakan utamanya terkait dengan perumusan kebijakan REDD+ (Gambar 5.1). Keluaran utama kebijakan berhubungan dengan pembentukan lembaga-lembaga baru, prosedur dan peningkatan kapasitas yang terkait dengan berbagai kegiatan kesiapan (readiness), sementara perumusan kebijakan dan pelaksanaan konkret sampai sekarang masih terbatas. Secara keseluruhan, lambatnya kemajuan mungkin mencerminkan keterlambatan dalam memperoleh pembiayaan dari negosiasi iklim global, tetapi perebutan kekuasaan di kancah domestik juga bisa merupakan salah satu penyebabnya.

Bab ini menggunakan kerangka analisis ekonomi politik, yang didasarkan pada kerangka '4I' yang diuraikan dalam Bab 2:"institutions, interests, ideas and information" (kelembagaan, kepentingan, gagasan dan informasi) dengan fokus khusus pada tiga hal pertama. Kami menyelidiki bagaimana terjadinya kebergantungan kelembagaan dan langkah politik, kepentingan-kepentingan yang mendorong pelaku deforestasi dan degradasi hutan, dan bagaimana gagasan-gagasan mereka diterjemahkan ke dalam praktik-praktik pewacanaan (Gambar 5.2). Semua faktor ini memengaruhi kekuatan koalisi dominan yang memungkinkanatau membatasi perubahan transformatifdalamarenakebijakan 
ini. Kami mendefinisikan perubahan transformatif sebagai perubahan dalam sikap, wacana, hubungan kekuasaan dan tindakan terarah (kebijakan dan/atau protes) yang diperlukan untuk mengarahkan perumusan dan implementasi kebijakan menjauh dari pendekatan kebijakan bisnis-seperti-biasa (business as usual) dan bergerak mendukung (secara langsung atau tidak langsung) pengurangan emisi dari deforestasi dan degradasi hutan serta peningkatan stok karbon hutan (Bab 2). Kami berpendapat bahwa ada empat prasyarat yang diperlukan guna mendorong perubahan transformatif: i) otonomi tingkat tinggi bagi negara vis-à-vis kepentingan ekonomi yang kuat yang mendorong deforestasi dan degradasi hutan dalam hal prasyarat kelembagaan dan politis yang diperlukan; ii) kepemilikan pemerintah nasional atas proses-proses kebijakan REDD+; iii) pelibatan para pemangku kepentingan dalam proses kebijakan REDD+, dan iv) dalam hal dinamika kebijakan diperlukan adanya koalisi dominan yang ingin menghentikan berlangsungnya praktik-praktik bisnis-seperti-biasa (Gambar 5.2).

\subsection{Metode}

Analisis berikut ini didasarkan pada temuan dari dua modul penelitian komponen analisis kebijakan dari Studi Komparatif Global (GCS) REDD+ yang sedang berlangsung di bawah pimpinan CIFOR (lihat Lampiran).

Modul pertama adalah analisis kebijakan yang meneliti konteks politik di mana strategi-strategi nasional REDD+ sedang dikembangkan dan mengidentifikasi alur-ketergantungan yang mungkin terjadi dan penghambat pelaksanaan REDD+. Fokus utamanya adalah kondisi politik-ekonomi, kelembagaan dan tata kelola di masing-masing negara. Penelitian di setiap negara mencakup desktop research, wawancara para pakar dan telaah dokumen kebijakan.

Modul kedua adalah analisis media tentang wacana kebijakan, yang meneliti komposisi arena kebijakan, pernyataan posisi (sikap pendirian) para pelaku utama dan potensi pembentukan koalisi guna mencapai perubahan transformatif. Kami menyoroti bagaimana media menyajikan perdebatan REDD+ dan membandingkan wacana dominan dengan kontra-wacana (Hajer 1995; Boykoff 2008). Bingkai media adalah "pola kognisi, interpretasi, dan presentasi, seleksi, penekanan pengecualian yang digunakan oleh pewacana secara rutin membingkai wacananya" (Gitlin 1980:7). Penetapaan tema dan analisis sistematis terhadap bingkai media mengidentifikasi pelaku utama yang mendukung bingkai yang dihadirkan dalam artikel-artikel, sikap mereka terhadap REDD+ dan praktik-praktik wacana yang mereka lakukan. Dalam analisis ini disertakan artikel-artikel dari tiga surat kabar besar di tingkat nasional dari Desember 2005 hingga Desember 2009. Analisis komparatif didasarkan pada data media yang dikumpulkan dalam sebuah studi kasus. 


Peristiwa Internasional

Bolivia

Brasil
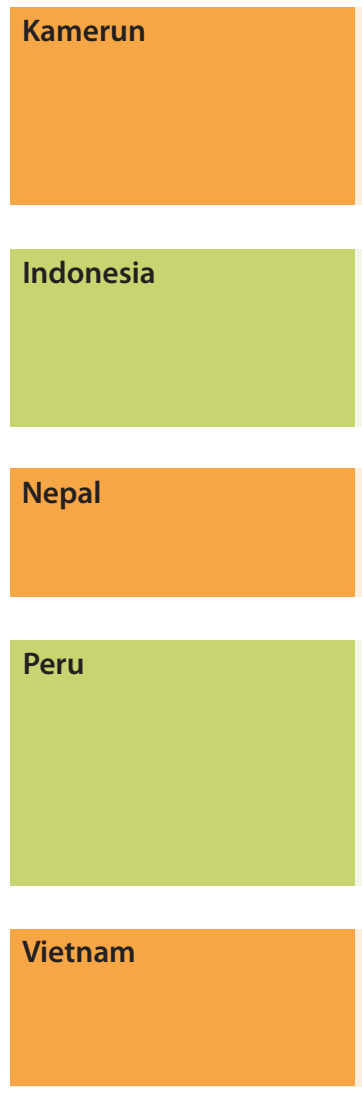

\section{Desember 2007}

COP13 di Bali

Desember 2007

Peluncuran fasilitas Carbon Partnership oleh Bank Dunia/ World bank

September 2007

Pertemuan Forest 11 di New York

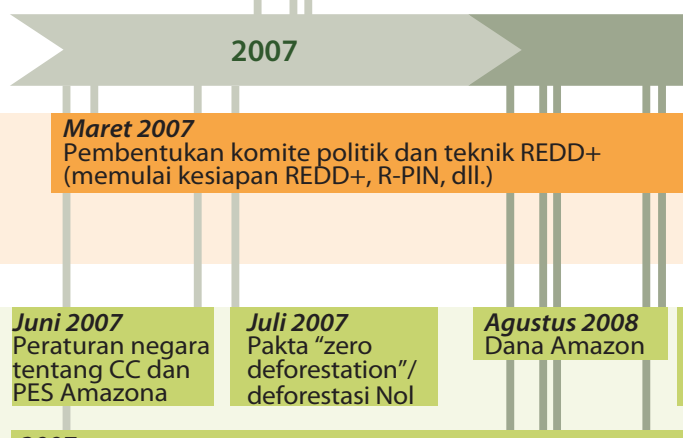

\section{7}

Komite antarkementerian di tingkat federal mengenai perubahan iklim

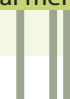

\section{Juli 2008}

Penyerahan R-PIN Kamerun kepada FCP
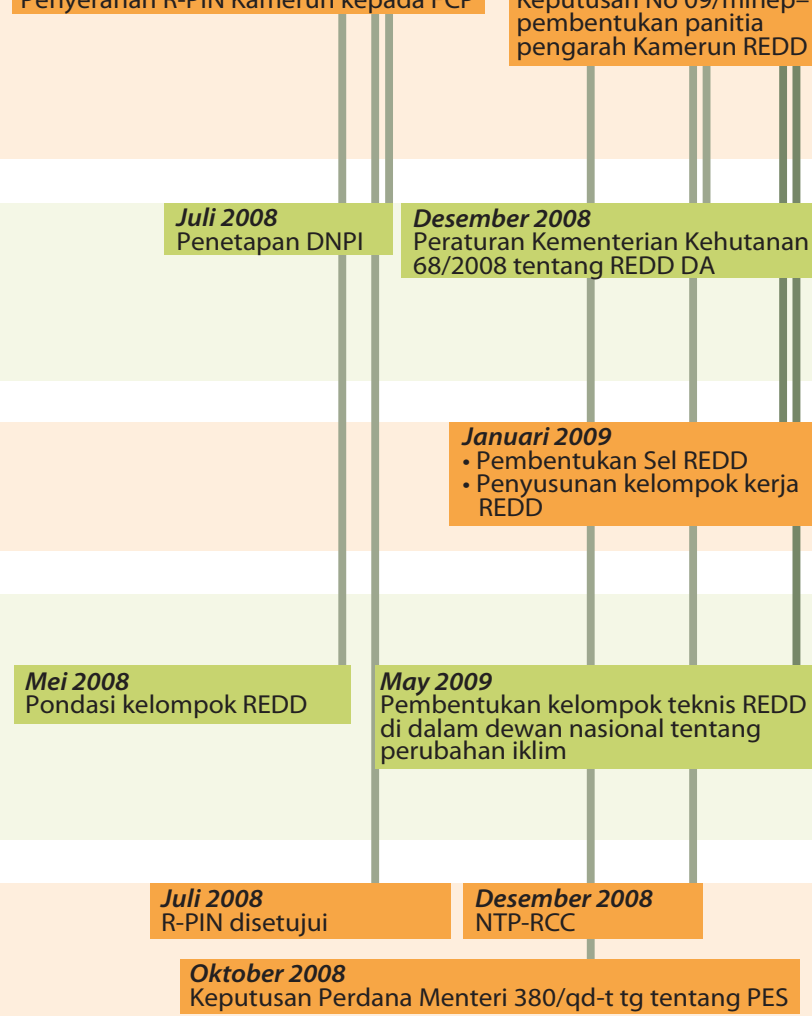

\section{Desember 2008}

2008

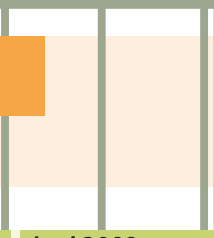

Juni 2009

Desember 2008

COP14 di Poznań

September 2008

Peluncuran

program PBB-REDD

Surat tocantins mengenai

"forum gubernur

wilayah amazona
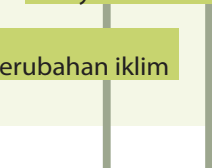

\section{Januari 2009}

Keputusan No 09/mineppembentukan panitia pengarah Kamerun REDD

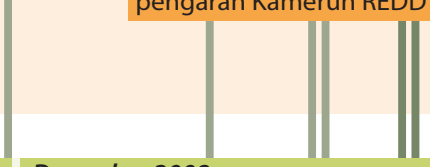




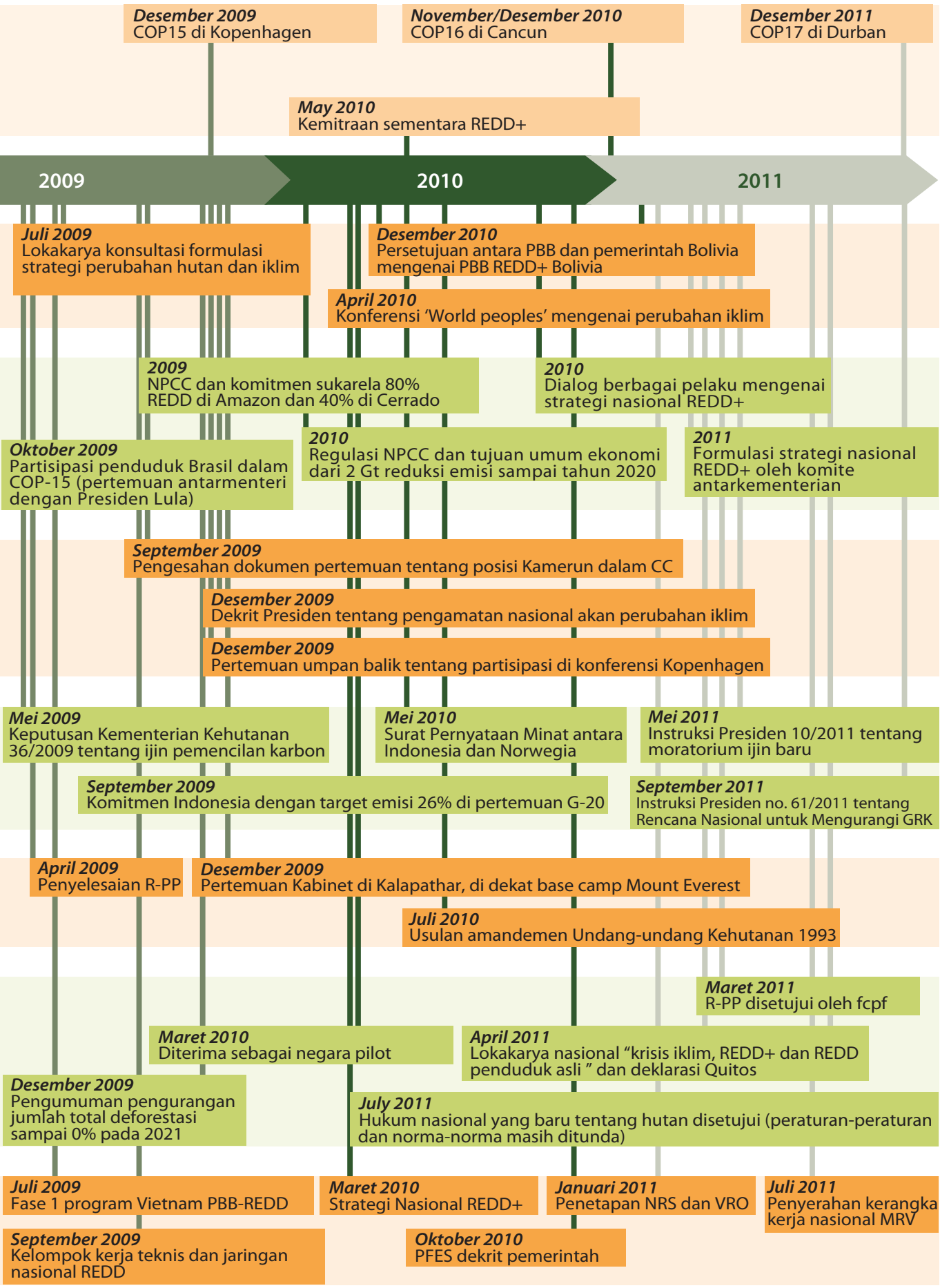


Alur-kebergantungan politik dan lembaga

- pengaturan kelembagaan (terutama yang terkait dengan penggunaan lahan)

- kebijakan masa lalu yang mendukung atau yang menentang REDD+

- Tingkat inklusi dalam proses politik

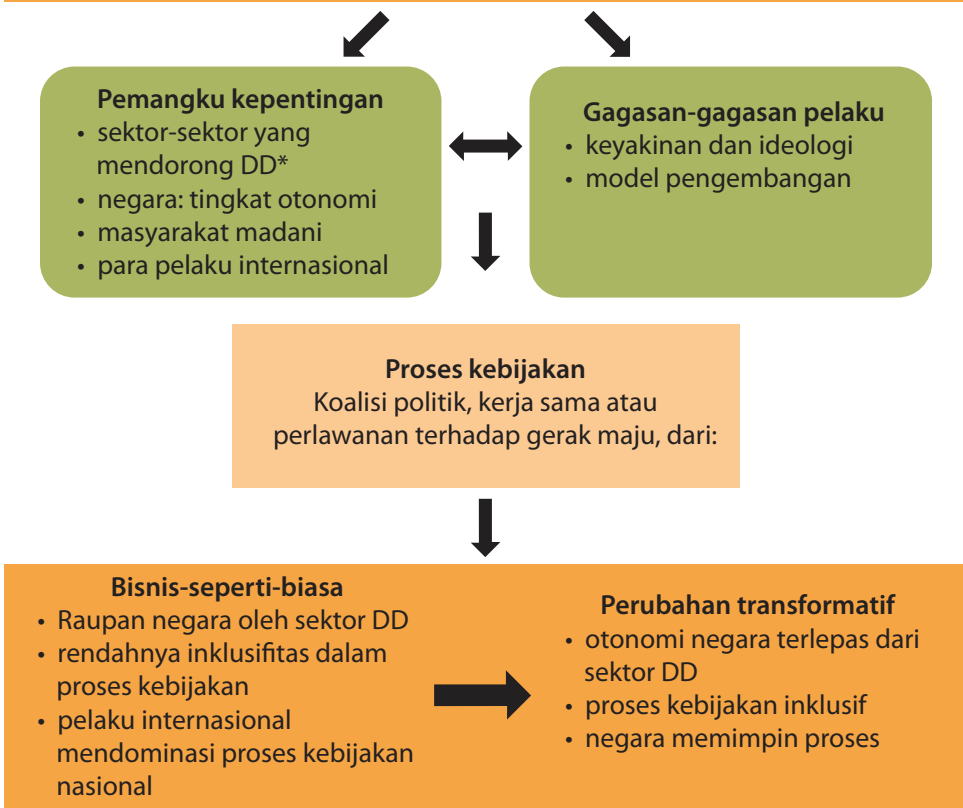

* DD: deforestasi dan degradasi hutan

Gambar 5.2 Kerangka kerja politik-ekonomi

\subsection{Konteks kelembagaan, alur-kebergantungan dan kepentingan-kepentingan}

Faktor-faktor yang menghambat perubahan transformatif ditentukan oleh interaksi tatanan kelembagaan, kebijakan-kebijakan terdahulu dan konsolidasi berbagai kepentingan yang beroperasi di sektor-sektor pemicu deforestasi dan degradasi hutan. Berbagai faktor ini bersama-sama membangun alur-kebergantungan yang sulit diatasi. Beberapa penyebab deforestasi dan degradasi telah disorot dalam kepustakaan, yang berkisar dari penyebab langsung seperti perluasan pertanian baik skala besar maupun kecil, sampai ke pemicu tidak langsung seperti kebijakan negara dan kepentingan bisnis besar, baik di dalam maupun di luar sektor kehutanan (Rudel 2007; Brockhaus dkk. 2012). Insentif ekonomi yang kuat sering ada di balik pemicu yang paling relevan, biasanya hal ini saling memperkuat atau berlangsung bersamaan (Lambin dkk. 2001). 
Perubahan transformatif membutuhkan adanya negara yang otonom dari sektor-sektor pemicu deforestasi dan degradasi hutan dan bekerja bagi kepentingan masyarakat umum (Karsenty dan Ongolo 2012). Otonomi negara mengacu pada sejauh mana pelaku penyelenggara negara dapat membuat berbagai keputusan kebijakan yang independen dari berbagai sektor. Bentuk otonomi yang dimiliki adalah produk dari sejarah spesifik suatu negara. Negara harus mampu menahan tekanan lobi dari berbagai sektor yang mendapatkan keuntungan dari eksploitasi hutan dan perubahan tata guna lahan sehingga memungkinkan terjadinya perubahan transformatif. Namun otonomi harus berjalan seiring dengan proses kebijakan inklusif yang diterjemahkan ke dalam bentuk otonomi yang sudah ada (Evans 1995). Semakin inklusif suatu sistem politik, semakin besar kemungkinan negara melayani masyarakat yang lebih luas, karena berbagai tuntutan kepentingan-kepentingan yang lebih lemah (seperti masyarakat sipil) terwakili secara lebih baik dalam sistem politik yang otonom (Jenkins 1995).

Ada bukti kuat mengenai kurangnya otonomi negara vis-à-vis sektor-sektor yang mendorong deforestasi dan degradasi hutan. Adanya kolusi dan korupsi, atau lemahnya tata kelola hutan, dipandang sebagai tantangan utama dalam pengembangan dan pelaksanaan kebijakan REDD+ yang efektif (Kanninen dkk. 2007). Pembalakan liar dan tidak adanya penegakan hukum umum terjadi di banyak negara berhutan tropis (Brack 2005). Analisis yang sedang berlangsung menunjukkan adanya hubungan kuat antara tata kelola hutan dan kondisi pemerintahan secara umum serta dampaknya bagi proses kebijakan REDD+ (WRI 2009).

Analisis berikut ini mempertimbangkan empat kondisi utama politik-ekonomi dan kelembagaan: i) pemicu utama deforestasi, yang mewakili kepentingan-kepentingan bisnis-seperti-biasa; ii) berbagai kebijakan yang memungkinkan atau menghambat tujuan REDD+ dan tatanan kelembagaan yang terkait; iii) otonomi negara vis - $\grave{a}$-vis pelaku ekonomi yang mendorong terjadinya deforestasi dan degradasi hutan, dan iv) tingkat inklusivitas proses kebijakan (Tabel 5.1).

Kondisi pertama mengacu pada berbagai kegiatan yang memicu deforestasi dan degradasi hutan. Perluasan pertanian, termasuk peternakan adalah penyebab utama deforestasi, meskipun dampak relatif pertanian skala besar versus skala kecil dan pertanian subsisten sangat bervariasi. Pemicu lainnya adalah penebangan hutan, pertambangan dan pembangunan infrastruktur (Tabel 5.1). Karena itu, agar dapat mengatasi deforestasi dan degradasi hutan secara efektif, para perumus kebijakan perlu mengidentifikasi kendala-kendala utama dalam kebijakan kehutanan, pertanian, peternakan dan sektor pertambangan dan menyusun struktur insentif baru (lihat Tabel 5.1 diskusi tentang Brasil). Tingginya rente atau keuntungan ekonomi di berbagai sektor ini membuat 


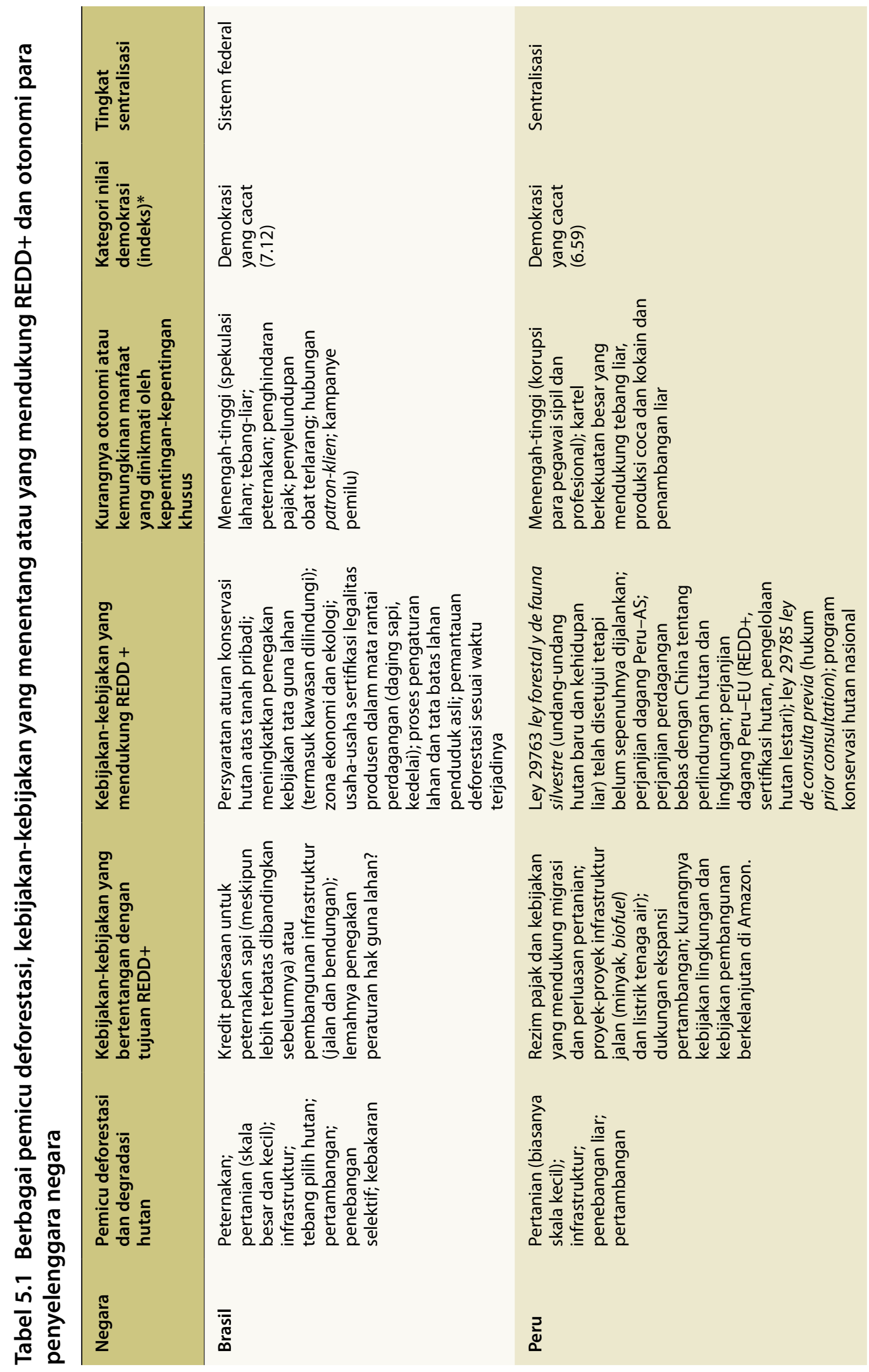




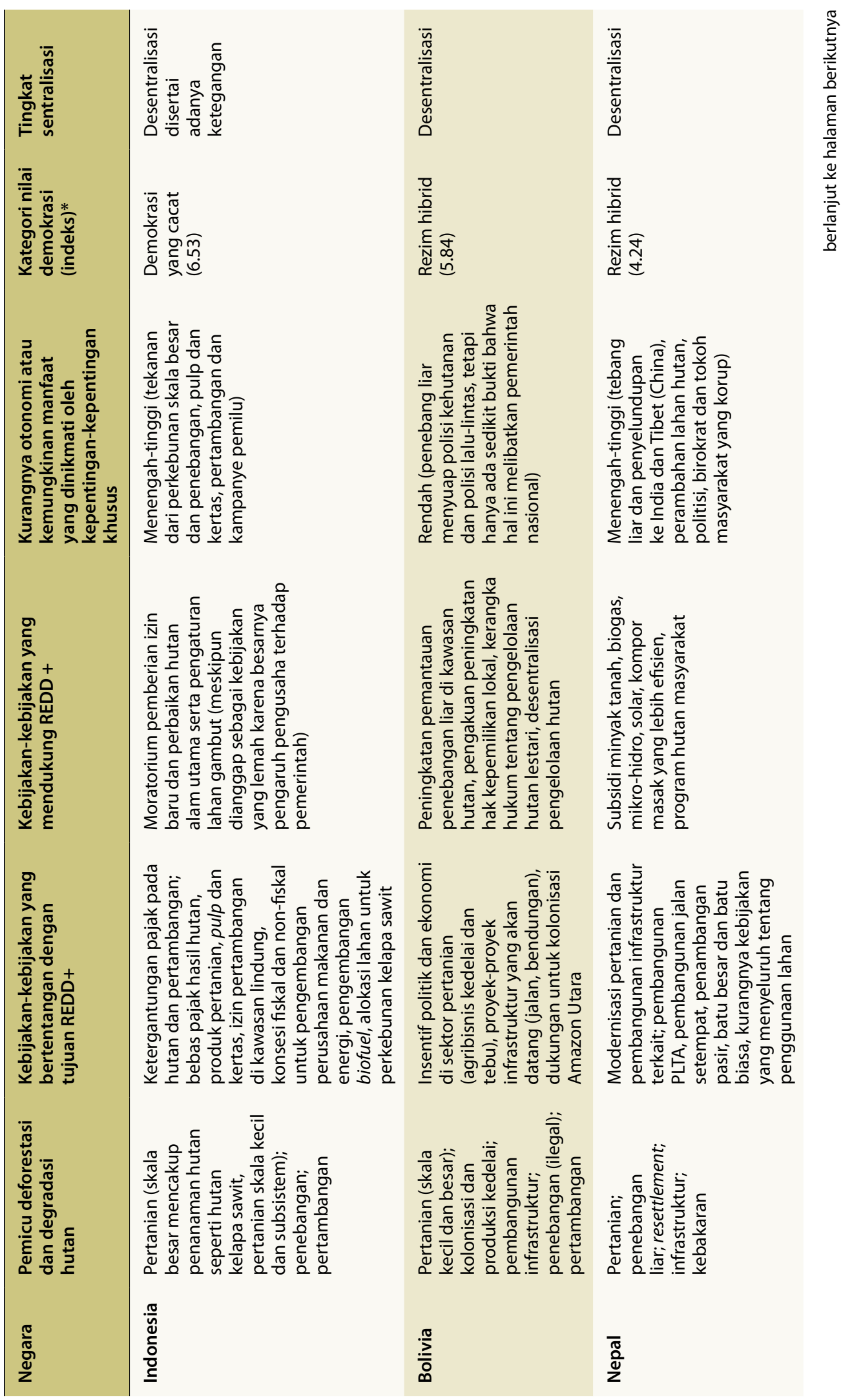




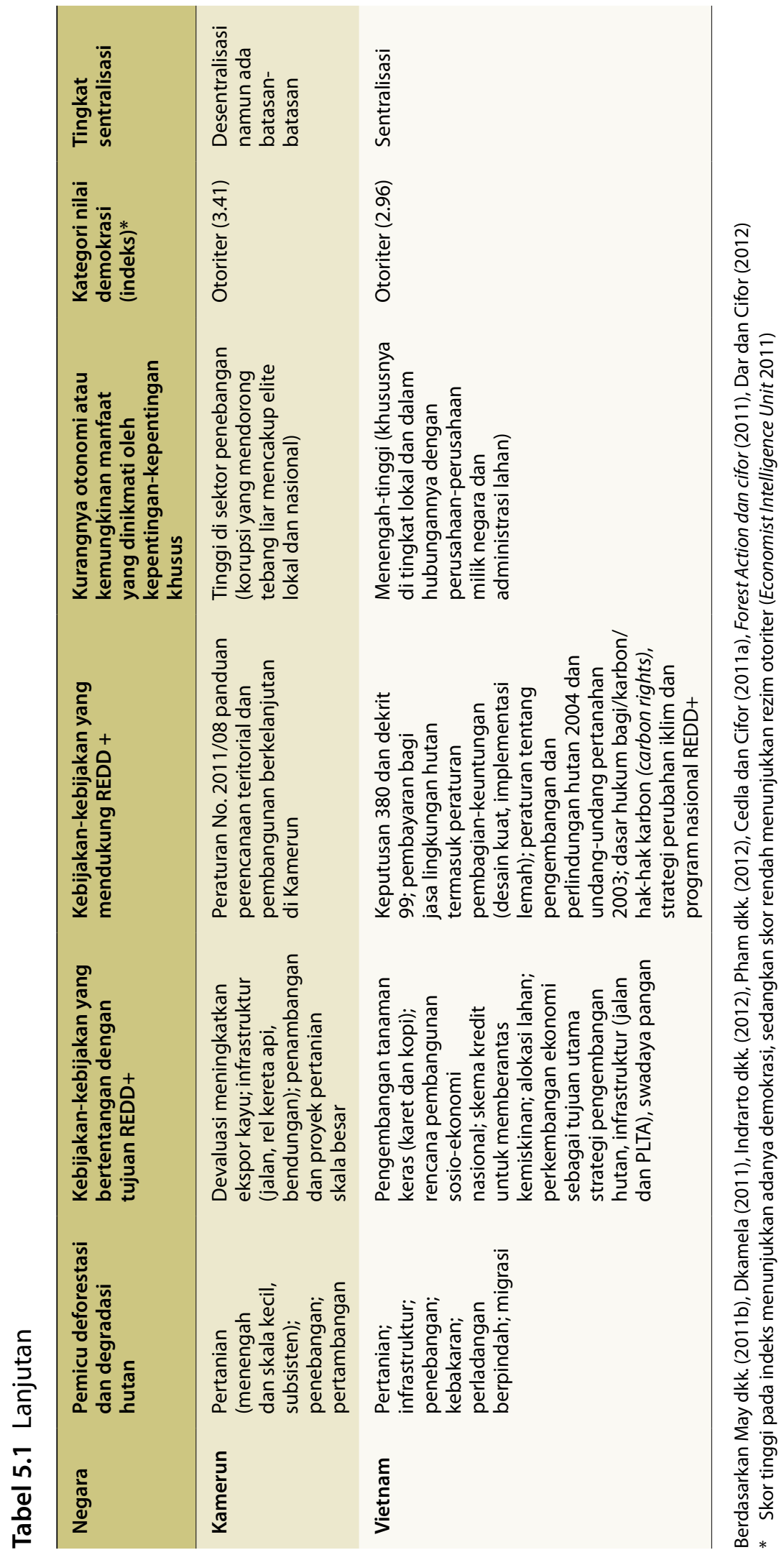




\section{Kotak 5.1 REDD+ cara Brasil: Memadukan tongkat tua dengan wortel baru}

Jan Börner dan Sven Wunder

Melaksanakan REDD+ memerlukan kebijakan yang efektif dalam mengubah keputusan penggunaan lahan dan hutan. Biasanya, perubahan seperti ini menyebabkan hilangnya manfaat ekonomi bagi pengguna lahan, setidaknya dalam jangka pendek. Selain biaya pelaksanaan, setiap kebijakan REDD+ yang efektif pasti memiliki konsekuensi distribusi manfaatnya. Idealnya, REDD+ bisa memaksimalkan keefektifan dari segi biaya dan kesetaraan. Namun dalam kenyataannya, perumus kebijakan cenderung menghadapi kesulitan negosiasi timbal balik di antara kedua tujuan ini.

Kepemilikan lahan dan hak pemanfaatan hutan penduduk Brasil sangat terkonsentrasi. Merebaknya pelanggaran menyebabkan Senat pemerintah Brasil kini sedang mempertimbangkan perluasan peraturan tata guna lahan yang saat ini sangat terbatas. Jika peraturan kehutanan yang berlaku sekarang ditegakkan secara efektif - misalnya, mewajibkan konservasi $80 \%$ tanaman hutan yang ada di lahan pertanian - maka negara ini akan mengorbankan agroindustri skala besar yang sedang berkembang pesat. Sebaliknya, pendekatan REDD+ yang murni berbasis insentif akan berarti memberikan kompensasi kepada pemilik lahan supaya tidak melanggar peraturan konservasi yang ada, yang secara politis sensitif. Karenanya, pada COP15 tahun 2009, Brasil mengusulkan pendekatan REDD+ yang menggabungkan penegakan peraturan yang lebih tegas diiringi program nasional yang memberikan kompensasi pembayaran jasa lingkungan (PES).

Usaha menemukan kombinasi optimal antara tongkat 'peraturan lama' dan 'wortel' PES memiliki implikasi tidak hanya dalam hal kesetaraan, tetapi juga dalam hal biaya pelaksanaan. Penegakan hukum konservasi memerlukan biaya mahal untuk operasi lapangan, tetapi juga dapat menghasilkan pemasukan denda yang sebagian dapat mengimbangi biaya pelaksanaan tersebut. Sebaliknya, PES memerlukan pengeluaran anggaran cukup besar sehingga mengorbankan peluang politik vis-à-vis pengeluaran pemerintah lainnya. Menambahkan aspek kesetaraan pada REDD+ dengan cara memberikan ganti rugi hilangnya peluang pemilik lahan - baik legal maupun ilegal tetapi ditoleransi - akan membutuhkan biaya besar, terutama jika para penjaga hutan di masa lalu yang mengabdi dengan baik (misalnya, banyak masyarakat adat Amazon dan penghuni hutan tradisional) juga diberi penghargaan.

Pendekatan yang memadukan tongkat-dan-wortel mengandung pro dan kontra. Sebagai instrumen yang berdiri sendiri, PES dapat ditegakkan dengan sekedar menangguhkan pembayaran kepada pengguna lahan yang tidak patuh. Penerima PES kemudian akan berharap untuk menerima paling sedikit kompensasi atas peluang mereka yang hilang. Meskipun demikian, dalam hubungannya dengan peraturan-peraturan sebelumnya 


\section{Kotak 5.1 Lanjutan}

yang sudah berlaku, maka PES menjadi subsidi atas kepatuhan, yang biasanya tidak bisa memberi kompensasi penuh kepada pengguna lahan atas kepatuhannya pada undang-undang konservasi. Di bawah kebijakan yang terpadu seperti ini, penangguhan pembayaran mungkin tidak cukup efektif untuk mendorong konservasi jika ancaman terhadap pelanggaran peraturan dianggap sebagai sesuatu yang mustahil dijalankan, misalnya di daerah perbatasan terpencil. Ketidaksempurnaan penegakan hukum dari komponen pelengkap 'tongkat' juga dapat mendorong pengguna lahan untuk mengantongi PES lalu melanjutkan bisnis seperti biasa. Karena itu pembuat kebijakan yang secara efektif mengintegrasikan tongkat-dan-wortel berbasis kebijakan REDD+ akan bergantung pada alat-alat perencanaan yang dapat mengantisipasi biaya pelaksanaan yang mencakup ruang yang heterogen dan bergantung pada efek kesejahteraan seperti yang dihasilkan oleh alat-alat konservasi yang dioperasikan secara sinergis. Dalam lingkungan sistem pemerintahan yang terdesentralisasi sebagian seperti Brasil, biaya penerapan kebijakan-kebijakan lingkungan ditanggung bersama oleh pemerintah pusat dan daerah. Dengan demikian mekanisme baru untuk pembagian biaya dan penerimaan manfaat juga diperlukan di seluruh entitas administratif untuk mencapai hasil yang efektif dan setara.

Sumber: Börner dkk. (2011)

pemerintah sangat kesulitan mendesain ulang sejumlah insentif. Di banyak negara, meskipun sektor yang mendorong deforestasi dan degradasi hutan sudah sangat dikenali, cara mengukur dampak masing-masing sektor pemicu deforestasi dan degradasi hutan tersebut tetap merupakan tantangan berat.

Kebijakan-kebijakan yang mendukung penyebab deforestasi dan tatanan kelembagaan yang terkait dengan kebijakan tersebut, menghambat perubahan transformatif dan menciptakan alur-kebergantungan yang sulit dicari jalan keluarnya. Di kebanyakan negara, rezim pajak lebih memilih eksploitasi hutan demi mendukung pembangunan ekonomi, seperti pemberian dukungan kredit pedesaan untuk peternakan sapi di Brasil (meskipun sekarang jumlahnya lebih rendah dan sudah terpaut dengan berbagai tindakan pelestarian lingkungan) dan potongan pajak untuk biofuel serta pengembangan penanaman di Indonesia (Tabel 5.1). Dana publik untuk pembangunan infrastruktur juga merupakan kunci pendukung perluasan kegiatan tersebut. Setelah sekian lama kebijakan-kebijakan ini menciptakan struktur kelembagaan yang meningkatkan keuntungan penggunaan lahan yang bersaing dengan pelestarian hutan, sehingga secara efektif mengokohkan kekuatan sektor utama yang mendorong deforestasi dan degradasi hutan. 
Tantangannya adalah bagaimana membebaskan diri dari alur-kebergantungan seperti ini. Di semua negara ada juga kebijakan-kebijakan yang sudah ada yang bisa dipakai mengaktifkan perumusan dan implementasi kebijakan REDD+. Kebijakan-kebijakan ini mencakup kebijakan pembayaran jasa lingkungan, peraturan kehutanan yang mendorong pengelolaan hutan lestari; konservasi, reboisasi dan rehabilitasi hutan; dan pengeluaran pemerintah yang bertujuan untuk meningkatkan efisiensi energi serta memberikan alternatif untuk produk-produk hutan. Masalahnya, kebijakan-kebijakan ini umumnya hanya memiliki sumberdaya yang lebih sedikit dan hanya mencakup wilayah yang sangat terbatas, dibandingkan dengan kebijakan-kebijakan yang mendukung penyebab-penyebab deforestasi (Tabel 5.1).

Terlepas dari sektor bisnis, negara sendiri memiliki kepentingan ekonomi dan politik untuk mengeksploitasi dan mengonversi hutan, karena kegiatan-kegiatan ini berkontribusi untuk tujuan pembangunan ekonomi dan menyediakan sumberdaya keuangan bagi negara dalam bentuk pajak dan pungutan lainnya. Agar dapat memberikan insentif, negara perlu memegang tingkat otonomi yang memadai sehingga bebas dari para pelaku ekonomi yang mendorong deforestasi (Karsenty dan Ongolo 2012). Kurangnya otonomi juga dapat terungkap melalui tingginya tingkat kolusi antara negara dan para pelaku sosial. Dari ketujuh negara yang diteliti, semuanya menghadapi tantangan ini (Tabel 5.1). Nepal dan Peru menghadapi tantangan dalam penerapan undang-undang kehutanan, khususnya di tingkat lokal di mana jaringan patron-client berperan kuat. Di Brasil dan Indonesia, agribisnis yang kuat, pemilik tanah peternakan, dan perusahaan kayu terus memberikan tekanan pada pemerintah untuk melindungi hak sewa mereka. Ini bisa dibuktikan dari serangan para pemangku kepentingan bisnis terhadap peraturan kehutanan di Brasil dan moratorium di Indonesia. Sebagian besar lobi berlangsung di belakang layar, namun efeknya terlihat dalam perumusan kebijakan akhir, sangat terbatasnya pelaksanaan kebijakan serta rendahnya tingkat kepatuhan terhadap kebijakan yang ada (Coen 2004). Dalam beberapa tahun terakhir terlihat bahwa Brasil meningkatkan kemampuan dalam menahan tekanan tersebut dibandingkan Indonesia, yang memiliki sejarah panjang hubungan erat antara pejabat pemerintah dan kepentingan bisnis di semua tingkatan. Di banyak negara ini, ijin penebangan liar juga secara rutin digunakan untuk menggalang sumberdaya untuk kampanye pemilu. Di Vietnam tantangan utamanya terkait dengan korupsi dan kolusi di perusahaan milik negara, pemerintah daerah dan pelayanan publik. Tingginya tingkat pendapatan negara dari kepentingan yang mendorong deforestasi, terlihat di Kamerun di mana lebih dari 90\% dari kegiatan penebangan liar melibatkan elite tingkat lokal dan nasional. Tidak satu pun dari tujuh negara yang dikaji memiliki otonomi memadai untuk mendukung perubahan kebijakan yang berani memberikan isyarat untuk memutuskan diri dari model pembangunan tradisional yang mengandalkan eksploitasi sumberdaya alam. Para pelaku penyelenggara negara di Vietnam, diikuti oleh Brasil, mungkin yang paling 


\section{Kotak 5.2 Mengaitkan pengetahuan dan tindakan: perumusan kebijakan REDD+ di Tanzania}

Salla Rantala

Bagaimana memetik berbagai jenis pengetahuan yang relevan dalam cara yang meningkatkan keefektifan, efisiensi dan kesetaraan dalam perumusan kebijakan merupakan tantangan mendesak yang dihadapi negara-negara saat mereka menyiapkan kebijakan nasional REDD+. Para perumus kebijakan semakin bergantung pada para pialang pengetahuan ilmiah yang kompleks yang berkaitan dengan perubahan iklim dan rezim yang diperlukan untuk mengatasinya. Pada saat yang sama, keluaran kebijakan sering mencerminkan proses tawar-menawar politik antara berbagai pelaku kebijakan yang berbeda dalam sumberdaya dan kapasitas masing-masing, dan bukannya sebagai cerminan dari proses linear pembuatan kebijakan berbasis bukti.

Di Tanzania, satuan tugas REDD+ yang dipimpin oleh pemerintah menyambut kontribusi masyarakat madani, lembaga penelitian, pemerintah daerah dan mitra internasional untuk pembangunan strategi nasional REDD+. Organisasi dengan tanggung jawab yang kuat untuk menyebarkan informasi yang relevan tentang REDD+ membagikan pengalaman-pengalaman mereka dalam proses perumusan kebijakan. Tindakan formal yang dilakukan mencakup penyelenggaraan berbagai lokakarya dan pelatihan. Namun, pintu masuk untuk memengaruhi kebijakan yang paling berhasil dan banyak dibicarakan adalah menemukan organisasi-organisasi yang tepat baik di dalam maupun di luar pemerintah untuk bekerja sama melakukan advokasi, serta diplomasi terselubung yang dilakukan terhadap orang-orang yang menduduki posisi tinggi dalam garis kewenangan di berbagai sektor yang berbeda. Ada cukup banyak konsensus mengenai kebutuhan untuk menampilkan kisah nyata tentang kesuksesan lokal guna meyakinkan para perumus kebijakan. Tantangan paling menonjol dalam mengaitkan pengetahuan relevan dengan pembuatan kebijakan REDD+ adalah biaya tinggi yang diperlukan untuk mendapatkan perhatian para pejabat penting. Pengelola acara yang bertujuan membagi informasi harus bersaing untuk bisa mendapatkan waktu yang sangat terbatas di antara pihak yang perlu dilibatkan. Dihadapkan pada banyaknya pilihan acara-acara yang perlu diikuti maka orang-orang ini bisa saja akhirnya mengambil keputusan berdasarkan sumberdaya yang tersedia, misalnya jumlah tunjangan yang diperoleh dan bukannya pada isi informasi apa yang disampaikan dalam acara tersebut.

Tantangan ini menggambarkan bagaimana saluran-saluran sumberdaya dan informasi dalam perumusan kebijakan saling terjalin satu sama lain. Hambatan-hambatan lain yang disebutkan oleh narasumber di Tanzania berkaitan dengan kapasitas dan kesediaan para pengambil keputusan untuk mempertimbangkan rekomendasi yang berbeda dari pandangan lama mereka, serta kelesuan sistem birokrasi dalam menanggapi bukti. Interaksi dengan para pejabat yunior dan cabang-cabang (kekuasaan) eksekutif dalam pemerintahan saja, dan bukannya berinteraksi dengan "pengambil keputusan yang sesungguhnya", juga dikatakan sebagai sebagian dari kegagalan dalam mengaitkan pengetahuan dengan tindakan. 
mandiri dalam mendukung perubahan tersebut. Di semua kasus lainnya, perubahan transformatif akan membutuhkan aliansi yang lebih luas antara berbagai bagian dari negara dan kerja sama kekuatan lain sehingga mampu memecahkan alur-kebergantungan. Pelaku internasional dan masyarakat sipil dapat mengambil bagian dengan mendorong terjadinya perubahan tersebut. Norwegia adalah salah satu donor internasional utama yang mendukung upaya ini (lihat Kotak 5.4).

Akhirnya, semakin inklusif sebuah proses kebijakan, semakin besar pula kemungkinan kebijakan REDD+ dapat mencakup pertimbangan kesetaraan dan kemungkinan potensi ketegangan dan konflik antara para pelaku kebijakan dan pemangku kepentingan menjadi lebih kecil. Proses kebijakan yang inklusif dipengaruhi oleh jenis rezim politik dan tingkat sentralisasinya. Kami menggunakan indeks demokrasi dan tingkat sentralisasi yang sebenarnya dari sistem politik sebagai proxy (sesuatu yang digunakan untuk mengukur sesuatu yang lain) untuk mengukur inklusivitas (Tabel 5.1) Rezim politik di tujuh negara yang diteliti bervariasi dari demokrasi ke otoriter, demikian juga tingkat sentralisasinya, dari sangat tersentralisasi (Vietnam) sampai ke negara-negara yang bersifat federal dan terdesentralisasi (Brasil, Indonesia). Secara umum, rezim yang lebih otoriter seperti Vietnam dan Kamerun cenderung lebih terpusat dan memiliki bentuk partisipasi eksklusif dalam proses kebijakannya. Sedangkan beberapa rezim, seperti Peru, bersifat demokratis namun relatif tersentralisasi. Negara yang lebih demokratis diharapkan menjadi lebih inklusif dalam pengambilan keputusan kebijakan. Negara seperti Indonesia dan Kamerun telah mengalami proses perubahan desentralisasi dan resentralisasi (Ribot 2003, Oyono 2004). Secara keseluruhan, Vietnam dan Kamerun mewakili rezim politik yang eksklusif, sedangkan Brasil, Peru dan Indonesia lebih inklusif. Bolivia dan Nepal memiliki rezim hibrid yang memiliki fitur demokratis maupun otoriter, ditandai dengan adanya inklusivitas terbatas. Inklusivitas rezim politik kemungkinan akan berdampak pada inklusivitas proses kebijakan spesifik, termasuk REDD+ (lihat Kotak 5.2 untuk analisis lebih rinci mengenai inklusivitas dalam proses konsultasi tentang REDD+ di Tanzania).

\subsection{Wacana kebijakan dan koalisi ke arah perubahan}

Media dapat dilihat sebagai cermin dari proses kebijakan yang sedang berlangsung, dan dalam penelitian ini analisis media digunakan untuk mengidentifikasi wacana kebijakan yang dominan dan sejauh mana wacana ini dirangkul di antara para pelaku. Koalisi transformatif menggunakan praktik-praktif wacana yang menantang skenario bisnis-seperti-biasa dan menghimbau adanya perubahan kelembagaan, kebijakan dan struktur insentif dari model pembangunan ekonomi tradisional, yang didasarkan pada eksploitasi sumberdaya hutan. Namun, pencerminan proses-proses kebijakan oleh media hanya bersifat parsial. Tidak semua pelaku menggunakan media 
Tabel 5.2 Pelaku yang membentuk wacana kebijakan (persentase jumlah total pelaku yang mengekspresikan posisinya tentang REDD+ melalui media)

\begin{tabular}{|c|c|c|c|c|c|c|c|}
\hline Kelompok pelaku & Indonesia & Brasil & Bolivia & Vietnam & Nepal & Kamerun & Peru \\
\hline Negara (nasional) & 45 & 26 & 50 & 67 & 17 & 8 & 12 \\
\hline $\begin{array}{l}\text { Negara } \\
\text { (subnasional) }\end{array}$ & 7 & 2 & 3 & 0 & 6 & 0 & 0 \\
\hline Korporasi & 3 & 4 & 10 & 6 & 6 & 0 & 0 \\
\hline Antarpemerintahan & 8 & 7 & 9 & 27 & 6 & 17 & 25 \\
\hline Riset (internasional) & 5 & 11 & 0 & 0 & 6 & 42 & 25 \\
\hline $\begin{array}{l}\text { LSM dan } \\
\text { LSM-Lingkungan } \\
\text { (internasional) }\end{array}$ & 16 & 17 & 10 & 0 & 0 & 0 & 25 \\
\hline Riset (nasional) & 6 & 13 & 3 & 0 & 12 & 25 & 0 \\
\hline $\begin{array}{l}\text { Pelaku masyarakat } \\
\text { madani (nasional } \\
\text { dan LSM } \\
\text { lingkungan) }\end{array}$ & 10 & 20 & 15 & 0 & 47 & 8 & 13 \\
\hline Total\% organisasi & 100 & 100 & 100 & 100 & 100 & 100 & 100 \\
\hline $\begin{array}{l}\text { Jumlah total } \\
\text { organisasi }\end{array}$ & 219 & 113 & 60 & 32 & 17 & 12 & 8 \\
\hline
\end{tabular}

sebagai alat untuk memengaruhi kebijakan dan opini publik; kalangan bisnis biasanya tidak ingin diekspos oleh media dan lebih memilih untuk melobi pemerintah dengan cara yang lebih tersembunyi (Coen 2004). Hal yang sama berlaku bagi para ilmuwan, meskipun lembaga-lembaga penelitian lebih banyak diliput oleh media daripada kalangan bisnis.

Di ketujuh negara ini, liputan media mengenai REDD+ dimulai setelah road map Bali diluncurkan pada COP13 tahun 2007. Sejak saat itu, artikel media meningkat jumlahnya, namun tingkat peliputannya berbeda secara substansial antarnegara. Antara Desember 2005 dan 2009, tiga surat kabar utama di Indonesia dan Brasil masing-masing memuat sekitar 190 dan 250 artikel yang membahas REDD+, sedangkan di negara-negara lain peliputan media tetap di bawah 15 artikel (Cronin dan Santoso 2010; cedla dan CIFOR 2011b, Kengoum 2011; May dkk. 2011a,. Pham 2011; forest action dan CIFOR 2012; Libelula dan CIFOR 2012).

\subsubsection{Kepemilikan}

Agar pemerintah di suatu negara dapat memimpin perubahan berkelanjutan dalam arena kebijakan nasional REDD+, maka mereka perlu berperan sebagai pemegang kendali atas proses kebijakan dan memperlihatkan kemauan politik untuk menerapkan 


\section{Kotak 5.3 Berbagai kendala dalam perumusan kebijakan REDD+ yang efektif di Nepal}

Bryan R. Bushley dan Dil Bahadur Khatri

Sejak akhir 1970-an, sektor kehutanan di Nepal telah mengalami proses yang mantap ke arah desentralisasi menuju peningkatan otonomi daerah dan pengelolaan hutan berbasis masyarakat, serta proses pembuatan kebijakan nasional yang semakin inklusif. Namun dalam beberapa tahun terakhir, pemerintah dan para petugas kehutanan telah berusaha membatasi otonomi kelompok-kelompok pengguna hutan dan mengambil lebih banyak nilai ekonomis hutan melalui perundang-undangan, arahan-arahan, dan instrumen pertanggungjawaban lainnya. Pemerintah, LSM-LSM internasional, donor dan masyarakat madani telah bersama-sama menyambut REDD+ dan terlibat dalam pembuatan kebijakan dan proses uji coba.

Namun, wacana dan kebijakan REDD+ telah dipengaruhi oleh sejumlah interaksi antara para pelaku dalam tubuh pemerintah, donor/LSM internasional dan masyarakat madani; ada beberapa kecenderungan yang bisa dilihat. Pertama, pertukaran informasi dan sumberdaya terkait dengan REDD+ dikendalikan oleh LSM-LSM nasional dan internasional yang sedang melaksanakan proyek-proyek percontohan tertentu, sedangkan organisasi pemerintah paling berpengaruh dalam membentuk kebijakan tertentu. Kedua, partisipasi masyarakat madani dalam perumusan kebijakan terbatas pada beberapa pelaku yang terlibat, sedangkan kepentingan kelompok tertentu terpinggirkan, seperti perempuan dan kaum Dalit (kasta rendah yang terkucil), kurang terwakili. Ketiga, belum ada keterlibatan langsung dari sektor swasta dalam uji coba atau proses perumusan kebijakan. Meskipun ada beberapa kekurangan di atas, muncul konfigurasi baru para pelaku di sekitar proyek percontohan dan usaha-usaha peningkatan kesadaran dan kampanye advokasi untuk membela hak-hak masyarakat yang bergantung pada hutan.

Ada juga sejumlah kendala kebijakan khusus yang dapat mengancam kelangsungan jangka panjang REDD+ di Nepal. Kendala pertama dan terpenting adalah kurangnya dasar hukum yang jelas akan penetapan hak-hak karbon. Terkait dengan hal ini adalah masalah kelemahan dan ketidakpastian hak-hak kepemilikan lahan, terutama untuk sejumlah masyarakat yang bergantung pada hutan. Tanpa salah satu dari hal ini maka akan sulit untuk menggalang dukungan keuangan dan politik yang kuat untuk REDD+, baik dukungan internal maupun eksternal. Kurangnya kejelasan dan konsensus dalam mengadopsi pendekatan berbasiskan dana vs pendekatan berbasiskan pasar untuk REDD+ juga merupakan kendala utama. Hambatan penting lainnya adalah kurangnya mekanisme yang inklusif, adil dan pembagian keuntungan yang bisa dipasarkan. Percontohan pembagian keuntungan telah dilakukan di tiga lokasi percontohan REDD+, dengan minoritas (40\%) dari kriteria untuk keuntungan berbasiskan stok karbon dan 


\section{Kotak 5.3 Lanjutan}

mayoritas (60\%) berbasiskan berbagai faktor sosial yang berbeda, seperti proporsi masyarakat adat, perempuan, dan kelompok-kelompok miskin di setiap komunitas. Namun pendekatan seperti itu tidak memiliki dasar dalam pasar karbon, mungkin tidak akan dapat bertahan dalam skema perdagangan karbon global, dan mengabaikan para pengelola lahan lainnya di luar komunitas pengguna hutan. Akhirnya, dibutuhkan kerangka kerja tata kelola menyeluruh yang demokratis, yang bisa meningkatkan mekanisme pembagian manfaat, mengawasi pemantauan, pelaporan dan verifikasi, dan membahas resolusi konflik yang terkait dengan implementasi REDD+.

Di Nepal, REDD+ tampaknya memperkuat kecenderungan negara untuk mengarah pada sentralisasi sekaligus meminggirkan pemangkukepentingan penting lainnya. Namun, modus baru kolaborasi juga muncul. Modus baru ini berpotensi mengubah lembaga-lembaga tata kelola hutan yang ada. Jika kolaborasi ini berhasil mengatasi kendala-kendala yang disampaikan di atas, maka berbagai kolaborasi baru ini bisa turut berkontribusi bagi realisasi mekanisme REDD+ yang lebih efektif, efisien dan setara.

strategi-strategi ini. Menganalisis sejauh mana penyelenggara negara di tingkat nasional bertindak aktif dalam membentuk wacana kebijakan di media dapat memberikan indikasi mengenai tingkat kepemilikan pemerintah atas proses kebijakan REDD+. Data yang disajikan di sini mengacu pada jumlah pelaku kebijakan (Tabel 5.2) dan berbagai wacana mengenai REDD+ yang mereka lakukan, sebagaimana ditunjukkan melalui bingkai media.

Di empat dari tujuh negara, para pelaku penyelenggara negara mendominasi wacana media. Di Bolivia, kebanyakan penyelenggara negara memahami REDD+ sebagai mekanisme yang merugikan dan menolaknya secara sepihak, namun penyelenggara negara tingkat nasional di Vietnam dan Indonesia menunjukkan sikap yang sangat mendukung REDD+. Wacana kebijakan di Brasil didominasi oleh penyelenggara negara di tingkat nasional (26\%), namun pemangku kepentingan yang sangat beragam juga diwakili di dalam media, terutama LSM internasional di bidang lingkungan hidup, lembaga-lembaga penelitian dan para pelaku dari kalangan masyarakat madani. Indonesia juga menyajikan para pelaku yang sangat beragam, terutama LSM internasional. Kekhasan Indonesia yang terdesentralisasi adalah jumlah pelaku subnasional yang relatif tinggi, sebagai cerminan negosiasi yang sedang berlangsung antara pemerintah pusat dan daerah mengenai kendali atas sumberdaya REDD+ dan keputusan-keputusan kebijakan (Cronin dan Santoso 2010; lihat juga Kotak 6.2). Hanya ada dua negara lain yang pelaku subnasionalnya masuk ke dalam liputan media, yaitu Brasil sebagai negara federal, dan Bolivia negara terdesentralisasi. 


\title{
Kotak 5.4 Analisis berbasis media tentang wacana REDD+ di Norwegia
}

\author{
Laila Borge
}

Tahun 2010, ilmuwan iklim terkenal James E. Hansen mengatakan bahwa efek utama dari pendanaan yang diberikan oleh Norwegia bagi perlindungan hutan adalah lahirnya hati nurani yang lebih jernih bagi anggota-anggota bangsa kaya minyak ini. Menteri Lingkungan Hidup Norwegia, Erik Solheim dengan cepat membalas pernyataan tersebut dengan sebuah surat kepada Aftenposten (surat kabar terkemuka Norwegia): "Norwegia mendukung upaya mencegah deforestasi karena ini adalah cara tercepat dan paling efisien dari segi biaya untuk mencapai pengurangan emisi gas rumah kaca secara mendasar. (...) Norwegia telah menunjukkan kepemimpinan internasional dengan inisiatifnya di bidang iklim dan kehutanan dan kami telah membuat beberapa negara lain mendukung pekerjaan penting ini". Sudut pandang ini telah menjadi pandangan yang paling banyak diungkapkan media Norwegia.

Tahun 2007, selama negosiasi iklim internasional di Bali, Norwegia menjanjikan 15 miliar nok (AS \$2,6 miliar) untuk mendanai upaya mengurangi emisi akibat deforestasi dan degradasi hutan di negara-negara sedang berkembang. Inisiatif Hutan dan Iklim Internasional Norwegia didirikan pada tahun 2008 untuk melaksanakan janji itu. Inisiatif ini mendatangkan dukungan politik yang luas dan media Norwegia sangat optimis mengenai gagasan ini. Perlindungan hutan hujan disajikan sebagai cara yang sederhana, murah dan efektif untuk mengurangi emisi gas rumah kaca. Beberapa komentator juga menyatakan bahwa dengan mendanai konservasi hutan, Norwegia cepat bisa menjadi negara netral karbon.

Beberapa tahun terakhir, suara-suara kritis meningkat lebih keras terutama dari komunitas peneliti dan kalangan masyarakat madani. Tidak ada yang menyangkal nilai yang terkandung dalam tujuan inisiatif, namun banyak yang meragukan apakah memungkinkan untuk mengukur dan mengontrol efeknya dan juga mengungkapkan bahwa sebagian besar uang itu belum dikucurkan. Pemerintah Norwegia juga dikritik karena membiayai proyek-proyek yang menghancurkan hutan hujan melalui dana pensiun pemerintah. Beberapa media telah menyoroti secara kritis beberapa dampak negatif tak disengaja dari REDD+. Selain itu, pemerintah Norwegia juga dikritik karena membeli jalan keluar dari pengurangan $\mathrm{CO}_{2}$ di dalam negeri yang kurang populer.

Secara keseluruhan, media Norwegia tetap positif, dan inisiatif hutan dan iklim internasional Norwegia dipandang sebagai upaya paling sukses dari pemerintah dalam mengurangi emisi. Perdebatan di Norwegia sebagian besar dibentuk oleh pemerintah dan LSM-LSM lingkungan dalam negeri. Pemerintah Brasil juga cukup mendapat tempat dalam liputan pers Norwegia. Pelaku paling sering dikutip adalah (mantan) menteri lingkungan dan menteri pengembangan koperasi, Erik Solheim, dan Perdana Menteri Norwegia, Jens Stoltenberg. 
Nepal menunjukkan kehadiran pelaku masyarakat madani yang tinggi di media, yang jauh melebihi pelaku penyelenggara negara. Lembaga-lembaga dalam badan pemerintahan dan lembaga-lembaga penelitian internasional menduduki peringkat berikutnya. Di kebanyakan negara, para pelaku masyarakat sipil bekerja sama dengan pemerintah, namun di Kamerun dan Peru mereka secara menyeluruh mendominasi wacana kebijakan. Pada kenyataannya, Kamerun menunjukkan kontrol pemerintah yang paling lemah atas wacana kebijakan. Secara dominan strategi REDD+ didorong oleh para pelaku internasional, dan kondisi yang sama terbukti juga di Peru. Hal ini memang bisa menunjukkan kemungkinan kurangnya kapasitas negara untuk terlibat dengan masalah-masalah teknis yang kompleks seperti REDD+, namun bisa juga menjadi indikator lambatnya kemajuan proses kebijakan dan kurangnya kemauan politik untuk mencurahkan sumberdaya dalam upaya perumusan dan pelaksanaan strategi nasional REDD+. Di Kamerun, kondisi ini menjadi tanda bahwa tindakan kebijakan yang berkelanjutan dan efektif di sekitar REDD+ mungkin dalam waktu dekat akan menjadi terbatas. Nepal menyajikan profil yang berbeda, masyarakat sipilnya memiliki representasi yang lebih menonjol di liputan media dibandingkan pemerintah dan mereka merupakan pendukung utama kebijakan REDD+ (lihat Kotak 5.3).

Secara keseluruhan, pemerintah di Brasil, Indonesia dan Vietnam memiliki kepemilikan yang kuat atas proses kebijakan REDD+ di tingkat nasional dan secara proaktif mendukung tindakan kebijakan REDD+, meskipun di Indonesia dan Vietnam tindakan ini dilakukan dalam aliansi kuat dengan donor internasional. Satu analisis yang dilakukan atas media Norwegia juga mengungkapkan hal senada, karena debat yang ada sebagian besar dipengaruhi oleh pemerintah Norwegia dan LSM-LSM lingkungan dalam negeri (untuk pandangan negara-negara donor, lihat Kotak 5.4). Di Nepal, kendali pemerintah lebih terbatas dan liputan REDD+ di media utamanya diisi oleh asosiasi pengguna hutan. Di Kamerun dan Peru, suara dan posisi pemerintah hampir tidak terdengar, menunjukkan rendahnya tingkat kepemilikan nasional atas proses kebijakan REDD+. Para pelaku internasional mungkin berusaha mendorong perumusan kebijakan REDD+, namun kemajuan kebijakan REDD+ kemungkinan akan terhambat oleh tidak adanya kepemilikan nasional.

\subsubsection{Tidak adanya suara dan wacana tersembunyi}

Otonomi negara vis-à-vis para pelaku pemicu deforestasi dan kepemilikan pemerintah atas proses kebijakan dan sikap positif terhadap REDD+ merupakan prasyarat untuk kemajuan kebijakan; tetapi sejumlah prasyarat ini tidak cukup untuk memastikan formulasi yang efektif dan seimbang bagi strategi nasional REDD+. Perubahan transformatif memerlukan pelaku kebijakan dan koalisi yang mampu memimpin diskusi ke arah kebijakan baru dibandingkan skenario bisnis-seperti-biasa, dengan demikian melepaskan diri 
dari alur-kebergantungan kelembagaan dan politik-ekonomi (Laumann dan Knoke 1987). Perlawanan dari koalisi konservatif yang mempertahankan status quo merupakan hal yang tidak dapat mereka hindari. Terjadinya perubahan transformatif atau tidak bergantung pada koalisi mana yang akhirnya akan mendapatkan dominasi dalam lingkaran kebijakan. Dominasi biasanya membutuhkan waktu untuk menunggu, setidaknya bagi sebagian elite negara dan kepentingan bisnis. Koalisi dapat didasarkan pada kepentingan bersama, keyakinan ideologis atau wacana umum (Hajer 1995; Sabatier 1999, Benford dan Snow 2000; Di Gregorio 2012).

Tidak hanya suara dominan di media yang mengungkapkan posisi para pelaku kebijakan - tidak adanya suara juga sama pentingnya. Analisis di atas menunjukkan bahwa pandangan kalangan bisnis dan hubungan negara dan kalangan bisnis hampir tidak dieksplorasi sama sekali di media. Ini terjadi bahkan di negara-negara seperti Indonesia dan Brasil, di mana peran sektor bisnis cukup signifikan. Pada umumnya, bisnis cenderung melobi para perumus kebijakan di balik layar (Coen 2004). Ini merupakan fenomena universal, terlebih lagi di tempat-tempat di mana lobi semacam ini dianggap bermasalah oleh publik. Ketika tekanan semacam ini melahirkan kegiatan-kegiatan ilegal, kerahasiaan menjadi lebih penting lagi. Kita telah melihat bagaimana korupsi dan kolusi antara negara dan kepentingan bisnis, legal maupun ilegal, merupakan keprihatinan utama di sebagian besar negara yang diteliti (Kotak 5.1). Kolusi semacam ini membentuk koalisi terselubung yang bisa sangat kuat dalam melawan perubahan transformatif dan dapat memengaruhi bukan hanya pelaksanaan, tetapi juga perumusan kebijakan.

Meskipun demikian ada sejumlah indikasi yang menunjukkan bahkan ketika koalisi semacam ini cenderung beroperasi secara rahasia, suara mereka bisa dicerminkan di media. Dukungan pelaku penyelenggara negara kepada praktik bisnis-seperti-biasa, dalam kondisi-kondisi di mana otonomi negara rendah, merupakan indikator kemungkinan adanya koalisi dominan tersebut. Misalnya, keengganan pemerintah untuk mengambil tindakan tegas terkait REDD+ saat ini mungkin mengancam keuntungan ekonomi yang telah ditetapkan dan terkait dengan deforestasi dan degradasi hutan.

Selain mengidentifikasi pelaku utama, analisis media membantu menentukan posisi para pelaku ini dalam kebijakan REDD+. Posisi kebijakan tunggal mereka telah digabungkan menjadi kategori lebih luas untuk mengidentifikasi koalisi mana yang mendukung perubahan transformatif, dan koalisi mana yang menolak perubahan tersebut. Hasil analisisnya disajikan dalam bagian berikutnya. ${ }^{1}$

1 Mengingat perlawanan pemerintah Bolivia terhadap REDD+ dan tidak adanya upaya untuk mewujudkan perubahan transformatif, maka negara ini tidak diikutkan dalam analisis yang dibahas dalam bagian ini. 


\subsubsection{Koalisi bisnis-seperti-biasa yang umum ditemui dan koalisi perubahan transformatif}

Di media, sejumlah koalisi kuat yang mendukung sektor-sektor utama yang memicu deforestasi dan degradasi hutan terlihat jelas di Brasil dan Indonesia. Para pelaku di Indonesia menekankan perlunya kebijakan REDD+ mengompensasi hilangnya kesempatan (opportunity cost) bisnis skala besar yang terkait dengan konversi hutan dan memperingatkan bahwa REDD+ tidak boleh mengesampingkan pembangunan ekonomi. Mengingat rendahnya tingkat otonomi pelaku penyelenggara negara yang telah digambarkan sebelumnya, pernyataan-pernyataan seperti ini konsisten dengan situasi di mana bagian dari sisi aparatur negara berpihak pada kepentingan bisnis yang mendapatkan keuntungan dari pemanfaatan lahan untuk peternakan, pengembangan perkebunan, penebangan hutan dan pertambangan. Namun pendapat para pelaku penyelenggara negara beragam. Sebagai contoh di Indonesia, bagian konservasi dari Kementerian Kehutanan dan Kementerian Lingkungan Hidup mengakui bahwa perkembangan kebijakan REDD+akan membutuhkan kebijakan yang luas dan reformasi kelembagaan.

Ada juga bagian di mana kebijakan REDD+ menghambat kerja koalisi. Di Brasil, baik pelaku penyelenggara negara maupun organisasi internasional yang bergerak di bidang lingkungan terpecah dalam hal kemungkinan pembiayaan REDD+ melalui mekanisme pasar. Debat yang sama terlihat di Nepal, di mana organisasi-organisasi lokal dan kelompok-kelompok lingkungan domestik mendukung mekanisme pasar namun menyuarakan keprihatinan tentang kurangnya pelibatan pengguna lokal dalam keputusan-keputusan kebijakan REDD+. Mereka menyerukan adanya perubahan prosedural dalam pembuatan keputusan kebijakan. Namun para pelaku penyelenggara negara tidak terlibat dengan isu pelibatan sosial di media.

Di Vietnam, perdebatan tentang kompensasi mengacu pada peraturan yang mewajibkan perusahaan-perusahaan milik negara/BUMN (pembangkit listrik tenaga air) menghargai pengguna hutan yang menyediakan jasa-jasa lingkungan yang berkaitan dengan hutan, karena pemerintah Vietnam memasukkan PES di bawah kebijakan REDD+. Media melaporkan dua kasus seperti ini, di mana perusahaan milik negara tidak setuju dengan pemerintahnya. Meskipun ada perlawanan ini, terlihat bahwa di Vietnam pemerintah tingkat nasional sedang mencoba mendorong adanya perubahan arah dari bisnis-seperti-biasa vis-à-vis beberapa kepentingan bisnis milik negara (Pham dkk. 2012).

Secara keseluruhan koalisi dan pernyataan sikap yang menyerukan perubahan transformatif kurang menonjol di media dibandingkan bisnis-seperti-biasa atau sikap netral. Ini menunjukkan bahwa, secara keseluruhan koalisi transformatif adalah koalisi minoritas yang menentang koalisi yang lebih kuat yang mendukung status quo. Di Indonesia, sebagian dari masyarakat sipil dalam 
negeri menentang dimasukkannya perkebunan di dalam skema REDD+. Hal ini menunjukkan adanya serangan langsung terhadap koalisi dominan bisnis-seperti-biasa. Namun, tidak ada indikasi adanya koalisi transformatif lebih luas yang mungkin mencakup pelaku lain seperti perwakilan bisnis atau pemerintah. Sejumlah LSM internasional di bidang lingkungan berpihak kepada masyarakat sipil domestik dalam mengekspresikan keprihatinan mereka mengenai potensi REDD+ yang akan membatasi akses pengguna hutan lokal atau bahkan mengusir kelompok yang bergantung pada hutan. Namun upaya mendorong para pembuat kebijakan untuk mempertimbangkan kembali pengaturan penguasaan hutan lokal tidak mendapat respon dalam wacana koalisi dominan.

Kekuatiran tentang tata kelola yang lemah dan korupsi disuarakan oleh kedua belah pihak, baik pelaku internasional maupun pelaku domestik masyarakat sipil di Indonesia. Secara khusus, mereka menekankan ancaman bahaya bahwa korupsi mengakibatkan ketidakefektifan implementasi REDD+. Posisi ini dapat dipahami sebagai seruan perlunya perubahan transformatif dan kecaman terhadap kolusi dan keuntungan ekonomi yang sering mendasari koalisi bisnis-seperti-biasa. Namun di sebagian besar negara lainnya, kekuatiran seperti ini tetap tak tertangani, meskipun fakta menunjukkan bahwa pemerintahan yang lemah merupakan kendala politik utama di sebagian besar negara.

Tuntutan utama dari koalisi dominan masyarakat sipil dalam negeri di Nepal adalah agar kelompok pengguna hutan memiliki peran yang lebih kuat dalam mengakses manfaat REDD+. Pandangan ini ditentang oleh pemerintah lokal, sementara pemerintah tingkat nasional tampaknya tidak terlibat dengan masalah REDD+ dalam perdebatan media. Federasi pengguna hutan membentuk satu-satunya koalisi REDD+ yang terlibat dengan media di negeri ini. Posisi sepenting ini sebagian terkait dengan sejarah panjang kelompok pengguna hutan dan hutan kemasyarakatan di Nepal. Ini adalah satu-satunya kasus dalam penelitian kami di mana jalur-ketergantungan tampaknya memberikan peluang kekuatan kepada masyarakat sipil. Namun, dengan tidak adanya koalisi yang lebih luas yang mencakup sekutu dari kalangan elit, keefektifannya dalam mendorong perubahan tetap diragukan.

Di Peru, LSM-LSM lingkungan internasional mendominasi perdebatan media dan pendapatnya sama dengan sejumlah organisasi masyarakat adat dalam keprihatinan mereka tentang hutan tanaman yang dimasukkan ke dalam skema REDD+. Namun, pelaku penyelenggara negara hampir tidak terlibat dalam diskusi sekitar REDD+ di media, sementara para pelaku bisnis menyerukan penguatan pengaturan properti swasta untuk memastikan akses ke kredit dan keamanan investasi. Koalisi business as usual, korupsi dan kolusi tetap tersembunyi dari pengawasan publik. Hal yang sama berlangsung di Kamerun, di mana media tidak menyebut adanya pelaku penyelenggara 
negara yang memberikan pernyataan tentang posisi REDD+, meskipun Kamerun dinyatakan sebagai negara yang turut mendukung pengembangan program-program REDD+. Tidak adanya koalisi transformatif di media mungkin berkontribusi pada kurangnya keterlibatan pelaku penyelenggara negara, yang tidak dihimbau untuk mengambil posisi atas REDD+. Hal ini menunjukkan bahwa perkembangan kebijakan REDD+ masih pada tahap sangat dini.

Singkatnya, pelaku penyelenggara negara di Indonesia, meskipun dalam pernyataan-pernyataan lisannya mendukung REDD+, mereka juga terbuka dalam mempertahankan kebijakan bisnis-seperti-biasa. Di Brasil, pelaku penyelenggara negara telah mengambil langkah-langkah untuk mendukung REDD+ tetapi kepentingan-kepentingan para pemicu deforestasi yang telah tertanam demikian dalam merupakan pemain kuat dan mencoba menanamkan pengaruhnya dalam berbagai keputusan kebijakan. Di Vietnam, pemerintah secara eksplisit menentang jalur-ketergantungan semacam ini, meskipun jelas terlihat ada resistensi dari para pemangku kepentingan bisnis. Di semua negara kecuali Nepal, koalisi yang mendukung perubahan transformatif, jika ada, merupakan koalisi minoritas. Hanya di Nepal koalisi semacam ini mendominasi wacana di media, sebagian besar berkat kurangnya keterlibatan para penyelenggara negara dalam diskusi kebijakan REDD+. Di Peru dan Kamerun bukti koalisi perubahan transformatif tidak ada.

\subsection{Kesimpulan}

Bukti-bukti di atas menggambarkan bagaimana empat faktor penting, yang dapat membantu mengatasi kendala ekonomi-politik dalam mewujudkan reformasi kebijakan dan menuju desain kebijakan REDD+ yang efektif dan berkesetaraan, telah dilaksanakan di negara yang berbeda-beda. Keempat faktor itu adalah: tingkat otonomi tinggi yang dimiliki pelaku penyelenggara negara yang bebas dari kepentingan bisnis yang terkait dengan eksploitasi dan konversi hutan; kepemilikan dan kontrol pemerintah nasional atas strategi nasional REDD+; tingkat inklusivitas yang tinggi dalam proses kebijakan; dan hadirnya koalisi untuk mencapai perubahan transformatif.

Temuan-temuan yang ada menggambarkan bahwa di sebagian besar negara, faktor-faktor tersebut tidak hadir sebelum REDD+ diperkenalkan, atau saat ini belum bisa dicapai, selain negara-negara sedang berjuang dengan proses reformasi baik di dalam maupun di luar sektor kehutanan. Salah satu tantangan yang sama-sama dihadapi ketujuh negara ini adalah tingkat otonomi pelaku penyelenggara negara. Sementara pernyataaan-pernyataan negara, dinyatakan dalam sikap media, menggambarkan skenario sama-sama menang, di mana tujuan ekonomi berjalan seiring dengan perlindungan lingkungan, namun pelaku penyelenggara negara tampaknya menemukan bahwa dalam praktiknya merangkul pandangan ini sangatlah sulit. Tingginya 
ketergantungan perkembangan ekonomi pada eksploitasi sumberdaya alam yang tak berkelanjutan telah begitu dalam tertanam dalam struktur politik-ekonomi. Tantangan utama ini masih terus dihadapi oleh ketujuh negara yang diteliti.

Tidak satu pun negara yang diteliti menunjukkan proses kebijakan sangat inklusif, seperti dinyatakan oleh indeks demokrasi dan indeks desentralisasi efektif, namun Indonesia dan Brasil terbukti lebih baik dibandingkan yang lain. Kamerun dan Vietnam menunjukkan proses yang paling eksklusif, meningkatkan kekuatiran bahwa konflik dan ketegangan tersembunyi (laten) antara para pemangku kepentingan mungkin terjadi dalam arena REDD+ dan ada kemungkinan memburuk seiring berjalannya waktu. Di sejumlah negara, kurangnya keterlibatan para pelaku penyelenggara negara di tingkat nasional menimbulkan pertanyaan serius tentang siapa yang mengendalikan proses kebijakan. Di tiga dari tujuh negara, kepemilikan nasional atas perkembangan kebijakan dan reformasi yang terkait REDD+ terlihat lemah. Di negara-negara ini peran penting pemain internasional dalam pembiayaan dan desain kebijakan - tanpa adanya kehadiran pemerintah nasional yang mengambil alih proses tersebut - mengarah pada lambatnya kemajuan dan kemungkinan akan menyebabkan munculnya berbagai masalah dalam penerapannya.

Berbagai upaya proaktif, yang utamanya dilakukan oleh organisasi masyarakat sipil untuk membangun konstituen domestik yang menantang kepentingan-kepentingan yang sangat kuat, jelas terlihat dalam debat media di beberapa negara, tetapi tetap saja mereka merupakan koalisi minoritas. Diperlukan kemajuan lebih lanjut jika REDD+ tidak ingin dianggap sebagai kegiatan yang dikendalikan oleh donor, tetapi sebagai kebijakan nasional yang sejati, kebijakan yang melayani kepentingan lebih luas di negara-negara berkembang kaya hutan dan tidak dianggap sebagai sesuatu yang bertentangan dengan pembangunan nasional. Bahkan di negara-negara yang paling maju dalam perumusan strategi nasional REDD+, kebijakan terkait sering dianggap sebagai ancaman bagi pembangunan ekonomi. Akibatnya, kepentingan-kepentingan ekonomi kuat melobi pemerintah untuk mengadopsi kebijakan yang mengurangi keefektifan atau memperlambat pembuatan keputusan tentang REDD+, seperti yang terlihat dari pengalaman moratorium Indonesia mengenai konversi hutan dan ancaman saat ini di Brasil untuk merevisi peraturan kehutanan sehingga melemahkan persyaratan untuk perlindungan hutan.

Sekarang yang dibutuhkan adalah koalisi yang mampu memutuskan jalur-ketergantungan seperti itu: aliansi baru, yang luas dan inklusif yang menggunakan keahlian ilmiah dan kapasitas teknis serta kelembagaan untuk mengatasi model kebijakan tradisional yang tidak dapat memproyeksikan bagaimana kebijakan REDD+ dapat diselaraskan dengan tujuan 
pembangunan. Partisipasi elite negara dan keterlibatan pelaku bisnis dalam koalisi-koalisi merupakan penentu untuk memengaruhi agenda politik secara signifikan. Di sebagian besar negara hal ini memerlukan munculnya wacana kontra-perubahan transformatif yang dapat menantang model lama pembangunan, membubarkan koalisi dominan dan menarik dukungan dari pelaku penyelenggara negara dan bisnis sehingga mereka bersedia menerima tantangan ini. 


\section{Bab}

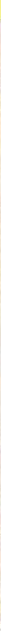

\section{Berbagai tataran dan tantangan REDD+}

Kaisa Korhonen-Kurki, Maria Brockhaus, Amy E. Duchelle, Stibniati Atmadja dan Pham Thu Thuy

- REDD+ adalah suatu upaya mengurangi emisi akibat deforestasi dan degradasi hutan yang melibatkan berbagai tataran, mulai dari tataran dunia internasional, nasional dan daerah, dan kebutuhan dan aspirasi masyarakat setempat. Semua tataran ini harus terkait. Jika saling keterkaitan antara berbagai tataran tersebut diabaikan, REDD+ bisa gagal.

- Arus informasi yang melintasi tataran lokal dan nasional sangat penting untuk pengukuran, pelaporan dan verifikasi emisi karbon yang bertanggung gugat, serta pengendalian kebocoran emisi. Arus informasi yang sehat lintas tataran juga dapat meningkatkan kekuatan negosiasi kelompok yang lemah dan memastikan REDD+ yang lebih efektif, efisien dan setara.

- Sistem tata kelola REDD+ yang melibatkan berbagai tataran pemerintah dan nonpemerintah dapat mengurangi risiko konflik bila menggunakan kelembagaan yang transparan, dan dapat memadukan insentif-insentif baru dari REDD+ dengan kepentingan-kepentingan berbagai pihak.

\subsection{Pengantar}

Pengurangan emisi akibat deforestasi dan degradasi (REDD+) pada dasarnya bagaikan suatu teka-teki yang berlapis-lapis. Masyarakat setempat dituntut 
dunia untuk meringankan dampak perubahan iklim melalui lembaga-lembaga dan struktur nasional dan lokal yang sudah ada maupun yang baru muncul. REDD+ membutuhkan pendekatan terpadu yang melibatkan tata kelola dari tataran lokal maupun internasional, dengan berbagai tantangan di setiap langkah. Berbagai struktur dan organisasi eksternal juga diperlukan untuk memastikan pelaporan dan verifikasi yang independen dan andal serta bertanggung gugat.

Awalnya, REDD+ menekankan pendekatan nasional karena pendekatan ini dapat membantu mengelola kebocoran emisi, mendorong penurunan emisi yang permanen dan pengukuran, pelaporan dan verifikasi yang dapat diandalkan (Measurement Reporting and Verification/MRV) (Phelps dkk. 2010b). Namun berbagai pemerintah nasional menghadapi tantangan dari berbagai tataran dan selama puluhan tahun menghadapi kesulitan dalam menegakkan hukum di sektor tata guna lahan (Corbera dan Schroeder 2011).

Ada beragam kajian teoritis tentang keragaman tataran tata kelola REDD+ (Armitage 2008; Skutsch dan Van Laake 2008; Forsyth 2009). Bab ini bergerak ke luar ranah teori dengan memberi contoh-contoh nyata tentang bagaimana mekanisme kelembagaan lintas tataran dapat menjawab tantangan inti REDD+ di berbagai negara, serta mengidentifikasi kendala dan peluang yang ada dalam REDD+.

Larson dan Petkova (2011) mendefinisikan tata kelola sebagai berikut: "tata kelola mengacu pada siapa yang membuat keputusan dan bagaimana proses pembuatan keputusan, dari skala nasional sampai ke skala lokal, mencakup lembaga-lembaga formal dan informal serta berbagai aturan, hubungan antarkekuasaan dan praktik-praktik pengambilan keputusan." Dalam bab ini, kami menggunakan definisi umum tentang Tata Kelola Lintas Tataran (TLT) menurut Forsyth (2009) yang menyatakan bahwa Tata Kelola Lintas Tataran adalah pelaksanaan kebijakan publik di skala spasial yang beragam (misalnya: nasional, propinsi, kabupaten, desa) dan dilakukan oleh berbagai pelaku yang memiliki pengaruh dan menganut nilai-nilai yang berbeda.

Saat ini, kemajuan REDD+ terpecah antara tataran internasional, nasional dan subnasional, dan di dalam masing-masing tataran tersebut. Mekanisme tata kelola lintas tataran dapat membantu menyelaraskan tataran-tataran tersebut secara lebih baik. Terdapat tiga proses yang memungkinkan hal ini (Pahl-Wostl, 2009). Pertama, pelaku dari satu tataran dapat ikut serta dalam proses di tataran lain. Kedua, lembaga yang diciptakan pada satu tataran dapat memengaruhi proses atau lembaga di tataran lainnya. Ketiga, pengetahuan yang dihasilkan pada satu tataran dapat memengaruhi proses pada tataran lainnya. 
Selanjutnya, berdasarkan kerangka kerja $4 \mathrm{I}^{1}$ yang telah disajikan dalam Bab 2 buku ini, sistem tata kelola REDD+ harus: i) memastikan insentif REDD+ pas dengan lembaga-lembaga yang terkait dalam setiap tataran REDD+, ii) menjamin aliran informasi yang diperlukan untuk melaksanakan REDD+ (termasuk informasi lokal), dan iii) memungkinkan negosiasi antara pihak dengan kepentingan masing-masing dari berbagai tataran.

$\mathrm{Bab}$ ini mengetengahkan pentingnya mengidentifikasi dan memahami mekanisme tata kelola lintas tataran yang ada dalam REDD+, dan manfaat serta risiko pelaksanaan REDD+ tanpa tata kelola lintas tataran. Bab ini juga menunjukkan bahwa perumus kebijakan, para perunding, lembaga-lembaga negara, para pemrakarsa proyek, organisasi lokal dan pihak-pihak lain perlu memahami bagaimana tata kelola lintas tataran dapat membantu REDD+ menjadi lebih efektif, efisien dan setara dan bagaimana memperkuat mekanisme tata kelola dalam kebijakan dan program REDD+ yang sedang berjalan. Ada contoh cukup positif yang menunjukkan adanya langkah-langkah ke arah penyerasian lintas tataran secara vertikal. Tata kelola lintas tataran dan hal-hal terkait telah diperdebatkan dalam wacana konservasi dan pembangunan. Hasil awal penelitian kami menunjukkan masih ada tantangan dalam proses kebijakan REDD+ dalam memadukan pemikiran dan tindakan untuk menghubungkan antara tataran-tataran yang berbeda.

Analisis yang kami lakukan mempertimbangkan dimensi lintas tataran dalam elemen-elemen inti REDD+. Untuk mendukung analisis ini, kami memberikan bukti anekdot tentang sejumlah tantangan dan peluang yang muncul, terutama yang berhubungan dengan elemen pengukuran, pelaporan dan verifikasi (MRV) dan kebocoran emisi di tiga negara yang terlibat dalam studi banding global CIFOR mengenai REDD+ (lihat Lampiran): Brasil, Vietnam dan Indonesia. Kajian kami berfokus ke tataran dalam negeri di tiga negara ini, dan bukan antara tataran nasional dan internasional.

\subsection{Kerangka kerja: dimensi tata kelola lintas tataran}

Angelsen dkk. (2009) dan Kanninen dkk. (2010) mengidentifikasi sejumlah tantangan dalam pelaksanaan REDD+, termasuk implementasi sistem MRV, pengendalian kebocoran, penurunan emisi yang permanen, mekanisme keuangan dan pembagian manfaat, serta partisipasi dan hak-hak masyarakat adat dan masyarakat lokal. Sebagian besar tantangan tersebut secara eksplisit memiliki dimensi lintas tataran yang jika diabaikan akan menimbulkan risiko bagi REDD+. Dalam Tabel 6.1, kami memberikan contoh bagaimana beragam tataran terlibat dalam REDD+, dan faktor-faktor risiko yang muncul jika mereka tidak turut diperhitungkan.

1 Kerangka Kerja 4I mengacu kepada konsep "Ide-ide” yang tidak dibahas di dalam bab ini. 
Di bagian berikut, kami membahas dua hal: MRV dan pengendalian kebocoran. Berbagai masalah lain yang tercantum dalam Tabel 6.1 akan dibahas dalam bab-bab yang lain dalam buku ini, misalnya pembagian manfaat (Bab 8), kepemilikan (Bab 9), dan tingkat emisi acuan (Bab 16). Dalam bab ini kami akan menyajikan contoh mekanisme tata kelola lintas tataran yang ada, tanggapan dari REDD+, dan contoh-contoh dari berbagai studi kasus di Brasil, Vietnam dan Indonesia. Akhirnya, kami akan menyoroti tantangan-tantangan yang berkaitan dengan kerangka kerja 4I.

\subsection{Tata kelola lintas tataran and tanggapan dari REDD+: bukti awal}

REDD + menghadapi beberapa tantangan lintas tataran, seperti yang terlihat pada Tabel 6.1. Sebagian besar dari tantangan yang ada terkait kegiatan di tingkat lokal, daerah dan nasional untuk memastikan informasi mengalir secara konsisten dan kepentingan antara beragam tataran terkelola dengan baik. Contoh dari Brasil, Vietnam dan Indonesia menunjukkan adanya tantangan tentang merancang mekanisme lintas tataran dan kebutuhan-kebutuhan lain yang harus dibenahi untuk mencapai tujuan-tujuan pokok REDD+ (lihat Tabel 6.2).

Pengukuran, pelaporan dan verifikasi (MRV) adalah sistem perkiraan kuantitatif gas rumah kaca (pengurangan dan penghapusan emisi). Fokus utama MRV adalah pemantauan perubahan cadangan dan/atau aliran/arus karbon hutan, melaporkan perubahan tersebut secara transparan dan tepat waktu dan menguji estimasinya melalui pihak ketiga yang independen (Herold dan Skutsch 2009). MRV menghadapi tantangan dalam mengintegrasikan berbagai jenis informasi di seluruh tataran (sistem pemantauan global, pembentukan sistem MRV nasional dan berbagai teknik MRV yang digunakan oleh proyek-proyek REDD+ di tingkat daerah/lokal).

Kebocoran emisi terjadi ketika kegiatan pengurangan emisi di satu kawasan (nasional atau daerah) menyebabkan kenaikan emisi di kawasan lain (lihat Wunder 2008). Jika kebocoran emisi tidak diperhitungkan, maka pengurangan emisi yang dilaporkan akan lebih dari angka yang seharusnya ${ }^{2}$. Kebocoran emisi yang terjadi di dalam batas wilayah negara dapat dilaporkan di bawah sistem penghitungan karbon nasional, tetapi hal ini menunjukkan perlunya sistem kompensasi finansial antara sumber kebocoran emisi (di mana pengurangan emisi terjadi) dan wilayah alihan emisi (di mana emisi yang bocor dari wilayah lain teralihkan).

2 Istilah 'kebocoran emisi' mengacu pada 'kebocoran emisi negatif', yaitu ketika pengurangan emisi yang terjadi di satu kawasan menyebabkan emisi di kawasan lainnya. Ini hanya penyederhanaan karena kami mengakui bahwa 'kebocoran emisi positif' (yaitu pengurangan emisi di satu kawasan juga menyebabkan berkurangnya emisi di kawasan lain) juga bisa terjadi. 


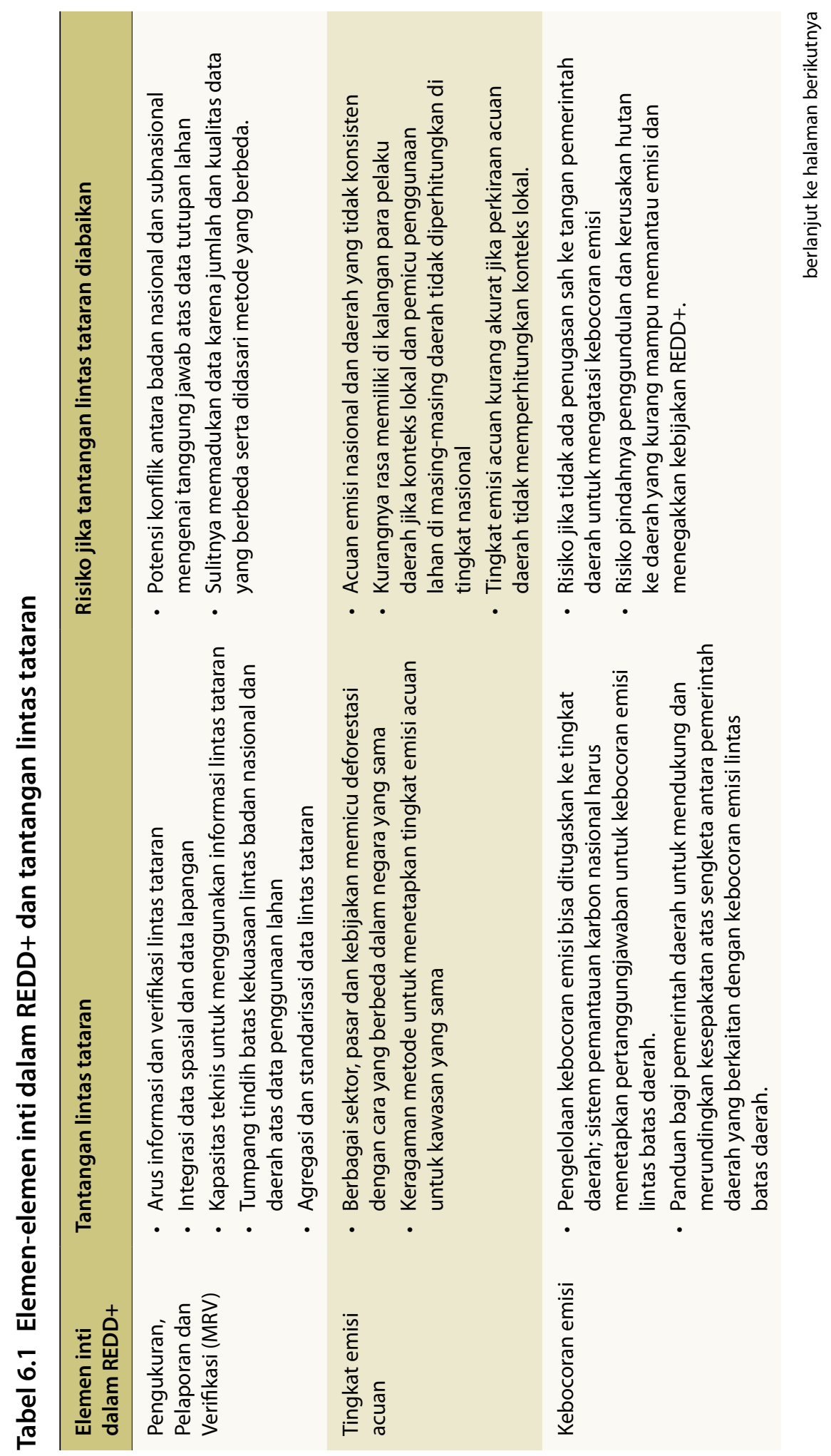




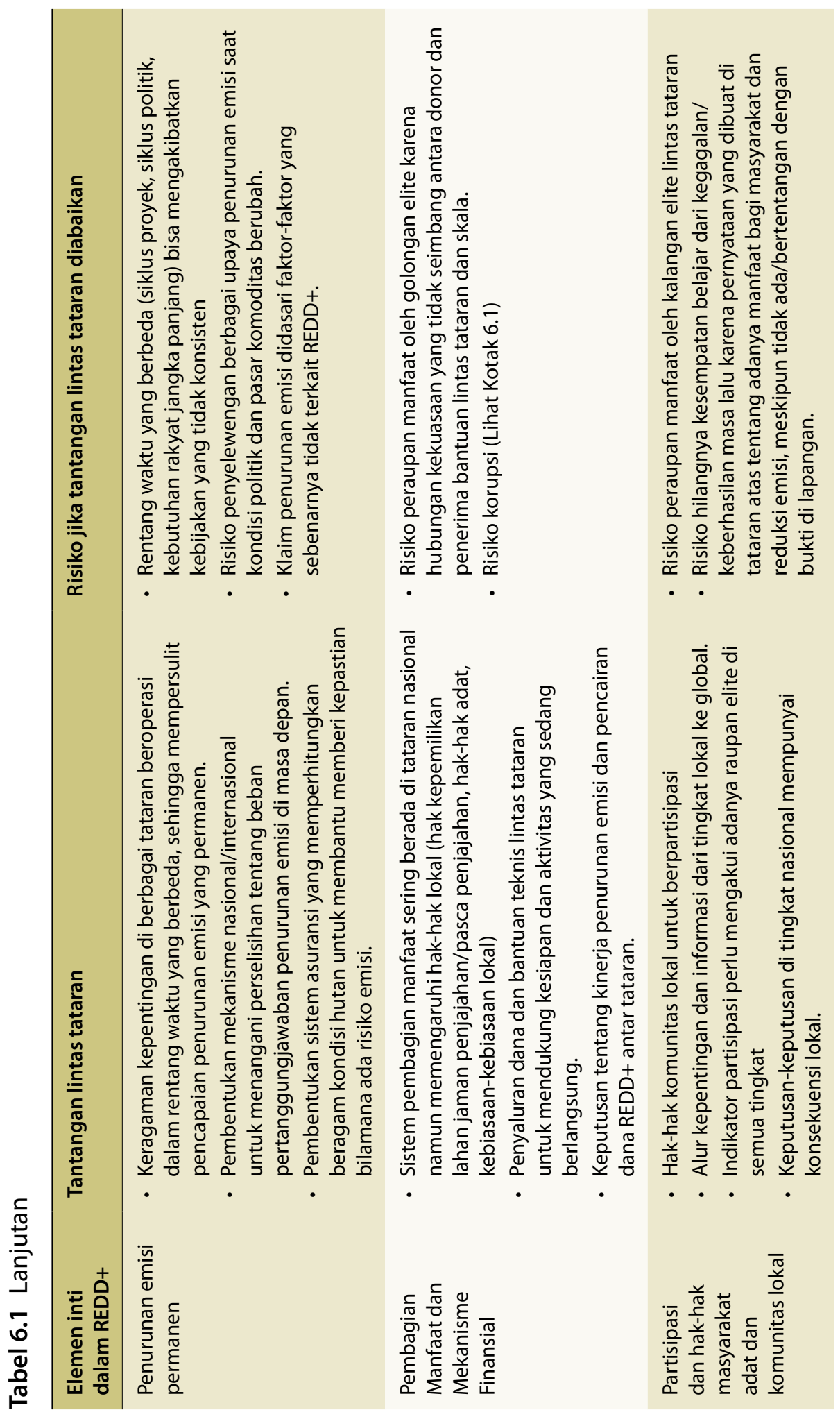




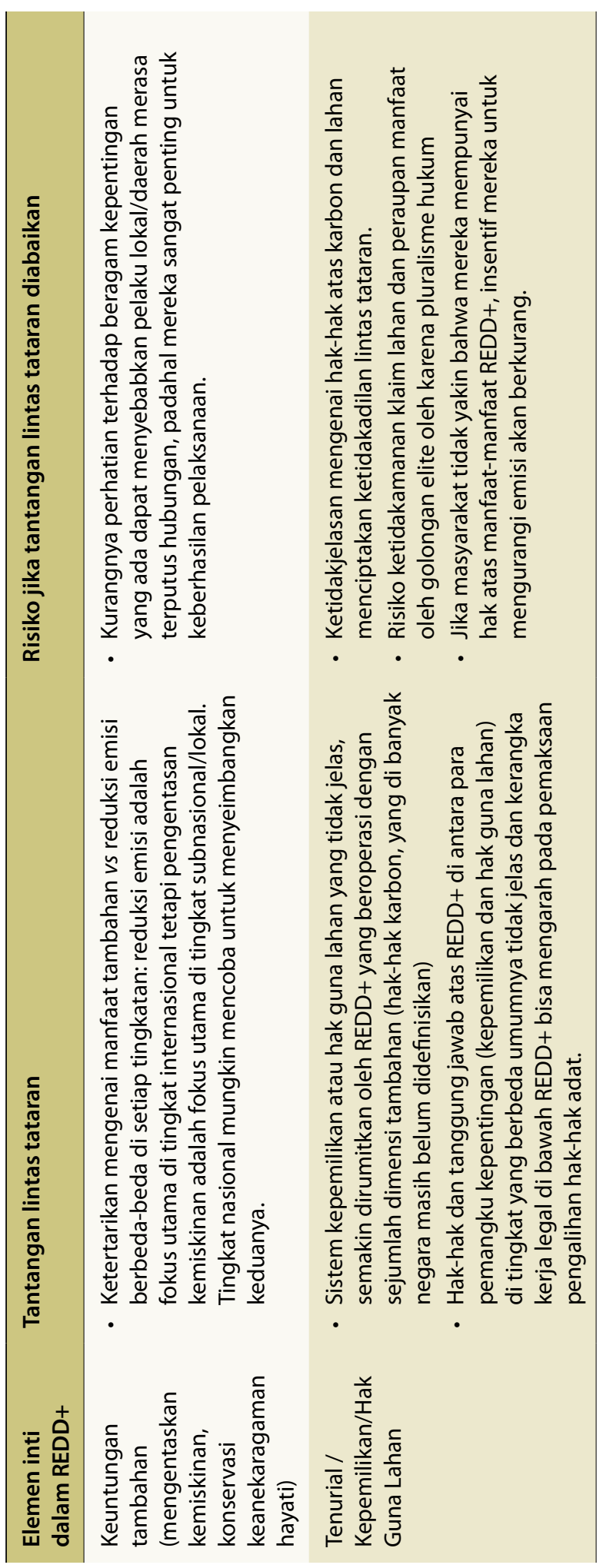




\section{Kotak 6.1 Risiko korupsi dalam REDD+: Pengalaman dari Indonesia}

Ahmad Dermawan

Fase persiapan REDD+ di Indonesia telah melibatkan dana yang besar dan terus bertambah, serta investasi pihak swasta. Fase ini juga melibatkan interaksi yang rumit antara para pelaku global sampai lokal. Keberhasilan penggunaan dana untuk reformasi kebijakan dan mengurangi emisi karbon memerlukan kerja sama antarlembaga. Namun, keadaannya masih jauh dari ideal.

Salah satu tantangan yang dihadapi adalah ketidakjelasan batas wilayah kawasan hutan negara. Pengajuan hak pengusahaan hutan, termasuk untuk proyek REDD+, harus memenuhi kriteria tertentu dan memastikan bahwa wilayah yang akan dikerjakan bebas dari segala hak (guna/pakai/milik) yang ada sekarang. Namun untuk memenuhi kriteria tersebut ada beberapa tantangan. Sebagai contoh, hutan tanaman dan izin restorasi ekosistem seharusnya hanya dikeluarkan untuk hutan terdegradasi dan bebas dari klaim lahan tumpang tindih. Kenyataannya, masih ada berbagai pengajuan izin untuk lahan dengan kondisi hutan bagus atau telah diklaim pihak lain. Hal ini memungkinkan para pemegang izin konsensi REDD+ untuk melakukan deforestasi sebelum periode penghitungan penurunan emisi dimulai. Selain itu, pemerintah daerah memiliki kewenangan untuk mengeluarkan izin perkebunan dan pertambangan. Ketidakjelasan batas-batas hutan memberikan kesempatan bagi mereka untuk mengeluarkan izin di dalam kawasan hutan negara.

Tantangan lain adalah rekonsiliasi laporan produksi kayu dan pajak yang diterima untuk memastikan bahwa para pemegang konsesi hutan membayar kewajiban mereka. Para pelaku dari tingkat kabupaten sampai pemerintah pusat terlibat dalam mencocokkan laporan produksi kayu dan laporan pembayaran pajak dengan jadwal yang ketat. Namun, Badan Pemeriksa Keuangan (BPK) menemukan bahwa rekonsiliasi tersebut tidak selalu dilakukan secara berkala. BPK juga menemukan perbedaan antara jumlah pajak yang benar-benar diterima oleh pemerintah dan jumlah yang seharusnya diterima. Jika terjadi lagi dengan REDD+, maka hal ini akan melemahkan penghitungan kredit penurunan emisi dan mendorong korupsi semakin merebak.

Korupsi dan penipuan juga dapat memengaruhi penyaluran pendapatan di berbagai tataran pemerintahan. Pengalaman masa lalu menunjukkan terjadinya keterlambatan dalam menyalurkan dan membelanjakan penerimaan dari sektor kehutanan di semua tataran pemerintahan. Peraturan perimbangan fiskal di Indonesia saat ini belum memungkinkan pembagian penerimaan negara dari sektor kehutanan secara langsung kepada masyarakat maupun lintas tataran pemerintahan. Bergantung pada 
bagaimana pendapatan REDD+ diperlakukan dalam sistem fiskal negara, persetujuan tentang tingkat-tingkat pendapatan masa depan dari REDD+ dan alokasinya dapat melibatkan banyak negosiasi antara kabupaten, provinsi dan instansi pusat. Hal ini meningkatkan biaya transaksi dan membuka pintu masuk untuk korupsi dan penyuapan.

Setelah setiap tataran pemerintahan menerima bagian pendapatan dari hutan, pengalaman menunjukkan bahwa kelemahan dalam pengelolaan keuangan, kalangan elite yang bertindak di luar hukum tanpa mendapat hukuman apapun, dan tidak adanya mekanisme pertanggunggugatan telah menyebabkan maraknya korupsi dan penyalahgunaan dana. Semuanya ini bisa menciptakan risiko tinggi munculnya korupsi dalam pendanaan iklim di Indonesia. Kegagalan mengantisipasi risiko ini dapat membahayakan kemampuan REDD+ dalam mencapai penurunan emisi dan target pendapatannya.

Sumber: Dermawan dkk. (2011)

\subsection{MRV}

Sebagian besar negara masih belum punya kerangka kerja dan kebijakan nasional REDD+, meskipun berbagai proyek percontohan REDD+ telah dilaksanakan dan berbagai keputusan subnasional/daerah telah diambil mengenai strategi REDD+. Akibatnya, banyak pendukung proyek subnasional yang menetapkan tingkat acuan emisinya sendiri dan mengembangkan sistem MRV mereka sendiri. Tautan antara berbagai tataran sangat penting guna menentukan bagaimana pengurangan emisi dari kegiatan subnasional akan dihitung di tingkat nasional. Selanjutnya, diperlukan lembaga eksternal untuk memastikan pelaporan dan verifikasi yang independen dan terpercaya, dan untuk menjamin pertanggunggugatannya. Berikut ini uraian kami tentang berbagai tantangan yang ada.

\subsubsection{Tantangan: tidak ada kerangka kerja MRV}

Di Brasil, interaksi antara badan-badan pemerintah dan masyarakat madani di berbagai tataran telah memengaruhi perkembangan REDD+, termasuk melalui usulan-usulan dalam penetapan sistem MRV dan tingkat acuan emisi nasional. Lembaga Penelitian Ruang Angkasa Nasional Brasil/Brazil's National Institute for Space Research siap untuk mengukur, melaporkan dan melakukan verifikasi emisi yang berasal dari penggundulan dan kerusakan hutan di Amazon melalui penggunaan penginderaan jarak jauh dan GIS yang tercanggih. Datanya telah digunakan beberapa pemrakarsa proyek REDD+ di Brasil untuk menetapkan tingkat emisi acuan lokasi proyek mereka berdasarkan riwayat deforestasi setempat. Para pemrakarsa ini 


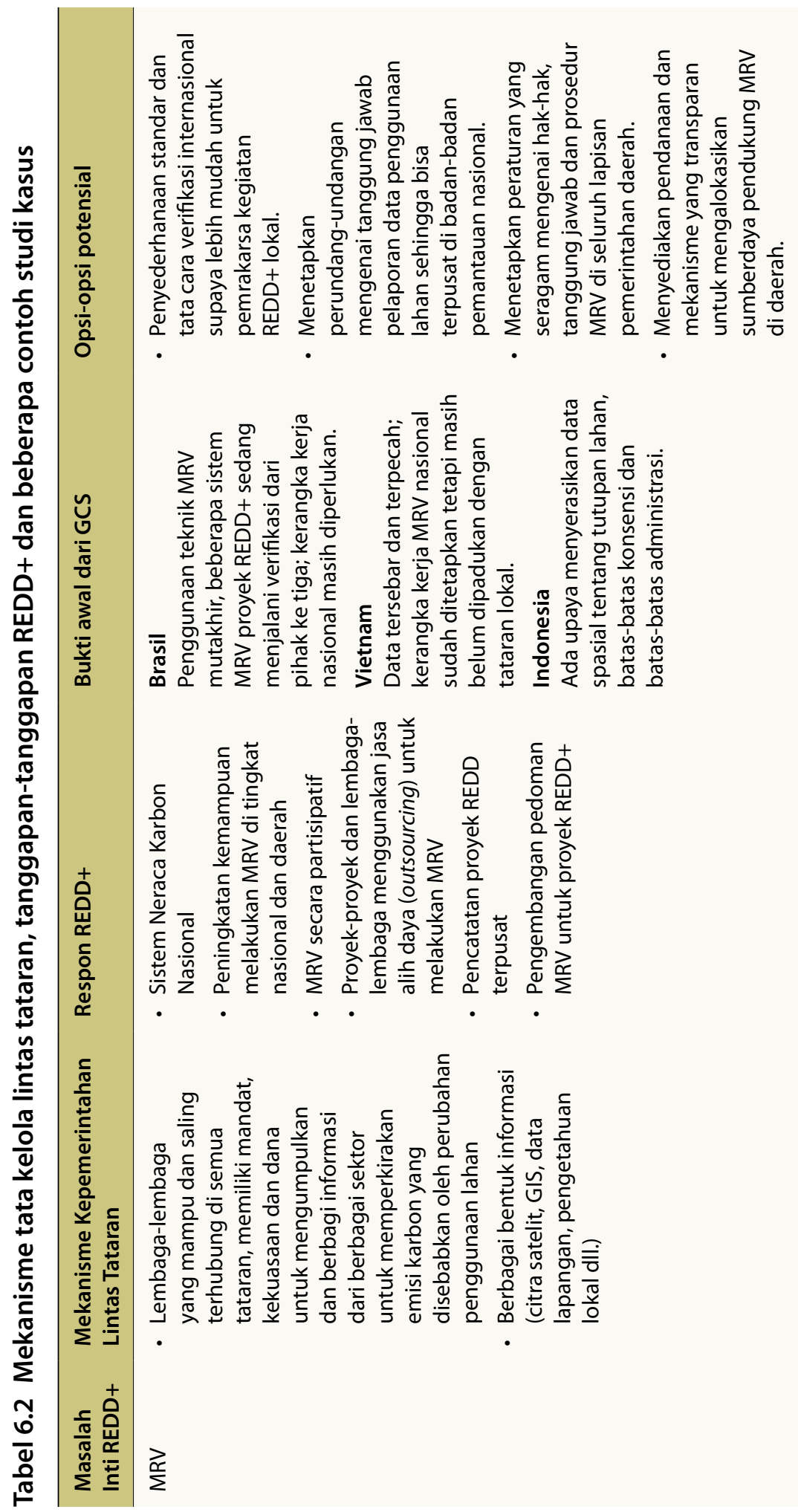




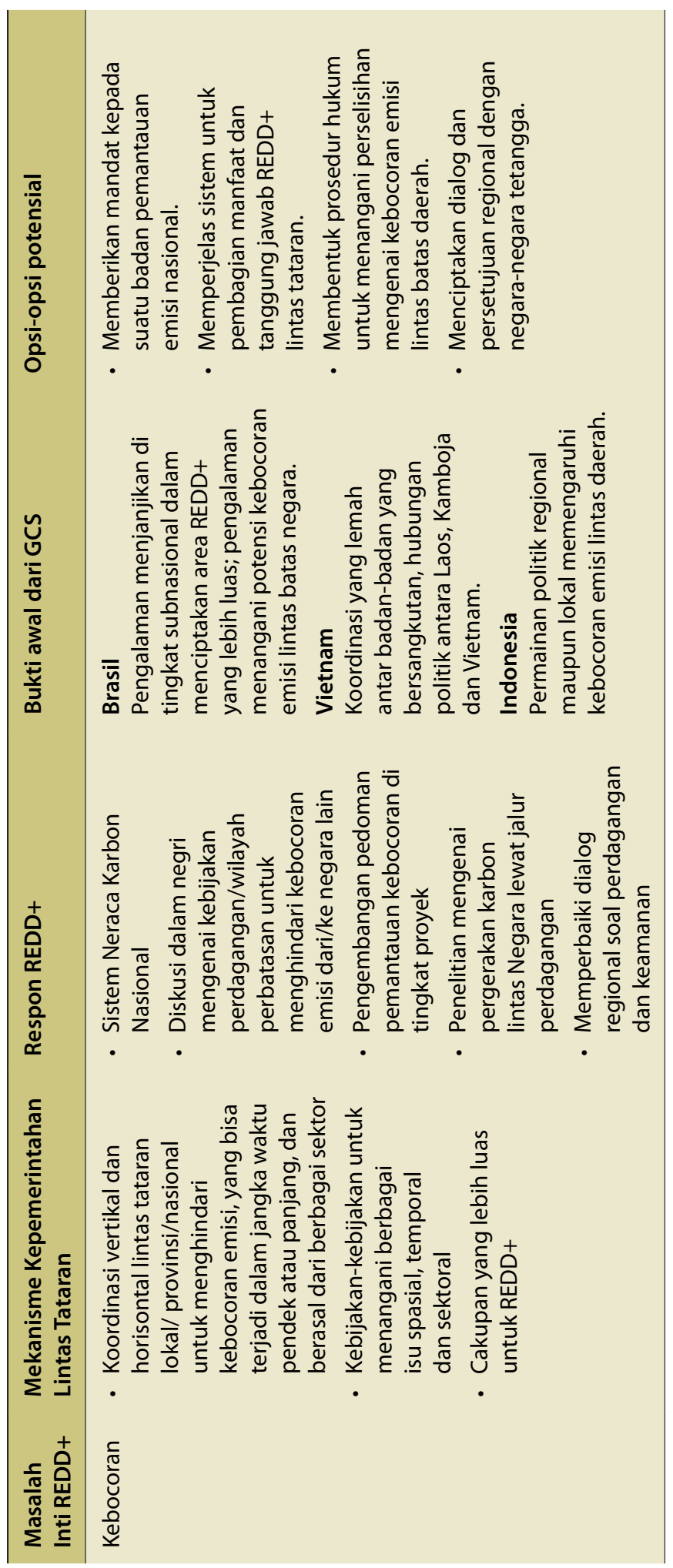


berencana menggunakan teknik-teknik canggih penginderaan jauh, termasuk data LiDAR (Asner dkk. 2010) dan algoritma baru untuk mendeteksi kebakaran hutan (Alencar dkk. 2011) guna memantau penggundulan dan kerusakan hutan. Meskipun demikian, masih banyak ketidakpastian dalam membangun sistem MRV di Brasil. Emisi karbon dari kerusakan hutan harus diikutsertakan dalam penentuan data acuan emisi karbon, pemantauan hutan tahunan, dan penginderaan jauh yang dipadukan dengan pengukuran lapangan yang mantap (Souza Jr., kom. pri., 9 Maret 2012. Lihat juga Bab 15 mengenai ketidakpastian faktor-faktor emisi). Brasil mempunyai setidaknya dua contoh di mana sistem MRV proyek REDD+ memadukan pemantauan berbasis masyarakat dengan analisis spasial. Meskipun ada kemajuan ini, dan mengingat luasnya Brasil, suatu proyek REDD+ tidak banyak pengaruhnya dalam pengurangan emisi jika tidak dikaitkan dengan kerangka kerja nasional yang lebih luas. Selain itu, standar dan metode verifikasi internasional untuk mengukur deforestasi bisa disederhanakan untuk mempermudah para pemrakarsa proyek REDD+, terutama sebelum ada petunjuk dari standar karbon terverifikasi (Verified Carbon StandardsNCS) dan kerangka kerja nasional MRV tentang pendekatan yurisdiksi.

\subsubsection{Tantangan: konflik kepentingan dan kurangnya minat}

Di Vietnam, konflik kepentingan dan perbedaan klasifikasi lahan yang berbeda di berbagai kementerian, dan bahkan di dalam satu kementerian, meningkatkan tantangan untuk mendapatkan informasi dan data yang akurat mengenai lahan dan sumberdaya kehutanan. Data tersebar dan terpecah di berbagai direktorat dan departemen, dan tidak tersedia untuk umum. Telah banyak pemangku dana yang telah mencoba membantu pemerintah untuk mengembangkan dan meningkatkan sistem MRV saat ini. Namun upaya ini gagal karena para pemangku kepentingan dalam negeri sering tidak berbagi data dan sumberdaya satu sama lain, sehingga banyak terjadi tumpang-tindih dan tindakan ganda. Perlu dicatat bahwa inisiatif MRV saat ini kesulitan menangani analisis dampak sosial sebab berbagai kementerian yang terkait bidang sosial tidak terlibat dalam diskusi.

Di Vietnam, muncul masalah dalam mengatur badan-badan tambahan dan badan independen untuk MRV karena tingginya biaya transaksi, konflik dengan kebijakan pemerintah yang ada (misalnya, berkaitan dengan keamanan nasional), ketidaksepakatan antara pemerintah pusat, daerah dan antara pemangku dana, dan kurangnya dukungan dari lembaga lokal. Pemerintah di daerah mempertanyakan apakah pembentukan badan-badan independen ini praktis dan realistis, serta meminta pendekatan yang lebih membumi dan efektif dari segi biaya. Jika potensi pendapatannya kecil, maka pemerintah daerah mungkin akan memilih untuk menggunakan mekanisme dan tata kelola kelembagaan yang sudah ada dengan menyertakan fungsi-fungsi tambahan. 
Walaupun MRV partisipatif tetap merupakan isu kontroversial di Vietnam, ada banyak proyek yang telah melakukan uji coba pemantauan karbon partisipatif. Pusat Agroforestri Dunia (The World Agroforestry Center) telah mengujinya, bekerja sama dengan mitra nasional di provinsi Bac Kan, Thai Nguyen dan Thua Thien Hue. Metode baru, yang dikenal sebagai RaCSA (rapid carbon stock appraisal) telah diuji karena berpotensi membantu masyarakat terlibat dalam pelaporan dan pemantauan sebagai bagian dari kesepakatan pembayaran jasa ekosistem (PES) (Kurniatun dkk. 2001). Pengujian ini juga untuk menjajaki pengetahuan lokal dan meneliti kegiatan-kegiatan yang dapat meningkatkan mata pencaharian lokal (Van Noordwijk 2007). Berdasarkan pengalaman tersebut, RaCSA memang bisa membantu masyarakat setempat untuk berpartisipasi aktif dalam MRV. Pelajaran yang dipetik dari penelitian percobaan ini dapat menjadi masukan dalam perancangan sistem MRV di Vietnam. Namun temuan-temuan ini belum disebarluaskan di antara para pemangku kepentingan ataupun dalam dialog kebijakan saat ini. Sekali lagi hal ini menunjukkan bahwa kegiatan REDD+ di tataran lokal dan nasional belum terhubung dengan baik.

\subsubsection{Peluang: kelompok kerja ad hoc}

Indonesia memberikan contoh menarik dalam upaya meningkatkan hubungan kelembagaan. Kelompok kerja ad hoc REDD+ di Kalimantan Tengah, Kalimantan Timur dan Aceh, bersama dengan satuan tugas nasional REDD+, membantu meningkatkan partisipasi pemangku kepentingan dan dialog antarkementerian, sektor swasta, masyarakat madani dan akademisi. Kelompok-kelompok kerja ini merupakan alat sementara untuk mengatasi kurangnya hubungan kelembagaan antarsektor, dan setidaknya di Indonesia, kelompok kerja adalah mekanisme yang dikenal baik untuk menangani isu-isu baru yang muncul. Tujuan langsungnya adalah meningkatkan dialog, membangun jejaring informal, membentuk visi terpadu REDD+ dan menciptakan kebijakan dan ruang pelaksanaan REDD+ di lembaga-lembaga yang relevan (lihat Kotak 6.2).

\subsubsection{Tantangan: tidak adanya kecocokan pemetaan dan pola pikir}

Masalah utama dalam membangun sistem nasional MRV di Indonesia dan Vietnam adalah kurangnya data spasial yang dapat diandalkan, harmonis, dan terpusat mengenai tata guna lahan, seperti konsensi kehutanan/ pertambangan/perkebunan, kawasan konservasi dan zona pengembangan ekonomi. Di Indonesia, langkah-langkah yang perlu telah diambil untuk meningkatkan transparansi data dan menyelaraskan peta penggunaan lahan lintas provinsi dan lintas sektor. Kelompok kerja REDD+ yang bernaung di bawah unit pengendalian pembangunan dan pemantauan (UKP4) di bawah Presiden, telah memaparkan data spasial di internet dan mengundang masukan serta analisis publik. Hal ini dilakukan sebagai tanggapan atas 


\section{Kotak 6.2 Jejaring dan kebijakan regional di Indonesia}

Caleb Gallemore dan Rut Dini

CIFOR sedang melakukan penelitian di Kalimantan Tengah (Kalteng) untuk lebih memahami bagaimana organisasi lembaga-lembaga pemerintah, swasta, dan masyarakat madani berinteraksi dalam proses membangun kebijakan REDD+ di tingkat provinsi. Dengan menggunakan pendekatan analisis jejaring kebijakan, CIFOR mempelajari pola pembagian informasi, kerja sama, pendanaan dan perselisihan yang terjadi di antara sekitar empat puluh organisasi kunci yang terlibat dalam kebijakan REDD+ di provinsi ini. Walau penelitian masih sedang berlangsung, sudah ada bukti jelas tentang pentingnya hubungan lintas tataran untuk memahami perkembangan kebijakan - atau ketiadaan perkembangan kebijakan - di Kalteng. Provinsi ini mendapatkan sorotan internasional ketika terpilih sebagai provinsi percontohan pertama untuk mendapatkan keuntungan dari kesepakatan dengan Norwegia yang bernilai AS \$1 miliar. Kesepakatan ini yang mengharuskan Kalteng mengembangkan kebijakan REDD+ tingkat daerah dalam konteks strategi nasional Indonesia tentang REDD+, dan mengadaptasi kebijakan yang dikembangkan di Jakarta ke kondisi-kondisi lokal. Organisasi-organisasi yang terkait kebijakan REDD+ di Kalteng melaporkan adanya kebingungan tentang status hukum REDD+, baik di tingkat lokal maupun di Jakarta. Kurangnya dasar hukum yang tegas untuk REDD+ menyebabkan kegiatan-kegiatan di provinsi, dan lembaga-lembaga REDD+, bersifat ad hoc.

Organisasi yang aktif dalam kegiatan REDD+ di tingkat provinsi bekerja sama dengan kelompok-kelompok lokal, dan dengan lembaga-lembaga di Jakarta atau dengan lembaga yang mempunyai ruang lingkup lebih luas lagi. Namun secara historis kerja sama ini melangkahi pemerintah provinsi. Artinya, upaya mengelola hubungan lintas sektor/tataran menjadi tugas utama lembaga daerah seperti kantor gubernur. Pada tahun 2009, kantor gubernur Kalteng membentuk Komisi Daerah untuk REDD+, seksi administratifnya, yaitu Sekretariat Bersama REDD+, serta Kantor PBB untuk Koordinasi REDD+ di Indonesia/United Nations Office for REDD+Coordination in Indonesia (UNORCID). Lembaga-lembaga ini menjadi jembatan antara pemerintah provinsi dan pemerintah nasional, dan bersama-sama berupaya menggabungkan prakarsa REDD+ lokal untuk menjadi strategi berskala provinsi. Tugas ini penuh tantangan, mengingat peran pemerintah kabupaten yang diperkuat di bawah kebijakan otonomi daerah.

Para responden penelitian kami melaporkan bahwa hubungan lintas skala menghadirkan berbagai tantangan dan menjadi sumber kebingungan. Pemangku kebijakan tingkat propinsi tidak yakin tentang dasar hukum mereka dalam peran pelaksanaan REDD+. Hal ini membuat mereka kadang-kadang merasa seperti sedang menunggu sesuatu yang tidak akan pernah terjadi.Didalam provinsi, banyak kegiatan tetap berfokus pada proyek REDD+ tertentu, karena pemerintah kabupaten memegang wewenang 
cukup besar atas penggunaan lahan. Meskipun pembicaraan kebijakan di tataran nasional dan provinsi cukup sering berhubungan, hanya ada sedikit hubungan langsung atau tidak langsung antara tataran desa dan kabupaten dengan jaringan lembaga-lembaga yang terlibat dalam pembahasan kebijakan di skala provinsi. Meskipun demikian, beberapa lembaga dalam jaringan kebijakan provinsi sedang bekerja untuk membangun hubungan ini. Inisiatif seperti www.borneoclimate.info, sebuah situs micro-blogging SMS yang menyediakan tempat diskusi tentang REDD+ dan isu-isu hutan lainnya, menyediakan satu cara untuk memanfaatkan jaringan luas telepon seluler di Indonesia. Ada juga diskusi tentang kemungkinan membangun satu atau lebih forum yang melibatkan berbagai pemangku kepentingan, sehingga tersedia latar kelembagaan untuk berdiskusi tentang REDD+, di antaranya bagi pemerintah, masyarakat madani, dan para pemimpin tradisional, serta pemangku kepentingan lainnya. Namun menyediakan lingkungan yang mendukung hubungan antara tataran yang berbeda juga akan memerlukan dasar hukum untuk REDD+ yang memperjelas peran di semua tataran.

moratorium deforestasi yang didorong oleh Surat Pernyataan Minat kerja sama antara pemerintah Indonesia dan Norwegia mengenai REDD+ (lihat Kotak 2.1 dalam Bab 2). Dukungan presiden Indonesia sangat penting untuk mengesahkan proses pemetaan. Proses ini menarik perhatian di tataran kabupaten. Contohnya di kabupaten Kapuas, yang menjadi kabupaten percontohan REDD+, rekonsiliasi data spasial telah menjadi bagian dari strategi REDD+ (observasi lapangan oleh Atmadja 2011). Sistem neraca karbon nasional Indonesia (Indonesian National Carbon Accounting System (INCAS) adalah sebuah inisiatif multilembaga di tingkat nasional yang sedang menetapkan berbagai metode untuk menghitung karbon nasional. Metode mereka mengikuti persyaratan IPCC, dan membantu mewujudkan data yang dapat dipercaya dan terstandarisasi. Namun upaya pemusatan data yang saat ini tersebar di bawah wewenang berbagai instansi masih sangat terbatas.

Pihak-pihak pelaksana proyek-proyek REDD+ sering mencoba melibatkan perumus kebijakan daerah supaya mereka dapat memahami tujuan dan sasaran kegiatan proyek. Namun karena mekanisme pembayaran REDD+ masih tidak jelas, maka minat terhadap kegiatan REDD+ masih sangat terbatas. Salah satu pengecualiannya adalah kemitraan karbon hutan Kalimantan (Kalimantan Forest Carbon Partnership/KFCP) antara pemerintah Indonesia dan pemerintah Australia (pemerintah Australia dan pemerintah Republik Indonesia 2007). Kehadiran kelembagaan dan pendanaan jangka panjang untuk kemitraan ini telah membantu melibatkan perumus lokal dalam dialog berkala dan pengambilan keputusan kolaboratif (Lihat Kotak 6.2 untuk informasi tambahan tentang tata kelola lintas tataran di Kalimantan Tengah). 


\subsection{Kebocoran emisi karbon}

Ada dua hal yang berkaitan dengan kebocoran karbon: i) pendekatan teknis untuk pemantauan dan pengukuran kebocoran karbon, dan ii) tata cara dan tindakan yang diperlukan untuk mengelola atau mengurangi kebocoran karbon.

Intervensi REDD+ dapat menyebabkan kebocoran karbon lokal/lintas provinsi/lintas nasional, dalam jenjang waktu jangka panjang maupun jangka pendek, dan berasal dari berbagai sektor (misalnya, pertanian, pertambangan, kehutanan dan infrastruktur; Wunder 2008).

Mekanisme tata kelola lintas tataran diperlukan untuk memastikan pengurangan emisi secara keseluruhan karena melibatkan hal-hal lintas daerah, lintas waktu dan lintas sektoral. Masih belum ada aturan tentang kebocoran karbon antar negara, mungkin karena strategi untuk membatasi kebocoran bisa mencakup instrumen perdagangan antarnegara yang mungkin mengungkit hukum internasional dan masalah kedaulatan (Lihat kajian dalam Droege 2011). Untuk menyelesaikan sengketa seperti ini diperlukan lembaga-lembaga yang bisa menentukan legalitas kebijakan kebocoran yang dipilih dan mengambil keputusan seputar tanggung gugat.

\subsubsection{Peluang: belajar dari pengalaman subnasional}

Cara penting untuk mengendalikan kebocoran karbon adalah dengan konsolidasi kerangka kerja REDD+ dalam skala seluas mungkin. Contohnya, pemerintah negara-negara bagian Brasil yang berada di wilayah Amazon bergabung dalam satuan tugas Governors' Climate and Forests Taskforce (GCF). Cara ini merupakan strategi penting untuk mengurangi risiko kebocoran di kawasan ini. Berlandaskan forum ini, sejak 2008 tujuh dari sembilan negara bagian Amazon telah memulai rencana untuk mengendalikan deforestasi dalam kerangka rencana nasional untuk mencegah dan mengendalikan deforestasi di Amazon (May dkk. 2011b). Mereka didukung LSM-LSM nasional dan dana Amazon (Amazon Fund). Negara-negara bagian Amazonas dan Acre telah mengesahkan peraturan untuk mengurangi emisi akibat deforestasi dan degradasi, yaitu Undang-undang Iklim dan Konservasi Amazonas/the Amazonas Climate and Conservation Law/(3135/2007) yang disahkan tahun 2007, dan Undang-undang untuk Sistem Jasa Lingkungan Negara Bagian Acre/Acre's State System for Environmental Services Law (Pemerintah Acre 2010; UU 2308/2010), yang disahkan tahun 2010. Kedua undang-undang ini mendukung transformasi lembaga-lembaga negara bagian tersebut. Dengan bantuan LSM-LSM lingkungan, pemerintah Acre juga telah mempertimbangkan cara pengendalian kebocoran karbon antarnegara dengan pemerintah daerah di Madre de Dios, Peru, melalui pertukaran informasi dan peningkatan kapasitas. 


\subsubsection{Tantangan: kebocoran emisi karbon lintas batas akibat ketidaksesuaian antara pasokan dan permintaan kayu dalam negeri}

Kebocoran karbon merupakan masalah sulit di Vietnam, terutama dalam hal mengumpulkan data serta perdebatan politik dalam negeri. Meskipun pemerintah telah berkomitmen untuk menangani masalah ini, penelitian menunjukkan adanya tantangan-tantangan (Meyfroidt dan Lambin 2009), khususnya yang berkaitan dengan ketidaksesuaian antara pembangunan ekonomi dan rendahnya produksi kayu nasional. Industri pengolahan kayu telah menjadi prioritas pemerintah karena kontribusinya penting bagi perekonomian nasional. Namun $80 \%$ bahan mentah industri kayu saat ini berasal dari kayu impor (Doan dkk 2005;.GSO 2009; Forest Trends 2010). Untuk mengatasi masalah ini, Strategi Pembangunan Kehutanan Vietnam 2006-2020 menargetkan supaya kebergantungan pada kayu impor menurun sampai menjadi 20\%. Namun sebagaimana yang dicatat oleh ProForest (2009), tujuan ini dipandang ambisius karena pengalihan lahan yang tak direncanakan untuk tujuan lain dan terbatasnya kerja sama antarperusahaan. Akibatnya, Vietnam kemungkinan akan tetap mengandalkan impor dari negara lain, yang melahirkan risiko pembelian kayu dari sumber yang tidak diketahui dan mungkin ilegal di negara-negara seperti Lao PDR dan Kamboja (GSO 2009; ProForest 2009; Forest Trends 2010). Selain itu, meskipun tutupan hutan di Vietnam meningkat selama beberapa tahun terakhir ini, terutama karena meningkatnya kawasan hutan tanaman, kualitas hutannya menurun sehingga stok karbonnya rendah.

Untuk menangani masalah ini, program UN-REDD bertujuan untuk mengukur probabilitas pengalihan emisi lintas batas negara dengan mengumpulkan dan menganalisis data yang ada serta melakukan dialog regional. Vietnam juga merencanakan untuk membangun kemitraan antarpemerintahan negara-negara di sepanjang Sungai Mekong untuk menghindari risiko pengalihan emisi di bawah REDD+. Konsep untuk membuat suatu badan pendukung teknis telah disiapkan dan diajukan ke Pertemuan kedua Fasilitas Kemitraan Karbon Hutan/Forest Carbon Partnership Facility (FCPF) di Panama, Maret 2009. Sejumlah diskusi telah dilangsungkan, namun belum ada kesepakatan yang diraih oleh keempat negara yang potensial menjadi anggotanya: Kamboja, Vietnam, Lao PDR dan Thailand (Scheyvens 2010).

\subsubsection{Tantangan: politik daerah sebagai faktor kebocoran karbon subnasional}

Di Indonesia, desentralisasi telah memberikan hak dan tanggung jawab baru kepada pemerintah kabupaten atas pengelolaan dan pengumpulan pendapatan dari sumberdaya lahan dan sumberdaya alam. Politik daerah telah 
memperkenalkan elemen tambahan untuk REDD+: pendanaan berbasiskan partai politik, dan penggalangan dana untuk kampanye pemilu. Dalam hal ini, dampak pemindahan emisi subnasional dalam implementasi REDD+ sangat penting. Jika sebuah kabupaten sangat ketat dalam membatasi deforestasi dan degradasi, kabupaten tersebut berisiko kehilangan potensi pendapatan dan investasi karena membuat industri-industri yang memerlukan konversi lahan menjadi merasa tidak nyaman/takut. Industri-industri seperti ini mungkin kemudian memilih untuk menjalankan bisnisnya di kabupaten tetangga, yang menjalankan kebijakan lebih longgar. Selain itu, pemerintah kabupaten mengandalkan penerimaan pajak dan kesempatan kerja yang dihasilkan oleh industri; elite kabupaten mengandalkan uang informal yang terkait menjalankan bisnis untuk membiayai kampanye politik dan mempertahankan posisi politis. Karena itu ada insentif yang kuat untuk berusaha mencegah investor untuk tidak meninggalkan kabupatennya. Di satu sisi, hal ini mengurangi kebocoran dari penggunaan lahan skala besar yang sangat mendatangkan keuntungan. Namun ini juga berarti mengorbankan tujuan-tujuan pengurangan emisi dan menurunkan kemungkinan kabupaten-kabupaten untuk melaksanakan REDD+.

Dalam mengurangi emisi gas rumah kaca di tingkat global, kebocoran karbon dipandang sebagai masalah penghitungan neraca emisi karbon dan penentuan penyebab pengurangan emisi. Penghitungan neraca emisi karbon dilakukan di tingkat nasional, namun emisi dapat beralih dari satu negara ke negara lain. Sulit untuk memastikan bagaimana emisi karbon beralih dari satu negara ke negara lain dan sejauh mana satu negara bertanggung jawab atas beralihnya emisi karbon mereka ke negara lain (Wunder 2008). Kebanyakan wacana akademis berfokus pada kebocoran internasional (Atmadja dan Verchot 2012), yang sampai sekarang belum ada struktur kelembagaan untuk menanganinya. Sebagaimana kisah kebocoran emisi antardaerah yang dijelaskan di atas, upaya mengurangi kebocoran emisi dapat membatasi pertumbuhan ekonomi dari sektor-sektor alternatif lahan hutan, dengan risiko kalah bersaing dengan negara lain yang lebih longgar dalam menerapkan kebijakan REDD+. Isu ini bergesekan dengan topik-topik sensitif, seperti kedaulatan negara dan hak-hak untuk mencapai pertumbuhan ekonomi. Pendekatan bilateral adalah suatu langkah awal yang bisa diambil, namun langkah ini mungkin terlalu terbatas sehingga kurang bisa menjamin emisi tidak beralih ke tempat lain. Karena itu dalam pelaksanaan REDD + di tingkat global, kebocoran emisi menjadi masalah ekonomi dan politik yang perlu penyeimbangan antara pengurangan emisi yang efektif melalui pengelolaan kebocoran emisi, dan kepentingan geopolitik masing-masing negara.

\subsection{Lembaga, kepentingan dan informasi: hambatan dan peluang}

Berdasarkan temuan di atas dan kerangka teoritis yang digunakan di bab ini (4I dalam Bab 2, Pahl-Wostl 2009), kami mengidentifikasi aspek-aspek 
penting berikut ini yang perlu diberi perhatian khusus oleh para pengambil keputusan REDD+: i) mendukung arus informasi dan insentif yang transparan dan bertanggung gugat; dan ii) menyesuaikan kepentingan dengan kelembagaan lintas tataran.

\subsubsection{Arus informasi dan insentif}

Kami menguraikan berbagai tantangan dalam tata kelola lintas tataran berdasarkan berbagai studi kasus yang ada, namun kami juga mengamati munculnya peluang-peluang yang menjanjikan. Tidak adanya kerangka kerja nasional REDD+ merupakan tantangan penting yang memengaruhi upaya pengembangan sistem MRV nasional yang bisa dipertanggungjawabkan dan penyelarasan kegiatan-kegiatan REDD+. Cara penting untuk menciptakan sistem tata kelola lintas tataran dalam REDD adalah dengan meningkatkan komunikasi dan arus informasi antara proyek-proyek subnasional REDD+ dengan tataran nasional.

Dalam dunia REDD+, informasi adalah kekuatan. Lembaga-lembaga yang memegang wewenang dan kemampuan untuk menyampaikan informasi, baik di tingkat proyek maupun nasional, berperan penting dalam politik nasional REDD+. Selain itu, integrasi pengetahuan lokal ke dalam sistem MRV juga penting, sebagaimana telah dicoba baru-baru ini di Brasil dan Vietnam. Pengetahuan adalah hasil dari kepentingan sosial dan hubungan antarkekuasaan. Karena itu, kita patut juga bertanya: pengetahuan macam apa yang tidak dihasilkan dan tidak disebarluaskan? Dengan demikian, arti sistem MRV dan pengetahuan yang mendasari sistem tersebut bukan hanya merupakan isu teknis tetapi juga isu politis.

Arus informasi yang sehat diperlukan untuk merancang sistem pembagian manfaat dan tanggung jawab REDD+. Mekanisme tata kelola lintas tataran memungkinkan aliran insentif yang adil dari tingkat nasional sampai ke tingkat subnasional dan lokal. Elemen kunci dalam pembahasan pembagian keuntungan adalah hubungan antara pemerintah pusat dan daerah, dan penerapan intervensi REDD+ yang lebih luas oleh pemerintah daerah (lihat Bab 8).

\subsubsection{Menyesuaikan skala dengan pokok persoalan dan kelembagaan}

Integrasi lembaga-lembaga di tataran yang berbeda juga dapat mendukung penyelarasan perencanaan spasial. Tatanan kelembagaan baru diperlukan untuk membangun sistem MRV yang bertanggung gugat, khususnya sebagai sarana mengatasi hambatan arus informasi lintas tataran. Tatanan ini bisa dibangun dengan lembaga-lembaga baru atau yang sudah ada. Namun di negara-negara yang telah kami teliti, masih ada tantangan politik dan ekonomi untuk menciptakan lembaga-lembaga seperti ini. Tugas ini juga 
membutuhkan keterampilan dan kemampuan baru untuk menangani berbagai jenis informasi, misalnya data lokal dan data spasial dengan kualitas yang bervariasi.

Di banyak negara, pemerintah daerah dapat berperanan penting dalam pelaksanaan REDD+. Di Indonesia dan Brasil, misalnya, desentralisasi telah menempatkan kekuatan pengelolaan lahan dan sumberdaya alam di tangan pemerintah daerah, sehingga mereka menjadi pemain kunci dalam pelaksanaan REDD+. Di kedua negara ini, sangat penting untuk membangun peraturan yang konsisten mengenai tanggung jawab, hak-hak dan prosedur MRV oleh pemerintah daerah, dan menetapkan pendanaan dan mekanisme transparan untuk mengalokasikan sumberdaya kepada para pelaku REDD+ di tingkat daerah. Di Indonesia, kelompok kerja sukarela membantu hubungan kelembagaan lintas sektor dan tataran, serta memberikan contoh penyelarasan kelembagaan lintas tataran.

Seperti contoh di Vietnam dan Brasil, meskipun sistem MRV yang konsisten di tingkat nasional adalah penting, pengelolaan kebocoran harus bersifat lintas negara. Masalah kebocoran emisi karena kesenjangan antara pasokan dan permintaan lintas batas dapat diatasi melalui integrasi kelembagaan lintas tataran dan koordinasi horizontal, seperti contoh yang cukup menjanjikan dari Komisi REDD Mekong untuk Kemitraan Antarnegara (Mekong REDD Commission for Intergovernmental Partnership) dan kerja sama pemerintah Acre di Brasil dengan pemerintah regional Madre de Dios di Peru.

\subsubsection{Perlunya partisipasi}

Umumnya REDD+ dikritik karena dilaksanakan melalui pendekatan top-down. Namun pendekatan tata kelola lintas tataran yang berfokus pada mencocokkan kepentingan lintas tataran bisa menghasilkan partisipasi yang kuat dari para pemangku kepentingan. Bukti dari negara-negara REDD+ menunjukkan bahwa potensi untuk meningkatkan partisipasi dalam REDD+ sangat besar (Indrarto dkk. 2012; Pham dkk. 2012). Kunci untuk meningkatkan koordinasi vertikal adalah partisipasi para pelaku dari satu tataran dalam proses di tataran lain (Pahl-Wostl 2009). Partisipasi dan konsultasi dengan berbagai kelompok masyarakat dibutuhkan dalam kerangka hukum REDD+ di semua negara. Tapi dalam kenyataannya hal ini jarang dilakukan (Lihat juga Kotak 6.3 Proses REDD+ di Madagaskar.)

Meskipun demikian, kelompok adat dan masyarakat berbasiskan hutan di Brasil bergerak untuk meningkatkan partisipasi lokal dalam proses REDD+, karena menyadari banyak tantangan terkait dengan keterlibatan masyarakat secara adil dalam REDD+. Kelompok-kelompok ini melihat adanya potensi manfaat maupun risiko yang terkait dengan REDD+, dan bertindak untuk menyertakan perlindungan lingkungan dan sosial dalam kegiatan REDD+ 
(Gomes dkk 2010; l lihat juga Bab 17 tentang Pengamanan/Perlindungan). Kebanyakan LSM dan badan pemerintah yang memprakarsai proyek REDD+ telah melakukan atau berencana untuk mengadakan konsultasi publik di lokasi proyek untuk menyajikan dan mendapatkan umpan balik.

Di Vietnam, proses politik di mana mekanisme konsultasi tidak efektif dan representasi yang lemah oleh berbagai kelompok menyebabkan terbatasnya partisipasi dalam REDD+. Sebagaimana disoroti oleh Pham dkk. (2010), para pemangku dana biasanya membayar tenaga perantara untuk melaksanakan konsultasi dengan masyarakat, namun karena banyak tekanan (waktu, prioritas donor dan biaya) konsultasi-konsultasi yang dilakukan tidaklah mencukupi. Contoh awal di Vietnam menunjukkan bahwa partisipasi lokal bisa dilakukan dan dapat meningkatkan sistem MRV. Namun buktinya tidak disebarluaskan secara efisien di berbagai tataran.

Di Indonesia, minat yang rendah untuk berpartisipasi dalam diskusi REDD+ sebagian besar berasal dari kejenuhan partisipasi, kurangnya bukti bahwa REDD+ memang dapat diterapkan, dan kuatnya kepentingan penggunaan lahan lain yang dapat menyebabkan emisi. Bahkan di tempat-tempat yang memiliki kelompok kerja sukarela untuk meningkatkan partisipasi para pemangku kepentingan, kejenuhan terhadap REDD+ terjadi akibat terlalu banyak lokakarya, diskusi pemangku kepentingan, dan seminar-seminar tentang REDD+.

\subsubsection{Negosiasi sejumlah kepentingan}

Arus informasi yang mengalir lintas tataran dapat terhambat oleh konflik kepentingan atau kurangnya minat dalam berbagi informasi dengan para pelaku lain, seperti kasus-kasus di Vietnam dan Indonesia. Kelembagaan yang alot dan struktur kekuasaan yang sudah mapan menghambat arus dan penyesuaian berbagai jenis informasi melintas antartataran. Kita harus mengakui bahwa hubungan dan jaringan informal sangat penting dalam menjembatani kesenjangan antarlembaga dalam berbagai tataran. Di Vietnam, sebagian besar pemangku kepentingan berbagi informasi melalui jalur informal, misalnya melalui hubungan pribadi atau jaringan informal. Namun jaringan informal ini jarang diketahui atau diakui, tidak transparan dan benar-benar eksklusif.

Membangun kerangka kerja nasional REDD+ yang konsisten akan membantu mengatasi banyak tantangan yang dihadapi dalam tata kelola lintas tataran. Walaupun begitu, seperti yang terlihat di Brasil, tata kelola yang kuat di tingkat daerah telah berperan penting untuk memajukan REDD+ di tingkat lokal dan nasional. Pengalaman dari Brasil memberikan contoh langkah-langkah yang diperlukan untuk koordinasi vertikal dan tata kelola lintas tataran dalam REDD+, meskipun masih banyak yang perlu dilakukan 


\section{Kotak 6.3 Desentralisasi atau "LSM-isasi" REDD+? Lemahnya kepemimpinan nasional dalam membangun strategi REDD+ di Madagaskar}

Emilia Runeberg

Madagaskar, negara pulau di Samudera Hindia yang terkenal sebagai tempat yang sangat kaya keanekaragaman hayatinya, ikut serta dalam Fasilitas Kemitraan Karbon Hutan (FCPF) Bank Dunia pada tahun 2008 dalam suatu proses kesiapan REDD+ untuk menyiapkan strategi nasional REDD+. Secara paralel, LSM internasional yang memimpin proyek-proyek percontohan REDD+ telah dibentuk di berbagai daerah di negara ini, dengan tujuan untuk memasok informasi untuk proses perumusan kebijakan nasional REDD+. Upaya untuk membangun strategi nasional REDD+ yang konsisten mengalami kesulitan karena kurangnya kepemimpinan nasional dalam menyelaraskan pengalaman-pengalaman dari berbagai proyek percontohan REDD+ yang terpisah. Hal ini menghambat transisi dari kegiatan-kegiatan terpisah yang dikendalikan LSM internasional menuju suatu sistem tata kelola REDD+ nasional.

Pengelolaan Hutan Kemasyarakatan (Community forest management - CFM), yang diharapkan sebagai tulang punggung tata kelola REDD+ Malagasi, dapat digunakan untuk memetakan kegiatan-kegiatan tata kelola yang sedang berlangsung di berbagai tataran. Di tingkat masyarakat umum, semua proyek percontohan REDD+ telah membentuk persatuan CFM, yang dikenal dengan sebutan COBA, dengan mengalihkan hak pengelolaan hutan dari negara kepada kelompok masyarakat dengan ikatan kontrak berjangka waktu tertentu. Di tingkat lokal, COBA melakukan kontrak dengan pemerintah daerah setempat dan dinas kehutanan. Pengalihan pengelolaan ini sering dipimpin oleh sebuah lembaga penengah, yang dalam kasus proyek-proyek REDD+ besar dilakukan oleh LSM internasional. Peran lembaga penengah sangat penting dalam desain kontrak CFM dan kegiatan terkait, misalnya penciptaan mata pencaharian alternatif untuk COBA. Di tingkat regional, beberapa proyek REDD+ sedang menggalang beberapa COBA untuk membentuk perserikatan. Namun demikian tetap ada satu mata rantai yang hilang, yaitu sebuah struktur tata kelola tingkat regional, yang saat ini masih diisi oleh sejumlah LSM Internasional.

Koordinasi tingkat nasional untuk kegiatan-kegiatan REDD+ disalurkan melalui sebuah komite ad hoc yang disebut CT-REDD, tersusun dari para pelaku pemerintahan, nonpemerintah, dan semipemerintah. Sebelum kerja komite ini terganggu (sementara?) di awal tahun 2011, CT-REDD berkomunikasi dengan para pemangku kepentingan dengan tujuan merangkum pengalaman-pengalaman dan mengatur konsultasi regional untuk menyiapkan Proposal Persiapan Kesiapan (R-PP/Readiness Preparation Proposal) yang akan diajukan kepada FCPF. Terlepas dari dokumen R-PP, setiap upaya di tingkat nasional untuk menentukan garis besar arah REDD+ 
hanya berjalan di tempat dan tidak mendapatkan pendanaan. Di tingkat supranasional, Madagaskar sulit mendapatkan pendanaan untuk visi R-PP-nya, sebagian karena krisis politik nasional yang bermula dengan kudeta tahun 2009. Sebagai gantinya, pemangku dana internasional terus mendukung LSM internasional agar terus mengembangkan berbagai metodologi REDD+ di area proyek yang terpisah.

Masing-masing proyek menjadi suatu dunia kecil, sehingga arus informasi dan kapasitas sangat bergantung pada LSM Internasional, individu tertentu yang mempunyai kemampuan teknis MRV, dan para individu di tingkat kepemerintahan yang telah dijelaskan di atas. Pengaturan dan partisipasi oleh para pelaku pemerintah dalam REDD+ diduga akan tetap lemah. Kemungkinan adanya motivasi tersembunyi untuk menjaga agar REDD+ terus dikendalikan proyek-proyek yang didominasi LSM internasional juga perlu mendapat perhatian khusus. Ketegangan antara sudut pandang dan kepentingan para pelaku pemerintah dan non-pemerintah mengungkapkan masalah kedaulatan negara, legitimasi dan transparansi. Pengamatan awal menunjukkan bahwa REDD+ dapat meningkatkan kekuatan pihak eksternal nonpemerintah dan memperkuat proyek tata kelola transnasional yang telah membentuk pengelolaan sumberdaya alam di Madagaskar sejak tahun 1980-an (Duffy 2006).

sebelum bisa mendefinisikan kerangka kerja nasional yang konsisten bagi negara ini. Meskipun kerangka kerja nasional penting untuk koordinasi menyeluruh, sebuah sistem tata kelola lintas tataran merupakan pergeseran ke arah menerima kenyataan bahwa semua aspek tata kelola di bidang lingkungan dapat melibatkan perdebatan dan perbedaan tujuan yang harus didamaikan atau diterima sebagai berbeda. Karena itu mekanisme tata kelola lintas tataran dapat membantu menyesuaikan berbagai perbedaan antara tataran yang berbeda.

REDD+ tidak bisa beroperasi dalam ruang hampa politik dan sosial; ia terjalin dengan proses politik dan struktur sosial yang ada. Di Indonesia, REDD+ telah memperketat permainan politik regional dan lokal dan hasil permainan ini pasti ikut memengaruhi struktur sistem MRV serta kebocoran emisi di dalam negeri. Tata kelola lintas tataran, termasuk pembentukan prosedur hukum, diperlukan untuk menyelesaikan perselisihan dalam pelaksanaan REDD+. REDD+ perlu dirancang sehingga melengkapi kebijakan-kebijakan hutan yang ada sekarang dan perlu didasari pengalaman lokal dan internasional selama puluhan tahun. Hal ini konsisten dengan usulan untuk mengembangkan tata kelola iklim yang bertingkat. (Forsyth 2009). 


\subsection{Kesimpulan}

Sudah jelas REDD+ adalah suatu upaya lintas tataran. Karena itu, REDD+ memerlukan sistem tata kelola lintas tataran yang unik dalam sejarah kebijakan lingkungan (Skutsch dan Van laake 2008). Dimensi dan mekanisme sistem semacam ini sangat bervariasi antara berbagai elemen REDD+. Sejumlah studi kasus juga menunjukkan bahwa mekanisme yang cocok sangat bervariasi sesuai kondisi negara masing-masing.

Tata kelola lintas tataran dalam REDD+, khususnya dalam menangani kebocoran emisi dan MRV, adalah persoalan harmonisasi informasi dan insentif di semua tataran. Sebagian dari harmonisasi ini menyangkut masalah praktis dan teknis: informasi dan data untuk REDD+ terbentuk melalui berbagai proses dan standar yang berbeda, sehingga sulit untuk menyusunnya sebagai satu kesatuan di tingkat nasional. Selanjutnya, perbedaan kualitas dan kuantitas data dari berbagai sumber data ternyata memberikan celah terjadinya kebocoran emisi yang tak terdeteksi dan tak dihitung.

Namun demikian, aliran informasi dan insentif dalam REDD+ dapat menimbulkan konflik antara pelaku daerah dan nasional yang bersumber pada konflik kepentingan di berbagai tataran. Informasi dan insentif adalah dua mata uang utama dalam dunia REDD+ yang rumit, yang terkait kembali dengan hubungan kekuasaan antara para pelaku yang mengendalikan informasi dan insentif tersebut. Sistem tata kelola lintas tataran di REDD+ perlu dirancang untuk mencapai dua tujuan: mencari cara membantu para pelaku di berbagai tingkat yang berbeda untuk lebih menyelaraskan kepentingan masing-masing, dan pada saat yang sama juga menyesuaikan dan melakukan diversifikasi sehingga berbagai pelaku bisa bekerja sama dalam REDD+ meskipun kepentingannya berbeda.

Ringkasnya, kesuksesan implementasi REDD+ memerlukan reformasi kebijakan dan kelembagaan untuk mendefinisikan kembali informasi, insentif dan struktur-struktur kekuasaan yang ada. REDD+ dapat mengubah permainan untuk memicu perubahan transformatif yang lebih luas dan mekanisme tata kelola lintas tataran dapat berperanan penting dalam proses perubahan ini. Arus informasi dan insentif yang sehat lintas tataran, disertai lembaga-lembaga yang transparan, akan menjadi kunci implementasi REDD+ yang efektif, efisien dan setara. 


\section{Bab}

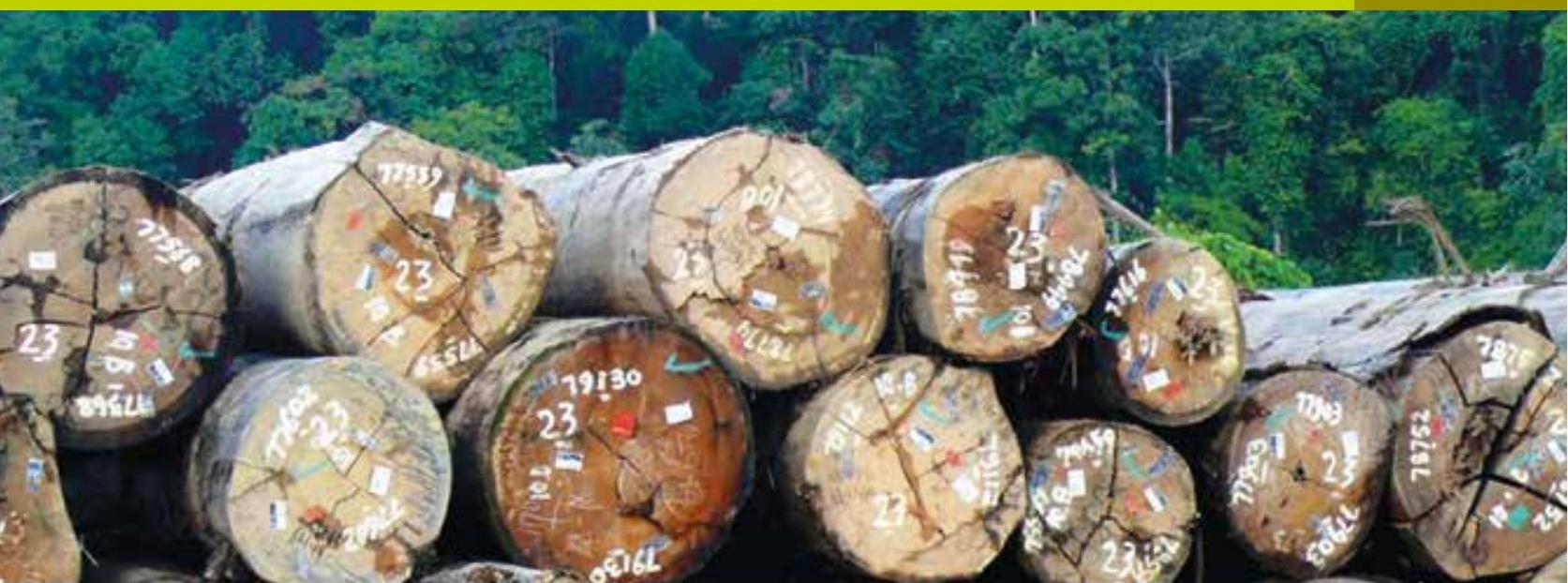

\section{Pendanaan REDD+}

Charlotte Streck dan Charlie Parker

- Pendanaan REDD+ berada di titik perubahan bentuk: pendanaan jangka pendek memang tersedia, namun pencairannya lambat dan kesempatan investasinya langka; pada saat yang sama, tidak ada strategi jangka panjang yang bisa diramalkan dan memadai untuk memenuhi kebutuhan pendanaan REDD+.

- Tidak adanya tujuan ambisius tentang mitigasi perubahan iklim, sejauh yang bisa dilihat di masa depan sebagian besar pendanaan REDD+ akan digalang oleh sektor publik. Selama masa peralihan, pendanaan REDD+ kemungkinan akan terbagi-bagi dan disalurkan melalui berbagai lembaga sehingga penting untuk menguji berbagai pilihan pendanaan yang memanfaatkan pendanaan sektor swasta dan menangani pemicu-pemicu deforestasi secara langsung.

- Negara-negara REDD+ yang lebih kaya dan memiliki lembaga yang lebih kuat mungkin memilih untuk mendanai sendiri salah satu bagian REDD+ yang penting. Mereka mungkin juga memilih untuk terlibat dalam kesepakatan berbasiskan-hasil dengan para donor dan lembaga-lembaga internasional. Negara-negara yang lebih lemah mungkin akan lebih bersandar pada jenis pendanaan bantuan pembangunan (official development assistance/ODA), yang mengombinasikan dukungan pendanaan dengan bantuan teknis dan panduan kebijakan. 


\subsection{Pengantar}

Mengurangi emisi karena deforestasi membutuhkan biaya, karena perlindungan hutan menyebabkan hilangnya pendapatan dari penebangan kayu, tanaman dan ternak. Tanpa mekanisme ekonomi dan hukum untuk menegakkan atau memberi kompensasi tindakan pemilik dan pengguna, maka hutan akan terus dianggap lebih bernilai kalau hutan itu mati daripada kalau tetap hidup. Kerangka kerja insentif yang muncul untuk mengurangi emisi karena deforestasi dan degradasi hutan (dan peran konservasi, pengelolaan berkelanjutan dan pengayaan hutan), disebut sebagai REDD+, berupaya untuk menggalakkan perkembangan dan pertumbuhan ekonomi tanpa merusak sumberdaya alam yang berharga. Dalam konteks REDD+, negara-negara telah sepakat untuk "secara kolektif bertujuan memperlambat, menghentikan dan memulihkan tutupan hutan dan karbon yang hilang", dan untuk melakukan hal ini "dalam konteks penyediaan dukungan yang memadai dan dapat diprediksi bagi negara-negara berkembang" (UNFCCC 2011a). Di dalam negara-negara ini, pihak-pihak yang telah menderita kerugian ekonomi (mantan pengguna dan penerima manfaat hutan) dan pelindung atau pelestari hutan saat ini bisa diberi kompensasi atas kehilangan yang dideritanya atau menerima imbalan atas tindakan yang dilakukannya. Pembayaran kompensasi atau imbalan dapat berasal dari sumber-sumber internasional atau nasional dan akan disalurkan melalui lembaga-lembaga nasional. Pendanaan dari sektor swasta juga dapat langsung disampaikan kepada penerima manfaat melalui mekanisme berbasiskan pasar.

Sebagai cerminan dari prinsip 'tanggung jawab bersama dalam bentuk yang berbeda', alokasi biaya pelaksanaan REDD + telah menjadi bagian integral dari negosiasi REDD+ di bawah Konvensi Kerangka Kerja PBB tentang Perubahan Iklim (UN Framework Convention on Climate Change/UNFCCC). Pendanaan merupakan bagian implisit dalam konteks masalah-masalah teknis, seperti pengukuran dan tingkat acuan yang didiskusikan oleh Subsidiary Body for Scientific and Technological Advice atau, secara eksplisit, dalam konteks negosiasi di bawah Kelompok Kerja Ad-Hoc dari Long-Term Cooperative Action. Pada bulan Desember 2011, yaitu sesi ke-17 dari Conference of the Parties to the UNFCCC (COP17), para pihak setuju bahwa "pendanaan berbasiskan-hasil yang disediakan bagi pihak-pihak negara berkembang yang bersifat baru, berupa tambahan dan dapat diprediksi bisa berasal dari berbagai sumber, publik maupun swasta, bilateral dan multilateral, termasuk sumber-sumber alternatif" dan bahwa "pendekatan berbasiskan-pasar yang tepat [...] untuk mendukung tindakan berbasiskan-hasil oleh negara-negara sedang berkembang" dapat dikembangkan (UNFCCC 2012). Dari berbagai kegiatan REDD+, para pihak juga mengadopsi pedoman tingkat acuan untuk memperhitungkan pengurangan emisi. Namun, masih belum jelas tentang syarat apa yang harus dipenuhi dan bagaimana tingkat-tingkat acuan tersebut bisa dikaitkan dengan insentif pendanaan 'berbasiskan-hasil' di masa depan (lihat Bab 16). 
Ada empat tantangan utama yang terkait pendanaan REDD+:

- Menetapkan biaya REDD+ dan memperkirakan kebutuhan pendanaan REDD+

- Menggalang pendanaan internasional dan nasional yang mencukupi untuk menutupi biaya dan langkah-langkah kebijakan REDD+

- Mengalokasikan dan menyalurkan pendanaan REDD+ secara efisien, efektif dan berkesetaraan untuk mencapai hasil yang terukur dan jelas

- Mencocokkan berbagai persyaratan dan kebutuhan perumus kebijakan dan pemangku kepentingan lainnya di negara-negara berkembang dengan persyaratan dan kebutuhan para donor atau investor REDD+, serta menciptakan dan/atau menguatkan lembaga-lembaga yang diperlukan untuk melaksanakan kebijakan dan mengelola dana REDD+.

Bab ini menyoroti tantangan-tantangan di atas dan membahas dampaknya bagi pelaksanaan REDD+. Bagian 7.2 merangkum cara paling umum untuk menghitung biaya REDD+ dan menyajikan perkiraan rentang biaya yang telah diajukan sehingga bisa mengurangi emisi secara signifikan yang terkait dengan hutan di negara-negara berkembang. Bagian 7.3 membahas berbagai pilihan yang ada untuk menggalang pendanaan REDD+ dalam jangka pendek dan panjang. Bagian 7.4 menjelaskan tantangan-tantangan yang dihadapi negara-negara REDD+ dalam pencairan dana serta sudut pandang negara-negara donor. Bab ini diakhiri dengan diskusi tentang berbagai pilihan kelembagaan dan kebijakan yang berbeda, yang dapat membantu mengatasi tantangan pendanaan saat ini maupun di masa depan.

\subsection{Biaya REDD+}

\subsubsection{Memperkirakan biaya REDD+}

Sebagian besar perkiraan biaya REDD+ menggunakan pendekatan biaya peluang (opportunity cost) (lihat antara lain Kindermann dkk. 2006; Blaser dan Robledo 2007; Kindermann dkk. 2008; Simula 2010). Para pakar di kalangan pemerintah dan konsultan telah mengusulkan berbagai variasi dalam pendekatan ini (misalnya, Republik Guyana 2008; UNDP dan Presiden Ekuador 2011). Biaya peluang adalah hilangnya pendapatan dari penggunaan lahan alternatif terbaik. Lahan hutan di berbagai lokasi yang berbeda memiliki produktivitas dan kandungan karbon yang berbeda, dan analisis semacam ini memperhitungkan biaya tambahan untuk perlindungan hutan. Mereka menyimpulkan seberapa banyak hutan yang dapat dilindungi pada tingkat harga karbon tertentu. Model-model ini tidak begitu saja mencerminkan insentif yang diperlukan oleh suatu negara untuk mencapai target pengurangan emisi tertentu (IWG-IFR 2009), juga bukan berarti mereka telah memperhitungkan konteks politik suatu pengambilan keputusan. Dalam kasus tertentu (misalnya, saat reformasi struktural berbiaya mahal harus dilaksanakan), biaya REDD+ bagi masyarakat mungkin jauh lebih tinggi 
daripada yang diperhitungkan, tetapi dalam situasi lain biayanya mungkin lebih rendah, misalnya saat REDD+ dapat dilaksanakan melalui penegakan hukum dan tindakan perintah-dan-pengendalian yang menguntungkan masyarakat (White dan Minang 2011). Dalam banyak kasus, kebijakan yang menghasilkan manfaat REDD+ juga akan mengejar manfaat lainnya kadang-kadang tujuan primer, seperti reformasi pertanian atau penguasaan lahan. Dalam kasus seperti ini, sulit untuk mendistribusikan biaya dan memilah-milahnya di antara berbagai tujuan yang saling melengkapi.

Pendekatan alternatifnya adalah memperkirakan biaya anggaran REDD+. Pendekatan ini melibatkan penilaian biaya pelaksanaan langkah-langkah dan kebijakan, dan reformasi kelembagaan yang diperlukan di suatu negara. Namun, pendekatan ini hanya menggeser masalah ke tingkat lain, yaitu mengungkapkan biaya dan manfaat kebijakan publik dengan cara yang bisa dibandingkan (Heinzerling dan Ackerman 2002). Untuk mencapai perbandingan seperti ini, setiap analisis biaya harus mengukur (secara kuantitatif) nilai suatu kebijakan tertentu bagi masyarakat yang menghasilkan barang publik (misalnya, infrastuktur yang kuat, tata kelola yang baik atau perlindungan lingkungan). Namun demikian sulit sekali untuk menangkap dan memberikan harga bagi ciri unik suatu hutan, termasuk mengukur nilai yang hilang saat kita kehilangan hutan tersebut (nilai tak terpulihkan) maupun nilai-nilainya yang bersifat nonmoneter, misalnya rekreasi, kenikmatan suasana dan keindahan (Ostrom dan Ostrom 1977).

Oleh karena itu, meskipun analisis biaya dapat menginformasikan kebijakan-kebijakan REDD+, ada banyak kekurangan yang signifikan. Asumsi-asumsi yang mendasarinya tidak bisa menangkap biaya dan manfaat sepenuhnya dari tindakan perlindungan hutan oleh suatu negara dan asumsi ini mungkin meremehkan atau melebih-lebihkan biaya yang sebenarnya, bergantung pada konteks kebijakannya. Dalam banyak kasus, terutama jika analisis biaya diusulkan oleh pemerintah nasional atau pemangku kepentingan lainnya, perkiraan biaya akan lebih dipengaruhi oleh hasil apa yang diinginkan daripada analisis rasional (lihat Kotak 7.1).

\subsubsection{Berbagai perkiraan biaya global}

The Eliasch Review memperkirakan biaya global REDD+ akan berjumlah sekitar AS \$17 sampai AS \$33 miliar per tahun, dengan asumsi emisi yang terkait hutan akan mengalami penurunan sebesar 50\% tahun 2020 (Eliasch 2008). Kindermann dkk. (2008) memperkirakan biayanya akan sekitar $€ 13$ dan $€ 21$ miliar per tahun. ${ }^{1}$ Sementara Komisi Eropa/European Commission menetapkan harga tahunan sebesar $€ 15-25$ miliar (EC 2008; ONFI 2008). 


\title{
Kotak 7.1 “Berapa besar biaya REDD+?" adalah pertanyaan yang (hampir) tidak ada artinya
}

\author{
Arild Angelsen
}

Berapa besar biaya REDD+? Setidaknya sejak Stern Review yang berpengaruh besar itu diterbitkan tahun 2006, banyak yang berpendapat bahwa REDD+ merupakan salah satu pilihan termurah yang tersedia untuk mengurangi perubahan iklim. Sementara sebagian orang melihat mekanisme REDD+ sebagai upaya mahal dengan hasil yang tak terduga, baik untuk iklim maupun bagi masyarakat hutan. Jadi siapa yang benar?

Karena itu, menanyakan "Berapa besar biaya REDD+?" sama tepatnya dengan menanyakan "Berapa besar biaya sebuah mobil?". Jawabannya bergantung pada jenis mobil, berapa banyak mobilnya, apakah biaya produksi, pembelian dan biaya operasional mobilnya ikut dihitung atau tidak, dan seterusnya. Kebanyakan perkiraan biaya REDD+ - termasuk yang tercantum dalam Stern Review - berfokus pada biaya peluang yang mengacu pada keuntungan yang hilang karena adanya penggunaan lahan alternatif terbaik, yaitu keuntungan yang hilang karena tidak melestarikan lahan hutan.

Sebuah negara yang melaksanakan REDD+ juga akan menghadapi biaya transaksi dan pelaksanaan, misalnya biaya menyiapkan sistem REDD+ dan melaksanakan kebijakan yang diperlukan untuk mencapai REDD+. Jumlah biaya peluang keseluruhan, biaya pelaksanaan (kecuali yang langsung memberi kompensasi biaya peluang) dan biaya transaksi (kepada pemerintah dan pengguna hutan) adalah perkiraan total biaya suatu negara yang berusaha menghindari deforestasi dan degradasi.

Namun pemerintah negara-negara REDD+ mungkin sama tertariknya pada variasi pertanyaan di atas tadi: apa saja biaya anggaran REDD+? Biaya peluang bisa merupakan indikator yang buruk untuk anggaran, sebab anggaran bergantung kepada kebijakan yang dipilih dan keefektifannya. Hanya dalam satu kasus khusus saja biaya anggaran akan identik dengan biaya peluang, yaitu dalam sistem hipotetis 'sempurna' untuk Pembayaran Jasa Lingkungan (PES). Artinya, biaya transaksi nol, yang menjadi sasaran hanya para pengguna hutan yang berencana menggunakan gergaji mesin mereka di tahun-tahun yang akan datang, dan mensyaratkan adanya informasi lengkap tentang biaya peluang para pengguna ini. Asumsi-asumsi ini tentu saja tidak realistis dan dalam praktiknya biaya sistem PES akan jauh lebih tinggi, bahkan meskipun kepemilikan lahan dan kondisi-kondisi lain yang sudah ada sebelumnya memungkinkannya.

Ada banyak kebijakan REDD+ lainnya yang tersedia. Pemerintah dapat menghentikan pemberian izin untuk konversi hutan, membangun kawasan 


\section{Kotak 7.1 Lanjutan}

hutan lindung, dan meningkatkan penegakan hukum dan peraturan kehutanan, tanpa ada kompensasi apapun kepada pengguna hutan saat ini atau calon pengguna. Biaya anggaran mungkin akan lebih rendah daripada biaya peluang. Atau pemerintah bisa mengurangi tingkat keuntungan dari perambahan pertanian dengan menghapus subsidi pemerintah sehingga menyelamatkan uang dalam anggaran pemerintah. Kebijakan-kebijakan pertanian lainnya, seperti intensifikasi pertanian, dapat membutuhkan biaya yang melebihi biaya peluang, tetapi mereka dapat mencapai tujuan tambahan, seperti meningkatnya produksi dan ketahanan pangan.

Jadi, pertanyaan "Berapa besar biaya REDD+?" harus lebih tepat dan kontekstual sebelum bisa dijawab. Pertama, biaya ini akan bergantung pada biaya siapa yang kita maksud: masyarakat luas, pemerintah, pengguna hutan lokal, atau pedagang komoditas. Kedua, biaya akan tergantung pada campuran instrumen kebijakan yang dipilih untuk melaksanakan REDD+ dan keefektifan mereka. Ketiga, bergantung pada skala pengurangan emisi yang disyaratkan dan seberapa cepat keinginan untuk mencapainya.

Sejumlah penelitian tersebut memperkirakan total potensi pengurangan ekonomi akibat aktivitas REDD+, membuat asumsi tingkat harga tertentu per ton karbon dioksida dan biaya tertentu yang terkait dengan konversi penggunaan lahan. Namun, jumlah angka potensi pengurangan yang sebenarnya kemungkinan cenderung lebih kecil dari yang diperhitungkan karena berbagai kendala dalam menghasilkan pengurangan emisi melalui REDD+. Dengan demikian, perkiraan biaya global menggambarkan potensi maksimum kegiatan penggunaan hutan dan lahan lainnya untuk menghilangkan atau mempertahankan gas-gas rumah kaca di titik harga tertentu daripada potensi realistis pengurangan emisi dalam jangka pendek hingga menengah (Lubowski 2008). Untuk menggambarkan pasokan pengurangan emisi dari REDD+, Tabel 7.1 menunjukkan perkiraan pasokan global pengurangan emisi akibat penurunan deforestasi di bawah berbagai skenario harga.

Di tingkat negara, biaya REDD+ bergantung pada kandungan karbon hutan dan pemicu deforestasi lokal. Misalnya, biaya peluang tertinggi untuk REDD+ di Indonesia terjadi saat konservasi hutan bersaing dengan produksi minyak sawit. Dalam kasus ini, biaya peluang berkisar dari AS \$0,49/ton $\mathrm{CO}_{2} \mathrm{e}$ untuk pertanian rakyat/skala kecil di Sumatera menjadi AS $\$ 19,6 /$ ton $\mathrm{CO}_{2} \mathrm{e}$ untuk konversi lahan hutan terdegradasi ke kelapa sawit (Olsen dan Bishop 2009). Sementara itu, Nepstad dkk. (2007) menghitung bahwa untuk menghilangkan deforestasi sepenuhnya di Amazon, Brasil akan menelan biaya AS $\$ 1,49 /$ ton $\mathrm{CO}_{2}$ e, tetapi mengurangi deforestasi sampai $94 \%$ dari 
Tabel 7.1 Pasokan global pengurangan emisi dari REDD+ ( $\mathrm{GtCO}_{2}$ e per tahun) (Meridian Institute 2009)

\begin{tabular}{|c|c|c|}
\hline & $\begin{array}{l}\text { Deforestasi yang } \\
\text { dihindari (RED) }\end{array}$ & REDD+ \\
\hline $\begin{array}{l}\text { Tidak ada } \\
\text { ketetapan harga }\end{array}$ & & 3,5-4,9 (Grieg-Gran 2008) \\
\hline AS $\$ 10 / \mathrm{tCO}_{2} \mathrm{e}$ & 1,8 (Murray dkk. 2009) & $\begin{array}{l}2,7 \text { (McKinsey and } \\
\text { Company 2009) }\left[3,6^{*}\right]\end{array}$ \\
\hline \multirow[t]{2}{*}{ AS $\$ 20 / \mathrm{tCO}_{2} \mathrm{e}$} & 2,5 (Murray dkk. 2009) & \multirow{2}{*}{$\begin{array}{l}4,3 \text { (McKinsey and } \\
\text { Company 2009) }\left[5,2^{*}\right]\end{array}$} \\
\hline & $\begin{array}{l}\text { 1,6-4,3 (Kindermann } \\
\text { dkk. 2008) }\end{array}$ & \\
\hline \multirow[t]{3}{*}{ AS $\$ 30 / \mathrm{tCO}_{2} \mathrm{e}$} & 2,8 (Kindermann dkk. 2008) & \multirow[t]{3}{*}{ 4,6 (Sohngen 2009) } \\
\hline & 2,8 (Sohngen 2009) & \\
\hline & 2,9 (Murray dkk. 2009) & \\
\hline \multirow{2}{*}{$\begin{array}{l}\text { AS } \$ 100 / \mathrm{tCO}_{2} \mathrm{e} \\
\text { atau potensial }\end{array}$} & 4,5 (Tavoni dkk. 2007) & 7,2 (Tavoni dkk. 2007) \\
\hline & $\begin{array}{l}\text { 3,1-4,7 (Kindermann } \\
\text { dkk. 2008) }\end{array}$ & $\begin{array}{l}\text { 7,8 (McKinsey and } \\
\text { Company 2009)* }\end{array}$ \\
\hline
\end{tabular}

* Termasuk pengurangan emisi dari lahan gambut

tingkat proyeksinya akan menelan biaya hanya setengah dari jumlah itu (AS $\$ 0,76 /$ ton $\left.\mathrm{CO}_{2} \mathrm{e}\right)$.

\subsection{Menggalang pendanaan REDD+}

\subsubsection{Sumber pendanaan REDD+ sekarang}

Saat ini terdapat beberapa sumber pendanaan REDD+ - publik, swasta, nasional dan internasional - serta mekanisme yang berbeda (misalnya, pajak, pasar karbon dan lelang tunjangan). Pendanaan sektor publik di sini didefinisikan sebagai pendapatan yang dihasilkan melalui mekanisme yang dikendalikan oleh sebuah badan publik, sementara pendanaan sektor swasta tidak masuk ke tangan sektor publik. Dengan menggunakan definisi ini, muncullah empat kategori pendanaan REDD+ (lihat Gambar 7.1).

Pendanaan internasional dari sektor publik sekarang ini bekisar AS $\$ 3$ miliar per tahun, termasuk yang dijanjikan dalam konteks UNFCCC serta pendanaan melalui saluran lain, seperti Global Environment Facility (GEF) dan Convention on Biological Diversity (Parker dkk. 2012). Dana ini dikucurkan terutama melalui jalur bilateral dan multilateral sebagai hibah dan pinjaman, dengan beberapa penggunaan terbatas untuk pembayaran berbasiskan-kinerja. 


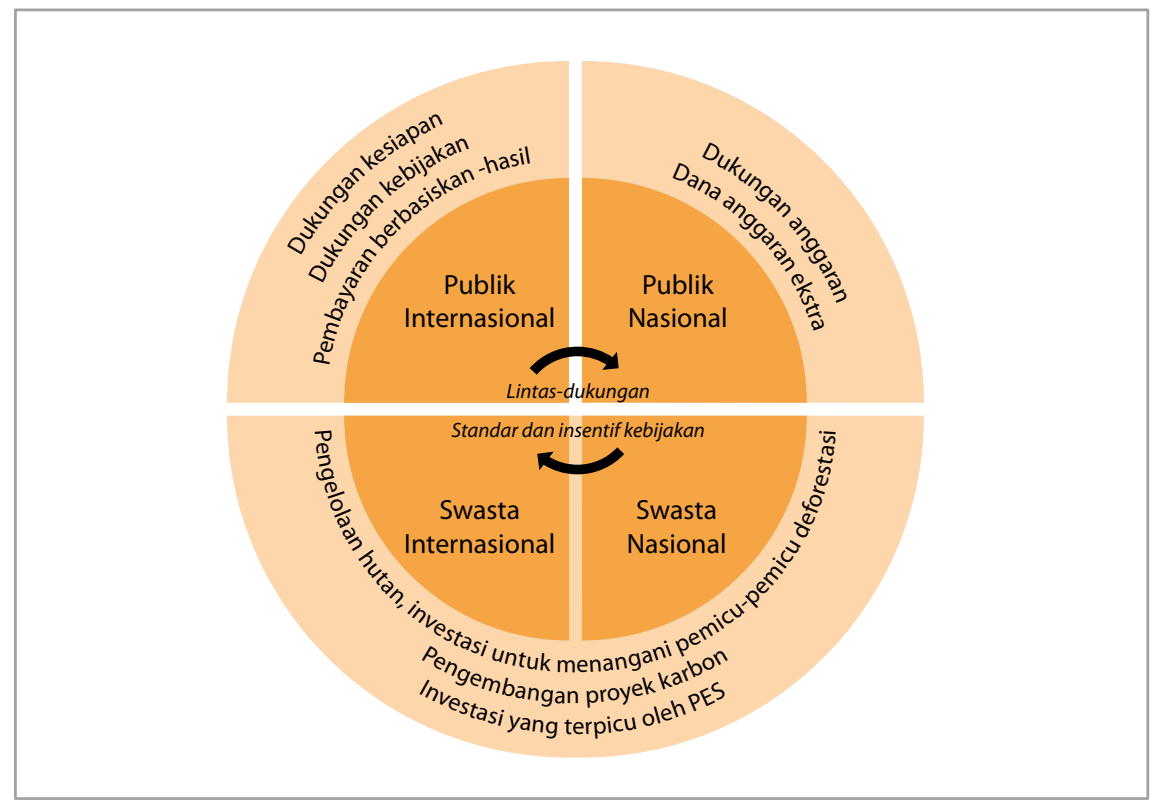

Gambar 7.1 Sumber-sumber pendanaan REDD+

Program-program dan proyek-proyek bilateral antarnegara saat ini mendanai dua pertiga dari seluruh kegiatan REDD+ yang mendapat dukungan internasional, sedangkan sumberdaya multilateral mendukung sisanya (Simula 2010; PWC 2011). Termasuk di dalamnya adalah program-progam kesiapan dan pada tingkat lebih rendah, dukungan kebijakan dan percontohan pembiayaan berbasiskan-hasil. Di tingkat negara, Norwegia adalah donor REDD+ terbesar. Pada COP13 tahun 2007, Pemerintah Norwegia meluncurkan International Climate and Forest Initiative dan menjanjikan NOK 15 miliar (AS \$2,6 miliar) selama 5 tahun. Sejak itu, Norwegia telah menandatangani perjanjian bilateral dengan Brasil, Guyana, Indonesia, Meksiko dan Tanzania, dan memberikan kontribusi kepada berbagai dana multilateral. Dalam perjanjian bilateralnya untuk REDD+ dengan Brasil, Guyana dan Indonesia, Norwegia telah melakukan pendekatan 'pembayaran-berbasiskan-kinerja'. Donor utama lainnya termasuk Australia, Perancis, Komisi Eropa, Jerman, Jepang, Inggris dan Amerika Serikat. Sampai saat ini, donor-donor ini sebagian besar telah mendukung progam-program kesiapan, pengembangan kebijakan dan proyek-proyek percontohan. Sejauh ini, tidak ada negara lain yang telah memasuki perjanjian bilateral mengikuti logika pembayaran-berbasiskan-kinerja dari Norwegia.

Data pendanaan domestik atau nasional untuk REDD+ masih kurang karena negara-negara berkembang tidak konsisten dalam melaporkan alokasi dana untuk REDD+. Namun, jelas bahwa pendanaan dalam negeri cukup besar, khususnya dari negara dengan tingkat pendapatan ekonomi yang baru muncul dan ekonomi menengah yang andilnya melampaui kontribusi internasional 
untuk REDD+. Brasil melaporkan catatan tahunan rata-rata AS \$500 juta untuk pemantauan dan inventarisasi kerja, penegakan hukum dan reformasi penguasaan lahan, serta untuk rencana nasional dan lokal dalam mengurangi deforestasi. Meksiko mengeluarkan jumlah yang serupa (AS \$460 juta) per tahun untuk berbagai program termasuk program aforestasi ProArbol-nya, subsidi hijau, kegiatan-kegiatan percontohan dan sistem-sistem pengukuran. Indonesia mengklaim telah menghabiskan AS \$1,5 miliar untuk perlindungan hutan dan rehabilitasi lahan kritis, selain kegiatan-kegiatan perlindungan hutan lainnya (PWC 2011). Sementara itu China telah menggunakan sekitar AS \$7 miliar setiap tahunnya untuk kegiatan aforestasi guna melindungi daerah aliran sungai dan 'mekanisme-kompensasi-lingkungan' lainnya di bawah progam-progam yang dimediasi oleh pemerintah, termasuk program 'Grain for Green' (Parker dkk. 2012).

Diharapkan sektor swasta akan menyumbangkan porsi yang cukup besar untuk pendanaan REDD+ di masa depan. Namun, kebijakan lingkungan saat ini hanya menyediakan insentif terbatas untuk sektor swasta melakukan investasi dalam REDD+. Beberapa investasi sedang dipicu oleh berbagai kombinasi faktor, termasuk tanggung jawab sosial perusahaan dan prakepatuhan, menjadi pasar karbon sukarela (sekitar AS \$140 juta pada tahun 2010) (Diaz dkk. 2011). Mekanisme pasar tidak langsung seperti coklat, kopi, kayu, minyak kelapa sawit dan kedelai bersertifikat yang bertujuan untuk memerangi pemicu-pemicu deforestasi juga menyediakan sumber pendanaan REDD+ dari sektor swasta, dalam skala yang bisa ditingkatkan. Saat ini, mekanisme ini menghasilkan lebih dari AS \$1 miliar per tahun untuk pelestarian hutan di negara-negara berkembang.

\subsubsection{Skala pendanaan REDD+ masa depan}

Perkiraan skala yang dibutuhkan untuk pendanaan REDD + masa depan sangat bervariasi dan sangat bergantung pada sumber-sumber keuangan di dalamnya. Dalam kategori keuangan sektor publik dan swasta yang diuraikan di atas, pendanaan REDD+ dapat dibagi ke dalam empat kelompok utama: investasi swasta langsung dan tidak langsung, dan pendanaan publik yang terkait-pasar serta pendanaan publik nonpasar (lihat Gambar 7.2). Diperlukan berbagai metode dan alat untuk meningkatkan pembiayaan dari berbagai sumber.

Mekanisme pasar langsung merupakan sumber pendanaan sektor swasta yang menghasilkan pendapatan langsung untuk pengurangan emisi dan mencakup kesukarelaan dan kepatuhan pasar karbon. Mekanisme ini dapat menghasilkan pendanaan melalui peraturan dan meningkatkan permintaan untuk kredit karbon hutan dan jasa langsung lainnya dari hutan (misalnya, penyeimbang keanekaragaman hayati). Jumlah pembiayaan yang tersedia akan ditentukan oleh jumlah negara yang dapat berpartisipasi dalam mekanisme ini, ambisi target, persyaratan untuk menerima kredit karbon dan faktor lain yang menghasilkan permintaan berbagai jasa ekosistem yang berbasis hutan. 


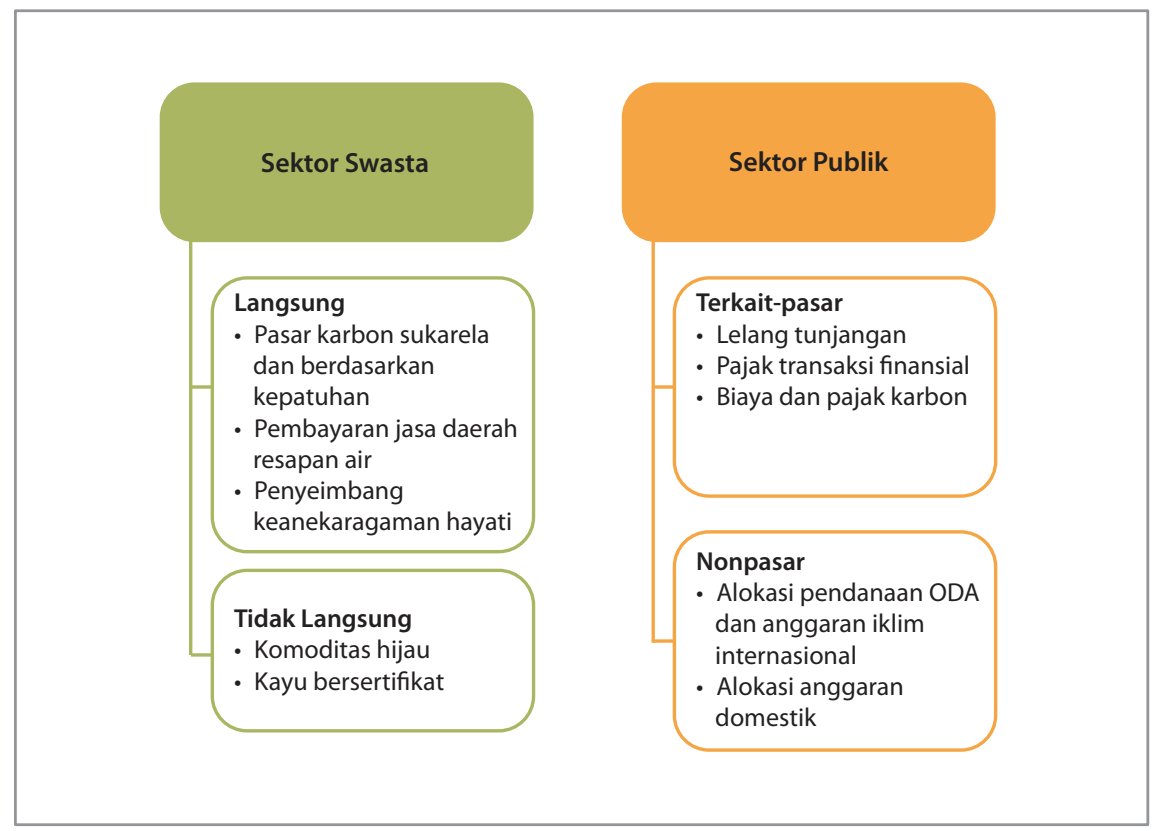

\section{Gambar 7.2 Pendanaan sektor publik dan sektor swasta untuk REDD+}

Diadaptasi dari Parker dkk. (2009a) dan Parker dkk. (2012)

Mekanisme pasar tidak langsung menggalang dana dengan cara mengaitkan konservasi hutan dengan pasar tradisional seperti kopi, kedelai dan daging sapi. Dengan menurunkan 'jejak hutan' dari pasar-pasar yang terkait, pendanaan dapat diberikan untuk mengurangi deforestasi, tetapi tidak harus dalam bentuk pertukaran dengan pengurangan emisi (misalnya, pasar kopi berkelanjutan atau sejumlah kesepakatan mengenai komoditas). Mekanisme pasar tidak langsung dapat ditingkatkan dengan menerapkan peraturan di sisi permintaan untuk komoditas hijau. Misalnya, undang-undang Uni Eropa (UE) atau China (dua importir global terbesar untuk kedelai) yang membutuhkan produksi kedelai berkelanjutan akan menciptakan sinyal kuat untuk kedelai dengan 'deforestasi nol'.

Baik mekanisme terkait-pasar maupun nonpasar merupakan sektor pendanaan publik; meskipun pendanaan akan dihasilkan dari berbagai badan publik dan swasta (misalnya, melalui pajak atau biaya lainnya), pendapatan dikumpulkan dan disalurkan oleh sebuah lembaga sektor publik. Mekanisme terkait-pasar menghasilkan pendanaan dari pasar yang tidak berkaitan dengan hutan (misalnya, lelang tunjangan emisi atau pajak transaksi pendanaan). Skala pendanaan melalui mekanisme ini akan bergantung pada koordinasi politik dari sejumlah agenda yang saling bersaingan. Misalnya, pendapatan dari pajak transaksi pendanaan saat ini sedang diusahakan berjalan di bawah berbagai agenda yang luhur, termasuk pengentasan kemiskinan, konservasi 
keanekaragaman hayati dan stabilisasi ekonomi daerah. Koordinasi politik antara agenda-agenda ini dapat membantu memastikan agar secara kolektif mereka mendapat keuntungan dari sumber-sumber pendapatan yang dimaksud.

Akhirnya, kategori mekanisme nonpasar mencakup bentuk pendanaan publik 'tradisional', seperti bantuan resmi untuk pembangunan dan pengeluaran domestik pemerintah yang dialokasikan melalui anggaran masyarakat. Karena mekanisme nonpasar murni dimotori oleh pemerintah, tingkat pendanaan yang dihasilkannya akan lebih merupakan pertanyaan sejauh mana kekuatan kemauan politik dan agenda nasional untuk konservasi hutan di dalam masing-masing pemerintahan. Bahkan di bawah peraturan internasional sekali pun (misalnya, Monterrey Consensus on Financing for Development), tidak ada jaminan bahwa komitmen akan ditaati.

Tabel 7.2 merangkum sejumlah mekanisme terpenting untuk menggalang pendanaan REDD+. Sebagian besar mekanisme ini dapat diterapkan secara nasional dan internasional. Skala pendanaan yang dapat diraih melalui mekanisme apapun akan bergantung pada sejauh mana REDD+, dan lebih umum lagi konservasi hutan, mempertahankan mandat yang secara politis mengikat baik di negara maju maupun negara berkembang. Selama jangka pendek dan menengah (hingga 2020), mekanisme sektor publik adalah sumber potensial terbesar untuk pendanaan REDD+, dengan tambahan AS \$9 miliar per tahun yang berasal dari mekanisme nonpasar dan potensi dana sebesar AS \$7 miliar dari mekanisme terkait pasar. Bagian terbesar kemungkinan besar berasal dari pemerintah nasional di negara-negara berkembang. Sementara sejumlah mekanisme yang ada berpotensi untuk menghasilkan pendanaan yang cukup besar bagi REDD+, pendanaan dari mekanisme terkait pasar tetap sulit dipahami. Kecuali lelang tunjangan, mekanisme ini cenderung tidak memungkinkan untuk dilakukan secara politis sebab ada di luar mandat pendukung REDD+.

Sektor swasta dapat menjadi sumber penting pendanaan REDD+, dengan potensi memberikan tambahan AS \$13 miliar per tahun pada tahun 2020 . Pasar karbon telah lama diusulkan sebagai strategi untuk menggalang dana swasta untuk mencapai tujuan REDD+. Berdasarkan perkiraan yang diambil dari Tabel 7.1 untuk potensi pengurangan (dengan tingkat harga karbon AS \$25/ $\mathrm{tCO}_{2}$ ), pasar karbon dapat memberikan AS \$7,5 miliar pada 2020. Angelsen dkk. (2012) menemukan bahwa, jika kredit REDD+ diizinkan untuk diperdagangkan di pasar karbon global, emisi karena deforestasi akan berkurang sebesar 22\%-62\% dibandingkan dengan tingkat bisnis-seperti-biasa (yaitu 42\%-71\% dibandingkan tingkat yang dicapai tahun 2005), bergantung pada skenario. Namun, pembentukan pasar karbon yang efektif bergantung pada penerimaan penyeimbang REDD+ di pasar karbon global. 
Tabel 7.2 Tingkat pembiayaan REDD+ sekarang dan masa depan dalam mekanisme sektor publik dan swasta (dalam AS\$ miliar tahun)

\begin{tabular}{|c|c|c|c|c|}
\hline Sektor & Pasar & Skala & $\begin{array}{c}\text { Sekarang } \\
2010\end{array}$ & $\begin{array}{c}\text { Masa } \\
\text { Depan } \\
2020\end{array}$ \\
\hline \multirow[t]{3}{*}{ Swasta } & \multirow[t]{2}{*}{ Langsung } & Pasar yang patuh & - & $7,5^{\mathrm{a}}$ \\
\hline & & Pasar sukarela & $0,14^{\mathrm{b}}$ & 0,6 \\
\hline & $\begin{array}{l}\text { Tidak } \\
\text { langsung }\end{array}$ & Komoditas hijau & $1^{\mathrm{c}}$ & $5^{d}$ \\
\hline \multicolumn{3}{|c|}{ Total Swasta } & 1,1 & 13,1 \\
\hline \multirow[t]{7}{*}{ Publik } & \multirow{4}{*}{$\begin{array}{l}\text { Pasar terkait } \\
\text { dan lainnya }\end{array}$} & Lelang tunjangan & 0,04 & $1,5^{\mathrm{e}}$ \\
\hline & & $\begin{array}{l}\text { Pajak atau iuran } \\
\text { kelautan/maritim }\end{array}$ & - & 1,7 \\
\hline & & Pajak transaksi keuangan & - & $3,8^{f}$ \\
\hline & & luran premi asuransi & - & $1,7^{9}$ \\
\hline & \multirow[t]{3}{*}{ Non-pasar } & $\begin{array}{l}\text { Pengeluaran domestik } \\
\text { pemerintah }\end{array}$ & $10^{\mathrm{h}}$ & $13^{i}$ \\
\hline & & $\begin{array}{l}\text { Bantuan resmi untuk } \\
\text { pembangunan }\end{array}$ & 4,4 & $10^{\mathrm{g}}$ \\
\hline & & $\begin{array}{l}\text { Penghapusan hutang } \\
\text { untuk konservasi } \\
\text { (debt for nature swaps) }\end{array}$ & 0,02 & $0,36^{k}$ \\
\hline \multicolumn{3}{|c|}{ Total publik } & 14,5 & 32,1 \\
\hline
\end{tabular}

Catatan: Tabel diadaptasi dari Parker dkk. (2009a) dan Parker dkk.(2012) a) berasumsi munculnya sebuah pasar karbon hutan dan pasokan global $3 \mathrm{GtCO}_{2}$ pada $\mathrm{AS} \$ 25 / \mathrm{tCO}_{2} ;$ b) Diaz dkk. (2011); c) AS $\$ 300$ miliar dari kayu bersertifikat dan AS $\$ 700$ miliar setara dengan $30 \%$ dari semua komoditas hijau; d) didasarkan pada pertumbuhan berkelanjutan sebesar $15 \%-20 \%$ di pasarpasar negara berkembang; e) $40 \%$ potensi penerimaan pendapatan dari lelang untuk kegiatankegiatan iklim, 50\% di negara-negara berkembang, 28\% berbasis-ekosistem; f) asumsi terendah: 5\% dari perpajakan di Uni Eropa atas transaksi finansial diberikan kepada REDD+; g) didasarkan pada pembangunan berkelanjutan dalam anggaran bantuan sebesar 3\% per tahun, dari jumlah ini $5 \%$ untuk perlindungan hutan; $h$ ) termasuk berbagai janji/komitmen baru di bawah REDD+ Partnership Voluntary REDD+ Database, lihat http://reddplusdatabase.org/; i) berdasarkan proyeksi peningkatan pendanaan kawasan-kawasan yang dilindungi; j) dari Organisation for Economic Cooperation and Development Assistance Committee database www.oecd.org/dac/stats/ rioconventions; k) didasarkan pada pertumbuhan tahunan berkelanjutan sebesar $30 \%$ per tahun.

Meskipun demikian, saat ini tidak ada pasar karbon global, ataupun sistem global yang muncul. Karena anggota parlemen AS (perumus hukum) tidak merenungkan undang-undang iklim dan Uni Eropa hanya akan mempertimbangkan untuk mengaitkan sistem perdagangan emisi REDD+ setelah tahun 2020, dalam jangka pendek pasar karbon tidak 
banyak menjanjikan. Selain itu, mengaitkan REDD+ dengan pasar karbon memerlukan evaluasi yang cermat, mengandalkan kerangka kerja kredit REDD+ yang telah teruji disertai pengamanan dan tata kelola pasokan dan permintaan. Tidak adanya instrumen pendanaan spesifik REDD+ membuat strategi-strategi untuk mendapatkan stabilitas pendanaan REDD+ jangka panjang beralih ke insentif penanaman modal di tingkat nasional (dan daerah).

Sumber utama pendanaan lainnya dari sektor swasta untuk REDD+ akan datang melalui mekanisme pasar tidak langsung. Namun keterbatasan data menyulitkan usaha untuk memperkirakan skala pendanaan yang dapat dihasilkan melalui komoditas hijau. Perkiraan konservatif untuk pertumbuhan komoditas bersertifikat melalui berbagai inisiatif seperti kesepakatan produksi yang bertanggung jawab untuk kedelai, kelapa sawit, dan gula menunjukkan bahwa mekanisme pasar tidak langsung bisa menghasilkan tambahan dana AS \$5 miliar per tahun pada tahun 2020.

\subsection{Pembelanjaan dana REDD+}

\subsubsection{Alokasi pendanaan}

Penggalangan dana REDD+ berkaitan erat dengan alokasi dan pencairannya. Alokasi mengacu pada distribusi pendanaan REDD+ ke negara-negara dan juga untuk kebijakan-kebijakan, strategi dan program-program yang relevan dalam suatu negara. Beberapa mekanisme mobilisasi sumberdaya juga mencakup pilihan untuk alokasi pendanaan tertentu. Pengalaman Clean Development Mechanism (CDM) menunjukkan bahwa pasar karbon menyalurkan mayoritas pendanaan kepada negara-negara yang iklim investasinya baik, ditandai oleh pemerintahan dan sistem peradilan yang berfungsi baik, dan memiliki emisi tinggi. Investasi melalui mekanisme pasar karbon langsung kepada proyek juga ditentukan oleh apakah suatu kawasan memiliki tingkat deforestasi yang tinggi, hutan dengan kandungan karbon tinggi, dan pemicu deforestasi lokal yang bisa diidentifikasi dengan jelas, di mana kebocoran dan kelanggengan bisa dipantau dan dikelola dalam konteks proyek. Pengalaman dari sistem-sistem nasional yang mengandalkan pembayaran jasa ekosistem juga menunjukkan bahwa sertifikat dan kepemilikan tanah yang jelas adalah syarat tambahan yang mendorong investasi menuju program penanaman hutan atau konservasi.

Donor-donor bilateral cenderung melakukan pembayaran kepada negara-negara mitra yang sudah dipilih sebelumnya. Pendanaan REDD+ yang mengalir ke anggaran atau dana yang dikelola publik kemudian harus dialokasikan ke sektor-sektor yang bekerja untuk melawan kehilangan karbon hutan. Alokasi semacam ini umumnya mengikuti kegiatan nasional yang diprioritaskan, yang mencerminkan potensi dan biaya pengurangan emisi, penerimaan politik dan komitmen, dan masukan dari para pemangku 
kepentingan. Anggaran dapat menciptakan lingkungan yang memberdayakan, seperti pelaksanaan perencanaan penggunaan lahan terpadu, melakukan klarifikasi sertifikat lahan dan hak milik, menguatkan kelembagaan dan membangun kapasitas. Kegiatan-kegiatan ini melayani beberapa tujuan, merupakan upaya untuk jangka waktu lama dan lebih bersifat menangani akar pemicu deforestasi ketimbang pemicu langsungnya. Sementara sumber-sumber ODA mungkin mendukung proses-proses ini, pendanaan internasional yang dikhususkan untuk mengatasi iklim mungkin akan tertarik pada tindakan yang lebih langsung untuk melawan pemicu-pemicu deforestasi. Tindakan ini bisa mencakup investasi di bidang pertanian untuk meningkatkan produktivitas, membiayai solusi infrastruktur alternatif, dan menciptakan sumber pendapatan alternatif.

Saat ini, porsi terbesar pendanaan REDD+ diberikan kepada Brasil, Republik Demokratik Kongo dan Indonesia (REDD+ Partnership 2011). Negara-negara ini mewakili bagian penting dari tiga kawasan hutan tropis terpenting (hutan tropis di Amazon, Kongo dan Asia Tenggara) yang tingkat kontribusi emisinya lebih dari setengah emisi global yang terkait dengan hutan. Alokasi pendanaan ke negara-negara ini mencerminkan potensi pengurangan emisi, meskipun tidak selalu mencerminkan kesiapan yang lebih mantap dibandingkan negara-negara yang lebih kecil dan lebih terlibat. Sebaliknya, keputusan Norwegia untuk menjalin strategi kemitraan dengan Guyana, menunjukkan penghargaan pada komitmen politik suatu bangsa berhutan kecil dengan emisi rendah.

\subsubsection{Pencairan dana REDD+}

Pencairan dana REDD+ menggunakan dana internasional dan nasional ${ }^{2}$, program-program bilateral dan insentif langsung bagi sektor swasta untuk menyalurkan pendanaan REDD+ kepada negara-negara dan di dalam suatu negara kepada penerima manfaat akhir. Dana internasional dan regional dikelola oleh organisasi-organisasi pendanaan multilateral, seperti Fasilitas Kemitraan Karbon Hutan/Forest Carbon Partnership Facility (FCPF), program REDD+ PBB/UN REDD+ Programme, dan Congo Basin Fund. Mengingat penyaluran pendanaan REDD+ untuk pelaku-pelaku nasional merupakan proses yang panjang, maka alokasi pendanaan untuk program internasional memiliki daya tarik besar bagi donor, tapi bisa ada penundaan yang cukup lama sebelum dana tersedia dan siap digunakan. Dalam evaluasi FCPF, $67 \%$ dari para pemangku kepentingan yang diwawancarai tidak setuju dengan pernyataan bahwa pendanaan disalurkan pada waktu yang tepat (NORDECO 2011).

2 Sebagai contoh, lihat proposal United Nations Development Programme untuk menyusun National Climate Funds (UNDP 2011). 
Menyalurkan dana melalui lembaga bilateral (misalnya, Agence française du Développement, Kreditanstalt für Wiederaufbau dan United States Agency for International Development) mungkin kurang strategis dibandingkan mendukung program-program khusus REDD+, namun bisa lebih cepat, khususnya ketika pendanaan disalurkan melalui program yang ada, tatanan kelembagaan dan mekanisme-mekanisme penilaian. Kemitraan Norwegia dengan Indonesia menunjukkan bahwa tata kelola inovatif dan mekanisme pencairan dana membutuhkan waktu lama, mungkin lebih lama dari perkiraan. Bahkan ketika negara-negara mengelola dana melalui lembaga-lembaga lokal yang profesional dan terbukti andal, seperti Amazon Fund, REDD+ yang masih baru dan kebutuhannya akan pelaku-pelaku dan standar ukuran kinerja baru kemungkinan akan menyebabkan penundaan dan menimbulkan frustrasi karena harapan yang tidak terpenuhi (meskipun frustasi mungkin akan berkurang ketika pelaku-pelakunya terbiasa dengan siklus pencairan yang lambat dari program-program lingkungan yang sudah ada seperti GEF).

Rintangan lain dalam aliran pendanaan disebabkan oleh ketidakefisienan organisasi-organisasi perantara, kurangnya daya serap dan tahapan 'penyakit yang terkait dengan pertumbuhan' secara alami dalam periode pembelajaran (The Prince's Rainforest Project 2011). Pertimbangan tingkat dukungan politik dan pemangku kepentingan dalam mencapai kesuksesan pelaksanaan REDD+, waktu yang diperlukan untuk konsultasi dan membangun konsensus sering diremehkan. Selain itu karena panjangnya rantai birokrasi dan kurangnya program $\mathrm{REDD}+$ yang siap menerima investasi, penundaan-penundaan di atas menunjukkan bahwa pencairan pendanaan internasional REDD+ tertinggal jauh dari yang dijanjikan oleh REDD+.

Selain itu, ada bukti jelas bahwa pelajaran yang didapat dari upaya meningkatkan keefektifan bantuan pembangunan tidak teralihkan ke pendanaan iklim umumnya dan khususnya pendanaan REDD+. Pada saat yang sama, mekanisme pendanaan berbasis proyek dan sifat pendanaan REDD+ yang menonjolkan apa yang penting berarti negara-negara harus menetapkan aturan tata kelola khusus dan bukannya menggunakan sistem nasional yang sudah ada. Singkatnya, jelas terbukti bahwa negara penerima maupun donor akan mendapat manfaat dari pengembangan strategi pendanaan REDD+, koordinasi yang lebih erat, penguatan kelembagaan dan peningkatan kapasitas. Ada kebutuhan khusus untuk menanggapi keadaan nasional serta memenuhi persyaratan kontributor luar supaya pendanaan REDD+ digunakan secara transparan dan bertanggung jawab.

\subsubsection{Peran lembaga-lembaga nasional}

Keberhasilan REDD+ bergantung pada kebijakan nasional dan lembaga-lembaga yang dapat membuahkan reduksi emisi REDD+ dalam skala besar dan dalam cara yang efektif, efisien dan setara. Selain itu juga 
dibutuhkan saluran yang efektif untuk pencairan dana dan daya serap, keduanya didukung oleh aturan-aturan, proses-proses dan perlindungan yang transparan dan sederhana serta memenuhi kebutuhan dan skala lokal secara tepat namun fleksibel (The Prince's Rainforest Project 2011).

Mekanisme pencairan nasional dapat dikaitkan dengan reformasi tata kelola secara umum, langkah-langkah sektor dan program-program insentif fiskal langsung. Dalam kasus reformasi tata kelola, sebagian besar pendanaan akan digunakan untuk mendukung sektor publik dengan menambahkan berbagai kapasitas dan sumberdaya. Langkah-langkah yang dilakukan oleh tiap sektor berusaha untuk menangani pemicu-pemicu kehilangan karbon hutan dan memasukkan penghapusan penyelewengan insentif dan pengenalan perencanaan dan pengamanan. Mekanisme nasional juga dapat menetapkan insentif fiskal langsung, di mana kelompok sasaran dibayar atas upayanya melakukan kegiatan tertentu (misalnya, penanaman pohon, pemantauan dan konservasi) atau menghentikan berbagai tindakan tertentu (misalnya, konversi lahan dan penebangan hutan).

Dalam jangka pendek, perantara internasional atau bilateral akan terus berperan penting dalam menyalurkan dana kesiapan. Namun, pendanaan REDD+ jangka panjang akan perlu dialokasikan dan disalurkan oleh lembaga-lembaga nasional. Dukungan pendanaan internasional memang dapat membantu mendorong perubahan kebijakan, namun penting untuk dicamkan bahwa REDD+ adalah strategi yang perlu diarahkan oleh negara yang bersangkutan, dengan mempertimbangkan kebutuhan dan prioritas nasional. Lembaga nasional adalah agen-agen penting dalam menggalang dan menyalurkan pendanaan dan harus patuh pada standar-standar kepercayaan di bidang keuangan yang diakui secara internasional. Amazon Fund di Brasil adalah contoh dari dana nasional yang melakukan berbagai peran keuangan dan teknis, yang dalam kasus-kasus lain mungkin penanganannya akan diserahkan saja kepada lembaga-lembaga internasional. Negara-negara dengan kelembagaan yang lebih lemah akan memerlukan waktu lebih lama untuk mengurangi kebergantungan mereka pada perantara internasional, seperti Bank Dunia dan PBB, atau program-program bantuan bilateral, untuk mengelola dan mengalokasikan pendanaan REDD+ (lihat Kotak 7.2).

\subsection{Kesimpulan: Mengaitkan pendanaan REDD+ dengan berbagai kebijakan dan program}

Pada tahun 2009, The Copenhagen Accord membuat negara-negara maju berkomitmen memberikan dana total AS \$3,5 miliar pendanaan awal-cepat untuk dicairkan selama fase kesiapan REDD+ tahun 2010-2012 (lihat Tabel 7.3 untuk tahap pelaksanaan dan pendanaan REDD+). Namun, pada akhir tahun 2011 (ketika janji tersebut telah mencapai AS \$4,17 miliar), hanya AS \$446 juta yang telah dialokasikan dan disetujui untuk negara-negara tertentu dan dana tertentu (Nakhooda dkk. 2011). Sebagian besar dananya 


\section{Kotak 7.2 Pendanaan REDD+ di Republik Demokratik Kongo}

André Aquino

Proses REDD+ di RDK dipimpin oleh Kementerian Lingkungan Hidup, Konservasi Alam dan Pariwisata melalui unit koordinasi REDD+ nasional yang berdedikasi, dengan para pakar nasional dan asing sebagai stafnya. Strategi nasional REDD+ masih dalam perumusan, sehingga biaya keseluruhan untuk mencapai REDD+ belum diketahui. Hampir seluruh pendanaan REDD+ berasal dari donor internasional dan sejauh ini baru ada sedikit keterlibatan sektor swasta, meskipun sebuah proyek wanatani dengan Mekanisme Pembangunan Bersih milik sebuah perusahaan swasta Kongo merupakan suatu perkecualian.

Kebutuhan kesiapan REDD+ diperkirakan mencapai AS \$23 juta dan didanai terutama oleh FCPF dan program UNREDD+. The Congo Basin Forest Fund akan menyediakan sekitar AS \$35 juta untuk serangkaian proyek percontohan REDD+ sedangkan Forest Investment Program yang dilaksanakan oleh Bank Dunia dan African Development Bank, akan menyediakan AS $\$ 60$ juta untuk mendanai investasi REDD+ di tiga kota besar di Kongo (Kinshasa, Kisangani dan Mbuji Mayi - Kananga). Pembayaran berbasiskan-hasil untuk reduksi emisi masih merupakan tujuan masa depan, tetapi negara ini telah menunjukkan minat dalam mengakses Dana Karbon dari FCPF melalui sebuah program subnasional REDD+.

Ada beberapa tantangan utama dalam pencairan dana. Koordinasi yang menyeluruh itu mahal biaya karena beragamnya sumber keuangan dan perbedaan standar kepercayaan serta prosedur pelaporan yang disyaratkan oleh donor yang berbeda. Ketidakpastian di tingkat global akan penerapan pendanaan REDD+ di tingkat nasional, termasuk bagaimana menangani keamanan, telah menyebabkan keterlambatan pencairan dana. Keterbatasan kapasitas nasional dalam pengelolaan standar kepercayaan merupakan tantangan lainnya. RDK mengatasi masalah keterlambatan pencairan dana ini dengan memastikan unit REDD+ nasional memegang mandat untuk mengatur koordinasi berbagai sumber pendanaan, menggunakan tenaga dari luar negeri untuk mengelola standar kepercayaan dan menambahkannya pada unit standar kepercayaan yang sekarang ada di bawah Kementerian Lingkungan Hidup serta meningkatkan kapasitas para staf yang memegang peranan penting.

Ke depan, RDK berencana untuk membentuk sebuah dana nasional independen untuk REDD+, tertanam dalam mekanisme alokasi dana partisipatif disertai kapasitas kelembagaan yang kuat untuk memberikan pendanaan nasional sejalan dengan strategi nasional yang mulai muncul. Donor internasional diharapkan untuk menyediakan sebagian besar dana yang diperlukan, dan pada awalnya hanya boleh digunakan untuk reformasi kebijakan, peningkatan kapasitas kelembagaan dan indikator-indikator proksi perantara. Seiring waktu, dengan meningkatnya kapasitas kelembagaan, dana tersebut bisa berkembang menjadi pembayaran reduksi emisi yang terverifikasi. Sejalan dengan dana ini, RDK mengijinkan transaksi karbon ditargetkan pada pasar yang berbeda (sukarela, sedang muncul dan yang diregulasi), dalam sebuah kerangka kelembagaan nasional untuk mengatur transaksi karbon, termasuk pembentukan pencatatan nasional yang transparan. 
masih ditahan dalam bentuk dana perwalian internasional, anggaran nasional dan dana negara penerima, dan kelihatannya tidak mungkin disalurkan di akhir tahun 2012. Jadi, sementara janji internasional tetap jauh lebih rendah dari perkiraan biaya, ada masalah besar dalam menyalurkan pendanaan yang sudah dijanjikan.

Biaya keseluruhan untuk mengurangi emisi karena deforestasi bergantung pada jenis pengeluaran yang dipertimbangkan, dan jenis serta keefektifan kombinasi kebijakan yang dipilih. Sebagian besar negara - maju dan berkembang - kurang memiliki strategi konkret bagaimana menerapkan REDD+. Oleh karena itu sulit untuk menentukan kebutuhan keuangan

Tabel 7.3 Ringkasan kebutuhan-kebutuhan REDD+ (diadaptasi dari Meridian Institute 2009)

\begin{tabular}{|c|c|c|c|}
\hline & \multirow[b]{2}{*}{$\begin{array}{l}\text { Biaya Persiapan REDD+ } \\
\text { Tahap 1: } \\
\text { Kesiapan dan biaya } \\
\text { awal dan peningkatan } \\
\text { kapasitas yang sedang } \\
\text { berlangsung dan biaya } \\
\text { penguatan lembaga- } \\
\text { lembaga }\end{array}$} & \multicolumn{2}{|c|}{ Biaya Pelaksanaan REDD+ } \\
\hline & & $\begin{array}{l}\text { Tahap 2: } \\
\text { Langkah-langkah } \\
\text { dan kebijakan }\end{array}$ & $\begin{array}{l}\text { Tahap 3: } \\
\text { Pembayaran } \\
\text { berbasiskan-hasil }\end{array}$ \\
\hline Tujuan & $\begin{array}{l}\text { Memampukan } \\
\text { partisipasi dalam } \\
\text { REDD+, menilai } \\
\text { berbagai pilihan } \\
\text { kebijakan, membentuk } \\
\text { strategi dan konsensus } \\
\text { Membentuk } \\
\text { dan memelihara } \\
\text { kemampuan untuk } \\
\text { melaksanakan dan } \\
\text { memantau aktivitas } \\
\text { REDD+ dengan sukses }\end{array}$ & $\begin{array}{l}\text { Menciptakan } \\
\text { lingkungan yang } \\
\text { memberdayakan, } \\
\text { meningkatkan } \\
\text { tata kelola dan } \\
\text { pengelolaan } \\
\text { hutan, } \\
\text { menangani } \\
\text { pemicu-pemicu } \\
\text { deforestasi } \\
\text { melalui investasi }\end{array}$ & $\begin{array}{l}\text { Memberi } \\
\text { kompensasi atas } \\
\text { reduksi emisi }\end{array}$ \\
\hline $\begin{array}{l}\text { Reduksi } \\
\text { Emisi }\end{array}$ & $\begin{array}{l}\text { Efek langsung emisi } \\
\text { karena penggunaan } \\
\text { lahan tidak ada atau } \\
\text { sedikit }\end{array}$ & $\begin{array}{l}\text { Efek emisi lebih } \\
\text { tidak langsung } \\
\text { terasa atau } \\
\text { ada sejumlah } \\
\text { penundaan }\end{array}$ & $\begin{array}{l}\text { Harus ada mata } \\
\text { rantai jelas yang } \\
\text { mengaitkan ke } \\
\text { reduksi emisi }\end{array}$ \\
\hline \multirow[t]{2}{*}{$\begin{array}{l}\text { Kebutuhan- } \\
\text { kebutuhan } \\
\text { Pendanaan }\end{array}$} & $\begin{array}{l}\text { Dibutuhkan pendanaan } \\
\text { awal kemungkinan } \\
\text { besar berbasis nonpasar }\end{array}$ & $\begin{array}{l}\text { Akan digunakan } \\
\text { sejumlah } \\
\text { campuran } \\
\text { pendanaan }\end{array}$ & $\begin{array}{l}\text { Pembayaran } \\
\text { bisa dilakukan } \\
\text { sesudah kegiatan } \\
\text { berlangsung }\end{array}$ \\
\hline & & & $\begin{array}{l}\text { Pasar langsung } \\
\text { dan pasar tidak } \\
\text { langsung }\end{array}$ \\
\hline
\end{tabular}


REDD+ global dan nasional. Namun demikian jelas bahwa penggalangan pendanaan jangka panjang untuk REDD+ masih tetap belum terpecahkan. Bahkan perhitungan paling konservatif dari biaya terkait dengan pelaksanaan REDD+ jauh melebihi AS \$4,17 miliar dijanjikan sebagai pendanaan awal segera. Pengembangan sejumlah metode dan saluran pencairannya, pembangunan dan penguatan lembaga-lembaga nasional dan internasional, dan perumusan mekanisme pendanaan yang kuat dan mekanisme maupun kebijakan akan menjadi ukuran kunci kemajuan REDD+ baik dalam jangka pendek maupun jangka panjang.

Dalam jangka pendek dan menengah (setidaknya sampai 2020), pendanaan REDD + akan datang dari berbagai sumber yang mengikuti aturan-aturan yang berbeda dan sasaran pelaku yang juga berbeda. Sebagian besar pendanaan perlu datang dari anggaran negara-negara maju. Skala pendanaan seperti ini akan bergantung pada kemauan politik yang berkelanjutan di negara-negara maju, tingkat ambisi target iklim nasional dan internasional, dan kemampuan untuk mengadopsi mekanisme yang menggalang dana dari berbagai sumber baru. Negara-negara berkembang yang kaya akan terus mendanai sendiri berbagai program REDD+nya.

Pembayaran bagi negara-negara miskin masih bisa dimasukkan dalam struktur untuk menciptakan insentif berinvestasi dalam kebijakan baru dan reformasi yang bertujuan mencapai transformasi sosial-ekonomi yang ada di titik kritis. Insentif akan diarahkan bagi mereka yang kemungkinan memberikan tanggapannya, misalnya pelaku ekonomi di lapangan, termasuk petani, kelompok masyarakat dan entitas swasta (Karsenty dan Ongolo 2012). Dukungan tambahan untuk memulai kegiatan REDD+ di tingkat nasional dan lokal bisa datang dari transaksi pasar karbon sukarela. The Governor's Climate and Forests Taskforce, diprakarsai oleh negara bagian California, dan pasar karbon Asia yang baru mulai muncul, memberikan contoh menarik tentang inisiatif subnasional.

Ringkasnya, REDD+ tidak mungkin memberikan pendanaan langsung untuk mencapai reduksi emisi secara cepat dan murah. Meskipun demikian, REDD+ menyediakan kesempatan penting bagi negara-negara untuk mengatasi penyebab struktural deforestasi dan memulai proses perubahan transformatif dalam mempertimbangkan sumberdaya hutan. Bagi negara yang mampu bertindak tanpa dukungan internasional, pemerintahnya mungkin lebih memilih pembayaran berbasiskan-hasil (Tahap 3). Namun, banyak negara akan membutuhkan dukungan tata kelola proyek maupun reformasi kebijakan (Tahap 2). Dalam tahun-tahun berikutnya, ketika pelaksanaan REDD+ meningkat, namun kerangka kerja kebijakan internasional yang secara legal mengikat masih belum ada, pendanaan harus berasal dari berbagai sumber yang secara langsung terlibat dengan sektor swasta untuk memerangi pemicu-pemicu deforestasi. 



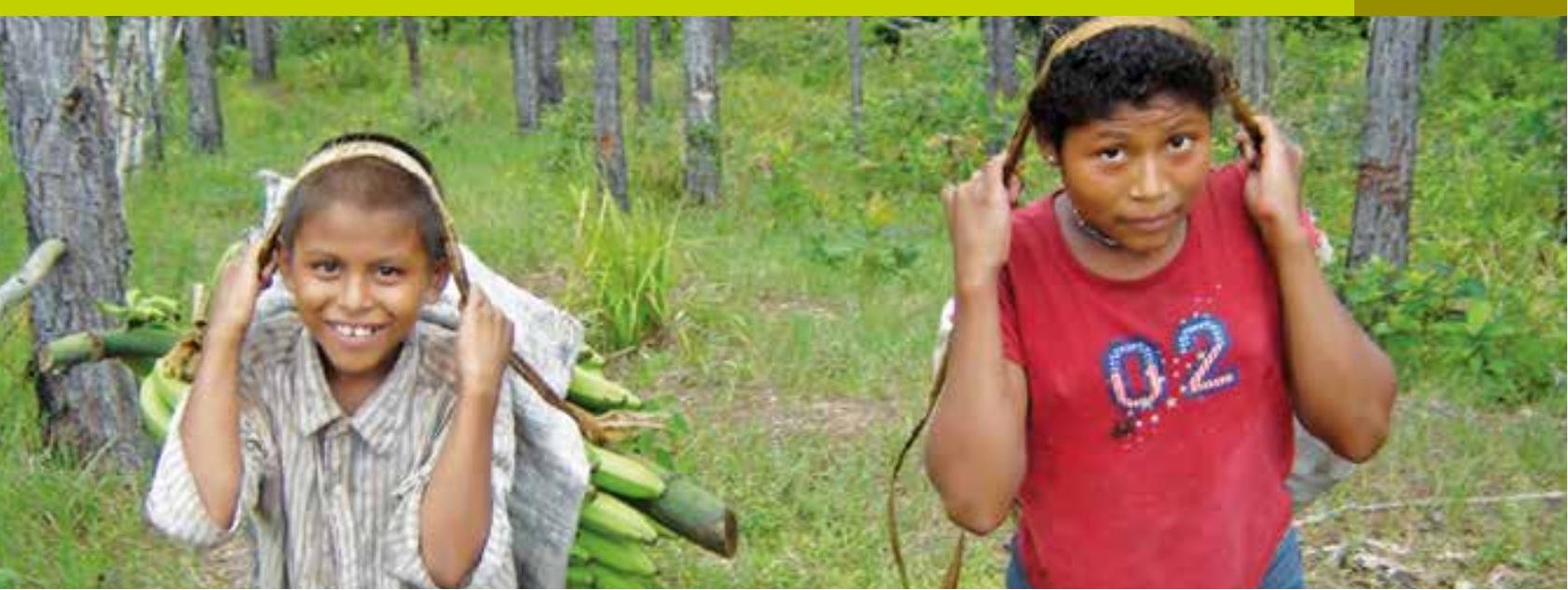

\section{Siapa yang seharusnya menerima manfaat dan mengapa? \\ Wacana tentang pembagian manfaat REDD+}

Cecilia Luttrell, Lasse Loft, Maria Fernanda Gebara dan Demetrius Kweka

- Sebelum merancang mekanisme pembagian manfaat yang efektif untuk REDD+, perlu dijawab lebih dulu pertanyaan tentang apa yang hendak dicapai oleh REDD+. Tujuan yang ingin dicapai sangat mempengaruhi desain mekanisme pembagian biaya dan manfaatnya.

- Manfaat tidak hanya bersifat finansial. Hanya sedikit proyek REDD+ yang menyediakan pembayaran langsung ke kalangan rumah tangga pada tahap awalnya, sehingga pembagian manfaat memerlukan perhatian untuk berbagai macam kegiatan.

- Legitimasi berbagai kelembagaan dan proses pengambilan keputusan sangat penting. Kejelasan hukum sangat penting, seperti konsensus mengenai lembaga-lembaga yang memiliki hak untuk mengambil keputusan dan perhatian terhadap hak-hak prosedural.

\subsection{Pengantar}

Distribusi manfaat telah diidentifikasi sebagai "salah satu rintangan paling menantang” yang dihadapi REDD+ (Costenbader 2011). Pembagian manfaat penting untuk menciptakan insentif positif guna mengurangi emisi karbon, 
tetapi harus dilihat secara bijak, jika tidak maka akan mengancam legitimasi dan dukungan bagi REDD+. Selain itu, pembagian manfaat dapat membantu menghindari kebocoran yang terkait dengan REDD+ dan memastikan kelanggengan pengurangan emisi (Peskett 2011a).

Pembagian manfaat bukanlah konsep yang unik untuk REDD+. Banyak sektor sumberdaya alam (misalnya, proyek-proyek pertambangan, minyak, konservasi dan pembangunan) dan sebagian besar pemerintah telah berurusan dengan pembagian manfaat melalui perpajakan dan subsidi. Ada banyak yang harus dipelajari dari pengalaman ini (lihat, misalnya, tinjauan oleh Lindhjem dkk. 2010). Seperti terjadi di sektor lain, perdebatan pembagian manfaat dalam REDD+ menimbulkan sejumlah persoalan, termasuk definisi manfaat, identifikasi penerima manfaat yang sah, biaya distribusi yang efisien, struktur kelembagaan yang diperlukan untuk transfer keuangan dan proses pengambilan keputusan dan implementasi (lihat Lindhjem 2010; Peskett 2011a, Vatn dan Vedeld 2011).

Bab ini menguraikan kebijakan dan sistem yang diusulkan untuk distribusi biaya dan manfaat di tingkat nasional dan subnasional di berbagai negara dan proyek. Fokusnya terutama pada wacana utama seputar pertanyaan tentang bagaimana biaya dan manfaat harus didistribusikan. Kami mendefinisikan 'wacana' sebagai "cara bersama memahami dunia" (menurut Dryzek, 1997:8). Bagian 8.2 menjelaskan konteks diskusi dengan mendefinisikan konsep-konsep kunci dan menjelaskan tatanan kelembagaan untuk mengalokasikan dana. Bagian 8.3 memaparkan wacana utama tentang bagaimana mendistribusikan biaya dan manfaat dan mengeksplorasi implikasi dari wacana yang berbeda untuk desain mekanisme pembagian manfaat. Bagian 8.4 membahas pentingnya legitimasi dalam proses pengambilan keputusan dan menjelaskan cara memantau berbagai pertimbangan yang menyangkut keefektifan, efisiensi dan kesetaraan yang mendasari masing-masing wacana. Bab ini menyimpulkan ringkasan pilihan yang diambil antara wacana yang berbeda yang terkait dengan pembagian manfaat dan menggarisbawahi pentingnya melegitimasi proses desainnya.

Bab ini bersumber dari informasi Studi Komparatif Global CIFOR (GCS) tentang REDD+ dan menggunakan informasi dari 22 lokasi proyek di tujuh negara (lihat Lampiran). Tabel 8.1 menyarikan status kebijakan dan praktik saat ini mengenai mekanisme pembagian manfaat nasional dan subnasional di negara tertentu. Data yang digunakan dalam bab ini dikumpulkan di tingkat nasional, proyek dan desa di masing-masing lokasi proyek dan dilengkapi dengan ulasan kepustakaan sekunder, wawancara, dan analisis kebijakan di tingkat nasional. 


\subsection{Memahami konteks}

\subsubsection{Mendefenisikan biaya dan manfaat REDD+}

Dalam bab ini kami mendefinisikan pembagian manfaat menurut REDD+ sebagai distribusi manfaat bersih langsung dan tidak langsung dari pelaksanaan REDD+. Kami membedakan antara dua jenis manfaat. Pertama, ada keuntungan moneter dari pendanaan internasional dan nasional yang terkait dengan REDD+, termasuk dari penjualan kredit karbon hutan atau dana bantuan yang terkait dengan kesiapan-REDD, reformasi kebijakan dan atau pembayaran berdasarkan pengurangan emisi. Kedua, karena REDD+ meningkatkan kelestarian pengelolaan hutan, kemungkinan menghasilkan manfaat melalui peningkatan ketersediaan beberapa hasil hutan (misalnya, hasil hutan nonkayu) dan dengan memberikan manfaat yang terkait dengan jasa ekosistem nonkarbon. Kotak 8.1 menjelaskan istilah-istilah kunci dan konsep yang terkait dengan pembagian manfaat REDD+.

Implementasi REDD+ juga membutuhkan biaya yang ditanggung oleh pelaku yang berbeda dan pada tingkat yang berbeda. Sekali lagi, ada perbedaan konseptual antara pengeluaran keuangan langsung terkait dengan implementasi REDD+ dan biaya yang timbul dari perubahan penggunaan lahan hutan dan sumberdaya hutan di bawah REDD+. Jenis biaya yang terakhir ini biasanya disebut sebagai biaya peluang: pendapatan yang dikorbankan dengan memanfaatkan hutan dengan cara-cara yang mengurangi emisi. Biaya langsung meliputi biaya transaksi dan implementasi. Biaya implementasi dapat mencakup biaya yang dikeluarkan oleh pemerintah atau pemrakarsa untuk memberi kompensasi kepada para pelaku karena kesempatan yang hilang (biaya peluang), sehingga harus berhati-hati untuk tidak menggandakan jumlahnya (Kotak 8.1, lihat juga Kotak 7.1).

Selain itu juga perlu dibedakan antara: i) biaya untuk negara; ii) biaya untuk para pelaku individu, dan iii) biaya anggaran untuk instansi pemerintah (lihat Tabel 8.2). Karena itu tidak tepat kalau berbagai jenis biaya, pelaku dan skala yang berbeda itu dicampurbaurkan karena dapat menghasilkan perkiraan yang menyesatkan mengenai keuntungan bersihnya (lihat Bab 7, termasuk Kotak 7.1).

Dalam bab ini, kami menggunakan istilah mekanisme pembagian manfaat untuk merujuk pada berbagai cara kelembagaan, struktur tata kelola dan instrumen yang mendistribusikan dana dan keuntungan bersih lainnya dari program REDD+ (menurut Vhugen dkk. 2011). Instrumen ini mungkin termasuk transfer tunai dalam sistem PES, pengelolaan hutan partisipatif (PKP) dan proyek-proyek konservasi dan pembangunan terpadu (ICDP) 


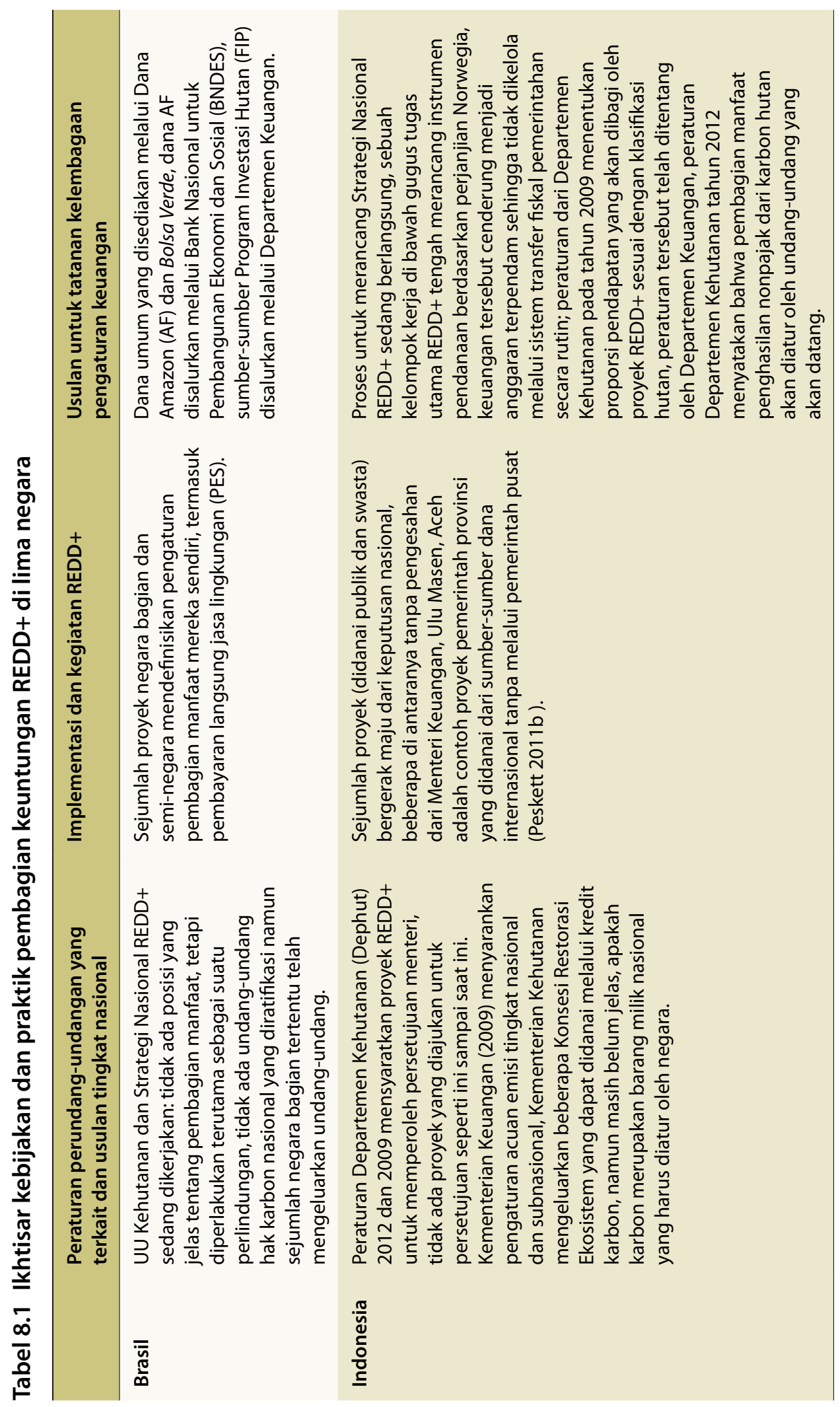




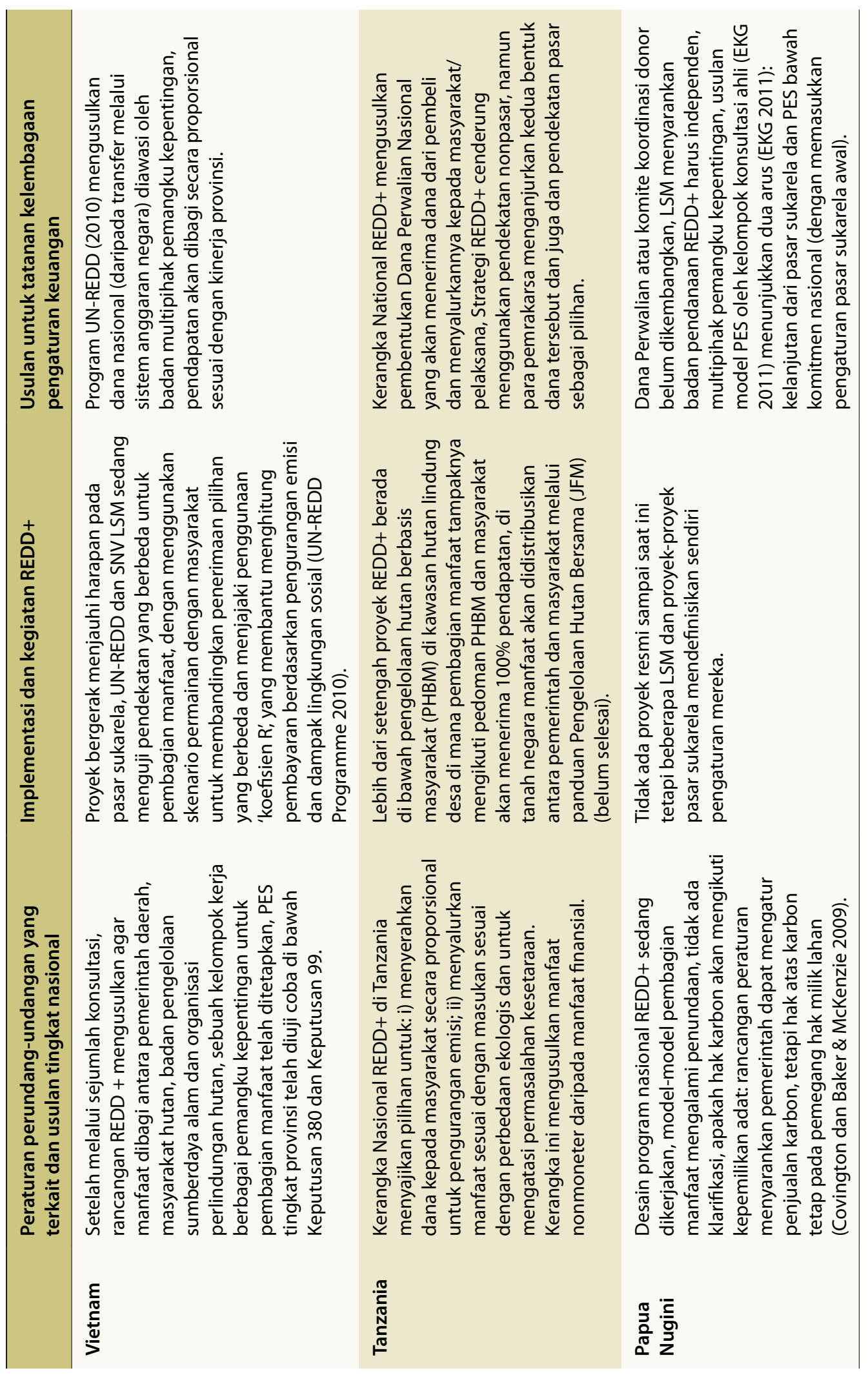




\section{Kotak 8.1 Konsep-konsep utama pembagian manfaat REDD+}

Kebanyakan definisi manfaat dalam kepustakaan REDD+ hanya mengacu pada manfaat moneter yang tersedia untuk pengurangan emisi dan peningkatan stok karbon (Streck 2009; Lindhjem dkk. 2010; Peskett 2011a). Namun, implementasi kegiatan REDD+ di tingkat nasional dan lokal dapat memberi peluang untuk menghasilkan berbagai manfaat, selain manfaat moneter langsung (lihat Tabel 8.2 sebagai contoh). Manfaat ini termasuk:

- Manfaat langsung yang timbul dari pelaksanaan REDD+. Dalam hal ini termasuk peningkatan pekerjaan, peningkatan mata pencaharian, dan manfaat ekosistem secara langsung, yang meliputi hasil hutan nonkayu (HHNK), kayu bakar, pakan ternak dll.

- Manfaat tidak langsung, yang terdiri dari perbaikan tata kelola seperti penguatan hak-hak penguasaan lahan dan penegakan hukum, yang terkait dengan fase kesiapan REDD+) dan meningkatkan partisipasi dalam pengambilan keputusan mengenai manfaat penyediaan infrastruktur. Manfaat ekosistem tak langsung mencakup perlindungan kualitas tanah dan air, perlindungan keanekaragaman hayati dan stabilisasi iklim.

Manfaat langsung dan tidak langsung tersebut dapat berupa manfaat moneter maupun nonmoneter. Manfaat moneter adalah yang dapat diukur dan dinilai dari segi keuangan, dan manfaat nonmoneter sulit untuk dinilai dari segi keuangan (misalnya, peningkatan aset alami, keterampilan dan pengetahuan).

Pelaksanaan REDD+ juga menimbulkan biaya, yang mencakup:

- Biayapeluang:keuntungan bersih yang dikorbankan karena mengonversi hutan untuk penggunaan lahan lainnya (Börner dkk. 2010). Biaya ini bervariasi sesuai dengan pemicu deforestasi di daerah atau negara tertentu.

- Biaya transaksi: biaya yang diperlukan untuk melakukan transaksi yang melibatkan pembayaran REDD+, termasuk biaya kepada pihak eksternal, seperti para pelaksana hukum pasar atau pengatur sistem pembayaran untuk menentukan bahwa program REDD+ telah mencapai pengurangan emisi (Pagiola dan Bosquet 2009).

- Biaya pelaksanaan: biaya "yang langsung terkait dengan tindakan yang mengarah pada pengurangan deforestasi, dan dengan demikian menurunkan emisi" (Pagiola dan Bosquet 2009:3). Jenis biaya ini termasuk, misalnya, biaya menjaga hutan untuk mencegah kegiatan penebangan kayu ilegal dan relokasi kegiatan pemanenan kayu jauh dari hutan alam. Biaya ini mungkin juga melibatkan pembayaran kompensasi kepada para pelaku atas biaya peluang dan biaya transaksi, sehingga tiga biaya yang berbeda di atas mungkin tumpang tindih. 
Namun menurut beberapa penulis, harus ada pembedaan antara pemulihan biaya (kompensasi) dan distribusi surplus setelah seluruh biaya lainnya dipenuhi (rente REDD+). Penulis lainnya berpendapat bahwa sistem REDD+, di mana biaya keseluruhan telah dikompensasi, secara teoritis seharusnya tidak ada kelebihan rentenya. Argumen ini menimbulkan dilema konseptual bagi pembagian manfaat, karena kalau mengejar keefektifan dalam mekanisme global di mana pendanaan secara langsung terbatas, maka dengan sendirinya rente REDD+ akan minimal (Meridian Institute 2009). Dengan demikian, merumuskan konsep REDD+ sebagai sumberdaya ekstraktif yang menghasilkan keuntungan bersih juga mungkin bermasalah.

Menghilangkan nilai manfaat tambahan berupa konservasi hutan dalam perhitungan biaya peluang bersih menjadikannya tampak lebih tinggi daripada sebelumnya (Pagiola and Bosquet 2009:15). Seperti yang tampak dalam berbagai manfaat nonkarbon, yang mungkin mengejutkan sebagian orang, kompensasi moneter kurang dibutuhkan untuk memperbaiki keadaan masyarakat lokal di bawah REDD+.

(IUCN 2009). Mekanisme pembagian manfaat lain yang terkait dengan proses kebijakan, adalah seperti reformasi tata kelola, insentif fiskal dan kebijakan yang menangani pemicu tertentu deforestasi dan degradasi (Chagas dkk. 2011).

Lindhjem dkk. (2010) mengelompokkan pembagian manfaat seperti memiliki dua dimensi penting: pembagian manfaat vertikal, yang melibatkan pembagian manfaat antara pemangku kepentingan tingkat nasional dan lokal dan pembagian manfaat horizontal antara anggota satu masyarakat dan masyarakat lainnya, di antara rumah tangga dan pemangku kepentingan lokal lainnya. Satu pertanyaan muncul terkait dengan pembagian manfaat vertikal menyangkut keseimbangan yang tepat antara manfaat yang digunakan sebagai insentif langsung untuk mengurangi deforestasi dan degradasi dan manfaat yang digunakan untuk meningkatkan tata kelola dan konteks kebijakan yang diperlukan untuk keberhasilan implementasi REDD+ (seperti argumentasi Gregersen dkk 2010; Karsenty dan Ongolo 2012).

Peningkatan tata kelola mungkin mencakup klarifikasi penguasaan lahan dan penguatan penegakan hukum. Dalam praktiknya, semua negara yang memberikan perhatian pada kedua jenis pembagian manfaat tersebut mengakui bahwa kebijakan lingkungan yang kondusif diperlukan untuk membuat PES atau kompensasi terkait lainnya berhasil. Penekanan relatif kepada dua dimensi pembagian manfaat bervariasi sesuai konteks spesifik suatu negara dan pemicu deforestasinya. Di Indonesia dan Kamerun, misalnya, kebanyakan 


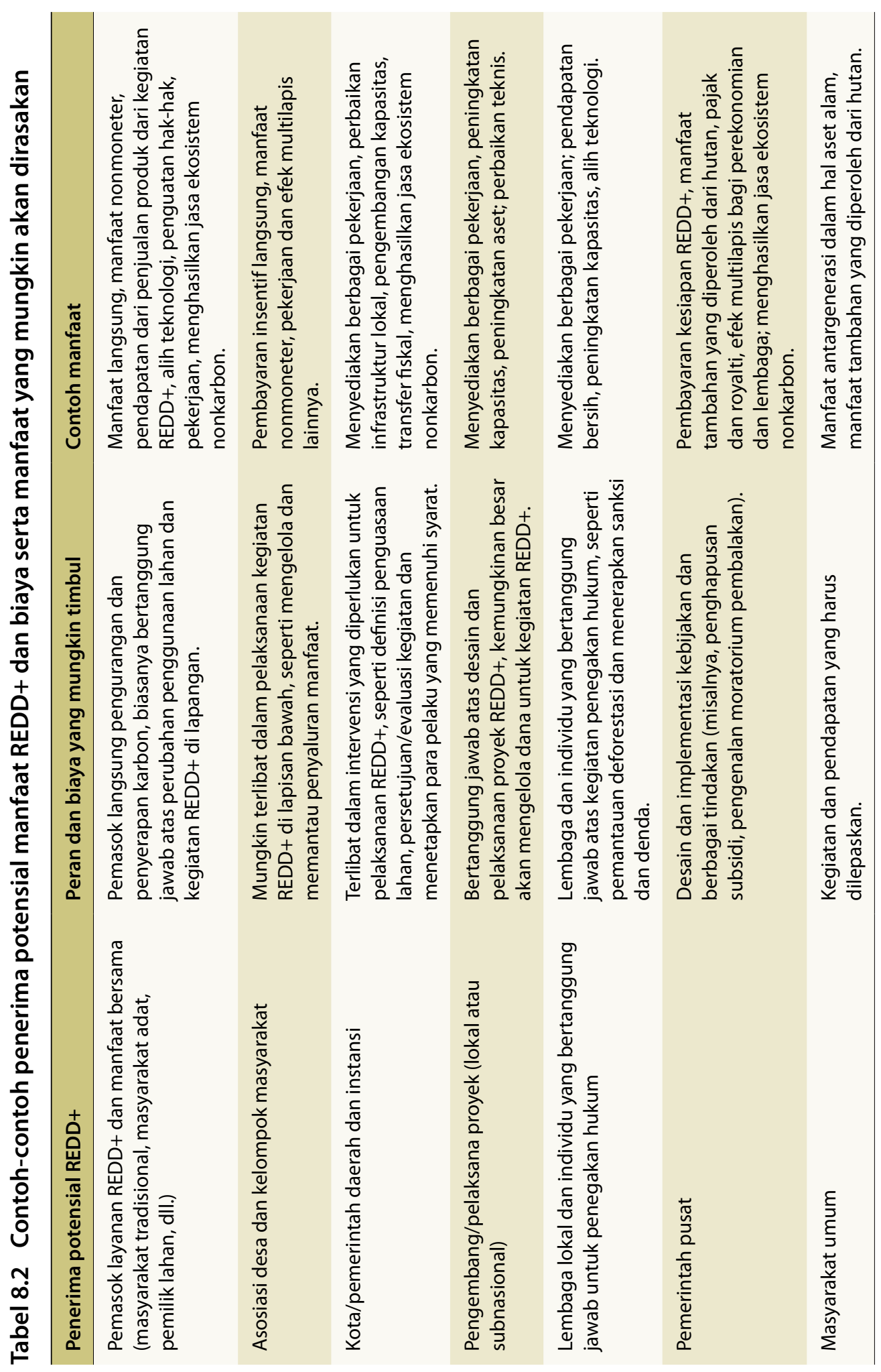


deforestasi dan degradasi hutan terjadi secara ilegal atau semilegal dan sering terjadi di lahan milik negara atau milik pemerintah di mana penegakan hak atas lahannya lemah. Dengan demikian, penegakan hukum yang lebih kuat, klarifikasi hak kepemilikan dan intensifikasi pertanian diperlukan sebelum mekanisme berbasiskan kinerja layak diterapkan. Fokus kebijakan nasional Brasil juga pada penguatan kebijakan dan penegakan hukum, sementara negara-negara seperti Vietnam saat ini lebih memperhatikan pendekatan PES.

Tabel 8.3 menyajikan sejumlah proyek REDD+ dan mekanisme pembagian manfaat aktual yang mereka usulkan sampai saat ini. Selama kami melakukan kajian, hanya satu proyek yang melakukan transfer dana langsung ke rumah tangga. Tidak satu pun mekanisme pembagian manfaat saat ini di lima proyek Indonesia yang dikaji melakukan pembayaran tunai. Para pemrakarsa lebih suka mendefinisikan manfaat dalam bentuk kegiatan, seperti peningkatan kapasitas, peningkatan mata pencaharian alternatif dan penguatan hak penguasaan lahan, yang dipandang perlu sebelum sistem PES berhasil diperkenalkan. Artinya, jenis mekanisme pembagian manfaat yang ada kemungkinan akan berubah seiring dengan perkembangan dari kesiapan REDD+ menjadi pembayaran untuk pengurangan emisi yang sebenarnya.

\subsubsection{Struktur kelembagaan bagi arus keuangan}

Pembagian manfaat bersih dan biaya pelaksanaan REDD+ di antara para pelaku yang berbeda memiliki dua aspek: keuntungan moneter dari pendanaan internasional dan manfaat yang terkait dengan kesinambungan peningkatan pengelolaan hutan. Dengan demikian, istilah 'mekanisme pembagian manfaat' mencakup berbagai sarana kelembagaan, struktur tata kelola dan instrumen yang diperlukan untuk mendistribusikan baik keuangan dan keuntungan bersih dari pelaksanaan REDD+. Dalam hal mekanisme keuangan, mekanisme pembagiannya bergantung pada tatanan kelembagaan yang sudah berjalan untuk mengalokasikan pendanaan internasional dan nasional. Sementara mekanisme pembagian keuntungan yang tidak terkait langsung dengan uang akan bergantung pada cara tertentu yang dipilih untuk implementasi REDD+, termasuk aturan penyaluran manfaat keuangan. Fokus utama bab ini adalah mekanisme pembagian manfaat kedua ini. Namun, untuk memberikan konteks pembahasannya, bagian ini membahas usulan tata kelola dan tatanan kelembagaan yang diperlukan untuk mengalokasikan dana dari tingkat nasional sampai subnasional dan menjelaskan implikasi pembagian manfaatnya.

Usulan yang dimaksud di atas dapat dibagi menjadi empat kategori utama (menurut Vatn dan Angelsen 2009, Vatn dan Vedeld 2011) (lihat Gambar 8.1 dan Tabel 8.1):

1. Mekanisme berbasiskan proyek, seperti Clean Development Mechanism (CDM) atau proyek standar atau pasar sukarela, seperti yang ada di Peru dan Tanzania 


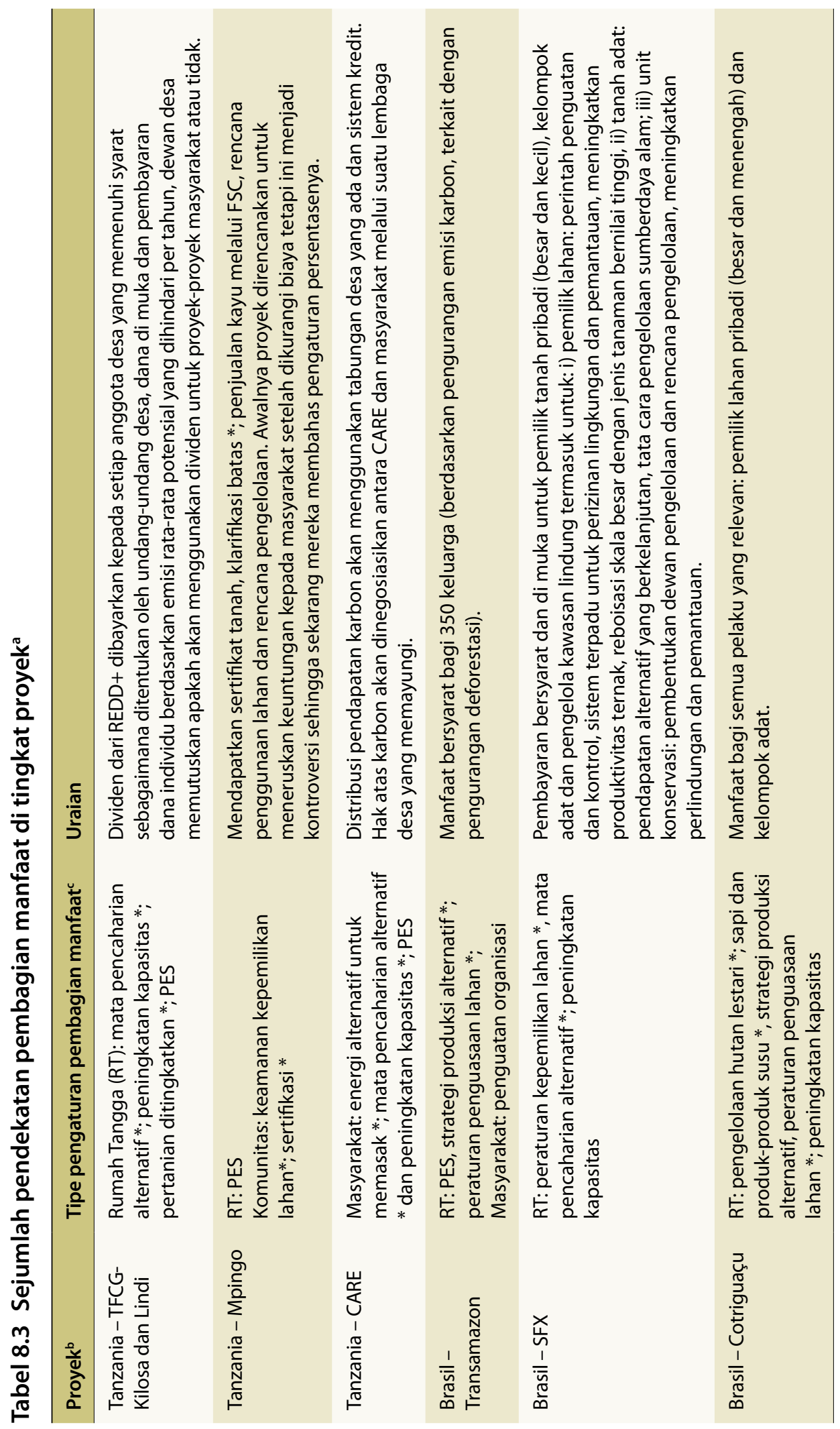




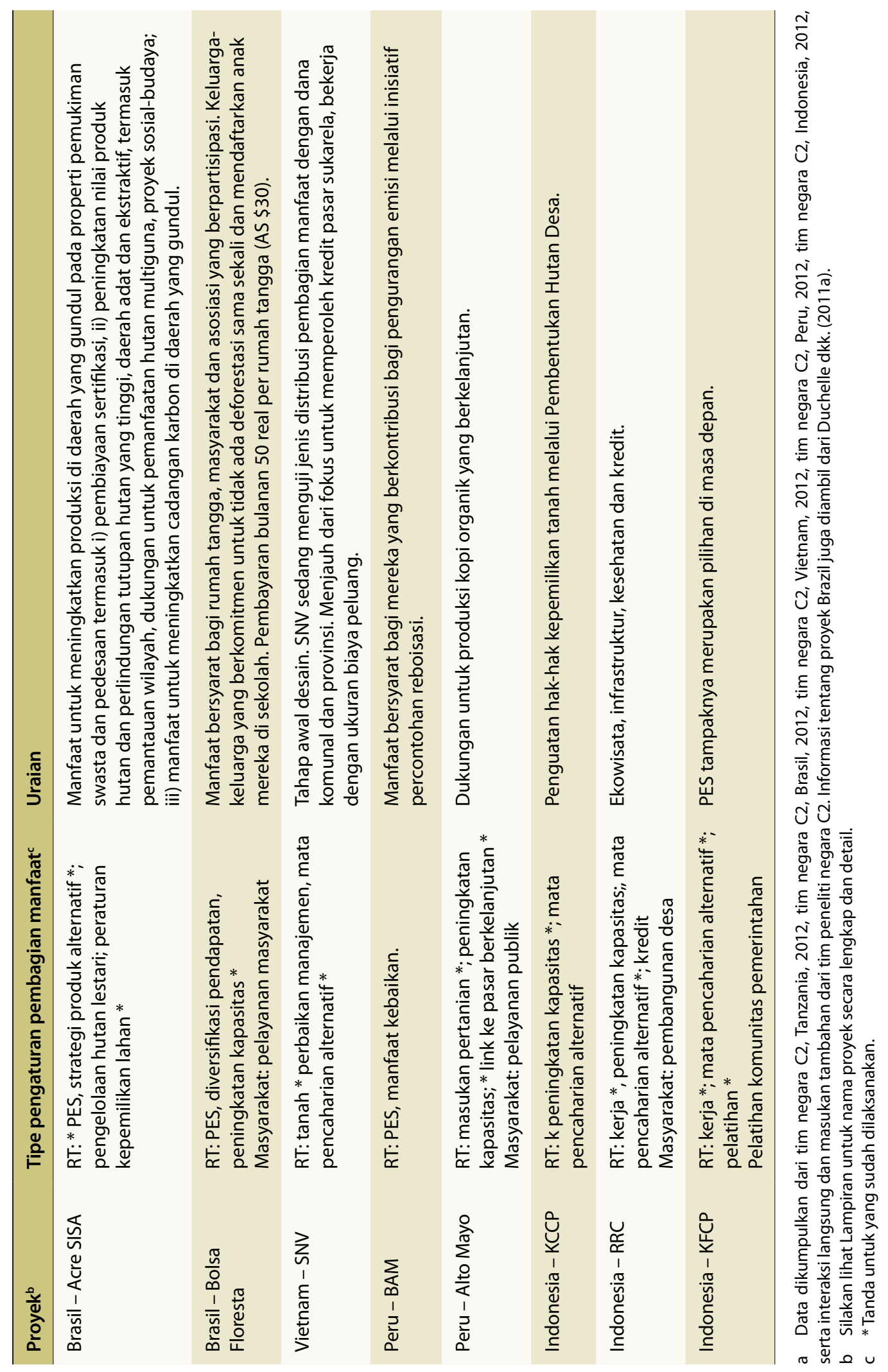


2. Dana yang beroperasi secara independen di luar pemerintahan nasional, seperti dana perwalian konservasi yang sudah ada atau yang diusulkan Dana Perwalian Nasional (National Trust Fund di Tanzania, lihat Tabel 8.1)

3. Dana yang mengandalkan kemampuan administrasi negara dan dapat mengarahkan pembiayaan ke sektor negara, tetapi dengan keputusan tentang penerima manfaat keuangan yang dibuat oleh komite independen. Contohnya Dana Amazon di Brasil, Dana Nasional untuk Lingkungan (FONAM) di Peru dan Perlindungan Hutan dan Dana Pembangunan di Vietnam.

4. Distribusi pembayaran bersyarat melalui sistem transfer fiskal negara, seperti yang diusulkan oleh Kementerian Keuangan di Indonesia (Departemen Keuangan 2009). Cara ini mungkin melibatkan anggaran rutin pemerintah, dana yang ditargetkan atau pendekatan desentralisasi yang melibatkan keputusan alokasi dana oleh pemerintah daerah dan pajak yang dibayarkan kepada pemerintah pusat, seperti di Vietnam (UN-REDD Programme 2010).

Pendekatan-pendekatan yang diusulkan untuk transfer keuangan tersebut memiliki implikasi penting bagi pembagian manfaat. Mekanisme berbasiskan proyek melibatkan kontrak antara pemasok dan pembeli, tetapi biasanya terpisah dari struktur negara. Sementara sistem nasional yang lebih kompleks memiliki jangkauan yang lebih luas dari pemain dan lapisan sistem subnasional untuk mengakomodasi cara penyalurannya (UN-REDD Programme 2010). Tabel 8.1 menunjukkan bahwa, kecuali di Brasil, hanya sedikit kejelasan di negara-negara yang memiliki pengaturan tata kelola kelembagaan untuk transfer keuangan REDD+ dan banyak negara memiliki sejumlah usulan di mejanya. Misalnya, naskah Strategi REDD+ Tanzania mengusulkan suatu sistem nasional yang terpusat dengan pembayaran ke Dana Perwalian Nasional, sedangkan proyek (dan naskah Kesiapan Persiapan [R-PP]) mengusulkan suatu pendekatan yang tergabung menjadi satu, yang memungkinkan pembayaran internasional langsung ke proyek. Di negara tertentu, seperti Indonesia, berbagai proses pendefinisian mekanisme pembagian manfaat sedang berlangsung, meskipun legalitas pengaturannya tidak jelas. Fakta bahwa banyak proyek REDD+ yang beroperasi dalam kerangka hukum dan kebijakan yang tidak aman menunjukkan bahwa pengaturan pembagian manfaat dapat sangat dipengaruhi oleh pergolakan di tingkat nasional setelah suatu kebijakan disahkan.

\subsection{Wacana tentang siapa yang akan menerima manfaat}

Satu pertanyaan pokok yang mendominasi perdebatan tentang pembagian manfaat, baik di tingkat nasional dan proyek, adalah siapa yang akan menerima manfaat yang terkait dengan REDD+. Fokus bagian ini adalah 


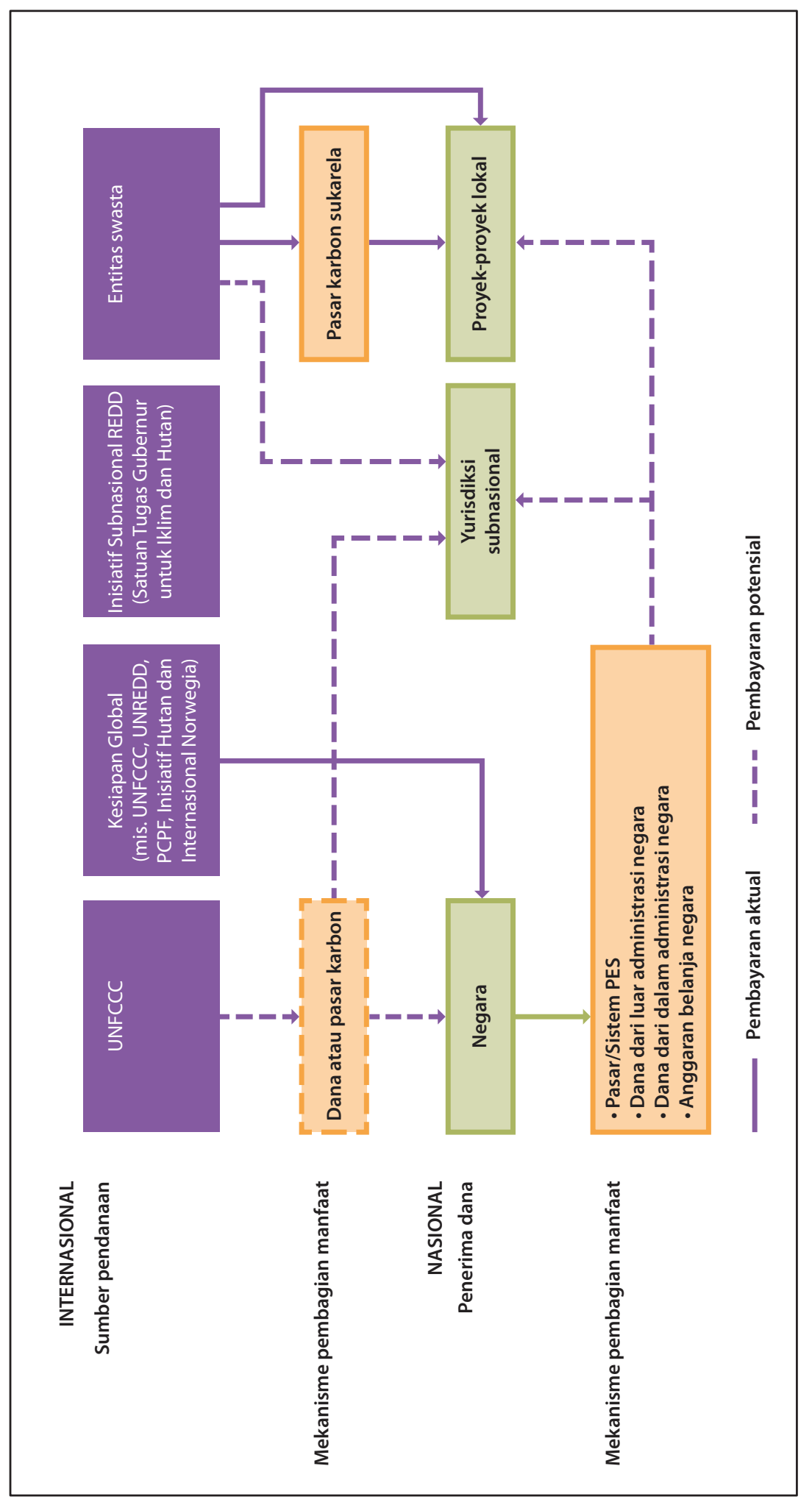

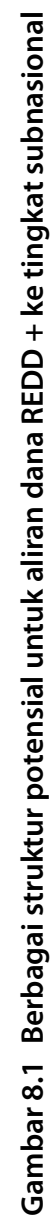


wacana-wacana utama mengenai hal ini, negosiasi timbal balik yang harus diterima berdasarkan pilihan-pilihan yang muncul dari masing-masing wacana dan implikasi pilihan desain mekanisme pembagian manfaatnya. Wacana yang berbeda memiliki dampak berbeda bagi perumusan kebijakan, karena masing-masing memandang masalah dan pilihan yang ada dengan cara yang berbeda (Hajer dan verSteeg 2005).

Ada perbedaan utama yang bisa dilihat mengenai keefektifan dan efisiensi di satu sisi dan kesetaraan (dan manfaat tambahan) di sisi lain.

1. Wacana keefektifan dan efisiensi berfokus pada tujuan pengurangan emisi karbon. Artinya, manfaatnya harus digunakan sebagai insentif dan dibagikan kepada orang-orang atau masyarakat yang mengusahakan pengurangan emisi dengan mengubah perilaku atau tindakan mereka. Argumen ini mengikuti logika PES: REDD+ berfungsi sebagai mekanisme untuk membayar pengguna hutan dan pemiliknya untuk mengurangi emisi. Karena itu, keuntungan finansialnya pada prinsipnya harus menjangkau orang-orang yang menyediakan layanan ini untuk memastikan bahwa layanan ini benar-benar diwujudkan. Hal ini juga dapat dianggap sebagai praktik yang adil, karena para pelaku menanggung biaya utama atas pemanfaatan hutan yang menjadi berkurang.

2. Sementara untuk wacana yang terkait dengan kesetaraan, fokus pertanyaannya adalah para pelaku mana saja yang berhak menerima manfaat REDD+, dengan perhatian yang lebih sedikit pada kontribusi mereka untuk mengurangi emisi karbon. Pendekatan ini muncul dari kekhawatiran bahwa fokus pada keefektifan dan efisiensi saja dapat menyebabkan insentif yang tidak adil (misalnya, penghargaan kepada pelaku kaya karena mengurangi perilaku ilegal mereka), meningkatkan ketimpangan dan merusak legitimasi moral dan politik REDD+. Wacana kesetaraan ini memiliki empat elemen utama, yang dibahas di bagian berikut.

Di tingkat nasional, penekanan yang lebih kuat pada berbagai wacana bervariasi sesuai dengan pemangku kepentingan mana saja yang terlibat dalam desain mekanisme, sifat pendanaan REDD+ yang dipertimbangkan dan tipe kegiatan REDD+ yang bersangkutan. Misalnya, di Vietnam ada kekhawatiran tentang perkembangan pembayaran berbasiskan kinerja yang juga menyediakan manfaat tambahan. Di Indonesia, ada penekanan untuk menyiapkan struktur insentif yang memadai untuk memastikan agar pemrakarsa proyek tetap terlibat. Sementara di Tanzania, ada kekhawatiran apakah pembayaran di muka yang bertujuan untuk menjaga komitmen awal itu memungkinkan untuk dilakukan.

Tabel 8.4 menggambarkan model yang diusulkan untuk alokasi dana subnasional, yang dikembangkan untuk memengaruhi perumusan strategi nasional REDD+ di Brasil. Model ini dikembangkan oleh Amazon 
Environmental Research Institute (IPAM) (Moutinho dkk. 2011) dan kelompok kerja yang diselenggarakan oleh Kementerian Lingkungan Hidup (KLH 2012). Tabel ini menunjukkan bagaimana variasi model ini sesuai dengan bobot yang diberikan untuk berbagai tujuan keefektifan dan efisiensi atau kesetaraan dan apa saja kemungkinan implikasinya bagi penyaluran keuntungan tersebut.

\section{Tabel 8.4 Usulan model dana alokasi subnasional REDD+ di Brazil (berdasarkan Moutinho dkk (2011) [i] dan MMA (2012) [ii].)}

\begin{tabular}{|c|c|c|}
\hline & Proposal alokasi dana & Implikasi \\
\hline $\begin{array}{l}\text { Model } 1 \\
{[\mathrm{i} ; \mathrm{ii}]}\end{array}$ & $\begin{array}{l}\text { Berdasarkan tingkat emisi acuan } \\
\text { subnasional, negara federal } \\
\text { akan diberi ganti rugi menurut } \\
\text { tiga kriteria: i) kontribusi untuk } \\
\text { mengurangi emisi, ii) stok karbon } \\
\text { hutan, dan iii) kinerja untuk } \\
\text { mencapai target pemerintah } \\
\text { mengurangi deforestasi. }\end{array}$ & $\begin{array}{l}\text { Pembagian manfaat berdasarkan } \\
\text { kinerja menyediakan keefektifan } \\
\text { terbesar, karena akuntabilitas } \\
\text { yang tinggi atas pengurangan gas } \\
\text { rumah kaca di tingkat nasional. } \\
\text { Kesetaraan diatasi dengan } \\
\text { mempertimbangkan stok karbon } \\
\text { hutan dan ini dapat membantu } \\
\text { menguntungkan masyarakat } \\
\text { adat. Namun, fakta bahwa } \\
\text { dana dialokasikan di tingkat } \\
\text { negara menimbulkan sejumlah } \\
\text { tantangan untuk menjangkau } \\
\text { masyarakat lokal. }\end{array}$ \\
\hline $\begin{array}{l}\text { Model } 2 \\
{[\mathrm{i} ; \mathrm{ii}]}\end{array}$ & $\begin{array}{l}\text { Memisahkan dana untuk } \\
\text { kontribusi kategori penggunaan } \\
\text { lahan tertentu (misalnya tanah } \\
\text { adat, kawasan lindung dan cagar } \\
\text { alam ekstraktif, pemukiman } \\
\text { dan lahan masyarakat) untuk } \\
\text { mengurangi deforestasi dan } \\
\text { melestarikan stok hutan. }\end{array}$ & $\begin{array}{l}\text { Keefektifan dan efisiensi } \\
\text { dapat ditingkatkan, karena } \\
\text { model ini memungkinkan } \\
\text { alokasi sumberdaya keuangan } \\
\text { berdasarkan kebutuhan } \\
\text { daerah yang berbeda. } \\
\text { Kesetaraan ditingkatkan } \\
\text { dengan mengalokasikan dana } \\
\text { secara langsung ke daerah } \\
\text { yang bersangkutan. Selain } \\
\text { itu masyarakat adat dapat } \\
\text { menerima manfaat dari alokasi } \\
\text { dana untuk kelompok pemilikan } \\
\text { tanah tertentu. }\end{array}$ \\
\hline $\begin{array}{l}\text { Model } 3 \\
\text { [ii] }\end{array}$ & $\begin{array}{l}\text { Alokasi dana didasarkan pada } \\
\text { pengurangan emisi tingkat } \\
\text { lokal (karbon dialokasikan } \\
\text { dalam unit). Tingkat referensi } \\
\text { dialokasikan langsung ke } \\
\text { pelaku yang bertanggung } \\
\text { jawab untuk mengurangi } \\
\text { deforestasi dan mempromosikan } \\
\text { konservasi hutan. }\end{array}$ & $\begin{array}{l}\text { Keefektifan dapat ditingkatkan, } \\
\text { karena biaya transaksi yang } \\
\text { rendah dan tidak ada lembaga } \\
\text { baru yang diperlukan. Namun } \\
\text { mengalokasikan tingkat } \\
\text { referensi langsung kepada } \\
\text { masyarakat setempat merupakan } \\
\text { sebuah tantangan. }\end{array}$ \\
\hline
\end{tabular}


Dalam praktiknya, sebagian besar mekanisme pembagian manfaat dirancang untuk mencapai berbagai tujuan, tetapi untuk masing-masing ada negosiasi timbal baliknya. Pertanyaan-pertanyaan mengenai hal ini menghadirkan berbagai pertanyaan yang sulit bagi desain REDD+, karena membutuhkan keputusan yang berisiko melemahkan dukungan implementasi REDD+.

Dalam bagian selanjutnya, kami membahas negosiasi timbal balik utama yang terlibat dalam wacana kesetaraan dan menjelaskan bagaimana masing-masing pilihannya berinteraksi dengan wacana keefektifan dan efisiensi untuk memengaruhi desain mekanisme pembagian manfaat.

\subsubsection{Wacana kesetaraan I: Manfaat harus mencapai berbagai pelaku yang memiliki hak legal}

Wacana yang dominan dalam perdebatan pembagian manfaat adalah bahwa manfaat harus disalurkan kepada mereka yang memiliki klaim atau hak legal (baik menurut undang-undang negara atau hukum adat) atas sejumlah manfaat REDD+. Hak-hak legal adalah hak yang diberikan kepada seseorang atau entitas dengan sistem legal tertentu, sebagai sesuatu yang bukan merupakan hak moral atau etika yang lebih luas, yang akan dibahas di bagian selanjutnya. Namun, di sebagian besar negara, termasuk yang merupakan lokasi sebagian besar proyek, menetapkan hak-hak legal ini tidak sederhana. Tidak satu pun negara yang dikaji memiliki undang-undang nasional mengenai hak milik atas pengurangan emisi karbon (lihat Kotak 8.2) dan sebagian besar proyek REDD+ beroperasi dalam ruang hampa ketidakpastian mengenai status legal hak atas karbon. Indonesia, Peru dan Tanzania, khususnya, memiliki sejumlah proyek REDD+ dengan mekanisme pembagian manfaat yang dikembangkan sebelum kebijakan nasional tentang hak karbon diklarifikasi.

\section{Kotak 8.2 Perdebatan atas hak karbon di beberapa negara yang melakukan REDD+}

Hak atas karbon dapat menjadi milik individu atau kelompok, seperti komunitas atau negara, bergantung pada undang-undang nasionalnya. Pelacakan perdebatan yang sedang berlangsung tentang masalah ini di sejumlah negara mencerminkan betapa rumitnya mendefinisikan hak legal untuk mendapat keuntungan dari pengurangan emisi karbon.

\section{Kamerun}

Sistem hukum Kamerun tidak membedakan antara hak atas pohon-pohon dan unsur-unsurnya (seperti karbon) yang tersimpan di dalamnya. Menurut Sama dan Tawah (2009), hak untuk menjual dan mendapatkan keuntungan 
dari karbon harus diperlakukan seperti kepemilikan sumberdaya alam lainnya. Karena itu kepemilikannya bergantung pada jenis hutan yang bersangkutan. Di Kamerun, sumberdaya alam yang terdapat di hutan negara atau komunal milik negara, di tanah nasional yang dikelola oleh negara, adalah milik bangsa Kamerun (Karsenty dan Assembe 2011). Sementara sumberdaya alam yang terdapat di hutan milik dewan kota adalah milik dewan kota dan hutan swasta adalah milik individu. Beberapa penulis berpendapat bahwa kredit karbon dapat dikategorikan sebagai aset tidak berwujud fisik (Correa 2009, seperti dikutip dalam Dkamela 2011) dan merupakan bentuk aset moneter yang mewakili hasil dari suatu tindakan. Kepemilikan kredit karbon akan diberikan kepada para pengelola hutan yang membuktikan diri bahwa mereka berada di belakang tindakan penyerapan karbon. Klaim ini tidak selalu didasarkan pada kepemilikan lahan, tetapi juga dapat mencakup hak leluhur, hak memanfaatkan, hak penggunaan atau penanaman modal.

\section{Brasil}

Menurut pendapat Hukum Federal nomor AGU-AFC-1/2011, penyediaan jasa lingkungan dapat diatur dengan perjanjian komersial dengan kelompokkelompok masyarakat asli; kredit karbon yang dihasilkan di tanah adat akan menjadi milik masyarakat adat berdasarkan Pasal 231 Konstitusi Federal. Di tingkat subnasional, Acre, Amazonas dan Tocantins telah mengeluarkan peraturan mengenai iklim dan konservasi, yang menyatakan bahwa hak karbon adalah milik negara. Berdasarkan undang-undang ini, para penyedia jasa ekosistem dapat mengakses ke sumberdaya keuangan, dengan asumsi mereka menerima persetujuan dan secara legal berada di daerah di mana jasa tersebut tersedia (Gebara 2011). Dalam kasus Amazonas, hak ini dapat disumbangkan kepada Amazonas Sustainable Foundation (FAS), yang bertanggung jawab untuk mengelola kawasan konservasi di negara bagian itu (Pasal 8, UU 3135/2007).

\section{Vietnam}

Konstitusi Vietnam menyatakan bahwa semua lahan dan sumberdaya hutan adalah milik negara, yang mengalokasikannya untuk organisasi dan individu untuk "penggunaan jangka panjang yang stabil". Oleh karena itu, tahun 2004 Perlindungan Hutan dan Hukum Pembangunan mengakui prinsip bahwa pembeli dapat membeli barang dan jasa hutan, memberikan pembayaran kepada mereka yang melindungi dan regenerasi hutan. Keputusan 178 (2001) menentukan cara-cara di mana rumah tangga dan individu dapat diberi alokasi atau menyewa lahan, atau dikontrak untuk mengelola hutan dan rincian pembayarannya dapat diterima untuk jasa ini. Dengan demikian, individu dan organisasi dapat memiliki hak untuk mendapatkan keuntungan dari penyediaan jasa ekosistem. Namun, menurut Pasal 84 UU 2005 tentang Perlindungan Lingkungan, transaksi emisi karbon dengan pembeli internasional harus disetujui oleh Perdana Menteri. 
Karena ketidakjelasan ini, banyak pengelola hutan menganggap bahwa penguasaan lahan dan hutan yang ada sekarang, dan instrumen kebijakan saat ini untuk pembagian manfaat hutannya, akan berfungsi sebagai dasar untuk mengalokasikan pembayaran untuk pengurangan emisi karbon (Cotula dan Mayers 2009). Penguasaan lahan penting pengaruhnya bagi cara pembagian keuntungan hutan, karena membantu menentukan pelaku mana yang berhak untuk melakukan kegiatan dan manfaat klaim dari kawasan tertentu atas tanah dan sumberdaya alam yang terkait dengannya (Peskett 2011a). Namun, masalah utama dalam perdebatan hak karbon adalah banyak pengguna hutan skala kecil tidak memiliki hak formal atas tanah dan/atau hasil hutan (lihat Bab 9) sehingga mereka menggunakan hutan secara ilegal. Menargetkan manfaat hanya untuk individu atau entitas dengan hak formal mungkin secara tidak langsung akan merugikan kelompok termiskin dan menimbulkan pertanyaan apakah pengurangan penggunaan hutan yang secara de jure adalah ilegal juga harus dikompensasi atau tidak.

Pemilik lahan atau pohon tidak selalu berarti memiliki hak legal untuk mendapatkan keuntungan penyerapan karbon atau pengurangan emisi karbon. Meskipun beberapa penulis tidak membedakannya, Peskett dan Brodnig (2011) berargumentasi (mengutip Strecn dan O'Sullivan 2007; Takacs 2009) bahwa hak atas karbon memiliki dua aspek mendasar yang berbeda:

1. Hak milik untuk karbon yang diserap, yang secara fisik terkandung dalam tanah, pohon-pohon dan tanah, tidak perlu harus bertepatan dengan hak milik atas sumberdaya fisik.

2. Hak milik untuk karbon yang diserap berbeda dari hak untuk mendapatkan keuntungan dari penjualan kredit karbon. Ketika tidak ada hukum yang eksplisit tentang hak untuk menyerap karbon, hak-hak legal dapat dikaitkan dengan hak atas aktivitas, aset atau sumberdaya yang melandasinya. Jika status legal tidak jelas, kontrak merupakan bagian penting untuk memperjelas hak dan tanggung jawab (Norton Rose 2010).

Salah satu pertimbangan utama dalam desain mekanisme pembagian manfaat adalah apakah pemerintah pusat akan mengklaim hak terpisah untuk mendapatkan keuntungan dari kredit perdagangan karbon atau tidak. Keputusan ini berakar pada pertanyaan mendasar apakah hutan dan produk yang terkait dengan hutan dipandang sebagai milik nasional. Dan sejauh mana, jika memang demikian, ada konsensus politik di seputar keputusan yang terkait dengannya. Di Tanzania, misalnya, sebagian besar proyek-proyek REDD+ berlangsung di tanah yang terdaftar sebagai Kawasan Lindung Hutan Desa. Artinya tidak ada persyaratan legal yang mengharuskan pendapatan proyek-proyek disetorkan ke pemerintah pusat. Hal ini karena pedoman CBFM dan Tanzania Forest Act of 1998 (revisi tahun 2002) memberikan hak kepada masyarakat untuk mengakses Kawasan Lindung Hutan Desa untuk 
menikmati pendapatan dan keuntungan yang berasal dari hutan tersebut (United Republic of Tanzania 1998). Implikasinya adalah bagaimana proyek ini bisa dipandang oleh pemerintah dan masyarakat luas, karena setiap pendapatan yang mereka peroleh tidak akan memberikan kontribusi untuk pembangunan nasional yang lebih luas. Karena itu resistensi laten terhadap berbagai reformasi yang mengalihkan pengendalian lahan dan hutan dari tangan negara ke masyarakat masih dijumpai di kalangan nasional, di mana beberapa kalangan berpendapat sumberdaya alam merupakan barang milik nasional (wawancara dengan pemangku kepentingan nasional 2012). Persepsi ini telah menghasilkan rekomendasi-rekomendasi agar pendapatan REDD+ disalurkan melalui Dana Perwalian Nasional sehingga memungkinkan pemerintah mengelola dan mendistribusikan dana ke masyarakat (United Republic of Tanzania 2010).

Jika pemerintah memegang hak kepemilikan atas karbon, desain mekanisme pembagian manfaat nasional perlu mengatasi bagaimana keuntungan yang diperoleh dari penjualan karbon disalurkan secara nasional. Jika hak karbon diswastakan, maka pemilik sumberdaya tersebut akan mengatur mekanisme pembagian manfaatnya. Namun dalam kasus ini, diperlukan perhatian lebih lanjut untuk benar-benar mengatasi pemicu emisi karbon, karena mereka yang memegang hak legal mungkin tidak bertanggung jawab atas perilaku mengeluarkan emisi yang tinggi.

\subsubsection{Wacana kesetaraan II: Manfaat harus menjangkau pihak-pihak yang tingkat emisinya rendah}

Dari sudut pandang kesetaraan, dapat dikatakan bahwa manfaat REDD+ tidak hanya menjangkau pelaku yang telah menyebabkan emisi tinggi tetapi juga kelompok adat atau pengguna hutan lainnya yang memiliki sejarah pengelolaan hutan yang bertanggung jawab. Misalnya, dengan pendekatan ini, sebuah komunitas yang hak adatnya tidak diakui secara legal, namun yang telah melindungi hutan untuk waktu yang lama, akan memiliki klaim yang kuat atas manfaat dari REDD+. Dilema kesetaraan--keefektifan adalah bahwa dalam banyak situasi rendah emisi, sifat manfaat tambahan tidak dapat dibuktikan karena tidak ada emisi yang harus dikurangi. Namun, sebagian orang akan berpendapat bahwa emisi cenderung meningkat di masa depan, karena basis realistisnya berada di atas tingkat emisi di masa lalu, dan karena itu pembayarannya dapat dianggap sebagai tambahan.

Pengakuan atas pemeliharaan hutan dengan baik dapat dilihat dalam beberapa proyek yang dikaji, di mana manfaatnya disalurkan kepada para pelaku yang bukan pemicu langsung deforestasi. Tindakan ini dilakukan agar mendukung kolaborasi dan menciptakan insentif untuk melindungi kawasan hutan yang dimaksud. Contoh-contoh seperti ini dapat dilihat dalam proyek BAM di Madre de Dios, Peru di mana para pemilik konsesi kacang Brasil diberi 
insentif untuk melindungi hutan, meskipun kontributor utama deforestasi, pembukaan lahan untuk pertanian dan pembalakan liar adalah pelaku yang berbeda sama sekali. Dalam skenario terbaik, pembayaran kepada masyarakat dapat mendorong mereka untuk menjaga hutan dari pelaku deforestasi dari luar.

\subsubsection{Wacana kesetaraan III: Manfaat harus menjangkau mereka yang harus menanggung biaya}

Wacana penting dalam perdebatan pembagian manfaat menyatakan bahwa para pelaku hutan yang menanggung biaya implementasi, transaksi dan biaya peluang harus menerima manfaat REDD+. Wacana ini mencerminkan kekhawatiran kesetaraan untuk memastikan bahwa mereka yang telah mengeluarkan biaya akan mendapatkan kompensasi, terlepas dari apakah pengurangan emisi karbon itu merupakan tanggung jawab langsung mereka.

Ketegangan antara pendekatan berbasiskan emisi, dan kebutuhan untuk menghargai upaya dan asupan yang dicurahkan bagi pelaksanaan REDD+, tercermin dalam desain sejumlah mekanisme pengaturan pembagian manfaat yang muncul (lihat Kotak 8.3). Ketegangan ini tidak hanya berkaitan dengan fakta bahwa asupan itu lebih mudah mendefinisikan dan mengukurnya daripada pengurangan emisi (lihat Bab 13). Namun karena sebagian besar proyek REDD+ berada dalam tahap awal pelaksanaan, maka kebutuhan untuk memberikan insentif kepada para pelaku untuk terlibat perlu diakui.

\subsubsection{Wacana kesetaraan IV: Manfaat harus menjangkau para pelaksana yang efektif}

Akhirnya, ada wacana yang kuat di mana manfaat REDD+ harus dibagi di antara para pengelola hutan yang perannya penting untuk pelaksanaan REDD+, baik sektor swasta, LSM atau pemerintah pusat atau lokal (Tabel 8.2). Namun, penentuan proporsi yang tepat dari manfaat yang seharusnya dinikmati oleh para pelaku ini merupakan isu utama perdebatan di banyak negara. Tantangannya adalah untuk memastikan bahwa pelaksana proyek menerima cukup insentif untuk menjamin pelaksanaan yang efektif, sementara juga menjaga supaya mereka tidak kebanjiran keuntungan dari mekanisme pembagian manfaat (seperti yang dibahas di Kertas Hijau Departemen Keuangan Indonesia [Kementerian Keuangan, 2009]). Misalnya, di PNG, pemilik tanah adat mendapatkan sedikit keuntungan dari penebangan kayu meskipun kepemilikannya jelas. Hal ini karena kesepakatan pembagian keuntungan dari penebangan kayu di antara pemilik tanah, negara dan kontraktornya mengenai harga yang dibayarkan kepada pemilik tanah untuk kayu yang ditebang adalah tetap, terlepas dari harga pasar yang meningkat. Di Indonesia, pengembang proyek sektor swasta melakukan lobi untuk memengaruhi isi kebijakan nasional tentang pengaturan aturan 


\section{Kotak 8.3 Proyek REDD + di Tanzania: Menjajaki sejumlah pilihan untuk mengatasi ketegangan antara pembagian manfaat berbasiskan kinerja dan berbasiskan asupan}

Pertanyaan terpenting dalam desain mekanisme pembagian manfaat untuk proyek REDD+ di Tanzania menyangkut dasar untuk melakukan pembayaran. Dua pilihan yang jelas untuk melakukan pembayaran adalah berdasarkan i) upaya dan asupan atau ii) kinerja dan keluaran. Dalam pilihan pertama, masyarakat akan diberikan penghargaan asal mereka melaksanakan kegiatan yang meningkatkan kondisi hutan dan stok karbon (misalnya, melalui pengembangan rencana penggunaan lahan, pengelolaan hutan partisipatif, penegakan hukum atau pelaksanaan rencana pengelolaan hutan). Metode ini biaya transaksinya rendah, karena kegiatan ini dengan mudah dapat diverifikasi, dan membutuhkan lebih sedikit bukti empiris. Namun ada beberapa kelemahannya. Misalnya, belum tentu ada hubungan langsung antara pembayaran dan pengurangan laju deforestasi. Pendekatan ini tidak memperhitungkan variasi kinerja pengelola hutan dan juga tidak memberikan insentif yang kuat untuk pengelolaan hutan yang baik karena pengelola hutan dibayar terlepas dari hasil pengelolaan hutannya (TFWG 2010). Namun, pendekatan ini tidak mengakui fakta bahwa masyarakat tertentu bisa bekerja sekeras orang lain tetapi memiliki hasil yang lebih rendah, karena keadaan yang berbeda.

Sistem pembayaran berbasiskan upaya tidak memperhitungkan perbedaan biaya peluang di antara masyarakat. Masyarakat yang berhasil menghentikan produksi arang atau perladangan berpindah akan mengorbankan pertanian dan kegiatan ekonomi lebih banyak dibandingkan yang mencoba menghentikan kegiatan tersebut dan akhirnya gagal (TFWG 2010). Masyarakat yang hutannya berkarbon tinggi (di daerah dataran tinggi) akan menanggung biaya peluang yang lebih besar dibandingkan masyarakat di hutan berkarbon rendah (seperti Miombo di Tanzania bagian selatan dan di Zanzibar) (United Republic of Tanzania 2009). Hal ini terjadi karena ada peluang ekonomi yang lebih berharga di lokasi hutan yang kandungan karbonnya tinggi (TFWG 2010). Jika biaya peluang dan biaya lainnya, seperti berbagai akses ke pasar, tidak diperhitungkan, atau diasumsikan konstan, maka sistem berbasiskan upaya bisa menjadi tidak adil.

Dalam sistem pembayaran berbasiskan keluaran atau kinerja, masyarakat dan pengelola hutan dibayar untuk kinerja aktual mereka dalam memperbaiki kondisi hutan dan mengurangi degradasi dengan cara yang dapat diverifikasi secara empiris. Hal ini dapat dilakukan meskipun stok karbon hutan lebih tinggi, dibandingkan dengan tingkat acuan emisi. Sistem ini menunjukkan kaitan langsung antara pembayaran REDD+ dan kegiatan konservasi hutan yang efektif. Namun, biaya transaksi untuk sistem berbasiskan kinerja lebih tinggi karena kebutuhan pengukuran karbon dan metode verifikasinya harus dilakukan oleh pihak ketiga. 
pembagian manfaat, dengan alasan bahwa pengembang proyek membutuhkan kompensasi yang memadai untuk menutupi biaya pelaksanaan dan biaya transaksi mereka dalam berbagai kegiatan kesiapan REDD+. Di Tanzania, semua pemrakarsa proyek REDD+ adalah LSM dan keuntungan ekonomi dari penebangan hutan yang diterima atau seharusnya mereka nikmati tidak diperdebatkan di tingkat nasional. Namun, hal ini merupakan isu utama yang mereka hadapi dalam melakukan negosiasi dengan masyarakat.

Pertanyaan ini juga berlaku untuk hak-hak pemerintah untuk mempertahankan pendapatan untuk menutupi biaya transaksi dan biaya pelaksanaan yang telah mereka keluarkan. Seperti pendapatan lain yang bersumber dari setiap komoditas hutan, pemerintah pusat dan daerah mungkin tetap berhak mempertahankan pendapatan untuk biaya lain, seperti menyiapkan sistem MRV dan penegakan berbagai sistem (Irawan dan Tacconi 2009). Program UN-REDD (2010) merekomendasikan bahwa jumlah dana yang diambil oleh pemerintah harus berbasiskan kinerja dan terkait langsung dengan biaya yang dikeluarkan.

Sebuah pertanyaan terkait dalam perdebatan pembagian keuntungan secara vertikal adalah bagaimana mendistribusikan rente REDD+ atau pajak yang dihasilkan melaluinya antara tingkatan pemerintah, termasuk sejauh mana pemerintah daerah berhak mengambil sumber pendapatan yang berasal dari daerah. Prinsip pendelegasian menunjukkan bahwa tingkat efisiensi yang dicapai akan lebih besar kalau kewenangan dan tugas pengelolaannya diserahkan ke tingkat administrasi serendah mungkin (Foellesdal 1998). Namun demikian, dalam kasus REDD+ ada kegiatan tertentu yang paling baik ditangani di tingkat pusat, misalnya mengatasi kebocoran emisi (Irawan dan Tacconi 2009).

\subsection{Negosiasi antara sejumlah pilihan dan legitimasi prosesnya}

Kendala umum yang dijumpai di negara-negara yang dikaji adalah ketidakjelasan tentang lembaga mana yang kompeten untuk mengambil keputusan tentang pengaturan pembagian manfaat. Dalam beberapa kasus, kelemahan ini memperlambat pengembangan mekanisme pembagian manfaat dan tentunya pelaksanaan REDD+. Sebagai contoh, di Indonesia, regulasi pembagian manfaat REDD+yang dikembangkan oleh Departemen Kehutanan ditentang oleh Departemen Keuangan, yang menyatakan bahwa Departemen Kehutanan tidak memiliki kewenangan hukum untuk mengambil keputusan fiskal. Sementara itu, Satuan Tugas REDD+ sedang mengembangkan usulan paralel untuk pembagian manfaat yang terkait dengan pendanaan REDD+ dari Norwegia. Di Tanzania, perdebatan yang sama juga terjadi mengenai 
kementerian yang mana yang berwewenang untuk mengambil keputusan tentang implementasi REDD+. Departemen Lingkungan Hidup di Kantor Wakil Presiden memegang kewenangan untuk pengambilan keputusan mengenai pelaksanaan REDD+, tetapi pelaksanaan proyek REDD+ berada di bawah Departemen Sumberdaya Alam dan Pariwisata (United Republic of Tanzania 2010), sementara Departemen Keuangan bertanggung jawab untuk memantau dan memastikan pengumpulan pendapatan. Sementara itu, Kementerian Pertanahan mengambil keputusan tentang kepemilikan tanah, sertifikasi dan batas-batas lahan hutan yang berbatasan dengan desa (di mana sebagian besar proyek-proyek REDD+ berada), sedangkan pemerintah daerah di tingkat kabupaten memiliki kewenangan untuk menyetujui rencana penggunaan lahan tersebut, yang dibutuhkan untuk menetapkan Kawasan Lindung Hutan Desa.

Di satu sisi, inisiatif tingkat proyek memiliki keunggulan untuk berfungsi sebagai uji kasus, menghasilkan sejumlah pelajaran inovatif untuk mekanisme pembagian manfaat, yang kemudian dapat dimasukkan ke dalam kebijakan nasional (seperti yang terjadi dalam kasus proyek SNV di Cat Tien, Vietnam). Di sisi lain, otonomi di tingkat proyek mengandung risiko inisiatif proyek yang berkembang secara paralel dengan kebijakan nasional, kemungkinan di luar ruang demokrasi yang sah, sehingga gagal membantu membangun kapasitas struktur pemerintahan dan prosesnya.

Mengatasi sejumlah kemungkinan bahaya di atas membutuhkan proses yang menyangkut legitimasi pada setiap keputusan yang diambil. Legitimasi bukan hanya fungsi keluaran dari keefektifan, efisiensi dan kesetaraan sistem pembagian manfaat, tetapi juga dari proses untuk merancang dan menerapkan sistemnya. Legitimasi dapat ditingkatkan dengan memastikan bahwa keputusan tentang mekanisme pembagian manfaat diambil oleh mereka yang memiliki mandat legal untuk melakukannya. Selain itu juga dengan menekankan kebutuhan untuk membangun proses hukum yang baik, yang memastikan bahwa keputusan yang diambil dapat diterima dan dapat dipertanggungjawabkan. Kajian kami menunjukkan bahwa proses seperti ini tidak mudah; di sebagian besar negara yang dikaji, mandat dan tanggung jawab berbagai instansi pemerintah tidak selalu jelas. Mengatasi hal ini membutuhkan semua organisasi pemerintah dan nonpemerintah yang terlibat dalam perancangan kebijakan pembagian manfaat dan mekanisme untuk berperan dalam mengatasi ketidakjelasan yang ada. Lembaga donor harus mendorong klarifikasi ini terjadi dan harus bekerja melalui proses dan kelembagaan pengambilan keputusan yang diamanatkan. LSM dan pelaksana sektor swasta dapat mendorong proses ini dengan melakukan lobi ke arah klarifikasi peran dan tanggung jawab. 


\subsection{Kesimpulan dan rekomendasi}

Kami telah menunjukkan bahwa banyak konflik mengenai visi REDD+ tampaknya terkait dengan desain mekanisme pembagian manfaat dan bahwa desain keputusan sering melibatkan negosiasi timbal balik antara efisiensi, keefektifan dan kesetaraan REDD+. Wacana, ideologi, dan definisi terkait dengan keprihatinan pembagian manfaat dan berbagai tujuannya, mulai dari kebutuhan untuk memberikan kompensasi atas biaya yang harus ditanggung, kebutuhan untuk memastikan manfaat tambahan, seperti keanekaragaman hayati, dan kebutuhan untuk mengakui hak-hak legal dan memastikan hasil yang adil. Keputusan yang menekankan keefektifan dan efisiensi atau kesetaraan masing-masing memiliki implikasi penting bagi pengembangan desain mekanisme pembagian manfaat.

Keberagaman tujuan yang dimaksud di atas adalah karena REDD+ itu sendiri sangat sarat dengan harapan yang terkait dengan hasil yang jauh melampaui tujuan pengurangan emisi karbon saja. Mengelola beragam harapan ini juga membutuhkan kejelasan, baik di tingkat nasional dan tingkat proyek mengenai: i) tujuan utama REDD+, dan ii) sejauh mana manfaat tambahan harus ditangani dan dapat dan/atau harus dibayar oleh REDD+. Namun, analisis kami tentang desain pembagian manfaat baik di tingkat nasional dan tingkat proyek menunjukkan bahwa sejumlah pertanyaan mendasar masih belum diselesaikan. Banyak proyek REDD+ yang beroperasi dalam ruang hampa ketidakpastian mengenai bentuk mekanisme pembagian manfaat seperti apa yang akhirnya digolongkan sebagai legal, dan karena itu seberapa tingkat dan jenis manfaat yang akan tersedia untuk dibagikan.

Ada argumen penting yang perlu ditegaskan untuk memperhatikan desain mekanisme pembagian manfaat. Namun karena realitas konteks kebijakan nasional yang belum optimal kita perlu bekerja berdasarkan kondisi ini daripada menunggu reformasi terjadi. Misalnya, karena mendapatkan kejelasan hukum atas hak karbon mungkin tidak realistis dalam waktu dekat, mekanisme pembagian manfaat mungkin dapat menggunakan kontrak yang menentukan hak dan tanggung jawab secara legal. Namun, memberikan terlalu banyak perhatian pada detail desain mekanisme pembagian manfaat sebelum pertanyaan-pertanyaan mendasar diselesaikan (seperti proses pengambilan keputusan tentang pembagian manfaat dan badan apa yang memiliki hak legal untuk melakukannya) bisa menimbulkan masalah.

Kami menyimpulkan bahwa masalahutamayangharus diatasiadalah bagaimana menjamin keabsahan proses untuk menangani pertanyaan-pertanyaan mendasar dan mengambil keputusan tentang desain mekanisme pembagian manfaat. Untuk itu dibutuhkan kejelasan hukum dan konsensus tentang lembaga dengan kewenangan untuk mengambil keputusan mengenai hal ini dan memperhatikan hak-hak prosedural, seperti transparansi, partisipasi 
dan persetujuan sukarela setelah menerima informasi sebelumnya. Tidak ada desain yang mutlak benar atau salah dalam desain pembagian manfaat sehingga resolusi atas sejumlah pertanyaan mendasar perlu didasarkan atas pertimbangan etis, politik dan penilaian praktis. Dasar-dasar pertimbangan ini juga harus memberi kejelasan seperti siapa yang akan menerima manfaat dari REDD+ dan pertimbangan hukum dan konstitusi tentang hak negara untuk menerima pendapatan dari barang-barang yang merupakan milik pribadi dan dan milik suatu bangsa. Oleh karena itu, kami sarankan agar mekanisme pembagian manfaat yang efektif tidak hanya memiliki prinsip-prinsip desain yang jelas, karena ini saja tidak bisa diharapkan untuk memuaskan kepentingan semua pemangku kepentingan. Namun proses untuk mengambil keputusan desain dan implementasi merupakan hal yang penting juga. 



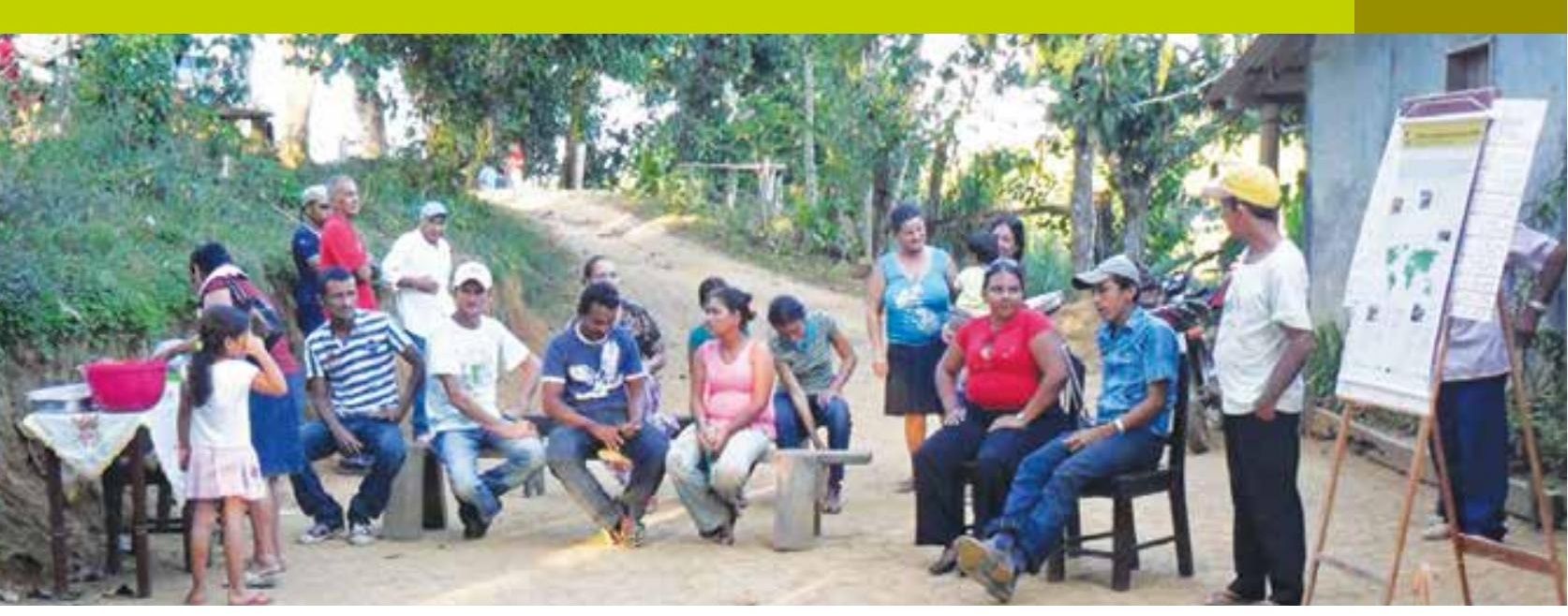

\title{
Penguasaan lahan dalam REDD+ Pembelajaran dari lapangan
}

\author{
Anne M. Larson, Maria Brockhaus dan William D. Sunderlin
}

- Di tingkat nasional, berbagai upaya untuk mengatasi masalah penguasaan lahan dan karbon sangat terbatas, walaupun REDD+ telah menarik perhatian internasional yang belum pernah terjadi sebelumnya mengenai penguasaan lahan dan hak-hak lainnya bagi masyarakat yang hidup di hutan.

- Intervensi tingkat proyek untuk menangani penguasaan lahan menghadapi kendala berat jika tidak didukung di tingkat nasional; sedangkan lembaga nasional pencatatan lahan sering tidak memadai untuk menangani masalah mendasar mengenai hak penguasaan lahan menurut adat secara efektif.

- Para perumus kebijakan REDD+ dapat melangkah maju ke berbagai pendekatan tingkat makro dengan menangani akar penyebab deforestasi, sambil melanjutkan untuk mencapai solusi atas berbagai masalah penguasaan lahan yang spesifik; namun keduanya kemungkinan akan menghadapi perlawanan.

\subsection{Berbagai tantangan reformasi penguasaan lahan hutan}

Di banyak negara, reformasi penguasaan lahan berjalan bergandengan dengan REDD+. Proses reformasi penguasaan lahan mendukung implementasi 
REDD+; pada saat yang sama REDD+ dapat memberikan insentif untuk mendorong kemajuan reformasi penguasaan lahan. Namun kedua proses ini menghadapi kendala yang penting. Berbagai tantangan reformasi penguasaan lahan hutan telah dibahas secara luas dalam kepustakaan. Sunderlin (2011) secara singkat menelusuri sejarah kontrol lokal dan hak-hak adat, melalui masa penindasan hak asasi dan perampasan hutan, terutama masa kolonialisme, sampai 'transisi global penguasaan lahan hutan' saat ini. Banyak pemerintah yang telah mulai mengakui - sampai taraf tertentu - klaim masyarakat. Bentuk dan taraf pengakuan hak adat sangat bervariasi, dalam beberapa kasus terkait sertifikasi wilayah adat yang luas; pada kasus lain, tanah hibah untuk hutan-hutan kemasyarakatan skala kecil. Sementara dalam reformasi yang setengah hati masyarakat tertentu menerima hak pemanfaatan sementara yang baru, yang merupakan perbaikan dari kondisi di masa lalu tetapi jauh dari reformasi substansial (Larson dkk. 2010).

Walaupun pemulihan dan formalisasi hak adat telah mendapat perhatian internasional yang subtansial, pergeseran ini tidak terlihat di semua negara. Bahkan di mana kebijakan telah diimplementasikan, mereka sering menghadapi masalah dan menghadapi perlawanan (Larson 2011); dan beberapa negara yang telah membuat langkah penting dalam mengakui hak hutan kemasyarakatan telah mencoba untuk memutar kembali kebijakan-kebijakan ini belakangan ini (RRI 2012).

Reformasi penguasaan lahan memerlukan waktu dan sumberdaya, baik untuk proses politik dalam negosiasi kompromi dan pengesahan berbagai peraturan baru untuk aspek-aspek teknis, seperti mereformasi kadaster, dan melakukan demarkasi dan sertifikasi lahan. Larson (2011) mengidentifikasi tiga jenis hambatan reformasi penguasaan lahan yang mendukung masyarakat adat dan kelompok masyarakat lainnya yang tinggal di hutan-hutan, terutama terkait dengan kerangka 4I yang diperkenalkan dalam Bab 2: keterbatasan kapasitas teknis, sumberdaya manusia dan ekonomi untuk melaksanakan demarkasi dan sertifikasi yang akurat dan efektif (Informasi); kepentingan politik dan ekonomi para pelaku yang bersaing untuk lahan dan sumberdaya hutan, termasuk beberapa pelaku negara (Kepentingan), dan hambatan ideologi, seperti oposisi terhadap, atau kekhawatiran tentang gagasan bahwa masyarakat yang bernaung di hutan dapat menjadi penjaga hutan yang efektif (Gagasan). Hambatan ini berakar dalam struktur kelembagaan nasional (Kelembagaan).

Terlepas dari berbagai kendala tersebut, penguasaan lahan hutan dalam REDD+ telah semakin banyak mendapat perhatian yang belum pernah terjadi sebelumnya. Tekanan "bisnis seperti biasa" untuk membuka hutan bertentangan langsung dengan kesadartahuan bahwa hutan-hutan yang masih tegak sangat penting untuk mitigasi perubahan iklim (Sunderlin dan Atmadja 2009). Kasus-kasus yang dibahas dalam bab ini menunjukkan lompatan besar, maupun langkah-langkah kecil yang lebih umum untuk 
melangkah maju ke arah pengakuan hak penguasaan lahan hutan. Pada umumnya masih banyak perubahan yang harus dilakukan.

Bab ini menelaah pengalaman selama ini dalam mengatasi berbagai tantangan penguasaan lahan di tingkat nasional dan proyek dan mempertimbangkan langkah maju bagi penguasaan lahan dan REDD+. Apa masalah utama penguasaan lahan yang dihadapi masing-masing negara dan sampai sejauh mana masalah ini diakui dan ditangani pada tingkat nasional? Bagaimana intervensi proyek REDD+ menyelesaikan masalah penguasaan lahan, dan apa saja hambatan untuk melakukannya? Penelitian sebelumnya tentang reformasi penguasaan lahan hutan menunjukkan bahwa bahkan jika hak-hak masyarakat lokal diakui oleh hukum, kemampuan untuk menggunakan hak-hak ini sering tertantang oleh persaingan pelaku dan kepentingan. Menghadapi berbagai kesulitan ini, bagaimana REDD+ dapat melangkah maju ke ranah kebijakan dan intervensi yang menyelesaikan masalah hutan maupun masyarakat lokal?

Hasil penelitian yang disajikan di sini berasal dari Studi Komparatif Global CIFOR (Global Comparative Study/GCS) tentang REDD+, khususnya di enam negara yang dikaji pada tingkat nasional dan proyek (lihat Lampiran untuk penjelasan lengkap tentang metode penelitian). Negara-negara ini adalah: Brasil, Kamerun, Indonesia, Tanzania dan Vietnam; data skala nasional tersedia untuk Peru, tapi informasi tingkat proyek masih sangat dini.

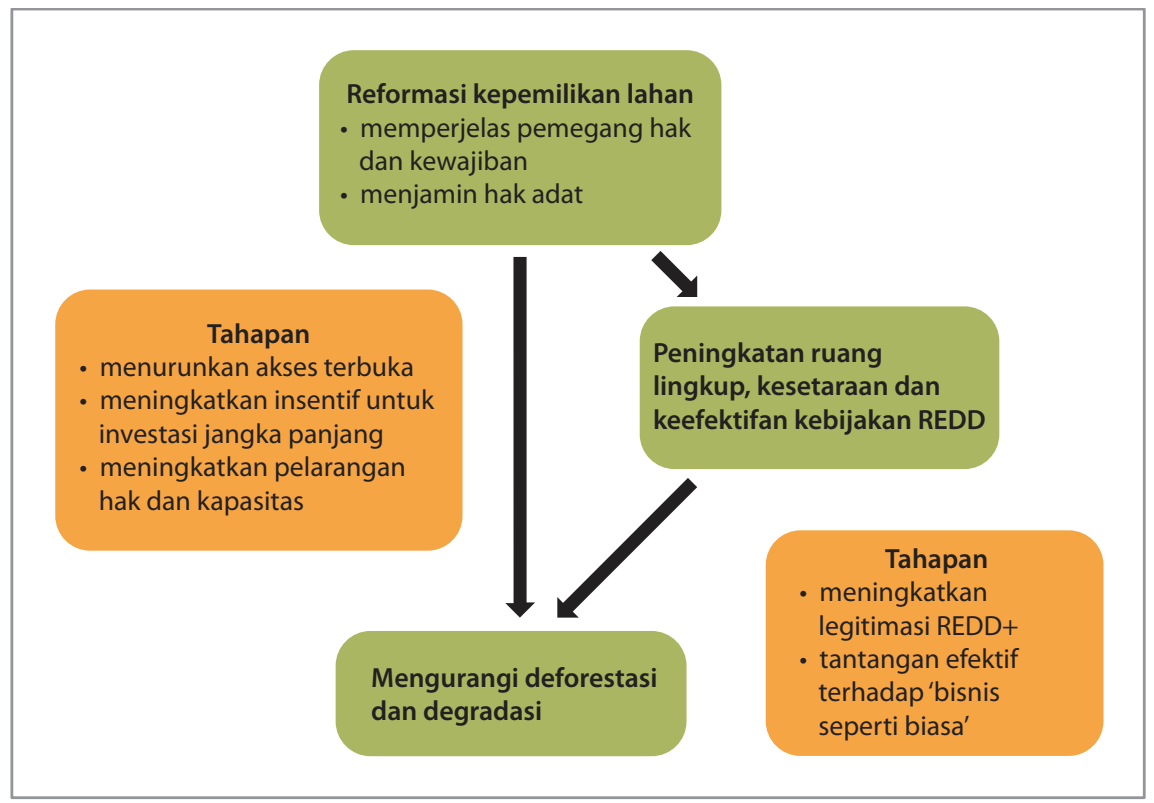

Gambar 9.1 Tahapan reformasi kepemilikan lahan untuk mengurangi deforestasi dan degradasi hutan 


\subsection{Mengapa penguasaan lahan penting bagi REDD+}

Hak penguasaan yang jelas dan aman atas lahan, hutan dan karbon telah diketahui sebagai elemen penting bagi keberhasilan strategi REDD+ (lihat Gambar 9.1). Di satu sisi, memperjelas dan memperkuat penguasaan lahan dengan sendirinya dapat memberikan kontribusi bagi penurunan deforestasi dan degradasi lahan. Banyak peneliti menemukan bahwa ketidakpastian penguasaan lahan umumnya mendorong pembukaan hutan, membuka dinamika akses dan penjarahan lahan. Karena itu persoalan ini telah banyak diperdebatkan, bahwa hak penguasaan lahan yang aman lebih cenderung mengarah pada konservasi hutan dan investasi hutan jangka panjang. Misalnya, petani sering membuka hutan untuk menegakkan hak asasi kadang-kadang sesuai dengan tuntutan hukum, tetapi juga untuk klaim hukum adat. Di mana hak-hak jangka panjang tidak aman, risiko untuk berinvestasi bagi produk yang lambat tumbuh seperti kayu terlalu tinggi; dan penetapan tata batas yang jelas dengan hak dan kemampuan untuk melarang orang luar mengurangi klaim yang saling bertentangan atau tumpang tindih. Namun dalam beberapa kasus, ketidakpastian telah dikaitkan dengan konservasi (karena takut kehilangan investasi) dan melindungi hak sama sekali tidak menjamin bahwa pemilik lahan tidak akan membuka hutan untuk alternatif yang lebih menguntungkan (Angelsen 2007). Meskipun demikian, penguasaan lahan yang terjamin umumnya membuat hutan lebih baik dibandingkan penguasaan lahan yang tidak terjamin. Namun kondisi keterjaminan ini saja tidak cukup untuk menjamin pengelolaan hutan yang lebih baik.

Karena itu, memperjelas penguasaan lahan, dan menjamin hak masyarakat berbasis hutan, juga meningkatkan kelangsungan kebijakan REDD+ dan menjamin kesetaraan, keefektifan dan efisiensi. Kebijakan spesifik yang mendukung REDD+ termasuk mengurangi rente dari kegiatan pertanian, meningkatkan rente hutan, dan menciptakan atau mengatur kawasan lindung, serta kebijakan lintas sektoral seperti desentralisasi atau reformasi tata kelola (Angelsen 2009b; Angelsen 2010b). Tidak setiap kebijakan harus melibatkan perhatian kepada penguasaan lahan. Misalnya, menciptakan peluang di luar lahan pertanian (off-farm) dan mendukung intensifikasi pertanian di lokasi-lokasi penting, sementara meninggalkan pembangunan jalan baru di kawasan hutan dapat memperlambat kolonisasi hutan dan bahkan merangsang migrasi keluar dari hutan. Hal ini mungkin menjadi penting bagi hutan jika migrasi dari produsen kecil dan menengah merupakan penyebab utama deforestasi dan degradasi lahan.

Menangani penguasaan lahan dapat secara substansial meningkatkan pilihan yang tersedia. Pilihan-pilihan ini termasuk kebijakan lain untuk mengurangi rente pertanian, seperti membangun jalan-jalan di hutan dengan peraturan yang ketat, atau kebijakan untuk meningkatkan rente hutan, seperti harga yang lebih baik bagi produk hutan, pengelolaan hutan kemasyarakatan atau 
pembayaran bagi skema jasa lingkungan. Berbagai peraturan kawasan lindung membutuhkan kejelasan dan penegakan hukum terkait dengan tata batas.

Pengabaikan persoalan penguasaan lahan membatasi lingkup dan potensi REDD+, menempatkan masyarakat berbasis hutan pada kondisi berisiko dan dapat menimbulkan pertentangan sehingga akan menjamin kegagalan (Larson dan Petkova 2011). Potensi risiko penyerobotan lahan oleh orang luar dan hilangnya hak pemanfaat lokal atas hutan dan lahan hutan adalah salah satu (meskipun bukan satu-satunya) alasan utama banyak masyarakat adat dan masyarakat lokal lainnya secara terbuka mengancam akan menentang REDD+, yang mengundang perhatian internasional yang substansial terhadap masalah ini di bawah slogan “Tanpa hak, Tidak ada REDD” (Tauli-Corpuz dkk. 2009; Kotak 9.1). Implikasi dari penguasaan lahan bagi REDD+ dapat diringkas sebagai berikut (lihat juga Sunderlin dkk. 2011):

\section{Keefektifan}

- Intisari REDD+ adalah untuk menghargai mereka yang memelihara atau meningkatkan penyerapan karbon dari hutan dan memberikan kompensasi kepada mereka untuk kesempatan yang hilang, yang dapat mencakup pembayaran langsung kepada pemilik lahan, yang akan memerlukan kejelasan pemegang hak atas lahan yang berhak untuk melarang pihak lain memegang hak yang sama (lihat Börner dkk. 2010).

- Pemegang hak atas karbon hutan harus bertanggung jawab jika mereka gagal memenuhi kewajiban mereka - bagian 'bersyarat' dari sejumlah insentif bersyarat.

\section{Efisiensi}

- Hak penguasaan lahan yang jelas mengurangi biaya transaksi, seperti waktu dan dana yang dibutuhkan untuk penyelesaian konflik.

- Hak penguasaan lahan yang terjamin meningkatkan pilihan kebijakan yang tersedia, sehingga memungkinkan pemerintah dan pemrakarsa proyek untuk memilih strategi implementasi yang lebih efektif biayanya.

\section{Kesetaraan}

- Ketika penguasaan lahan tidak jelas atau tidak diformalkan, masyarakat hutan dapat tersingkirkan dari hutan dan/atau menikmati berbagai manfaat REDD +. Khususnya, jika REDD + meningkatkan nilai hutan yang masih tegak, hal ini dapat menyebabkan serbuan terhadap sumberdaya yang menempatkan hak warga saat ini menghadapi risiko.

- Tidak terelakkan bahwa REDD+ akan melarang pemanfaatan sumberdaya hutan tertentu. Karena itu harus dilakukan proses dan kompensasi yang tepat, dan tanpa meningkatkan penderitaan masyarakat hutan yang miskin. 


\section{Kotak 9.1 Papua Nugini: Hak adat versus koboi karbon} Andrea Babon dan Daniel Mclntyre

Papua Nugini adalah unik di antara negara-negara REDD+ karena sekitar 97\% dari luas daratannya, dan hampir semua hutannya, dimiliki oleh pemilik tanah adat dan diatur oleh adat, bukan oleh negara. Penguasaan tanah adat ini tertera dalam konstitusi, dan pemilik tanah adat harus dimintai pendapat dan memberikan persetujuan mereka untuk setiap kegiatan pembangunan di lahan mereka. Tentunya pemilik lahan dapat memveto setiap kegiatan yang tidak mereka setujui. Dalam hal hak masyarakat adat, pemilik tanah adat memiliki hak akses, pemanfaatan, pengelolaan, dan pelarangan pihak luar. Namun, tanah adat tidak dapat 'dijual'.

Hak penguasaan lahan yang de jure kelihatannya kuat di Papua Nugini membuat negara ini menjadi sebuah studi kasus yang menarik untuk REDD+. Dalam banyak hal, pemilik lahan di Papua Nugini berada dalam posisi yang sangat kuat, sebagai pemilik sumberdaya, untuk berpartisipasi dalam REDD+ dengan kemauan mereka sendiri. Namun, dalam praktiknya, pemilik lahan banyak yang tidak menyadari hak mereka - sehingga mereka mudah dieksploitasi. Hal ini terlihat paling jelas dalam hal pemberian dan pembaruan konsesi penebangan, dan yang semakin banyak baru-baru ini dalam hal pemberian Special Agriculture dan Business Leases (SABLs) di wilayah lahan yang sangat luas. REDD+ ini terbukti tidak berbeda.

Pada tahun 2008-2009, laporan media mulai meliput pemilik lahan menandatangani hak atas karbon kepada para 'koboi karbon' - agen lokal yang jahat yang sering bekerja untuk pemrakarsa proyek karbon asing yang sebenarnya tidak memiliki kesadartahuan tentang apa yang mereka lakukan dan tidak ada kerangka hukum di dalamnya untuk melakukannya. Pada satu tahap, salah satu 'koboi karbon' yang paling terkenal mengklaim telah menegosiasikan sekitar 90 penawaran karbon yang berbeda dengan pemilik lahan, meskipun tidak ada strategi REDD+ tingkat nasional.

Pemerintah Papua Nugini mencoba untuk mengontrol 'serbuan karbon' dengan mewajibkan setiap kelompok yang tertarik dengan perdagangan karbon memiliki kewenangan tertulis untuk beroperasi di negara dan harus terdaftar pada Kantor Perubahan Iklim. Pemerintah juga mendesak para pemilik lahan untuk tidak menandatangani transaksi karbon apapun dengan pemrakarsa proyek luar sampai ada kerangka kebijakan dan hukum diberlakukan, dan tidak akan ada jalur hukum bagi pemilik lahan yang melakukannya.

Kebingungan dan skandal seputar 'koboi karbon' menyoroti kebutuhan untuk meningkatkan kesadartahuan secara umum dan informasi tentang REDD+ bagi pemilik lahan. Sebagai tanggapan, pemerintah dan LSM telah mengadakan sejumlah pertemuan konsultasi tingkat provinsi dan 
penyebaran informasi melalui berbagai media. Namun, sangat sulit untuk membuat informasi tersebut menjangkau masyarakat terpencil yang sering menjadi sasaran pemrakarsa proyek karbon.

Sorotan negatif dari media internasional, ditambah tekanan dari LSM dan para donor, tampaknya telah menarik perhatian besar kepada tantangan untuk mencapai REDD+ yang efektif, efisien dan setara dalam konteks penguasaan lahan tanah adat. Sang 'koboi karbon' sebagian besar telah menghilang dari lanskap REDD+ di Papua Nugini, dan kontrak yang mereka tandatangani umumnya dipandang tidak sah. Namun, para pemangku kepentingan terus bergulat dengan cara terbaik untuk melibatkan pemilik lahan dalam desain dan implementasi kebijakan REDD+; bebas aman, sebelum dan sesudah persetujuan; dan memastikan pemilik lahan menerima manfaat yang berarti. Bekerja di tengah semua masalah ini akan memakan waktu jika ingin dilakukan secara efektif - sesuatu yang gagal dimengerti oleh para 'koboi karbon'.

\subsection{REDD+ dan penguasaan lahan: Bukti dari lapangan}

Di lima dari enam negara yang diteliti, hutan utamanya merupakan milik publik dan secara resmi dikelola oleh negara (Tabel 9.1). Brasil merupakan pengecualian, karena $73 \%$ hutannya dimiliki oleh perorangan, perusahaan, masyarakat dan masyarakat adat pada tahun 2008. Data resmi menunjukkan hampir 200 juta hektar hutan berpindah tangan dari publik ke tangan swasta antara 2002 dan 2008 (Sunderlin dkk. 2008). Luas lahan yang dimiliki perorangan di negara-negara lainnya jauh lebih kecil. Di lima dari enam negara, sebagian dari lahan hutan publik telah dialokasikan untuk dimanfaatkan sementara oleh masyarakat dan masyarakat adat, dan juga oleh pihak perorangan di Brasil.

\subsubsection{Berbagai masalah dan kebijakan tingkat nasional}

Penelitian di tingkat nasional mengidentifikasi masalah serius yang terkait penguasaan lahan di semua negara yang diteliti (Tabel 9.2). Masalah yang umum di antaranya adalah tumpang tindih penguasaan atau klaim, penyerobotan lahan dan perebutan oleh elite, dan pencatatan pertanahan yang ketinggalan jaman atau tidak dilakukan. Secara khusus, di Kamerun, Indonesia, Tanzania, Vietnam, dan dalam beberapa hal di Peru, terdapat perbedaan besar antara pandangan masyarakat lokal mengenai hak adat mereka dengan perspektif negara mengenai hak formal mereka. Banyak masalah yang dihadapi orang dan masyarakat yang tinggal di dekat hutan timbul dari rasa ketidakpastian yang disebabkan oleh sifat penguasaan lahan hutan oleh publik. 
Tabel 9.1 Distribusi kepemilikan lahan hutan (data tahun 2008, dalam jutaan hektar)

\begin{tabular}{lrccr}
\hline Negara & \multicolumn{2}{c}{ Umum (jutaan ha, \%) } & \multicolumn{2}{c}{ Swasta (jutaan ha, \%) } \\
\cline { 2 - 5 } & $\begin{array}{l}\text { Dikelola oleh } \\
\text { pemerintah }\end{array}$ & $\begin{array}{l}\text { Ditetapkan untuk } \\
\text { digunakan oleh } \\
\text { masyarakat dan } \\
\text { masyarakat adat }\end{array}$ & $\begin{array}{l}\text { Dimiliki oleh } \\
\text { masyarakat dan } \\
\text { masyarakat adat }\end{array}$ & $\begin{array}{l}\text { Dimiliki oleh } \\
\text { perorangan } \\
\text { dan } \\
\text { perusahaan }\end{array}$ \\
\hline Brasil* & $88,6(21 \%)$ & $25,6(6 \%)$ & $109,1(26 \%)$ & $198,0(47 \%)$ \\
\hline Peru & $42,3(67 \%)$ & $2,9(5 \%)$ & $12,6(20 \%)$ & $5,3(8 \%)$ \\
\hline Kamerun & $20,1(95 \%)$ & $1,1(5 \%)$ & $0,0(0 \%)$ & $0,0(0 \%)$ \\
\hline Tanzania & $31,8(89 \%)$ & $1,6(4 \%)$ & $2,1(6 \%)$ & $0,1(0 \%)$ \\
\hline Indonesia & $121,9(98 \%)$ & $0,2(0 \%)$ & $0,0(0 \%)$ & $1,7(1 \%)$ \\
\hline Vietnam & $9,7(73 \%)$ & $0,0(0 \%)$ & $3,5(26 \%)$ & $0,1(0 \%)$
\end{tabular}

Sumber: Sunderlin dkk. 2008, kecuali untuk Vietnam (Dahal dkk. 2011)

* Sumber-sumber lain menemukan bahwa 24\% dari Amazon Brasil adalah lahan publik yang tidak terklasifikasikan dan 13\% terdiri dari proyek lahan pemukiman bagi pemilik lahan perorangan (Börner dkk. 2010).

Meskipun kepentingan penguasaan lahan hutan sudah nyata, penelitian sejauh ini menunjukkan bahwa hanya ada sedikit alasan untuk mempercayai strategi REDD+ akan membawa perubahan yang penting dari kondisi sekarang. Analisis yang didasarkan pada penggunaan analisis profil di negara yang dibahas di sini menunjukkan beberapa inisiatif penguasaan lahan baru yang penting dalam kaitannya dengan berbagai masalah yang diidentifikasi. Walaupun $90 \%$ dari Persiapan Proposal REDD+ (RPPs) dan Program Nasional dari UNREDD menyorot ketidakpastian penguasaan lahan sebagai keprihatinan (White dan Hatcher 2012), dan walaupun penguasaan lahan adalah topik yang populer selama wawancara dengan para pemangku kepentingan yang dilakukan untuk profil negara, perdebatannya masih pada tingkat retorika (lihat juga Williams dkk. 2011). Ukuran kebijakan yang tercantum dalam Tabel 9.2 paling sering merujuk pada kebijakan yang sudah ada di suatu negara dan tidak cukup untuk memecahkan masalah, atau dalam beberapa kasus adalah sumber masalah penguasaan lahan lainnya. Sebagai contoh, alokasi lahan yang ada dan inisiatif pencatatan lahan kadang menimbulkan ketidakpastian karena keterbatasan kapasitas teknis dan sumberdaya keuangan, peraturan dan prosedur yang tidak konsisten, dan kegagalan untuk 'mencocokkan' kebijakan dengan realitas di lapangan.

Di antara berbagai kasus, Brasil jelas merupakan pengecualian. Pemerintah Brasil meluncurkan program regularisasi lahan yang penting (alokasi dan pencatatan) yang mengaitkan reformasi penguasaan lahan dan pemenuhan kewajiban lingkungan di Amazon. Program ini juga mengakui dan memetakan 


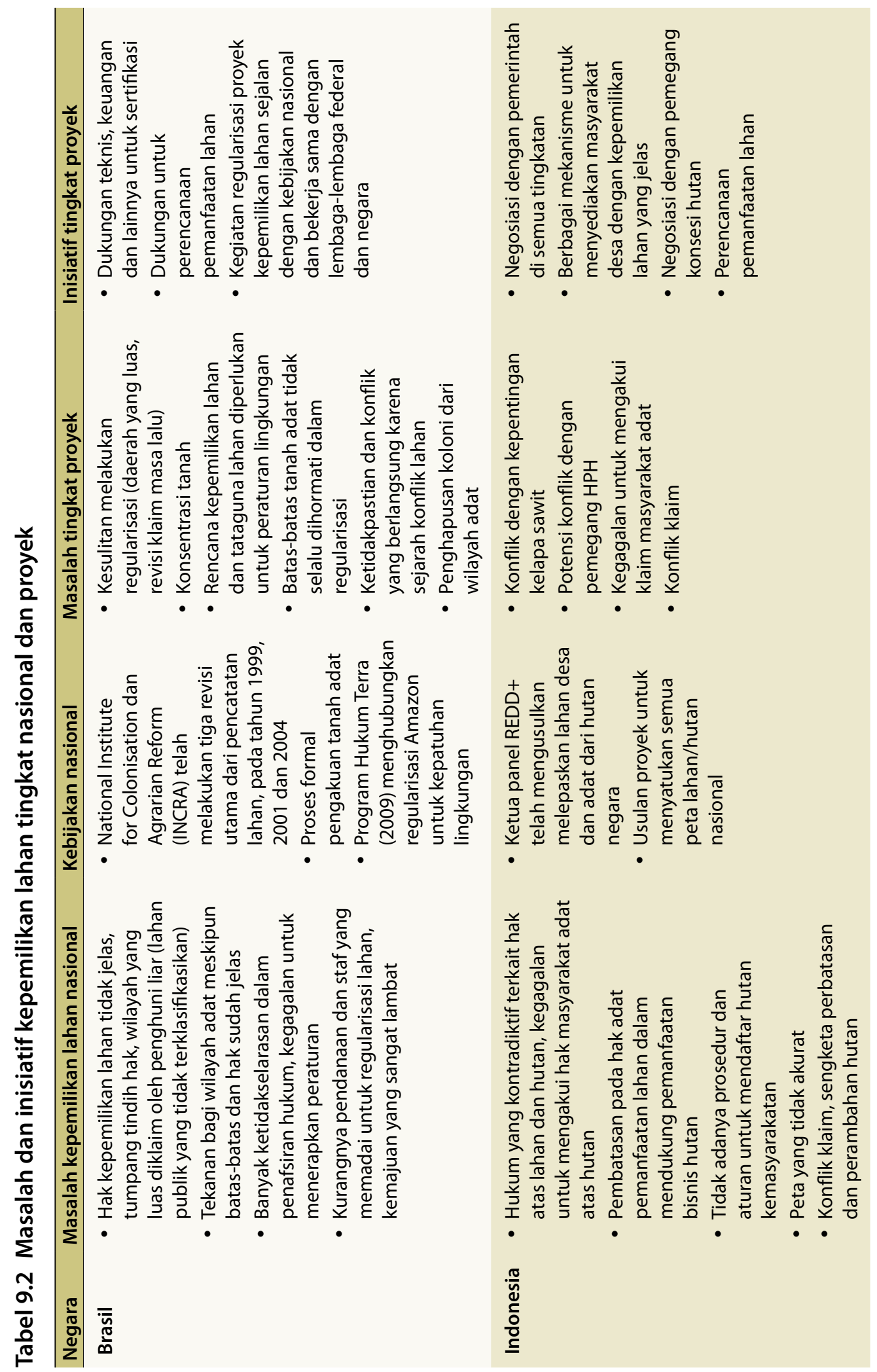

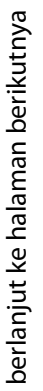




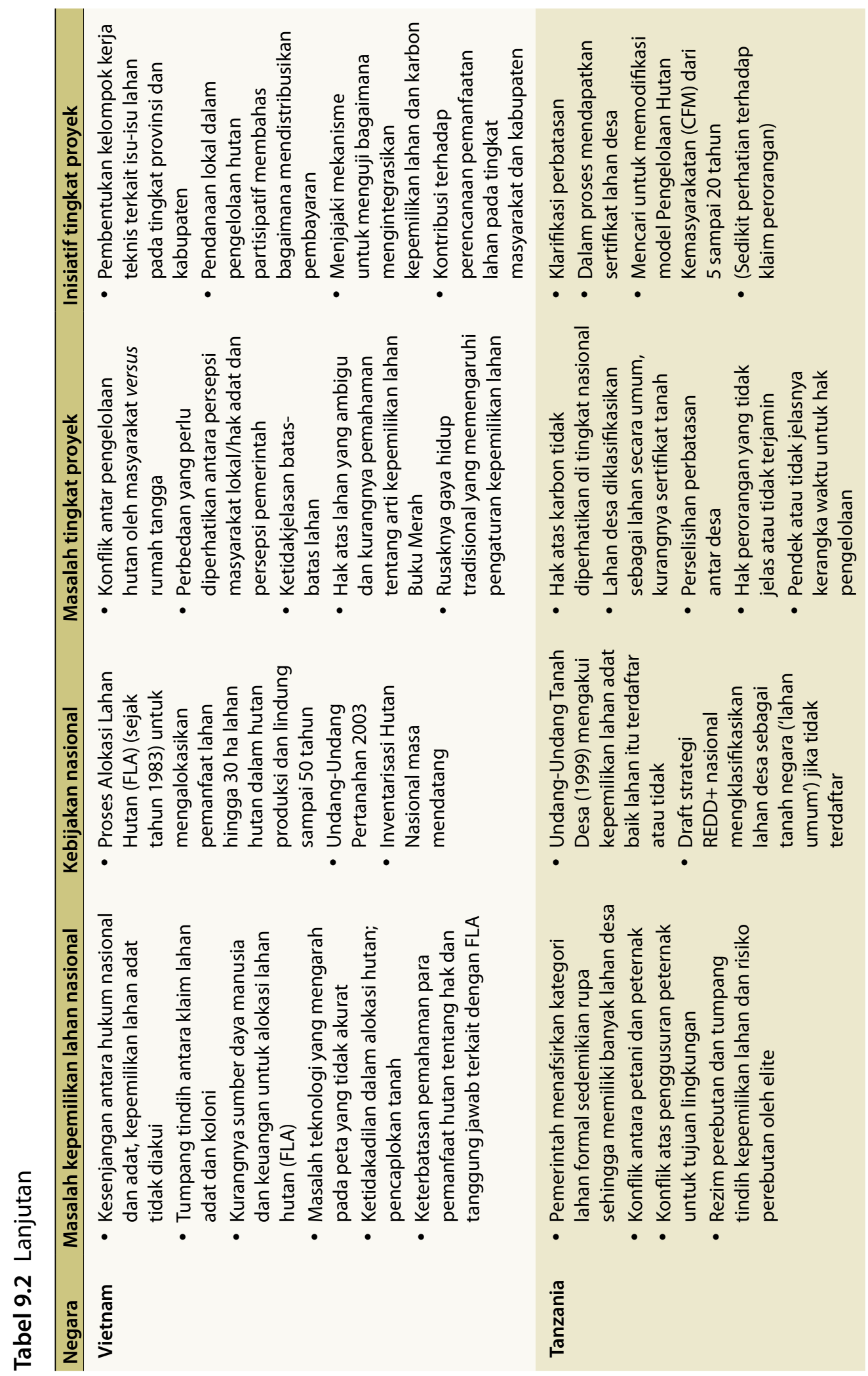




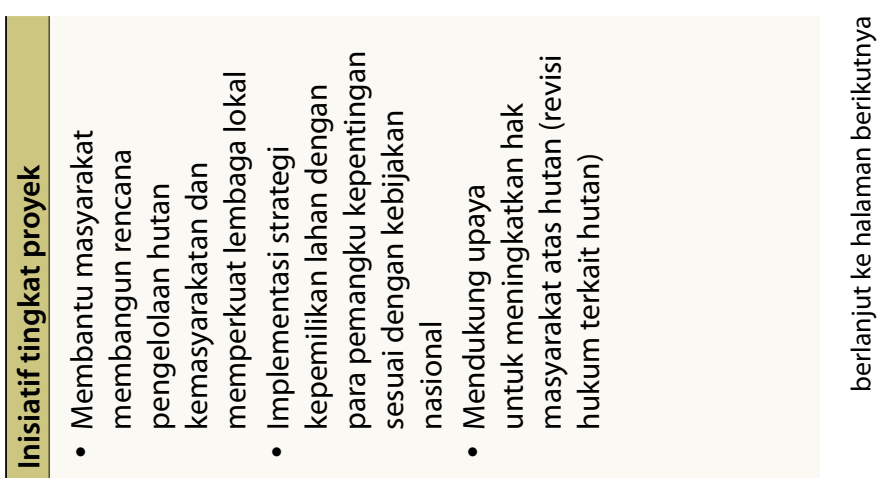

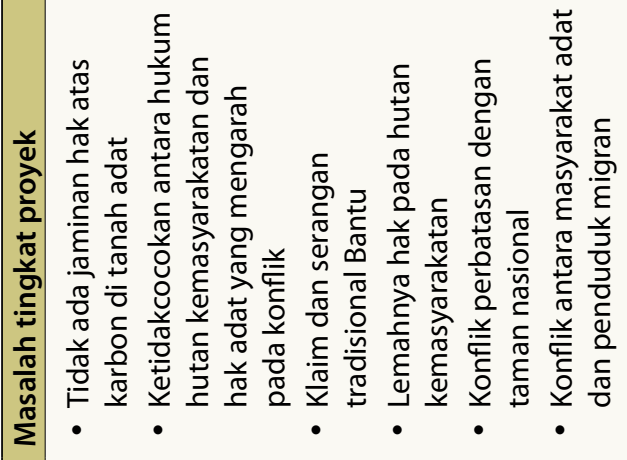
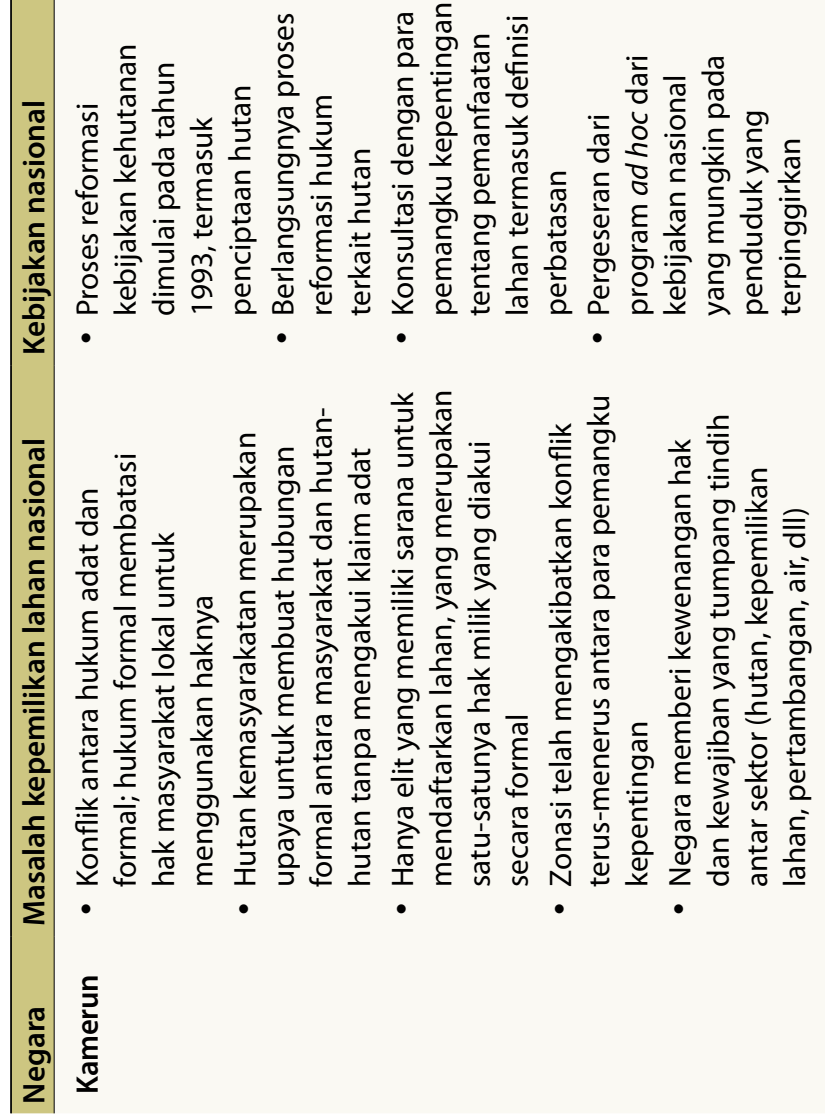


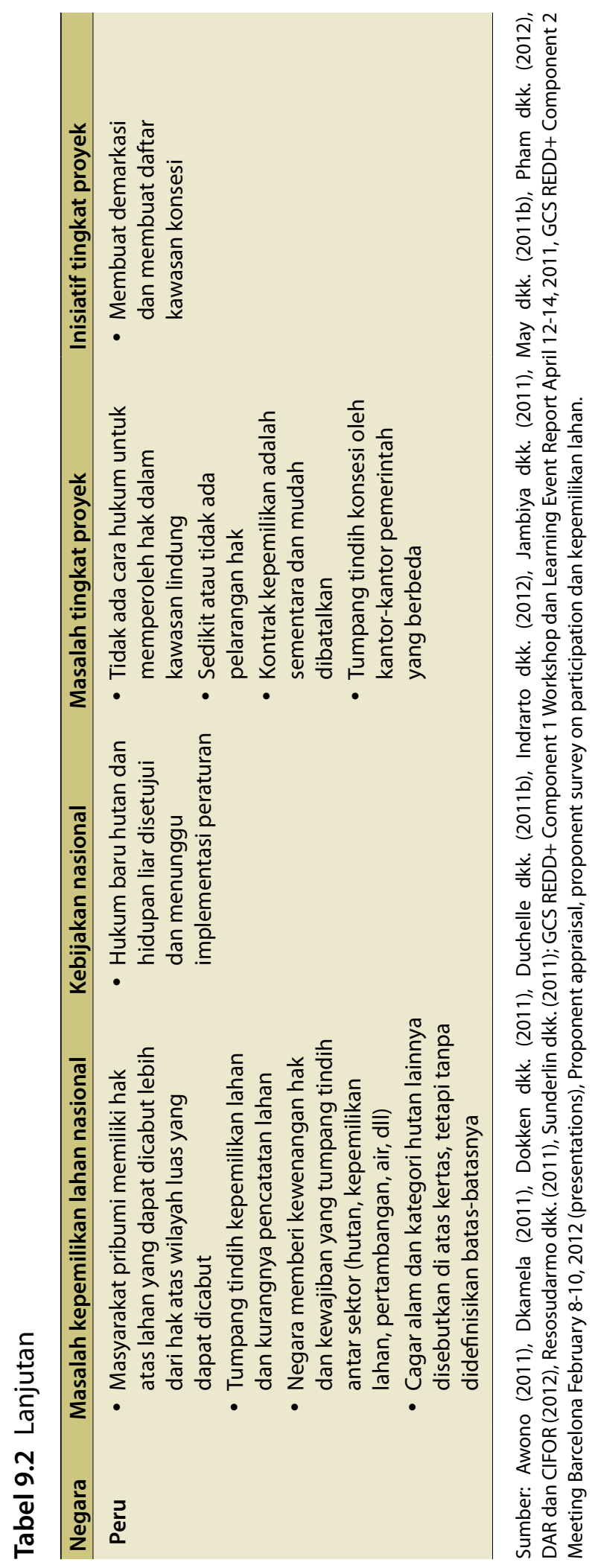


lahan adat, dan proses ini terus berlanjut, walaupun lambat dan penuh masalah. Negara-negara lain telah berusaha mengambil langkah-langkah kecil. Di Vietnam, proses Alokasi Lahan Hutan (Forest Land Allocation/ FLA) mendapat komentar yang beragam (Pham dkk. 2012) dan masih jauh dari mengakui hak adat (Kotak 9.2). Hal yang sama berlaku pada hutan kemasyarakatan di Kamerun. Baru-baru ini tuntutan atas pengakuan hak adat bagi hutan-hutan di Indonesia mendapat perhatian di tingkat tinggi, namun masih belum ada artinya dalam praktiknya.

Liputan tentang tata kelola dan penguasaan lahan masih sangat kurang dalam pemberitaan tentang REDD+ di media nasional di sebagian besar negara yang diteliti. Sebuah analisis atas sekitar 500 artikel surat kabar nasional tentang REDD+ yang diterbitkan antara tahun 2005 dan 2009 di lima dari enam negara (data Tanzania belum tersedia) menunjukkan bahwa isu-isu tata kelola tidak terlalu ditonjolkan dalam artikel media massa di berbagai negara tersebut

\section{Kotak 9.2 Mitos dan kenyataan: Jaminan hak atas hutan di Vietnam}

Thu Thuy Pham, Thu-Ba Huynh dan Moira Moeliono

Sistem penguasaan lahan hutan di Vietnam sebagian besar diatur oleh Undang-Undang Pertanahan $(1993,2003)$ dan Undang-Undang Perlindungan dan Pengembangan Hutan (2004). Undang-Undang Pertanahan menjamin keluarga petani dengan hak atas tanah yang stabil dan untuk jangka panjang: 20 tahun untuk lahan yang ditanami tanaman setahun atau semusim, dan 50 tahun untuk tanaman keras atau tahunan. Menurut Undang-Undang, tanah dan sumberdaya alam milik 'masyarakat' secara keseluruhan dan dikelola oleh 'negara' atas nama mereka. Oleh karena itu, negara memiliki hak pengelolaan dan pengambilan keputusan secara eksklusif atas hutan alam, kemudian mengalokasikan pemanfaatan hak tersebut kepada rakyat. Sejak tahun 1999 (SK 163), hak pemanfaatan lahan, yang diterbitkan melalui sertifikat pemanfaatan lahan yang disebut Buku Merah, dapat dipindahkan, digadaikan, disewakan, dipertukarkan, atau diwariskan dan berlaku selama 50 tahun.

Pada 2004, Undang-Undang Perlindungan dan Pengembangan Hutan disahkan, yang memberikan pemanfaat hutan hak pengelolaan atas hutan, serta hak untuk menghasilkan pendapatan dan manfaat lain dari kerja dan investasi mereka di lahan hutan. Sorotan utama dari Undang-Undang ini adalah pengakuan negara atas peran dan hak masyarakat sebagai salah satu cara pengelolaan lahan hutan. 


\section{Kotak 9.2 Lanjutan}

Undang-Undang ini memberikan landasan hukum yang penting bagi masa depan implementasi REDD+. Namun demikian, dua masalah utama telah muncul dan perlu mendapat perhatian dari para pengambil keputusan dan penyusun strategi REDD+.

Pertama, lebih dari 50\% hutan negara dan sering hutan-hutan kualitas tertinggi dikelola oleh perusahaan negara dan dewan pengelola. Sementara rumah tangga mengelola $18 \%$ dan masyarakat hanya $1 \%$ dari sebagian besar hutan yang berkualitas buruk dan terdegradasi (Hoang dkk. 2010). Walaupun perusahaan negara diharuskan untuk menyewakan lahan hutan di bawah kendali mereka kepada pihak ketiga untuk pemanfaatan atau perlindungan jangka panjang, dalam praktiknya mereka sering mengontrak pihak ketiga secara tahunan. Selain itu, hampir tidak mungkin bagi masyarakat untuk masuk ke dalam kontrak hukum karena persyaratan yang berlebihan di bawah Hukum Perdata 2005 Vietnam untuk mendapatkan status legal mereka. Dalam kenyataannya, masyarakat tidak dapat menandatangani kontrak REDD+. Karena itu dana REDD+ di masa depan mungkin dipegang oleh pemerintah, dengan hanya sangat sedikit pembayaran dan manfaat karbon yang diperoleh rumah tangga dan masyarakat yang merupakan pengelola hutan yang sebenarnya.

Kedua, pengalaman dari implementasi Undang-Undang Pertanahan dan Undang-Undang Perlindungan dan Pengembangan Hutan, serta program nasional lainnya seperti Alokasi Lahan Hutan (FLA), menunjukkan hasil yang beragam. Di beberapa tempat program ini berpengaruh positif pada petani miskin, sedangkan dampak keseluruhan tidak jelas. Rumah tangga dan masyarakat masih tidak dapat mengontrol hutan-hutan mereka, karena mereka masih perlu meminta izin dari instansi terkait untuk menggunakan lahan hutan atau menebang pohon. Selain itu, tiga masalah lain menghalangi pemilik adat dan bahkan pemilik yang diakui dan mungkin sebenarnya menciptakan kondisi akses terbuka:i) kesenjangan antara hukum nasional dan praktik pemanfaatan lahan berdasarkan hukum adat, ii) akumulasi modal bagi rumah tangga yang memiliki akses ke politik kekuasaan dan jaringan sosial, dan iii) penegakan peraturan yang buruk yang memengaruhi keefektifan FLA. Lahan hutan yang dialokasikan sering tidak subur dan, dengan tidak adanya dukungan keuangan dan teknis dari pemerintah, lahan sering mudah ditinggalkan. Namun yang lebih serius, lahan yang diklasifikasikan oleh pemerintah sebagai 'tidak terpakai' sebenarnya di bawah penguasaan lahan adat, yang tidak secara resmi diakui hukum. FLA tidak mengizinkan penguasaan bersama pada tingkat rumah tangga dan masyarakat, yang membatasi hak perempuan dan melemahkan sistem produksi dataran tinggi yang didasarkan pada pendekatan lahan milik bersama. 


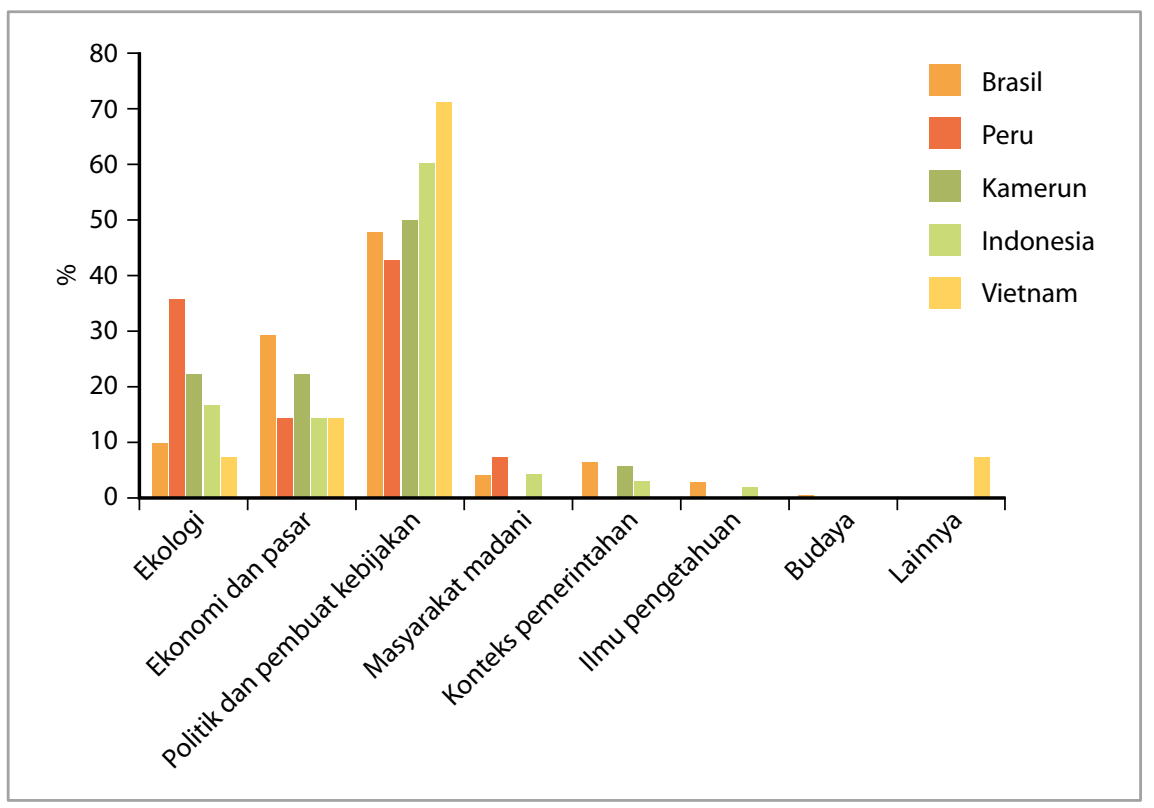

Gambar 9.2 Metatopik artikel media nasional (persentase dari total artikel surat kabar yang dianalisis per negara)

(Gambar 9.2). ${ }^{1}$ Satu pengamatan yang lebih dekat mengenai subtopik yang spesifik berkaitan dengan reformasi penguasaan lahan dan hak atas karbon di bawah meta-topik 'Politik dan pengambilan kebijakan' menegaskan kesenjangan ini. Hanya di Indonesia dan Brasil terdapat artikel media yang secara eksplisit membingkai seputar masalah ini: di Brasil, 11 artikel subtopik 'REDD+ dan kebijakan hak adat' yang diadvokasi oleh perwakilan organisasi hak asasi manusia dan pelaku negara subnasional. Di Indonesia satu artikel juga menggunakan bingkai ini dan diadvokasi oleh organisasi penelitian internasional, sementara artikel kedua memberikan perhatian dengan penegakan hak atas karbon dan didukung oleh pelaku pemerintah tingkat nasional. Analisis awal artikel dari tahun 2010-2011 di Indonesia, Vietnam dan Peru tidak menunjukkan perubahan yang penting.

Namun demikian, dengan memeriksa pernyataan posisi masing-masing pendukung atau lawan yang menanggapi isu yang dibingkai dalam artikel,

1 Sebuah bingkai media adalah "satu tema pengorganisasian yang luas untuk memilih, menekankan dan menghubungkan berbagai elemen dari sebuah cerita seperti adegan, karakter, tindakan mereka dan dokumentasi pendukung" (Bennett 1996, seperti dikutip dalam Boykoff 2008:555). Dalam praktiknya sebuah bingkai adalah lensa konseptual yang membawa aspek-aspek tertentu dari realitas pada fokus yang lebih tajam (menekankan cara tertentu untuk memahami masalah) sementara menurunkan lainnya untuk latar belakang. 
kami mengidentifikasi sejumlah sikap yang berkaitan dengan tata kelola. Di Indonesia, Brasil dan Peru, para pelaku menyatakan bahwa REDD+ akan memerlukan reformasi tata kelola dan reformasi kelembagaan. Di Indonesia lebih dari $10 \%$ dari semua posisi yang dinyatakan (yaitu 27 dari 258) yang menunjukkan perhatian bahwa REDD+ berisiko merampas atau mengurangi akses ke sumberdaya hutan dan merugikan para pemanfaat hutan tradisional (lihat Bab 5). Temuan awal menunjukkan bahwa walaupun artikel jarang terbingkai dengan isu tata kelola dan kelembagaan, sejumlah pelaku menempatkan diri mereka di seputar isu ini.

Organisasi-organisasi yang menyatakan kepedulian terhadap penguasaan lahan utamanya adalah hanya pelaku dari organisasi lingkungan nonpemerintah internasional dan organisasi masyarakat madani dalam negeri. Namun analisis tingkat-pelaku menunjukkan bahwa tidak satu pun dari kelompok-kelompok ini yang oleh para pelaku lain dipandang berpengaruh di ranah kebijakan di sebagian besar jaringan kebijakan nasional, di mana Kementerian Kehutanan dan entitas negara lainnya berada di pusat pengambilan keputusan.

\subsubsection{Penguasaan lahan tingkat proyek}

Penelitian GCS menelaah masalah penguasaan lahan di tingkat desa dan proyek melalui wawancara dengan para pemrakarsa, dan wawancara tingkat desa dan kelompok terfokus. Para pemrakarsa melaporkan tentang tantangan utama penguasaan lahan di lokasi mereka masing-masing, dan kelompok terfokus desa ditanya tentang konflik dan ketidakpastian penguasaan lahan, kehadiran pengguna hutan eksternal dan tingkat kepatuhan terhadap peraturan, yang secara khusus terkait dengan desa mereka.

Sebagian besar lahan di lokasi penelitian proyek REDD+ secara formal dimiliki oleh negara. Di Indonesia, Kamerun dan Peru, sebagian besar lahan di desa-desa yang diteliti adalah milik dan dikelola oleh pemerintah tetapi secara de facto di bawah kendali rumah tangga dan desa. Di Indonesia, penguasaan timbul dari tumpang tindih klaim lahan, termasuk konsesi pembalakan yang ditinggalkan, pembalak skala kecil, kepentingan kelapa sawit, pertambangan dan penebangan yang lebih besar. Kepentingan kelapa sawit mengancam sejumlah lokasi proyek. Satu lokasi, masing-masing di Kamerun dan Peru, terletak di dalam kawasan lindung di mana hak lahan secara hukum tidak diberikan kepada masyarakat lokal. Lokasi lainnya di Kamerun adalah di area yang ditetapkan sebagai hutan kemasyarakatan (HKM). Isu penguasaan lahan mencakup sifat ketidakterjaminan hak masyarakat (diperpanjang setiap 5 tahun), tumpang tindih klaim dan konflik antara warga desa yang berada di dalam dan di luar kawasan HKM. Pengguna hutan di lokasi kedua di Peru memiliki kontrak konsesi 40 tahun untuk budidaya kacang Brasil. Kebijakan pemerintah merupakan sumber konflik, karena instansi pemerintah yang berbeda memberikan konsesi yang tumpang tindih untuk wilayah hutan yang sama kepada pemangku kepentingan yang berbeda (Selaya, komunikasi pribadi). 
Di Brasil, hampir semua lahan di desa-desa dalam studi adalah lahan negara yang secara resmi ditetapkan bagi perorangan yang tinggal di proyek pemukiman reformasi lahan atau menempati lahan publik yang tidak terklasifikasi. Dua dari lokasi proyek ini berada di kawasan dengan sejarah konflik lahan dan sumberdaya yang serius, namun proyek penyelesaian dan pencatatan telah berjalan selama beberapa tahun. Di lokasi ketiga, regularisasi adalah kegiatan baru di bawah program penyiapan REDD+. Sementara masih terjadi konflik, tumpang tindih klaim dan rumah tangga tanpa hak atau penguasaan formal, masalah pokok yang terkait penguasaan lahan berkisar pada logistik regularisasi - sebuah proses yang mahal, lambat, dan birokratis dan kadang gagal menghormati adat yang ada atau klaim yang sah secara lokal (Duchelle dkk. 2011b).

Di Vietnam, di empat desa yang diteliti di satu lokasi proyek, sebagian besar hutan telah diberikan kepada perorangan melalui sertifikat lahan yang dikenal sebagai Buku Merah. Sertifikat ini telah menimbulkan masalah, karena pemegang hak tidak memahami keterbatasan mereka. Terdapat masalah pasar lahan ilegal yang penting dan masalah dengan batas-batas tidak jelas (Huynh, komunikasi pribadi). Hak tanah adat masih kuat, tetapi ada perbedaan yang penting antara persepsi dan pemahaman pemerintah dan warga desa.

Di Tanzania, proyek REDD+ sedang dikembangkan di daerah di mana bagian penting dari lahan sedang dalam proses ditetapkan untuk atau dimiliki oleh masyarakat (lihat Kotak 9.3). Masalah penguasaan lahan di lokasi proyek timbul terutama dari kurangnya sertifikat lahan desa formal di lahan yang ditetapkan, yang menyebabkan sengketa lahan secara formal berada di bawah penguasaan negara, dan sengketa perbatasan.

Tabel 9.3 dan 9.4 merangkum hasil dari kelompok fokus tingkat desa atas pertanyaan tentang kejelasan dan jaminan penguasaan lahan. Pertanyaan-pertanyaan ini tidak ditanyakan dalam kaitannya dengan REDD + atau intervensi proyek tetapi ditujukan untuk mengatasi situasi penguasaan lahan keseluruhan sebelum intervensi. Tabel 9.3 menunjukkan tanggapan atas konflik lahan, persepsi ketidakpastian hak dan kepatuhan terhadap peraturan tentang hutan oleh warga desa. Adanya konflik perlu diperhatikan terutama di lokasi penelitian di Kamerun (83\%), Indonesia (55\%) dan Brasil (44\%), walaupun bagian penting dari desa-desa di Tanzania juga memiliki lahan yang berada dalam konflik (24\%). Pertanyaan langsung tentang masalah ketidakpastian juga ditemukan bahkan di luar desa-desa yang diteliti, berkisar dari 100\% di Kamerun, sampai 85\% di Indonesia, 50\% di Brasil dan 32\% di Tanzania. Hanya di Vietnam tidak terdapat laporan di tingkat desa, baik tentang konflik ataupun rasa ketidakpastian. Kepatuhan terhadap peraturan pemanfaatan hutan masih penuh masalah di desa lokasi penelitian di semua negara. Hanya di Vietnam saja yang tidak ada laporan mengenai sengketa atau ketidakamanan di tingkat desa. Tingkat kepatuhan terhadap peraturan pemanfaatan hutan merupakan masalah di desa-desa 


\section{Kotak 9.3 Pengelolaan hutan partisipatif sebagai landasan kelembagaan untuk REDD+ di Tanzania}

Therese Dokken

Sejak tahun 1990-an, Tanzania telah menggalakkan Pengelolaan Hutan Partisipatif (PFM) sebagai strategi untuk konservasi dan pengelolaan berkelanjutan hutan-hutan mereka. Pada tahun 2006 sekitar $10 \%$ lahan hutan berada di bawah perjanjian PFM. Dalam Strategi Nasional Tanzania, PFM diidentifikasi sebagai landasan kelembagaan untuk REDD+, dan akses keuangan REDD+ dapat berpotensi melancarkan dan mempercepat implementasinya.

Tujuan utama PFM adalah untuk meningkatkan mata pencaharian pedesaan, melestarikan dan regenerasi sumberdaya hutan, danmendorong tatakelolayang baik. Ada dua pendekatan PFM yang berbeda dalam hal tingkat desentralisasi hak dan tanggung jawab. Pendekatan pertama adalah pengelolaan hutan berbasiskan masyarakat (PHBM/CBFM). CBFM berlangsung di lahan yang terdaftar di bawah Undang-Undang Tanah Desa (1999) dan dikelola oleh dewan desa. Desa ini memiliki hak penguasaan penuh dan tanggung jawab pengelolaan serta menguasai semua pendapatan yang dihasilkan dari hutan. Pendekatan kedua adalah pengelolaan kolaboratif, disebut pengelolaan hutan bersama (PHB/JFM). Pendekatan ini berlangsung di cagar alam hutan nasional atau pemerintah daerah. Penguasaan lahan tetap di tangan negara, sementara tanggung jawab pengelolaan hutan dan pendapatan dibagi antara negara dan masyarakat dan diresmikan melalui perjanjian JFM.

Hasil evaluasi menunjukkan bahwa kedua pendekatan PFM berkontribusi terhadap perbaikan pengelolaan hutan, namun CBFM tampaknya lebih efektif daripada JFM (Blomley dkk. 2011). Hak penguasaan yang eksklusif dan dilaksanakan memberikan insentif bagi masyarakat untuk berinvestasi dalam pengelolaan jangka panjang. Sebaliknya, di bawah JFM hakyang tidakjelas serta pemanfaatan lokal dan panen produk hutan sangat dibatasi. Hal yang sama juga berlaku pada mekanisme pembagian keuntungan dan aspek kesetaraan dari dua pendekatan PFM. Sementara semua manfaat ditransfer ke masyarakat di bawah PHBM, tidak ada kesepakatan mengenai porsi manfaat pengelolaan hutan yang harus ditransfer ke masyarakat yang terlibat dalam JFM. Keefektifan dan kesetaraan merupakan pertimbangan penting untuk memilih strategi PFM yang diikuti dalam proyek-proyek REDD+. Diperlukan perbaikan dan klarifikasi mekanisme penguasaan lahan dan pembagian manfaat, khususnya di bawah JFM, untuk memastikan insentif yang cukup untuk pengelolaan hutan yang berkelanjutan.

yang menjadi lokasi penelitian di semua negara. Namun Vietnam melaporkan tingkat kepatuhan rendah sampai sedang di semua semua desa penelitian, di Brasil 75\% dari desa-desa yang diteliti dan di tiga negara lainnya tingkat kepatuhannya 50\%-55\%. 
Tabel 9.3 Konflik lahan, ketidakpastian dan kepatuhan peraturan hutan lokal di desa-desa sampel menurut negara (dalam angka dan persen)

\begin{tabular}{|lcccc}
\hline Negara & $\begin{array}{l}\text { Desa dengan } \\
\text { wilayah lahan } \\
\text { dalam konflik }\end{array}$ & $\begin{array}{l}\text { Desa dengan } \\
\text { ketidakpastian } \\
\text { kepemilikan } \\
\text { lahan } \\
\text { setidaknya } \\
\text { sebagian dari } \\
\text { lahan desa }\end{array}$ & $\begin{array}{l}\text { Desa dengan } \\
\text { kepatuhan } \\
\text { peraturan } \\
\text { hutan } \\
\text { rendah atau } \\
\text { sedang oleh } \\
\text { warga desa }\end{array}$ & $\begin{array}{l}\text { Jumlah total } \\
\text { desa dalam } \\
\text { sampel }\end{array}$ \\
\hline Brasil & $7(44 \%)$ & $8(50 \%)$ & $12(75 \%)$ & 16 \\
\hline Cameroon & $5(83 \%)$ & $6(100 \%)$ & $3(50 \%)$ & 6 \\
\hline Tanzania & $6(24 \%)$ & $8(32 \%)$ & $13(52 \%)$ & 25 \\
\hline Indonesia & $11(55 \%)$ & $17(85 \%)$ & $11(55 \%)$ & 20 \\
\hline Vietnam & $0(0 \%)$ & $0(0 \%)$ & $4(100 \%)$ & 4 \\
\hline
\end{tabular}

Catatan: mencakup semua lokasi proyek kecuali Berau, Indonesia dan Peru

Sumber: Sunderlin dkk. (2011) dan Database Survei Desa

Tabel 9.4 membahas hak untuk tidak mengijinkan pihak luar yaitu hak dan kemampuan untuk melarang pemanfaat hutan dari luar yang tidak diinginkan. Menariknya, hampir semua desa melaporkan memiliki hak untuk melarang orang luar dari lahan mereka (88\%-100\%). Namun yang paling mencolok adalah bahwa di Brasil, Kamerun, Tanzania dan Indonesia karena sebagian besar desa-desa menyatakan bahwa dasar dari hak adalah adat, sedangkan hanya 6\%-20\% dari desa-desa di negara-negara ini menyatakan bahwa hak ini didasarkan pada hukum formal. ${ }^{2}$ Sebaliknya, sekali lagi desa-desa di Vietnam semuanya menekankan hak formal.

Tiga pertanyaan terakhir dalam Tabel 9.4 mengacu pada keberadaan aktual pemanfaat lahan eksternal, apakah mereka dilarang, dan apakah upaya yang telah dilakukan untuk melarang masuk pemanfaat eksternal mengalami kegagalan. Proporsi pemanfaat eksternal mencapai 44\% (di Tanzania) sampai 90\% (di Indonesia) dari desa yang diteliti. Pengguna hutan eksternal dilarang di kebanyakan kasus atau semua di Tanzania dan Kamerun, dan sekitar setengahnya di Brasil. Selain itu, fakta bahwa beberapa pengguna memiliki 'izin' tidak selalu berarti mereka memiliki izin desa. Sebagai contoh, meskipun hanya $28 \%$ dari desa-desa di Indonesia melaporkan bahwa pengguna eksternal dilarang, pada $72 \%$ lainnya, pengguna musiman dan secara adat kemungkinan memiliki izin dari desa, sedangkan perkebunan, perusahaan agroindustri dan

2 Pertanyaan-pertanyaan ini ditanyakan dengan cara enumerator membacakan pilihan, dan diperbolehkan memberi lebih dari satu jawaban. 


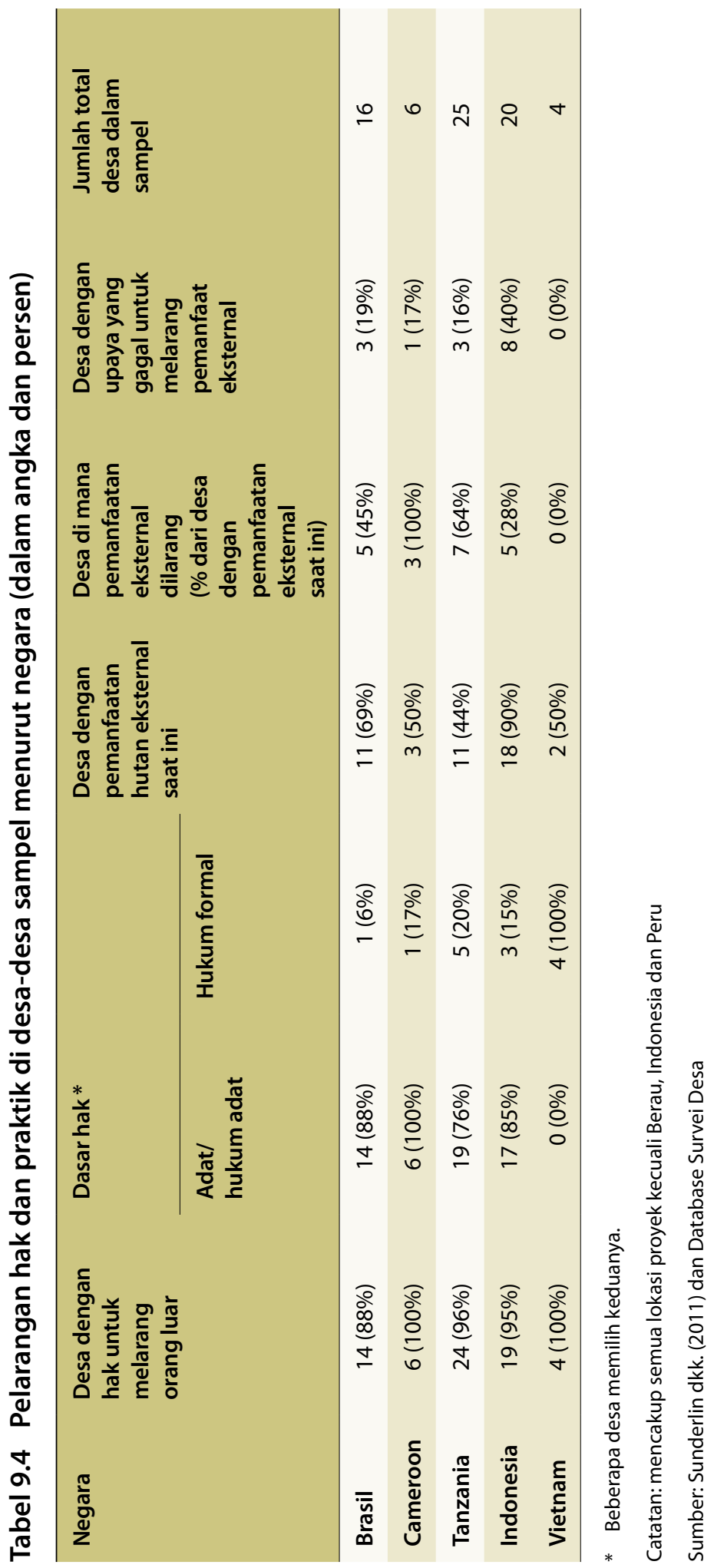


konsesi pembalakan kemungkinan besar memiliki izin dari kantor pemerintah tetapi bukan dari desa. Akhirnya, beberapa desa di setiap negara, kecuali Vietnam, telah gagal mencoba untuk melarang pengguna hutan eksternal (16\%-19\% di Brasil, Kamerun dan Tanzania dan 40\% di Indonesia).

\subsubsection{Solusi di tingkat proyek}

Hampir semua pemrakarsa proyek mengidentifikasi masalah penguasaan lahan di lokasi mereka dan melihat resolusi hal ini sebagai hal pokok untuk melangkah maju dengan proyek-proyek REDD+ (Tabel 9.2). Mereka mengambil tindakan awal untuk mengidentifikasi sumber-sumber ketidakpastian dan konflik, dan untuk mengatasi penyebab di mana mungkin, dengan menjamin penguasaan lahan bagi para pemangku kepentingan lokal saat hal ini tepat dan mungkin, memperjelas batas-batas desa dan hutan jika diperlukan; dan mengidentifikasi dan melakukan pembatasan wilayah hutan untuk disisihkan (Sunderlin dkk. 2011). Menjamin hak penguasaan lahan sering melibatkan negosiasi atau bekerja sama dengan badan ${ }^{3}$ pemerintah yang bertanggung jawab atas lahan, dan kadang mendukung lembaga-lembaga melalui bantuan teknis atau dana.

Ketika mekanisme yang ada untuk menjamin hak tidak memadai, beberapa pemrakarsa telah memainkan peran advokasi, seperti melobi untuk mereformasi konsesi hutan kemasyarakatan di Kamerun, yang hanya menyediakan hak selama jangka lima tahun. Beberapa menggalakkan strategi untuk memperjelas hak atas karbon, dan dalam beberapa kasus juga mengadvokasi hak desa. Di lokasi di mana terdapat tumpang tindih klaim yang penting - seperti konsesi kelapa sawit di Indonesia - pemrakarsa mencurahkan bagian penting dari energi mereka untuk penguasaan lahan agar mengatasi berbagai kontradiksi ini.

Hanya sekitar setengah dari pendukung yang diwawancarai (9 dari 19) merasa puas dengan hasil berbagai upaya mengatasi masalah penguasaan lahan di lokasi mereka, tiga merasa puas dan juga tidak puas, dan lima merasa tidak puas (dua tidak memiliki pendapat). Namun, bahkan mereka yang merasa puas menyatakan bahwa masih banyak lagi yang harus dilakukan. Di beberapa lokasi, seperti satu di Tanzania, pemrakarsa menyatakan bahwa mereka telah dipaksa untuk mengecualikan beberapa wilayah karena masalah dengan penguasaan lahan tidak dapat diatasi (Sunderlin dkk. 2011).

3 Perhatikan bahwa dalam beberapa kasus para pemrakarsa adalah entitas pemerintah, seperti di Acre, Brasil. 


\subsection{Mengatasi kendala}

Masalah penguasaan lahan menghadirkan hambatan bagi keefektifan, efisiensi dan kesetaraan hasil REDD+. Pada tingkat lokasi, pemrakarsa proyek hampir semuanya telah memberikan perhatian serius terhadap penguasaan lahan dan berusaha mengatasi masalah ini dengan cara terbaik menurut kemampuan mereka. Namun demikian, mereka sangat terbatas untuk bekerja melalui jalur birokrasi pemerintah yang ada dan berada di bawah kendala dari kebijakan saat ini. Oleh karena itu, dalam banyak kasus berbagai upaya pendukung dibatasi oleh kurangnya perhatian serius terhadap penguasaan lahan pada tingkat kebijakan nasional (lihat Bab 6).

Hal ini tidak terjadi di Brasil, di mana regularisasi lahan sudah berlangsung sebelum perjanjian REDD+, namun REDD+ telah menghasilkan insentif tambahan untuk melangkah maju dengan reformasi, melalui kegiatan-kegiatan seperti dukungan terhadap Hukum Pertanahan di lokasi proyek. Pendukung dapat bekerja sama dengan pemerintah untuk mengatasi isu-isu penguasaan lahan (Duchelle dkk. 2011b). Namun, bahkan di Brasil, sistem regularisasi yang ada tidak memecahkan semua masalah dan dalam beberapa kasus menciptakan masalah baru.

Di sebagian besar negara-negara lainnya yang diteliti, reformasi kebijakan secara substansial di bidang penguasaan lahan saat ini tampaknya tidak mungkin. Di Vietnam, usulan untuk reformasi kebijakan Buku Merah menghadapi perlawanan. Demikian pula, ada indikasi bahwa pendekatan hak adat di Tanzania atau Kamerun akan mengalami perubahan radikal. Baru-baru ini di Indonesia, pernyataan berani dari seorang pemimpin pemerintahan tingkat tinggi untuk mendukung hak penguasaan lahan hutan secara adat menunjukkan bagaimana mobilisasi kesaksian dan para pemangku kepentingan yang berani melalui inisiatif REDD+ telah memberikan dukungan bagi kebijakan penguasaan lahan yang baru. Meskipun tuntutan untuk reformasi telah datang dari tingkat tinggi, ada banyak lapisan pemerintahan dan banyak pemangku kepentingan yang kuat lainnya yang telah menolak semua reformasi seperti di masa lalu.

Dalam keadaan ini, bagaimana REDD+ bisa melangkah maju? Masalah penguasaan lahan yang dibahas di atas dapat dikelompokkan ke dalam beberapa masalah utama. Ringkasannya dapat dilihat dalam Tabel 9.5, beserta implikasinya bagi REDD+ dan solusi potensialnya. Beberapa masalah jelas membutuhkan regularisasi atau reformasi lahan, seperti kurangnya kejelasan penguasaan dan tumpang tindih klaim atau resolusi konflik antara hak adat dan penguasaan negara. Masalah lain meliputi perambahan oleh pelaku eksternal, konsesi ganda di lahan yang sama, kelemahan dalam penegakan peraturan, masalah dengan proses regularisasi lahan dan representasi lokal yang tidak bertanggung gugat. Masalah-masalah ini dapat diatasi dengan berbagai cara lain di luar reformasi kelembagaan, termasuk penguatan 
lembaga negara dan lokal, harmonisasi kebijakan negara dan penggunaan metode partisipatif dan proses persetujuan sukarela, dengan pemberian informasi lebih dahulu (FPIC).

Perlu dicatat bahwa semua kebijakan ini - apakah bertujuan untuk menyelesaikan masalah penguasaan lahan secara spesifik atau memajukan inisiatif REDD + secara umum - menghadirkan tantangan bagi ekonomi yang berakar dalam dan kepentingan politik 'bisnis seperti biasa'. Bisnis seperti biasa di hutan mengacu pada konstelasi kepentingan yang berusaha untuk melanggengkan hak istimewa akses komersial atas lahan dan sumberdaya hutan dan sering melibatkan konversi Hutan. REDD+ merupakan upaya yang dilembagakan untuk menghadapi bisnis seperti biasa dan menahan proses deforestasi dan degradasi, dan karena itu menghadapi tantangan yang sama dengan reformasi penguasaan lahan hutan.

\subsection{Kesimpulan}

Di tingkat nasional maupun tingkat proyek, isu penguasaan lahan secara luas diakui sebagai hal yang relevan dengan REDD+. Pemrakarsa proyek telah berusaha untuk meningkatkan jaminan hak lokal atas hutan, sedangkan perhatian tingkat nasional masih sangat retoris. Di tingkat lokal, sebagian besar pendukung bekerja "melalui inisiatif mereka sendiri dan dengan sedikit saja bantuan eksternal" (Sunderlin dkk. 2011). Intervensi proyek sepotong-sepotong ini tidak mencukupi untuk menjamin hak masyarakat lokal, atau untuk mengatasi isu pelarangan pengguna hutan eksternal secara formal - yang telah diberikan oleh beberapa komunitas dalam penelitian ini.

Dapatkah REDD+ terus maju ketika penguasaan lahan jelas dan aman? Apakah hambatan untuk meningkatkan penguasaan lahan di tempat lain yang tidak dapat diatasi? Jelas, mengatasi penguasaan lahan sangat memperluas pilihan-pilihan kebijakan dan lebih mungkin mengarah pada kesuksesan, sementara kalau hanya penguasaan lahan saja yang diurus, maka potensi pilihan-pilihan intervensi untuk keberhasilan REDD+ menjadi lebih terbatas. Penguasaan lahan dapat dilihat sebagai bagian dari perubahan transformatif bagi REDD+ dalam jangka panjang. Kami berpendapat bahwa mengatasi hak penguasaan lahan tidak lebih menantang daripada reformasi kebijakan lainnya yang akan membuktikan komitmen serius terhadap REDD+, dan bahwa perhatian yang belum pernah terjadi sebelumnya atas isu-isu penguasaan lahan di bawah REDD+ menunjukkan ruang untuk optimis. Para perumus kebijakan REDD+ dapat melangkah maju pada tingkat makro dengan berbagai pendekatan untuk menyerang akar pemicu deforestasi, sementara menjalankan secara paralel untuk menargetkan solusi atas masalah penguasaan lahan yang spesifik. Kemajuannya akan bergantung pada pengembangan aliansi yang luas untuk mengatasi perlawanan. 
Tabel 9.5 Masalah kepemilikan lahan, implikasi bagi REDD+ dan potensi solusinya

\begin{tabular}{|c|c|c|}
\hline Isu kepemilikan lahan & Implikasi bagi REDD+ & Potensi solusi \\
\hline $\begin{array}{l}\text { Kurangnya kejelasan } \\
\text { kepemilikan, tumpang } \\
\text { tindih klaim }\end{array}$ & $\begin{array}{l}\text { Batas-batas untuk pilihan } \\
\text { kebijakan dan rendahnya } \\
\text { potensi untuk sukses, kurangnya } \\
\text { kejelasan mengenai manfaat dan } \\
\text { akuntabilitas dalam pembayaran } \\
\text { berbasis kinerja }\end{array}$ & $\begin{array}{l}\text { Alokasi lahan dan pencatatan } \\
\text { (regularisasi) }\end{array}$ \\
\hline $\begin{array}{l}\text { Hak adat vs } \\
\text { kepemilikan negara }\end{array}$ & $\begin{array}{l}\text { Ketidakpastian kepemilikan } \\
\text { lahan dan/atau kegagalan untuk } \\
\text { menghormati hak penduduk } \\
\text { desa dapat menimbulkan konflik, } \\
\text { masalah kepatuhan, kesulitan } \\
\text { lokal dan distribusi manfaat yang } \\
\text { tidak adil }\end{array}$ & $\begin{array}{l}\text { Pastikan FPIC } \\
\text { Pengakuan hak }\end{array}$ \\
\hline $\begin{array}{l}\text { Konflik keputusan } \\
\text { pemanfaatan lahan/ } \\
\text { konsesi di lintas } \\
\text { tingkatan dan } \\
\text { lembaga negara }\end{array}$ & $\begin{array}{l}\text { Kegagalan untuk mengurangi } \\
\text { emisi karbon }\end{array}$ & $\begin{array}{l}\text { Menyelaraskan kebijakan negara } \\
\text { Memperkuat lembaga-lembaga } \\
\text { pemerintahan multi-tingkatan }\end{array}$ \\
\hline $\begin{array}{l}\text { Kurangnya hak dan/ } \\
\text { atau kemampuan untuk } \\
\text { melarang (termasuk } \\
\text { kolonisasi tanah adat) }\end{array}$ & $\begin{array}{l}\text { Pemangku kepentingan lokal } \\
\text { dalam REDD+ (pemegang hak } \\
\text { pihak yang akuntabel) berpotensi } \\
\text { tidak dapat memenuhi kewajiban } \\
\text { dalam pengaturan berbasis kinerja, } \\
\text { kegagalan untuk mengurangi emisi }\end{array}$ & $\begin{array}{l}\text { Hibah dan menegakkan hak } \\
\text { pelarangan } \\
\text { Menjamin batas-batas tanah adat } \\
\text { dan desa (lokal dan lembaga negara) } \\
\text { Mengembangkan peluang ekonomi } \\
\text { alternatif untuk koloni }\end{array}$ \\
\hline $\begin{array}{l}\text { Buruknya penegakan, } \\
\text { pemantauan dan sanksi } \\
\text { hukum; kegagalan } \\
\text { untuk melaksanakan } \\
\text { perencanaan tata } \\
\text { guna lahan }\end{array}$ & $\begin{array}{l}\text { Kegagalan untuk mengurangi } \\
\text { emisi karbon }\end{array}$ & $\begin{array}{l}\text { Memperkuat lembaga lokal } \\
\text { dan negara untuk perencanaan } \\
\text { dan regulasi } \\
\text { Menerapkan proses perencanaan } \\
\text { pemanfaatan lahan partisipatif, FPIC }\end{array}$ \\
\hline $\begin{array}{l}\text { Masalah teknis dalam } \\
\text { proses regularisasi, } \\
\text { ketidaksesuaian antara } \\
\text { hak yang baru, formal } \\
\text { dan hak de facto } \\
\text { atau hak adat yang } \\
\text { sebelumnya }\end{array}$ & $\begin{array}{l}\text { Peta yang tidak akurat mengarah } \\
\text { pada ketidaksesuaian antara } \\
\text { wilayah lahan dan pemilik lahan; } \\
\text { perebutan oleh elite }\end{array}$ & $\begin{array}{l}\text { Memperkuat lembaga yang } \\
\text { bertanggung jawab atas } \\
\text { pencatatan tanah } \\
\text { Partisipasi pemangku } \\
\text { kepentingan yang lebih besar } \\
\text { dalam proses pemetaan }\end{array}$ \\
\hline $\begin{array}{l}\text { Representasi lahan } \\
\text { kolektif yang tidak } \\
\text { demokratis, keputusan } \\
\text { tanpa kesepakatan lokal } \\
\text { yang luas* }\end{array}$ & $\begin{array}{l}\text { Masalah kepatuhan dan karenanya } \\
\text { kegagalan untuk mengurangi emisi, } \\
\text { perebutan manfaat oleh elite }\end{array}$ & $\begin{array}{l}\text { Memastikan FPIC mencakup } \\
\text { anggota masyarakat, bukan hanya } \\
\text { 'perwakilan' }\end{array}$ \\
\hline
\end{tabular}

* Masalah tidak teridentifikasi di lokasi proyek, tetapi dalam kasus lain, seperti Papua Nugini (Kotak 9.1) dan di tempat lain. 


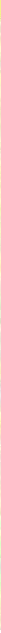

\title{
Proyek-proyek REDD+ sebagai turunan berbagai pendekatan lama dan baru untuk konservasi hutan
}

\author{
William D. Sunderlin dan Erin O. Sills
}

- Sebagian besar proyek subnasional REDD+ bermaksud untuk memadukan pendekatan proyek konservasi dan pembangunan terpadu (ICDP) dengan pendekatan pembayaran jasa ekosistem (PES).

- Dalam kondisi ketidakpastian kebijakan dan pasar, struktur turunan seperti ini memungkinkan para pemrakarsa untuk mengambil langkah awal pendirian proyek, dan pendekatan ICDP dapat berfungsi sebagai pilihan untuk berbalik jika PES gagal diwujudkan.

- Namun struktur hibrida seperti ICDP merupakan tantangan karena sering menunjukkan kinerja yang kurang bagus, dan karena para pemrakarsa cenderung membesar-besarkan manfaat ICDP dan mengecilkan PES dalam konsultasi mereka dengan para pemangku kepentingan lokal, sehingga menimbulkan konsekuensi negatif dalam hal keefektifan dan kesetaraan.

\subsection{Pengantar}

Secara luas REDD+ didefinisikan sebagai "tindakan-tindakan lokal, nasional dan global yang mengurangi emisi karena deforestasi dan degradasi hutan, serta meningkatkan cadangan karbon hutan di negara-negara berkembang" (Angelsen 2009a: 2). Sebagaimana dicatat oleh Sillsdkk. (2009), REDD+ sering 
dipahami sebagai sistem pembayaran berbasiskan-kinerja. Pembayaran seperti ini dapat diterapkan pada berbagai skala, dari tingkat pemerintah nasional sampai ke tingkat rumah tangga. Dalam bab ini, kami meneliti ciri-ciri inti dan intervensi REDD+ pada skala lokasi proyek. Temuan kami menunjukkan bahwa proyek-proyek ini sebagian besar merupakan turunan dari berbagai strategi konservasi hutan tradisional dan pembayaran berbasiskan-kinerja, atau pembayaran jasa ekosistem (PES). ${ }^{1}$

REDD+ menjadi bagian integral agenda mitigasi global tahun 2007 dalam Konvensi Kerangka Kerja PBB tentang Perubahan Iklim/United Nations Framework Convention on Climate Change (UNFCCC) COP13. Walaupun saat itu tidak ada proyek dengan label REDD+, sudah banyak sejarah proyek pencegahan deforestasi yang dimulai saat Clean Development Mechanism (CDM) dinegosiasikan (Caplow dkk. 2011). Sekarang ada lebih dari 200 proyek subnasional dalam tahap pengembangan atau pelaksanaan (Kshatriya dkk. 2011).

Di antara proyek-proyek REDD+, hanya sedikit sekali pembayaran berbasiskan-kinerja yang benar-benar telah dilaksanakan. Tindakan pemberian insentif bersyarat dalam proyek-proyek ini terhambat oleh tiga faktor utama: i) perkembangan kerangka internasional yang lambat di bawah UNFCCC, terkait dengan kurangnya kesepakatan mengenai mekanisme pendanaan dan mobilisasi dana, ii) penundaan dalam pembentukan pasar karbon hutan yang kuat, dan iii) kebijakan nasional yang belum memadai untuk mencapai tujuan REDD+ (lihat Bab 5).

Bab ini menggambarkan struktur turunan REDD+ yang sedang bermunculan pada skala proyek. Banyak proyek menggabungkan unsur-unsur proyek konservasi dan pembangunan terpadu (ICDP) dan PES. Kami mulai dengan menjelaskan metode yang diterapkan dalam Komponen 2 Studi Komparatif Global CIFOR tentang REDD+, sumber utama kami tentang bukti ciri-ciri turunan REDD+ (Bagian 10.2). Bagian 10.3 menggambarkan logika dan kegunaan pendekatan turunan bagi para pemrakarsa REDD+ dan memperhitungkan alasan-alasan apa yang mendasari keberadaannya. Kami kemudian menjelaskan kondisi kebijakan dan ketidakpastian pasar yang mencirikan REDD+ dan menjelaskan mengapa ada penundaan dalam

1 Kami mendefinisikan proyek REDD+ sebagai suatu aktivitas yang: “i) bermaksud untuk menghitung secara kuantitatif dan melaporkan perubahan stok karbon hutan, mengikuti pedoman IPCC dan pedoman lain yang diterima secara luas, dan kemungkinan untuk melakukan transaksi kredit karbon hutan; dan ii) beroperasi di lokasi-lokasi yang ditetapkan secara geografis, dengan batasan-batasan yang sudah ditentukan sebelumnya sebagaimana disarankan dalam panduan United Nations Framework Convention on Climate Change (UNFCCC), termasuk kegiatan yang bertujuan untuk memadukan karbon ke dalam keputusan dan perencanaan penggunaan lahan di lanskap yang heterogen pada skala subnasional". (Sills dkk.2009:266-267). 
memperkenalkan pembayaran berbasiskan-kinerja (Bagian 10.4). Penjelasan ini memberikan latar belakang untuk menunjukkan cara-cara model turunan dapat berfungsi sebagai peluang bagi para pemrakarsa REDD+ (Bagian 10.5), tetapi kami juga menyampaikan tantangan-tantangan yang ada (Bagian 10.6). Kami menutup bab ini dengan mengungkapkan pengamatan tentang pentingnya temuan-temuan kami (Bagian 10.7).

\subsection{Data dan metode}

Sumber informasi untuk bab ini adalah kombinasi kepustakaan umum tentang REDD+ dan data lapangan tentang Komponen 2 dari Studi Perbandingan Global CIFOR tentang REDD+. Untuk penjelasan tentang tujuan, ruang lingkup dan metode-metode dalam Komponen 2, serta daftar dari 22 proyek yang diteliti, lihat Lampiran.

Informasi lapangan diambil dari 19 dari 22 lokasi proyek Komponen 2 yang telah melakukan pengumpulan data pada awal 2012. Beberapa data berasal dari wawancara survei yang dilakukan atas beberapa pemrakarsa proyek, di bawah judul 'Update informasi tentang intervensi REDD+' mulai April sampai Oktober 2011. Wawancara ini berusaha untuk menentukan apakah, seperti yang diduga, pengenalan insentif-insentif REDD+ di lokasi proyek tertunda. Temuan-temuannya menggambarkan pengerahan berbagai jenis intervensi (baik REDD+ dan nonREDD+) di lokasi-lokasi proyek.

Data dalam bab ini juga diambil dari survei lain yang dilakukan selama periode yang sama berjudul 'Survei tambahan tentang partisipasi dan penguasaan lahan'. Data dari survei ini memberikan wawasan tentang berbagai tantangan yang dihadapi oleh para pemrakarsa dalam mengembangkan proyek-proyek REDD+ dan bagaimana mereka menangani berbagai tantangan yang muncul.

Sampel lokasi proyek REDD+ yang kami teliti mungkin lebih condong ke proyek-proyek yang sedang melakukan persiapan awal. Kami memilih lokasi-lokasi proyek yang tidak berisiko bahwa intervensi REDD+ telah dimulai sebelum kami berkesempatan untuk menyelesaikan pengumpulan data dasar 'sebelum proyek' (sebelum pengenalan insentif REDD+). Dengan demikian, hasil yang kami ungkapkan mungkin terasa terlalu melebih-lebihkan kelambatan kemajuan proyek. Meskipun demikian, hanya sedikit proyek REDD+ yang telah mulai memperkenalkan pembayaran berbasiskan-kinerja. Sebagai pengecualian adalah lokasi proyek di Juma, Brasil, salah satu proyek berprofil bagus yang sudah berjalan (lihat Kotak 12.2).

Kami tidak tahu sampai sejauh mana pola turunan yang terlihat jelas di semua lokasi penelitian Komponen 2 merupakan perwakilan REDD+ secara keseluruhan. Hampir semua proyek REDD+ di Brazil dan Indonesia yang berencana untuk menerapkan PES juga merencanakan intervensi untuk 
meningkatkan penegakan hukum hutan dan/atau sepenuhnya berfungsi sesuai modus ICDP (lihat Bab 12). Kami menduga bahwa pola turunan akan muncul di sebagian besar proyek-proyek REDD+ di mana PES dijadikan intervensi proyek, namun hal ini masih harus dibuktikan karena data tidak selalu mewakili semua proyek.

\subsection{Sebuah turunan dari pendekatan ICDP dan PES}

Semua proyek REDD+ dalam sampel penelitian CIFOR melibatkan campuran dari dua perangkat intervensi yang sangat berbeda. Pertama, ada pemaduan antara membatasi akses ke hutan dan memperkenalkan mata pencaharian alternatif serta proyek-proyek pembangunan lainnya. Pemaduan ini didasarkan pada asumsi bahwa adanya mata pencaharian alternatif akan mengurangi kebutuhan untuk mengandalkan pendapatan dari hutan, dan juga akan membuat pembatasan-pembatasan akses yang diperkenalkan nantinya lebih dapat diterima oleh masyarakat lokal (Wells dan Brandon 1992, Brandon dan Wells 2009; Blom dkk. 2010). Brandon dan Wells (2009) menunjukkan bahwa intervensi ICDP ini selalu diterapkan di kawasan lindung (sesuai definisinya), namun dalam REDD+ ICDP dapat diterapkan di berbagai macam lanskap, termasuk kawasan lindung.

Intervensi-intervensi ICDP dapat dicirikan sebagai 'praREDD+' dalam arti bahwa mereka telah lama dilakukan sebelum ada REDD+. Intervensi serupa lainnya yang umum ditemukan dalam sampel Komponen 2 adalah: pemetaan partisipatif atas penggunaan lahan, penentuan tata batas, penyusunan rencana penggunaan lahan desa, klarifikasi kepemilikan lahan, dan pengenalan atau peningkatan teknologi alternatif penggunaan kayu bakar dan arang (misalnya, kompor hemat energi).

Selain ICDP dan intervensi praREDD+ lainnya, masih ada rencana-rencana inisiatif yang merupakan ciri khas REDD+. Intervensi ini adalah pembayaran berdasarkan kesuksesan perlindungan atau peningkatan potensi penyerapan karbon dari hutan lokal. Pada dasarnya, intervensi ini adalah PES. Pembayarannya sesuai proporsi karbon yang berhasil diserap dalam cara yang terukur dan dapat diverifikasi.

Mengapa kombinasi ICDP dan insentif PES ini jelas terlihat di semua lokasi proyek Komponen 2? Mengapa para pemrakarsa memilih model turunan ini? Penjelasannya harus dirangkai dari berbagai bukti dan pengambilan kesimpulan karena kami tidak mengajukan pertanyaannya secara sistematis dalam survei kami. Kami mengajukan pertanyaan kepada Tim Jessup dari Indonesia-Australia Forest Carbon Partnership, yang mengerjakan desain proyek dari Kalimantan Forests and Climate Partnership (KFCP) di Kalimantan Tengah, Indonesia. Ia mengatakan tidak secara sengaja menjatuhkan pilihan untuk menggabungkan dua model. Sebaliknya ia menyebutkan 
adanya semacam 'logika di lapangan' yang membuat kombinasi tersebut terasa nyaman. Diperlukan tindakan tepat waktu untuk menunjukkan manfaat proyek sejak awal. Ini terlihat nyata dalam bentuk proyek-proyek pembangunan kebun karet yang sebagiannya merupakan kompensasi atas pembatasan akses ke hutan (dengan menutup kanal yang ikut menyebabkan deforestasi di kawasan rawa gambut). Ia menekankan bahwa pembatasan yang diberlakukan harus berdasarkan persetujuan lokal. Nantinya, pembayaran REDD+ berbasiskan-kinerja akan menjadi bagian penting; jika tidak ada persyaratan, masalah pengelolaan hutan tidak akan sepenuhnya bisa diatasi. Jessup mencatat bahwa persyaratan melekat pada REDD+ harus dibangun sejak awal, meskipun hasil yang terkait dengan reduksi emisi gas rumah kaca (GRK) - yang pada akhirnya akan menjadi dasar pembayaran - tidak akan segera terlihat (Jessup, komunikasi pribadi).

Pesan yang disampaikan Jessup adalah pendekatan praREDD+ dan REDD+ saling melengkapi. Intervensi ICDP menyediakan cara untuk bertindak lebih awal dan mendapatkan dukungan masyarakat, sementara REDD+ dalam wujud PES memberikan pijakan pengaruh yang tidak selalu tersedia dalam model ICDP. Kombinasi insentif praREDD+ dan REDD+ berpotensi membangun strategi pengelolaan yang terpadu dengan baik dan optimal yang mendukung pemenuhan tujuan proyek dan mengurangi risiko kegagalan intervensi REDD+.

Pengetahuan kami tentang pendekatan pengelolaan hutan dan konservasi di negara-negara berkembang, serta beberapa bukti dari penelitian lapangan, membantu dalam pemahaman kami tentang kegunaan kombinasi ICDP/ PES. Ada beberapa kemungkinan penjelasan untuk pendekatan turunan ini:

Mengemas ulang upaya yang sedang berlangsung. Banyak proyek REDD+ yang sebenarnya merupakan pengelolaan hutan dan upaya konservasi yang sebelumnya sudah ada, yang mungkin atau mungkin tidak termasuk ICDP. Masuk akal jika para pemrakarsa menangkap proyek REDD + sebagai suatu gagasan baru dalam pengelolaan hutan sehingga kemudian mencampurkannya dengan upaya terdahulu yang sedang mereka jalankan sekarang, terutama jika apa yang sudah dilakukan terbukti belum berhasil mencapai semua yang ingin diraih. Di 13 dari 18 lokasi proyek GCS, sudah ada kegiatan-kegiatan dari para pendukung sebelum REDD+ diluncurkan sebagai bagian dari agenda mitigasi iklim global tahun 2007. Di 13 lokasi ini, rata-rata pemrakarsa sudah hadir selama 5,2 tahun sebelum peluncuran REDD+. Desa-desa yang termasuk dalam proyek REDD+ cukup jelas menunjukkan bahwa selama 5 tahun terakhir di desanya sudah ada LSM yang aktif dalam konservasi hutan (lihat Bab 12).

REDD+ berpotensi menyediakan sumber pendanaan jangka panjang yang tidak bisa diberikan oleh ICDP. REDD+ dimaksudkan untuk memberikan 
sumber pendanaan jangka panjang yang berkelanjutan, sedangkan ICDP, sesuai definisinya, adalah proyek yang berjangka waktu dan pendanaannya terbatas (suatu waktu akan berakhir). Pembayaran bersyarat dari REDD+ dimaksudkan untuk memberikan kompensasi yang cukup besar dan insentif bagi pemanfaatan hutan terbatas, idealnya pada tingkat lebih tinggi ketimbang insentif yang diterima sebelumnya. Dengan demikian aliran pendapatan REDD+ yang bertindak sebagai insentif bersyarat diharapkan akan memberikan perbedaan penting dan keberhasilan di tempat di mana upaya konservasi dan restorasi hutan di masa lalu masih belum berhasil mencapainya (misalnya, ICDP). Catatan kegagalan ICDP didokumentasikan dengan baik (Wells dan Brandon 1992; Wells dkk., 1999; Brooks dkk. 2006; Garnett dkk. 2007). Insentif praREDD+ adalah landasan yang di atasnya bangunan REDD+ akan berdiri. Pada beberapa proyek GCS, diharapkan aliran pendapatan REDD+ akan berfungsi sebagai sumber pendanaan bagi mata pencaharian alternatif dan/atau perbaikan kesejahteraan tidak langsung, menggantikan peran yang dimainkan oleh dana awal proyek. Para pemrakarsa mengharapkan aliran pendapatan REDD+ akan memungkinkan proyek yang ada untuk membebaskan diri dari dana awal dan tumbuh mandiri. Seperti dijelaskan oleh Steve Ball dari proyek Mpingo di Tanzania: "Pasar karbon akan menutup biaya transaksi kami. Sulit mendapatkan dana donor. Kami menjumpai hambatan investasi dan kami ingin mengatasinya melalui pasar karbon" (Ball, komunikasi pribadi). Dan seperti dijelaskan oleh Nike Doggart dari lokasi TFCG Kilosa di Tanzania: "Sumber (awal) dana akan menjadi modal proyek tersebut. Pendapatan dari karbon akan sepenuhnya menjadi penyangga dana" (Doggart, komunikasi pribadi).

Dalam keadaan REDD+ tidak dapat menyediakan dana, pendekatan praREDD+ mungkin harus memberikan kompensasi untuk mengisi kesenjangan yang ada. Meskipun REDD+ diharapkan akan menghasilkan aliran dana besar, kecuali sumber dananya bisa diyakinkan maka ada risiko bahwa REDD + bisa mengulangi pengalaman proyek aforestasi/reforestasi CDM. Seperti dijelaskan oleh Ecosecurities (2007:6): "Pendapatan karbon umumnya menjadi sebagian kecil dari pendapatan total sebagian besar proyek CDM." Ini berarti bahwa sebagian besar proyek CDM harus menghasilkan tambahan dana sendiri yang cukup besar - misalnya, melalui penjualan energi terbarukan. Karena proyek REDD biasanya tidak dapat diharapkan untuk menghasilkan produk sampingan semacam ini, maka penjualan karbon perlu mampu menutup sebagian besar biaya pelaksanaan dan biaya transaksi. Dalam beberapa kasus, penghasilan tambahan dapat dihasilkan dari produksi kayu yang berkelanjutan dari lokasi proyek atau dari peningkatan efisiensi produksi pertanian melalui peningkatan perencanaan."

PES saja tidak mencukupi. Hal ini memperkuat apa yang disampaikan Tim Jessup di atas. REDD+ dan PES tidak bisa menjadi proses yang berdiri sendiri dalam proyek subnasional. Dari sudut pandang pemrakarsa proyek, PES harus disertai tidak hanya oleh pembatasan akses ke hutan dan kompensasi mata 
pencaharian, tetapi juga dibarengi berbagai kebijakan dan langkah-langkah di tingkat nasional yang ditujukan untuk menahan/membatasi para pelaku skala besar dan mengatasi akar penyebab deforestasi.

Adanya manfaat 'tambahan' mengurangi deforestasi ilegal melalui pembayaran REDD+ adalah sesuatu yang problematis. Sebagai salah satu komponen REDD+, pembayaran bersyarat untuk mengurangi deforestasi hutan ilegal banyak diragukan. Misalnya, Börner dan Wunder (2008) menunjukkan bahwa di kawasan Amazon Brasil secara legal tentu saja tidak patut untuk membayar penurunan deforestasi di kawasan lindung atau membayar kegiatan yang melanggar Peraturan Kehutanan. Ketidakjelasan hukum soal memberikan pembayaran dengan tujuan untuk menghentikan deforestasi ilegal telah memicu perdebatan tentang peran kawasan lindung dalam REDD+ secara umum (Boucher 2009; Dudley 2010). Pertama, untuk proyek REDD+, sistem sertifikasi seperti Standar Karbon Terverifikasi (VCS) memungkinkan terjadinya deforestasi tak terencana dan tak mendapat sanksi dalam skenario awal, namun untuk ini diperlukan bukti pendukung bahwa peraturan memang tidak ditegakkan secara efektif. Kedua, ada kekhawatiran bahwa pembayaran untuk mengurangi deforestasi hutan ilegal sangat mungkin menciptakan insentif yang merugikan, yang mendorong kecenderungan untuk mengabaikan hukum lingkungan. Namun, fakta menunjukkan bahwa di kawasan di mana deforestasi meningkat cepat, hukum lingkungan secara luas diabaikan dan banyak kegiatan deforestasi ilegal berlangsung. Dengan demikian, proyek-proyek REDD+ harus menemukan beberapa cara untuk menangani masalah deforestasi ini, selain pertanyaan tentang dasar hukum dan insentif yang merugikan yang diciptakan oleh pembayaran langsung. Salah satu respon yang bisa diberikan adalah berkolaborasi dengan pemerintah/ penguasa setempat untuk meningkatkan pemantauan dan penegakan hukum yang ada - suatu pendekatan yang merupakan ciri khas ICDP.

Menggabungkan ICDP dan PES membantu menghindari kebocoran di luar lokasi. Terakhir, ICDP dan PES merupakan kombinasi optimal di tingkat lokal untuk mencegah perpindahan deforestasi dan degradasi dari dalam ke luar batas-batas proyek REDD+. Mereka yang dicegah dari melakukan tindakan deforestasi dengan adanya pembatasan akses hutan lokal akan termotivasi untuk tidak hanya berpindah ke tempat lain karena waktu kerja mereka diserap untuk melakukan berbagai kegiatan baru. Bilamana mata pencaharian alternatif yang ditawarkan tidak cukup untuk mencegah terjadinya kebocoran ini, maka aliran dana tambahan yang ditawarkan melalui REDD + sebagai PES, membantu menjamin adanya insentif tambahan (baik dalam bentuk penghargaan maupun sanksi) untuk menjamin tujuan proyek tercapai.

Mengelola risiko. Di bawah syarat-syarat kebijakan REDD+ dan ketidakpastian pasar (lihat bagian berikutnya), masuk akal untuk melakukan diversifikasi strategi pengelolaan hutan. 


\subsection{Kebijakan dan ketidakpastian pasar}

Dalam bagian ini kami menjelaskan bagaimana kebijakan REDD+ dan ketidakpastian pasar telah memengaruhi sudut pandang dan tindakan para pemrakarsa REDD+. Bagian ini merupakan pengantar untuk menjelaskan bagaimana ketidakpastian ini memengaruhi pengerahan insentif praREDD+ dan REDD+.

Mengapa perlu lebih banyak waktu daripada yang diharapkan untuk melihat terwujudnya proyek-proyek subnasional, dan apa konsekuensinya bagi REDD+ di lapangan? Pada dasarnya ada tiga sudut pandang berbeda dalam tiga skala yang berbeda: tingkat internasional, nasional dan proyek.

Pertama, para pemrakarsa dalam beberapa kasus menunggu kebijakan yang lebih jelas dan adanya sinyal pasar di tingkat internasional. Kegagalan untuk mencapai kesepakatan perubahan iklim di Kopenhagen tahun 2009 membuat banyak pemrakarsa berkecil hati. Kesuksesan relatif dalam mencapai kesepakatan mengenai beberapa isu REDD+ di Cancun dan Durban telah menghidupkan kembali minat dan moral para pemrakarsa, meskipun mereka tetap frustrasi karena kerangka umum dan pedoman untuk REDD+ (misalnya, perlindungan) tetap tidak jelas.

Kedua, para pemrakarsa yang bertujuan mengandalkan pemasaran karbon hutan bersemangat untuk mendapatkan sinyal yang meyakinkan. Dalam beberapa tahun terakhir, terjadi ledakan pasar karbon hutan sukarela dan REDD+ memainkan peran yang sangat kuat di dalamnya. Kredit karbon hutan dari REDD+ meningkat dari $1,2 \mathrm{MtCO}_{2} \mathrm{e}$ pada tahun 2007 sampai ke $19,5 \mathrm{MtCO}_{2}$ e pada tahun 2010. Berdasarkan perhitungan ini, nilainya mencapai dua pertiga dari 29,0 $\mathrm{MtCO}_{2} \mathrm{e}$ kredit karbon hutan total yang diperdagangkan tahun 2010 (Diaz dkk 2011: ii-iii). Amerika Latin telah memainkan peran yang sangat kuat dalam tren ini (Diaz dkk 2011: iii). Sementara pasar sukarela relatif sehat, pasar ini semakin lebih bersandar pada tanggung jawab sosial perusahaan dan motivasi merek hijau lainnya dan bukannya pada persiapan kepatuhan pasar di masa depan. Dan sementara pasar sukarela relatif sehat, pasar prakepatuhan terlihat mandek. Meskipun ada ledakan dalam kredit karbon hutan sukarela, ada ketidakpastian para pemicu pasar dan permintaan di masa mendatang akan bergantung pada peraturan yang mengarahkan dan keputusan-keputusan politik yang tetap perlu dibuat (Diaz dkk. 2011: viii). Kurangnya keamanan jangka panjang tentang masa depan permintaan dan harga di pasar karbon melemahkan kemampuan para pemrakarsa untuk menjamin pembayaran kepada para pemangku kepentingan lokal dalam jangka panjang. Hal ini mendasari ketakutan para pemrakarsa untuk meningkatkan harapan para peserta lokal 
tentang pendapatan yang nantinya tidak akan bisa direalisasikan. ${ }^{2}$ Kami akan membahas tantangan ini secara mendalam di akhir bab ini.

Ketiga, kebijakan lingkungan di berbagai negara belum kondusif untuk mengambil langkah-langkah mantap dalam membangun REDD+ di lapangan. Peraturan Kehutanan/Forest Code di Brazil dan Moratorium di Indonesia adalah contoh kasusnya. Tidak jelas apakah revisi Forest Code tahun 2011 akan memotivasi perlindungan hutan swasta melalui insentif pasar, atau meningkatkan insentif untuk deforestasi (Sparovek dkk. 2012). Moratorium Hutan Indonesia yang dimulai tahun 2011 dengan berani mengklaim untuk menghentikan deforestasi besar-besaran, tetapi telah menyerah kepada tekanan lobi dan sekarang membebaskan hutan sekunder dan menyerahkan kayu tebangan hutan bekas konversi (Murdiyarso dkk 2011; Lihat juga Kotak 2.1 untuk ringkasan). Dengan begitu banyaknya persoalan yang belum terselesaikan tentang kebijakan mendasar dalam penggunaan lahan hutan, dan banyaknya klaim penggunaan lahan hutan yang tumpang tindih, maka ketidakpastian yang terus berlangsung memberi peluang kepada para pemrakarsa untuk menuai hasil keuntungan dari investasi yang telah mereka lakukan. Di Indonesia, banyak perhatian diberikan pada kasus proyek Rimba Raya di Kalimantan Tengah, di mana para pemrakarsa berpendapat bahwa mereka telah bermain sesuai aturan namun belum juga memperoleh izin pemerintah untuk melanjutkan kegiatannya (Fogarty 2011).

Berbagai kebijakan dan faktor pasar bukanlah hambatan satu-satunya dalam membangun proyek-proyek REDD+. Beberapa faktor spesifik-proyek telah memperlambat gerak para pemrakarsa. Meletakkan dasar untuk lokasi-lokasi percontohan REDD+ ternyata lebih kompleks dari yang diharapkan, khususnya dalam menyelesaikan masalah penggunaan lahan lokal dan isu-isu penguasaan lahan, ${ }^{3}$ mendefinisikan tujuan-tujuan proyek, menulis dokumen-dokumen desain proyek, mendaftar dan mendapatkan sertifikasi pihak ketiga, melakukan konsultasi pemangku kepentingan (khususnya melakukan persetujuan sukarela, setelah menerima informasi lebih dahulu) dan kegiatan penyuluhan, serta isu-isu lainnya.

\subsection{Model turunan sebagai peluang}

Sebelumnya kami telah membahas alasan para pemrakarsa proyek merangkul model turunan. Dalam konteks kebijakan dan ketidakpastian pasar,

2 Sebagai contoh kasus Setulang di Kalimantan Timur, Indonesia, di mana para pembeli potensial dari jasa keanekaragaman hayati tidak terlibat dalam skema PES hanya karena waktu mereka sangat terbatas dan ketidaknyamanan tentang prinsip-prinsipnya yang bersyarat (Wunder dkk. 2008).

3 Misalnya, di Indonesia, di setiap lokasi proyek kami ada satu perusahaan besar mengklaim bahwa mereka mempunyai hak atas lahan proyek. 
tampaknya ada dua aspek dari model ini yang sangat berguna untuk para pemrakarsa: i) mereka dapat bergerak maju dalam meletakkan dasar untuk REDD + bahkan dengan adanya penundaan dan kebijakan dan ketidakpastian pasar, dan ii) mereka dapat menggunakan ICDP sebagai cadangan seandainya ada insentif bersyarat REDD+ gagal terwujudkan atau tidak mencukupi.

\subsubsection{Kesempatan untuk melangkah maju}

Ada alasan-alasan bagus bagi para pemrakarsa untuk melangkah maju lebih awal. Idealnya, intervensi praREDD + dan REDD + akan dilakukan kira-kira pada waktu yang sama, sehingga aliran dana REDD+ dapat meringankan proyek dari kebergantungan pada dana awal proyek yang hanya sekali saja. Pada kenyataannya, di lokasi-lokasi proyek REDD+ dalam studi GCS, pengenalan insentif praREDD+ telah dimulai sebelum insentif bersyarat REDD+ diperkenalkan (Lihat Tabel 10.1). Ada beberapa alasan untuk hal ini.

Pertama, insentif praREDD + dapat berlanjut mengikuti jadwal yang tidak ditentukan oleh pembentukan mekanisme pendanaan REDD+. Pelaksanaan intervensi-intervensi ini (pembatasan pemanfaatan hutan, mata pencaharian alternatif dll.) secara umum tidak memerlukan kerangka REDD+, kebijakan nasional atau pasar karbon hutan. Kendala pelaksanaan langkah-langkah ini adalah pengorganisasian pemrakarsa yang merencanakan pendanaan dan apa saja yang ingin dicapai. Intervensi-intervensi konservasi hutan konvensional didasarkan pada gagasan bahwa intervensi awal memberikan pengetahuan, infrastruktur atau lembaga baru yang dapat menghasilkan perubahan berkelanjutan dalam pengelolaan hutan. Dengan demikian, pendanaan jangka pendek sesuai dengan logika intervensi-intervensi ini, meskipun pengalaman menunjukkan bahwa pendanaan jangka pendek merupakan hambatan serius untuk menghasilkan dampak yang diinginkan. Di sisi lain, logika PES merupakan salah satu dari pembayaran berkelanjutan untuk aliran jasa ekosistem, bukan hanya membutuhkan kecukupan dana untuk membentuk dana perwalian untuk proyek namun juga menuntut kepastian yang cukup tentang pasar masa depan bagi layanan jasa ekosistem tersebut.

Kedua, banyak proyek percontohan diharapkan untuk terus bergerak maju menjalankan berbagai kegiatan di lapangan dalam jangka waktu tertentu, dan intervensi praREDD+ merupakan cara penggunaan dana proyek yang layak. Hasil dalam bentuk reduksi emisi tidak dapat dicapai dalam waktu dekat, tetapi hanya tercapai setelah beberapa tahun. Sementara itu penduduk lokal perlu mendapatkan manfaatnya lebih awal.

Ke tiga, seperti disebutkan di atas, ketidakpastian dan penundaan dalam perumusan kebijakan dan mekanisme REDD+ membuat pemrakarsa tidak bisa atau ragu-ragu untuk memperkenalkan insentif REDD+. Seperti dijelaskan oleh Raja Jarrah dari proyek Hifadhi ya Misitu ya Asili (HIMA) 


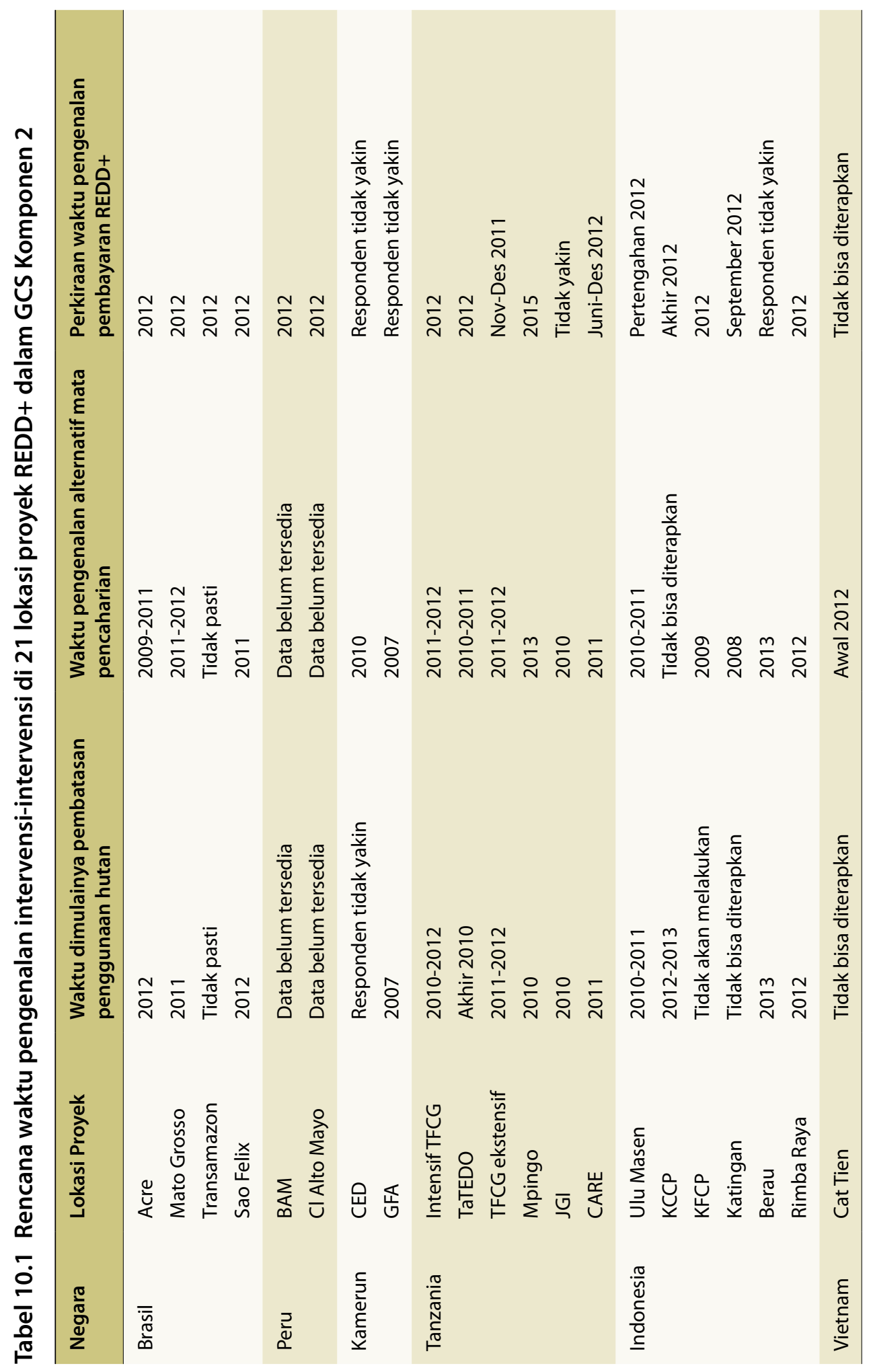


di Tanzania: "Pembayaran akan dilakukan dari dana proyek saat perjanjian ditandatangani. Jika tidak demikian maka pembayaran PES tidak akan dimulai selama bertahun-tahun "(Jarrah, komunikasi pribadi).

Ke empat, ada beberapa alasan fungsional untuk terus melangkah maju melakukan berbagai kegiatan praREDD+. Misalnya, penetapan batas desa dan hutan serta perumusan strategi penggunaan lahan desa sering harus dilakukan sebelum menerapkan pembatasan akses ke hutan, dan sebelum melakukan pemantauan dan memberikan imbalan atas kinerja.

\subsubsection{Intervensi-intervensi ICDP sebagai pilihan cadangan}

Hal ini dapat terjadi jika prasyarat untuk REDD+ gagal terwujud, jika para pemrakarsa memutuskan mereka tidak bisa atau tidak akan melanjutkan mendukung REDD+ atau jika pembayaran REDD+ berhenti. Seperti dijelaskan oleh Dharsono Hartono dari P.T. Rimba Makmur Utama di Kalimantan Tengah, Indonesia: "Kami tidak ingin menjadi terlalu bergantung pada REDD. Dalam keadaan REDD bukan sebagai sumber utama pendapatan, kami ingin tetap lentur. Mungkin ekowisata akan menjadi sumber pendapatan utama di masa depan"(Hartono, komunikasi pribadi).

Beberapa dari 19 pemrakarsa dalam sampel kami telah menyuarakan kekhawatiran tentang kesiapan mereka untuk memperkenalkan insentif bersyarat berdasarkan pengurangan emisi. Salah satu proyek (TNC Berau di Indonesia) tidak yakin bagaimana menggunakan insentif-insentif ini karena metode karbon untuk pembayaran di tingkat kabupaten mungkin tidak dapat dikembangkan tepat waktu, atau program nasional yang sedang muncul tidak melibatkan pembayaran subnasional di tingkat kabupaten. Proyek lain (ICV di Brasil) telah memutuskan untuk tidak melanjutkan pendapatan bersyarat dari REDD+ karena tidak suka berurusan dengan pasar karbon hutan.

Kami bertanya kepada pemrakarsa 19 proyek tentang insentif mana saja, dari antara semua yang ada, yang cenderung memiliki efek positif terkuat dalam menjaga atau meningkatkan kapasitas hutan dalam batas-batas wilayah proyek untuk menyerap karbon. Jawaban mereka ditampilkan pada Gambar 10.1.

Jawaban-jawaban mereka harus diperlakukan dengan hati-hati karena kemungkinan adanya variabel pengganggu. Pada beberapa proyek, aliran pendapatan PES dimaksudkan sebagai alternatif mata pencaharian jangka panjang. Meskipun demikian, respons yang muncul menunjukkan indikasi sejauh mana tingkat perhatian para pemrakarsa difokuskan pada alternatif mata pencaharian ketimbang PES sebagai ukuran kunci untuk mencapai tujuan proyek. Hal ini mungkin mencerminkan popularitas model ICDP atau memudarkan harapan terhadap prospek jangka pendek REDD+. 


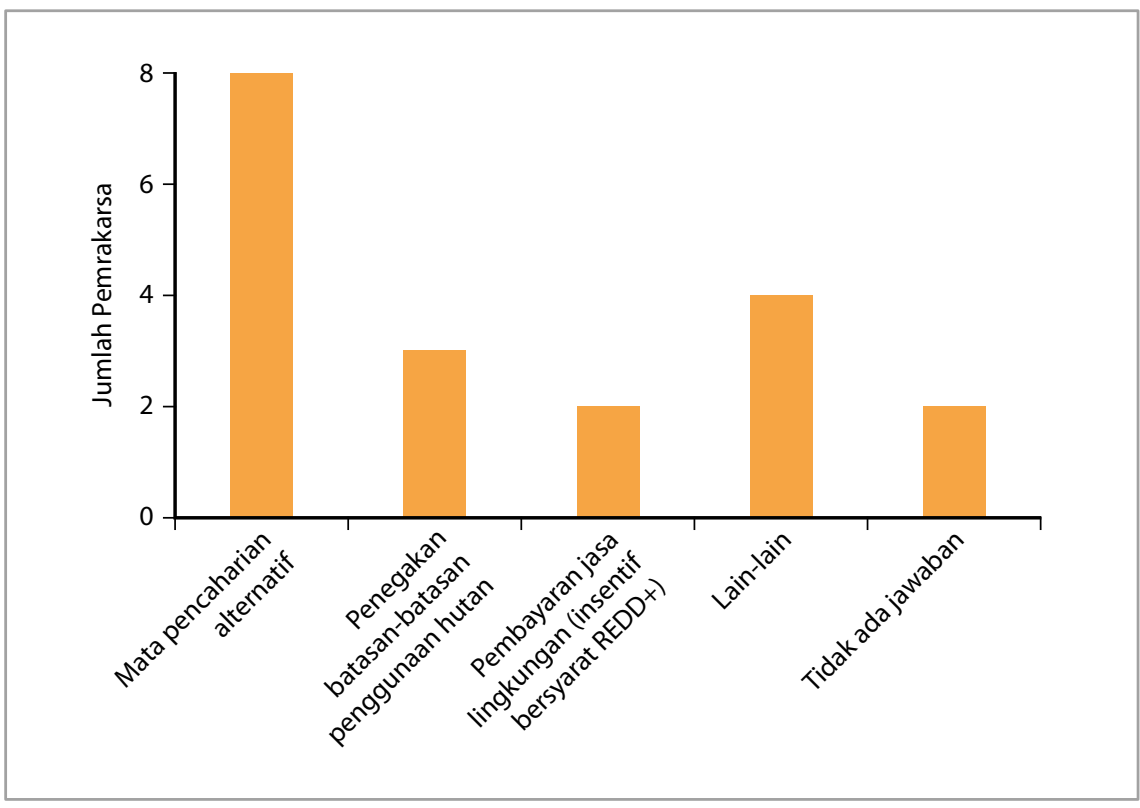

Gambar 10.1 Para pemrakarsa intervensi berharap untuk memiliki dampak paling positif dalam penyerapan karbon

Catatan: Berdasarkan pertanyaan-pertanyaan berikut ini, yang diajukan kepada 19 pendukung GCS: "Mana di antara insentif-insentif ini (mata pencaharian alternatif, meningkatnya penegakan, $P E S$, yang lain) yang kemungkinan mempunyai efek positif terbesar dalam memelihara atau meningkatkan kapasitas hutan di lingkup batas-batas proyek untuk menyerap karbon?"

\subsection{Model turunan sebagai tantangan}

Model turunan memang memberikan berbagai peluang yang dijelaskan di atas, namun ini juga memperkenalkan dua kemungkinan tantangan dalam konteks kebijakan dan ketidakpastian pasar. Keduanya terkait dengan beban yang timbul karena sepenuhnya mengandalkan ICDP jika terbukti dibutuhkan, dan tertundanya atau tidak lengkapnya penyuluhan lokal mengenai REDD+.

\subsubsection{Kebergantungan pada ICDP dapat menjadi beban}

Seperti disebutkan sebelumnya, pendekatan ICDP untuk pengelolaan hutan telah menemui sejumlah masalah. Jika para pemrakarsa proyek REDD+ memilih atau dipaksa meninggalkan usaha mereka sehingga bisa memperkenalkan pembayaran bersyarat, mereka berisiko mengulang kesalahan desain dan pelaksanaan yang dihadapi dalam menjalankan upaya ICDP di masa lalu. Beberapa masalah yang dihadapi ICDP di antaranya adalah: kurangnya kejelasan tujuan; upaya yang tidak efektif dalam melibatkan masyarakat lokal; rencana yang terlalu ambisius; kapasitas terbatas untuk mengembangkan lembaga-lembaga negara yang terlibat dalam menerapkan 
ICDP; ketidakmampuan menciptakan mata pencaharian alternatif yang layak dan meningkatkan pendapatan di dalam dan di sekitar wilayah yang dilindungi; kecenderungan untuk kurang menghargai ancaman yang dipicu oleh pelaku eksternal seperti perusahaan dan infrastruktur besar; dan penegakan hukum perlindungan hutan yang tidak memadai (Brandon dan Wells 2009).

Jika para pemrakarsa proyek berfokus sepenuhnya pada ICDP, risiko mereka mungkin rendah jika yang diharapkan adalah untuk melembagakan perubahan pengelolaan melalui pelibatan masyarakat satu kali saja. Sebaliknya, risikonya mungkin tinggi jika harapan dari awal adalah mereka diharuskan mencapai aliran pendapatan REDD+ yang berlangsung lama dan mampu mempertahankan perubahan pengelolaan hutan yang dicita-citakan.

\subsubsection{Beberapa pemrakarsa menunda atau tidak menyelesaikan penyuluhan REDD+}

Semua pemrakarsa REDD+ harus melakukan penyuluhan di tingkat lokal tentang perubahan iklim dan bagaimana proyek ini bertujuan untuk turut menyumbang mitigasi perubahan iklim, serta bagaimana masyarakat lokal dapat turut menyumbang pencapaian tujuan ini dan apa keuntungan serta risikonya bagi mata pencaharian mereka. Penyuluhan ini pada dasarnya adalah bagian 'informasi' dari persetujuan sukarela setelah menerima informasi lebih dahulu (FPIC). FPIC didukung oleh konvensi internasional, dalam beberapa kasus diwajibkan oleh hukum nasional, dan merupakan prasyarat untuk sertifikasi independen dan memenuhi keamanan sosial. Semua proyek telah menyisihkan dana sehingga proyek dapat melakukan banyak upaya FPIC, yang sering melibatkan pertemuan-pertemuan di semua desa dalam lingkup batas-batas proyek, dan dalam beberapa kasus di tingkat subdesa.

Di antara 19 proyek yang diteliti, enam sengaja menunda penyuluhan tentang REDD+ di tingkat lokal. Di beberapa lokasi, peserta lokal tidak tahu sama sekali bahwa pembayaran bersyarat dari REDD+ adalah sesuatu yang sedang dipertimbangkan (lihat juga Bab 11). Salah satu alasan utama penundaan itu adalah para pemrakarsa ingin menghindari meningkatnya harapan sumber pendapatan yang mungkin nantinya gagal terwujud. Mungkin bukan kebetulan bahwa penyuluhan-penyuluhan yang tertunda, semuanya berada di lokasi-lokasi proyek yang berada di kawasan hutan yang lembab. Kandungan karbon dan karenanya penambahan potensi dan aliran pendapatan di hutan lembab lebih tinggi daripada di hutan kering. Di wilayah sampel proyek-proyek kawasan hutan kering tidak terlihat kecenderungan untuk menunda penyuluhan, mungkin karena aliran pendapatan karbon hutan bisa diduga akan kecil, sehingga konsekuensi merugikan dalam bentuk putusnya harapan aliran pendapatan juga menjadi kecil. 
Dalam menjelaskan alasan penyuluhan tentang REDD+ yang tidak memadai atau tertunda kepada para pemangku kepentingan lokal para pemrakarsa menyampaikan:

- [Mengenai mengapa mereka mungkin tidak bisa mendidik warga di tempat-tempat di mana REDD+ belum dilakukan:] "Alasan utama adalah keterbatasan waktu dan sumberdaya manusia. Ada juga kekhawatiran tentang meningkatnya harapan.” (Monica de los Rios dari proyek Acre di Brazil).

- "Kami tidak cukup dini membagikan informasi yang cukup. Sekarang ada kesalahpahaman dan orang-orang salah mengerti konsep REDD. Kami sendiri tidak memiliki informasi yang cukup untuk menjelaskan REDD secara rinci ... Kami kekurangan informasi terinci karena kami sendiri tidak menghitungnya dengan baik/tidak melakukan apa yang menjadi tugas kami” (Raja Jarrah dari proyek HIMA di Tanzania).

- "Warga desa mungkin tidak dapat memahami REDD seperti kami memahaminya. Kami tidak menggunakan istilah 'REDD'. Terlalu membingungkan bagi mereka. Kami harus menghindari jargon. Selain itu, tujuan kami adalah restorasi. Kami tidak ingin membesarkan harapan. Kami harus memperkenalkan gagasan ini secara bertahap" (Dharsono Hartono di lokasi Katingan di Indonesia).

- "Bagi kami, situasinya terlalu rumit untuk bisa menyampaikan secara efektif kepada masyarakat lokal rencana REDD kami dengan rincian penuh. Kami mungkin akan menghabiskan banyak uang untuk melakukan hal ini, sementara masyarakat tetap tidak akan memiliki pemahaman penuh tentang REDD. Kami menganggarkan jumlah yang sewajarnya dan berharap untuk tetap berpegang pada anggaran itu "(Steve Ball dari lokasi Mpingo di Tanzania)

Dari satu sudut pandang, keterlambatan penyuluhan sepenuhnya masuk akal dan bersih dari kesalahan. Jelas masukakal untuk tidak menaikkan harapan yang tidak perlu. Para pemrakarsa ini sepenuhnya berniat melakukan penyuluhan ini setelah ada kebijakan dan sinyal pasar yang kondusif, dan saat mereka telah berhasil mengatasi penundaan karena sejumlah hambatan yang muncul dalam proyek itu sendiri. Di sisi lain, ada beberapa bahaya laten. Dalam beberapa kasus, kegiatan FPIC telah dilakukan tanpa melakukan penyuluhan tentang REDD+, yang berarti bahwa di beberapa titik di masa depan para pemrakarsa perlu kembali ke desa-desa dan melakukan penyuluhan ini dan membingkai ulang kondisi-kondisi yang diperlukan untuk mendapatkan persetujuan dari mereka. Usulan ini mahal. Beberapa proyek mendekati akhir ketersediaan dana dan sulit untuk melakukan penyuluhan ini dengan anggaran yang tersisa. Skenario terburuk, di proyek-proyek seperti ini, REDD+ akan terus berlanjut tanpa adanya persetujuan sepenuhnya. 


\subsection{Kesimpulan}

Proyek subnasional REDD+ berencana untuk menggabungkan praREDD+ (utamanya ICDP) dan ciri khas pendekatan pengelolaan REDD+ (pembayaran berbasiskan-kinerja) untuk mewujudkan tujuan mereka. Pendekatan ini memberikan keuntungan yang jelas bagi para pemrakarsa proyek, termasuk: cara untuk melanjutkan apa yang bisa dilakukan oleh para pemrakarsa dan apa yang telah dilakukannya; sinergi di tempat yang mengoptimalkan dua model (dengan satu model mencapai apa yang tidak bisa dicapai oleh model lainnya); sebuah cara untuk mengatasi ketidakpastian pendanaan; dan cara untuk meminimalkan kebocoran di luar lokasi.

Kami telah melihat bahwa intervensi praREDD+ telah bergerak maju, sementara intervensi REDD+ lambat terwujud, sebagian karena ketidakpastian kebijakan dan pasar yang terkait dengan REDD+. Keputusan para pemrakarsa dalam konteks ketidakpastian ini menggarisbawahi manfaat dan kelemahan pendekatan turunan. Di satu sisi, pendekatan ICDP memungkinkan pemrakarsa proyek untuk melangkah maju sebelum kebijakan dan kondisi pasar untuk REDD+ siap sepenuhnya, dan memiliki pilihan mundur dalam keadaan yang memungkinkan kondisi-kondisi gagalnya REDD+ dengan cara yang meyakinkan mereka bahwa risiko yang diambilnya itu layak dibandingkan manfaat yang nantinya diperoleh. Di sisi lain, model ICDP sendiri memiliki sejarah bermasalah, dan kesenjangan antara penerapan awal intervensi ICDP dan keterlambatan pengenalan PES menunjukkan adanya kecenderungan di mana para pemrakarsa menunda untuk terbuka sepenuhnya kepada para pemangku kepentingan lokal tentang sifat dan ruang lingkup intervensi-intervensi REDD+ yang sudah direncanakan.

Apa yang perlu terjadi agar REDD+ dapat bergerak maju pada tingkat proyek subnasional dengan cara yang mengoptimalkan potensi sinergi antara ICDP dan PES? Titik awal yang penting adalah belajar dari masa lalu. Brandon dan Wells (2009:232-235) dan Blom dkk. (2010:167-170) memberikan petunjuk yang berguna tentang bagaimana merencanakan dan melaksanakan proyek-proyek ICDP yang lebih baik.

Langkah-langkah ini utamanya berada dalam wilayah kendali para pemrakarsa itu sendiri, sedangkan apa yang harus terjadi ada dalam kendali mereka yang lebih tinggi dari skala proyek. Agar REDD+ bisa bergerak maju di tingkat bawah maka harus ada cara untuk mengatasi kelembaman kebijakan dan pasar. Hal ini memerlukan penyempurnaan kerangka internasional dan mekanisme pendanaan REDD+, pengembangan kerangka regulasi untuk mendorong perkembangan pasar karbon hutan yang layak, dan penciptaan perumusan undang-undang nasional dan peraturan yang terkait dengan REDD+ yang memprioritaskan perlindungan dan kesejahteraan pemangku kepentingan lokal. 


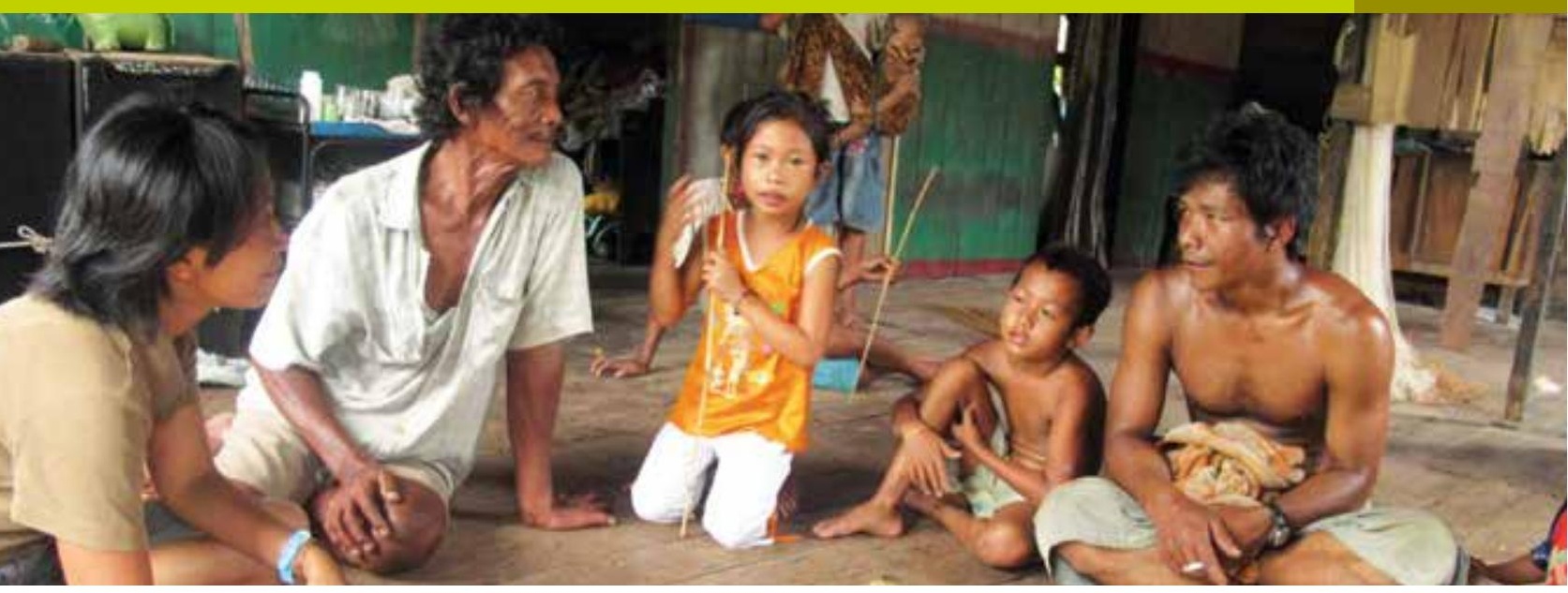

\section{Harapan dan kekhawatiran penduduk lokal mengenai proyek-proyek REDD+}

Ida Aju Pradnja Resosudarmo, Amy E. Duchelle, Andini D. Ekaputri dan William D. Sunderlin

- Para pengguna hutan lokal di wilayah proyek REDD+ yang dijadikan sampel memahami REDD+ pada dasarnya sebagai perlindungan hutan; sementara itu, mereka berharap proyek-proyek REDD+ lokal akan memperbaiki pendapatan mereka dan khawatir bahwa proyek-proyek REDD+ dapat berpengaruh negatif bagi mata pencaharian mereka.

- Penduduk desa sangat bergantung kepada para pemrakarsa untuk mendapatkan informasi mengenai REDD+ dan proyek REDD+ lokal, dan mungkin perantara informasi independen atau penasihat hukum akan dibutuhkan.

- Sejumlah tantangan utama proyek-proyek REDD+ ialah: i) mengomunikasikan kepada penduduk desa bagaimana cara kerja proyek REDD+, peluang dan risikonya, dan hak dan tanggung jawabnya; ii) melibatkan para penduduk desa secara berarti dalam perancangan dan penerapan proyek; dan iii) menyeimbangkan perlindungan hutan dengan masalah kesejahteraan penduduk desa.

\subsection{Pengantar}

Menghentikan deforestasi dan degradasi hutan di negara-negara berkembang melibatkan negosiasi timbal balik antara konservasi dan pengembangan mata 
pencaharian. Karena para pengguna hutan sangat bergantung pada lahan dan sumberdaya hutan, mereka mungkin mengalami kerugian karena berbagai intervensi untuk melindungi hutan, kecuali bila mereka menerima ganti rugi yang cukup untuk perubahan strategi mata pencaharian mereka. Salah satu alasan REDD+ menjadi gagasan yang begitu populer sedemikian cepat ialah potensinya untuk menghasilkan aliran pendanaan yang cukup besar untuk mengganti rugi sepenuhnya biaya peluang yang ditanggung oleh para pengguna hutan lokal dalam jangka panjang. Dengan demikian, REDD+ dapat dipandang sebagai sebuah solusi sama-sama-menang untuk menjaga tegakan hutan dan mendukung mata pencaharian lokal (Brown dkk. 2008; Phelps dkk. dalam proses pencetakan; lihat juga Bab 3).

Sebagai inisiatif mitigasi perubahan iklim, REDD+ dapat diterapkan dalam berbagai cara berbeda, termasuk melalui pendekatan proyek subnasional. Proyek-proyek subnasional REDD+ sedang dalam berbagai tahap pengembangan di banyak negara (Kshatriya 2011; lihat juga Bab 10). Proyek-proyek ini melibatkan para pemangku kepentingan yang berkisar dari masyarakat lokal sampai badan-badan swasta atau negara berskala besar. Para pengguna hutan lokal yang terlibat saat ini, atau mungkin akan terlibat dalam berbagai kegiatan yang berkontribusi dalam emisi gas rumah kaca merupakan target utama proyek REDD+, karena mereka akan membantu menentukan bagaimana proyek-proyeknya diterapkan dan sekaligus mereka terkena dampak langsungnya.

Para perumus kebijakan dan para peneliti sama-sama telah menekankan pentingnya melibatkan sungguh-sungguh penduduk lokal dalam pengambilan keputusan dan mendukung mata pencaharian lokal untuk mendorong hasil pengelolaan hutan yang positif (misalnya, Ostrom dan Nagendra 2006). Usaha-usaha pelestarian hutan diyakini memiliki kesempatan untuk berhasil bila masalah-masalah ekonomi lokal ikut dipertimbangkan (Ferrarro dan Hanauer 2011). Namun dalam praktiknya, menyejajarkan sasaran-sasaran konservasi dengan perbaikan mata pencaharian lokal sering menghadapi berbagai tantangan yang substansial (Sunderland dkk. 2007; McShane dkk. 2011).

Keterlibatan sungguh-sungguh penduduk desa dan dukungan mereka bagi proyek-proyek REDD+ dapat membantu memastikan bahwa proyek-proyeknya akan mencapai sasaran pengurangan emisi jangka panjang (Harvey dkk. 2010b; Helvetas Swiss Intercooperation dkk. 2011). Keterlibatan semacam itu memerlukan pemrakarsa proyek (misalnya, organisasi yang dapat mengoordinasikan proyek-proyek REDD+) untuk melibatkan para pemangku kepentingan lokal dalam semua fase proyek. Pelibatan ini berkisar dari memastikan hak dasar untuk mendapatkan informasi sebelum proyek investasi dilaksanakan di wilayah mereka, dan berdasarkan informasi tersebut, mereka secara sukarela menyatakan persetujuan atau menolak (FPIC) sejak 
awal proyek sampai fase untuk menetapkan mekanisme transparansi dan kesetaraan selama keseluruhan proyek (May dkk. 2004). Melalui proses FPIC, para pemrakarsa yang terlibat dalam kegiatan-kegiatan penyuluhan di kalangan masyarakat di wilayah proyek dapat menjelaskan konsep dasar REDD+ dan sejumlah strategi spesifik proyek. Proyek-proyek REDD+ harus dirancang dan diterapkan sedemikian rupa sehingga masalah-masalah mata pencaharian lokal tertangani dan dapat bergerak ke arah hasil sama-sama menang.

Satu prasyarat penting agar masyarakat dapat berpartisipasi secara berarti dalam REDD+ ialah pengetahuan lokal mengenai perubahan iklim dan proyek REDD+ (Sunderlin dkk. 2011). Untuk mendapatkan persetujuan setelah masyarakat mendapatkan informasi sebelumnya, mereka perlu sekali memahami pentingnya hutan dalam konteks perubahan iklim, bagaimana proyek-proyek REDD+ akan diatur dan dilakukan sebagai sarana untuk mencapai sasaran mitigasi perubahan iklim, dan bagaimana intervensi ini akan memengaruhi hidup mereka. Informasi ini mencakup pembagian keuntungan, hak dan tanggung jawab, dan juga risiko dan biaya yang terkait dengan keterlibatan penduduk lokal dalam proyek REDD+. Tanpa penyuluhan semacam ini, REDD+ berisiko mengulang kesalahan inisiatif konservasi di masa lalu yang sering melangkahi dan meminggirkan penduduk lokal, sehingga kehilangan dukungan mereka. Lebih jauh, dari segi moral, penduduk lokal harus memiliki suara - dan suara itu harus didengar - dalam perancangan dan penerapan proyek (Newell dan Wheeler 2006). Jadi pengetahuan, harapan dan kekhawatiran penduduk lokal mengenai proyek-proyek REDD+ perlu sekali dipahami, demikian pula rekomendasi mereka mengenai bagaimana meningkatkannya.

Mengingat sifat potensial sama-sama menang dari REDD+, dalam bab ini kami mengajukan pertanyaan berikut: Apakah pemahaman penduduk lokal mengenai REDD+ dan harapan untuk proyek-proyeknya mencerminkan sasaran REDD+ yang sama-sama menang untuk meningkatkan konservasi dan memperbaiki mata pencaharian penduduk lokal secara bersamaan? Untuk menjawab pertanyaan ini, kami mencari informasi melalui penelitian masyarakat di sembilan lokasi proyek REDD+ yang terdapat di empat negara: Brasil, Kamerun, Indonesia dan Tanzania. ${ }^{1}$ Untuk penelitian ini, fokus kami adalah masyarakat lokal atau kelompok-kelompok petani kecil dan bukan pada pemangku kepentingan lainnya yang potensial penting dalam proyek-proyek REDD+ lokal.

1 Kesembilan proyek ini dipilih dari 22 lokasi (intensif dan ekstensif) dari enam negara (lihat Lampiran). Analisis ini sangat bergantung pada data rumah tangga dan dengan demikian berfokus hanya pada lokasi intensif. Selain itu, data dari lokasi lainnya tidak tersedia pada saat bab ini ditulis karena pekerjaan lapangannya belum dilakukan atau karena kami tidak dapat mengajukan pertanyaan-pertanyaan yang relevan di berbagai lokasi tersebut. 
Bab ini terdiri dari tiga bagian: dalam Bagian 11.2 menjelaskan metode dan data lapangan dari penelitian ini; Bagian 11.3 menyajikan temuan-temuan dan mendiskusikan relevansinya; dan di Bagian 11.4 kami menawarkan kesimpulan dan mengusulkan langkah-langkah ke depan.

\subsection{Data lapangan}

Kesembilan proyek REDD+ yang dianalisis terletak di Brasil (2), Kamerun (3), Indonesia (3) dan Tanzania (2). Proyek-proyek ini beragam dalam hal pemicu deforestasi dan degradasi, sasaran-sasaran proyek, mekanisme intervensi, dan tahap perkembangan proyek (Tabel 11.1). Meskipun semua proyek bertujuan (sesuai definisinya) untuk menghindari deforestasi dan degradasi hutan, sebagian besar proyek mempunyai tujuan khusus tambahan untuk konservasi, penggunaan sumberdaya berkelanjutan, memperbaiki mata pencaharian lokal atau pengentasan kemiskinan. Para pemrakarsa proyek di lokasi-lokasi ini mencakup lembaga-lembaga pemerintah, badan-badan swasta dan/atau LSM. Mekanisme intervensi mencakup kombinasi peningkatan penegakan hukum, dukungan untuk pengembangan mata pencaharian alternatif dan imbalan untuk jasa lingkungan (PES).

Analisis ini terutama didasarkan pada data dari survei kuantitatif dengan 1243 rumah tangga di kesembilan lokasi proyek. Kami melaksanakan pengumpulan data lapangan dari pertengahan Juni sampai Oktober 2010, ketika sebagian besar proyek berada pada tahap awal pengembangannya. Survei rumah tangga ini dilengkapi wawancara dengan para pemrakarsa proyek REDD+ mengenai mekanisme-mekanisme intervensi khusus. Namun yang terpenting kami menyadari bahwa sembilan lokasi proyek merupakan sampel yang terlalu kecil untuk dapat mewakili sepenuhnya lokasi-lokasi proyek REDD+ yang masih dalam tahap awal di seluruh kawasan tropis, dan tidak sepenuhnya mewakili negara-negara yang menjadi lokasi proyek.

Dalam melaksanakan survei, pertama kami menanyakan pengetahuan penduduk desa mengenai REDD+ secara umum dan mengenai proyek REDD+ lokal, khususnya, dengan mengajukan pertanyaan: i) "Apakah Anda telah mendengar tentang REDD+ sebelum wawancara ini?" dan ii) "Apakah Anda telah mendengar mengenai (proyek REDD+ lokal) sebelum wawancara ini?” Untuk mereka yang menjawab "ya" sedikitnya satu dari kedua pertanyaan di atas, kami kemudian meminta penjelasan singkat mengenai REDD+ dan/ atau mengenai proyek REDD+ untuk mendapatkan perkiraan pemahaman mereka mengenai konsep-konsep ini. Pertanyaan-pertanyaan ini bersifat terbuka, dan mereka boleh memberikan lebih dari satu (banyak) tanggapan. Bila responden menyatakan dengan benar sedikitnya satu ciri REDD+ atau proyek REDD+ lokal, maka orang tersebut dinilai memiliki pemahaman dasar mengenai REDD + atau proyek REDD+ lokal. Pertanyaan-pertanyaan ini hanya digunakan sebagai cara penyaringan untuk menilai ketepatan 


\section{Tabel 11.1 Proyek-proyek REDD+ yang dianalisis}

\begin{tabular}{|c|c|c|c|}
\hline $\begin{array}{l}\text { Proyek-proyek } \\
\text { REDD+ }\end{array}$ & $\begin{array}{l}\text { Pemicu utama deforestasi } \\
\text { atau degradasi di lokasi } \\
\text { proyek }\end{array}$ & $\begin{array}{l}\text { Sasaran spesifik proyek } \\
\text { (selain REDD+) }\end{array}$ & $\begin{array}{l}\text { Pemrakarsa- } \\
\text { (pemrakarsa) } \\
\text { utama }\end{array}$ \\
\hline Brasil - Acre & $\begin{array}{l}\text { Perladangan berpindah } \\
\text { Pemanenan kayu bulat } \\
\text { Peternakan } \\
\text { Pembangunan jalan }\end{array}$ & $\begin{array}{l}\text { Penerapan Rencana } \\
\text { Negara untuk } \\
\text { Pengendalian dan } \\
\text { Pencegahan Deforestasi }\end{array}$ & $\begin{array}{l}\text { Pemerintah } \\
\text { negara bagian }\end{array}$ \\
\hline $\begin{array}{l}\text { Brasil - } \\
\text { Transamazon }\end{array}$ & $\begin{array}{l}\text { Perladangan berpindah } \\
\text { Pemanenan kayu bulat } \\
\text { Peternakan }\end{array}$ & $\begin{array}{l}\text { Pendamaian sistem } \\
\text { produksi petani } \\
\text { kecil dan konservasi } \\
\text { sumberdaya alam }\end{array}$ & LSM Penelitian \\
\hline $\begin{array}{l}\text { Kamerun - } \\
\text { CED }\end{array}$ & $\begin{array}{l}\text { Perladangan berpindah } \\
\text { Pemanenan kayu bulat }\end{array}$ & $\begin{array}{l}\text { Perlindungan lingkungan } \\
\text { hidup dan peningkatan } \\
\text { mata pencaharian }\end{array}$ & $\begin{array}{l}\text { LSM } \\
\text { lingkungan } \\
\text { hidup dan } \\
\text { pembangunan }\end{array}$ \\
\hline $\begin{array}{l}\text { Kamerun - } \\
\text { Mount } \\
\text { Cameroon }\end{array}$ & $\begin{array}{l}\text { Perladangan berpindah } \\
\text { Pertanian permanen (coklat } \\
\text { dan kelapa sawit) }\end{array}$ & $\begin{array}{l}\text { Penggunaan } \\
\text { sumberdaya hutan yang } \\
\text { bertanggung jawab }\end{array}$ & $\begin{array}{l}\text { Pemerintah } \\
\text { provinsi }\end{array}$ \\
\hline $\begin{array}{l}\text { Indonesia - } \\
\text { Ulu Masen }\end{array}$ & $\begin{array}{l}\text { Pemanenan kayu bulat } \\
\text { Perladangan berpindah } \\
\text { Pertanian permanen coklat) }\end{array}$ & Konservasi air & $\begin{array}{l}\text { Pemerintah } \\
\text { provinsi }\end{array}$ \\
\hline $\begin{array}{l}\text { Indonesia - } \\
\text { KCCP }\end{array}$ & $\begin{array}{l}\text { Pertanian permanen } \\
\text { (perkebunan kelapa sawit } \\
\text { yang sedang disiapkan) } \\
\text { Konsesi hutan } \\
\text { Pertambangan ilegal }\end{array}$ & $\begin{array}{l}\text { Hak pengelolaan hutan } \\
\text { desa yang pasti }\end{array}$ & $\begin{array}{l}\text { LSM konservasi } \\
\text { Masyarakat } \\
\text { desa }\end{array}$ \\
\hline $\begin{array}{l}\text { Indonesia - } \\
\text { KCCP }\end{array}$ & $\begin{array}{l}\text { Pengeringan lahan gambut } \\
\text { dan pembakaran gambut* }\end{array}$ & $\begin{array}{l}\text { Rehabilitasi gambut dan } \\
\text { revegetasi }\end{array}$ & $\begin{array}{l}\text { Negara } \\
\text { penyandang } \\
\text { dana - } \\
\text { pemerintah } \\
\text { nasional }\end{array}$ \\
\hline $\begin{array}{l}\text { Tanzania - } \\
\text { TaTEDO }\end{array}$ & $\begin{array}{l}\text { Pembersihan lahan untuk } \\
\text { pemukiman } \\
\text { Kayu bakar untuk mata } \\
\text { pencaharian, arang kayu }\end{array}$ & $\begin{array}{l}\text { Akses ke teknologi energi } \\
\text { modern berkelanjutan di } \\
\text { masyarakat terpinggirkan; } \\
\text { pengentasan kemiskinan; } \\
\text { konservasi; kemandirian }\end{array}$ & $\begin{array}{l}\text { LSM yang } \\
\text { mengerjakan } \\
\text { isu energi }\end{array}$ \\
\hline $\begin{array}{l}\text { Tanzania - } \\
\text { TFCG Kilosa }\end{array}$ & $\begin{array}{l}\text { Kekeringan dan kebakaran } \\
\text { Perladangan berpindah } \\
\text { Pemanenan kayu bulat } \\
\text { Kayu bakar untuk mata } \\
\text { pencaharian, arang kayu } \\
\text { Peternakan }\end{array}$ & $\begin{array}{l}\text { Konservasi hutan dengan } \\
\text { keanekaragaman } \\
\text { hayati tinggi }\end{array}$ & LSM konservasi \\
\hline
\end{tabular}

Catatan: *Sebagian besar emisi dari KFCP bukan berasal dari deforestasi dan degradasi hutan, karena wilayah yang paling besar emisi GRKnya ialah lahan gambut yang telah terdeforestasi/terdegradasi 
untuk mengajukan pertanyaan-pertanyaan lebih jauh yang berkaitan dengan harapan dan kekhawatiran lokal mengenai REDD+ dan tidak dirancang untuk mendapatkan pandangan penuh mengenai pemahaman responden akan REDD+.

Kepada mereka yang telah mendengar mengenai proyek REDD+ lokal dan menunjukkan pemahaman dasar tentang REDD+ atau proyek REDD+ lokal, kami mengajukan pertanyaan-pertanyaan berikut: i) "Apakah harapan Anda mengenai (proyek REDD+ lokal) dan manfaatnya bagi rumah tangga Anda?" ii) "Apakah kekhawatiran Anda mengenai bagaimana (proyek REDD+ lokal) akan memengaruhi rumah tangga Anda?" dan iii) "Apa rekomendasi Anda untuk menyempurnakan penerapan (proyek REDD+ lokal) di desa Anda? Responden yang tidak dapat menunjukkan pemahaman dasar REDD+ atau proyek REDD+ lokal tidak diminta menjawab pertanyaan-pertanyaan ini.

\subsection{Temuan dan diskusi}

\subsubsection{Pengetahuan lokal mengenai REDD+}

Pengetahuan, atau pengenalan penduduk desa mengenai REDD+ dan/atau proyek REDD+ lokal umumnya rendah. Dari 1243 rumah tangga yang diwawancarai, hanya $327(26 \%)$ telah mendengar mengenai konsep REDD+ dan 502 (41\%) telah mendengar mengenai proyek REDD+ lokal (Tabel 11.2). Hanya di dua lokasi yang lebih dari separuh responden seluruhnya mengenal REDD+, dan hanya di tiga lokasi yang lebih dari separuh respondennya mengenal proyek REDD+ di daerah mereka. Jumlah kecil ini sebagian mencerminkan waktu pengajuan pertanyaan-pertanyaan tersebut; beberapa pemrakarsa belum memulai atau menyelesaikan pekerjaan penyuluhan mereka untuk menjelaskan proyek REDD+. Pada kasus-kasus lain, pekerjaan penyuluhan mungkin telah dilakukan tetapi para responden (karena alasan apa pun) tidak dapat dijangkau atau tidak mencerna pengetahuan yang disampaikan.

Sebagaimana diharapkan, kami menemukan pemrakarsa proyek sebagai sumber terpenting tunggal bagi penduduk desa untuk mendengar tentang REDD+ atau proyek REDD + lokal. Di tujuh dari sembilan lokasi, lebih banyak penduduk desa mendengar tentang REDD+ dari pemrakarsa daripada dari sumber-sumber lain. Demikian pula di enam dari sembilan lokasi, penduduk desa mendengar mengenai proyek REDD+ lokal dari para pemrakarsanya. Di tiga lokasi sisanya, informasi mengenai proyek REDD+ terutama diperoleh dari: LSM yang ketika itu menopang pemrakarsa (Ulu Masen Indonesia); kepala desa (Tanzania TFCG Kilosa); atau beberapa sumber lainnya (KCCP Indonesia). Pemerintah atau lembaga-lembaga penyuluhannya (namun mereka bukan pemrakarsa) merupakan sumber informasi terbatas mengenai REDD+ dan proyek REDD+. Secara mencolok, satu dari dua kasus yang 
Tabel 11.2 Status proyek dan pengetahuan mengenai REDD+ dan proyek REDD+ lokal (2010)

\begin{tabular}{|c|c|c|c|}
\hline Proyek & $\begin{array}{l}\text { Status proyek pada waktu kerja } \\
\text { lapangan (2010) }\end{array}$ & $\begin{array}{l}\text { Pengetahuan } \\
\text { mengenai REDD+ } \\
\text { secara umum (\% } \\
\text { responden) }\end{array}$ & $\begin{array}{l}\text { Pengetahuan } \\
\text { mengenai proyek } \\
\text { REDD+ lokal } \\
\text { (\% responden) }\end{array}$ \\
\hline Brasil - Acre & $\begin{array}{l}\text { Penerapan insentif uang untuk } \\
\text { pertanian berkelanjutan }\end{array}$ & 15 & $92^{*}$ \\
\hline $\begin{array}{l}\text { Brasil - } \\
\text { Transamazon }\end{array}$ & $\begin{array}{l}\text { Rapat desa untuk mengenalkan } \\
\text { proyek REDD+ yang diajukan }\end{array}$ & 30 & 39 \\
\hline $\begin{array}{l}\text { Kamerun - } \\
\text { CED }\end{array}$ & $\begin{array}{l}\text { Analisis mata pencaharian } \\
\text { terpadu di dua desa; pelatihan } \\
\text { organisasi di satu desa; pemetaan } \\
\text { terpadu dan basis karbon di } \\
\text { satu desa }\end{array}$ & 74 & 72 \\
\hline $\begin{array}{l}\text { Kamerun - } \\
\text { Mount } \\
\text { Cameroon }\end{array}$ & $\begin{array}{l}\text { Teknik peternakan yang lebih } \\
\text { baik; pembangunan kapasitas } \\
\text { untuk komite pengelolaan hutan } \\
\text { desa; penegakan hukum }\end{array}$ & 25 & 63 \\
\hline $\begin{array}{l}\text { Indonesia - } \\
\text { Ulu Masen }\end{array}$ & $\begin{array}{l}\text { Konsultasi di tingkat } \\
\text { kelompok desa }\end{array}$ & 2 & 6 \\
\hline $\begin{array}{l}\text { Indonesia - } \\
\text { KCCP }\end{array}$ & $\begin{array}{l}\text { Kegiatan persiapan untuk } \\
\text { pembangunan Hutan Desa, } \\
\text { termasuk konsultasi dengan para } \\
\text { pemangku kepentingan utama, } \\
\text { memperkuat kapasitas desa, } \\
\text { pemetaan desa untuk Hutan } \\
\text { Bernilai Konservasi Tinggi }\end{array}$ & 5 & 23 \\
\hline $\begin{array}{l}\text { Indonesia - } \\
\text { KCCP }\end{array}$ & $\begin{array}{l}\text { Rapat desa untuk mengenalkan } \\
\text { proyek REDD+ yang diusulkan, } \\
\text { penempatan fasilitator di desa- } \\
\text { desa, rancangan mendetail } \\
\text { bendungan untuk saluran-saluran } \\
\text { di rawa gambut, pemantauan } \\
\text { hidrologi }\end{array}$ & 13 & 27 \\
\hline $\begin{array}{l}\text { Tanzania - } \\
\text { TaTEDO }\end{array}$ & $\begin{array}{l}\text { Pengumpulan informasi basis } \\
\text { sosio-ekonomi; pengaturan } \\
\text { penguasaan lahan }\end{array}$ & 52 & 28 \\
\hline $\begin{array}{l}\text { Tanzania - } \\
\text { TFCG Kilosa }\end{array}$ & $\begin{array}{l}\text { Rapat desa untuk mengenalkan } \\
\text { proyek REDD+ yang diajukan }\end{array}$ & 18 & 11 \\
\hline Rata-rata & & 26 & 41 \\
\hline
\end{tabular}

Catatan: *Penduduk desa di lokasi ini tidak ditanya mengenai program REDD+ di seluruh negara sebagai keseluruhan, tetapi lebih ke proyek spesifik di dalam program yang lebih besar, yang berfokus pada insentif untuk pertanian berkelanjutan dan merupakan tindakan pertama yang diterapkan di wilayah proyek tersebut. 
pemrakarsanya adalah pemerintah (Indonesia, Ulu Masen), penduduk desa telah mendengar tentang REDD+ dan proyek REDD+ dari LSM yang beroperasi di daerah itu dan bukan dari para pejabat pemerintah.

Karena itu masuk akal bila para pemrakarsa merupakan sumber informasi utama mengenai proyek-proyek REDD+, karena mereka dapat berbicara penuh percaya diri atas nama proyek-proyek mereka. Kurangnya pengenalan menyeluruh mengenai REDD+ dan proyek-proyek REDD+ lokal yang diamati dalam studi ini menyarankan bahwa informasi yang dikomunikasikan kepada penduduk desa mungkin fokusnya pada kegiatan-kegiatan proyek khusus dan tidak selalu terkait dengan proyek REDD+ yang lebih luas atau konsep mengenai REDD+ secara umum. Namun yang menarik, di lokasi-lokasi proyek di Tanzania, pemahaman mengenai konsep REDD+ lebih besar daripada tentang proyek khususnya sendiri.

Ada beragam alasan mengapa komunikasi mengenai REDD+ secara umum dan proyek-proyek REDD+ di lokasi-lokasi proyek tidak memadai. Namun yang lebih penting, laju negosiasi internasional telah memperlambat penetapan kebijakan-kebijakan nasional dan lembaga-lembaga yang terkait dengan REDD+. Semuanya ini memengaruhi kemajuan proyek-proyek REDD+ subnasional (lihat Bab 10). Dalam keadaan ketidakpastian ini, beberapa pemrakarsa takut akan membangkitkan harapan para pemangku kepentingan sehingga mereka menunda mengomunikasikan konsep REDD+ dan juga dalam membagikan informasi mengenai proyek REDD+ lokal kepada penduduk desa lokal di lokasi proyeknya (Sunderlin dkk. 2011). Namun yang penting, sejak kami melaksanakan penelitian lapangan, beberapa pemrakarsa telah melakukan penyuluhan REDD+ dasar di lokasi-lokasi mereka, yang kelihatannya telah meningkatkan pengetahuan lokal di tempat-tempat tersebut. Misalnya, di KCCP dan KFCP Indonesia, ketika kegiatan semakin berlanjut dan ketika proyek menarik lebih banyak perhatian, lebih banyak penduduk desa yang tampaknya mengenal REDD+.

\subsubsection{Pemahaman lokal mengenai proyek-proyek REDD+}

Pemahaman rumah tangga mengenai sasaran proyek-proyek REDD+ di Brasil, Kamerun dan Indonesia diringkas dalam Gambar 11.1. Hasil dari kedua lokasi proyek di Tanzania tidak dicantumkan karena jumlah responnya rendah.

Di ketiga negara tersebut, sebagian besar rumah tangga memahami REDD + dan/atau proyek REDD+ lokal terfokus pada perlindungan hutan/ lingkungan. Penekanan pada perlindungan hutan mungkin dapat dijelaskan dengan mengamati sumber informasi penduduk desa mengenai REDD+/ proyek REDD+. Sebagaimana digambarkan di atas, sumber informasi utama mengenai REDD+/proyek REDD+ bagi penduduk lokal adalah para pemrakarsanya atau mitra-mitra mereka, dan beberapa di antara organisasi 


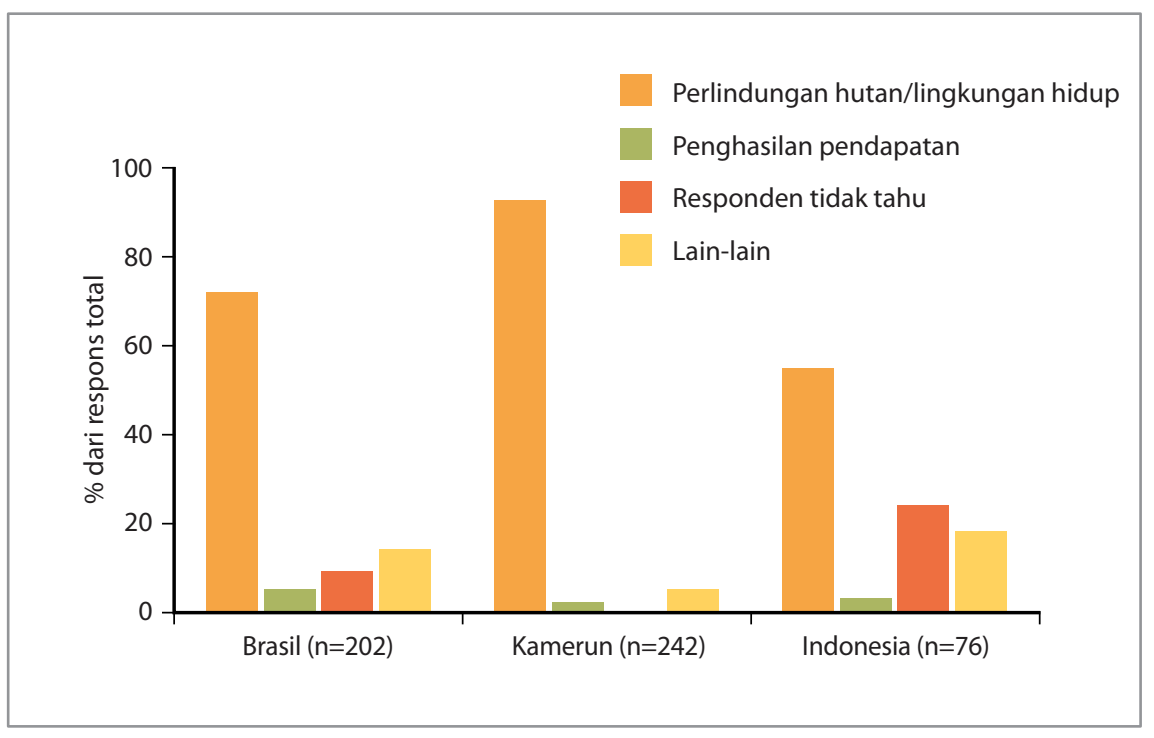

Gambar 11.1 Pemahaman lokal mengenai sasaran-sasaran proyek REDD+ lokal

pemrakarsa memiliki fokus konservasi. Lebih jauh, para pemrakarsa mungkin enggan membicarakan atau menekankan aliran pendapatan potensial atau isu-isu mata pencaharian, karena takut membangkitkan harapan-harapan yang tidak perlu sebelum perencanaan proyek memasuki tahap lebih lanjut. Tanggapan dalam kategori "lain-lain" termasuk persepsi bahwa sasaran proyek REDD+ lokal adalah untuk mengubah praktik-praktik pertanian atau memberdayakan masyarakat.

Para responden menyatakan serangkaian harapan dan kekhawatiran terkait dengan proyek REDD+ lokal (Gambar 11.2). Sebagian besar tanggapan mereka dapat dikelompokkan dalam lima tema: peningkatan pendapatan, perlindungan hutan, pengurangan ancaman perubahan iklim, keamanan penguasaan lahan dan realisasi proyek. Harapan-harapan lokal mencerminkan realisasi dari tema-tema tersebut (yaitu peningkatan pendapatan, perlindungan hutan dll.), sementara kekhawatiran mencerminkan ketakutan bahwa proyek akan gagal mencapai sasaran-sasaran ini (yaitu ketidakmampuan untuk meningkatkan pendapatan, melindungi hutan, dll.)

Peningkatan pendapatan: secara umum, keluaran berupa pendapatan merupakan harapan dan kekhawatiran yang paling sering dinyatakan dalam kaitannya dengan proyek-proyek REDD+ lokal. Jenis peningkatan pendapatannya beragam di antara setiap lokasi. Di Brasil dan Indonesia, menyediakan pendapatan alternatif atau tambahan dianggap sebagai harapan yang lebih penting daripada ganti rugi hilangnya pendapatan dari hutan. Hal ini menekankan bahwa penduduk desa menginginkan berbagai 


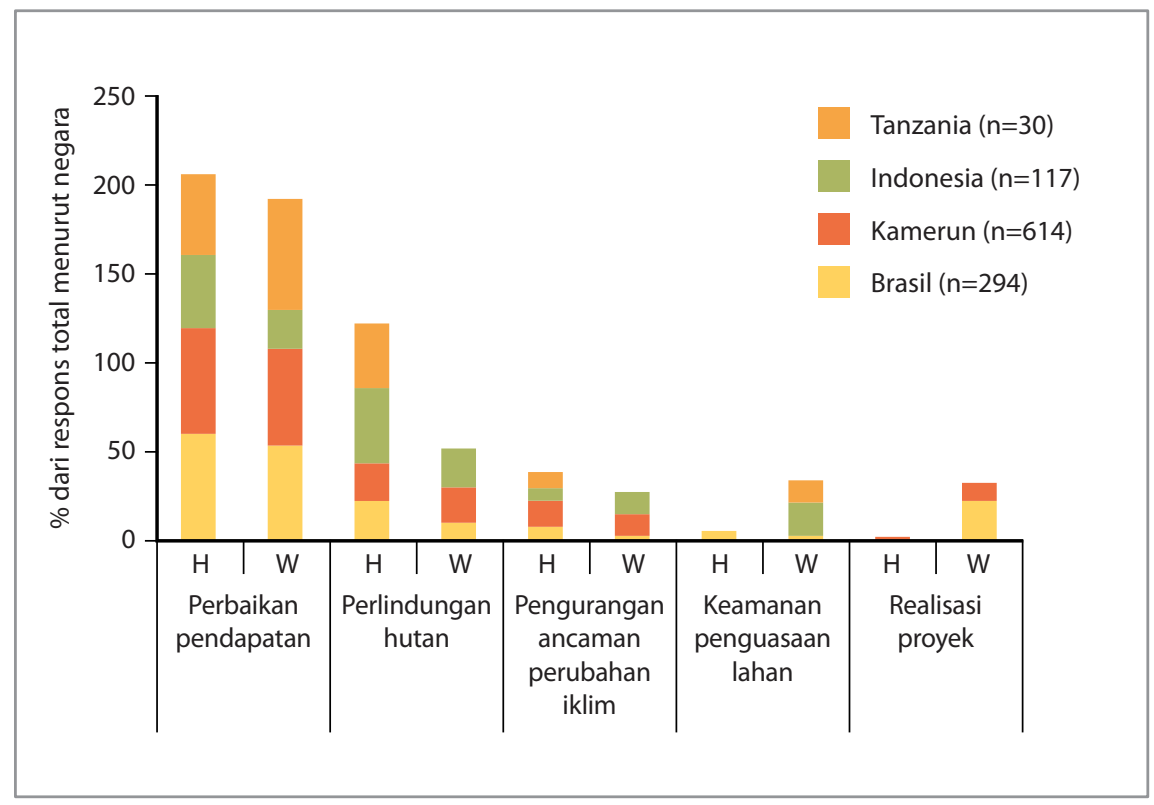

Gambar 11.2 Harapan dan kekhawatiran lokal terkait proyek REDD+

kesempatan penggunaan lahan baru, dan bukan hanya sekadar larangan untuk menggunakan hutan. Sebaliknya, ganti rugi atas hilangnya pendapatan dari hutan adalah harapan sebagian besar responden di kedua lokasi di Kamerun. Hal ini menunjukkan bahwa responden sudah membayangkan bahwa penggunaan hutan akan terbatas. Di Kamerun CED, kemungkinan pergeseran proyek untuk menetapkan hutan kemasyarakatan dipandang berpotensi membatasi eksploitasi kayu dan membuka hutan untuk pertanian sekarang. Di Mount Cameroon Kamerun, penduduk desa membabat hutan di sebuah taman nasional untuk pertanian, yang mungkin akan dibatasi oleh proyek REDD+. Secara umum, dibandingkan dengan ketiga negara lainnya, penduduk desa di Kamerun tampaknya secara umum lebih waspada dengan proyek lokal mereka.

Perlindungan hutan: sementara sebagian besar penduduk desa memahami fokus proyek-proyek REDD+ pada perlindungan hutan, bagi mereka manfaat ini adalah sekunder. Temuan ini menunjukkan bahwa penduduk desa membedakan antara sasaran-sasaran proyek dengan potensi manfaat pribadi yang dapat mereka peroleh dari proyek. Temuan ini juga menyarankan bahwa pendapatan yang lebih baik sebagai imbalan perlindungan hutan (yaitu konsep REDD+ mengenai kompensasi untuk pengurangan emisi) mungkin telah dipahami oleh beberapa orang di tingkat lokal. Temuan kami menunjukkan bahwa dari 295 orang responden yang mengatakan bahwa proyek REDD+ adalah untuk perlindungan hutan, 197 di antaranya mengemukakan harapan untuk - antara lain - perbaikan pendapatan. 
Di satu proyek di Indonesia (KCCP), harapan untuk peningkatan perlindungan hutan mungkin terkait dengan keinginan yang diungkapkan bahwa proyek REDD+ akan menghentikan perusahaan-perusahaan besar dari deforestasi lahan masyarakat dan mengizinkan akses masyarakat ke hasil dan layanan hutan secara terus-menerus. Konsisten dengan harapan yang dikemukakan oleh penduduk desa di Brasil Acre, Kamerun (CED dan Mount Cameroon) dan di Indonesia (Ulu Masen dan KCCP), ketidakmampuan untuk mencegah perusahaan-perusahaan besar mengonversi hutan lokal merupakan kekhawatiran penting di tempat-tempat tersebut. Di Indonesia, penduduk desa terutama memandang kegiatan pertanian berskala besar sebagai yang bertanggung jawab atas konversi hutan-hutan di sekitarnya, bersama dengan kegiatan penebangan kayu. Temuan ini konsisten dengan kecenderungan mengenai tekanan untuk pengembangan kebun kelapa sawit dan konversi hutan di desa-desa yang berdekatan di wilayah tersebut. Demikian pula beberapa penduduk desa di lokasi-lokasi di Brasil dan Kamerun mengaitkan keinginan mereka untuk perlindungan dengan kehadiran perusahaan-perusahaan besar yang mendegradasi hutan kemasyarakatan, seperti perusahaan penebangan kayu, yang dianggap sebagai pemicu utama degradasi di wilayah-wilayah proyek tersebut (Tabel 11.1).

Pengurangan ancaman perubahan iklim: tema ini dikemukakan sebagai harapan di semua proyek kecuali dua lokasi proyek, tetapi dianggap kurang penting daripada perbaikan pendapatan dan perlindungan hutan. Mungkin penyebabnya adalah keterbatasan pemahaman lokal tentang kaitan antara tindakan-tindakan proyek REDD + dan konsep mengenai REDD+ sebagai sarana mitigasi perubahan iklim.

Keamanan penguasaan lahan: gagasan bahwa proyek REDD+ mungkin membatasi hak-hak atas lahan atau hutan merupakan kekhawatiran penting di Indonesia. Hal yang sama terjadi di Tanzania, yaitu kekhawatiran akan terciptanya ketidakpastian penguasaan lahan. Di Indonesia, para responden mungkin salah mengaitkan proyek REDD+ dengan berbagai kegagalan proyek pertanian skala besar oleh pemerintah di masa lalu, yang mengarah pada konversi hutan, atau pada proyek konservasi yang lebih baru yang melarang penduduk desa untuk terus mengakses hutan mereka. Di sebagian besar lokasi proyek, harapan atas berbagai keluaran yang terkait dengan hak, yaitu penguasaan lahan yang lebih baik, sikap menghargai hak-hak lokal, dan akses ke hasil dan layanan hutan tidak muncul kuat. Temuan ini dapat ditafsirkan dalam banyak cara berbeda, termasuk bahwa penduduk lokal tidak yakin pada kemampuan REDD+ untuk menyelesaikan isu-isu ini, atau bahwa masalah terkait pendapatan yang lebih mendesak mendominasi. Ada pengecualian dari temuan secara umum, yaitu di Brasil Acre di mana usaha-usaha regularisasi lahan, sebagai bagian kegiatan kesiapan REDD+, membangkitkan harapan untuk mendapatkan hak atas lahan. 
Realisasi proyek: kekhawatiran bahwa proyek tidak akan maju ditemukan di beberapa lokasi di Brasil dan Kamerun. Dan ini merupakan masalah utama di Transamazon Brasil, di mana sebuah proyek serupa-PES berakhir dini. Sama halnya, di CED Kamerun, penduduk desa khawatir bahwa janji-janji proyek tidak akan terwujud atau mereka akan ditipu oleh para pemrakarsa. Tidak seperti penduduk desa yang memiliki lahan di luar hutan kemasyarakatan yang sedang dikerjakan proyek untuk dimantapkan, penduduk desa yang memiliki tanah di dalam hutan tidak lagi dapat dengan bebas mengeksploitasi lahan mereka. Akibatnya, kelompok yang disebut terakhir merasa telah dihukum karena akses mereka dibatasi tanpa melihat adanya hasil yang konkret dari proyek REDD+. Meskipun pemrakarsa telah mulai melaksanakan kegiatan-kegiatan tertentu, penduduk desa harap-harap cemas melihat investasi REDD+ yang akan membedakan REDD+ dari kegiatan konservasi konvensional lainnya.

\subsubsection{Tanggapan lainnya}

Selain kelima tanggapan kategori utama yang dibicarakan di atas, ada juga beberapa tanggapan yang beragam dan spesifik untuk lokasi tertentu. Misalnya, di kedua lokasi di Brasil, pengadaan bantuan teknis dan pelatihan penting untuk mendorong praktik-praktik pertanian berkelanjutan (lihat Kotak 11.1). Harapan-harapan lain mencakup pengadaan layanan pemerintah dan kesejahteraan yang meningkat secara umum. Di Indonesia bantuan untuk pendidikan anak-anak (KCCP) dan penghargaan akan hak-hak lokal (KCCP dan KFCP) dicatat sebagai harapan, sementara di CED Kamerun dukungan untuk perumahan yang lebih baik juga dikemukakan.

Di Brasil, ada kekhawatiran tertentu yang terkait dengan keharusan meninggalkan perladangan berpindah. Kekhawatiran ini terkait langsung dengan intervensi pemrakarsa di Brasil Acre, di mana para petani diminta untuk menghentikan penggunaan api dan memakai praktik-praktik pertanian yang lebih berkelanjutan melalui penggunaan tanaman kacang-kacangan pengikat nitrogen untuk memenuhi syarat pembayaran tunai langsung.

Tidak ada harapan atau kekhawatiran yang diungkapkan: Sebagian besar responden yang memiliki pemahaman dasar tentang proyek REDD+ tidak mengungkapkan harapan atau kekhawatiran. Setidaknya ada dua penjelasan yang masuk akal untuk temuan ini. Pertama, kriteria kami untuk mengukur pemahaman penduduk mengenai REDD+ atau proyek REDD+ lokal hanya tingkat minimum, karena kami ingin merekam sebanyak mungkin pandangan, termasuk dari mereka yang memiliki pemahaman yang sangat dasar. Oleh karenanya, para responden kami mungkin telah mengikutsertakan penduduk desa yang memiliki sedikit pemahaman dasar mengenai REDD+ atau proyek REDD+ sehingga mereka tidak memiliki pandangan kritis apakah proyek REDD+ bermanfaat atau menjadi beban untuk kepentingan mereka. 


\section{Kotak 11.1 Apakah insentif REDD+ sejalan dengan persepsi penduduk lokal? Pelajaran dari kawasan Transamazon di Brasil Marina Cromberg}

Selama dekade terakhir, konsep imbalan untuk jasa lingkungan (PES) disambut hangat. Konsep ini dipandang sebagai pelengkap untuk program konservasi dan pembangunan terpadu (ICDP) dan pendekatan perintah dan kendalikan. Dalam konteks REDD+, PES telah diadopsi oleh para pemrakarsa dari banyak proyek percontohan REDD+ subnasional di seluruh kawasan tropis. Namun dalam banyak kasus, pemilihan jenis insentif mungkin lebih sejalan dengan sasaran-sasaran teknis dibandingkan dengan kebutuhan para peserta lokal.

Proyek percontohan RED ‘Pemukiman Berkelanjutan di Amazon: Tantangan dari transisi dari produksi keluarga di kawasan perbatasan menjadi ekonomi rendah karbon', diajukan oleh Amazon Environmental Research Institute (IPAM) memiliki tiga tingkatan kegiatan, salah satunya menargetkan 350 keluarga di wilayah Transamazon Brasil yang berpartisipasi dalam Proambiente (sebuah program pemerintah yang bertujuan untuk menggabungkan produksi petani kecil dengan konservasi sumberdaya alam). Untuk keluarga-keluarga ini, IPAM berusaha menyediakan sebuah paket insentif untuk melestarikan hutan dan meningkatkan produksi pertanian di kawasan yang terdeforestasi, termasuk pembayaran tunai langsung dan investasi dalam teknik produksi yang berkelanjutan.

Untuk memahami apakah insentif proyek REDD+ sejalan dengan minat dan kebutuhan penduduk, kami mewawancarai 137 keluarga di lokasi proyek dalam bulan Juli dan Agustus 2010. Pertama kami menanyakan apakah keluarga-keluarga ini telah mendengar tentang proyek REDD+, dan bila sudah, apakah mereka dapat menggambarkannya. Untuk keluarga-keluarga yang dengan tepat menggambarkan proyek ini (43 keluarga; 31\%), kami menanyakan mengenai harapan dan rekomendasi mereka mengenai proyek ini.

Hasilnya menunjukkan bahwa mayoritas keluarga-keluarga tersebut (26) berharap proyek REDD+ akan meningkatkan pendapatan mereka. Harapan paling umum yang kedua adalah proyek ini akan berkontribusi pada produksi berkelanjutan (14), dan ketiga ialah proyek ini akan membantu melindungi hutan (10). Para petani lokal merekomendasikan agar proyek dapat membantu membuat sistem produksi lebih berkelanjutan, melalui akses ke bantuan teknis, permesinan dan pelatihan (17). Rekomendasi lainnya mencakup pengadaan manfaat sesuai dengan kebutuhan para petani (8), menerima pembayaran yang cukup/lebih tinggi (6), menghindari janji-janji palsu (4), dan investasi di bidang infrastruktur (3). 


\section{Kotak 11.1 Lanjutan}

Meskipun hampir semua responden mengharapkan proyek REDD+ akan meningkatkan pendapatan rumah tangga, rekomendasi mereka menyingkapkan bahwa bentuk-bentuk kompensasi nonuang, dan digunakan untuk meningkatkan sistem produksi, mungkin lebih penting daripada pembayaran tunai langsung. Bahkan, para petani menyatakan bahwa praktik pertanian tebas-dan-bakar saat ini mendatangkan laba ekonomi rendah dan dampak negatif bagi lingkungan, tetapi mereka kekurangan sumberdaya dan keterampilan untuk mengubah praktik-praktik ini. Karenanya, meningkatkan pendapatan rumah tangga secara tidak langsung melalui teknik-teknik produksi yang lebih baik, sebagaimana dipikirkan dalam proyek REDD+ mereka, mungkin lebih efektif daripada PES sendiri dalam mewujudkan pengurangan emisi dari deforestasi. Dengan semua pertimbangkan di atas, berbagai alternatif praktik pertanian dan produksi semacam itu harus diperkenalkan sesuai dengan realitas dan pengetahuan lokal untuk menghindari intervensi yang terlalu sulit diterapkan oleh produsen lokal. Proyek-proyek REDD+ dengan struktur insentif yang secara erat disesuaikan dengan kebutuhan lokal mungkin akan menghasilkan keefektifan, efisiensi dan kesetaraan proyek yang lebih besar.

Kedua, kami mengajukan pertanyaan pada tahap dini pengembangan proyek REDD+, jauh sebelum sebagian besar intervensi proyek diperkenalkan dan mungkin bahkan dibicarakan, karena alasan-alasan yang dibicarakan sebelumnya. Di berbagai lokasi proyek yang sudah mendapat informasi atau tindakan terkait proyek, masuk akal bahwa harapan dan kekhawatiran yang diungkapkan oleh penduduk lokal hanya sedikit.

\subsubsection{Rekomendasi lokal bagi proyek-proyek REDD+}

Rekomendasi penduduk desa di sembilan lokasi proyek mencakup berbagai isu dan dapat dikelompokkan dalam enam kategori utama (Tabel 11.3).

Rekomendasi lokal untuk perbaikan proyek beragam, tetapi secara umum tema-temanya konsisten dengan harapan dan kekhawatiran penduduk. Sekali lagi, perbaikan dan/atau pengelolaan pendapatan mencuat sebagai tanggapan yang paling sering di sebagian besar lokasi, mengacu pada peningkatan pendapatan, sarana mata pencaharian yang lebih baik untuk menghasilkan pendapatan, dan peningkatan kesejahteraan. Selain itu, ada beragam pendapat mengenai bagaimana meningkatkan pendapatan. Beberapa responden memilih pembayaran tunai langsung, lainnya memilih ganti rugi bukan uang, dan yang lainnya lagi memilih dukungan tidak langsung seperti bantuan teknis untuk meningkatkan sistem produksi pertanian. Perlindungan hutan dan reforestasi 
Tabel 11.3. Rekomendasi penduduk lokal untuk proyekproyek REDD+

\begin{tabular}{|c|c|}
\hline $\begin{array}{l}\text { Pendapatan dan } \\
\text { kesejahteraan } \\
\text { yang lebih baik }\end{array}$ & $\begin{array}{l}\text { Meningkatkan, } \\
\text { atau sedikitnya } \\
\text { tidak membatasi, } \\
\text { mata pencaharian } \\
\text { lokal }\end{array}$ \\
\hline
\end{tabular}

\begin{tabular}{lll}
$\begin{array}{l}\text { Keterlibatan } \\
\text { masyarakat } \\
\text { dalam proses dan } \\
\text { penerapan REDD+ }\end{array}$ & $\begin{array}{l}\text { Menyediakan } \\
\text { informasi/ } \\
\text { kesadaran } \\
\text { masyarakat } \\
\text { yang lebih baik } \\
\text { mengenai proyek }\end{array}$ & $\begin{array}{l}\text { Presentasi yang lebih baik dari proyek } \\
\text { tersebut oleh para pemrakarsa untuk } \\
\text { meningkatkan kesadaran masyarakat, } \\
\text { klarifikasi mengenai sasaran proyek } \\
\text { dengan penduduk lokal; keterbukaan } \\
\text { dan transparansi mengenai proyek; } \\
\text { informasi mengenai kemajuan proyek; } \\
\text { pembangunan kapasitas. }\end{array}$ \\
\cline { 2 - 3 } & $\begin{array}{l}\text { Mendorong } \\
\text { partisipasi } \\
\text { masyarakat }\end{array}$ & $\begin{array}{l}\text { Keterlibatan penduduk lokal dalam } \\
\text { proyek dan pengelolaan proyek; } \\
\text { promosi partisipasi yang setara; } \\
\text { konsultasi yang cukup dengan } \\
\text { penduduk desa sebelum diambil }\end{array}$ \\
& $\begin{array}{l}\text { keputusan; melibatkan penduduk } \\
\text { desa dalam pembuatan keputusan. }\end{array}$ \\
& $\begin{array}{l}\text { Mendorong kerja } \\
\text { sama masyarakat- } \\
\text { pemerintah dalam } \\
\text { mengelola hutan }\end{array}$ & $\begin{array}{l}\text { Penegan hukum yang lebih baik } \\
\text { dan keterikatan pada peraturan- } \\
\text { peraturan. }\end{array}$ \\
\cline { 2 - 3 } & &
\end{tabular}

Dukungan untuk sistem produksi lokal seperti penyediaan asupan pertanian, irigasi, perbaikan tanah, pengurangan biaya transportasi, pencegahan hama, efisiensi yang lebih baik dari produksi pertanian dalam keadaan tidak ditanami dan perluasan lahan pertanian untuk meningkatkan pendapatan. Proyek tidak boleh terlalu membatasi tata guna lahan atau mata pencaharian lokal.

\begin{tabular}{ll}
\hline Meningkatkan & Bantuan pemerintah untuk \\
pendapatan & menambah pendapatan; pembayaran \\
& tunai langsung; pembayaran berkala \\
& dan lebih besar dari proyek.
\end{tabular}

Layanan yang Dukungan untuk meningkatkan lebih baik dan layanan lokal (air, listrik) dan infrastruktur infrastruktur (jalan, sekolah, pusat kesehatan, waduk).

\begin{tabular}{ll}
\hline Menyediakan & Penyediaan pendapatan \\
insentif atau & terdiversifikasi bila penduduk tidak \\
kompensasi bila & lagi diizinkan menebang pohon, \\
tidak melakukan & kompensasi untuk melindungi hutan. \\
deforestasi &
\end{tabular}

Menyediakan Presentasi yang lebih baik dari proyek informasi/ tersebut oleh para pemrakarsa untuk kesadaran meningkatkan kesadaran masyarakat, masyarakat klarifikasi mengenai sasaran proyek yang lebih baik dengan penduduk lokal; keterbukaan dan transparansi mengenai proyek; informasi mengenai kemajuan proyek; 
Tabel 11.3 Lanjutan

\begin{tabular}{lll}
\hline Rekomendasi penduduk desa & \\
\hline $\begin{array}{l}\text { Praktik tata } \\
\text { guna lahan } \\
\text { berkelanjutan } \\
\text { dan perlindungan } \\
\text { hutan }\end{array}$ & $\begin{array}{l}\text { Memperkuat } \\
\text { pertanian } \\
\text { berkelanjutan }\end{array}$ & $\begin{array}{l}\text { Praktik-praktik pertanian yang lebih } \\
\text { berkelanjutan dan ramah konservasi; } \\
\text { melarang penggunaan api. }\end{array}$ \\
\cline { 2 - 3 } & $\begin{array}{l}\text { Mengonservasi } \\
\text { atau } \\
\text { mempertahankan } \\
\text { hutan yang } \\
\text { masih ada }\end{array}$ & $\begin{array}{l}\text { Pengelolaan hutan lindung untuk } \\
\text { mata pencaharian penduduk; } \\
\text { perlindungan kebun-kebun karet } \\
\text { dari agribisnis berskala besar dan } \\
\text { perkebunan kayu; pendidikan untuk } \\
\text { konservasi; pengenaan sanksi pada } \\
\text { orang yang membersihkan terlalu } \\
\text { banyak lahan dengan mengharuskan } \\
\text { mereka melakukan penanaman } \\
\text { kembali, reforestasi dan melindungi } \\
\text { dan mengawetkan hutan. }\end{array}$ \\
& &
\end{tabular}

Keuntungan

yang terkumpul

pada tingkat

lokal; pembagian

keuntungan

yang setara dan

transparan

Hak-hak

masyarakat yang

diperkuat
Uang harus menjangkau masyarakat dan meningkatkan nilai pembayaran tunai langsung; kompensasi harus sejenis dan tidak dalam bentuk tunai; manfaat untuk masyarakat harus terus-menerus; khususnya bila orang harus menghentikan aktivitas mereka; keuntungan harus dibagi merata di antara penduduk desa; harus ada pengelolaan dana terpadu dan transparansi.

Penetapan hak pengelolaan desa yang jelas; usaha bersama untuk mengklaim hak masyarakat; perawatan hak adat penduduk desa; hak atas lahan; penetapan batas desa yang jelas; promosi hak kepemilikan untuk kepentingan masyarakat.

Realisasi janji-janji Realisasi hasil-hasil proyek yang konkret; efisiensi yang lebih proyek besar dalam proyek sehingga bukan sekadar percobaan, tetapi merupakan kegiatan yang pasti.

lahan terdegradasi termasuk rekomendasi dan disarankan untuk dikaitkan dengan fungsi hutan secara luas dalam memelihara kesejahteraan penduduk.

Isu-isu penting lain yang tidak muncul dalam harapan dan kekhawatiran terekam secara jelas dalam rekomendasi penduduk. Khususnya, penduduk desa menginginkan para pemrakarsa untuk berkomunikasi lebih baik mengenai proyek-proyek mereka dan menunjukkan transparansi yang lebih baik. Penduduk juga menginginkan untuk terlibat dan berpartisipasi secara berarti dalam penerapan proyek. Selain itu, yang penting rekomendasi penduduk desa mencerminkan harapan yang kuat bahwa proyek-proyek REDD+ menghormati dan menjunjung hak-hak masyarakat. 


\subsubsection{Menyatukan semua temuan}

Temuan-temuan tersebut jelas menyatakan bahwa, dari sudut pandang penduduk desa, hasil-hasil terkait pendapatan yang positif menduduki prioritas tertinggi. Proses untuk memantapkan dan menerapkan proyek-proyek REDD+ juga merupakan hal penting bagi penduduk desa. Misalnya, mereka ingin diberi informasi mengenai suatu proyek, berpartisipasi dalam proyek, dan menginginkan agar penerapan proyek dilakukan setransparan mungkin. Hal ini terkait dengan 'Informasi' dalam kerangka 41 yang dibahas dalam Bab 2. Aliran informasi yang tidak memadai mengenai REDD+ dan proyek REDD+, setidaknya pada saat penelitian lapangan, tercermin dalam keterbatasan pengetahuan dan pemahaman penduduk desa mengenai REDD+. Hal ini pada gilirannya menjelaskan jumlah responden yang agak tinggi yang tidak mempunyai harapan atau kekhawatiran untuk diungkapkan mengenai proyek REDD+ lokal. Sementara banyak pemrakarsa merencanakan untuk melakukan penyuluhan REDD+ dan proses FPIC, penduduk lokal harus mampu memberikan persetujuan mereka untuk, atau sebaliknya, menolak sebuah proyek, berdasarkan informasi yang cukup dan akurat.

Ada orang yang akan mendebat bahwa penduduk desa tidak perlu dibebani penyuluhan mengenai konsep REDD+ yang luas, rumit dan agak abstrak, karena tidak akan berpengaruh langsung pada pencapaian pengurangan emisi dan peningkatan mata pencaharian lokal. Namun, kami menyanggah pendapat ini; pengguna hutan lokal harus mengetahui mengenai konsep dasar REDD+ agar dapat memahami bagaimana proyek REDD+ bekerja, peluang dan risikonya, dan juga hak dan tanggung jawab yang terkait dengan partisipasi mereka, sebelum mereka dapat memberikan persetujuan untuk menerima atau menolak proyek REDD+ sesuai kerangka FPIC. Namun, menerapkan FPIC dengan benar mungkin sukar, khususnya karena FPIC dipandang bukan sebagai proses sekali jalan, dan harus berdaur sejalan dengan kemajuan dan perubahan REDD+ (Bab 17), memerlukan banyak kesempatan untuk berbagi pengetahuan selama masa proyek berlangsung.

Sampai sejauh mana intervensi proyek dapat sejalan dengan keinginan masyarakat lokal? Semua proyek yang dianalisis merencanakan untuk menyediakan mata pencaharian alternatif bagi penduduk desa, yang berpotensi menangani sebagian dari harapan dan kekhawatiran masyarakat lokal. Menanggapi kekhawatiran lokal memang penting untuk mendapatkan dukungan para pemangku kepentingan ini. Namun mengharapkan proyek REDD+ untuk memenuhi keinginan dan kebutuhan penduduk secara sempurna tampaknya di luar kapasitas proyek dan mungkin tidak realistis, khususnya mengingat sasaran pokok REDD+ adalah untuk mengurangi emisi gas rumah kaca. 
Ada juga sejumlah risiko dan biaya besar yang terkait dengan penerapan proyek-proyek REDD+ yang harus diperhitungkan oleh para pemrakarsa proyek. Lebih jauh, rancangan proyek-proyek REDD+ umumnya rumit, khususnya dimensi-dimensi teknologinya, dan pemantauannya memerlukan usaha keras. Misalnya, manfaat akhir yang dapat dibagikan kepada penduduk lokal akan bergantung pada pendapatan karbon yang dapat dikumpulkan suatu proyek. Waktu dan sumberdaya yang diperlukan untuk memastikan partisipasi penuh dan setara bisa sangat mahal bagi proyek. Pertanyaannya, sampai sejauh mana proyek-proyek akan tetap menarik untuk masyarakat lokal agar memilih REDD+ daripada inisiatif-inisiatif lain yang merugikan hutan, tetapi lebih menjanjikan dalam menghasilkan pendapatan atau mata pencaharian. Tantangan utamanya ialah memenuhi kebutuhan dan keinginan para pengguna hutan lokal dalam kendala dan keterbatasan suatu proyek.

\subsection{Kesimpulan dan langkah-langkah ke depan}

Sebagian dari yang membedakan REDD+ dengan berbagai cara pendekatan konvensional ialah kemungkinan aliran pendapatan besar yang akan memberi hasil sama-sama-menang bagi perlindungan hutan dan mata pencaharian yang lebih baik. Bab ini mengulas apakah pandangan para pengguna hutan lokal mengenai proyek-proyek REDD+ mencerminkan pernyataan sama-sama-menang ini. Temuan-temuannya menyoroti fakta bahwa di lokasi yang penduduk desanya sadar akan REDD+ dan/atau proyek REDD+ lokal, mereka memahami sasaran utamanya adalah perlindungan hutan. Namun, mereka tidak mengaitkan perlindungan hutan dengan perbaikan pendapatan sebagai sasaran proyek REDD+, padahal ada fakta bahwa semua proyek berencana untuk mendukung mata pencaharian alternatif, dan dalam beberapa kasus, menerapkan PES. Partisipasi lebih jauh dalam proyek-proyek REDD+ bergantung pada perbaikan pendapatan, dan para pemrakarsa perlu menangani masalah mata pencaharian dan kesejahteraan para pemangku kepentingan lokal.

Tantangan lain untuk usaha REDD+ keseluruhan ialah bahwa penduduk desa bergantung kepada para pemrakarsa untuk mendapat informasi mengenai REDD+ dan proyek REDD+ lokal. Karena itu para pemrakarsa berperan penting dalam memupuk pengetahuan lokal mengenai intervensi REDD+. Diharapkan para pemrakarsa akan berusaha untuk memastikan bahwa keprihatinan penduduk lokal diperhatikan dan dihormati dalam proyek-proyek REDD+, tetapi konflik kepentingan dan ketidakseimbangan kekuasaan dapat menyulitkan usaha para pemrakarsa untuk memberikan informasi. Karena itu mungkin akan diperlukan penghubung informasi independen atau penasihat hukum untuk masyarakat desa, misalnya ketika kesepakatan hukum ditandatangani, untuk memungkinkan mereka mengambil keputusan berdasarkan informasi yang telah mereka terima. 
Ringkasnya, studi ini menyoroti pentingnya memasukkan harapan dan keprihatinan penduduk lokal ke dalam rancangan dan penerapan REDD+. Bab ini juga menggarisbawahi kebutuhan untuk memperbaiki komunikasi antara para pemrakarsa proyek dan para pemangku kepentingan lokal. Harapan, kekhawatiran dan rekomendasi yang diungkapkan oleh penduduk lokal di lokasi-lokasi yang diambil sampelnya tampaknya mencerminkan pengalaman dan kekecewaan terhadap inisiatif konservasi dan pembangunan sebelumnya. Karena REDD+ mengandung janji untuk meningkatkan konservasi hutan dan juga mata pencaharian lokal, penduduk lokal secara potensial dapat meraih banyak hal, tetapi juga kehilangan banyak bila rezim pengelolaan hutan baru ini gagal. Mengingat pertaruhan REDD+ tinggi, suara penduduk lokal penting didengarkan, bukan hanya oleh pemrakarsa proyek, tetapi juga oleh para perumus kebijakan nasional dan internasional. 


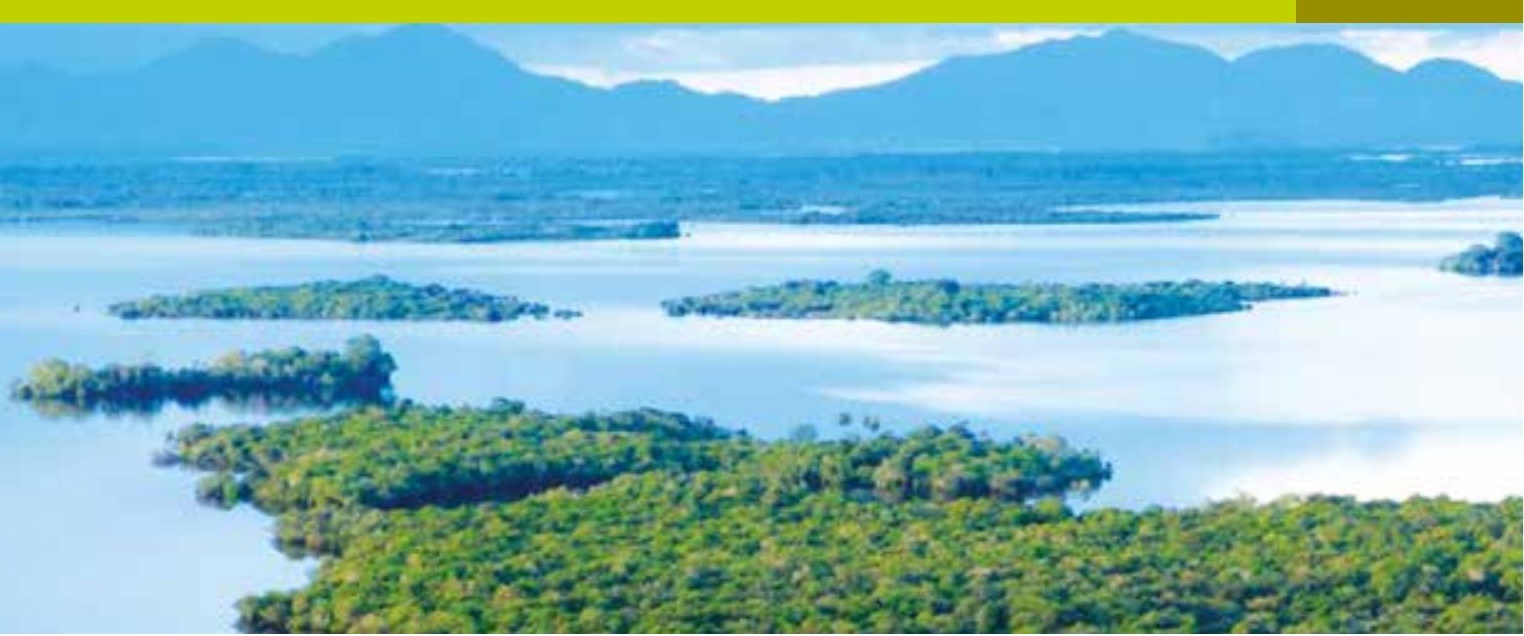

\section{Pemilihan lokasi untuk proyek karbon hutan}

Liwei Lin, Subhrendu K. Pattanayak, Erin O. Sills dan

William D. Sunderlin

- Negara-negara yang indeks keanekaragaman hayatinya lebih tinggi dan wilayahnya memiliki kawasan lindung yang lebih luas tampaknya lebih mungkin untuk memiliki proyek karbon, menguatkan penegasan para pemrakarsa bahwa mereka menganggap keanekaragaman hayati sebagai manfaat tambahan ketika memilih lokasi.

- Wilayah yang laju deforestasi dan kerapatan karbon hutannya lebih tinggi di Brasil dan Indonesia lebih memungkinkan untuk memiliki proyek karbon hutan, konsisten dengan fokus pada prinsip penambahan. Namun, proyek-proyeknya juga cenderung berlokasi di daerah yang lebih jauh (dan mungkin tidak terlalu terancam) di Brasil.

- Desa-desa di dalam batas proyek (dalam satu sampel proyek REDD+ yang diteliti oleh CIFOR) sebagian besar bergantung pada pertanian, menekankan tantangan untuk mengurangi deforestasi tanpa merusak mata pencaharian berbasiskan pertanian.

\subsection{Pengantar}

Proyek merupakan bagian utama dari lanskap REDD+. Lebih dari 200 proyek sedang diterapkan atau dikembangkan di kurang lebih 40 negara 
(Kshatriya dkk. 2011). Pada tahun 2010, proyek REDD+ merupakan bagian terbesar dalam nilai transaksi dalam pasar karbon sukarela (Peters-Stanley dkk. 2011). Sebagai unit yang paling konkret dari diskusi kebijakan internasional mengenai REDD+, proyek merupakan titik acuan kunci untuk memahami bagaimana REDD+ akan berkembang di lapangan. Proyek juga merupakan sumber pelajaran untuk implementasi REDD+ di masa depan, sebagaimana dibahas dalam Bab 9, 10, 11 dan 14 (hak penguasaan, tantangan pemrakarsa, harapan dan kekhawatiran, dan MRV di proyek lokal) demikian juga kepustakaan lainnya (misalnya, Harvey dkk. 2010b; Hajek dkk. 2011).

Penelitian sebelumnya yang menilai distribusi gagasan REDD + di berbagai negara menemukan bias menentang Afrika dan mendukung negara-negara yang stok karbonnya lebih tinggi (Wertz-Kanounnikoff dan Kongphan-Apirak 2009; Cerbu dkk. 2011). Selain itu, Cerbu dkk. (2011) menemukan bahwa indikator keanekaragaman hayati dan tata kelola yang lebih tinggi meningkatkan probabilitas suatu negara untuk memiliki proyek REDD+. Namun sampai hari ini belum ada usaha untuk menilai geografi subnasional proyek REDD+. Usaha ini lebih menantang karena kurangnya informasi yang kokoh mengenai perbatasan proyek REDD+ (misalnya, tidak seperti kawasan lindung) dan karena batas-batasnya yang tepat sering berubah-ubah dan/atau bersifat rahasia sampai proyek itu dipresentasikan untuk validasi oleh standar penyeimbangan (offset) karbon.

Dalam bab ini, kami menggunakan data yurisdiksi (negara, kabupaten, dan desa) di mana proyek berada untuk mendapat wawasan dalam pemilihan lokasi. Lokasi proyek penting karena membentuk kemungkinan penambahan dan untuk belajar dari pengalaman. Namun, pertama kami membicarakan sumber-sumber informasi mengenai proyek karbon hutan dan memutakhirkan informasi yang tercantum dalam Sills dkk. (2009) mengenai siapa dan apa yang terlibat dalam proyek-proyek ini.

\subsection{Sumber-sumber informasi mengenai proyek}

Bab ini mengambil dari tiga sumber informasi mengenai proyek REDD+ (Gambar 12.1). Pertama ialah sebuah katalog mengenai proyek karbon global yang dikembangkan oleh Studi Komparatif Global (GCS) tentang REDD+ (lihat Lampiran) (Kshatriya dkk. 2011). Katalog ini terus dikembangkan dan melengkapi usaha-usaha lain untuk melacak proyek, sebagaimana dijelaskan dalam Kotak 12.1. Katalog ini dikumpulkan melalui pencarian di Internet (termasuk situs-situs Web yang tercantum di Kotak 12.1), korespondensi melalui surat elektronik dan wawancara dengan para pemrakarsa proyek, sebuah tinjauan pustaka lama mengenai proyek penyeimbangan karbon, dan masukan para pakar dari masing-masing negara. Katalog ini mencakup proyek dalam berbagai tahap implementasi, dari perencanaan awal sampai proyek yang menjual kredit karbon terverifikasi. 


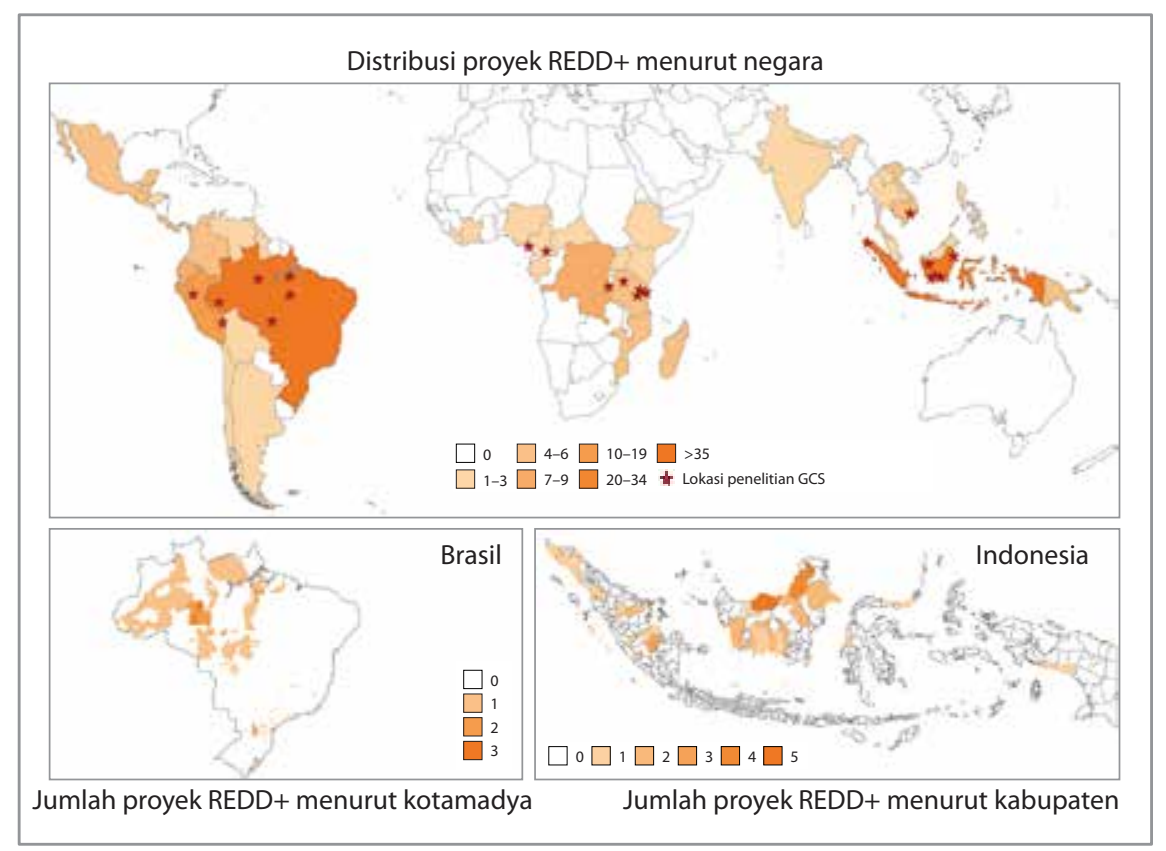

Gambar 12.1 Distribusi proyek REDD+

Kedua, dengan bantuan staf CIFOR dan rekan-rekan sekerja di Brasil dan Indonesia, kami mampu memperoleh informasi yang lebih terperinci mengenai para pemrakarsa dan yurisdiksi (kotamadya atau kabupaten) di mana proyek berada di negara-negara tersebut. Kami juga menghubungi banyak pemrakarsa - $33(75 \%)$ dari proyek di Indonesia dan $20(56 \%)$ dari Brasil - untuk informasi mengenai strategi dasar mereka. Fokus kami di Brasil dan Indonesia dimotivasi oleh fakta bahwa kedua negara ini menghasilkan lebih dari separuh emisi global dari deforestasi (Murray dan Olander 2008), memiliki jumlah proyek karbon hutan terbanyak (Kshatriya dkk. 2011) dan merupakan tiga negara yang stok karbon hutan totalnya tertinggi (Saatchi dkk. 2011).

Ketiga, untuk 20 proyek di GCS (di enam negara), kami juga memiliki informasi dasar mengenai desa-desa yang terletak di dalam dan berdekatan dengan proyeknya, dikumpulkan sebagai bagian dari proses pemilihan sampel pada metode evaluasi sebelum-setelah-pengendalian-dampak (BACI) yang diuraikan dalam Lampiran. Informasi ini dikumpulkan dari informan-informan kunci, statistik sekunder dan kunjungan lapangan. ${ }^{1}$ Basis datanya mencakup 148 desa yang berada di perbatasan proyek REDD+ dan 170 desa yang berada di luar perbatasan proyek tetapi di daerah yang sama.

1 Instrumen penelitian GCS dan basis data ini disebut "Formulir Penilaian Desa". 


\section{Kotak 12.1 Katalog proyek-proyek REDD+}

Mrigesh Kshatriya dan Liwei Lin

Ada beberapa landasan dalam mengatalogkan dan menyajikan informasi mengenai proyek REDD+. Pada tahun 2011, CIFOR meluncurkan katalog proyek karbon hutan dan sebuah peta antarmuka dan tautan-tautan ke informasi lebih jauh mengenai proyek tadi, tersedia di http://www. forestsclimatechange.org/redd-map. Organisasi lain yang sedang melacak perkembangan proyek REDD+ atau proyek karbon hutan dapat dikategorikan sebagai berikut:

- Organisasi penentu standar seperti CCBA, VCS dan Plan Vivo

- LSM lingkungan hidup seperti Institute for Conservation and Sustainable Development of Amazonas (IDESAM), Global Canopy Programme, dan Forest Trends (termasuk Forest Carbon Portal and Carbon Catalog)

- Organisasi riset seperti CIFOR dan IGES (lihat di bawah)

- Organisasi antarpemerintah seperti UNFCCC Clean Development Mechanism (CDM) dan World Bank Carbon Finance Unit.

Sebagai tambahan pada katalog CIFOR, situs-situs web berikut merupakan titik awal yang baik untuk informasi mengenai proyek REDD+:

\section{The Climate, Community and Biodiversity Alliance (CCBA)}

(http://www.climate-standards.org)

CCBA merupakan konsorsium berbagai LSM lingkungan hidup dan organisasi antarpemerintah yang telah mengembangkan standar-standar untuk mengevaluasi proyek karbon. Dari ke-75 proyek yang telah, dan sedang diaudit saat ini, 20 terdapat di Afrika, 17 di Asia, dan 25 di Amerika Latin, dan selebihnya di AS dan Eropa.

\section{Standar Karbon Terverifikasi (VCS)}

(http://www.vcsprojectdatabase.org)

VCS didirikan untuk menyediakan jaminan mutu sertifikasi proyek dalam pasar karbon sukarela. Situs-situs web ini berisi informasi dari lebih dari 750 proyek dari konservasi hutan sampai sektor pembuangan sampah, tetapi hanya 22 yang masuk dalam kategori pertanian, kehutanan atau tata guna lahan di negara-negara berkembang.

\section{Plan Vivo}

(http://www.planvivo.org/projects/registeredprojects/)

Yayasan Plan Vivo merupakan LSM Inggris terdaftar yang telah menciptakan berbagai standar untuk perancangan dan sertifikasi proyek hutan berbasiskan masyarakat. Daftar proyek Plan Vivo memiliki 17 proyek, 10 beroperasi di Afrika, 3 di Asia dan 4 di Amerika Latin. 


\section{Forest Carbon Portal}

(http://www.forestcarbonportal.com)

Dikembangkan oleh Ecosystem Marketplace, sebuah program untuk LSM Forest Trends yang berbasis AS, Forest Carbon Portal memiliki basis data proyek penyeimbangan karbon hutan di seluruh dunia di mana dapat dilakukan pencarian. Tujuan inventarisasi adalah untuk menautkan proyek karbon hutan ke pasaran karbon, dan inventaris ini dirancang untuk kisaran pemangku kepentingan yang luas. Dari ke-40 proyek REDD+ dalam sistem ini, 11 terdapat di Afrika, 2 di Asia dan 21 di Amerika Latin, sisanya di Amerika Utara dan Eropa.

\section{Carbon Catalog}

(http://www.carboncatalog.org/)

Carbon Catalog merupakan daftar independen dari kredit karbon, baru-baru ini juga dibeli oleh Ecosystem Marketplace. Daftar ini berisi 136 penyedia karbon dari berbagai organisasi nirlaba dan komersial, dan mencakup 627 proyek di seluruh dunia. Dari proyek di sektor kehutanan, 27 terdapat di Afrika, 16 di Asia dan 22 di Amerika Latin.

\section{The REDD Countries Database (RCD)}

(http://www.theredddesk.org/countries)

RCD - bagian dari REDD - merupakan basis data independen dari kegiatan di lapangan, yang telah dikembangkan oleh Global Canopy Programme dan Forum on Readiness untuk REDD+ dalam kerja sama dengan organisasi riset di negara bersangkutan. Saat ini, RCD mencakup informasi mengenai 144 inisiatif REDD+ (proyek subnasional dan kegiatan kesiapan) di tujuh negara.

\section{Institute for Global Environmental Strategies (IGES)}

(http://redd-database.iges.or.jp/redd/)

IGES merupakan lembaga penelitian internasional yang didirikan di bawah pemerintah Jepang. Basis data IGES REDD+ menggambarkan proyek dan kegiatan kesiapan negara. Dengan total 29 proyek, 3 terdapat di Afrika, 17 di Asia dan 9 di Amerika Latin.

Meskipun data ini tidak mewakili sampel acak dari desa-desa, secara umum desa-desa menunjukkan ciri-ciri desa dalam proyek REDD+.

\subsection{Tinjauan mengenai proyek karbon hutan}

Kami mendefinisikan proyek REDD+ sebagai intervensi untuk meningkatkan, menguantifikasi dan melaporkan stok karbon hutan dibandingkan dengan skenario acuan bisnis seperti biasa dalam suatu wilayah subnasional yang 
ditetapkan secara geografis di negara berkembang (nonAneks I). Sering terjadi ambiguitas mengenai apakah tanda "plus" dalam REDD+ mencakup penghutanan kembali (AR). Dalam pasar kepatuhan yang ada, ada pembedaan yang nyata antara proyek REDD (yang dimaksudkan untuk mengurangi deforestasi atau degradasi hutan) dan proyek AR (yang menciptakan hutan-hutan baru). Menurut aturan yang telah digariskan dalam protokol Kyoto, hanya proyek AR yang memenuhi syarat untuk berpartisipasi dalam CDM. Namun, garis ini baur untuk proyek REDD+. Banyak proyek yang menganggap dirinya sebagai REDD + memasukkan beberapa komponen seperti penanaman pohon, baik dimotivasi oleh keinginan untuk memastikan pasokan produk kayu, atau menciptakan peluang kerja atau kredit pasar yang dapat dikaitkan dengan pohon-pohon baru di lanskapnya. Kami memasukkan proyek aforestasi yang menanam pohon di luar hutan-hutan yang sudah ada dalam kategori proyek 'karbon hutan' yang lebih luas. Kami mendefinisikan 'proyek REDD+' sebagai proyek karbon hutan yang melibatkan sedikitnya sebagian intervensi di wilayah hutan yang ada, berupa menghindari deforestasi, menghindari degradasi, memulihkan hutan atau memperbaiki pengelolaan hutan.

Definisi ini mencakup proyek menghindari deforestasi sebelumnya (dikatalogkan dalam Caplow dkk. 2011) yang diluncurkan sebelum REDD+ tetapi yang tetap aktif sejak kehadirannya.

Tabel 12.1 Jumlah proyek REDD+ di Brasil dan Indonesia berdasarkan sasaran dan kegiatan

\begin{tabular}{llc}
\hline & \multicolumn{2}{c}{$\begin{array}{c}\text { Jumlah proyek yang mengejar } \\
\text { masing-masing sasaran/kegiatan }\end{array}$} \\
\cline { 2 - 3 } & Brasil & Indonesia \\
\hline Sasaran & & \\
\hline Menghindari deforestasi & 20 & 28 \\
\hline Menghindari degradasi & 14 & 23 \\
\hline Restorasi & 13 & 21 \\
\hline Kegiatan & 12 & 18 \\
\hline Pengelolaan hutan kemasyarakatan & 15 & 22 \\
\hline Pemantauan dan penegakan (Penegakan) & 16 & 23 \\
\hline $\begin{array}{l}\text { Proyek Konservasi dan Pembangunan } \\
\text { terpadu (ICDP) }\end{array}$ & 14 & 20 \\
\hline Imbalan untuk jasa lingkungan (PES) & 20 & 33 \\
\hline Total proyek REDD+ yang dihubungi & & \\
\hline
\end{tabular}




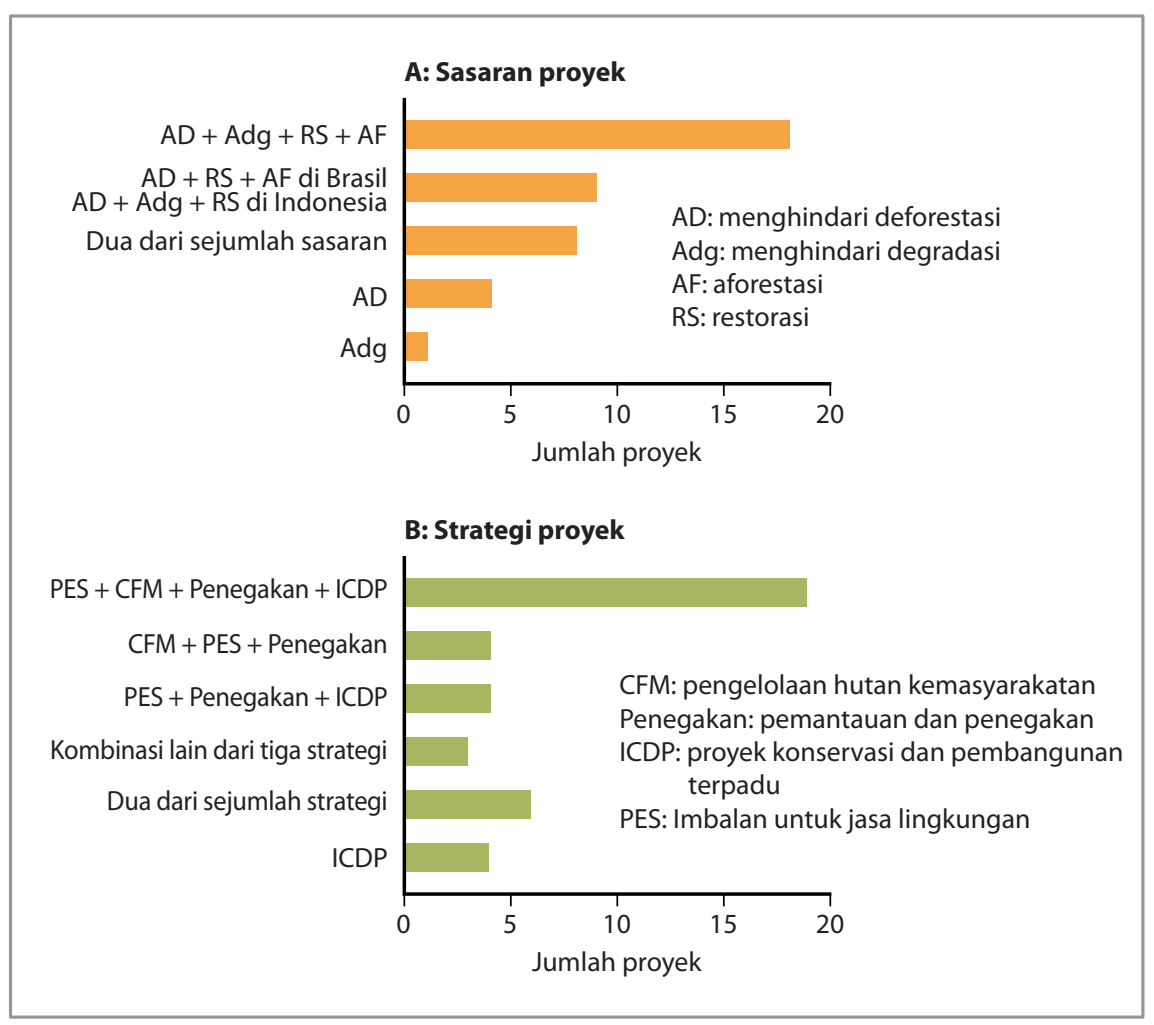

Gambar 12.2 Jumlah proyek di Brasil dan Indonesia dengan kombinasi sasaran dan kegiatan yang berbeda

\subsubsection{Sasaran dan kegiatan}

Berfokus pada Brasil dan Indonesia, hampir semua (48 dari 53) pemrakarsa proyek REDD+ yang kami hubungi menyebutkan pengurangan deforestasi sebagai salah satu sasaran mereka, dan dari kesemuanya ini, lebih dari 40 juga menyebutkan pengurangan degradasi atau restorasi hutan (Tabel. 12.1). Banyak pemrakarsa mengindikasikan bahwa mereka mengejar semua sasaran yang kami daftarkan: menghindari deforestasi, menghindari degradasi, memulihkan hutan dan aforestasi (Gambar 12.2). Kami menanyakan kepada para pemrakarsa apakah mereka mencapai sasaran-sasaran ini melalui pengelolaan hutan kemasyarakatan, pemantauan dan penegakan hukum dan peraturan kehutanan, inisiatif konservasi dan pembangunan terpadu di sekeliling kawasan lindung (ICDP), dan/atau imbalan untuk jasa ekosistem (PES, sebagai uang tunai atau imbalan sejenis). Sejumlah kecil pemrakarsa mencatat kegiatan tambahan, seperti penyebaran teknologi baru, seperti kompor masak yang lebih baik dan pembalakan dengan dampak tereduksi. Tabel 12.1 dan Gambar 12.2 meringkaskan hasil-hasilnya, yang menegaskan bahwa sebagian besar pemrakarsa merencanakan pembayaran 
berbasiskan kinerja bersyarat seperti imbalan untuk jasa lingkungan (PES). Semua proyek Indonesia yang merencanakan PES dan hampir semua (13) proyek Brasil yang merencanakan PES juga berinvestasi dalam pemantauan dan penegakan yang lebih baik untuk berbagai intervensi seperti ICDP, konsisten dengan model turunan yang dibahas dalam Bab 10.

Gabungan strategi ini juga konsisten dengan serangkaian tekanan deforestasi yang diemban oleh proyek. Di Indonesia, para pemrakarsa yang kami hubungi mengindikasikan dalam jumlah yang kira-kira setara bahwa fokus utama mereka pada "mengubah perilaku para pelaku yang saat ini melakukan deforestasi atau degradasi hutan dalam wilayah spesifik lokal proyek" atau mengenai "pencegahan ancaman deforestasi atau degradasi di masa depan yang dapat diantisipasi" (misalnya, pengembangan perkebunan kelapa sawit oleh perusahaan-perusahaan dari luar wilayah proyek). Di Brasil, para pemrakarsa lebih besar kemungkinannya untuk mengatakan bahwa fokus proyek mereka adalah pencegahan ancaman di masa depan dan bukan mengubah perilaku para pelaku masa kini. Penegakan hukum yang lebih baik mungkin merupakan strategi yang paling sering disebutkan, sebagian karena hal ini relevan dengan kedua tipe ancaman. Sementara itu pengelolaan hutan kemasyarakatan, konservasi dan pembangunan terpadu, dan PES umumnya diimplementasikan bersama masyarakat lokal yang memiliki tradisi untuk menggunakan (dan memiliki hak kepemilikan adat) hutan lokal. Di lokasi-lokasi proyek di mana para pelaku dari luar (yang tidak memiliki tradisi atau hak untuk menggunakan hutan) merupakan ancaman deforestasi utama, lebih sulit untuk mengatasi ancaman ini dengan pembayaran berbasiskan kinerja, konservasi dan pembangunan terpadu, atau pengelolaan hutan kemasyarakatan. Tipe strategi turunan lain yang diterapkan oleh proyek ialah menggunakan strategi-strategi ini untuk membangun aliansi lokal dan menghalau ancaman-ancaman deforestasi eksternal (lihat Kotak 12.2).

\subsubsection{Para pemain utama}

Proyek karbon hutan sedang diimplementasikan oleh pemerintah, berbagai lembaga masyarakat dan sektor swasta, yang menghasilkan variasi penting dalam penekanan dan keefektifannya (Agrawal dkk. 2011). Mayoritas proyek karbon hutan yang kami katalogkan sedang diimplementasikan oleh berbagai LSM, biasanya dengan misi lingkungan hidup atau pembangunan berkelanjutan (lihat Virgilio dkk. 2010). Sampel GCS mengilustrasikan tren ini, dengan proyek yang dipimpin oleh berbagai organisasi lingkungan hidup internasional seperti Conservation International, The Nature Conservancy, Fauna and Flora International, dan Jane Goodall Institute; organisasi pembangunan internasional seperti CARE dan SNV; dan berbagai organisasi lingkungan hidup nasional seperti Amazon Environmental Research Institute, Tanzania Forest Conservation Group dan Centre for Environment and Development (lihat daftar lokasi proyek CIFOR dalam Lampiran mengenai GCS). Dari 107 proyek 


\section{Kotak 12.2 Memadukan sarana konservasi dalam program Bolsa Floresta, Amazon Brasil}

Jan Börner dan Sven Wunder

Proyek REDD Juma Sustainable Development Reserve (SDR Juma) dimulai tahun 2007 sebagai bagian dari program Bolsa Floresta di negara bagian Brasil terbesar, Amazonas. Bolsa Floresta merupakan program konservasi yang ambisius, mencakup 1 juta hektar di 15 kawasan lindung di negara bagian Amazonas. SDR Juma terletak relatif dekat dengan batas daerah pertanian yang meluas pesat di Apui, di sudut tenggara Amazonas. Populasinya terutama terdiri dari produsen tradisional skala kecil yang, selain dari produksi tanaman pangan, sangat bergantung pada produk hutan dan memancing untuk mata pencaharian mereka. Deforestasi terproyeksi di masa depan tetap tinggi untuk Juma, karena produksi ternak diharapkan secara bertahap akan melanggar batas di bagian selatan dan timur.

Program Bolsa Floresta terutama melibatkan masyarakat lokal di kawasan lindung dan bermaksud mendorong pengelolaan hutan yang baik melalui insentif konservasi bersyarat dan intervensi yang ditujukan untuk meningkatkan kualitas hidup. Dengan demikian, program ini menggabungkan kebijakan-kebijakan konservasi yang berbeda, termasuk ICDP dan PES. Pertama, PES langsung di bawah Bolsa Floresta merupakan inovasi yang sangat terinformasi dan populer secara lokal di Amazonas, tetapi hanya mewakili sedikit bagian dari total pembelanjaan program. Kedua, Bolsa Floresta meningkatkan layanan kesehatan dan pendidikan setempat, dengan demikian mengompensasi kekurangan penyediaan layanan publik umum di daerah lindung terpencil ini. Ketiga, asosiasi penduduk lokal diperkuat, termasuk misalnya, di SDR Juma, melalui perbaikan transportasi sungai yang diberikan kepada penduduk melalui asosiasi lokal. Keempat, Bolsa Floresta mendorong strategi produksi alternatif di desa-desa melalui intervensi tipe ICDP (misalnya, peternakan skala kecil, pemrosesan di lokasi pertanian untuk produk-produk bernilai tambah) agar membuat sistem produksi lebih intensif dan berkelanjutan.

Dengan demikian, program ini bertujuan untuk menangani titik lemah yang sudah lama dikenal dari strategi Brasil yang baru-baru ini sangat sukses untuk mengurangi deforestasi Amazon melalui pemantapan kawasan lindung dan penegakan berbagai peraturan konservasi lainnya. Peraturan yang efektif bergantung pada kehadiran di lapangan yang mahal dan sering dan mungkin ada biaya penghidupan lokal. Sebagai tanggapan, Bolsa Floresta dirancang untuk menyangga kehilangan pendapatan tingkat rumah tangga lokal yang terjadi karena kepatuhan terhadap aturan-aturan kawasan lindung (komponen PES), menyediakan manfaat organisasi dan ganti rugi kolektif (komponen asosiasi dan sosial) dan mengurangi ketergantungan lokal pada kegiatan yang mendegradasi hutan (komponen pendapatan alternatif). Dengan demikian, pelaksana program Sustainable Amazon Foundation (FAS) berharap untuk meningkatkan ikatan konservasi dengan penduduk setempat melalui integrasi komponen-komponen tersebut, dan dengan demikian mendukung keutuhan kawasan lindung, bahkan jika tekanan dari luar meningkat ketika perbatasan pertanian secara bertahap mendekat. Bukti dari batas kolonisasi Amazon yang lebih dulu menunjukkan bahwa mosaik hutan-pertanian yang stabil dapat muncul dari lanskap yang didominasi petani kecil, dengan demikian menghindari konversi yang lebih umum menjadi padang penggembalaan ekstensif. Bolsa Floresta merupakan usaha untuk bergerak ke arah itu, dan waktu akan menunjukkan tingkat keberhasilannya. 
karbon hutan di Brasil dan Indonesia, 65 (61\%) dipimpin oleh LSM. Dari ke 65 proyek ini, 20 (30\%) dipimpin oleh LSM yang basisnya di Amerika Serikat, dengan LSM lainnya dari Eropa (misalnya, Jerman, Swiss dan Inggris), Asia (misalnya, Australia dan Jepang) dan negara-negara tuan rumah. Di Brasil dan Indonesia, 43\% proyek adalah pemrakarsa dari sektor swasta. Contoh-contoh sampel proyek GCS termasuk berbagai kelompok konsultan swasta seperti Mazars Starling Resources di Indonesia dan GFA Consulting Group di Kamerun. Akhirnya, pemerintah setempat sering bermitra dalam implementasi proyek dan berperan sebagai pemimpin dalam proyek-proyek dalam yurisdiksi mereka (misalnya, negara bagian Acre di Brasil dan provinsi Aceh di Indonesia).

Pemain utama lainnya dalam lanskap proyek mencakup para pemberi dana dan organisasi (penentu) standar, bersama para pemberi sertifikasi atau auditor yang memverifikasi kepatuhan dengan standar-standar yang ditetapkan. Sebagaimana dibicarakan dalam Bab 7, pendukung dana termasuk donatur filantropis, sektor swasta (mencari laba), dan pemerintah melalui inisiatif multilateral (US-REDD-Programme, Forest Carbon Partnership Facility Forest Investment Program dan Congo Basin Forest Fund) dan bantuan bilateral. Donatur yang terkemuka untuk bantuan bilateral adalah pemerintah Norwegia melalui Inisiatif Iklim dan Hutan Internasional, yang telah mengikrarkan lebih dari AS \$680 juta untuk REDD+ (Tipper 2011) untuk proyek REDD+ dan kegiatan kesiapan. Donatur bilateral terbesar kedua untuk REDD+ ialah Inggris (Climate Funds Update 2012).

Standar-standar yang memimpin proyek REDD+ ialah Climate, Community and Biodiversity Project Design Standards (CCB Standards) dan Verified Carbon Standard (VCS) (Diaz dkk. 2011), dibahas lebih jauh dalam Bab 14 dan 17. Winrock's American Carbon Registry juga memiliki standar untuk proyek karbon hutan, mencakup metode untuk REDD+ berdasarkan penghindaran deforestasi terencana, dan sedang mengembangkan standar untuk proyek yang terdapat di sistem yurisdiksi REDD+. California Climate Action Reserve mencakup proyek karbon hutan di AS dan sedang mengembangkan sebuah protokol untuk proyek REDD+ di Meksiko. Plan Vivo telah digunakan terutama untuk agroforestri dan proyek AR tetapi terdapat proyek REDD+ dalam jalur sertifikasinya. Standar-standar lain mencakup CarbonFix untuk proyek AR dan Global Conservation Standard untuk stok karbon di kawasan lindung, yang relatif baru (Merger dkk. 2011). Baik organisasi yang melakukan pengembangan standar-standar ini dan sebagian besar auditor yang mengeluarkan sertifikasi kepatuhan dengan standar-standarnya berasal dari grup negara-negara OECD yang sama seperti para donatur. Namun, Brasil merupakan pengecualian karena memiliki dua standar nasional (Social Carbon dikelola oleh the Ecologica Institute dan Brazil Mata Viva dikelola oleh the Bolsa de Títulos e Ativos Ambientais do Brazil), dan juga Social and Environmental Principles and Criteria yang dikembangkan oleh LSM Brasil sebagai panduan implementasi REDD+ di Amazon Brasil. 


\subsection{Lokasi proyek}

\subsubsection{Mengapa lokasi penting}

Agar mencapai nilai penambahan, tentunya sama masuk akal untuk menempatkan proyek di mana deforestasi atau degradasi hutan yang signifikan diduga dapat terjadi. Sebagaimana disarankan oleh kepustakaan mengenai PES di Kosta Rika, suatu intervensi tidak akan berdampak riap dalam mengurangi deforestasi ketika laju deforestasinya memang sudah rendah (Sánchez-Azofeifa dkk. 2007). Namun, hal ini tidak menghilangkan kemungkinan bahwa intervensi dapat mendorong regenerasi hutan dan/atau pengelolaan hutan yang lebih baik (Daniels dkk. 2010; Arriagada dkk. 2012), khususnya dalam konteks seperti Kosta Rika dengan hak penguasaan lahan yang relatif jelas dan tata kelola yang baik (Pagiola 2008). Meluaskan semua faktor ini dalam REDD+, sebuah kondisi yang diperlukan - namun tidak cukup - untuk mengurangi emisi dari deforestasi (RED) adalah keberadaan stok karbon hutan yang signifikan tetapi terancam oleh deforestasi di masa depan, sebagaimana diindikasikan oleh tren-tren deforestasi baru-baru ini dan kehadiran para pemicu deforestasinya (misalnya, pembangunan jalan raya). Bila kondisi ini tidak dipenuhi, berarti intervensi REDD+ harus mencapai penambahan melalui $\mathrm{D}+$ (menghindari degradasi atau peningkatan stok karbon hutan).

Beberapa pihak mempertanyakan "berapa banyak proyek REDD+ akan berada di daerah batas pertanian, yang tanpa adanya REDD+, sebagian besar deforestasi tampaknya akan terjadi sehingga penambahan terbesar dapat dicapai. Sebuah kajian atas beberapa kasus di Meksiko dan Honduras, misalnya, menyingkapkan deforestasi tertinggi di berbagai daerah di mana lembaga-lembaga kehutanan dan lingkungan hidup pemerintah memiliki akses paling sedikit karena konflik sosial dan di mana tidak ada kegiatan REDD+ yang direncanakan (Louman dkk. 2011:368). Hal ini menggarisbawahi negosiasi timbal balik antara menempatkan proyek di mana terjadi deforestasi terbanyak yang harus dihindari dan menempatkan proyek di mana intervensi efektif dapat diimplementasikan secara realistis. Hal ini bergantung tidak saja pada kondisi tata kelola, tetapi juga pada biaya peluang konservasi hutan dan biaya operasional untuk proyek. Analisis oleh Busch dkk. (2012) menyarankan pemilihan lokasi yang mungkin untuk proyek REDD+ di Indonesia didasarkan pada harga karbon yang telah ditetapkan dan distribusi biaya peluangnya. Agrawal dan para penulis pendamping menyarankan bahwa proyek REDD+ yang ada telah dikembangkan, terutama untuk memberikan manfaat sosial dan ekologis tambahan yang dihargai oleh para investor awal. Sementara di masa depan, "segmen pasar karbon cenderung akan paling meluas mungkin adalah proyek-proyek yang manfaat sosial dan ekologis tambahannya tidak terlalu banyak menerima perhatian" (Agrawal dkk. 2011:384). Dengan demikian kami mempertimbangkan stok karbon hutan, laju deforestasi dan 
pemicunya, dan indikator tata kelola, biaya peluang dan manfaat tambahan sebagai penentu potensial untuk pemilihan lokasi yang optimal. Memahami pola pemilihan lokasi pada saat ini merupakan langkah pertama menghadapi tantangan untuk mengidentifikasi lokasi-lokasi optimal untuk proyek di masa depan, merancang sistem REDD + terpusat yang mencakup berbagai proyek, dan mengambil kesimpulan atau memetik pelajaran-pelajaran dari berbagai proyek REDD+.

\subsubsection{Distribusi lintas negara}

Kedua negara yang emisi dari perubahan tata guna lahannya tertinggi adalah Brasil dan Indonesia (Houghton 2009). Sebagaimana dilaporkan oleh Houghton (2009), perbedaan metode yang digunakan untuk memberikan peringkat menghasilkan peringkat yang berbeda bagi negara-negara lain. Namun selain Brasil dan Indonesia, yang termasuk negara yang emisinya tertinggi termasuk Republik Demokratik Kongo, Myanmar, Nigeria dan Venezuela. Distribusi lintas negara dari proyek REDD+ dapat juga dibandingkan dengan distribusi stok karbon hutan total, yang diperkirakan tertinggi di Brasil, Kolombia, Republik Demokrasi Kongo, Indonesia dan Peru (Saatchi dkk. 2011) walaupun ada variasi signifikan antara masing-masing studi (Gibbs dkk. 2007).

Terhitung sejak bulan November 2011, katalog global CIFOR mendaftarkan proyek karbon hutan di 51 negara nonAneks I. Dari negara-negara ini, sembilan negara hanya memiliki proyek yang terlibat dalam AR saja, tetapi ada 43 negara dengan sedikitnya 200 proyek REDD+ di seluruh dunia. Proyek yang tersebar luas melintasi banyak negara merupakan hal penting untuk meneguhkan perkembangan rezim REDD+ di masa depan, yang harus inklusif untuk menghindari kebocoran internasional (Murray dan Oleander 2008). Namun, sementara banyak negara memiliki satu atau dua proyek, sebagian besar terpusat di tiga negara saja: Brasil, Indonesia dan Peru. Kami meneliti pola-pola lintas negara ini dan kemungkinan penyebab mendasarnya.

Di Indonesia, terdapat 51 proyek karbon hutan, tujuh di antaranya tampaknya terlibat dalam AR saja. Ke-44 proyek lainnya (banyak di Kalimantan) melibatkan kombinasi pengurangan deforestasi, pengurangan degradasi, restorasi (pemulihan), reforestasi dan pengelolaan hutan. Kami telah mengatalogkan 56 proyek di Brazil: 20 proyek yang hanya melibatkan AR, sebagian besar terletak di daerah hutan pesisir Atlantik, dan 36 proyek yang melibatkan kombinasi berbagai strategi yang dapat diberi label REDD+, sebagian besar terletak di Amazon. Peru memiliki 41 proyek karbon hutan, termasuk 22 proyek yang kelihatannya hanya mengejar AR. Konsentrasi proyek di Brasil dan Indonesia konsisten dengan kepentingan global kedua negara sebagai sumber emisi GRK dari perubahan tata guna lahan (Murray dan Oleander 2008). Namun, sebagaimana disarankan oleh Phelps dkk. (2010a) dan Calmel dkk. (2010), faktor-faktor selain karbon hutan jelas juga berperan penting dalam pemilihan negara untuk 
proyek REDD+. Republik Demokratik Kongo, misalnya, hanya memiliki 11 proyek (empat proyek secara khusus mengerjakan AR), meskipun negara ini penting dalam hal emisi dan stok karbon hutannya. Demikian pula Kolombia yang memiliki stok karbon hutan tinggi namun hanya ada 10 proyek (lima khusus mengerjakan AR), dan kami telah mengidentifikasi satu proyek saja, masing-masing di Venezuela dan Nigeria dan tidak ada proyek di Myanmar.

Lin (dalam persiapan penerbitan) meneliti distribusi proyek REDD+ di berbagai negara berkembang tropis (sebuah subset negara-negara nonAneks I di bawah Protokol Kyoto). Dari 86 negara di Afrika, Asia dan Amerika Latin, 48 di antaranya memiliki sedikitnya satu proyek karbon hutan. Setelah mengontrol faktor luas lahan, populasi, GDP, indeks tata kelola dan laju kehilangan hutan, ia menemukan bahwa probabilitas proyek karbon hutan terkait positif dengan keanekaragaman hayati suatu negara (sebagaimana diukur oleh Global Environment Facility Benefit Index for Biodiversity (Pandey dkk. 2008)), persentase wilayah negara yang berada di dalam kawasan lindung darat (dari World Database on Protected Areas (IUCN dan UNEP 2010)), dan pengalaman suatu negara dengan penginderaan jarak jauh dan CDM (dari Resources for the Future Forest Carbon Index (Deveny dkk. 2009)). Semua ini konsisten dengan prioritas yang dinyatakan untuk keanekaragaman hayati dalam dokumen proyek, sebagaimana dilaporkan oleh Cerbu dkk. (2011). Karena itu masuk akal bahwa banyak proyek di Peru, yang memiliki indeks keanekaragaman hayati tinggi (peringkat 7 dari 86 negara) selain stok karbon yang besar dan kebijakan pemerintah yang mendukung.

\subsubsection{Geografi subnasional}

Untuk menilai pola-pola subnasional dalam pemilihan lokasi, kami mengidentifikasi jumlah proyek di setiap kotamadya di Brasil dan kabupaten di Indonesia. Cara ini memungkinkan kami untuk mengevaluasi apakah proyek telah ditargetkan pada yurisdiksi yang emisi karbonnya dari deforestasi tinggi dan berpotensi dapat dikurangi dengan intervensi proyek. Kami memperoleh data mengenai deforestasi dari Hansen dkk. (2008), yang memetakan kehilangan tutupan hutan secara kasar antara tahun 2000 dan 2005; karbon hutan dari Forest Carbon Index oleh RFF (Deveny dkk. 2009); dan persen tutupan hutan pada 2000 dari basis data tutupan daratan global (EC 2003).

Gambar 12.3 dan 12.4 menunjukkan plot kotak-garis (box and whisker plots $^{2}$ untuk laju deforestasi, kerapatan karbon hutan, dan perbandingan tutupan hutan di berbagai kotamadya Brasil dan kabupaten di Indonesia dengan dan tanpa proyek REDD+. Kami membagi lagi setiap negara menjadi

2 Plot kotak menunjukkan distribusi set data. Garis di dalam segi empat mewakili median distribusi. Batas atas dan bawah dari segi empat menunjukkan kuartil atas (25\%) dan kuartil bawah (25\%). Kedua garis di luar segi empat adalah nilai ekstrem bawah dan ekstrem atas. 

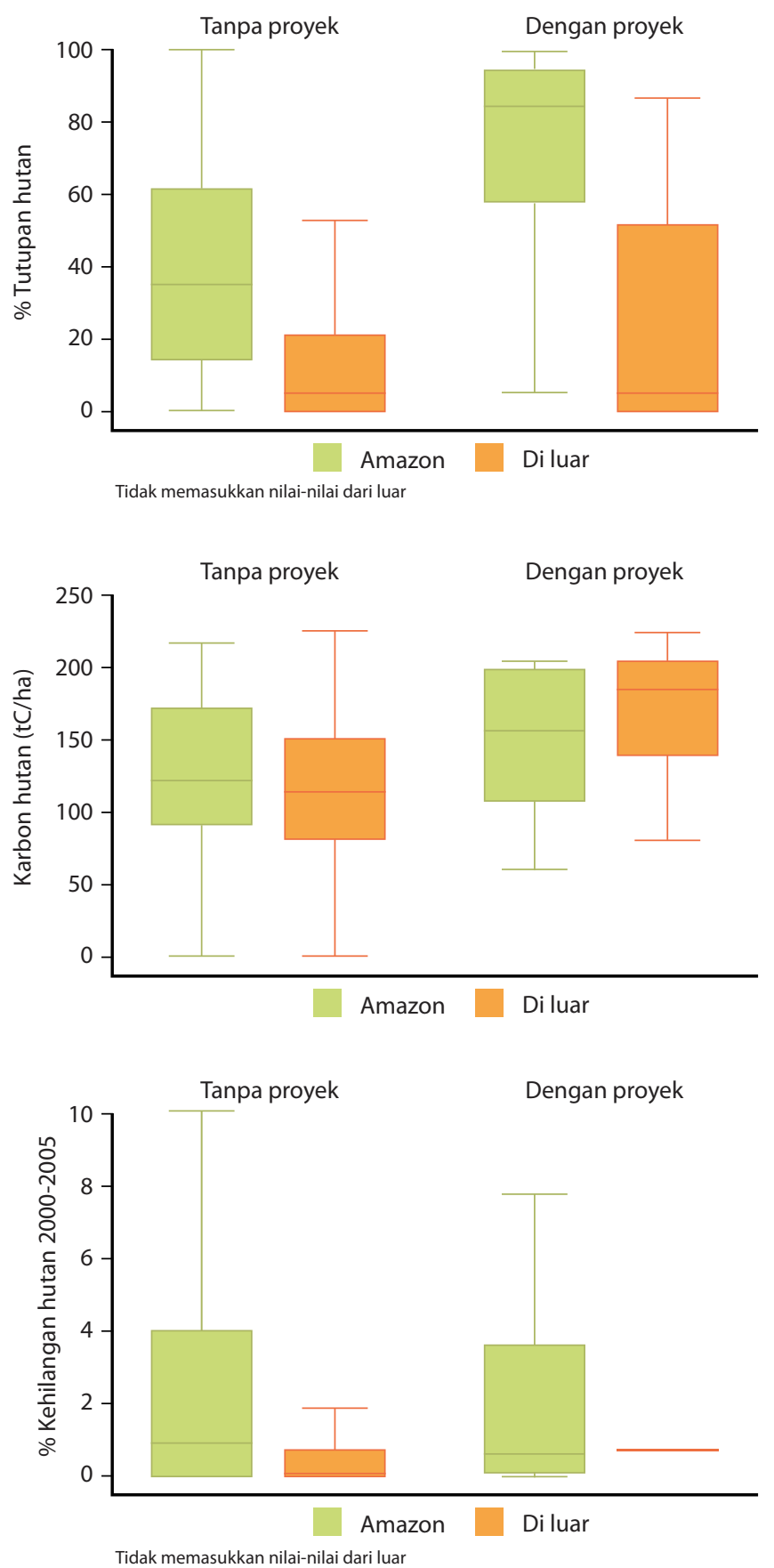

Gambar 12.3 Perbandingan kotamadya dengan sedikitnya satu proyek REDD+ terhadap kotamadya tanpa proyek REDD+, dibagi lagi dalam kotamadya dalam Legal Amazon vs. bagian Brasil lainnya (di luar) 

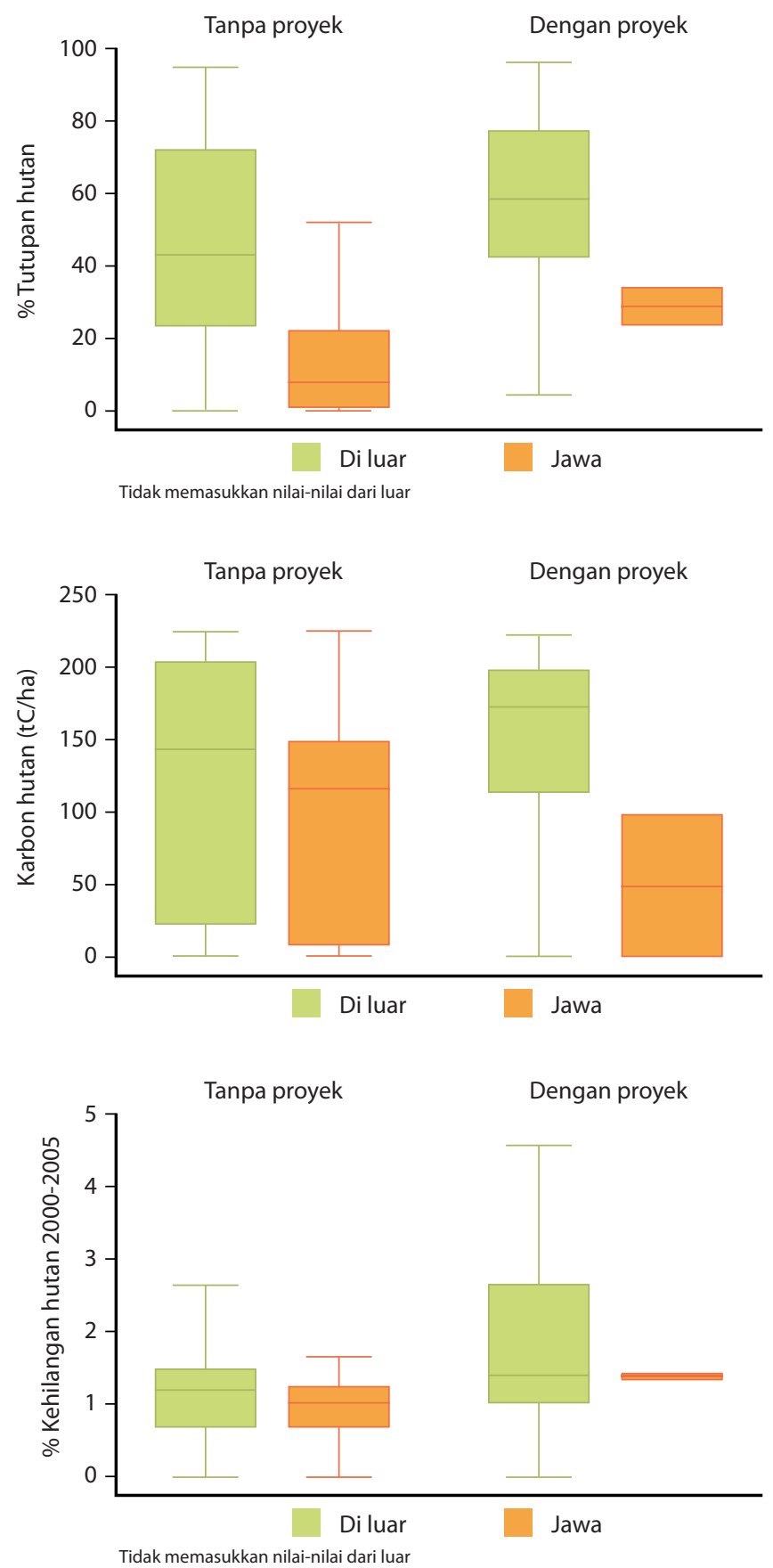

Gambar 12.4 Perbandingan kabupaten dengan sedikitnya satu proyek REDD+ terhadap kabupaten tanpa proyek REDD+, dibagi lagi dalam kabupaten di Pulau-pulau Luar (di luar provinsi-provinsi di Jawa) vs. Jawa 
wilayah perbatasan hutan (Brazilian Legal Amazon dan Pulau-pulau Luar Indonesia, digambarkan dengan abu-abu muda) dan daerah-daerah yang secara ekonomi lebih berkembang (Brasil di luar Amazon dan pulau Jawa, digambarkan dengan warna abu-abu gelap). Untuk Legal Amazon dan Pulau-pulau Luar Jawa, plot kotak menunjukkan bahwa proyek cenderung berada di tempat-tempat yang tutupan hutan dan karbon hutannya lebih tinggi, tetapi tidak selalu dengan laju deforestasi yang lebih tinggi. Hal ini menunjukkan bahwa proyek ditargetkan untuk tempat-tempat yang stok karbon hutannya besar, tetapi stok ini tidak menghadapi ancaman. Namun, sementara median tutupan hutan dan kerapatan karbon hutan lebih tinggi untuk kotamadya dan kabupaten dengan proyek REDD+, kuartil bagian dalamnya tumpang tindih. Dengan kata lain, ada juga variabilitas besar dalam ketiga ukuran karbon hutan, yang mengindikasikan bahwa ada faktor-faktor lain yang mendorong pemilihan lokasi. Kontrol terhadap faktor-faktor ini dapat memberikan gambaran yang lebih jelas mengenai bagaimana pemilihan lokasi terkait dengan karbon hutan.

Dalam memilih lokasi untuk proyek REDD+, para pemrakarsa juga cenderung mempertimbangkan biaya atau kesulitan untuk mengurangi emisi dan potensi untuk manfaat tambahan (lihat daftar ukuran proksi dalam Tabel 12.2). Banyak faktor yang memicu deforestasi juga cenderung meningkatkan kesulitan dan biaya implementasi proyek, misalnya biaya peluang tinggi, kerapatan penduduk tinggi, hak penguasaan lahan tidak jelas dan tata kelola buruk. Jadi, faktor-faktor seperti jalan raya atau kerapatan penduduk mungkin meningkatkan kemungkinan proyek dengan menciptakan potensi untuk penambahan, atau mengurangi kemungkinannya dengan membuatnya sulit untuk mengurangi deforestasi secara efektif. Kami mengumpulkan data subnasional mengenai kerapatan penduduk dari lembaga-lembaga sensus nasional, dan mengenai kerapatan jalan dari Digital Chart of the World (jumlah total meter jalan dibagi dengan ukuran unit administratif dalam meter persegi) (DMA 1992). Indeks Karbon Hutan RFF juga mencakup ukuran langsung biaya kesempatan (Naidoo dan Iwamura 2007). Manfaat tambahan utama yang diharapkan dari REDD+ mencakup konservasi keanekaragaman hayati dan pengentasan kemiskinan. Kami menggunakan proksi untuk manfaat tambahan keanekaragaman hayati potensial dengan persen lahan di kawasan lindung (IUCN dan UNEP 2010) dan untuk manfaat tambahan pengentasan kemiskinan potensial dengan indeks kemiskinan (dari lembaga sensus nasional).

Tabel 12.3 melaporkan hasil-hasil penghitungan model regresi dari jumlah proyek karbon hutan di kotamadya Brasil atau kabupaten di Indonesia dengan variabel-variabel ini. Jumlah proyek positif dan signifikan terkait dengan kerapatan karbon hutan dan laju deforestasi, mengendalikan faktor-faktor lain dalam model multivarian ini. Tidak ada hubungan 
Tabel 12.2 Nilai tengah faktor-faktor yang dipertimbangkan dalam pemilihan lokasi di berbagai kotamadya atau kabupaten dengan dan tanpa proyek REDD+

\begin{tabular}{|c|c|c|c|c|}
\hline & \multicolumn{2}{|c|}{ Brasil } & \multicolumn{2}{|c|}{ Indonesia } \\
\hline & $\begin{array}{l}\text { Dengan } \\
\text { REDD+ }\end{array}$ & $\begin{array}{l}\text { Tanpa } \\
\text { REDD+ }\end{array}$ & $\begin{array}{l}\text { Dengan } \\
\text { REDD+ }\end{array}$ & $\begin{array}{l}\text { Tanpa } \\
\text { REDD+ }\end{array}$ \\
\hline Karbon hutan (tC/ha) & 145 & 117 & 153 & 116 \\
\hline $\begin{array}{l}\text { Laju deforestasi } \\
\text { (\% tutupan hutan) }\end{array}$ & 2,4 & 0,9 & 2,3 & 1,3 \\
\hline Biaya kesempatan (AS \$/ha) & 915 & 833 & 547 & 788 \\
\hline Lahan di kawasan lindung (\%) & 28,2 & 8,3 & 25,9 & 11,8 \\
\hline $\begin{array}{l}\text { Kemiskinan } \\
\text { (rasio hitungan kepala) }\end{array}$ & 0,39 & 0,41 & 0,14 & 0,17 \\
\hline Kerapatan penduduk (per km²) & 112 & 105 & 98,7 & 959 \\
\hline Kerapatan jalan (per km²) & 0,03 & 0,08 & 0,09 & 0,11 \\
\hline Luas $\left(\mathrm{km}^{2}\right)$ & 12132 & 1262 & 10191 & 3923 \\
\hline Observasi & 155 & 5414 & 48 & 392 \\
\hline
\end{tabular}

signifikan secara statistik dengan biaya peluang, tetapi kerapatan jalan berkorelasi negatif dengan jumlah proyek di Brasil. Mengendalikan laju deforestasi, proyek lebih cenderung berada di wilayah yang sulit dijangkau, mungkin karena ada harapan bahwa akan lebih mudah dan lebih sedikit biayanya untuk mengurangi kegiatan yang melibatkan deforestasi atau degradasi di wilayah-wilayah yang jauh dari pasar. Kerapatan penduduk dan laju kemiskinan hanya signifikansi secara statistik di Brasil, dengan lebih banyak proyek diharapkan di kotamadya dengan kerapatan penduduk yang lebih tinggi tetapi kemiskinan lebih rendah (hal-hal lainnya setara). Jadi, buktinya bercampur mengenai manfaat tambahan peranan pengentasan kemiskinan yang diharapkan dalam pemilihan lokasi. Namun, koefisien persen lahan di daerah-daerah yang dilindungi positif dan sangat signifikan dalam kedua model ini, menunjukkan bahwa para pemrakarsa dan donatur tertarik dengan potensi manfaat keanekaragaman hayati dalam melindungi hutan dekat kawasan lindung. Hal ini mungkin karena proyek dan kawasan lindung terletak di hutan-hutan yang keanekaragamannya tinggi, atau karena para pemrakarsa memilih untuk menetapkan proyek dekat kawasan lindung, yang menandakan manfaat tambahan keanekaragaman hayati kepada pasar dan mungkin juga menawarkan beberapa keuntungan dalam pemantauan dan penegakan. 
Tabel 12.3 Model binomial negatif dari penghitungan proyek karbon hutan di kotamadya Brasil atau kabupaten di Indonesia

\begin{tabular}{|c|c|c|c|c|}
\hline \multirow[b]{2}{*}{ Variabel } & \multicolumn{2}{|c|}{ Brazil } & \multicolumn{2}{|c|}{ Indonesia } \\
\hline & Koefisien & $\begin{array}{l}\text { Nilai } \\
\text { tengah }\end{array}$ & Koefisien & $\begin{array}{l}\text { Nilai } \\
\text { Tengah }\end{array}$ \\
\hline $\begin{array}{l}\text { Karbon hutan } \\
\text { (dalam } 100 \mathrm{tC} / \mathrm{ha} \text { ) }\end{array}$ & $0,970^{* * *}$ & 1,18 & $0,487^{* *}$ & 1,21 \\
\hline Laju deforestasi & $0,087^{* * *}$ & 1,06 & $0,104^{* *}$ & 1,46 \\
\hline $\begin{array}{l}\text { Biaya kesempatan } \\
\text { (dalam } 1000 \$ A S \text { ) }\end{array}$ & 0,121 & 0,83 & $-0,191$ & 0,76 \\
\hline $\begin{array}{l}\text { \% lahan di kawasan } \\
\text { lindung }\end{array}$ & $0,586^{* * *}$ & 9,95 & $1,877^{* * *}$ & 13,38 \\
\hline $\begin{array}{l}\text { Laju kemiskinan (rasio } \\
\text { penghitungan kepala } \\
\text { untuk kemiskinan) }\end{array}$ & $-1,162^{*}$ & 0,41 & 1,472 & 0,17 \\
\hline $\begin{array}{l}\text { Kerapatan penduduk } \\
\text { (dalam } 1000 \text { per } \mathrm{km}^{2} \text { ) }\end{array}$ & $0,411^{* * *}$ & 0,07 & $-1,581$. & 0,87 \\
\hline Kerapatan jalan & $-10,850^{* * *}$ & 0,08 & $-2,047$ & 0,11 \\
\hline Luas (dalam 10000 km²) & $0,428^{* * *}$ & 0,18 & $0,568^{* * *}$ & 0,48 \\
\hline Konstan & $-4,061^{* * *}$ & & $-3,181^{* * *}$ & \\
\hline Observasi & 4134. & & 391. & \\
\hline
\end{tabular}

Signifikan pada tingkat $1 \%(* * *), 5 \%(* *)$ atau $10 \%\left({ }^{*}\right)$.

Catatan: Dalam model binomial negatif, sebuah parameter overdispersi diperkirakan. Sebagaimana diharapkan, parameter ini berbeda signifikan dari nol dalam model-model untuk Brasil dan Indonesia.

Banyak dari faktor yang sama signifikan dalam versi-versi yang berbeda dari model tersebut. Misalnya, kita dapat memperkirakan model tersebut hanya untuk proyek REDD+ (dan bukan untuk semua proyek karbon hutan), termasuk hanya kotamadya atau kabupaten di perbatasan hutan (Amazon dan Pulau-pulau Luar Jawa) dan hanya mempertimbangkan probabilitas memiliki sedikitnya satu proyek (dan bukan sejumlah proyek). Dalam berbagai ragam kombinasi yang mungkin, hasil yang paling kuat adalah asosiasi positif dengan persentase lahan di kawasan lindung, laju deforestasi dan karbon hutan. ${ }^{3}$

3 Misalnya, dalam regresi logistik dari probabilitas dari sedikitnya satu proyek REDD+ di sebuah kotamadya di Amazon atau kabupaten di pulau-pulau luar Indonesia (hasil perkiraan tidak dilaporkan di sini), sebagian besar variabel mempertahankan tanda dan signifikansi statistiknya. Satu-satunya perubahan tanda dari suatu koefisien yang dapat diamati ialah pada deforestasi di Amazon Brasil: laju deforestasi yang lebih tinggi dikaitkan dengan probabilitas yang lebih rendah dari sebuah proyek REDD+, mungkin karena area-area tersebut dianggap penyebab yang hilang dan oleh karenanya tidak menarik proyek. 
Akhirnya, kami perhatikan bahwa ada faktor-faktor penting yang dihilangkan dari model ini karena kekurangan data. Berdasarkan wawancara dengan para pemrakarsa proyek $\mathrm{REDD}_{+}{ }^{4}$ selama COP15 UNFCCC bulan Desember 2009, Lin dkk. (2012) menemukan bahwa lima faktor teratas dalam keputusan pemrakarsa mengenai pemilihan lokasi proyek REDD+ di negara-negara adalah laju deforestasi, kandungan karbon hutan, keanekaragaman hayati, minat para donatur dan tata kelola. Model kami menegaskan bahwa ketiga faktor pertama penting dalam pemilihan lokasi proyek REDD+, tetapi kami tidak dapat menguji tata kelola atau minat geografis para donatur karena keterbatasan data.

\subsubsection{Batas-batas lokal}

Untuk proyek REDD+ dalam sampel GCS, kami mendapat pengertian lebih jauh mengenai pemilihan lokasi dengan mengumpulkan ciri-ciri desa-desa yang terletak dalam batas-batas proyek (yang kami beri label 'desa-desa REDD+') sebagai perbandingan dengan desa-desa di wilayah yang sama tetapi di luar batas proyek. Sekali lagi, kami memiliki sampel lebih besar untuk Brasil dan Indonesia, jadi kami melaporkan hasil untuk negara-negara ini secara terpisah, selain hasil keseluruhan untuk proyek di enam negara di mana GCS sedang melakukan penelitian pada skala proyek (Tabel 12.4).

Perbandingan ini menunjukkan bahwa desa-desa cenderung dipilih untuk proyek REDD + bila LSM konservasi hutan aktif di desa tersebut selama lima tahun terakhir. Hasil ini konsisten dengan persepsi umum mengenai REDD + sebagai sumber dana baru untuk proyek konservasi hutan yang ada, meningkatkan potensi kekhawatiran mengenai kepenambahan (Ingram dkk. 2009; Sills dkk. 2009). Namun, hal ini dapat juga ditafsirkan sebagai tanda bahwa proyek REDD+ akan berhasil, karena mereka membangun di atas usaha-usaha sebelumnya oleh berbagai organisasi konservasi hutan. Di Brasil, hal ini konsisten dengan pola dalam modal sosial: rata-rata terdapat lebih banyak kelompok fungsional atau organisasi (misalnya, kelompok petani, kelompok kredit dan dewan pendidikan) di desa-desa REDD+ dibandingkan dengan desa-desa lain di wilayah tersebut. Namun, hal yang berlawanan berlaku di Indonesia dan dalam sampel global: secara statistik kelompok fungsional di desa-desa REDD+ lebih sedikit.

Rata-rata, desa-desa REDD+ lebih terpencil, sebagaimana diukur berdasarkan jarak dari jalan terdekat dengan kendaraan roda empat. Perbedaan ini signifikan secara statistik dalam sampel global dan agak signifikan di Brasil, tetapi tidak demikian di Indonesia. Meskipun tutupan hutan yang diperkirakan tidak berbeda secara statistik dan kami tidak dapat memperoleh estimasi laju deforestasi berkualitas baik, fakta bahwa desa-desa REDD+ secara sistematis lebih jauh dari jalan raya menunjukkan bahwa desa-desa tersebut mendapat

4 Para pendukung proyek yang diwawancarai dalam COP15 berasal dari LSM (72\%), sektor swasta (16\%) dan Bantuan Pembangunan Resmi (12\%). 


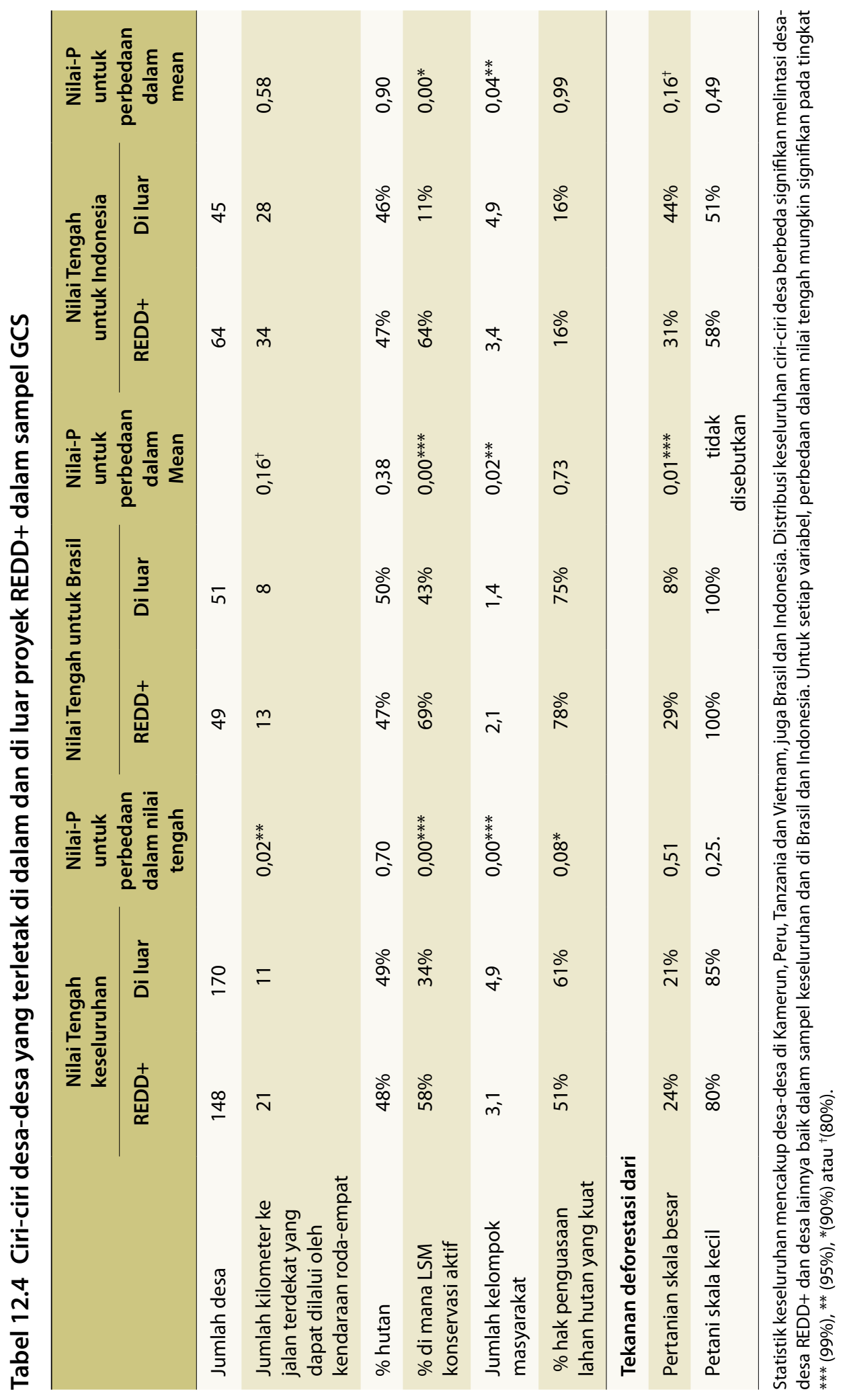


tekanan deforestasi yang relatif lebih rendah dan memiliki biaya peluang yang lebih rendah dari penghindaran deforestasi. Ini konsisten dengan temuan bahwa kotamadya di Brasil yang kerapatan jalannya lebih tinggi kemungkinannya untuk mempunyai proyek REDD lebih kecil dan memiliki proyek karbon hutan lebih sedikit secara menyeluruh. Artinya, sementara banyak proyek REDD+ ini berada di wilayah di bawah tekanan deforestasi (dikonfirmasi oleh koefisien positif dan signifikan secara statistik mengenai deforestasi dalam Tabel 12.2), tampaknya para pemrakarsa memilih untuk bekerja di sudut-sudut yang terpencil di daerah ini. Hal ini mungkin karena intervensi REDD+ diharapkan lebih kompetitif dengan alternatif-alternatif pembangunan atau karena manfaat tambahan keanekaragaman yang lebih tinggi diharapkan di lokasi yang lebih jauh dari pusat-pusat pasar yang menghasilkan permintaan untuk produk-produk pertanian. Penjelasan terakhir ini didukung oleh penilaian para pemrakarsa yang dilakukan oleh GCS: 65\% pemrakarsa proyek REDD+ mengindikasikan bahwa mereka mempertimbangkan keanekaragaman hayati ketika memutuskan desa mana yang akan dicakup, dan separuh (3 dari 7) dari pemrakarsa yang memeringkatkan kriteria pemilihan lokasi mengindikasikan bahwa keanekaragaman hayati merupakan pertimbangan terpenting.

Para petani skala kecil merupakan tekanan deforestasi primer di lebih dari separuh desa seluruhnya (baik di dalam maupun di luar proyek) di semua negara. Sementara di Brasil para pelaku skala besar lebih cenderung merupakan sumber utama deforestasi di desa-desa REDD+ daripada di desa-desa di luar perbatasan, hal sebaliknya berlaku di Indonesia. Jadi profil lokasi yang dipilih untuk proyek REDD+ di Brasil ialah lokasi yang lebih terpencil, dengan LSM konservasi yang aktif, modal sosial lokal yang kuat, dan tekanan deforestasi oleh para pelaku skala besar dari luar wilayah (misalnya, lihat Kotak 12.2 yang menggambarkan proyek Bolsa Floresta). Pola ini konsisten dengan keinginan para pemrakarsa proyek Brasil untuk menciptakan aliansi lokal untuk mencegah ancaman deforestasi dari luar. Sebagai kontrasnya, profil lokasi di Indonesia adalah lokasi dengan LSM konservasi yang aktif, tetapi modal sosialnya lebih lemah, dan ancaman dari para pelaku skala besar dari luar wilayah lebih rendah. Perbedaan-perbedaan semacam itu di kedua negara ini layak untuk diteliti dan dipertimbangkan lebih jauh ketika kami berusaha menarik pelajaran dari proyek ini.

Akhirnya, ada beberapa kesamaan di antara semua desa dalam sampel kami (tidak dilaporkan dalam Tabel 12.4). Sebagian besar desa dengan proyek REDD+ adalah desa pertanian. Di mayoritas desa (57\%) dalam proyek REDD+, tanaman pertanian merupakan sumber pendapatan primer untuk hampir semua rumah tangga. Dalam 63\% dari desa-desa ini, kurang dari $20 \%$ rumah tangga sumber utama pendapatan tunai mereka dari hutan. Sumber pendapatan lain termasuk peternakan (terutama sapi), menangkap ikan dan pertambangan. Kebergantungan pada pertanian ini menunjukkan 
bahwa ada deforestasi yang dilakukan oleh pelaku-pelaku lokal yang secara potensial dapat dikurangi dengan intervensi. Lebih jauh, hal ini menunjukkan bahwa kekhawatiran tentang mata pencaharian utama terkait dengan proyek REDD+ tampaknya adalah pembatasan kegiatan pertanian seperti perladangan berpindah.

\subsubsection{Kesenjangan dan rekomendasi untuk analisis lebih jauh}

Memodelkan proses pemilihan lokasi berdasarkan yurisdiksi (negara, kotamadya atau kabupaten, dan komunitas) memungkinkan kami untuk mengumpulkan data dari sejumlah besar proyek, dan dengan demikian menghindari potensi bias dari pembatasan sampel kami pada proyek yang bersedia berbagi peta perbatasan mereka. Namun, cara ini juga jelas memungkinkan kesalahan pengukuran karena nilai median untuk negara, kotamadya atau kabupaten tidak selalu menunjukkan ciri-ciri lokasi secara spesifik untuk setiap proyek. Analisis yang sama dapat dilakukan dengan proyek yang bersertifikat dan dengan demikian memiliki peta yang tersedia untuk publik, tetapi temuan-temuannya mungkin tidak dapat diterapkan secara umum melampaui proyek bersertifikat. Sampai tingkat tertentu, basis data mengenai desa-desa di dalam dan bersebelahan dengan proyek REDD+ dalam sampel GCS menyediakan informasi yang lebih terseleksi ini. Kesenjangan data ini ialah bahwa desa-desa tersebut tidak disensus dan juga tidak disampel secara acak. Namun, para peneliti lapangan berusaha mengidentifikasi desa-desa serupa di dalam dan di luar batas proyek, dan dengan demikian biasnya mendekati nol.

Selain mengumpulkan informasi yang lebih tepat mengenai batas-batas proyek, daerah kedua untuk penelitian di masa depan harus memperhitungkan variasi tata kelola pada tingkat subnasional. Demikian pula analisis ini dapat diperbaiki dengan data keanekaragaman hayati yang lebih baik dan manfaat tambahan mata pencaharian potensial pada tingkat subnasional (dalam hitungan persentase di kawasan lindung dan statistik kemiskinan resmi). Akhirnya, penelitian kualitatif yang lebih mendalam mengenai proses pengambilan keputusan dari para pemrakarsa tertentu dan untuk proyek tertentu dapat memperkaya pemahaman kita mengenai pemilihan lokasi proyek dan implikasinya.

\subsection{Kesimpulan}

Bila proyek-proyek REDD+ diharapkan untuk berkontribusi secara langsung pada aneka tujuannya (pertama dan yang utama, pengurangan emisi karbon hutan, tetapi juga manfaat tambahan sosial dan lingkungan hidup), maka mereka harus berada di lokasi di mana proyek dapat menangani emisi karbon 
hutan secara signifikan, dan ancaman terhadap keanekaragaman hayati dan tingkat pendapatan rendah. Jelaslah, kemampuan untuk memenuhi tujuan-tujuan tersebut bergantung pada banyak faktor, termasuk keahlian geografis pemrakarsa dan kondisi tata kelola lokal. Namun hal ini secara mendasar juga bergantung pada kondisi keanekaragaman hayati, kemiskinan dan emisi karbon hutan yang ada.

Dengan memasukkan semua negara berkembang tropis dalam pertimbangan, laju deforestasi yang lebih tinggi tidak terkait dengan kemungkinan yang lebih besar bagi proyek REDD+. Namun, jumlah proyek terbesar sejauh ini sedang dikembangkan di dua negara yang mendominasi emisi karbon hutan global: Brasil dan Indonesia. Di negara-negara ini, pemberian prioritas bagi daerah berkerapatan karbon hutan tinggi dan deforestasi nyata pada tingkat subnasional, meskipun ada juga suatu preferensi untuk yurisdiksi yang lebih jauh (dan dengan demikian mungkin tidak terlalu terancam) di Brasil dan desa-desa dari keenam negara sampel GCS. Khususnya, kotamadya di Brasil dan kabupaten di Indonesia memiliki lebih banyak proyek bila lokasi-lokasinya memiliki kerapatan karbon hutan yang lebih tinggi dan laju deforestasi yang lebih tinggi. Namun, di tingkat lokal, desa-desa REDD+ secara sistematis lebih jauh dari jalan raya daripada desa-desa nonREDD+. Dan di Brasil, kerapatan jalan berhubungan negatif dengan jumlah proyek di berbagai kotamadya, setelah dilakukan kontrol terhadap beberapa faktor lain. Setelah mengendalikan faktor-faktor lain tersebut, ada hubungan statistik lemah antara lokasi proyek dengan kemiskinan di Brazil, tetapi tidak di Indonesia.

Secara menyeluruh ada preferensi kuat atas lokasi-lokasi yang berpotensi untuk menghasilkan manfaat tambahan keanekaragaman hayati tinggi. Negara dengan indeks keanekaragaman hayati tinggi lebih cenderung memiliki proyek. Kotamadya dan kabupaten dengan proporsi lahan mereka yang lebih tinggi dari kawasan lindung lebih cenderung memiliki proyek. Dan para pemrakarsa melaporkan bahwa keanekaragaman hayati merupakan pertimbangan penting dalam pemilihan lokasi.

Akhirnya, sampel desa-desa kami di dalam dan di sekitar proyek REDD+ menegaskan bahwa desa-desa itu utamanya mengandalkan pertanian dan para petani skala kecil dipandang sebagai salah satu ancaman primer deforestasi dan degradasi. Meskipun ada pengecualian, sebagian besar desa tidak terlalu bergantung pada produk-produk hutan untuk pendapatan rumah tangganya. Hal ini menunjukkan bahwa tantangan utama untuk REDD+ di lapangan adalah memperlambat deforestasi lokal tanpa merusak mata pencaharian pertanian atau mengasingkan orang-orang yang merupakan sekutu potensial utama untuk menghadapi ancaman deforestasi eksternal yang juga nyata di lokasi-lokasi tersebut. 



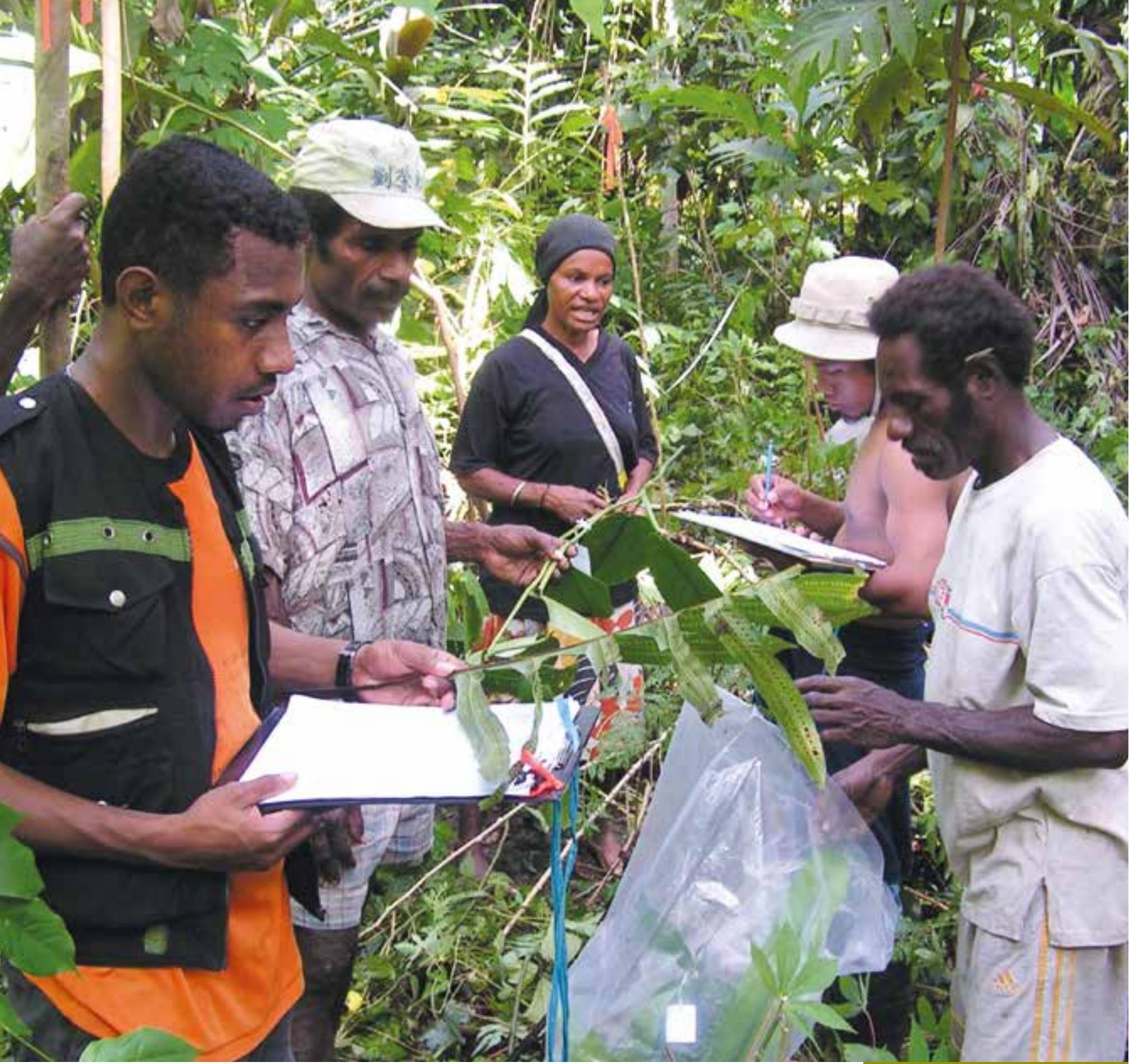

\section{Bagian}

Mengukur

kinerja REDD+ 



\section{Bab 13}

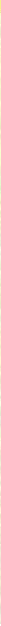

\section{Indikator kinerja dan penerapan REDD+}

Sheila Wertz-Kanounnikoff dan Desmond McNeill

- REDD+ bertujuan untuk meraih dampak yang pasti - pengurangan emisi - dan pembayaran yang mungkin dilakukan berdasarkan kinerja untuk pencapaian sasaran ini. Untuk itu diperlukan penilaian atas hasil-hasil REDD+.

- Dalam jangka menengah, sebagian besar pembayaran adalah untuk kesiapan dan reformasi kebijakan, dan bukan untuk pengurangan emisi yang sudah terbukti. Dengan demikian indikator-indikator kinerja yang baik penting untuk ketiga fase REDD+, khususnya untuk fase 2 yang fokusnya adalah kinerja kebijakan.

- Berbagai pelajaran penting mengenai indikator tata kelola dapat dipelajari dari sektor bantuan pembangunan: hindari mencari indikator yang sempurna dan gunakan penilaian ahli secara ekstensif.

\subsection{Berbagai tantangan}

REDD+ bertujuan untuk meraih dampak yang pasti - pengurangan emisi dan pembayaran mungkin dilakukan berdasarkan kinerja untuk pencapaian sasaran ini. Untuk itu harus ada penilaian atas hasil-hasil REDD+. 
Penerapan REDD+ akan terjadi dalam tiga fase: kesiapan (fase 1); tindakan kebijakan (fase 2), dan 'tindakan berbasiskan hasil' (misalnya, pembayaran berdasarkan perubahan emisi dan penyerapan karbon) (fase 3). Proses ini sekarang diformalkan dalam sebuah kesepakatan internasional (UNFCCC 2111e). Meskipun program-program bilateral REDD+ saat ini bergerak maju lebih cepat dari proses-proses multilateral, program-program yang ada berusaha melengkapi proses UNFCCC dan harus mengikuti prinsip yang sama (misalnya, REDD+ Partnership 2010).

Berbagai indikator kinerja dapat digunakan untuk memantau hasil-hasilnya. Indikator ini harus dapat dipercaya sehingga semua pihak yang melakukan dan mendanai kegiatan REDD+ dapat memastikan bahwa mereka berhasil (Daviet 2009). Indikator kinerja perlu dipilih dengan mempertimbangkan sejumlah sasaran berbeda dari ketiga fase penerapan REDD+.

Pengukuran REDD+, inisiatif pelaporan dan verifikasi (MRV) sebelumnya cenderung memfokuskan pada fase 3, yang tantangannya sebagian besar bersifat teknis - mengukur emisi gas rumah kaca (GRK) dan penyerapannya (Bab 14-16). Namun tantangan yang lebih mendesak, yang sejauh ini belum banyak mendapat perhatian ialah mengukur kinerja pada fase-fase awal, dan terutama fase 2 yang fokusnya adalah kinerja kebijakan. Bab ini bertujuan untuk menjernihkan dan menjelaskan perdebatan sekitar tindakan kebijakan REDD+.

\subsection{Dasar pemikiran dan jenis-jenis indikator kinerja}

Pengukuran kinerja bukanlah tujuan akhirnya, tetapi sarana menuju berbagai tujuan akhir yang berbeda: untuk mengevaluasi, mengendalikan, menganggarkan, memotivasi, mendorong, merayakan, belajar dari atau meningkatkan kinerja (Behn 2003). Tidak satu pun indikator yang memadai untuk semua kegunaan. Karena itu, ketika memilih berbagai indikator harus jelas tujuan pengukuran yang dilakukan.

Kinerja harus diukur menurut tolok ukur yang telah disepakati. Biasanya, berbagai jenis indikator yang berbeda diperlukan pada tiap tahap (Tabel 13.1). Indikator menengah (asupan dan proses) memungkinkan pemantauan sebelumnya untuk menjaga agar proyek berada pada jalurnya; umumnya yang diinginkan adalah mengukur kinerja di akhir rantai hasilnya - keluaran, hasil dan dampak. Namun, perlu ditekankan di sini untuk tidak tergesa-gesa dalam mengenalkan terlalu dini suatu sistem berbasiskan emisi dengan sistem MRV yang buruk dan data yang tidak memadai untuk menetapkan tingkat acuan. Sistem seperti ini mungkin menciptakan pembayaran untuk pengurangan emisi yang tidak riil, yang akan menghancurkan kredibilitas dan membahayakan keabsahan sistem tersebut. 


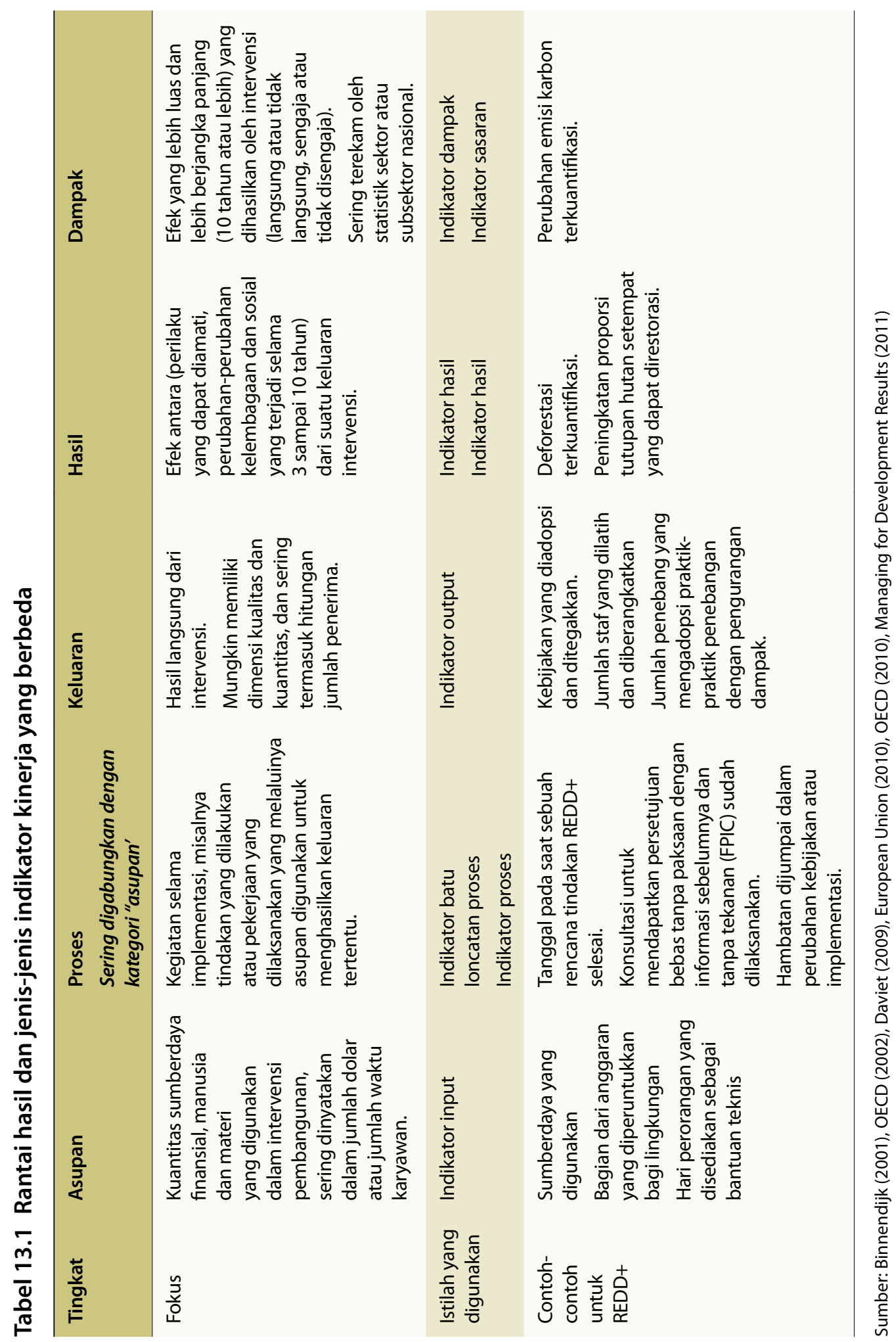


Indikator kinerja telah digunakan secara luas untuk evaluasi di sektor bantuan pembangunan. Menurut Komite Bantuan Pembangunan (DAC) dari Organisasi Kerja Sama Ekonomi dan Pembangunan (OECD), indikator kinerja mengacu pada berbagai variabel yang memungkinkan verifikasi perubahan-perubahan dalam suatu intervensi pembangunan atau menunjukkan hasil relatif dari apa yang telah direncanakan (OECD 2002). Indikator harus sederhana dan 'SMART' (specific, measurable, attainable, relevant and time bound) - spesifik, terukur, dapat dicapai, relevan dan terikat waktu) dan dapat dibandingkan dengan negara-negara (lain) (OECD 2008).

\subsection{Pelajaran dari sektor bantuan pembangunan}

Menjelang akhir tahun 1990-an dan 2000-an, negara-negara yang menerima bantuan pembangunan mulai dipandang sebagai mitra, dan bantuan donatur terus meningkat untuk mendukung anggaran. Hal ini memberikan kebebasan lebih besar kepada negara-negara penerima, tetapi menawarkan pertanggungjawaban kinerja yang lebih ringan bagi para donatur. Pada tahun-tahun terakhir ini negara-negara donatur lebih menekankan bantuan menjadi lebih berbasiskan hasil. Alasan untuk hal ini beragam, tetapi terkait dengan meningkatnya tuntutan untuk 'keefektifan pembangunan' sebagaimana dinyatakan dalam Deklarasi Paris 2005 Mengenai Keefektifan Bantuan Pembangunan (OECD 2005). Sekarang tuntutan untuk pengukuran kinerja semakin besar - bukan hanya berupa keluaran, tetapi juga hasil dan dampak - berdasarkan indikator sasaran. Perubahan ini khususnya menantang karena bertepatan dengan pergeseran bantuan, bukan lagi investasi untuk infrastruktur seperti jalan raya, pemasokan air dan klinik kesehatan, tetapi untuk intervensi dalam tata kelola, hak asasi manusia, pemberdayaan dan penyelesaian konflik, yang jauh lebih sukar untuk dievaluasi.

REDD+, seperti semula dibayangkan, bukanlah bantuan untuk pembangunan tetapi pembayaran untuk layanan yang diberikan (Bab 3). Sebagai sebuah transaksi bisnis, sangat wajarlah bila pembayaran dilakukan sesuai hasil. Namun setidaknya dalam jangka pendek REDD+ seolah-olah akan dibiayai sebagian besar dari anggaran bantuan atau sumber-sumber swasta (Bab 7). Sementara pembayaran akan tetap berbasiskan hasil, motivasi untuk mengukur kinerjanya kemungkinan akan berbeda. Penerapan REDD+ dapat belajar dari penggunaan indikator kinerja di sektor bantuan pembangunan (Kotak 13.1).

Meskipun idealnya penilaian akan didasarkan pada hasil dan dampak, dalam pelaksanaannya cara ini sukar karena tiga alasan utama: waktu penilaian, penjelasan hasil intervensi, dan keandalan informasi.

Semakin jauh rantai tahapan hasil yang diinginkan untuk mengukur kinerja, semakin banyak waktu yang harus berlalu. Dampak tidak dapat diukur 


\section{Kotak 13.1 Indikator kinerja dalam dana bantuan pembangunan}

Indikator berbasis asupan, termasuk indikator proses, belum terbukti efektif untuk mengukur kinerja. Indikator-indikator ini mungkin terputus dari hasil akhir dan akan berisiko menimbulkan insentif merugikan (misalnya, di mana 'pengeluaran' atau 'jumlah rapat' digunakan sebagai indikator kinerja). Praktik terbaik saat ini menekankan penggunaan indikator yang dimulai pada tingkat keluaran (Adam dan Gunning 2002; Mumssen dkk. 2010).

Indikator hasil yang dapat dikuantifikasi sering tidak tersedia dan lebih mudah didapat untuk sektor-sektor sosial (seperti kesehatan dan pendidikan) daripada untuk proses-proses kelembagaan seperti tata kelola dan pengelolaan keuangan publik (Koeberle dkk. 2006). Hal yang sama juga merupakan tantangan untuk mengukur implementasi berbagai kebijakan REDD+ dan reformasi transformatif seperti reformasi penguasaan lahan dan langkah-langkah antikorupsi.

Penjelasan hasil suatu intervensi spesifik menjadi semakin sulit dan memakan waktu (dan mahal) semakin jauh seseorang bergerak sepanjang rantai hasilnya. Dalam kenyataan, penilaian kinerja sering terbatas pada indikator keluaran/hasil saja. Akibatnya, penilaian hanya berfokus pada hasil antara, yang tidak menjamin pencapaian sasaran akhirnya (Gunning 2006).

Semakin jauh seseorang bergerak sepanjang rantai hasilnya, semakin besar tanggung jawab pemasok layanan (misalnya, pemerintah negara REDD+) untuk mengukur kinerjanya. Karena itu kemampuan pemasok layanan untuk memikul tanggung jawab dan berapa biayanya penting untuk dipertimbangkan (Binnendijk 2001; Mumssen dkk. 2010).

Karena sejumlah faktor di luar proyek dapat menghambat kinerja, pemerintah mungkin enggan menggunakan target hasil (apalagi dampak) sebagai pemicu untuk pendanaan, karena mereka dapat dimintai akuntabilitasnya atas hasil di luar kendali mereka (misalnya, peristiwa alam ekstrem dan krisis keuangan global). “Indikator risiko' (Binnendijk 2001) dan asuransi sebagian (Gunning 2006) direkomendasikan untuk melengkapi indikator hasil.

Koleksi data independen untuk pengukuran kinerja juga penting. Bila mitra kontrak (pemerintah) terlibat dalam pengumpulan data, ada risiko bencana moral (Gunning 2006; Mumssen dkk. 2010). Kemungkinan ini menyoroti kebutuhan untuk prosedur verifikasi independen untuk REDD+.

Akhirnya, terlepas dari semua saran praktik terbaik, pengukuran kinerja memiliki dimensi politik kuat di mana kemitraan yang baik jauh lebih berharga daripada kinerja sebenarnya. 
sampai beberapa tahun telah lewat, sesuatu yang tidak memungkinkan untuk banyak donatur, LSM atau pemerintah. Meskipun donatur ingin membayar berbasiskan kinerja, dalam kenyataannya mereka tidak dapat menunggu 10-15 tahun untuk mengukur apakah dampak yang diinginkan telah tercapai.

Terlebih lagi, semakin jauh seseorang bergerak sepanjang rantai hasilnya, semakin sukar untuk mengaitkan hasil akhir dengan suatu intervensi spesifik. Dampak dipengaruhi oleh sejumlah faktor, sehingga sukar untuk menentukan apa saja penyebabnya. Semakin sukar pula untuk mengukur kinerja proyek-proyek 'lunak', seperti tata kelola yang lebih baik (misalnya, keadilan yang lebih baik, reformasi penguasaan lahan, dll.) dan pengembangan kapasitas. Kinerja dalam proyek seperti ini lebih sulit diukur daripada untuk proyek-proyek infrastruktur 'keras' seperti penyediaan air atau transportasi, yang keluarannya lebih konkret untuk diukur, dan keterkaitan antara keluaran, hasil dan dampak lebih mudah menetapkannya. Karena itu anggapan bahwa orang dapat mengembangkan sebuah sistem penilaian kinerja yang murni ilmiah atau teknis untuk semua aspek keberhasilan merupakan khayalan belaka.

Akhirnya, informasi yang diperlukan untuk pengukuran kinerja tidak selalu tersedia atau mungkin secara politis ditentang dan tidak dapat diandalkan. Informasi harus dikumpulkan secara sistematis sebagai kegiatan tambahan dengan biaya tambahan, yang cenderung meningkat ketika bergerak ke arah ujung dampak di sepanjang rantai hasil.

\subsection{Sejumlah pilihan untuk mengukur kinerja REDD+}

Apakah arti kerumitan pengukuran kinerja ini untuk REDD+? Secara global, hanya sedikit indikator kinerja REDD+ yang disepakati, kecuali bahwa indikator itu harus dikembangkan sendiri oleh negara dan akhirnya, dalam fase 3, indikatornya harus mengukur perubahan emisi dan penyerapan GRK. The Meridian Options Assessment Report (OAR) menyarankan agar indikator kinerja dapat dikembangkan dan disetujui sebagai bagian dari rencana implementasi REDD+ nasional (Meridian Institute 2009). Demikian pula proposal persiapan kesiapan (R-PP) yang diserahkan kepada Forest Carbon Partnership Facility (FCPF) diminta untuk membuat garis besar bagaimana suatu negara mitra REDD+ akan mengembangkan ukuran kinerja (sementara). Artinya, indikator kinerja REDD+ akan beragam di berbagai negara, sesuai keadaan nasional, pandangan para pemangku kepentingan dan sasaran strategi REDD+. Pengalaman di Guyana, Republik Demokrasi Kongo (DRC) dan Indonesia membuktikan hal ini (Tabel 13.2).

Pengukuran kinerja penting untuk akuntabilitas dan untuk mendorong implementasi REDD+ yang efektif. Indikator kinerja harus memenuhi dua tujuan berbeda, yang harus dipertimbangkan dalam pemilihannya: i) untuk memantau dan mengukur efek proyek dan kebijakan untuk melihat apa yang 
berhasil diterapkan dan mana yang tidak, agar dapat merancang proyek dan kebijakan yang lebih baik; dan ii) untuk mengevaluasi hasil sebagai dasar pembayaran imbalan finansial dan kemajuan ke fase-fase selanjutnya. Tujuan ini serupa dengan diskusi tentang tingkat acuan (Bab 16), yaitu skenario bisnis seperti biasa digunakan untuk mengukur dampak, dan untuk menetapkan dasar pembayaran sesuai pengukuran yang dilakukan.

Fokus tujuan pertama dari indikator kinerja adalah berbagai langkah untuk meningkatkan rancangan proyek. Untuk ini diperlukan suatu metrik implementasi yang menilai kemajuan, efek, perencanaan, penetapan plot percobaan dan implementasi kerangka REDD+ nasional (dalam fase 1 dan 2). Dalam kasus Guyana (Tabel 13.2), indikator dalam kategori ini disebut 'indikator pemampu' untuk mencerminkan ciri persiapan suatu proyek atau kebijakan. Contoh-contoh indikator pemampu ini termasuk 'sistem MRV yang sudah ada' atau 'mekanisme finansial sudah ditetapkan'.

Tujuan kedua dari indikator kinerja REDD+ ialah untuk mengevaluasi hasil agar dapat menilai tingkat pembayaran. Untuk ini diperlukan metrik kinerja, dan juga sebuah tolok ukur yang disepakati (atau dasar penetapan pembayaran). Dalam fase 3, metrik kinerja mungkin berupa indikator hasil (perubahan dalam laju deforestasi secara kasar) atau indikator dampak (perubahan dalam emisi karbon). Dalam fase 2, ketika fokusnya adalah implementasi kebijakan dan tindakan, indikator kinerja 'sementara' dapat digunakan. Dalam Kemitraan Norwegia-Indonesia, misalnya, pembayaran didasarkan pada indikator-indikator seperti "kegiatan MRV yang ada sudah teridentifikasi dan penilaian awal tentang kesenjangan data untuk tujuan penyelesaian MRV telah diselesaikan" (Tabel 13.2). Indikator kinerja 'sementara' ini akan digantikan oleh indikator hasil atau indikator dampak segera setelah sistem MRV matang dan negara yang bersangkutan memasuki fase 3 .

Indikator hasil (laju deforestasi) kadang-kadang dibedakan dari indikator dampak (emisi karbon). Indikator hasil disebut indikator kinerja 'sementara' Namun, indikator hasil cukup sebagai dasar untuk melakukan pembayaran, dalam kombinasi dengan faktor-faktor emisi standar IPCC. Dengan demikian laju deforestasi tidak benar-benar dapat dipakai sebagai indikator kinerja 'sementara' untuk fase 2 (misalnya, Kemitraan Norwegia-Guyana dalam Tabel 13.2), meskipun indikator-indikator ini sering dipakai.

Gambar 13.1 menunjukkan jenis-jenis indikator kinerja yang relevan dengan ketiga fase REDD+. Dalam fase 1, yang fokusnya pada kesiapan (dan semua negara yang terlibat dalam proses REDD+ nasional berada dalam fase ini), ukuran kinerja terutama didasarkan pada ukuran asupan (misalnya, konsultasi yang dilakukan) dan sebagian ukuran keluaran (misalnya, rencana tindakan REDD+ nasional disetujui). 


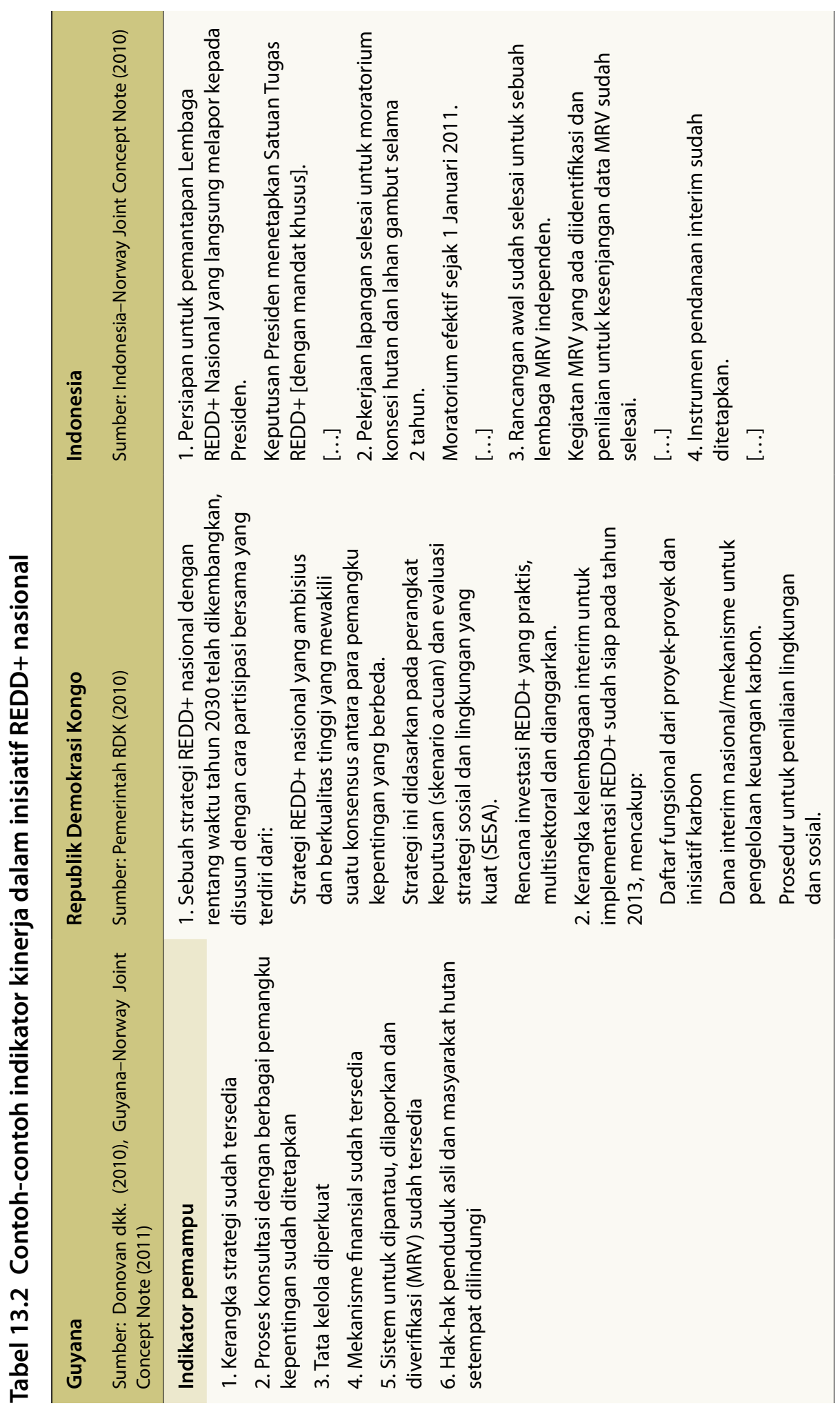




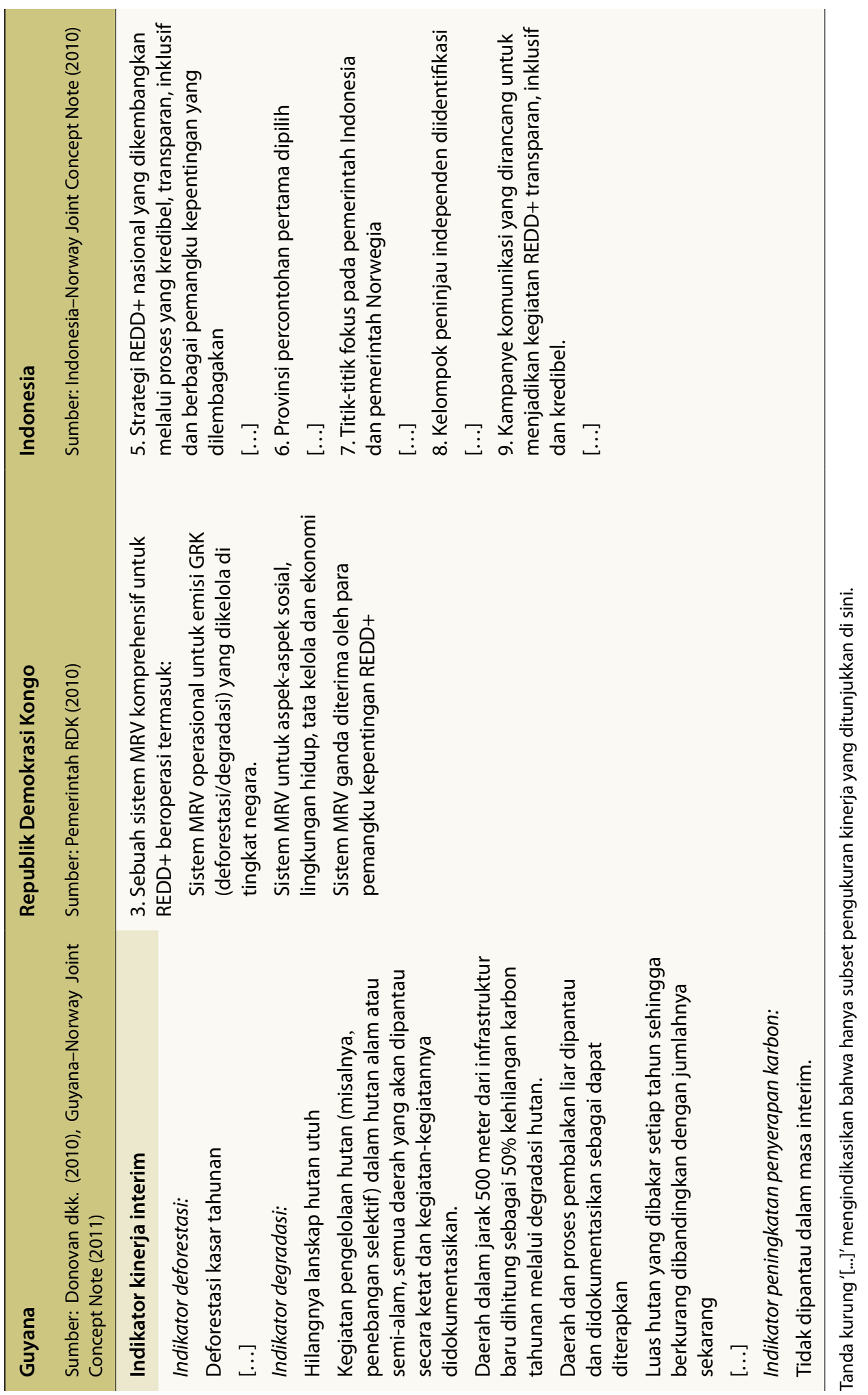




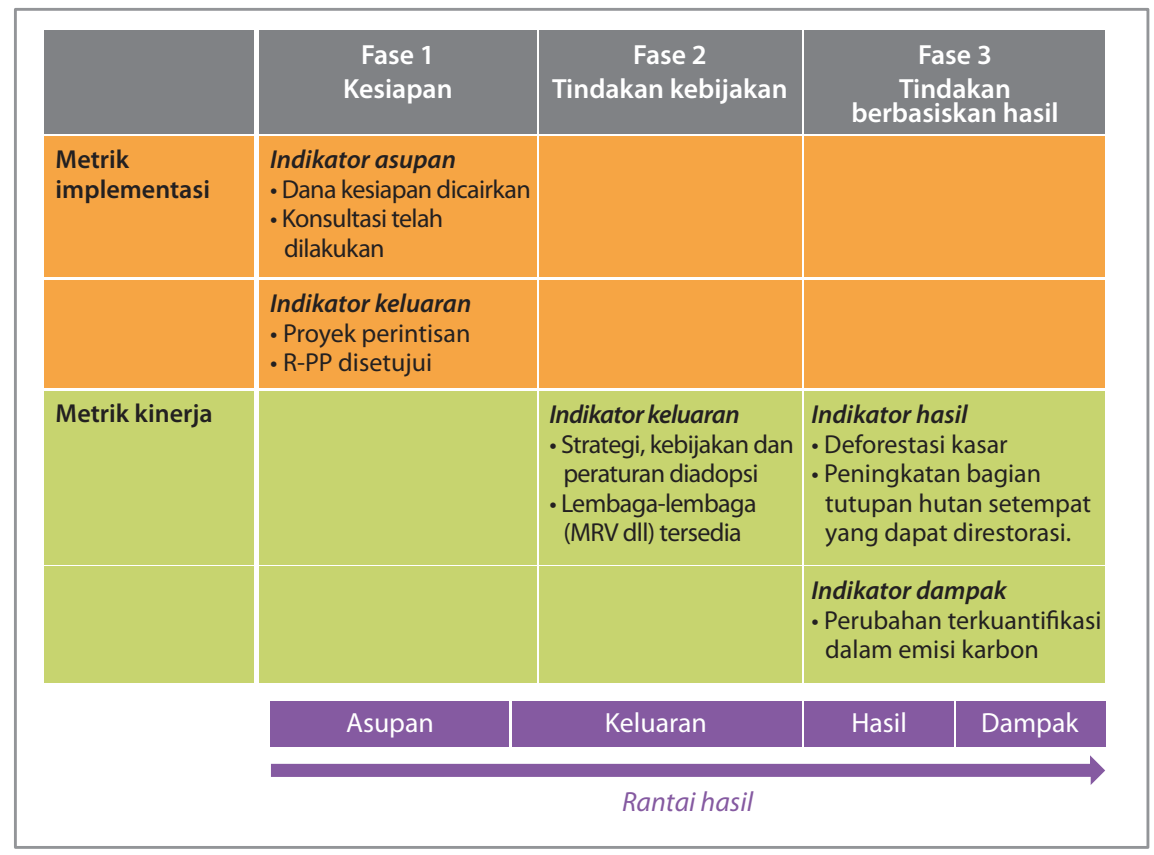

Gambar 13.1 Sejumlah pilihan indikator kinerja bagi semua fase REDD+

Definisi indikator kinerja penting dalam fase 2, yang fokusnya ialah implementasi langkah kebijakan untuk menetapkan rancangan REDD+ nasional yang tepat. Dalam fase ini, indikator-indikatornya perlu memainkan dwifungsi: i) untuk mengukur peningkatan rancangan REDD+ nasional untuk mendukung kemajuan menuju fase 3, dan ii) untuk mengevaluasi kinerja, terutama menggunakan ukuran keluaran, sebagai dasar untuk pembayaran.

Ketika mencapai fase 3, rancangan REDD+ nasional harus sudah tersedia dan kinerja REDD+ dapat diukur dengan indikator hasil atau dampak. Brasil saat ini salah satu dari sedikit negara yang mampu melakukan tindakan-tindakan fase 3. Meskipun secara teknis dampakREDD + merupakan pengurangan dalam perubahan iklim, untuk ini diperlukan pengurangan emisi jangka panjang. Karena itu untuk alasan operasional kami mendebat bahwa pengurangan emisi menawarkan sebuah indikator dampak yang sah untuk REDD+.

Pengukuran kinerja REDD+ juga akan menghadapi sejumlah tantangan spesifik. Pertama, indikator yang sesuai dengan tata kelola terkait perubahan kebijakan dalam fase 2 harus ditentukan. Pengalaman dari sektor bantuan pembangunan menyarankan bahwa lebih sukar mengukur peningkatan tata kelola (proyek-proyek lunak) daripada investasi infrastruktur (proyek-proyek keras). Dalam hal ini REDD+ adalah kombinasi dari keduanya: pencapaian akhirnya, yaitu pengurangan deforestasi dan degradasi dengan hasil pengurangan emisi, bersifat 'konkret', tetapi agar dapat mencapai tahap 
ini lebih dulu diperlukan kemajuan yang dicapai dalam aspek-aspek kinerja 'lunak'.

Kedua, pengukuran kinerja REDD + tak terhindarkan akan membangkitkan isu-isu politik, yang paling jelas pertanyaan 'Dengan standar apakah kinerja dinilai?' dan 'Siapa yang melakukan penilaian?' Sebagaimana ditunjukkan oleh kasus Guyana (Kotak 13.2), tidaklah mudah untuk mencapai kesepakatan tentang indikator-indikator kinerja yang tepat, dan penafsiran berbagai standar untuk evaluasi dapat sangat berbeda di antara para pemangku kepentingan. Penilai mana pun memiliki bias subyektif tertentu dan sukar (dan mahal) untuk mengendalikannya. Bahkan pada fase 3, ketika standar teknis yang jelas sedang ditetapkan untuk pengurangan emisi karbon hutan dan peningkatan penyerapan (misalnya, Verified Carbon Standard), masih tersisa sebuah dimensi politik kuat, sebagaimana ditunjukkan dalam penetapan tingkat acuan (Bab 16). Karena itu evaluasi kinerja REDD+ perlu realistis dalam hal ini.

Satu solusinya mungkin dengan menentukan sasaran kualitatif dan mengaitkannya dengan tindakan-tindakan yang lebih konkret dan terjadwal. Sasaran ini mungkin mencakup hal-hal seperti transparansi, partisipasi dan hak. Fokus tindakan-tindakannya pada implementasi untuk mengokohkan sasarannya: rencana spesifik, sistem dan aturan-aturan yang harus disiapkan, disetujui dan diimplementasikan. Misalnya, daripada menyebutkan 'aturan ditegakkan' dalam indikator kinerja, lebih baik adalah 'aturan ditegakkan dan dipraktikkan. Kinerja menjadi seperangkat ketentuan yang harus dipenuhi, dengan indikator-indikator kinerja yang ditentukan sejelas mungkin pada awalnya, sehingga kemungkinan terjadinya perbedaan penafsiran dapat diperkecil.

Selain itu, mungkin akan berguna sekali untuk melibatkan penilaian ahli dalam penilaian keseluruhan untuk tujuan REDD+. Indikator juga merupakan sarana penting untuk penilaian kinerja secara obyektif, tetapi akan ada kekurangannya dalam merekam kinerja yang sebenarnya (kinerja kurang baik). Sebagaimana dikemukakan oleh Albert Einstein, "tidak semua yang dapat dihitung dapat diandalkan, dan tidak semua yang dapat diandalkan dapat dihitung." Untuk menghindari terlalu menyederhanakan pengukuran kinerja - yang berisiko penyimpulan yang tidak tepat - penggunaan ukuran kinerja yang disederhanakan harus didahului analisis yang saksama mengenai kemungkinan efeknya bagi perilaku para pemangku kepentingan. Pelajaran berharga juga dapat diambil dari verifikasi independen atas kinerja REDD+ di Guyana (Kotak 13.2).

Akhirnya, pengalaman yang semakin bertambah mungkin akan mengarah pada konsensus internasional mengenai standar pengukuran kinerja REDD+, yang kemudian dapat dikaji oleh para ahli. Sebuah sistem penilaian terstandarisasi, 


\section{Kotak 13.2 Pengukuran kinerja dalam kemitraan REDD+ Guyana-Norwegia}

Sebuah Nota Kesepahaman (MoU) antara Guyana dan Norwegia ditandatangani tanggal 9 November 2009 untuk memformalkan kerja sama di berbagai bidang yang terkait dengan perubahan iklim, khususnya dengan proyek REDD+ (Guyana-Norway Joint Concept Note 2011).

Sebuah dana perwalian Guyana REDD+ Investment Fund (GRIF) ditetapkan sebagai mekanisme finansial untuk kerja sama ini. Norwegia menyediakan kontribusi awal kira-kira AS $\$ 30$ juta, dengan harapan bahwa negara-negara lain juga akan berkontribusi. Dana perwalian ini akan menerima sampai dengan AS $\$ 250$ juta dari Norwegia dalam pembayaran berbasiskan kinerja sampai dengan 2015, berdasarkan verifikasi independen atas deforestasi dan degradasi hutan Guyana dan kemajuan dalam berbagai kegiatan yang memampukan pelaksanaan REDD+. Bank Dunia ditunjuk sebagai wali dan bertanggung jawab untuk memberikan layanan keuangan kepada GRIF (Pemerintah Norwegia 2010).

Sebuah Komite Pengarah (Steering Committee, SC) yang terdiri dari berbagai pemangku kepentingan menjadi badan pengawas dan pembuat keputusan untuk pembayaran dana GRIF. Komite ini terdiri dari Pemerintah Guyana dan Norwegia, Bank Dunia (Wali), United Nations Development Programme (UNDP) dan Inter-American Development Bank (IDB) sebagai 'Badan Mitra', dan Pengamat (LSM dari Norwegia dan Guyana) (Pemerintah Norwegia 2010).

Proyek-proyek yang berkontribusi pada Strategi Pembangunan Rendah Karbon Guyana (LCDS) memenuhi syarat untuk menerima pembayaran dari GRIF. Pembayaran ini didasarkan pada kinerja dalam hal pengurangan emisi. Proposal proyek mencakup proyek Amaila Falls Hydro tetapi sejak Januari 2012, hanya dua nota konsep yang disetujui untuk penguatan kelembagaan, dan kegiatan usaha kecil dan mata pencaharian alternatif (Guyana REDD+ Investment Fund 2012).

Kinerja Guyana dalam implementasi REDD+ dan LCDS diukur, dan diverifikasi secara independen berdasarkan dua set indikator (Guyana-Norway Joint concept Note 2011, lihat juga Tabel 13.2):

Indikatorkegiatanyangmemampukan:seperangkatkebijakan dan pengamanan untuk memastikan bahwa REDD+ berkontribusi bagi pencapaian sasaran yang ditetapkan dalam MoU antara Guyana dan Norwegia (2009) untuk proses REDD+/LCDS yang inklusif dan transparan.

Indikator kinerja REDD+: seperangkat indikator emisi GRK berbasis hutan. Indikator kinerja ini bersifat 'sementara' yang secara bertahap akan digantikan ketika sistem MRV sudah ditetapkan. 
Guyana dan Norwegia sepakat bahwa penilaian kemajuan tahunan secara independen atas indikator pemampu akan dilaksanakan oleh satu atau lebih organisasi ahli yang akan ditunjuk bersama. Untuk periode sampai 30 September 2010, Rainforest Alliance melakukan penilaian independen tersebut (Donovan dkk. 2010), mengikuti proses tender internasional sesuai dengan peraturan pengadaan Norwegia.

Meskipun digambarkan sebagai 'indikator', jelaslah bahwa kedua konsep di atas (dan dalam Tabel 13.2) bukanlah indikator dalam pengertian sesungguhnya. Keduanya bukan indikator yang terukur, tercapai, relevan dan terikat waktu (SMART) atau dapat dibandingkan di berbagai negara. Lebih jauh, tidak ada kriteria yang ditentukan untuk mengevaluasi bukti-bukti yang diberikan oleh Pemerintah (Lang 2011a).

Untuk verifikasi penilaian independen pertama, Rainforest Alliance menetapkan indikator tambahan yang lebih nyata (Donovan dkk. 2010). Laporan verifikasi ini dikritik keras oleh masyarakat madani karena dangkal dan terlalu lunak, jadi tidak memberikan gambaran yang akurat mengenai kemajuan di lapangan (Global Witness dkk. 2011; Lang 2011a). Dalam sebuah surat terbuka kepada Menteri Lingkungan Hidup Norwegia, beberapa anggota masyarakat madani mempertanyakan transfer dana kedua untuk tahun 2010-2011 (Lang 2011a).

Pemerintah Norwegia menerima kritik ini sebagai sarana untuk perbaikan (Lang 2011b) dan mengeluarkan cicilan kedua sebesar AS \$38 juta bulan Juli 2011. Kucuran dana ini menaikkan anggaran GRIF menjadi AS \$68 juta (Earle 2011)

bila diimplementasikan dengan benar, kemudian dapat digunakan untuk i) membandingkan kinerja REDD+ suatu negara dengan perangkat norma regional atau internasional, dan ii) menilai kinerja negara-negara sejalan dengan waktu. Kedua hal ini mungkin mengurangi risiko sabotase politik terhadap penilaian kinerja, memungkinkan lebih banyak intervensi yang ditargetkan, memfasilitasi kerja sama dan koordinasi antara para donatur, dan meningkatkan kepemilikan reformasi suatu negara. Usaha semacam ini akan memerlukan dukungan berbagai organisasi internasional dan pemerintah, dan juga lembaga-lembaga regional yang relevan, ketika merancang dan merintis kerangka kerja pengukuran kinerja. Selain pelajaran dari sektor bantuan, proses-proses UNFCCC lain, seperti diskusi sekitar 'programmatic CDM' (Climate Focus 2011), sejumlah mekanisme pasar baru (OECD 2012) atau tinjauan ahli oleh Greenhouse Gas Inventories negara-negara Aneks I (UNFCCC 2011b) dapat membantu menginformasikan perkembangan kerangka kerja pengukuran kinerja REDD+ yang lebih terstandarisasi. 


\subsection{Kesimpulan}

REDD+ bertujuan untuk meraih suatu dampak yang pasti - pengurangan emisi - dan pembayaran mungkin dilakukan berdasarkan kinerja menuju pencapaian sasaran ini. Untuk itu diperlukan penilaian atas hasil-hasil program REDD+ dengan menggunakan indikator kinerja. Meskipun secara umum ada keinginan untuk mengukur kinerja sampai ujung rantai hasil, agar dapat mengukur langsung pencapaian suatu proyek atau tujuan kebijakan, dalam jangka menengah sebagian besar pembayaran ditujukan untuk kesiapan dan reformasi kebijakan, dan bukan untuk pengurangan emisi yang sudah terbukti.

Fokus pada dampak sebagai dasar untuk penilaian kinerja telah mengarah pada pengabaian hasil menengah/antara, pada tahap-tahap kesiapan dan reformasi kebijakan (fase 1 dan 2), yang menentukan prasyarat untuk mencapai hasil REDD+ yang efektif biaya dan setara. Namun indikator kinerja yang baik untuk REDD+ dibutuhkan di masing-masing dari ketiga fase dan tidak hanya pada fase 3 yang merupakan fokus diskusi sebelumnya. Tantangan mendesak yang terkait dengan pengukuran kinerja adalah fase 1 dan 2 dan khususnya pada fase 2, yang fokusnya adalah pada kinerja kebijakan. Di sini, pelajaran-pelajaran berharga dapat diperoleh dari sektor bantuan pembangunan, khususnya mengenai indikator kinerja reformasi tata kelola dan kebutuhan untuk melengkapinya dengan penilaian ahli untuk menghasilkan gambaran kemajuan aktual dan pencapaian yang dicapai secara lebih lengkap.

Semakin banyaknya pengalaman dan data mengenai pengukuran kinerja yang terkumpul akhirnya memungkinkan penetapan standar penilaian kinerja REDD+ yang disepakati secara internasional. Sistem penilaian terstandarisasi, bila diimplementasikan dengan benar, akan memberikan banyak manfaat termasuk pengurangan risiko sabotase politik. Selain pelajaran dari sektor bantuan pembangunan, usaha semacam ini juga dapat belajar dari proses-proses UNFCCC lainnya seperti berbagai diskusi mengenai 'programmatic CDM', sejumlah mekanisme pasar baru dan tinjauan para ahli dari Greenhouse Gas Inventories negara-negara yang termasuk Aneks I. 


\section{Bab \\ 14}

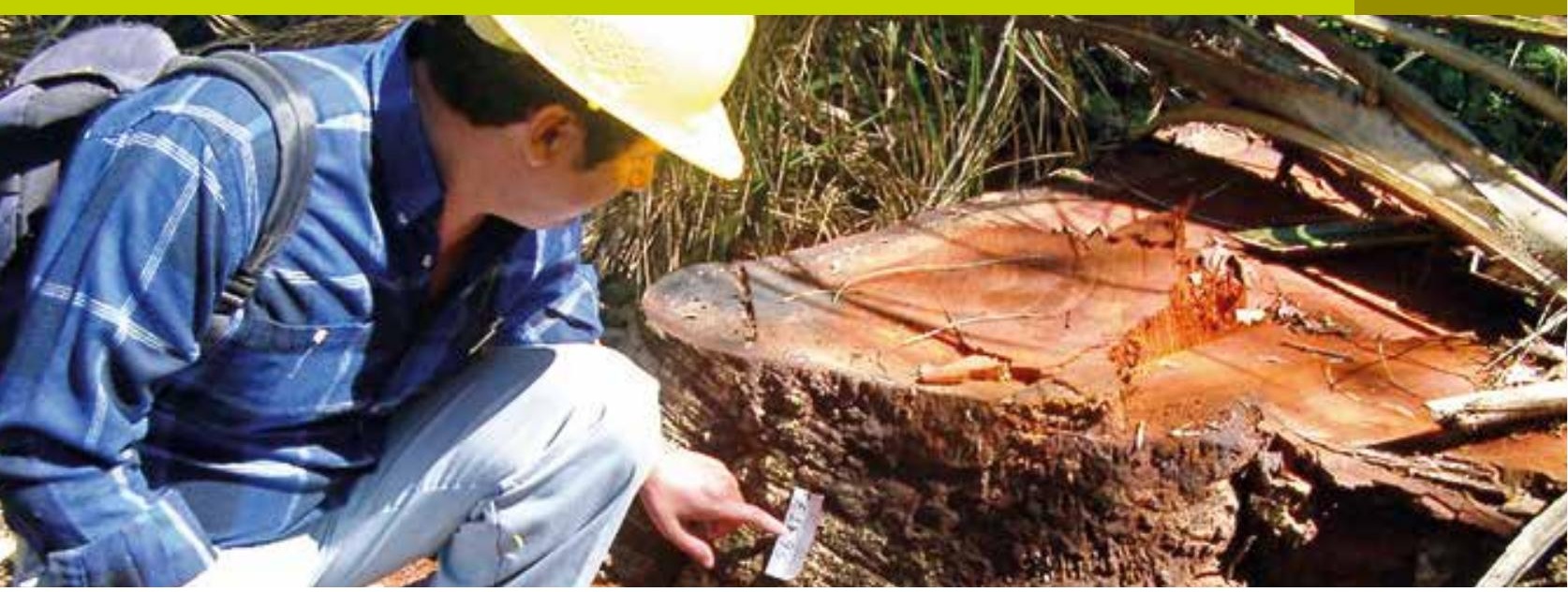

\section{Kondisi awal dan pemantauan dalam proyek-proyek REDD+}

Manuel Estrada dan Shijo Joseph

- Selama beberapa tahun terakhir, berbagai standar dan metode yang kuat telah dikembangkan untuk memperkirakan emisi dari deforestasi di tingkat proyek.

- Karena titik tolak dan metodologi REDD+ pertama yang telah berkembang penuh baru-baru ini saja diadopsi, banyak proyek perintisan mungkin tidak menaatinya, sehingga ada risiko kehilangan kesempatan dalam pasar karbon.

- Generasi proyek-proyek berikutnya harus belajar dari pengalaman ini dengan mengidentifikasi atau mengembangkan metodologi yang sesuai sebelum berinvestasi dalam pengembangan sistem titik tolak dan pengukurannya, pelaporan dan verifikasi (MRV).

\subsection{Pengantar}

Perkiraan akurat dan transparan atas emisi gas rumah kaca (GRK) yang berasal dari deforestasi dan degradasi hutan dan peningkatan stok karbon sangat penting untuk menilai manfaat mitigasi proyek-proyek REDD+. Perkiraan yang tepat dari manfaat semacam itu diperlukan untuk menjamin integritas kegiatan 
mitigasi perubahan iklim yang menggunakannya untuk memenuhi komitmen pengurangan emisi yang terikat secara hukum atau dengan sasaran-sasaran sukarela. Pada waktu yang sama, kualitas perkiraan semacam itu memengaruhi potensi sebuah proyek untuk mengakses dana (kredit karbon berkualitas tinggi lebih besar kemungkinannya untuk menarik sejumlah pembeli dan investor potensial yang lebih luas di pasar karbon daripada kredit yang diperkirakan dengan metode yang kurang kuat) dan juga jumlah dana yang mereka hasilkan (kredit yang tercipta dengan mengikuti metode dan praktik yang baik biasanya dijual dengan harga yang lebih tinggi). ${ }^{1}$

Bab ini mengidentifikasi berbagai tantangan umum yang dihadapi para pengembang proyek ketika menetapkan standar dengan menilai kapasitas dan ketersediaan data dalam proyek-proyek yang sedang berjalan terhadap standar dan metode yang telah diakui secara internasional. Hasil penilaian ini memberikan sedikit arahan bagi para pengembang proyek, donatur dan komunitas REDD+ internasional mengenai cara mengatasi sejumlah tantangan ini dan bidang-bidang apa saja yang perlu diprioritaskan untuk investasi, agar estimasi standar yang handal dapat disempurnakan.

Sumber analisis ini didasarkan pada informasi yang dikumpulkan melalui Studi Komparatif Global REDD+ (GCS) yang dilakukan CIFOR dan mewakili pengalaman dari 17 proyek perintisan REDD+ dari Brasil, Kamerun, Indonesia, Peru, Tanzania dan Vietnam (lihat Lampiran). Sebagaimana ditunjukkan dalam Tabel 14.1, fokus proyek-proyek ini adalah pengurangan emisi dari deforestasi dan degradasi hutan. Beberapa proyek juga memasukkan berbagai kegiatan peningkatan stok karbon, seperti pengelolaan hutan yang lebih baik dan aforestasi, reforestasi atau regenerasi hutan.

Lingkup analisis ini ditentukan oleh dua fakta: pertama, proyek-proyek berada pada tahap pengembangan awal (hanya dua dari sembilan proyek yang informasinya tersedia telah terlibat dalam persiapan Deskripsi Proyek²). Salah satu implikasinya adalah bahwa informasi yang sekarang tersedia mengenai rencana pemantauan proyek dan tekniknya tidak memungkinkan untuk dinilai kualitasnya. Kedua, sebagian besar proyek (10 dari 17) sedang mencari validasi di bawah Standar Karbon Terverifikasi (VCS) ${ }^{3}$ - yang saat ini merupakan standar yang paling umum digunakan di pasar karbon sukarela. Karena itu, analisis ini menggunakan persyaratan yang ditentukan

1 Meskipun harus dicatat bahwa, semakin meningkat nilai dari kredit semacam itu mempertimbangkan bukan hanya kekuatan 'metodologis'-nya, tetapi juga kontribusi proyek-proyek dari mana mereka berasal yang akan bermanfaat bagi lingkungan hidup dan manfaat sosial yang lebih luas.

2 Deskripsi Proyek memerinci pengurangan emisi GRK sebuah proyek atau kegiatan pembuangan dan diperlukan untuk mendaftarkan proyek tersebut di bawah VCS.

3 Dulu Voluntary Carbon Standard (VCS). 
oleh VCS untuk proyek-proyek REDD+ sebagai dasar untuk mengevaluasi metode dan data yang digunakan untuk mengestimasi manfaat karbon dari proyek-proyek GCS. ${ }^{4}$ Selain itu, karena keterbatasan data mengenai sistem pemantauan, penilaiannya terbatas pada estimasi kondisi awal proyek.

Bab ini memperkenalkan berbagai metode yang tersedia untuk mengestimasi emisi dalam REDD+ (Bagian 14.2), dan juga persyaratan umum VCS untuk proyek-proyek REDD+ dan tipe proyek yang dikenali (Bagian 14.3). Bab ini juga menggambarkan langkah-langkah penting dan data yang harus menaati ketentuan-ketentuan untuk membangun standar sesuai dengan metodologi VCS (Bagian 14.4), kemudian mengevaluasi status proyek-proyek GCS saat ini dalam kaitannya dengan persyaratan tadi (Bagian 14. 5). Akhirnya, berdasarkan penilaian ini, Bagian 14.6 menyediakan kesimpulan sementara dan rekomendasi.

\subsection{Berbagai metode yang tersedia untuk mengestimasi manfaat mitigasi dari proyek REDD+.}

Pengurangan GRK secara dalam jangka panjang, penambahan dan peningkatan stok karbon yang terukur melalui proyek-proyek REDD+ memerlukan penetapan kondisi awal yang dapat dipercaya (skenario tanpa proyek), pemantauan yang tepat dan pelaporan hasil-hasil proyek serta standar yang kuat dan kerangka kerja kelembagaan agar verifikasinya tidak berat sebelah dan konsisten.

Dasar ilmiah dan metodologis untuk mengestimasi emisi dan penyerapan GRK akibat kegiatan di sektor pertanian, hutan, dan penggunaan lahan lainnya (AFOLU) terdapat dalam 'Pedoman untuk Inventarisasi GRK Nasional 2006 ' (IPCC 2006) dan 'Panduan Praktik yang Baik untuk Penggunaan Lahan, Perubahan Tata Guna Lahan dan Kehutanan' 2003, yang disusun oleh Dewan antarPemerintah Mengenai Perubahan Iklim (IPCC, 2003). Panduan IPCC dimaksudkan untuk digunakan pada tingkat nasional, namun dapat diadaptasi, berdasarkan panduan yang disediakan IPCC, GPG-LULUCF, dan diterapkan pada tingkat proyek. Kajian yang lebih luas mengenai Panduan IPCC terdapat dalam Bab 15 buku ini.

Panduan IPCC menjadi landasan untuk pengembangan sejumlah standar yang kuat yang menetapkan persyaratan penting untuk kuantifikasi pengurangan emisi dan penyerapan GRK dan untuk pembuatan kredit karbon terkaitnya. Landasan ini mencakup VCS dan American Carbon Registry (ACR), yang dianggap mewakili praktik-praktik terbaik di pasar karbon sukarela.

4 Harus dicatat bahwa semua proyek dinilai berdasarkan panduan VCS, bahkan bila para pengembang proyek belum memutuskan mengenai standar yang akan mereka terapkan atau bila mereka bermaksud menggunakan standar lain (misalnya, Plan Vivo). 


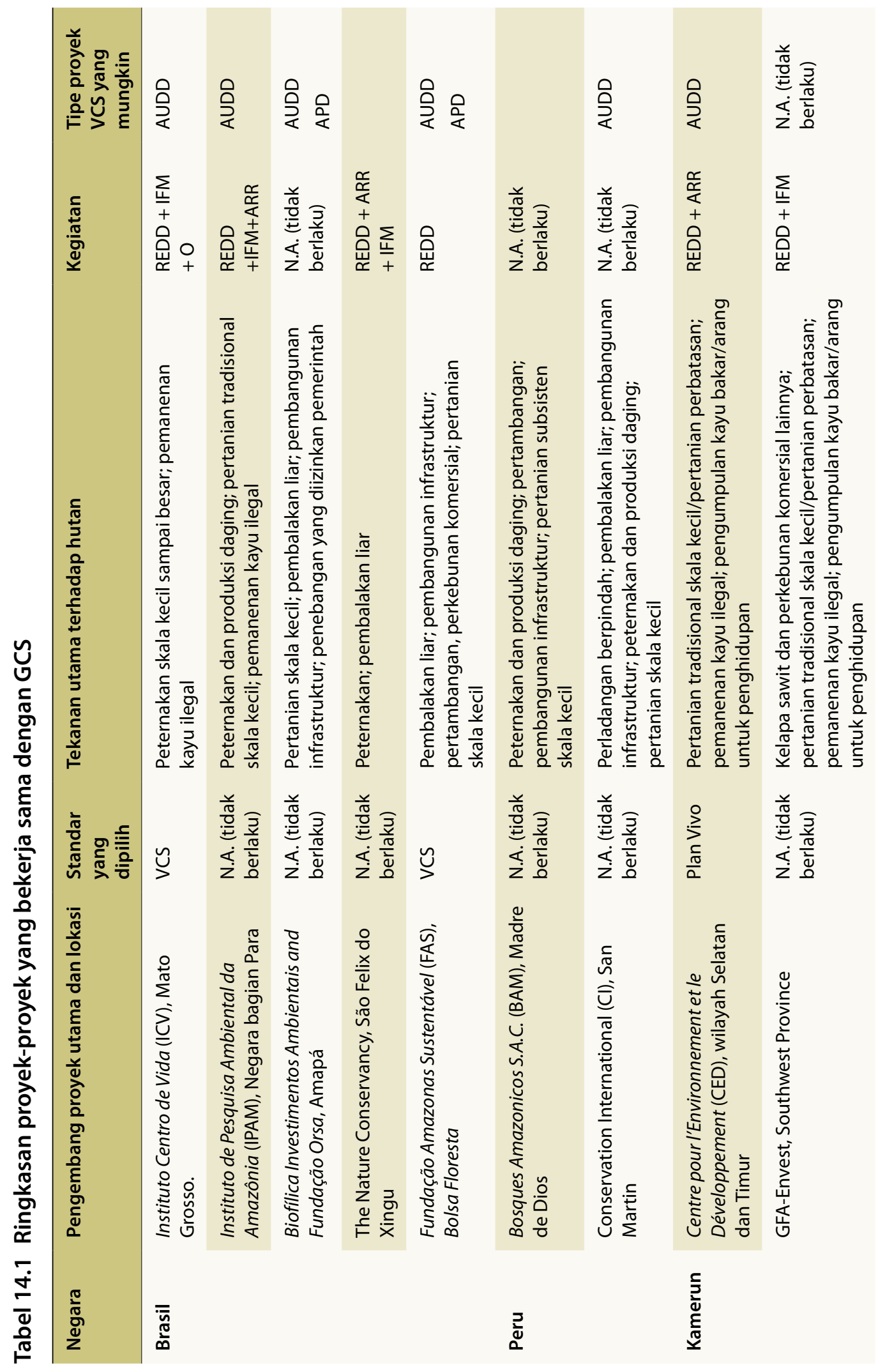




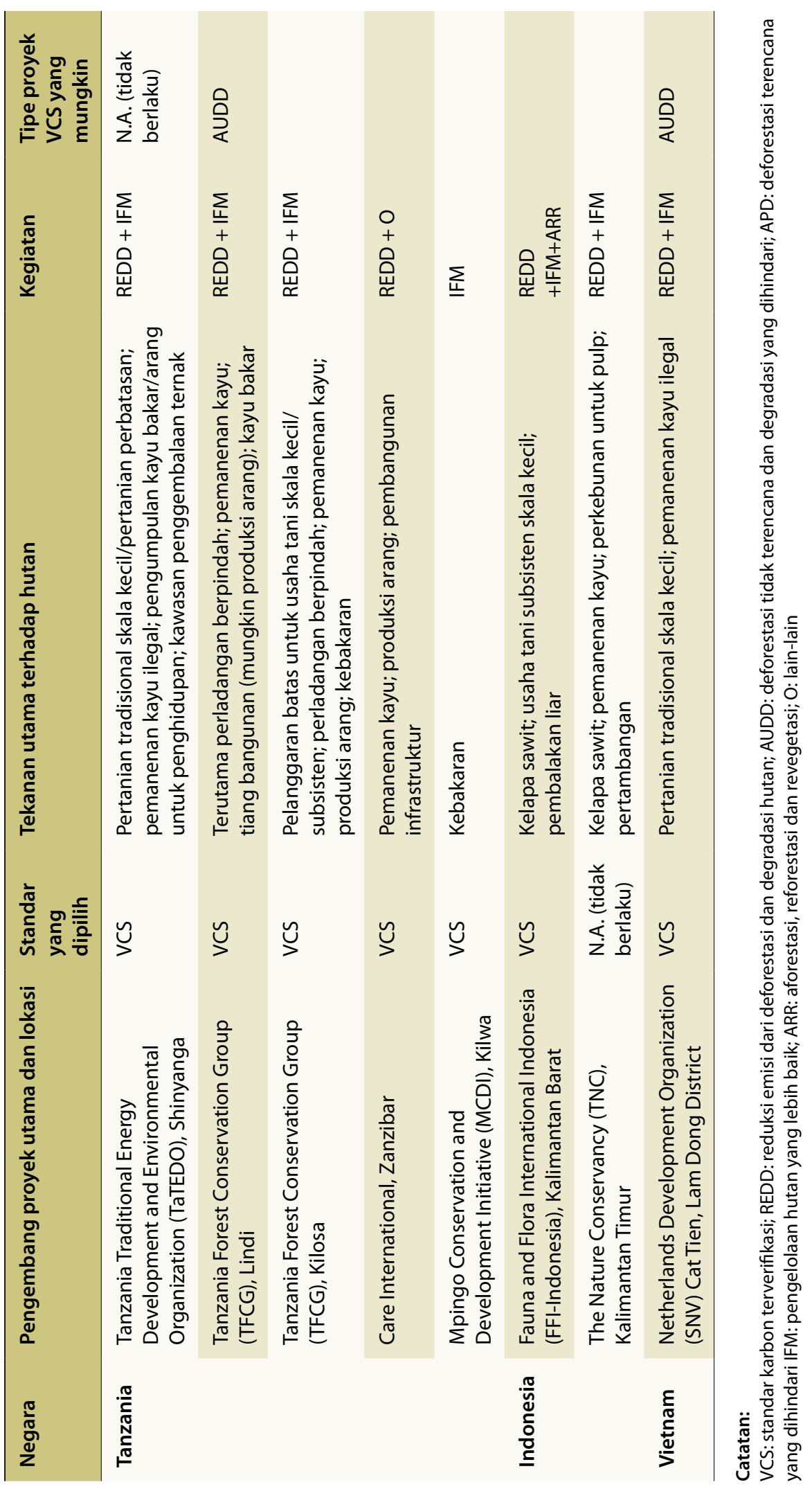


Dalam praktiknya, standar-standar tersebut diterapkan melalui metodologi kondisi awal dan pemantauan, yang menetapkan prosedur dan persamaan yang terperinci untuk menguantifikasikan manfaat mitigasi proyek, termasuk berbagai metode untuk menetapkan perbatasan proyek, menilai ke penambahan (yaitu apakah inisiatif tersebut hanya terjadi karena penghasilan kredit karbon), menetapkan skenario kondisi awal yang paling masuk akal dan menguantifikasikan emisi GRK yang telah berkurang atau diserap karena kegiatan proyek. Sebelum diterapkan, berbagai metodologi tersebut - yang diuraikan oleh para pemrakarsa - harus divalidasi oleh pihak ketiga sesuai persyaratan yang ditetapkan oleh standar tersebut. Pihak yang melakukan validasi harus diberi kewenangan oleh badan yang bertanggung jawab atas standar tersebut untuk mengaudit metodologi yang diajukan. Sampai sekarang, ada lima metodologi yang telah disetujui VCS untuk proyek-proyek ${ }^{5}$ REDD (lihat Tabel 14.2). Setiap metodologi dirancang agar sesuai dengan kondisi awal spesifik dan skenario proyek; sesudah divalidasi, metodologi tersebut menjadi terbuka untuk umum ${ }^{6}$ dan dapat diterapkan pada proyek mana pun yang memenuhi kondisi penerapannya. Para pengembang proyek bebas untuk menggunakan metodologi mana pun yang sesuai dengan ciri-ciri proyek mereka atau untuk mengembangkan metodologi baru bila pendekatan yang sudah ada tidak sesuai.

\subsection{Persyaratan VCS umum dan tipe-tipe proyek REDD+}

Persyaratan VCS mengandung aturan-aturan umum untuk semua proyek REDD+. Antara lain aturannya mencakup isu-isu seperti kondisi yang memenuhi syarat untuk daerah proyek, definisi perbatasan proyek (perbatasan geografis, masa pengreditan dan sumber-sumber emisi GRK dan tampungan karbon), perwujudan penambahan dan perlakuan terhadap risiko ketidakpastian (yaitu risiko bahwa penyerapan karbon mengalami pembalikan setelah kreditnya diciptakan). Dalam konteks VCS, kegiatan REDD+ terbagi menjadi dua tipe: Proyek REDD+, yang terkait dengan deforestasi (legal dan ilegal, lihat di bawah), dan degradasi (ilegal) dan proyek pengelolaan hutan yang lebih baik, yang mencakup inisiatif untuk menghadapi degradasi 'legal' akibat pengelolaan yang buruk, pengelolaan hutan berkelanjutan dan peningkatan stok karbon. Dua persyaratan utamanya ialah bahwa wilayah proyek untuk REDD harus memenuhi definisi hutan yang diakui secara internasional, seperti definisi yang didasarkan pada ambang batas negara tuan rumah UNFCCC atau FAO (FAO

5 Kami menggunakan REDD tanpa tanda '+' bila proyek-proyek hanya berurusan dengan deforestasi dan degradasi hutan.

6 Para pengembang metodologi yang disetujui di bawah Program VCS pada atau sesudah 13 April 2010 memenuhi syarat untuk menerima ganti rugi. Jumlah ganti rugi ini mencapai 0,02 dolar AS per unit karbon terverifikasi (VCU) yang diberikan kepada proyek yang menggunakan metodologi tersebut atau revisi dari metodologi tersebut. 


\title{
Tabel 14.2 Metodologi yang disetujui VCS untuk proyek-proyek REDD* terhitung sejak Maret 2012 (VCS 2012)
}

\author{
VM0004 - Metodologi untuk Proyek Konservasi yang Menghindari Konversi \\ Penggunaan Lahan Terencana di Hutan-hutan Rawa Gambut, v1.0 \\ VM0006 - Metodologi untuk Neraca Karbon dalam Kegiatan Proyek yang \\ Mengurangi Emisi dari Deforestasi Mosaik dan Degradasi, v1.0 \\ VM0007 - Modul Metodologi REDD (REDD-MF), v1.1 \\ VM0009 - Metodologi untuk Deforestasi Mosaik yang Dihindari pada Hutan \\ Tropis, v1.1 \\ VM0015 - Metodolog Untuk Deforestasi Tidak Terencana yang Dihindari, v1.0 \\ * Perlu dicatat bahwa dalam konteks VCS, kegiatan-kegiatan " + " memenuhi syarat sebagai \\ pengelolaan hutan yang lebih baik dan tidak dipertimbangkan dalam Tabel ini.
}

2006) dan harus memenuhi syarat sebagai hutan selama sekurangnya 10 tahun sebelum proyek dimulai.

Aturan-aturan umum mengenai proyek REDD dilengkapi dengan berbagai ketentuan yang menangani sebuah subset dari proyek-proyek ini: i) menghindari deforestasi terencana (APD), yaitu proyek yang mengurangi emisi GRK bersih dengan menghentikan deforestasi dan/atau degradasi dari hutan secara legal diberi izin untuk dikonversi menjadi lahan nonhutan; dan ii) menghindari deforestasi terencana dan/atau degradasi (AUDD), yaitu proyek yang mengurangi emisi GRK bersih dengan menghentikan deforestasi dan/atau degradasi hutan yang mungkin terjadi sebagai akibat kekuatan sosio-ekonomi yang mendorong penggunaan lahan hutan alternatif. Perbedaan ini penting karena pemicu, agen dan dinamika deforestasi yang terkait dengan setiap jenis proyek memiliki implikasi metodologis yang berbeda, misalnya, dalam hubungannya dengan penetapan kondisi awal dan perkiraan kebocoran. Dalam proyek deforestasi, wilayah di mana diduga akan terjadi deforestasi dibatasi oleh izin pemerintah dan laju deforestasi ditentukan oleh izin ini atau oleh praktik-praktik umum yang diamati pada konsesi serupa. Dalam proyek deforestasi tidak terencana, penentuan wilayah di mana diduga akan terjadi deforestasi bergantung pada berbagai keputusan sejumlah orang yang relatif banyak pada suatu daerah yang serupa dengan wilayah proyek dan laju deforestasi yang diharapkan yang berasal dari, misalnya, evolusi sejarah pemicunya, agen dan keadaan sosio-ekonomi yang memengaruhi daerah, dan juga dari karakteristik geografisnya.

Sebagaimana ditunjukkan dalam Tabel 14.1, sebagian besar proyek GCS yang menyerahkan informasi mengenai pemicu deforestasi memenuhi syarat terutama sebagai AUDD; dengan demikian penilaian berikut khusus difokuskan pada proyek dan metode AUDD. 


\subsection{Persyaratan VCS utama untuk mengestimasi kondisi awal REDD+}

\subsubsection{Sejumlah ketentuan untuk menetapkan kondisi awal proyek REDD}

Kondisi awal sebuah proyek REDD adalah skenario yang secara wajar mewakili perubahan-perubahan antropogenis dalam stok karbon di tampungan dan emisi GRK yang mungkin timbul bila tidak ada proyek. Kondisi awal diestimasi secara ex ante (sebelum terjadinya peristiwa) dan harus dinilai dan divalidasi ulang setiap sepuluh tahun agar mencerminkan perubahan dalam konteks proyek yang mungkin memengaruhi laju deforestasi. Kondisi awal REDD mencakup dua unsur utama: komponen perubahan penggunaan lahan dan tutupan lahan (data kegiatan) dan komponen perubahan stok karbon terkait (faktor emisi).

Persyaratan untuk komponen penggunaan lahan/tutupan lahan dalam skenario kondisi awal: Untuk proyek-proyek AUDD, komponen data kegiatan dari skenario basis didasarkan pada kecenderungan menurut sejarah yang diamati di daerah acuan selama sedikitnya sepuluh tahun sebelumnya; ${ }^{7}$ kecenderungan ini digunakan untuk membuat proyeksi deforestasi masa depan. Tabel 14.3 meringkaskan beberapa data utama dan tugas yang diperlukan untuk mengestimasi komponen perubahan penggunaan lahan dan tutupan lahan dari sebuah skenario kondisi awal proyek AUDD dalam masing-masing metodologi VCS REDD+ yang berlaku untuk AUDD. Tabel 14.4 menyajikan persyaratan data penginderaan jauh untuk penyusunan titik pangkal berbagai metodologi AUDD yang telah disetujui VCS.

\subsubsection{Persyaratan untuk komponen stok karbon dalam kondisi awal}

Sebuah skenario kondisi awal harus mencakup perubahan stok karbon yang signifikan dalam semua tampungan terkait dan emisi GRKdari sumber-sumber yang akan muncul dalam batas-batas wilayah proyek. Menurut persyaratan VCS untuk AFOLU, proyek-proyek AUDD harus selalu mencakup tampungan karbon biomassa pohon di atas tanah. Pencakupan tampungan karbon lainnya diperlukan hanya bila ada kemungkinan bahwa kegiatan proyek akan mengurangi tampungan tersebut secara signifikan.

Sebagian besar metodologi yang telah disetujui mengharuskan agar perkiraan stok karbon hutan didasarkan pada inventarisasi langsung di

7 Daerah acuannya adalah domain analitis dari mana informasi mengenai sejarah deforestasi didapat dan diproyeksikan ke masa depan untuk menempatkan secara spasial area yang akan dianggap sebagai terdeforestasi dalam skenario dasar. 
wilayah proyek atau pada pengukuran yang dilakukan dari hutan yang mewakili wilayah proyek tersebut. Beberapa metodologi juga mengizinkan penggunaan perkiraan konservatif dari kepustakaan atau standar IPCC. Untuk kondisi awal penggunaan lahan (konversi pascahutan), semua metodologi VCS REDD mengizinkan penggunaan nilai stok karbon standar dari studi lokal atau kepustakaan atau, bila kedua sumber ini tidak tersedia, dari pengambilan sampel langsung di lokasi proyek. Penggunaan data dari kepustakaan atau standar IPCC biasanya akan berbeda implikasinya dalam hal ketidakpastian. Jadi beberapa metodologi memerlukan kisaran nilai bawah dan atas untuk digunakan untuk kelas-kelas hutan dan nonhutan. Bila pemodelan spasial tidak termasuk

\section{Tabel 14.3 Data dan tugas utama yang diperlukan untuk menetapkan kondisi awal laju deforestasi/degradasi dan /atau lokasi proyek- proyek AUDD}

\begin{tabular}{|c|c|c|c|c|}
\hline Data/Tugas & VM0006 & VM0007 & VM0009 & VM0015 \\
\hline $\begin{array}{l}\text { Analisis } \\
\text { GIS untuk } \\
\text { menerapkan } \\
\text { kriteria yang } \\
\text { menunjukkan } \\
\text { kemiripan } \\
\text { daerah acuan } \\
\text { dengan } \\
\text { daerah proyek }\end{array}$ & Diperlukan & $\begin{array}{l}\text { Diperlukan } \\
\text { kecuali } \\
\text { menggunakan } \\
\text { pendekatan } \\
\text { pemicu } \\
\text { populasi }\end{array}$ & Diperlukan & Diperlukan \\
\hline $\begin{array}{l}\text { Pemodelan } \\
\text { laju } \\
\text { deforestasi } \\
\text { (dari analisis } \\
\text { perubahan } \\
\text { tutupan } \\
\text { hutan historis) }\end{array}$ & $\begin{array}{l}\text { Rata-rata } \\
\text { historis } \\
\text { sederhana atau } \\
\text { kecenderungan }\end{array}$ & $\begin{array}{l}\text { Rata-rata } \\
\text { historis } \\
\text { sederhana atau } \\
\text { kecenderungan } \\
\text { atau dorongan } \\
\text { populasi }\end{array}$ & $\begin{array}{l}\text { Model } \\
\text { logistik } \\
\text { didasarkan } \\
\text { pada rata- } \\
\text { rata historis } \\
\text { dan kovariat } \\
\text { (pemicu) }\end{array}$ & $\begin{array}{l}\text { Rata-rata historis } \\
\text { sederhana atau } \\
\text { kecenderungan } \\
\text { atau berdasarkan } \\
\text { kovariat }\end{array}$ \\
\hline $\begin{array}{l}\text { Pemodelan } \\
\text { spasial } \\
\text { deforestasi } \\
\text { dan cakupan } \\
\text { GIS (yaitu } \\
\text { shape file) } \\
\text { dari pemicu } \\
\text { spasial } \\
\text { (misalnya } \\
\text { model elevasi } \\
\text { digital, } \\
\text { jaringan jalan } \\
\text { raya, dll.) }\end{array}$ & Diperlukan & $\begin{array}{l}\text { Diperlukan } \\
\text { bila deforestasi } \\
\text { perbatasan } \\
\text { tidak terencana } \\
\text { atau bila }<25 \% \\
\text { dari perbatasan } \\
\text { proyek berada } \\
\text { dalam jarak } \\
120 \text { meter dari } \\
\text { deforestasi } \\
\text { terbaru. }\end{array}$ & $\begin{array}{l}\text { Tidak ada } \\
\text { (tidak } \\
\text { eksplisit } \\
\text { secara } \\
\text { spasial) }\end{array}$ & Diperlukan \\
\hline
\end{tabular}


Tabel 14.4 Persyaratan data penginderaan jauh untuk analisis perubahan tutupan hutan (historis) untuk metodologi AUDD

\begin{tabular}{|c|c|c|c|c|}
\hline Data/Tugas & VM0006 & VM0007 & VM0009 & VM0015 \\
\hline $\begin{array}{l}\text { Penginderaan } \\
\text { jauh/ } \\
\text { pencitraan: }\end{array}$ & $\leq 30 \mathrm{~m}$ & $\leq 30 \mathrm{~m}$ & $\leq 30 \mathrm{~m}$ & $\leq 100 m$ \\
\hline $\begin{array}{l}\text { Kebutuhan } \\
\text { seri waktu } \\
\text { penginderaan } \\
\text { jauh/pencitraan } \\
\text { untuk daerah } \\
\text { acuan: }\end{array}$ & $\begin{array}{l}\text { Pencitraan } \\
\text { dari empat } \\
\text { titik waktu dari } \\
\text { periode } 0-15 \\
\text { tahun sebelum } \\
\text { proyek dimulai }\end{array}$ & $\begin{array}{l}\text { Pencitraan } \\
\text { dari tiga titik } \\
\text { waktu dari } \\
\text { periode } 2-12 \\
\text { tahun sebelum } \\
\text { proyek dimulai }\end{array}$ & $\begin{array}{l}\text { Pencitraan } \\
\text { dari sedikitnya } \\
\text { dua titik waktu } \\
\text { sebelum } \\
\text { proyek } \\
\text { dimulai; } \\
\text { sedikitnya } 90 \% \\
\text { dari daerah } \\
\text { acuan harus } \\
\text { memiliki } \\
\text { tutupan dari } \\
\text { sedikitnya dua } \\
\text { titik waktu }\end{array}$ & $\begin{array}{l}\text { Pencitraan dari } \\
\text { sedikitnya tiga } \\
\text { titik waktu dari } \\
\text { periode } 10-15 \\
\text { tahun sebelum } \\
\text { proyek dimulai, } \\
\text { dengan satu } \\
\text { pencitraan } \\
\text { dilakukan } \\
\text { dalam jangka } \\
\text { waktu dua } \\
\text { tahun sebelum } \\
\text { proyek dimulai }\end{array}$ \\
\hline $\begin{array}{l}\text { Keakuratan } \\
\text { klasifikasi } \\
\text { minimum } \\
\text { penginderaan } \\
\text { jauh/pencitraan }\end{array}$ & $\begin{array}{l}70 \% \text { dari piksel } \\
\text { yang disampel } \\
\text { (dengan } \\
\text { pengurangan } \\
\text { ketidakpastian) }\end{array}$ & $\begin{array}{l}90 \% \text { dari piksel } \\
\text { yang disampel }\end{array}$ & $\begin{array}{l}\text { Tidak berbasis } \\
\text { piksel; } \\
\text { panduan } \\
\text { kendali } \\
\text { mutu untuk } \\
\text { memperkecil } \\
\text { galat } \\
\text { interpretasi } \\
\text { titik }\end{array}$ & $90 \%$ \\
\hline $\begin{array}{l}\text { Metode } \\
\text { klasifikasi } \\
\text { minimum } \\
\text { penginderaan } \\
\text { jauh/pencitraan }\end{array}$ & $\begin{array}{l}\text { Tinjau } \\
\text { pencitraan } \\
\text { resolusi tinggi } \\
\text { atau basis data } \\
\text { dari kelas atau } \\
\text { lokasi yang } \\
\text { diketahui }\end{array}$ & $\begin{array}{l}\text { Tinjau } \\
\text { pencitraan } \\
\text { resolusi tinggi } \\
\text { atau metode } \\
\text { kebenaran di } \\
\text { lapangan }\end{array}$ & $\mathrm{N} / \mathrm{A}$ & $\begin{array}{l}\text { Tinjau } \\
\text { pencitraan } \\
\text { resolusi tinggi } \\
\text { atau metode } \\
\text { kebenaran di } \\
\text { lapangan }\end{array}$ \\
\hline $\begin{array}{l}\text { Penginderaan } \\
\text { jauh/pencitraan } \\
\text { minimum } \\
\text { bebas awan }\end{array}$ & $80 \%$ & $90 \%$ & $\begin{array}{l}\text { Tidak } \\
\text { terspesifikasi- } \\
\text { pendekatan } \\
\text { titik sampel } \\
\text { bergeser } \\
\text { fleksibel } \\
\text { di wilayah } \\
\text { dengan } \\
\text { tutupan awan } \\
\text { signifikan dan } \\
\text { bervariasi }\end{array}$ & $\begin{array}{l}\text { Tidak } \\
\text { terspesifikasi }\end{array}$ \\
\hline
\end{tabular}


dalam konstruksi kondisi awal, dan dengan demikian faktor emisinya tidak dicocokkan dengan piksel-piksel spesifik pada sebuah peta, metodologi umumnya menggunakan faktor emisi rata-rata tertimbang luas dari sampel terstratifikasi atau mengasumsikan bahwa strata dengan stok karbon rata-rata terendah akan dideforestasi lebih dahulu (Shoch dkk. 2011). Tabel 14.5 meringkaskan berbagai metode yang digunakan dalam setiap metodologi untuk mengukur stok karbon, dan juga frekuensi untuk penilaian ulang stok tersebut.

\subsection{Penilaian sementara proyek-proyek GCS}

Persyaratan umum yang diperkenalkan dalam bagian 14.3 dan tugas-tugas dan data yang diperlukan dalam metodologi VCS yang disajikan dalam bagian 14.4.1 dibandingkan dengan data proyek GCSyangada untuk mengidentifikasi kesenjangan data dan kebutuhan kapasitas. Perbandingan ini mengungkapkan bahwa:

\section{Tabel 14.5 Sumber-sumber estimasi stok karbon yang diperlukan dalam skenario kondisi awal}

\begin{tabular}{|c|c|c|c|c|}
\hline $\begin{array}{l}\text { Perkiraan } \\
\text { stok }\end{array}$ & VM0006 & VM0007 & VM0009 & VM0015 \\
\hline $\begin{array}{l}\text { Daerah } \\
\text { proyek } \\
\text { tampungan } \\
\text { karbon hutan }\end{array}$ & $\begin{array}{l}\text { Inventarisasi } \\
\text { biomassa } \\
\text { hutan dari } \\
\text { setiap strata } \\
\text { hutan yang } \\
\text { teridentifikasi } \\
\text { dengan } \\
\text { plot sampel } \\
\text { permanen }\end{array}$ & $\begin{array}{l}\text { Inventaris } \\
\text { biomassa } \\
\text { hutan dengan } \\
\text { plot radius } \\
\text { daerah } \\
\text { tetap atau } \\
\text { bervariasi } \\
\text { (harus terjadi } \\
\text { dalam kurun } \\
=/-5 \text { tahun } \\
\text { dari tanggal } \\
\text { mulai proyek) }\end{array}$ & $\begin{array}{l}\text { Inventaris biomassa } \\
\text { hutan dengan plot } \\
\text { daerah tetap (harus } \\
\text { terjadi pada periode } \\
\text { pemantauan } \\
\text { pertama, yaitu } \\
\text { sebelum verifikasi } \\
\text { pertama) }\end{array}$ & $\begin{array}{l}\text { Inventaris } \\
\text { biomassa } \\
\text { hutan } \\
\text { dengan plot } \\
\text { sementara } \\
\text { atau } \\
\text { permanen } \\
\text { atau standar } \\
\text { konservatif }\end{array}$ \\
\hline Pascakonversi & $\begin{array}{l}\text { Faktor-faktor } \\
\text { standar dari } \\
\text { kepustakaan } \\
\text { atau } \\
\text { pengukuran } \\
\text { dari plot } \\
\text { sementara } \\
\text { di daerah- } \\
\text { daerah yang } \\
\text { mewakili }\end{array}$ & $\begin{array}{l}\text { Faktor-faktor } \\
\text { standar dari } \\
\text { kepustakaan } \\
\text { atau } \\
\text { pengukuran } \\
\text { dari plot } \\
\text { sementara } \\
\text { di daerah- } \\
\text { daerah yang } \\
\text { mewakili }\end{array}$ & $\begin{array}{l}\text { Tidak diperlukan } \\
\text { bila daerah proyek } \\
\text { merupakan hutan } \\
\text { tropis setengah } \\
\text { kering. Bila } \\
\text { tidak, diperlukan } \\
\text { pengambilan } \\
\text { sampel karbon } \\
\text { tanah dari usaha } \\
\text { tani proksi di } \\
\text { daerah acuan untuk } \\
\text { memparameterisasi } \\
\text { model kehilangan } \\
\text { karbon tanah }\end{array}$ & $\begin{array}{l}\text { Faktor-faktor } \\
\text { standar dari } \\
\text { kepustakaan } \\
\text { atau } \\
\text { pengukuran } \\
\text { dari plot } \\
\text { sementara } \\
\text { di daerah- } \\
\text { daerah yang } \\
\text { mewakili }\end{array}$ \\
\hline
\end{tabular}


Persyaratan umum: data yang tersedia tidak mencukupi untuk menentukan apakah wilayah proyek sepenuhnya tertutup hutan di awal proyek atau apakah hutan di wilayah tersebut telah ada selama sedikitnya sepuluh tahun, sebagaimana disyaratkan oleh VCS.

Kemiripan proyek dan wilayah acuan: sebagian besar proyek GCS membatasi ruang lingkup pemantauannya di wilayah proyek. Artinya, proyek-proyek ini tidak mempertimbangkan adanya daerah acuan (atau sabuk kebocoran ${ }^{8}$ ), yang menunjukkan ketidakpatuhan pada persyaratan VCS. Meskipun demikian, lima dari kesembilan pengembang proyek yang menyerahkan informasi mengenai topik ini telah mengembangkan skenario kondisi awal, tiga proyek sedang mengembangkan skenario dan satu proyek belum memulai prosesnya.

Pemodelan laju deforestasi: sembilan dari 17 pengembang proyek telah memodelkan laju deforestasi historis di wilayah proyek dan tiga proyek lagi sedang dalam proses melakukannya. Lima pengembang proyek menggunakan rata-rata historis sederhana atau sebuah proyeksi linier untuk mengestimasi laju deforestasi, empat proyek menggunakan pemodelan berbasis GIS dengan kovariat pemicu deforestasi dan satu pengembang bergantung pada opini para pakar. Dua proyek tidak menyebutkan secara spesifik pendekatan yang mereka gunakan untuk mengestimasi laju deforestasi historis. Proyek yang hanya bergantung pada pengetahuan ahli saja mungkin akan menghadapi masalah dalam memenuhi persyaratan VCS.

Pemodelan spasial untuk memproyeksikan lokasi deforestasi: hanya tiga dari ke-17 proyek telah menggunakan model spasial untuk memproyeksikan lokasi deforestasi di masa depan, yang sejalan dengan persyaratan VCS. Ke-14 proyek lainnya sebagian besar bergantung pada pengetahuan para pakar atau pada keluaran yang dimodelkan berskala nasional.

Citra penginderaan jauh berseri untuk daerah acuan: sebagaimana dicatat sebelumnya, hampir semua proyek tidak memasukkan daerah acuan dalam perhitungan ketika mengestimasi kondisi awal mereka. Jadi tidaklah jelas apakah citra penginderaan jauh yang mereka miliki akan mencakup daerah acuan itu. Informasi yang tersedia mengindikasikan bahwa kira-kira sepuluh dari ke-17 proyek memiliki data yang cukup untuk mengestimasi laju deforestasi historis dalam periode sepuluh tahun dan 13 proyek lainnya memiliki citra penginderaan jauh untuk lebih dari tiga titik yang tersedia untuk jangka waktu tersebut (Gambar 14.1)

Resolusi pencitraan jarak jauh: hanya tujuh dari ke-17 proyek melaporkan bahwa mereka memiliki data dengan resolusi tinggi $(<10 \mathrm{~m})$, sementara semua

8 'Sabuk kebocoran' adalah daerah di luar perbatasan proyek di mana setiap deforestasi di atas proyeksi kondisi awal akan dianggap sebagai kebocoran. 


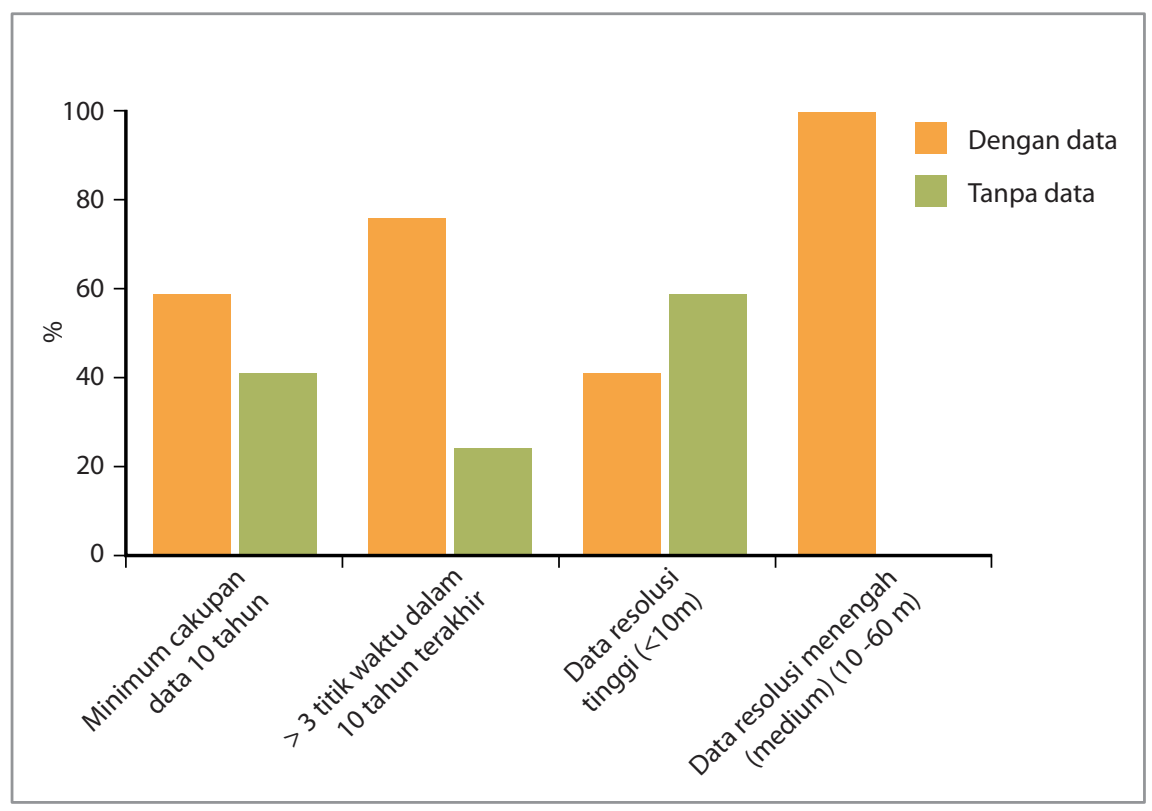

\section{Gambar 14.1 Data penginderaan jauh historis yang tersedia untuk lokasi-lokasi proyek GCS}

proyek memiliki data resolusi sedang (medium) (10-60m). Akibatnya, dapat diduga bahwa sedikitnya tujuh proyek akan dapat memenuhi persyaratan VCS mengenai penginderaan jauh.

Analisis ini menunjukkan bahwa 13 dari 17 proyek GCS yang diteliti telah mulai mengukur biomassa di atas permukaan tanah, jadi secara potensial memenuhi persyaratan VCS. Dalam banyak kasus, proyek berencana untuk menggunakan rasio akar-batang sebagai alternatif untuk pengukuran biomassa di bawah permukaan tanah. Proyek akan menggunakan rasio yang diacu oleh IPCC atau diperoleh melalui penelitian lokal. Perlu dicatat bahwa sembilan dari ke-17 proyek menggunakan persamaan alometrik ${ }^{9}$ spesifik untuk lokasinya dalam mengestimasi stok karbon hutan, hanya tiga proyek memiliki koefisien konversi karbon dan lokasi-lokasi proyek lainnya berencana untuk menggunakan persamaan alometrik umum dan nilai konversi karbon standar yang tersedia dalam kepustakaan. Proyek-proyek tersebut tidak memberikan spesifikasi mengenai metode dan data apa yang akan mereka gunakan untuk mengestimasi perubahan stok karbon dari penggunaan lahan lainnya dalam skenario kondisi awal mereka.

9 Persamaan alometrik menyatakan hubungan kualitatif antara dimensi sebuah pohon dan biomassanya. Persamaan ini digunakan untuk memperkirakan biomasa pepohonan berdasarkan ukuran yang mudah, seperti misalnya tinggi pohon atau diameter setinggi dada (DBH). 
Mengenai metode pengambilan sampel stok karbon, delapan proyek menggunakan pengambilan sampel acak distratifikasi dan dua proyek menggunakan pengambilan sampel acak sederhana. Hanya satu proyek menggunakan pengambilan sampel permanen, meskipun sebenarnya pengambilan sampel permanen disyaratkan oleh VCS. Selain itu, tiga proyek menggunakan teknik pengambilan sampel sistematik.

\subsection{Kesimpulan dan rekomendasi}

Analisis yang diuraikan dalam bab ini menunjukkan bahwa sebagian besar proyek yang berpartisipasi dalam penelitian GCS mungkin akan menghadapi berbagai masalah dalam mematuhi beberapa persyaratan VCS. Penyebab utamanya adalah metode yang digunakan untuk prediksi deforestasi di masa depan, keterbatasan data untuk menyusun laju deforestasi historis dan penggunaan plot pengambilan sampel stok karbon nonpermanen.

Dapat diperdebatkan bahwa sebagian besar metode yang saat ini tersedia untuk pengembangan kondisi awal dan MRV belum dikembangkan waktu proyek-proyek perintisan ini dimulai. Dengan demikian para pengembang proyek tidak dapat menggunakannya untuk memandu usaha-usaha awal mereka (meskipun perlu diakui bahwa dalam beberapa kasus, proyek tidak dirancang utamanya untuk menghasilkan kredit pengurangan emisi yang dapat diperdagangkan atau untuk menggunakan metodologi tingkat proyek). Situasi ini mungkin telah menyebabkan penggunaan waktu dan sumberdaya yang tidak efektif, karena beberapa kegiatan proyek yang telah diselesaikan harus diulang untuk memastikan kepatuhan pada VCS. Terlebih lagi, pada proyek-proyek AUDD mungkin muncul situasi pelaksanaan kegiatan dengan urutan yang keliru, di mana suatu lokasi proyek dipilih sebelum luas deforestasi sebenarnya di masa depan di daerah tersebut dibuat modelnya. Hal ini dapat membuat lokasi awal menjadi lebih ringan risikonya daripada yang diperkirakan sebelumnya, yang dapat menimbulkan implikasi finansial dan dampak untuk para pengembang proyek.

Perlu diingat juga bahwa berbagai pengalaman yang diuraikan dalam bab ini adalah mengenai proyek REDD+ pertama di dunia. Dengan demikian tantangan yang mereka hadapi cenderung lebih sulit daripada berbagai masalah yang akan dihadapi proyek di masa depan, khususnya mengingat kecenderungan untuk bergerak dari kondisi awal pada tingkat proyek dan sistem MRV ke kondisi awal subnasional dan nasional. Meskipun demikian, beberapa rekomendasi mungkin akan membantu memfasilitasi pengembangan proyek-proyek yang metodologinya kuat (dalam skema VCS atau lainnya) dan untuk memandu berbagai keputusan kebijakan dan pendanaan REDD+, khususnya untuk proyek-proyek AUDD. 
- Sebaiknya digunakan praktik dan standar MRV terbaik yang tersedia, yaitu praktik dan standar yang didasarkan pada Panduan IPCC.

- Sebelum mengembangkan kondisi awal proyek dan merancang rencana pemantauan, para pengembang proyek harus mencari metodologi yang sesuai untuk memandu perencanaan MRV mereka dan investasi terkait teknologi dan data; apabila metodologi yang sesuai tidak tersedia, unsur-unsur yang relevan dan metodologi yang ada dapat digunakan sebagai dasar untuk mengembangkan metodologi baru.

- Pemodelan kondisi awal harus digunakan untuk menetapkan lokasi daerah proyek untuk memastikan bahwa fokus kegiatan-kegiatan proyek adalah di lokasi di mana deforestasi terjadi sangat tinggi dan dapat memastikan penambahan. 



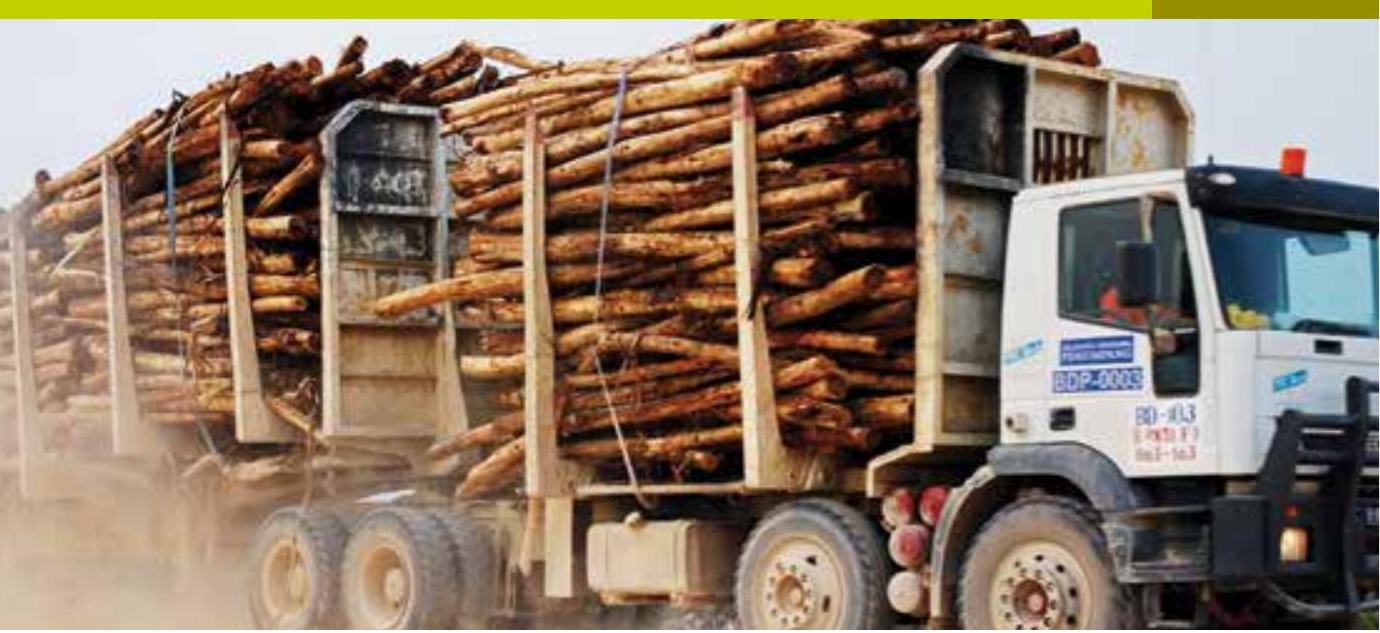

\section{Faktor-faktor emisi}

\section{Mengonversi perubahan tata guna lahan menjadi estimasi $\mathrm{CO}_{2}$}

Louis V. Verchot, Kamalakumari Anitha, Erika Romijn, Martin Herold, dan Kristell Hergoualc'h

- Kekurangan data spesifik suatu negara dan kawasan menimbulkan keterbatasan yang serius untuk mengonversi estimasi luas deforestasi dan degradasi hutan menjadi estimasi perubahan stok karbon untuk sebagian besar negara tropis. Dengan demikian kita tidak dapat mengestimasi secara akurat dan tepat mengenai emisi dan penyerapan dalam program REDD+ nasional dan aktivitas percontohan REDD+.

- Kemajuan dalam peningkatan kapasitas kelembagaan negara-negara untuk melakukan inventarisasi hutan dan pengukuran lainnya untuk meningkatkan inventarisasi gas rumah kaca di sektor kehutanan dan penggunaan lahan lainnya selama ini berlangsung lambat di sebagian besar negara nonAneks I.

- Sejumlah kendala di atas dapat diatasi jika investasi yang dilakukan terkoordinasi dan bertarget dan ada kemitraan produktif yang dikembangkan antara lembaga layanan teknis di negara tuan rumah REDD+, lembaga antarpemerintah dan lembaga penelitian lanjutan di negara maju selama fase kesiapan. 


\subsection{Pengantar}

Kemampuan untuk mengukur kinerja merupakan prasyarat untuk menerapkan mekanisme berbasiskan hasil. Dalam konteks REDD+, keakuratan dalam mengukur pengurangan emisi ini merupakan bagian dari tantangan ini (lihat Bab 13). Banyak kelompok yang tengah mengembangkan sistem pengukuran untuk mendukung pelaksanaan REDD+ di negara-negara yang tidak memiliki kapasitas teknis untuk menilai emisi dari deforestasi dan degradasi secara akurat. Ada dua jenis parameter pengukuran untuk menilai emisi yang harus dilakukan oleh suatu negara. 'Data aktivitas' yaitu jargon yang digunakan untuk pemantauan, pelaporan, dan verifikasi (MRV) untuk menggambarkan data tentang besaran aktivitas manusia yang menghasilkan emisi atau penyerapan. Untuk REDD+, data ini biasanya merujuk ke daerah-daerah yang ada di bawah suatu sistem pengelolaan, deforestasi atau degradasi, tetapi juga bisa merujuk ke hal-hal lain, seperti jumlah asupan, yaitu pupuk. Untuk mengestimasi perubahan stok karbon dan emisi gas rumah kaca (GRK) lainnya yang dihasilkan dari penggunaan lahan dan perubahan penggunaan lahan, termasuk di kawasan hutan dengan biomassa meningkat, negara-negara membutuhkan 'faktor emisi/penyerapan' (untuk sederhananya, kita akan menyingkatnya sebagai faktor emisi [FE]). Faktor-faktor ini mewakili emisi atau pengurangan di semua tampungan karbon yang relevan dan dari semua GRK yang relevan per unit aktivitas. Misalnya, jika hutan rata-rata kehilangan 200 ton karbon per hektar bila ditebang dan deforestasi pada tahun tertentu adalah 2.000 hektar, suatu negara bisa mengestimasi emisi deforestasinya dengan menggabungkan kedua jenis data ini. Penggunaan lahan selanjutnya juga memiliki stok karbon dan emisi GRK (misalnya, dinitrogen oksida dari pupuk atau metana dari ternak) dan keduanya harus diperhitungkan ketika mengestimasi efek atau efek terhilang dari penggunaan lahan dan perubahan penggunaan lahan (untuk emisi acuan, lihat Bab 16).

Sejumlah inisiatif melibatkan peningkatan teknologi penginderaan jauh untuk mendeteksi deforestasi, reforestasi, dan degradasi hutan. Beberapa upaya telah difokuskan pada peningkatan sistem untuk pengukuran nasional dan internasional dan pemantauan deforestasi dan degradasi hutan (Achard dkk. 2002; Bucki dkk. 2012). Upaya ini melibatkan metode yang ditingkatkan untuk mengukur daerah terdeforestasi, mendeteksi daerah-daerah yang telah terdegradasi dan memantau daerah yang telah ditanami kembali dll. Namun sebagian besar pendekatan ini tersandung masalah mengubah estimasi wilayah ke nilai emisi atau pengurangan karena kurangnya faktor emisi yang dapat diandalkan untuk berbagai ekosistem yang sangat bervariasi. Sejumlah studi menunjukkan bahwa sebanyak 60\% dari ketidakpastian estimasi emisi adalah karena kurangnya pengetahuan tentang stok karbon di hutan dan sistem penggunaan lahan lainnya (Houghton dkk. 2000; Baccini dkk. 2012).

Karena berbagai alasan, pengetahuan kita mengenai stok karbon dan fluks GRK yang terkait dengan penggunaan lahan dan perubahan penggunaan 
lahan sebagai bagian dari tahap kesiapan REDD+ harus ditingkatkan. Peningkatan pengetahuan dapat membantu menentukan target intervensi yang lebih baik dan meningkatkan efisiensi implementasinya. Selain itu juga akan meningkatkan skema pembagian manfaat dengan memastikan bahwa aktivitas tidak memberi peluang klaim palsu pengurangan emisi dan akan membantu memberikan kredit untuk pengurangan nyata secara tepat.

Bab ini bertujuan untuk melihat secara kritis kendala untuk MRV karena kurangnya faktor emisi untuk jenis perubahan penggunaan lahan yang penting dan tampungan karbon utama dalam berbagai ekosistem tropis. Kami memulainya dengan kajian singkat atas konsep-konsep penting yang mendasari metode inventarisasi GRK dan rekomendasi Intergovernmental Panel on Climate Change (IPCC) untuk praktik-praktik yang baik di kawasan ini. Selanjutnya kami akan melihat pentingnya faktor emisi dalam kerangka ini, memeriksa berbagai kendala dalam sejumlah ekosistem tropis dan beberapa kemajuan terbaru yang membantu mengurangi kendala ini. Akhirnya, kami akan membahas peran berbagai pemangku kepentingan dan menganalisis prioritas investasi untuk lebih mengurangi tantangan yang dihadapi MRV.

\subsection{Pengantar: hubungan antara IPCC, UNFCCC, dan REDD+}

Upaya utama untuk mengembangkan metode inventarisasi GRK telah dirintis oleh Program Inventarisasi Gas Rumah Kaca Nasional (NGGIP) dari IPCC, yang mengeluarkan seperangkat pedoman pertama untuk inventarisasi GRK nasional pada tahun 1994. Pedoman ini direvisi tahun 1996 (GL1996) dan telah menyediakan kerangka kerja yang berguna untuk penyusunan estimasi nasional emisi dan pengurangan di berbagai sektor dan masih berfungsi sebagai dasar untuk inventarisasi GRK nasional. Namun, ada kebutuhan akan petunjuk lebih lanjut tentang cara terbaik untuk menghadapi ketidakpastian sehingga suatu negara dapat menghasilkan inventarisasi yang "akurat dalam arti tidak memberikan estimasi yang berlebihan atau terlalu rendah, dan yang sedapat mungkin dapat mengurangi ketidakpastian" (IPCC 2000). Pedoman ini memicu perkembangan dua laporan tambahan mengenai praktik yang baik untuk membantu negara-negara dalam “... pengembangan inventarisasi yang transparan, terdokumentasikan, konsisten dari waktu ke waktu, lengkap, sebanding, dinilai ketidakpastiannya, tunduk pada kendali dan jaminan mutu, efisien sesuai dalam penggunaan sumberdaya yang tersedia untuk lembaga yang melakukan inventarisasi dan yang dapat mengurangi ketidakpastian secara bertahap dengan tersedianya informasi lebih lanjut" (IPCC 2000; 2003). 'Good Practice Guidance and Uncertainty Management in National Greenhouse Gas Inventories' (GPG2000) diterbitkan tahun 2000 dan menyediakan pedoman yang diperbarui untuk mengumpulkan inventarisasi di beberapa sektor, termasuk pertanian (IPCC 2000). 'Panduan Praktik yang Baik untuk Penggunaan Lahan, Perubahan Tata Guna Lahan dan 
Kehutanan' (GPG-LULUCF) diterbitkan tahun 2003 (IPCC 2003). Laporan 'Good Practice' tidak menggantikan Panduan IPCC tetapi memberikan petunjuk tambahan atau revisi, yang melengkapi dan konsisten dengan pedoman tersebut.

Pada tahun 2006, IPCC menerbitkan revisi GL1996 yang dikembangkan berdasarkan GPG2000 dan GPG-LULUCF. Pedoman yang direvisi ini (GL2006) merekomendasikan penggunaan metode inventarisasi yang konsisten untuk pertanian, kehutanan, dan penggunaan lahan lainnya untuk memungkinkan inventarisasi emisi dari sebagian besar kategori penggunaan lahan yang lebih komprehensif.

Dalam keputusan yang diadopsi oleh COP15 di Kopenhagen tahun 2009 (UNFCCC 2009b), UNFCCC meminta agar negara-negara yang ingin berpartisipasi dalam mekanisme REDD+ "menggunakan petunjuk dan pedoman Panel antarPemerintah tentang Perubahan Iklim (Intergovernmental Panel on Climate Change) terbaru, seperti yang diadopsi atau didorong oleh Konferensi Para Pihak, sebagaimana mestinya, sebagai dasar untuk mengestimasi emisi GRK karena kegiatan manusia yang terkait dengan hutan berdasarkan sumber dan penyerapan karbon, stok karbon hutan, dan perubahan luas hutan.” Dengan demikian, GL1996 dan GPG-LULUCF menyediakan kerangka kerja bagi upaya saat ini dalam REDD+. Namun keputusan pada COP17 di Durban tahun 2011 telah menetapkan UNFCCC ke arah adopsi 2006GL untuk digunakan pada tahun 2015, sehingga pedoman tersebut juga dapat digunakan.

Struktur dasar prosedur inventarisasi diatur menurut persamaan sederhana:

Emisi $=A \cdot E F$

Persamaan ini meresmikan jenis data yang diperlukan untuk mengembangkan estimasi emisi yang disebutkan dalam pengantar. $A$ merupakan data aktivitas dalam persamaan. IPCC menyediakan tiga pendekatan yang mungkin untuk memperoleh data aktivitas, yang dapat disesuaikan dengan kebutuhan situasi inventarisasi tertentu (lihat Bab 14; IPCC 2006). Adapun $E F$ dalam persamaan tersebut merupakan faktor emisi. Faktor-faktor ini sering didasarkan pada sampel data pengukuran yang dapat dirata-ratakan untuk menghasilkan angka emisi yang representatif untuk aktivitas tertentu yang berkaitan dengan perubahan penggunaan lahan (misalnya, konversi dari hutan menjadi padang rumput) atau dengan lahan yang tersisa dalam suatu kategori penggunaan lahan (misalnya, lahan hutan yang direhabilitasi).

Dalam kebanyakan kasus, inventarisasi mencakup lima sumber karbon: biomassa di atas permukaan tanah, biomassa di bawah permukaan tanah, kayu mati, serasah, dan materi organik tanah. IPCC menggunakan konsep kategori utama untuk menentukan tingkat ketelitian yang perlu diterapkan untuk 
mengestimasi data aktivitas dan faktor emisi (IPCC 2000). Sebuah kategori sumber/tampungan utama adalah suatu aktivitas dan/atau tampungan karbon yang berpengaruh signifikan pada estimasi GRK dalam hal kecenderungan tingkat absolut, atau ketidakpastian dalam emisi dan penyerapan. Kategori utama menerima perlakuan prioritas dalam inventarisasi GRK. Dalam agregat, sumber dan tampungan nonutama berjumlah kurang dari 10\% dari ketidakpastian inventarisasi atau kurang dari 5\% dari total emisi. Metode terperinci perlu digunakan untuk mengestimasi emisi dan penyerapan untuk kategori utama. Analisis kategori utama diperlukan untuk menentukan hal-hal berikut:

- Penggunaan lahan dan pengelolaan aktivitas mana yang signifikan

- Subkategori penggunaan lahan atau peternakan mana yang signifikan

- Emisi atau penyerapan mana dari berbagai tampungan karbon yang signifikan

- Gas nonCO $\mathrm{CO}_{2}$ mana dan dari kategori mana yang signifikan

- Pendekatan mana (lihat keterangan tingkatan di bawah) yang diperlukan untuk pelaporan.

IPCC juga mengidentifikasi tiga 'tingkat akurasi' (tier) untuk pelaporan. Tingkat akurasi mewakili kerumitan metodologis yang diperlukan untuk mengestimasi emisi dan pengurangan dari suatu kategori, berdasarkan pengaruhnya terhadap inventaris total suatu negara, ketersediaan data, dan kondisi nasional. IPCC merekomendasikan penginventaris untuk menerapkan metode Tier 2atau 3 untuk kategori utama aktivitas lahan yang menjadi sumber utama ketidakpastian atau emisi dan menggunakan metode Tier 1 untuk kategori nonutama (Gambar 15.1).

Tier 1 merupakan pendekatan yang paling sederhana dan berlaku untuk kategori nonutama yang faktor emisinya tidak tersedia untuk negara atau wilayah tertentu. Para penginventaris harus menggunakan data aktivitas spesifik untuk suatu negara atau wilayah, tetapi mereka dapat menggunakan nilai standar (default) global dengan faktor emisi yang ketidakpastiannya tidak diketahui. Metode Tier 1 memungkinkan penginventaris untuk menghasilkan inventarisasi lengkap dan menghindari investasi dalam pengumpulan data untuk kategori aktivitas yang hanya bernilai sebagian kecil dari total emisi atau penyerapan atau hanya sebagian kecil dari ketidakpastian. Estimasi ketidakpastian berdasarkan kategori sumber pada Tier 1 dilakukan dengan menggunakan persamaan propagasi kesalahan statistik.

Metode Tier 2 mengikuti kerangka kerjayang sama dengan Tier 1. Data aktivitas spesifik negara atau kawasan digunakan, tetapi emisi dan penyerapannya diestimasi dengan menggunakan faktor emisi negara atau kawasan tertentu. Resolusi temporal dan spasial yang lebih tinggi dan data aktivitas yang lebih terpilah biasanya digunakan dalam metode Tier 2 , dan terkait dengan faktor 


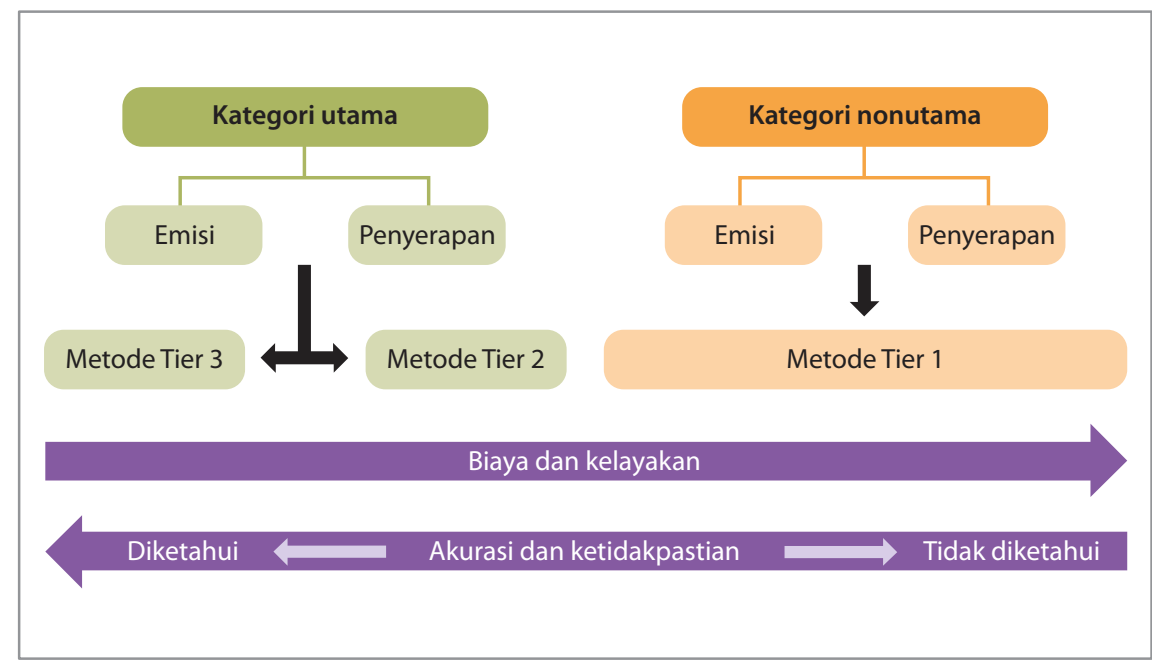

Gambar 15.1 Hubungan antara kategori utama dan tingkat tier untuk kompilasi inventarisasi dan akurasi vs pengorbanan biaya (Diadaptasi dari Maniatis dan Mollicone 2010)

emisi spesifik untuk kondisi klimatologis atau geologis subregional yang tepat dan kategori penggunaan lahan atau peternakan khusus.

Metode Tier 3 memerlukan data spasial eksplisit dan resolusinya tinggi tentang dinamika tutupan lahan. Tier 3 menggunakan metode yang lebih tinggi tingkat terincinya, termasuk model dan sistem pengukuran inventarisasi, yang berulang dari waktu ke waktu. Wilayah lahan yang telah mengalami perubahan penggunaan lahan biasanya dapat dilacak dari waktu ke waktu, setidaknya secara statistik. Kebanyakan model sudah mencakup variasi terkait iklim dalam aspek-aspek seperti pertumbuhan, penuaan, dan kematian, sehingga memungkinkan untuk melakukan estimasi dengan variabilitas tahunan. Semua model harus menjalani pemeriksaan dan validasi mutunya. Tier 3 menghasilkan keluaran berkualitas tinggi dalam hal presisi dan akurasi karena biasnya dapat dikurangi dan kompleksitas sistemnya terwakili dengan baik. Hambatan utama untuk menerapkan metode Tier 3 adalah biaya dan upaya yang dibutuhkan untuk menghasilkan set data berkualitas dan pengukuran yang spesifik untuk lokasi tertentu.

\subsection{Metode IPCC untuk pengembangan EF}

IPCC memiliki dua pendekatan untuk pengembangan faktor emisi untuk persamaan inventarisasi. Perubahan stok karbon di segala sumber dapat diestimasi dengan menggunakan pendekatan yang disebut metode Penambahan-Pengurangan (Gain-Loss), yang dapat diterapkan ke semua perubahan karbon (IPCC 2006). Penambahan terjadi karena pertumbuhan atau perpindahan karbon dari tampungan lain (misalnya, perpindahan 
karbon dari sebuah tampungan karbon biomassa di atas permukaan tanah ke tampungan materi organik mati karena panen). Pengurangan terjadi melalui perpindahan karbon dari satu sumber ke sumber lain atau emisi akibat pembusukan, pembakaran, panen, dll. Dalam sistem ini, perpindahan karbon penting diperhitungkan, karena setiap perpindahan dari satu tampungan ke tampungan lainnya adalah pengurangan bagi sumber donor dan penambahan bagi tampungan penerima. Karenanya, penyerapan $\mathrm{CO}_{2}$ adalah perpindahan dari atmosfer ke tampungan karbon (biasanya biomassa); emisi $\mathrm{CO}_{2}$ adalah perpindahan dari tampungan karbon ke atmosfer.

Pendekatan kedua disebut metode Stok-Perbedaan (Stock-Difference), yang diterapkan ketika stok karbon di tampungan yang relevan diukur pada dua titik waktu untuk menilai perubahan stoknya. Pada umumnya, perubahan stok karbon diestimasi dengan dasar per hektar dan nilai ini kemudian dikalikan luas total di setiap strata (data aktivitas) untuk memperoleh estimasi perubahan total stok untuk tampungan tersebut. Terkadang, data aktivitas dapat berupa total negara (misalnya, volume kayu dalam meter kubik yang dipanen), yang dalam hal ini estimasi perubahan persediaan untuk tampungan biomassa di atas permukaan tanah dihitung langsung dari data aktivitas, setelah menerapkan faktor yang tepat untuk mengonversi ke unit masa karbon. Ketika menggunakan metode Stok-Perbedaan untuk kategori penggunaan lahan tertentu, perlu dipastikan bahwa wilayah lahan di kategori tersebut pada waktu $t_{1}$ dan $t_{2}$ identik untuk menghindari kerancuan estimasi perubahan persediaan karena perubahan luas. Tabel 15.1 menyajikan contoh cara menurunkan faktor standar Tier 1 dengan menggunakan nilai standar IPCC untuk biomassa di atas permukaan tanah.

Metode Penambahan-Pengurangan cocok untuk pendekatan pemodelan ekologis menggunakan koefisien stok dan aliran yang berasal dari penelitian empiris. Pendekatan ini akan memuluskan variabilitas antartahun ke tingkat yang lebih besar daripada metode Stok-Perbedaan. Kedua metode tersebut valid dan dapat memberikan hasil yang sebanding dari waktu ke waktu, tetapi masing-masing metode lebih tepat untuk tampungan tertentu. Misalnya, pendekatan Stok-Perbedaan berdasarkan inventarisasi hutan adalah cara yang paling praktis untuk mengestimasi perubahan karbon biomassa di atas permukaan tanah (Brown 2002; Qureshi dkk. 2012). Untuk sumber lainnya, misalnya, tanah dan tampungan karbon materi organik di lahan gambut (lihat Kotak 15.1), metode Penambahan-Pengurangan lebih praktis. Gambar 15.2 merangkum langkah-langkah yang diperlukan untuk menghasilkan faktor emisi dengan menggunakan kedua metode. Untuk menerapkan pendekatan mana pun, terlebih dahulu diperlukan stratifikasi lanskap yang bermakna dan menentukan aktivitas dan sumber yang membutuhkan neraca tier yang lebih tinggi dan yang dapat diatasi dengan menggunakan metode Tier 1. Kemudian, data harus dihimpun dan disusun sedemikian rupa sehingga memberikan estimasi representatif bagi ekosistem dan sistem pengelolaan yang bersangkutan. 


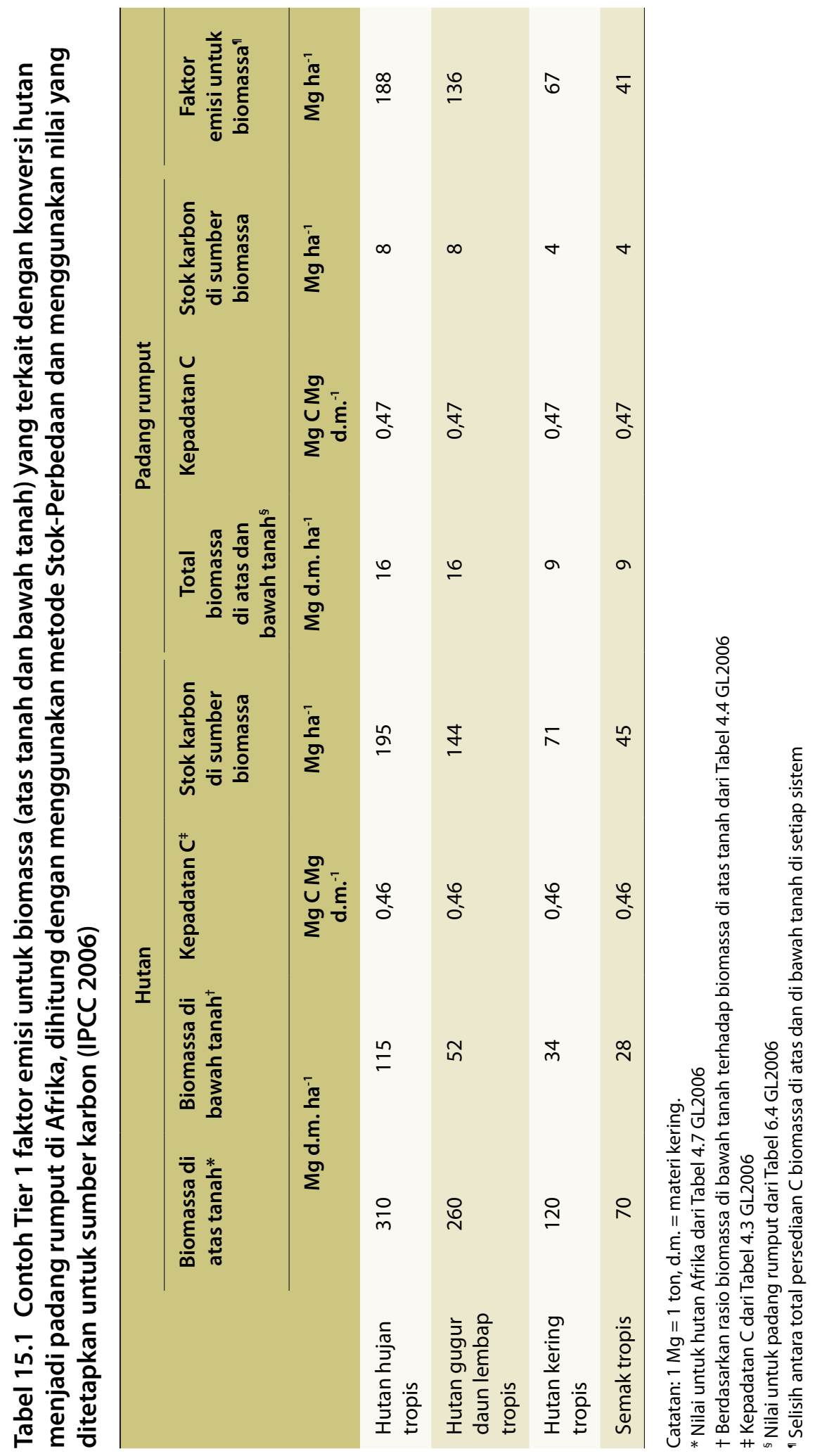




\section{Kotak 15.1 Menggunakan metode Penambahan-Pengurangan untuk meningkatkan fasilitas estimasi faktor emisi untuk lahan gambut tropis}

Indonesia merupakan salah satu penghasil emisi GRK terbesar di dunia; sekitar $80 \%$ dari emisi nasional berasal dari penggunaan lahan dan perubahan penggunaan lahan. Di kepulauan Asia Tenggara, laju deforestasi di hutan rawa gambut dua kali lebih tinggi dibandingkan di setiap jenis hutan lainnya (Miettinen dkk. 2011). Karena alasan ini, mengukur emisi GRK dari perubahan penggunaan lahan di lahan gambut adalah sangat penting. Adapun yang menjadi perhatian utama adalah estimasi berkurangnya karbon dari gambut. Estimasi terbaru menyebutkan bahwa karbon yang hilang terkait dengan konversi hutan rawa gambut untuk perkebunan kelapa sawit memberikan kontribusi lebih dari $63 \%$ terhadap total kehilangan. Kehilangan biomassa sebesar $158 \mathrm{Mg} \mathrm{C} \mathrm{ha}^{-1}$ sedangkan yang dari gambut mencapai $270 \mathrm{Mg} \mathrm{C} \mathrm{ha-1}^{-1}$ selama lebih dari 25 tahun, yang merupakan periode rotasi perkebunan kelapa sawit (Hergoualc'h dan Verchot 2011).

Pengurangangambut dapat dinilaidengan mengukurperubahan stokkarbon (pendekatan Stok-Perbedaan) atau perubahan arus karbon (pendekatan Penambahan-Pengurangan). Penilaian akurat atas perubahan stok karbon tanah setelah perubahan penggunaan lahan memerlukan pengukuran stok karbon dalam kedalaman penuh dari profil gambut, karena perubahan terjadi pada kedalaman yang lebih besar di tanah yang dikeringkan; pengurangan tidak terbatas pada $30 \mathrm{~cm}$ atas karena berada di tanah mineral. Memang, kombinasi aktivitas fisik dan kimia yang terkait dengan drainase, subsidensi gambut, dan kebakaran dapat mempersulit penentuan lapisan tanah yang harus dibandingkan sebelum dan setelah perubahan penggunaan lahan. Namun, jelas bahwa mempelajari lapisan permukaan tanah gambut saja bukan merupakan pendekatan yang valid untuk studi banding tentang perubahan stok karbon gambut terkait dengan perubahan penggunaan lahan. Selain itu, sebagian besar formasi gambut di Asia Tenggara berada dalam bentuk kubah, maka pemilihan lokasi yang representatif dan konsisten dalam kubah sebelum dan setelah perubahan penggunaan lahan diperlukan untuk menghindari estimasi emisi atau penyerapan yang salah. Mengembangkan skema pengambilan sampel yang memadai khususnya sangat menantang, mengingat kurangnya peta lokasi posisi kubah gambut di banyak lanskap, aksesibilitas terbatas (lahan gambut murni sering terpencil dan sulit dijangkau) dan kendala otorisasi.

Mengingat masalah di atas, pendekatan yang lebih baik untuk menilai pengurangan karbon gambut setelah perubahan penggunaan lahan adalah metode Penambahan-Pengurangan. Pendekatan ini memerlukan pengetahuan tentang masukan karbon utama (kematian serasah dan akar) dan keluaran utama (laju respirasi heterotrofik tanah, pengurangan yang terkait dengan kebakaran, metanogenesis, limpasan, pelindian dan erosi). Arus ini lebih mudah diestimasi secara akurat dan tanpa bias dibandingkan perubahan dalam tampungan. Respirasi tanah dapat menjadi indikator yang berguna untuk berkurangnya karbon gambut. Akan tetapi, komponen heterotrofik harus diestimasi dan pengurangan harus diseimbangkan dengan penambahan dalam rangka untuk mengevaluasi berapa banyak karbon gambut yang hilang atau diserap. Keseimbangan antara penambahan dan pengurangan sebelum dan setelah perubahan penggunaan lahan harus dibandingkan untuk menilai emisi dan penyerapan yang terkait dengan perubahan penggunaan lahan. 


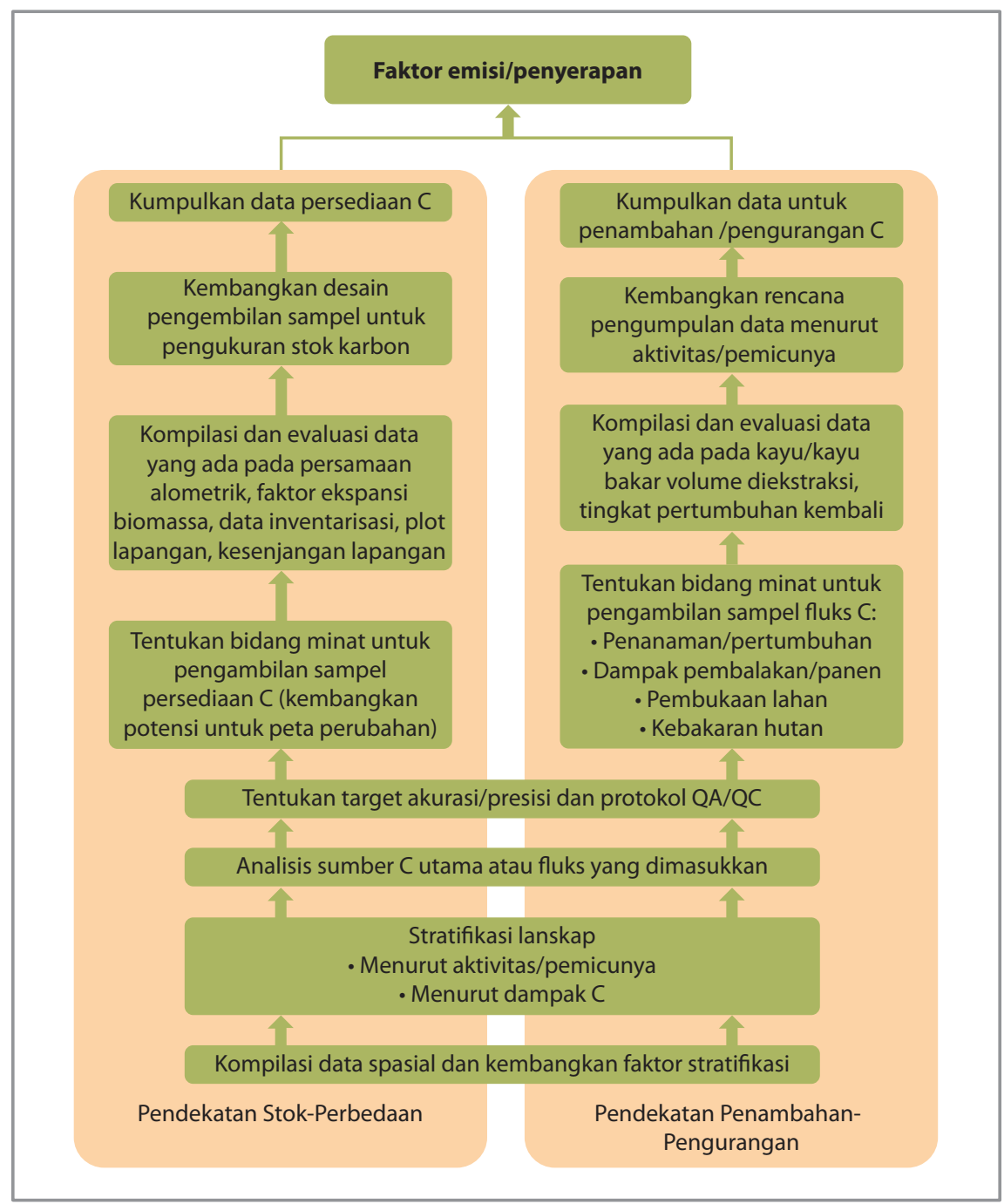

Gambar 15.2 Langkah-langkah yang diperlukan dalam estimasi faktor emisi (Diadaptasi dari Meridian Institute 2011a)

\subsection{Keadaan FE saat ini dan peluang perbaikannya}

\subsubsection{Kapasitas MRV dan FE}

Sebagai bagian Studi Komparatif Global (GCS) CIFOR mengenai REDD+ (lihat Lampiran), kami melakukan analisis kapasitas MRV di 99 negara tropis nonAneks I. Penelitian ini menghitung skor masing-masing negara mengenai sejumlah kapasitas (misalnya, penginderaan jauh, inventarisasi hutan, penilaian stok karbon) dan keterlibatan nasional (misalnya, kelengkapan pelaporan nasional, keterlibatan dalam negosiasi teknis UNFCCC REDD+). 
Penelitian ini kemudian menghitung skor tantangan REDD+ (misalnya, peristiwa kebakaran, keberadaan lahan gambut, kepadatan karbon tinggi) dan tantangan penginderaan jauh (misalnya, tutupan awan tinggi, daerah pegunungan) di setiap negara. Kemudian, kesenjangan dihitung menggunakan perbedaan antara skor untuk tantangan dan kapasitas dan negara-negara dikelompokkan ke dalam kategori berdasarkan pada besaran nilai mereka.

Hasil analisis menunjukkan bahwa sebagian besar negara tidak memiliki kapasitas untuk menerapkan sistem pemantauan nasional yang lengkap dan akurat untuk mengukur kinerja implementasi REDD+ sesuai dengan pedoman IPCC, seperti yang diperlukan dalam Tahap III ketika pembayaran akan didasarkan pada pengurangan emisi terukur (Romijn dkk. 2012). Empat puluh sembilan negara memiliki kesenjangan kapasitas yang sangat besar, hanya empat negara yang memiliki kesenjangan kapasitas yang sangat kecil. Negara-negara yang disebut terakhir ini memiliki kapasitas yang baik hingga sangat baik untuk mengukur perubahan kawasan hutan dan untuk melakukan inventarisasi hutan nasional pada pertumbuhan stok dan biomassa hutan. Di negara-negara yang kesenjangan kapasitasnya sangat besar, masalahnya bersumber dari keterlibatan yang terbatas dalam proses UNFCCC REDD+, kurangnya pengalaman dalam penerapan pedoman IPCC dan kurangnya akses ke data yang sesuai untuk inventarisasi Tier 2 (Hardcastle dkk. 2008; Herold 2009). Penelitian ini mendokumentasikan di mana saja kapasitas tidak memadai pada tataran teknis, politis, dan kelembagaan untuk memungkinkan estimasi yang lengkap dan akurat untuk perubahan kawasan hutan dan perubahan stok karbon terkait, serta menunjukkan bahwa mekanisme REDD+ menciptakan persyaratan yang berada di luar pengalaman banyak lembaga layanan teknis nasional.

Kesenjangan kapasitas ini juga terlihat jelas selama dua Forest Resources Assessments (FRA) global (FAO 2006; 2010) yang baru-baru ini dilakukan oleh (FAO 2007; Food and Agriculture Organization Mollicone dkk. 2007). Marklund dan Schoene (2006) menganalisis pengajuan negara ke FRA 2005 dan menemukan kualitas dan keandalan data yang sangat bervariasi. Kebanyakan negara tidak memiliki data inventarisasi hutan yang baik dan bergantung pada faktor konversi dan nilai-nilai standar untuk mengestimasi stok karbon. Dari negara-negara yang memiliki data inventarisasi, sebagian besar hanya memiliki pengukuran pada satu titik waktu. Dari 229 negara dan kawasan yang dilaporkan ke FRA 2005, hanya 143 yang melaporkan karbon di sumber biomassa dan hanya 50 yang melaporkan karbon di sumber serasah dan tanah. Tiga puluh empat negara tidak memberikan data stok karbon. Ada sedikit peningkatan di FRA 2010 (lihat Kotak 15.2).

Dalam studi GCS lainnya, CIFOR menyurvei 17 lokasi percontohan REDD+ di seluruh Amerika Latin (7), Afrika (7), dan Asia Tenggara (3). Lima puluh tiga persen dari proyek ini ditemukan menggunakan persamaan 


\section{Kotak 15.2 Bukti Perkembangan antara FRA 2005 dan FRA 2010}

Antara periode pelaporan 2005 dan 2010 untuk Forest Resources Assessment (FRA) FAO, ada beberapa peningkatan sederhana dalam hal kapasitas pemantauan. Gambar 15.3 menunjukkan perubahan kapasitas untuk melaporkan karbon dari sumber-sumber yang berbeda. Sebagian besar peningkatan terjadi di negara-negara Afrika, yang kapasitas pemantauan keseluruhannya tidak dikembangkan dengan baik pada tahun 2005. Perkembangan ini biasanya terkait dengan fakta bahwa negara-negara ini melaporkan dari dua tampungan karbon pada tahun 2010 (biomassa di atas tanah dan tanah) bukan hanya satu sumber (biomassa di atas tanah). Namun, mereka masih melaporkan pada tingkat Tier 1, menggunakan nilai default IPCC. Kapasitas penginderaan jauh dan penggunaan data seri waktu untuk memantau perubahan di kawasan hutan nyaris tidak meningkat antara tahun 2005 dan 2010. Kapasitas inventarisasi hutan juga menunjukkan sedikit peningkatan selama periode ini. Penurunan kapasitas pemantauan dapat ditemukan di beberapa negara, dalam beberapa kasus karena situasi politik internal.

Kurangnya peningkatan signifikan yang terlihat nyata dalam kapasitas pemantauan antara laporan FRA 2005 dan 2010 menunjukkan bahwa upaya REDD+ untuk membangun kapasitas belum berdampak banyak bagi pelaporan nasional. Masyarakat internasional perlu menyediakan sumber daya manusia dan keuangan yang lebih besar untuk mengatasi kesenjangan kapasitas untuk mengubah situasi ini.

alometrik spesifik lokasi atau spesifik negara untuk menilai biomassa di atas permukaan tanah, karena akan diperlukan untuk pendekatan 2 Tier. Empat puluh tujuh persen dari proyek menggunakan persamaan umum untuk seluruh daerah tropis. Tampungan karbon lainnya biasanya kurang penting dalam proyek-proyek ini, tetapi masih dapat mewakili porsi yang signifikan dari emisi bersih. Tidak mengherankan, kapasitas untuk menginventarisasi sumber-sumber ini bahkan lebih rendah. Hanya 24\% dari tim proyek yang sudah mengenal metode untuk mengestimasi biomassa di bawah permukaan tanah. Dalam kasus pengukuran karbon kayu mati, 41\% dari tim sudah mengenal metode ini. Untuk tampungan karbon serasah dan tanah, sebagian besar responden berencana untuk menggunakan nilai-nilai yang ditetapkan oleh IPCC atau mengabaikan sumber ini. Sebagian besar proyek yang disurvei tidak memiliki informasi yang cukup untuk menangani estimasi karbon di berbagai sumber. Kecuali proyek di Brasil, yang menggunakan persamaan alometrik spesifik lokasi untuk mengestimasi koefisien biomassa di atas tanah (Higuchi dkk. 1982; Silva 2007), biomassa di bawah tanah, dan kayu mati (Silva 2007). Serasah diestimasi menggunakan nilai standar Tier 1. Proyek ini tidak akan menginventarisasi tampungan karbon tanah. 


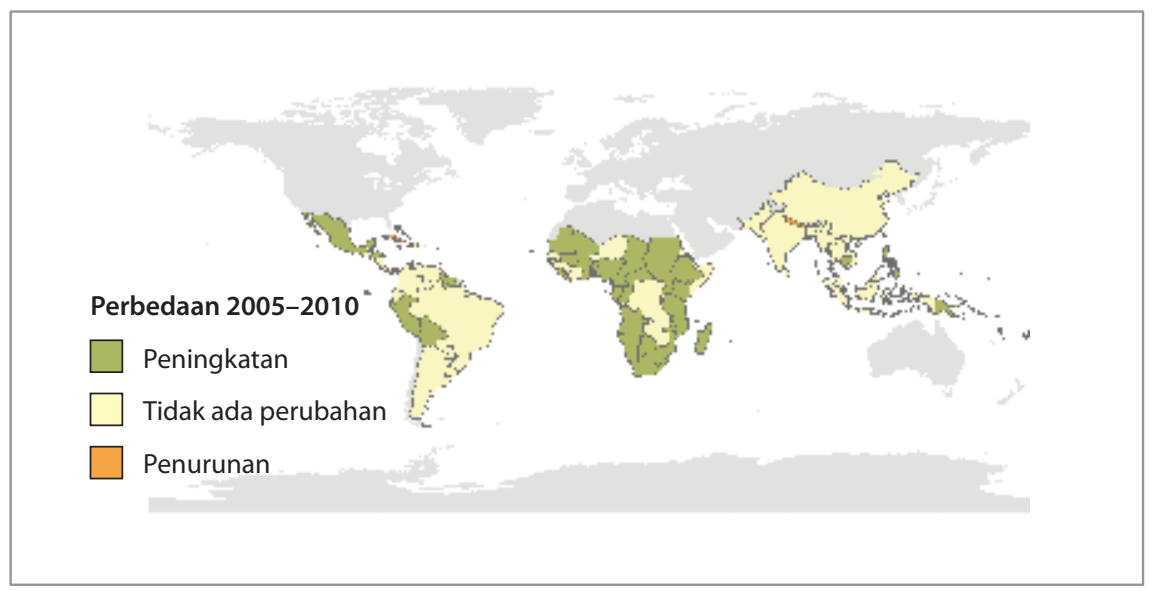

Gambar 15.3 Perubahan kapasitas untuk 99 negara tropis nonAneks I berdasarkan perbedaan antara pelaporan FAO/FRA 2005 dan 2010 pada lima sumber karbon hutan yang berbeda

Sumber: Romijn dkk. (2012)

Akhirnya, fokus pengembangan metode MRV untuk proyek-proyek REDD + terutama pada penginderaan jauh dan inventarisasi tanah oleh rimbawan profesional (GOFC-GOLD 2010). Cara ini mahal dan mungkin keefektifannya terbatas dalam mengikuti perkembangan aktual di lapangan pada skala yang diperlukan untuk menginformasikan implementasi proyek. Ada pengalaman yang berkembang dengan MRV berbasis masyarakat (lihat Kotak 15.3) untuk mengatasi kurangnya keterlibatan masyarakat yang tinggal di lahan tempat pelaksanaan skema REDD+ atau hidupnya bergantung pada lahan yang sama. Pendekatan praktis sedang dikembangkan dan diuji untuk melibatkan masyarakat lokal secara efektif dalam pemantauan (Skutsch 2010).

\subsubsection{FE untuk sumber karbon biomassa}

Untuk menerapkan metode Stok-Perbedaan atau Penambahan-Pengurangan, penginventaris membutuhkan data tentang ekosistem hutan dan nonhutan untuk menghasilkan faktor emisi untuk perubahan bersih yang terkait dengan penggunaan lahan atau perubahan penggunaan lahan. Dalam kasus ekosistem pertanian dan padang rumput yang vegetasi berkayunya sedikit atau tidak ada, mengestimasi biomassa secara teknis tidaklah sulit. Kebanyakan penelitian agronomi yang dilakukan oleh berbagai universitas dan lembaga penelitian pertanian di seluruh dunia mengukur produktivitas total, bukan hanya panen. Dengan demikian nilai standar biomassa yang berkembang untuk sebagian besar sistem tanam akan memerlukan tinjauan kepustakaan, meskipun hal ini mungkin rumit di banyak negara nonAneks I karena fakta bahwa data ini sering ditemukan dalam kepustakaan abu-abu dan mungkin tidak tersedia secara internasional. Biomassa dan produktivitas juga diukur 


\title{
Kotak 15.3 MRV dari global ke lokal dalam REDD+: Menghubungkan pendekatan masyarakat dan pemerintah
}

\author{
Finn Danielsen, Neil D. Burgess, dan Martin Enghoff
}

Dalam beberapa tahun terakhir, sejumlah buku panduan telah dikembangkan untuk mengarahkan pengumpulan data lokal biomassa hutan (Verplanke dan Zahabu 2009; Subedidkk. 2010;An dkk. 2011;UN-REDD Programme 2011b; Walker dkk. 2011). Penelitian menunjukkan bahwa masyarakat lokal dipercaya dapat mengumpulkan data tentang biomassa di atas tanah dan penggunaan hutan dan dapat memenuhi persyaratan dalam laporan di tingkatan yang lebih tinggi dalam IPCC (Danielsen dkk. 2011).

Keterlibatan masyarakat dalam REDD+ MRV terutama sangat berguna di kawasan hutan yang masyarakatnya memiliki penguasaan lahan tertentu, yang hak atas sumberdayanya diakui oleh pemerintah dan mereka berkemauan lokal untuk mengelola kawasan hutan. Melibatkan masyarakat akan membantu menghubungkan implementasi nasional REDD+ dengan pengambilan keputusan dan pengelolaan hutan lokal (Danielsen dkk. 2010). Selain itu, tindakan ini mengurangi risiko REDD+ akan melemahkan penguasaan hutan lokal. Selain itu juga membantu meningkatkan transparansi dan akuntabilitas inisiatif REDD+ dan memberikan kontribusi tata kelola dan pembagian keuntungan yang adil.

Namun ada pertanyaan yang timbul, yaitu bagaimana caranya agar pengintegrasian pemantauan masyarakat berhasil demi keefektifan REDD+ dengan pemantauan yang dilakukan oleh lembaga pelaksana REDD+ nasional. Di masa lalu, sebagian besar inisiatif pemantauan hutan rakyat telah dilokalkan (Fry 2011), namun tidak ada contoh cara masyarakat yang telah ditingkatkan ke tingkat nasional.

Untuk menghubungkan pemantauan masyarakat dan negara untuk REDD+ secara efektif, pemantauan masyarakat harus dimasukkan ke dalam program yang memberikan data ke dalam inisiatif MRV nasional. Program REDD+ nasional juga harus memastikan bahwa masyarakat diberi kompensasi atas kerja keras mereka. Keterlibatan masyarakat dalam MRV REDD+ harus didukung oleh kebijakan nasional untuk memastikan ada alokasi dana dan staf yang memadai untuk pengembangan komponen pemantauan masyarakat dalam program REDD+ nasional.

Di kebanyakan negara, organisasi masyarakat sudah berpengalaman dalam pemantauan hutan masyarakat. Organisasi-organisasi ini, atau lembaga lain yang mewakili masyarakat, harus didorong untuk mengambil peran sentral dalam perancangan, pengembangan, dan percontohan komponen pemantauan masyarakat dalam program REDD+ nasional. Pendekatan ini disarankan untuk memulainya dengan langkah kecil, melihat apa yang berhasil dan kemudian mengembangkannya setelah mendapatkan banyak pengalaman (Herold dan Skutsch 2011). 
Di tingkat nasional, diperlukan standar minimum pemantauan hutan masyarakat sehingga pendekatan yang sama dapat digunakan di semua lokasi di suatu negara. Standar ini harus menentukan format data mentah (pengukuran ketebalan pohon, kerapatan kayu) dan informasi pendukung tambahan (lokasi, tanggal). Setiap persyaratan tambahan untuk data tentang status sumberdaya hutan dan perkembangan tata kelola hutan juga harus ditentukan. Standar ini harus menjelaskan bagaimana dan kapan data harus dikirim dari organisasi berbasis masyarakat kepada pemerintah. Selain itu cara mengumpulkan, membuktikan, memeriksa, mengolah, dan menganalisis data juga harus ditetapkan (Pratihast dan Herold 2011). Pemeriksaan kualitas harus membandingkan tempat pemeriksaan acak dengan rangkaian data dari sumber lain. Program REDD+ nasional harus memberi tahu organisasi masyarakat dan masyarakat tentang tanda-tanda perpindahan emisi karbon dari pengurangan dan degradasi hutan di kawasan hutan tetangganya.

Staf pemerintah juga perlu diberi waktu untuk memberikan umpan balik kepada masyarakat, khususnya mengenai pertanyaan tentang data mereka, dan membantu mereka untuk memecahkan masalah pengelolaan lahan yang mungkin timbul. Kemungkinan juga akan ada kebutuhan staf REDD+ nasional untuk mengunjungi masyarakat. Bila memungkinkan, akan sangat membantu untuk melibatkan staf pemerintah dengan pengalaman dalam teknik penilaian pedesaan partisipatif dan dalam menyelenggarakan dialog dengan anggota masyarakat.

untuk sistem padang rumput yang dikelola dan kebanyakan untuk padang rumput adat. Untuk tampungan biomassa karbon, tantangan teknisnya adalah mengestimasi biomassa dari vegetasi berkayu.

Salah satu keterbatasan utama untuk meningkatkan faktor emisi adalah kurangnya persamaan biomassa yang tepat untuk mengubah pengukuran skala lahan yang dikumpulkan dalam inventarisasi hutan tradisional menjadi estimasi biomassa, kemudian menjadi jumlah karbon (IPCC 2006). Persamaan biomassa yang paling umum - persamaan alometrik - menggunakan dimensi pohon yang mudah diukur, seperti diameter dan tinggi, untuk memrediksi biomassa. Suatu kajian atas 850 persamaan alometrik di subSahara Afrika menemukan bahwa kurang dari $1 \%$ spesies pohon di kawasan ini memiliki model spesifik negara dan kurang dari $2 \%$ persamaan adalah untuk biomassa akar (Henry dkk. 2011). Selain itu, tujuh spesies pohon menyumbang $20 \%$ dari persamaan yang tersedia (semua persamaan tersedia dalam database akses terbuka Carboafrica: www.carboafrica.net). Dengan demikian, untuk banyak spesies, kita harus bergantung pada persamaan yang tidak spesifik untuk spesies yang menjadi sampel dan yang belum divalidasi. Tinjauan ini juga meragukan kualitas persamaan yang tersedia, karena kebanyakan memberikan nilai-nilai 
yang secara teratur berada di luar rentang yang diharapkan. Para penulis menyimpulkan bahwa tidak ada negara di subSahara Afrika yang memiliki cukup model biomassa nasional yang tepat untuk digunakan dalam menilai stok karbon hutan dan variasinya dengan pendekatan Tier 2 atau Tier 3 IPCC. Misalnya, Kamerun memiliki sekitar 600 spesies pohon hutan, 20 spesies di antaranya memiliki model alometrik yang spesifik. Model umum atau rata-rata harus digunakan untuk spesies lain dan biasnya tidak diketahui.

Pendekatan yang paling umum untuk inventarisasi hutan tropis yang sangat bervariasi adalah dengan menggunakan persamaan umum, yang didasarkan pada pengukuran berbagai spesies pohon dari ekosistem yang berbeda di seluruh daerah tropis. Argumen geometris sederhana menunjukkan bahwa biomassa total pohon di atas tanah harus proporsional dengan perkalian dari luas bidang dasar batang dan total tinggi pohon, yang memberikan estimasi volume. Volume ini, dikalikan dengan berat jenisnya, memungkinkan estimasi massa per unit volume (Chave dkk. 2005). Beberapa persamaan pantropik ada dan banyak digunakan (Brown dkk. 1989; Brown dan Lugo 1992; Brown dkk. 1997; Fearnside 1997; Chave dkk. 2005). Akan tetapi, kekuatan prediksi dari model ini hanya dapat ditentukan jika modelnya divalidasi menggunakan data biomassa pohon yang diperoleh langsung dari percobaan panen destruktif, yang jarang dilakukan (Crow 1978; Cunia 1987; Brown dkk. 1989; Chave dkk. 2001; Houghton dkk. 2001). Ketterings dkk. (2001) mengusulkan metode pengambilan sampel nondestruktif untuk 'menyesuaikan' persamaan biomassa ke lokasi dengan menggunakan hubungan antara berat jenis, diameter, atau luas bidang dasar dan tinggi. Pendekatan ini menjanjikan tapi membutuhkan lebih banyak kerja sebelum dapat menjadi alat praktis untuk inventarisasi. Baru-baru ini, Picard dkk. (2012) mengusulkan pendekatan rata-rata model Bayesian untuk menggabungkan model biomassa yang berbeda dan meningkatkan estimasi biomassa alometrik. Pendekatan ini tepat ketika ada beberapa model yang tersedia untuk suatu kawasan dan kita tidak bisa menilai secara apriori model mana yang terbaik untuk digunakan.

Kami menyimpulkan pembahasan biomassa di atas tanah dengan kata akhir pada sifat alometrik dari persamaan ini. Di sebagian besar ekosistem, diameter pohon relatif mudah mengukurnya. Rimbawan menggunakan ukuran standar diameter setinggi dada, atau setinggi $1,3 \mathrm{~m}$ di atas permukaan tanah. Ada berbagai rekomendasi untuk mengukur pohon yang tidak teratur (misalnya, pohon bercabang, pohon berbanir, dll.) atau pohon-pohon di lereng, tetapi ini di luar lingkup bab ini. Di hutan tropis yang lebat, mengukur tinggi pohon secara akurat adalah hal yang sulit. Walaupun tinggi pohon umumnya meningkatkan akurasi persamaan biomassa, kebanyakan persamaan dalam situasi hutan tropis lembap tidak melakukan pengukuran ini dan hanya mengandalkan pada diameter atau diameter dan densitas kayu. Dalam survei persamaan biomassa Afrika yang dikutip di atas, hanya 15\% yang menggunakan ketinggian (Henry dkk. 2011). 
Sebagaimana disebutkan di atas, biomassa di bawah tanah tidak terwakili dalam persamaan alometrik. Kebanyakan pendekatan inventarisasi menggunakan pendekatan Stok-Perbedaan, sedangkan biomassa di bawah tanah diestimasi melalui rasio akar:batang, yang menggunakan hubungan antara biomassa di bawah tanah dan di atas tanah (IPCC 2003; 2006). Survei atas sejumlah kecil proyek percontohan REDD+ menunjukkan bahwa data persamaan alometrik dan rasio akar:batang tidak cukup untuk estimasi karbon di semua tingkat: lokal, regional, dan nasional. Dengan beberapa pengecualian, sebagian besar proyek yang disurvei berencana untuk menggunakan persamaan umum yang ditemukan dalam Cairns dkk. (1997) dan Mokany dkk. (2006). Beberapa proyek berencana untuk menggunakan nilai default Tier 1 IPCC.

Mokany dkk. (2006) meninjau sejumlah besar rasio akar:batang yang diterbitkan dan mengatakan bahwa kualitas juga merupakan masalah bagi pengukuran ini. Menggali sistem perakaran dengan benar sulit dilakukan dan perlu dilakukan oleh individu terlatih; kadang-kadang bahkan para ilmuwan pun tidak bisa melakukannya dengan benar. Dari 786 nilai akar:batang yang dikumpulkan, 63\% harus dibuang, baik karena nilai-nilai yang tidak dapat diverifikasi maupun karena metode yang digunakan untuk menghasilkannya tidak memadai. Di antara yang dikumpulkan, hanya 20 observasi yang berasal dari ekosistem hutan tropis. Sistem tropis lainnya sama-sama buruk pengambilan sampelnya. Terlepas dari keterbatasan serius ini, penulis mengesahkan hubungan yang diketahui dari penelitian ekologis skala kecil dan menemukan bahwa rasio akar:batang bervariasi dengan prediktabilitas tertentu dan dapat berguna untuk kepentingan inventarisasi ketika lebih banyak data dikumpulkan. Sebagai contoh, rasio akar:batang menurun dengan meningkatnya curah hujan di hutan dan ekosistem hutan, meskipun hubungan ini bergantung pada variasi yang luas. Dalam semua ekosistem, rasio akar:batang juga menurun ketika biomassa batang meningkat. Perilaku ini bisa diharapkan untuk alasan matematis, tetapi juga dapat digunakan untuk menetapkan prioritas dalam pengumpulan data.

\subsubsection{FE untuk sumber karbon dan fluks GRK lainnya}

Sejumlah pendekatan telah dikembangkan untuk inventarisasi perubahan di tampungan karbon lainnya. Namun data untuk lokal, regional, dan inventarisasi sebagian besar masih kurang. Palace dkk. (2012) meninjau 49 penelitian tentang kayu mati di hutan tropis. Banyak dari penelitian ini menggunakan persentase total kayu mati yang jatuh untuk mengestimasi kayu mati yang tersisa. Kayu mati yang jatuh dan tersisa sama-sama diukur dalam 21 penelitian, dengan rasio kayu mati tersisa terhadap total kayu mulai dari $6 \%$ di hutan terganggu hingga 98\% di lokasi yang sangat terganggu. Di hutan terganggu, stok kayu mati yang tersisa terhadap yang jatuh berkisar antara $11 \%$ sampai $76 \%$. Para penulis menemukan bahwa di hutan tropis kering (2,5-118,6 Mg d.m. ha $\left.{ }^{-1}\right)$, persentase kayu mati yang jatuh cenderung 
lebih kecil dibandingkan di hutan tropis lembap (1,0-178,8 Mg d.m. ha $\left.{ }^{-1}\right)$. Proporsi kayu mati terhadap total massa di atas tanah bisa menjadi sangat tinggi: 18 sampai $25 \%$, bahkan di hutan yang tidak dikelola. Buku sumber GOFC-GOLD (GOFC-GOLD 2008) menunjukkan bahwa kayu mati dapat menghasilkan sampai sekitar 7\% dari stok karbon total; nilai-nilai vegetasi lapisan bawah dan serasah biasanya kurang dari 3\% dari tampungan karbon total. Dalam survei proyek percontohan REDD+kami, sebagian ditemukan menggunakan metode yang didefinisikan dengan baik untuk mengukur karbon di kayu mati, berdasarkan pendekatan yang dikembangkan oleh beberapa penulis (Heath dan Chojnacky 1995; IPCC 2003; Pearson dkk. 2005; Zanne dkk. 2009). Dua proyek di Tanzania tidak berencana untuk mengukur kayu mati karena masyarakat setempat menggunakannya sebagai kayu bakar. Sebagian besar proyek tidak berniat untuk mengukur karbon serasah.

Pada akhirnya, emisi dari kebakaran menjadi perhatian penting yang data dan metodenya masih belum dikembangkan dengan baik. Contohnya, kebakaran melepaskan sejumlah besar $\mathrm{CO}_{2}$, tapi juga menjadi sumber utama untuk emisi GRK nonCO $\mathrm{O}_{2}$, seperti $\mathrm{CO}, \mathrm{CH}_{4}, \mathrm{~N}_{2} \mathrm{O}, \mathrm{NO}_{\mathrm{x}}$. Untuk persamaan IPCC, massa bahan bakar yang benar-benar membakar adalah faktor penting untuk memperkirakan emisi nonCO $\mathrm{CO}_{2}$ Namun umumnya faktor khusus negara dan ekosistem untuk emisi ini tidak ada. Pembakaran masing-masing elemen bahan bakar melalui urutan tahapan: pengapian, menyala dan bersinar dan pirolisis (membara), bercahaya dan pirolisis, bercahaya dan punah. Masing-masing tahap melibatkan proses kimia yang berbeda, yang menghasilkan emisi yang berbeda (Yokelson dkk. 1997).

Kajian komprehensif faktor emisi untuk kebakaran dilakukan oleh Andreae dan Merlet (2001). Mereka menyimpulkan bahwa ada data yang memadai untuk faktor emisi dari sabana tropis, tetapi tidak ada data yang cukup untuk sebagian besar ekosistem utama lainnya untuk menghasilkan faktor emisi yang kuat untuk gas yang berbeda. Pengaruh komposisi spesies dalam campuran bahan bakar juga sebagian besar wajar, meskipun berpotensi memiliki dampak penting pada emisi. Misalnya, emisi $\mathrm{NO}_{x}$ dan $\mathrm{N}_{2} \mathrm{O}$ dari kebakaran dapat berbeda karena fungsi dari muatan $\mathrm{N}$ pada bahan bakar. Spesies dengan konsentrasi $\mathrm{N}$ tinggi, seperti kacang-kacangan, diperkirakan akan memiliki emisi gas yang lebih tinggi.

\subsection{Prospek ke depan}

Kesimpulan pertama yang dapat ditarik dari analisis di atas adalah bahwa meskipun ada informasi yang memadai untuk inventarisasi GRK Tier 1, untuk kebanyakan sistem tropis tidak cukup data yang tersedia untuk mengembangkan pendekatan tingkat yang lebih tinggi. Untungnya, lebih banyak data tersedia untuk mengestimasi emisi dari tampungan karbon besar 
seperti biomassa di atas tanah, tetapi sebagian besar data ini dikumpulkan untuk tujuan tertentu dan tidak mewakili suatu ekosistem di skala besar. Dengan demikian, kita tidak dapat memperkirakan biasnya. Sumber lain, seperti biomassa di bawah tanah atau karbon tanah, memberikan kontribusi penting bagi tampungan total karbon ekosistem, tetapi kurang dicirikan dengan baik. Sementara tujuan yang dinyatakan untuk REDD+ adalah pengurangan emisi yang dihitung dalam skema berbasiskan kinerja, kita masih jauh dari mampu untuk membuat yang lebih baik dari urutan besaran estimasi emisi dari sumber dan penyerapan oleh emisi dengan kepastian yang memadai di program-program REDD+ nasional. Kami tahu tentang presisi karena sebagian besar sintesis menghitung kesalahan standar. Kami juga tahu bahwa data yang digunakan untuk menghasilkan persamaan dan faktor emisi global tidak representatif dan dengan demikian bias dalam estimasi ini tidak kami ketahui.

Kesimpulan kedua adalah bahwa kemajuan selama dekade terakhir terasa lambat, baik yang terkait dengan pembuatan data baru untuk mendukung inventarisasi GRK yang lebih baik maupun kapasitas negara untuk melaksanakan inventarisasi tingkat yang lebih tinggi di sektor kehutanan. Ada beberapa upaya peningkatan kapasitas MRV yang dilakukan sebagai bagian dari kegiatan kesiapan REDD+, namun dampaknya tidak terlihat jelas dalam FRA 2010. Ada tanda-tanda bahwa komunitas ilmiah menanggapi kebutuhan kebijakan untuk data yang lebih baik untuk memungkinkan inventarisasi yang lebih akurat dan tepat dan sejumlah sintesis baru dan penting telah diterbitkan. Namun demikian, upaya-upaya yang saat ini dilakukan baru serba sedikit dan tidak terkoordinasi.

Ada beberapa kemitraan multilateral dan bilateral antara negara maju dan lembaga MRV dalam tindakan awal negara-negara REDD+. Program UN-REDD dan para mitranya bekerja dengan sejumlah negara untuk membangun sistem MRV yang transparan. Kemitraan Australia di Indonesia merupakan salah satu contoh kerja sama bilateral. Kemitraan ini telah terkonsentrasi pada penilaian penggunaan lahan dan pendeteksian perubahan penggunaan lahan; masalah keterbatasan akibat faktor emisi baru mulai dibahas.

Sebagian besar negara berkembang memiliki lembaga penelitian kehutanan dan universitas dengan fakultas kehutanan. Perjanjian Cancún menetapkan pendekatan tiga-tahap untuk REDD+ dan, sebagai bagian dari pengembangan kapasitas di Fase 1 dan 2, personil terlatih akan perlu dikerahkan untuk memberikan kontribusi data dan pengetahuan yang diperlukan untuk memfasilitasi inventarisasi tingkat yang lebih tinggi. Selama Tahap 1, inventarisasi harus dilaksanakan dengan kombinasi pendekatan Tier 1 dan Tier 2 untuk aktivitas yang memenuhi kriteria kategori utama. Upaya investasi dan terkoordinasi akan dibutuhkan untuk mengatasi kendala 
inventarisasi GRK faktor emisi yang terbatas. Dengan semakin banyaknya data yang dikumpulkan, estimasi Tier 1 yang harus dilakukan dalam kategori utama semakin sedikit. Banyak kemajuan yang dapat dicapai selama sepuluh tahun ke depan jika investasi terkoordinasi dan ditargetkan dibuat dalam peningkatan kapasitas dan mobilisasi. Sementara itu, kemitraan antara lembaga penelitian dan fakultas universitas yang bekerja di sektor kehutanan, pertanian, dan sistem pengelolaan lahan lainnya di negara tuan rumah REDD+, lembaga antarpemerintah berkapasitas teknis (misalnya, GEO, UNEP, CGIAR) dan lembaga penelitian terkemuka di negara maju harus dibentuk untuk memungkinkan koordinasi, saling melengkapi keterampilan teknis, dan peningkatan kapasitas. Kerja sama Selatan-Selatan dan jaringan teknis wilayah juga harus dikembangkan. 


\section{Bab 16}

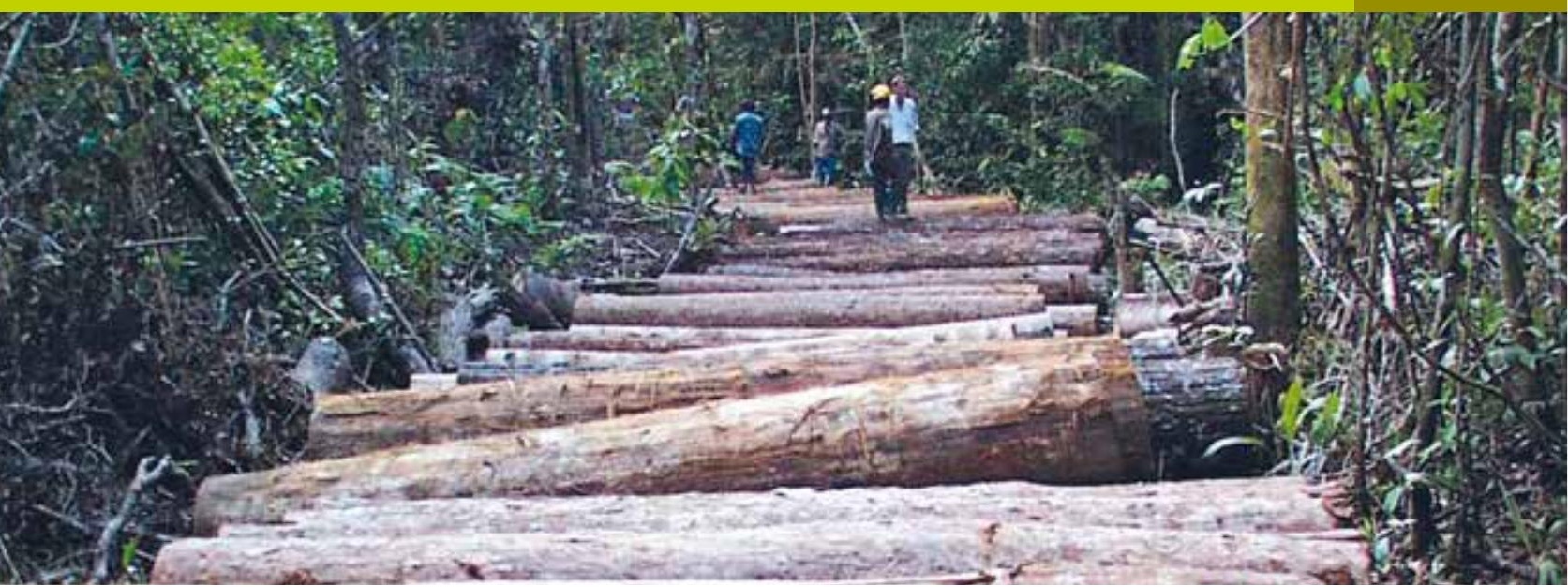

\section{Kerangka bertahap untuk menentukan tingkat acuan REDD+}

Martin Herold, Arild Angelsen, Louis V. Verchot, Arief Wijaya, dan John Herbert Ainembabazi

- Mengembangkan tingkat acuan (emisi) hutan untuk REDD+ merupakan tugas yang mendesak dan menantang, mengingat kurangnya data berkualitas di banyak negara, ketidakpastian tentang prediksi laju deforestasi dan degradasi hutan di masa depan, dan hal-hal lain yang mendorong terjadinya bias pengukuran.

- Ketersediaan dan kualitas data menentukan metode yang digunakan untuk mengembangkan tingkat acuan emisi. Faktor pemicu dan aktivitas yang menyebabkan terjadinya deforestasi dan degradasi hutan menjadi penting dan harus dipertimbangkan dalam menentukan tingkat acuan yang disesuaikan dengan kondisi nasional.

- Kerangka pendekatan bertahap untuk mengembangkan tingkat acuan emisi dapat mencerminkan kondisi dan kapasitas suatu negara dan mendorong partisipasi yang lebih luas, rintisan awal dan adanya motivasi dari negara untuk memperbaikinya dari waktu ke waktu. Sejalan dengan itu, perlu dilakukan upaya untuk meningkatkan kapasitas pengukuran dan pemantauan. 


\subsection{Pengantar}

Tingkat acuan hutan (RL) dan tingkat acuan emisi hutan (REL) sudah umum digunakan sebagai acuan skenario bisnis seperti biasa (BAU) untuk menilai kinerja suatu negara dalam menerapkan REDD+ (UNFCCC 2011c). ${ }^{1}$ RL diperlukan sebagai pembanding atau tolok ukur dari tingkat emisi (dan penyerapan) aktual. Bahkan, pengurangan emisi tidak dapat ditentukan tanpa terlebih dahulu menyepakati RL. Karena itu RL sangat penting kaitannya dalam mengukur keefektiffan kebijakan dan aktivitas REDD+.

Penggunaan RL yang kedua adalah sebagai tolok ukur pembayaran dalam mekanisme berbasiskan hasil, seperti REDD+. Dalam kaitannya dengan basis insentif keuangan (FIB), RL digunakan untuk menentukan tingkat emisi di mana suatu negara, unit administrasi subnasional, atau suatu proyek dapat mulai menerima pembayaran sebagai kompensasi upaya mereka mengurangi emisi karbon. Penetapan RL sebagai FIB memiliki implikasi penting dalam proses transfer pembayaran mekanisme REDD+, dan akan berdampak bagi integritas lingkungan (keefektifan karbon), efisiensi biaya dan kesetaraan pembagian keuntungan.

Meskipun memiliki arti yang sedemikian penting, konsensus politik tentang cara menetapkan tingkat acuan masih terbatas pada petunjuk umum UNFCCC (UNFCCC 2011c, lihat Kotak 16.1). Hingga sekarang belum ada pendekatan ilmiah yang dapat memberikan kontribusi nyata tentang upaya perhitungan RL yang lebih akurat (Huettner dkk. 2009; Obersteiner dkk. 2009; Estrada 2011). Ada tiga tantangan yang menonjol. Pertama, ketidaktersediaan data dan akurasi data yang masih sering diragukan. Langkah penting dalam mengestimasi RL adalah dengan mendapatkan data historis aktivitas deforestasi dan degradasi hutan, tetapi untuk sebagian besar negara hal ini masih sangat terbatas, karena keterbatasan kapasitas pemantauan hutan (Meridian Institute 2011b; Romijn dkk. 2012).

Kedua, skenario bisnis seperti biasa (BAU) pada hakikatnya adalah masalah masa depan. Sementara memprediksi masa depan selalu sulit, laju deforestasi dan degradasi menunjukkan variasi tahunan jauh lebih besar daripada, misalnya, emisi dari bahan bakar fosil. Ada ketidakpastian yang tidak dapat sepenuhnya diselesaikan oleh data dan model yang lebih baik. Karena itu, memasukkan faktor ketidakpastian menjadi aspek kunci dalam pengaturan RL.

1 Perbedaan antara tingkat acuan (RL) dan tingkat emisi acuan (REL) tidak selalu jelas. Salah satu cara membedakannya yang sering diungkapkan adalah bahwa REL mengacu pada emisi bruto dari deforestasi dan degradasi hutan, sedangkan RL mengacu pada deforestasi dan degradasi hutan, serta aktivitas REDD+ lainnya dalam hal peningkatan persediaan karbon, pengelolaan dan konservasi hutan yang berkelanjutan. Dalam bab ini kita menggunakan RL sebagai istilah umum, yang juga mencakup REL; karena banyak pembahasan di sini berfokus pada emisi. 


\section{Kotak 16.1 Pedoman COP17 UNFCCC dan implikasinya}

UNFCCC (2011c) menyediakan petunjuk untuk menetapkan RL hutan, didukung oleh lampiran mengenai 'Pedoman pengajuan informasi RL hutan'. RL ini harus konsisten dengan emisi gas rumah kaca (GRK) sebagai akibat aktivitas manusia di wilayah hutan, dijelaskan berdasarkan sumber emisi dan penyerapan karbon dalam inventarisasi GRK. Demikian pula, perkiraan $\mathrm{RL}$ harus disesuaikan dengan data historis yang tersedia. Ketika mengembangkan $\mathrm{RL}$, setiap negara diminta untuk menyerahkan data kondisi nasional spesifik mereka dan jika RL telah disesuaikan dengan kondisi nasional spesifik tersebut, rincian mengenai bagaimana data tersebut dipertimbangkan dalam perhitungan $\mathrm{RL}$ juga harus dijelaskan. Selain itu, UNFCCC telah sepakat bahwa pendekatan bertahap untuk RL nasional dapat membantu negara-negara meningkatkan kualitas prediksi $\mathrm{RL}$ mereka dari waktu ke waktu dan merekomendasikan agar setiap negara memperbarui RL mereka secara berkala dengan mempertimbangkan data dan tren terbaru. Keputusan UNFCCC menyatakan bahwa RL subnasional merupakan langkah sementara, sebagai pijakan untuk prediksi RL nasional. Alternatif untuk tidak mengikutsertakan sumber karbon nonsignifikan atau aktivitas tertentu REDD+ dalam perhitungan $\mathrm{RL}$ - seperti yang dinyatakan dalam keputusan UNFCCC - dapat dilakukan agar setiap negara dapat segera melakukan perhitungan yang konservatif terhadap estimasi perubahan stok karbon hutan (Grassi dkk. 2008).

Ketiga, bisa ada insentif di kalangan pelaku untuk mendistorsi hasil estimasi (Bab 2). Para donor, pemerintah, dan pemrakarsa proyek, misalnya, mungkin berkepentingan untuk menggunakan kondisi awal bisnis seperti biasa (BAU) yang tinggi, yang akan berdampak pada setiap kebijakan supaya tampak lebih menguntungkan. LSM, misalnya, harus menunjukkan keberhasilan mereka untuk menjamin keberlangsungan pendanaan, sementara pemerintah perlu membuktikan kepada pemilih atau masyarakat internasional bahwa kebijakan mereka berjalan efektif. Penurunan tajam dalam deforestasi Brasil sejak tahun 2004 adalah contoh kasus nyata, yang dapat diperdebatkan apakah hal itu berkat kebijakan yang baik atau karena penurunan harga komoditas dan krisis ekonomi global. Kepentingan keuangan bahkan lebih jelas lagi dalam menetapkan basis insentif keuangan (FIB) dalam mekanisme REDD+ berbasiskan hasil: setiap tingkat emisi, pembayarannya langsung terkait dengan tingkat FIB. Situasi ini membutuhkan sistem kelembagaan dengan panduan yang jelas tentang cara mengembangkan RL dan elemen kuat dari penilaian ahli dan verifikasi independen.

Pedoman internasional untuk pengembangan RL sebenarnya sudah ada, termasuk yang disediakan oleh UNFCCC (2011c) (Kotak 16.1) dan metode 
VCS untuk proyek REDD+ (Bab 14). Namun apabila pedoman yang lebih spesifik belum tersedia dan terjadi keterbatasan pada ketersediaan data skala nasional yang baik dan faktor-faktor ketidakpastian lainnya, setiap negara harus memilih suatu cara untuk melanjutkan proses penghitungan RL mereka. Ini termasuk, misalnya, periode acuan historis yang pasti untuk digunakan dan kondisi nasional spesifik yang akan disertakan dalam penghitungan kondisi awal BAU.

Bab ini tidak akan membahas tentang pedoman internasional dan cara-cara menetapkan RL, tetapi pembaca harus merujuk pada keputusan UNFCCC (Kotak 16.1) dan diskusi dalam makalah Meridian Institute (2011a; 2011b). Bab ini juga tidak banyak membahas RL dalam proyek REDD+, isu penting yang sudah dibahas secara lengkap dalam Bab 14. Sambil berupaya fokus pada penghitungan RL skala nasional, bab ini juga berusaha agar relevan terhadap RL di tingkat proyek dan untuk pengembangan pedoman internasional mengenai pengaturan RL lebih lanjut.

Salah satu cara untuk menghadapi tiga tantangan terkait masalah data, ketidakpastian, dan kepentingan strategi pendekatan bertahap, akan disajikan dalam bab ini. Strategi ini bertujuan untuk mendapatkan struktur yang lebih baik dan menangani berbagai metode RL yang ada, variasi data dan kualitasnya, faktor ketidakpastian dan kondisi spesifik suatu negara. Kerangka kerja ini akan membantu mendorong partisipasi negara seluas-luasnya dalam mengestimasi RL, dan menyediakan titik awal, bahkan dengan data yang terbatas. Hasilnya kemudian dapat digunakan untuk meningkatkan kualitas penghitungan RL seiring perkembangan negara melalui tahapan implementasi REDD+ dan membangun kapasitas mereka.

Bagian 16.2 memberikan uraian singkat tentang konsep-konsep utama, termasuk perbedaan antara kondisi awal BAU dan FIB. Kemudian dilanjutkan dengan pembahasan mengenai metode utama untuk menetapkan kondisi awal BAU dan pertimbangan yang relevan ketika bergerak dari kondisi awal BAU ke FIB. Bagian 16.3 menyajikan strategi kerangka bertahap dan menguraikan lebih lanjut tiga langkah dari strategi tersebut, dimulai dari ekstrapolasi historis sederhana dengan data terbatas yang tersedia, hingga prediksi yang lebih akurat pada skala yang lebih detail. Bagian 16.4 membahas masalah ketidakpastian dan berbagai cara penanganannya. Bagian akhir menawarkan beberapa pemikiran sebagai kesimpulan.

\subsection{Berbagai konsep dan metode}

\subsubsection{Dua makna RL}

Tingkat Acuan (RL) memiliki dua makna dan penggunaan yang berbeda. Pertama, RL digunakan sebagai kondisi awal BAU. Dalam hal ini RL 
digunakan untuk mengukur dampak kebijakan dan tindakan REDD+ serta menentukan pengurangan emisi, yaitu selisih antara emisi aktual dan RL. Kedua, RL digunakan sebagai tolok ukur estimasi insentif berbasiskan hasil, misalnya pembayaran langsung kepada negara, unit subnasional, atau proyek untuk pengurangan emisi. Istilah lain untuk menyebut hal ini adalah dasar kredit (Angelsen 2008a), dasar kompensasi (Meridian Institute 2011b), atau tolok ukur insentif keuangan (FIB) (Ecofys 2012). Dalam bab ini kami menggunakan istilah yang terakhir.

Perbedaan antara berbagai makna dan peran RL ini penting karena mereka menjawab pertanyaan yang berbeda: i) akan seperti apakah jadinya emisi bila tanpa REDD+; dan ii) pada tingkat pengurangan emisi berapakah suatu negara, unit subnasional, atau proyek dapat mulai menerima pembayaran? Namun perbedaan antara BAU dan FIB secara politis masih kontroversial karena adanya kemungkinan bahwa FIB dapat ditetapkan lebih rendah dari kondisi awal BAU, sehingga pembayaran kurang dari yang seharusnya untuk hasil yang sudah dicapai. Hal ini menyentuh isu-isu yang lebih luas dalam negosiasi iklim, seperti alokasi tanggung jawab dan biaya antarnegara. Karena itu, konsep BAU dan FIB tidak diakui dalam keputusan UNFCCC. Namun dari sudut pandang analitis, perbedaan ini penting untuk memperjelas analisis dan diskusi.

Ada kesepakatan umum bahwa RL harus memperhitungkan data historis dan disesuaikan dengan kondisi nasional (UNFCCC 2009a: Decision 4/ CP.15). Hal ini masuk akal baik dari perspektif analitis: deforestasi dan degradasi historis adalah prediktor yang baik dalam waktu dekat, namun laju deforestasi dan degradasi pada umumnya bersifat dinamis. Faktor-faktor yang dapat menyebabkan laju deforestasi dan degradasi yang lebih tinggi atau lebih rendah, dibandingkan dengan yang historis, sering disebut sebagai 'kondisi nasional'. Ini adalah istilah yang umum, dan ditafsirkan dengan cara yang berbeda oleh masing-masing negara dan hingga saat ini upaya-upaya untuk menentukannya secara lebih spesifik belum mencapai konsensus.

Setelah membedakan antara BAU dan FIB, perlu juga dipikirkan untuk membedakan antara kondisi nasional yang relevan untuk menetapkan kondisi awal BAU dan kondisi nasional yang relevan untuk dipertimbangkan ketika menetapkan FIB. Hal ini diilustrasikan pada Gambar 16.1. Pertanyaan yang diajukan mengenai apakah kondisi nasional relevan untuk kondisi awal BAU adalah: 'Apakah tercakupnya kondisi nasional tertentu menghasilkan prediksi kondisi awal BAU yang lebih akurat (bias pengukuran yang lebih rendah) dan lebih tepat (variasi data lebih rendah)?' Kita kembali ke pertanyaan ini di Bagian 16.3.6). Kondisi nasional yang relevan untuk FIB didasarkan pada pertimbangan politis, misalnya apa yang dianggap 'adil' dan dibahas lebih lanjut dalam Bagian 16.2.3. 


\subsubsection{Metode untuk estimasi kondisi awal BAU}

Tiga metode untuk estimasi deforestasi dan degradasi hutan di masa depan pada kondisi BAU telah diusulkan dalam kepustakaan, misalnya oleh Gutman dan Aguilar-Amuchastegui (2012).

1. Pendekatan historis murni: Pendekatan ini hanya menggunakan rata-rata laju deforestasi tahunan pada tahun-tahun sebelumnya (biasanya lebih dari 10 tahun) (Santilli dkk. 2005). Contoh yang menonjol dari pendekatan ini adalah RL yang digunakan oleh Amazon Fund di Brasil, yang tercakup dalam perjanjian antara Brasil dan Norwegia dan menggunakan deforestasi rata-rata selama 10 tahun terakhir, data akan diperbarui setiap 5 tahun.

2. Pendekatan historis yang disesuaikan: Tingkat emisi historis menjadi titik tolak, namun faktor-faktor lain yang dianggap penting dimasukkan untuk meningkatkan kesesuaian prediksi. Contoh faktor lainnya adalah tahapan dalam teori transisi hutan, yaitu sejauh mana negara-negara dengan tutupan hutan yang tinggi dan laju deforestasi rendah mengharapkan percepatan terjadinya deforestasi di masa depan dalam skenario BAU.

3. Model simulasi: Deforestasi dan emisi yang dihasilkan di masa depan dapat diprediksi dengan model simulasi, yang dikembangkan dalam berbagai aplikasi terapan (Huettner dkk. 2009). Model ini dapat mencakup tingkat historis deforestasi, namun pada dasarnya adalah masalah sewa lahan atau mempertimbangkan faktor permintaan dan ketersediaan lahan baru untuk pertanian. Ketersediaan lahan ditentukan oleh faktor-faktor seperti ketersediaan akses (misalnya, jalan) dan potensi pertanian. Contoh yang banyak dikutip adalah model automata seluler oleh Soares-Filho dkk. (2006) untuk Hutan Amazon di Brasil.

Analisis regresi dapat digunakan untuk menguji pentingnya berbagai faktor pemicu deforestasi dan degradasi hutan ketika data nasional terpilah pada berbagai jenis aktivitas dan laju deforestasi ini tersedia untuk berbagai titik waktu. Sebuah studi terbaru (Ecofys 2012) menguji model regresi berganda untuk memprediksi deforestasi di tiga negara dengan data historis yang berkualitas baik, yaitu: Brasil, Indonesia, dan Vietnam (lihat Kotak 16.2). Dengan tersedianya kualitas data yang lebih baik, pengujian lebih lanjut atas model ini diharapkan dapat menghasilkan kesimpulan yang lebih terpercaya tentang apa dan bagaimana kondisi nasional yang berbeda dapat dimasukkan dalam kondisi awal BAU untuk meningkatkan prediksi.

Pendekatan pemodelan yang lebih kompleks cocok untuk pengembangan RL di negara-negara yang memiliki data berkualitas tinggi. Ini dapat digunakan untuk menguji berbagai metode untuk penghitungan RL, pemodelan faktor penyebab deforestasi dan mengeksplorasi implikasi berbagai skenario kebijakan. Contoh dari model-model ini termasuk model IIASA GLOBIOM dan perangkat pemodelan OSIRIS (Martinet dkk. 2009). 
Pemodelan penyebab deforestasi menjadi sangat penting untuk menangani faktor ketidakpastian. Namun perlu diperhatikan bahwa pemodelan yang lebih kompleks dan canggih tidak selalu memberikan prediksi yang lebih akurat tentang emisi BAU. Ketika ketersediaan data terbatas, ekstrapolasi dan pemodelan kompleks yang sering didasarkan pada asumsi dapat memberikan risiko untuk melipatgandakan kesalahan estimasi dan meningkatkan ketidakpastian yang dapat yang dapat membahayakan integritas REDD+. Ketidakpastian lainnya terkait dengan aplikasi model simulasi adalah tingkat penerimaan politis yang relatif rendah oleh para perumus kebijakan sebagai dasar untuk menentukan kondisi awal BAU atau FIB, baik dalam rezim REDD + berbasis UNFCCC di masa mendatang atau dalam perjanjian bilateral. Penyesuaian yang relatif sederhana dari emisi historis tampaknya merupakan pendekatan yang lebih dapat diterima, seperti yang diilustrasikan dalam perjanjian Guyana-Norwegia.

\subsubsection{Dari BAU ke insentif keuangan}

Alasan untuk menetapkan FIB berbeda dengan kondisi awal BAU telah dibahas panjang lebar oleh penulis dalam Ecofys (2012) dan ringkasannya disajikan di sini. Tiga pertimbangan berbeda yang relevan dapat dilihat dalam Gambar 16.1.

Pertama, adanya hal-hal khusus di suatu negara yang mungkin relevan dengan FIB. Salah satu kemungkinan adalah melibatkan prinsip 'tanggung jawab bersama namun berbeda sesuai kemampuan masing-masing' (CBDRRC) dan menggunakan FIB untuk alokasi berbagai tingkat pembayaran di antara negara-negara REDD+. Pertanyaan kunci menyangkut kriteria khusus yang digunakan untuk membedakan antara tanggung jawab dan kemampuan. Ini, misalnya, bisa jadi pendapatan per kapita: negara-negara berpenghasilan

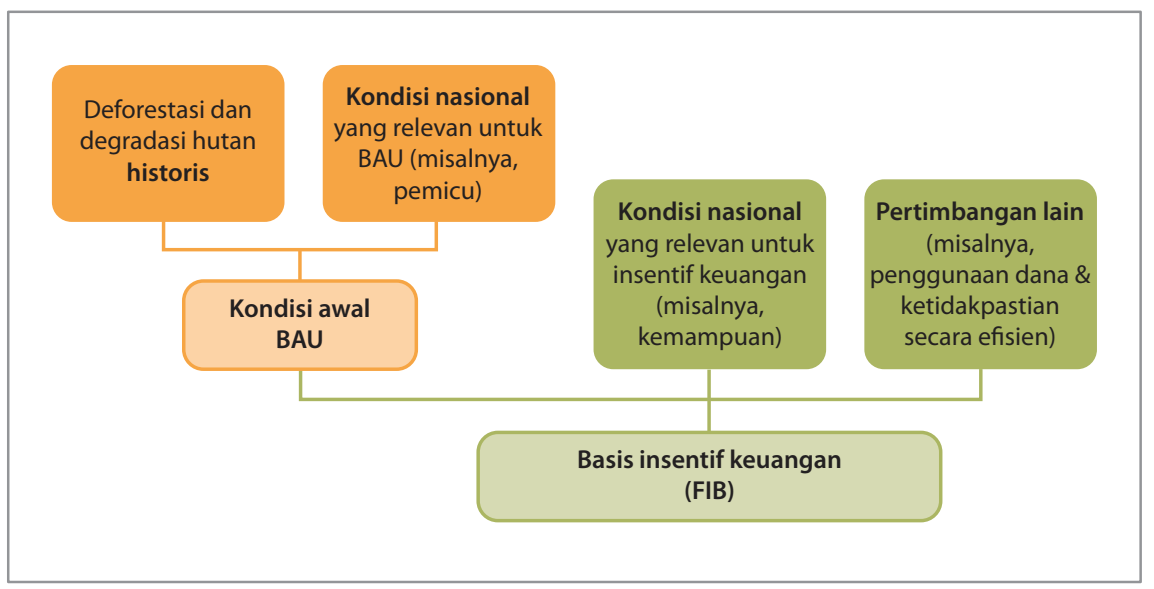

Gambar 16.1 Elemen-elemen utama untuk menetapkan tingkat acuan 
menengah ke bawah menyesuaikan FIB mereka, sedangkan negara-negara berkembang menerima FIB yang relatif lebih tinggi. Meskipun interpretasi tertentu dari prinsip CBDRRC adalah salah satu isu paling kontroversial dalam negosiasi iklim (dan melampaui REDD+), diskusi pascaDurban menjadikan hal ini menjadi pembahasan yang semakin penting.

Kedua, ada pertimbangan keefektifan dan efisiensi yang menunjukkan bahwa FIB harus ditetapkan di bawah kondisi awal BAU. Sebagai contoh, ketika negara donor memiliki sejumlah dana tetap untuk dibelanjakan untuk REDD+ dan membuat kesepakatan dengan negara REDD+. Selama negara REDD + memiliki keuntungan bersih positif dari kesepakatan itu, semakin rendah nilai FIB maka semakin tinggi harga karbon dan semakin besar insentif untuk pengurangan emisi yang lebih besar (Angelsen 2008a; Meridian Institute 2009). Sebagai alternatif, untuk harga karbon yang diberikan, semakin rendah FIB, semakin rendah biaya bagi pembeli karbon dan uang yang disimpan dapat digunakan untuk kegiatan REDD+ di tempat lain.

Ketiga, kami menyarankan agar basis insentif keuangan (FIB) menjadi kondisi awal BAU yang disesuaikan untuk menggambarkan faktor ketidakpastian. Pilihan untuk menangani ketidakpastian dibahas dalam Bagian 16.4.

\subsection{Pendekatan bertahap}

\subsubsection{Dimensi-dimensi utama dalam pendekatan bertahap}

Pendekatan bertahap yang diusulkan oleh UNFCCC (2011c), seperti halnya dengan banyak masalah lain dalam implementasi REDD+, akan berkembang dan terkonsolidasi dari waktu ke waktu (Kotak 16.3). Ketika negara-negara memasuki fase implementasi REDD+, mereka harus mengembangkan RL hutan nasional atau subnasional sebagai langkah sementara. Pemahaman, keandalan, dan validitas data untuk RL cenderung akan meningkat melalui proses bertahap ini. Mengingat variabilitas data yang tersedia, yang digunakan untuk estimasi tren masa depan dan keterbatasan kapasitas di banyak negara (Herold 2009; Romijn dkk. 2012), pendekatan bertahap menyediakan titik awal untuk situasi di semua negara. Pendekatan ini secara konseptual mirip dengan penggunaan pendekatan Pedoman Praktik yang Baik (GPG) IPCC yang berbeda untuk estimasi data aktivitas dan tingkatan untuk estimasi cadangan karbon/faktor emisi (lihat Kotak 16.3 dan Bab 15 untuk rinciannya) dan mencerminkan perbaikan bertahap dalam beberapa dimensi (Tabel 16.1).

\subsubsection{Tiga langkah}

Konsep pendekatan bertahap sangat bergantung pada data yang tersedia dan kapasitas suatu negara. Karena itu diperlukan tindakan penyesuaian untuk kondisi nasional dan penyesuaian menghadapi berbagai faktor ketidakpastian. 


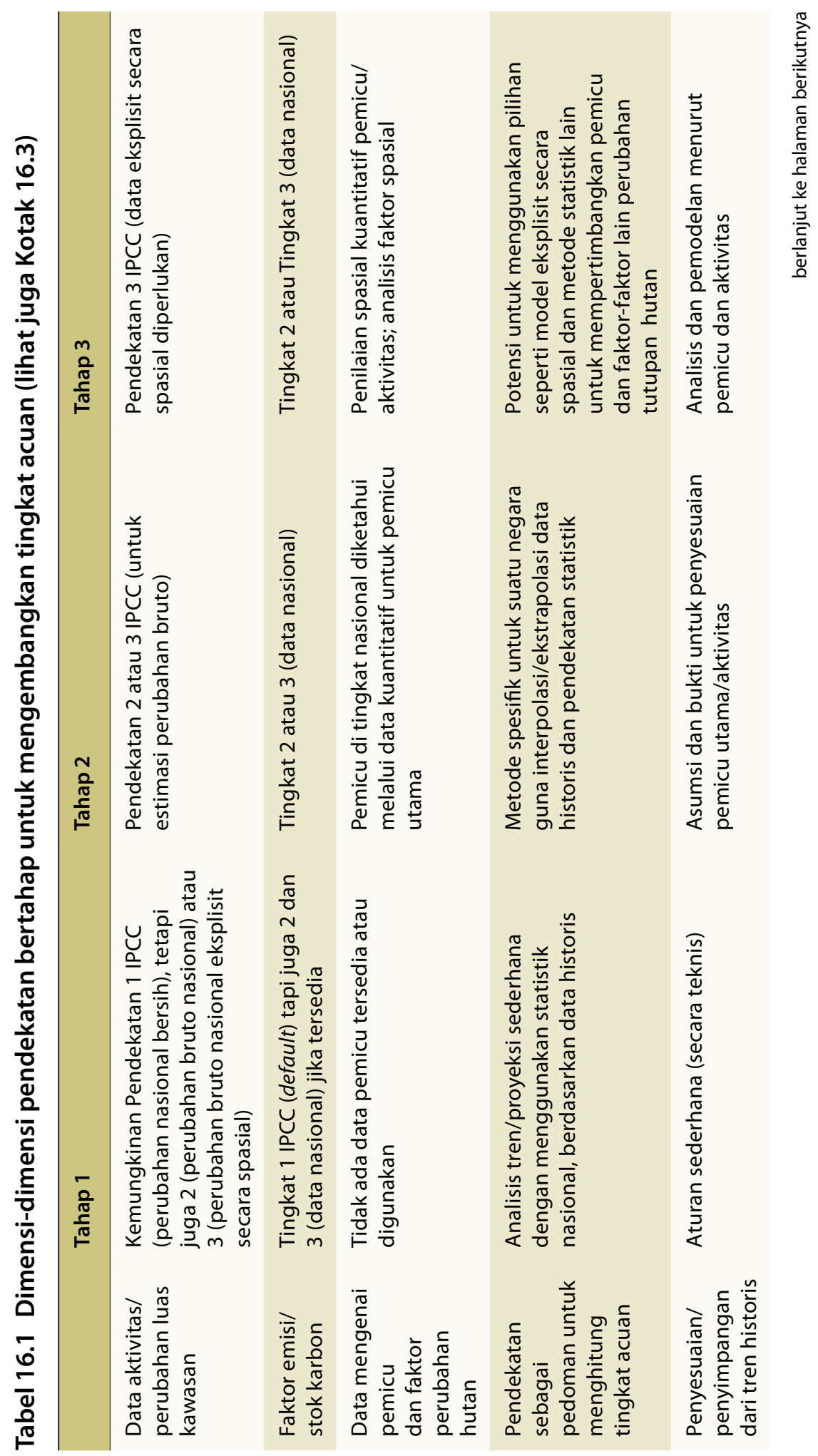




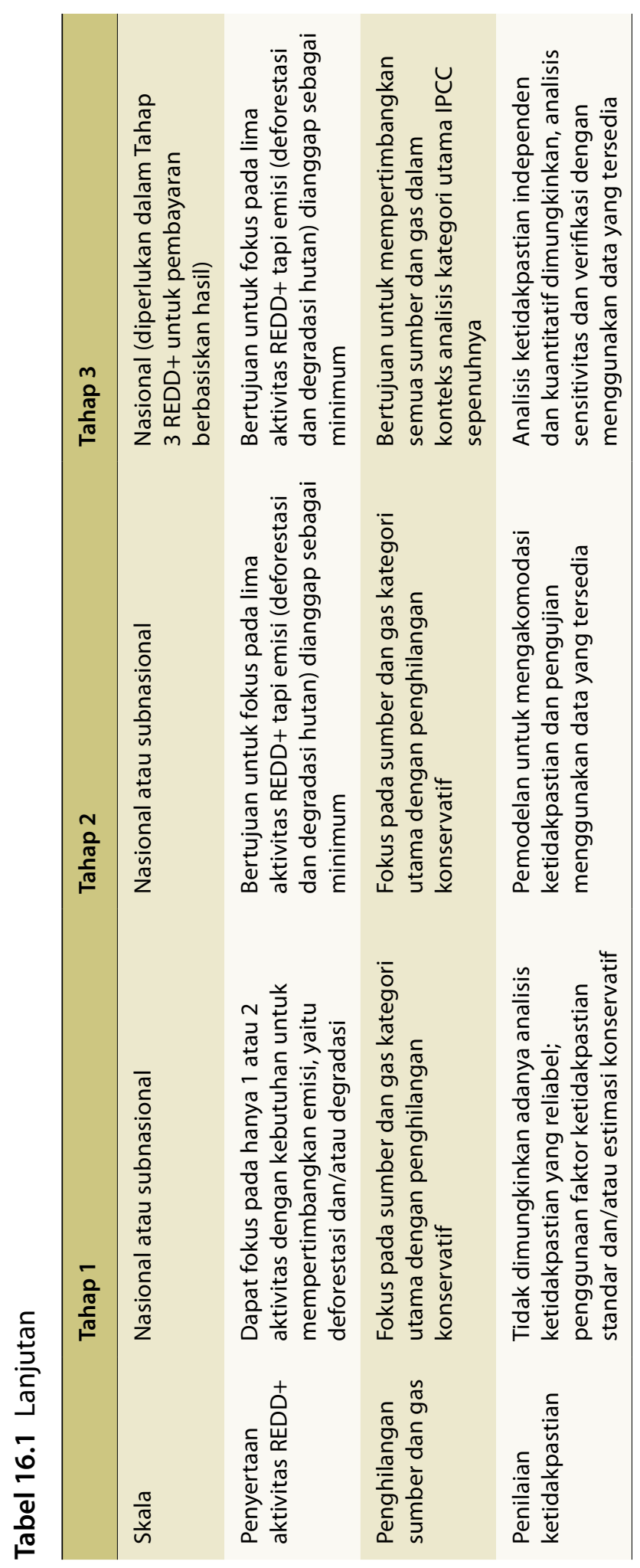


Langkah 1 adalah titik awal bagi negara-negara untuk mulai menghitung RL yang dapat didasarkan pada data tingkat nasional saja. Pada tahap ini, tantangan terbesar adalah untuk menyediakan bukti kuantitatif yang dapat dijadikan deviasi terhadap tren data historis yang diproyeksikan, dan prinsipnya hanya aturan sederhana yang dapat diterapkan untuk penyesuaian perhitungan data nasional. Secara umum, setiap negara akan mampu melakukan pendekatan Langkah 1 dengan upaya sederhana berdasarkan data yang tersedia, bahkan jika akurasi data meragukan. Contoh dari metodologi Langkah 1 dapat diambil dari Amazon Fund Brasil (pendekatan subnasional) dan Guyana (pendekatan nasional). REL Amazon Fund didasarkan pada deforestasi bruto dan estimasi konservatif persediaan karbon di atas tanah dengan $100 \mathrm{tC} / \mathrm{ha}$. Laju deforestasi tahunan yang digunakan dalam penghitungan pengurangan emisi dibandingkan dengan laju deforestasi rata-rata selama lebih dari periode sepuluh tahun, yang diperbarui setiap lima tahun (Amazon Fund 2009). Untuk Guyana, prediksi deforestasi BAU ditetapkan sebagai rata-rata antara laju deforestasi rata-rata nasional tahun 2000-2009 dan laju deforestasi rata-rata global. Stok karbon di atas tanah $100 \mathrm{tC} /$ ha juga diasumsikan untuk Guyana, dan ini menjadi dasar untuk pembayaran (Kementerian Lingkungan Hidup Norwegia 2011).

Langkah 2 melakukan upaya pertama untuk menyertakan kondisi nasional spesifik secara kuantitatif, yaitu dengan mengambil bukti atau penilaian berbasiskan faktor penyebab deforestasi untuk menyesuaikan laju deforestasi historis, dan dengan menggunakan data negara yang lebih baik (misalnya, Tier 2 untuk stok karbon) daripada yang bisa diperoleh dengan mengandalkan Langkah 1. Namun pada tahap ini data tren historis cenderung mendominasi estimasi tren masa depan. Contoh tentang hal ini dapat dilihat dalam hasil analisis regresi (Ecofys 2012) yang membuat prediksi berdasarkan data aktivitas subnasional, setidaknya untuk satu dekade atau lebih di Brasil, Indonesia, dan Vietnam. Contoh-contoh ini dipaparkan lebih lanjut dalam Kotak 16.2. Saat ini, hanya beberapa negara yang memiliki data untuk dapat melakukan pendekatan Langkah 2, tapi situasi ini diharapkan dapat membaik pada dua hingga tiga tahun ke depan (Kotak 16.4).

Langkah 3 mengembangkan pendekatan Langkah 2 lebih lanjut, dengan menggunakan data yang lebih akurat dan detail serta memungkinkan pilihan metode pemodelan yang lebih luas. Secara khusus, data aktivitas yang memiliki referensi ruang (data spasial) dan dukungan informasi yang lebih spesifik mengenai penyebab deforestasi, misalnya penggunaan model regresi spasial atau simulasi yang lebih kompleks yang memungkinkan hasil estimasi yang lebih kokoh sebagai proyeksi data ke depan. Pendekatan ini bahkan dapat menghindari kebutuhan untuk menggunakan deforestasi historis sebagai prediktor utama karena pemicu dan aktivitas spesifik dapat dianalisis, dimodelkan, dan diprediksi secara individual (dikalibrasi dengan tren historis). Pendekatan untuk RL Langkah 3 telah disajikan dalam kepustakaan ilmiah (misalnya, Soares-Filho dkk. 2006), tapi sejauh ini belum ada negara REDD+ yang mengembangkan RL menggunakan pendekatan ini. 


\section{Kotak 16.2 Metode regresi berganda untuk analisis faktor penyebab deforestasi hutan}

Salah satu cara untuk menghitung RL melampaui Tahap 1 adalah menggunakan analisis regresi berganda. ${ }^{a}$ Metode ini dapat digunakan untuk menguji pentingnya data historis deforestasi dan berbagai kondisi nasional spesifik, meliputi faktor penyebab deforestasi. Hal ini membutuhkan data nasional terpilah (tingkat subnasional) mengenai deforestasi, tutupan lahan, dan faktor-faktor lain yang relevan, setidaknya pada dua periode perubahan (atau meliputi tiga titik waktu pengukuran). Kami melakukan analisis ini di tiga negara tropis: Brasil, Indonesia, dan Vietnam.

Gambar 16.2 menunjukkan arti penting berbagai faktor dalam memprediksi tingkat deforestasi di masa depan. Data deforestasi historis adalah prediktor yang baik untuk deforestasi masa depan di tiga negara tersebut, dengan efek (elastisitas) deforestasi tertinggi di Vietnam $(0,57)$, diikuti oleh Brasil $(0,51)$, dan terakhir oleh Indonesia $(0,21)$. Elastisitas mengacu pada persentase perubahan laju deforestasi terkait dengan kenaikan $1 \%$ pada variabel yang diselidiki. Sebagai contoh, pada Gambar 16.2, kenaikan 1\% pada laju deforestasi historis di sebuah provinsi di Vietnam memberikan prediksi laju deforestasi masa depan

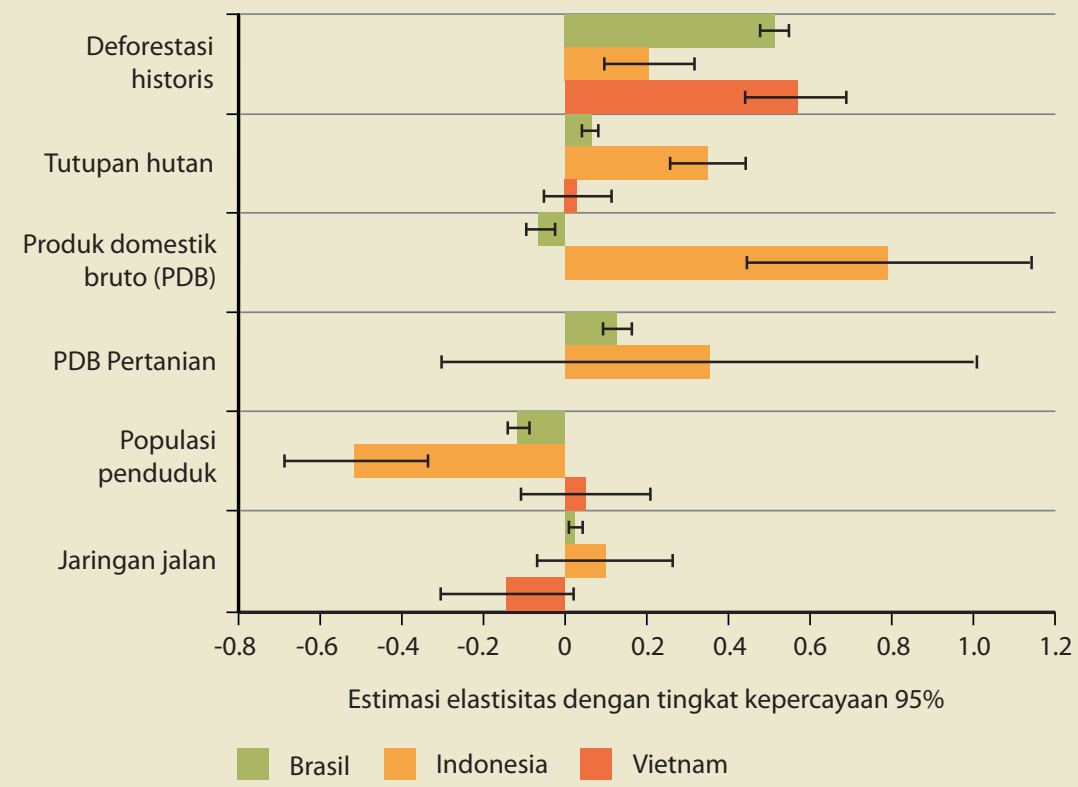

Gambar 16.2 Faktor penyebab deforestasi di Brasil, Indonesia, and Vietnam

Catatan: Regresi Brasil dan Vietnam mencakup variabel tren waktu yang tidak termasuk dalam bagan. Semua variabel dalam bentuk logaritma. Garis hitam memberikan interval kepercayaan $95 \%$ dari estimasi koefisien, yaitu jika jalur yang melintasi ' 0 ' pada sumbu horizontal, koefisien regresi tidak signifikan. 
0,57\% lebih tinggi. Fakta bahwa elastisitas kurang dari satu menunjukkan bahwa ekstrapolasi sederhana dari tingkat historis masa lalu dapat menyebabkan prediksi yang tidak akurat untuk menghitung deforestasi yang akan datang.

Kawasan hutan yang luas berkontribusi atas tingginya laju deforestasi, meskipun efeknya kecil: Indonesia $(0,35)$, Brasil $(0,06)$, dan Vietnam $(0,03)$. Luas kawasan hutan merupakan faktor penguji hipotesis teori transisi hutan, yang menyatakan bahwa negara-negara dengan tutupan hutan yang luas akan cenderung mengalami percepatan deforestasi (Mather dan Needle 1998; Mather dkk. 1999). Efek kecil dan tidak signifikan pada kasus di Vietnam sesuai dengan tren laju pertumbuhan hutan yang melebihi laju deforestasi (Meyfroidt dan Lambin 2008). Sebaliknya, Indonesia masih mengalami laju deforestasi yang tinggi sehingga prediksi nilai elastisitas yang tinggi tidaklah mengherankan.

Studi ini juga memasukkan faktor-faktor lain yang berpotensi penting dalam penghitungan RL. Di Indonesia, pertumbuhan ekonomi dikaitkan dengan laju deforestasi yang lebih tinggi. Indikasi lain dari banyaknya propinsi di negara ini yang berada pada tahap awal transisi hutan (tingkat pendapatan juga merupakan faktor penguji bagi hipotesis transisi hutan). Di Brasil, pertumbuhan penduduk yang tinggi dapat dikaitkan dengan laju deforestasi yang rendah. Studi ini juga menemukan bahwa perluasan pembangunan jalan di negara ini tidak berpengaruh signifikan bagi perubahan laju deforestasi, di luar apa yang sudah dipahami mengenai dampak laju perubahan deforestasi historis.

Analisis regresi berganda semacam ini tidak akan mampu menangkap semua pemicu dan variabel yang menyebabkan deforestasi. Variabel yang tidak menunjukkan adanya variasi data, meskipun mungkin merupakan penyebab utama deforestasi, tidak akan dapat dimasukkan dalam perhitungan model regresi. Demikian pula, faktor pemicu deforestasi atau kebijakan baru sulit untuk dianalisis menggunakan metode regresi, karena prediksi model didasarkan pada hubungan historis antara sejumlah variabel tertentu.

Sumber: Ecofys (2012)

a Analisis regresi adalah metode statistik yang bertujuan untuk membangun hubungan kuantitatif antara satu variabel dependen (misalnya, laju deforestasi saat ini) dengan sejumlah variabel independen lainnya (misalnya, laju deforestasi historis, tutupan hutan saat ini, dan pendapatan per kapita). Analisis regresi mengestimasi perkiraan bersyarat dalam bentuk satu set koefisien regresi, misalnya berapa banyak deforestasi saat ini diperkirakan akan meningkat jika terjadi kenaikan tingkat pendapatan meningkat sedangkan variabel lainnya tetap konstan. Satu alternatif model yang dapat digunakan dalam analisis ini adalah model logaritmik (log-log), yang menggunakan nilai transformasi logaritma natural dari data-data kuantitatif, seperti laju deforestasi, luas kawasan hutan, dan variabel lainnya, ketimbang nilai riil dari data kuantitatif tersebut. Hal ini membuat interpretasi hasil lebih mudah karena koefisien dari masing-masing variabel dapat diartikan sebagai elastisitas, yang menjawab pertanyaan tentang seberapa banyak deforestasi mengalami perubahan dalam persen ketika nilai variabel independen (misalnya, luas tutupan hutan) meningkat sebesar satu persen. 
Dasar pemikiran strategi kerangka bertahap adalah menyediakan jalur untuk mengurangi ketidakpastian dan melangkah maju ke tahap yang lebih tinggi dari waktu ke waktu. Kemajuan ini akan memungkinkan negara-negara untuk mengembangkan RL hutan yang lebih akurat guna menilai dampak dari kebijakan dan langkah-langkah, jika misalnya, tingkat pembayaran menjadi lebih tinggi untuk RL yang berkualitas lebih akurat. Berbagai pendekatan telah didokumentasikan menggunakan sumber data yang tersedia guna meningkatkan kapasitas pemantauan untuk menyediakan data aktivitas dan faktor emisi yang lebih berkualitas (GOFC-GOLD 2011). Negara-negara dapat memperoleh data untuk menghitung RL hutan pada tahapan yang lebih tinggi dengan cukup cepat dan menggunakan biaya yang wajar (UNFCCC 2009a).

\subsubsection{Arti penting data historis}

Mendapatkan informasi yang handal tentang data terbaru perubahan hutan sangat penting dalam perhitungan RL (Meridian Institute 2011b; Romijn dkk. 2012). Pedoman UNFCCC (Kotak 16.1) menyoroti arti penting pendekatan berbasis data untuk menetapkan RL. Selain memasukkan data tentang perubahan kawasan hutan terbaru dan emisi terkait serta menggunakan pendekatan yang disarankan dalam pedoman praktik yang baik IPCC (IPCC 2003), pengembangan RL hutan juga memerlukan informasi tentang pemicu deforestasi dan aktivitas di sektor kehutanan. Analisis empiris hubungan antara faktor penyebab deforestasi dan kontribusinya terhadap emisi nasional merupakan salah satu pendekatan yang dapat dilakukan. Keputusan COP 1/CP.16 (UNFCCC 2010) mendorong negara-negara untuk mengidentifikasi aktivitas penggunaan lahan, perubahan penggunaan lahan, dan kehutanan (LULUCF), khususnya yang terkait dengan deforestasi dan degradasi hutan dan untuk menilai potensi kontribusi masing-masing aktivitas ini bagi mitigasi perubahan iklim.

Untuk Langkah 1, konsistensi dan transparansi sangat penting, karena data yang tersedia dapat memiliki ketidakpastian yang signifikan, namun sebagian besar ketidakpastian tersebut tidak diketahui serta harus dinilai dan dikelola dengan menggunakan ketidakpastian standar dan asumsi konservatif. Langkah 2 dan Langkah 3 untuk mengembangkan RL akan didasarkan pada data nasional yang lebih akurat serta berasal dari data aktivitas sesuai standar IPCC untuk Pendekatan 2 dan 3 (Kotak 16.3).

\subsubsection{Sejumlah kondisi nasional}

Kondisi nasional menjadi persyaratan pelaporan bagi setiap negara anggota UNFCCC. Penilaian kondisi nasional dapat mencakup informasi (UNFCCC 2003) mengenai ciri-ciri geografis (misalnya, iklim, kawasan hutan, penggunaan lahan, dan ciri-ciri lingkungan lainnya), populasi 


\section{Kotak 16.3 Tiga Tahap, Tiga Pendekatan, Tiga Tingkat, Tiga Langkah}

'Tahap', 'pendekatan', 'tingkat' dan 'langkah'. Bingung? Pasti tidak setelah membaca kotak ini. Semua istilah yang berbeda ini memiliki arti cukup spesifik dalam REDD+ dan debat mengenai mitigasi perubahan iklim.

\section{Tahap implementasi REDD+}

Implementasi REDD+ mengikuti pendekatan bertahap, yang diusulkan oleh Meridian (2009) dan disepakati dalam COP16 (UNFCCC 2010). Ketiga tahap itu adalah:

Tahap 1 - tahap kesiapan: tahap awal ini berfokus pada pengembangan strategi nasional atau rencana aksi, kebijakan, dan strategi pengukuran, peningkatan kapasitas, dan kegiatan percontohan.

Tahap 2 - reformasi kebijakan dan kegiatan percontohan berbasiskan hasil: tahap ini berfokus pada pelaksanaan kebijakan nasional dan strategi pengukuran, serta pada kegiatan percontohan yang menggunakan mekanisme pembayaran berbasiskan hasil.

Tahap 3 - tindakan berbasiskan hasil: transisi ke Tahap 3 akan melibatkan transisi ke tindakan berbasis hasil yang lebih langsung, yaitu pengukuran emisi dan penyerapan karbon yang harus sepenuhnya dilaporkan dan diverifikasi, dan dilanjutkan dengan mekanisme pembayaran terhadap hasil reduksi emisi karbon yang terverifikasi.

Pendekatan untuk estimasi perubahan luas area penggunaan lahan (data aktivitas)

Pedoman IPCC memberikan tiga pendekatan dan tingkatan untuk estimasi emisi, ditandai dengan meningkatnya tingkat kebutuhan data, kompleksitas analisis, dan akurasi data untuk perhitungan emisi pada tingkatan dan pendekatan yang lebih tinggi (GOFC-GOLD 2011). Negara-negara REDD+ didorong untuk menggunakan pedoman 'Good Practice Guidance for Land Use, Land Use Change and Forestry' (Panduan Praktik yang Baik untuk Penggunaan Lahan, Perubahan Penggunaan Lahan, dan Kehutanan) (IPCC 2003) guna membantu mereka dalam melaporkan emisi dan penyerapan gas rumah kaca. Untuk estimasi emisi dan penyerapan karbon, ada dua variabel utama yang mutlak dibutuhkan, yaitu data aktivitas dan faktor emisi, Kedua variabel ini dapat diestimasi pada berbagai tingkat ketelitian. Tiga pendekatan dapat digunakan untuk menghitung data aktivitas atau perubahan kawasan hutan:

Pendekatan 1: total luas area untuk setiap kategori penggunaan lahan telah tersedia, tetapi tidak ada informasi mengenai luas wilayah yang terkonversi (hanya tersedia data mengenai luas bersih) 


\section{Kotak 16.3 Lanjutan}

Pendekatan 2: melacak perubahan antara kategori penggunaan lahan (hanya data pengamatan antara 2 titik waktu)

Pendekatan 3: penggunaan data spasial yang secara eksplisit mengetahui jumlah dan lokasi perubahan konversi penggunaan lahan dari waktu ke waktu.

\section{Tingkat untuk estimasi perubahan stok karbon hutan (faktor emisi)}

Faktor emisi memberikan perubahan stok karbon hutan untuk berbagai jenis tutupan hutan yang terdapat pada lima sumber karbon yang berbeda, yaitu: karbon di atas tanah, di bawah tanah, kayu mati, serasah, dan karbon organik tanah. Faktor emisi digunakan untuk menentukan berapa banyak karbon per hektar yang hilang dan dilepaskan ke atmosfer sebagai akibat kegiatan manusia, misalnya deforestasi. Data untuk estimasi bisa berasal dari berbagai tingkat.

Tingkat 1: nilai default untuk biomassa hutan dan pertumbuhan tahunan biomassa hutan sesuai dengan klasifikasi generik tutupan hutan di setiap benua (misalnya, hutan hujan tropis Afrika). Tingkat 1 juga menggunakan asumsi sederhana untuk menghitung emisi.

Tingkat 2: data spesifik untuk suatu negara (data yang dikumpulkan mewakili kondisi spesifik suatu negara) dan data biomassa hutan dicatat pada skala yang lebih tinggi melalui deskripsi strata hutan yang lebih rinci.

Tingkat 3: inventarisasi aktual dengan kegiatan pengukuran berulang pada plot permanen untuk memprediksi perubahan biomassa hutan dan/atau model dengan parameter spesifik dikombinasikan dengan data pengukuran plot.

\section{Langkah untuk mengembangkan tingkat (emisi) acuan}

Menggunakan strategi pendekatan bertahap untuk mengembangkan tingkat emisi acuan adalah sebuah ide baru, yang dikembangkan dalam bab ini dan dalam publikasi sebelumnya oleh tim penulis. Konsep pendekatan bertahap ini telah diakui oleh COP17 (Decision 12/CP.17, par. 10: "Sepakat bahwa pendekatan bertahap untuk [RL/REL] akan berguna, dan memungkinkan setiap negara untuk meningkatkan kualitas [RL/REL] dengan memasukkan data yang lebih baik, metodologi yang ditingkatkan dan, bila sesuai, pengukuran pada sumber karbon lain yang relevan ..."). Strategi pendekatan bertahap ini berguna karena memberikan kesempatan bagi setiap negara untuk melakukan perhitungan awal RL. Kualitas dan akurasi nilai perhitungan awal RL ini akan ditingkatkan sejalan dengan ketersediaan sarana untuk meningkatkan kualitas RL yang disertai dengan meningkatnya kapasitas dan ketersediaan data yang lebih akurat dan 
terperinci. Pendekatan ini dirancang untuk menghasilkan RL yang lebih komprehensif dan akurat untuk tahapan langkah yang lebih tinggi, menuju kompensasi berbasiskan hasil (yaitu di tahap 3):

Tahap 1: Menggunakan data yang tersedia (bahkan jika jumlahnya terbatas dan kurang akurat) untuk memberikan titik awal penetapan RL menggunakan metode proyeksi sederhana, berdasarkan data historis.

Tahap 2: Mengumpulkan data tambahan yang lebih akurat pada skala nasional yang akan memberikan hasil lebih baik bagi ekstrapolasi dan penyesuaian model sesuai kondisi suatu negara, termasuk data kuantitatif mengenai penyebab deforestasi.

Tahap 3: Integrasi penilaian dan pemodelan menggunakan data spasial, memanfaatkan informasi reliabel tentang data aktivitas dan data kuantitatif penyebab deforestasi.

Untuk mempelajari lebih lanjut mengenai hal ini, silakan lihat Tabel 16.2.

(misalnya, tingkat pertumbuhan dan distribusi), ekonomi (misalnya, energi, transportasi, industri, pertambangan), pendidikan (termasuk lembaga-lembaga penelitian ilmiah dan teknis), dan informasi lain yang dianggap relevan oleh suatu negara. Karena belum ada panduan yang jelas, saat ini setiap negara memiliki keleluasaan untuk memilih variabel-variabel tersebut sesuai dengan metode yang mereka pilih.

Dasar pemikiran umum untuk memasukkan kondisi nasional tertentu adalah untuk menghasilkan prediksi kondisi awal BAU yang lebih akurat dan tepat. Pertanyaannya tetap, apakah pedoman, misalnya dalam bentuk daftar variabel potensial yang dapat digunakan untuk mengatur tingkat emisi historis, dianggap layak dari sudut pandang politik dan ilmiah. Alternatifnya adalah memutuskan dokumentasi yang diperlukan untuk validasi di luar emisi historis. Kemungkinan lain adalah dengan mengombinasikan daftar singkat variabel yang dapat diterima dan persyaratan dokumentasi jika suatu negara melampaui daftar tersebut. Potensi untuk estimasi yang bias menunjukkan perlunya pedoman yang jelas dan proses verifikasi independen.

Diskusi ilmiah baru saja dimulai tentang cara membuat penyesuaian yang kokoh untuk perhitungan data historis dan beberapa bukti awal disajikan dalam Kotak 16.2. Meridian Institute (2011b) membahas tiga faktor utama sebagai penyesuai potensial: perhitungan data historis, yaitu: tahapan dalam 
transisi hutan, peran pemicu deforestasi spesifik dan rencana pembangunan masa depan. Walaupun demikian, juga tercatat kurangnya bukti untuk aplikasi ketiga aspek ini. Pertimbangan kondisi nasional diharapkan dapat meningkat sejalan dengan kualitas perhitungan RL yang lebih akurat secara bertahap. Hal ini dimungkinkan dengan ketersediaan data yang lebih banyak dan lebih baik serta kapasitas yang terus meningkat.

\subsubsection{Pendekatan nasional versus subnasional}

Strategi Pendekatan bertahap mencakup pilihan untuk RL subnasional sebagai nilai pengukuran sementara, namun negara-negara membutuhkan dasar pemikiran yang jelas untuk melakukannya dan mereka perlu memahami bagaimana nilai ini dapat dikompilasi menjadi RL nasional. Meningkatkan RL subnasional menjadi RL nasional yang transparan, lengkap, konsisten, dan akurat sering sulit dilakukan.

Menguji perhitungan RL hutan pada skala subnasional merupakan bagian dari proses pembelajaran langsung (learning by doing) yang dapat memberikan wawasan berguna tentang cara menghitung RL untuk skala nasional pada Tahap 3 REDD+, ketika penghitungan keuangan akan didasarkan pada tindakan berbasiskan hasil. Dalam konteks ini, perhitungan RL tahap 3 akan didasarkan pada analisis subnasional, misalnya dengan memasukkan kondisi ekologi yang berbeda serta berbagai faktor pemicu deforestasi di setiap unit subnasional.

\subsubsection{Kelenturan dalam mempertimbangkan sumber karbon, gas lain, dan aktivitas REDD+}

Negara-negara diberikan pilihan untuk menghilangkan sumber karbon nonsignifikan, beberapa jenis GRK lainnya, dan aktivitas spesifik REDD+ dalam pengembangan RL hutan (UNFCCC 2011c). Hal ini sangat masuk akal hanya memfokuskan pada kategori utama pada periode awal penghitungan RL ketika data yang ada sangat tidak pasti (lihat juga Bab 15). Dalam konteks ini, estimasi emisi karbon umumnya lebih penting daripada estimasi penyerapan karbon. Sama dengan konsep kategori sumber utama IPCC (Bab 15), setiap negara diwajibkan melaporkan emisi karbon sedangkan pelaporan mengenai penyerapan karbon bersifat pilihan. Emisi dari deforestasi harus dilaporkan sama seperti emisi degradasi hutan, kecuali jika ada bukti kuat bahwa emisi degradasi hutan tidak signifikan. Selain itu, konsistensi adalah hal pokok: ketika sumber emisi karbon dan/atau perubahan data aktivitas dihilangkan dari RL, mereka tidak dapat dimasukkan ke dalam laporan kinerja REDD+. Jika sumber tambahan, gas, dan aktivitas ditambahkan, maka RL perlu disesuaikan secara retrospektif dengan data yang baru guna memastikan konsistensi dalam pelaporan kinerja. 


\section{Kotak 16.4 Mengembangkan RL di Indonesia}

Beberapa negara tengah berupaya untuk mengembangkan RL pada strata yang lebih tinggi, melakukan investasi signifikan dalam upaya konsolidasi dan meningkatkan kualitas data historis serta menganalisis kondisi nasional spesifikmereka secara lebih baik, termasukanalisis terhadap faktor penyebab deforestasi dan degradasi hutan (misalnya, Pham dan Kei 2011; Sugardiman 2011). Di Indonesia, Kementerian Kehutanan, didukung oleh AUSAID di melalui proyek 'Sistem Penghitungan Karbon Nasional Indonesia (INCAS)', terus menyempurnakan pemantauan karbon hutan dan kapasitas penghitungan sebagai pelengkap inventarisasi hutan nasional (NFI), yang digunakan sebagai dasar untuk mengestimasi faktor emisi. Untuk data aktivitas, peta tutupan lahan saat ini dihasilkan dari data mosaik satelit Landsat TM/ETM (untuk tahun 2000, 2003, 2006, dan 2009) dengan resolusi spasial 30 meter yang sebagian telah diverifikasi dengan data lapangan. Metode untuk menghitung RL dan proyeksi deforestasi di masa mendatang didasarkan pada kombinasi data perencanaan spasial dengan laju deforestasi historis pada sejumlah wilayah administrasi subnasional. Termasuk di dalamnya adalah rencana pembangunan provinsi/kabupaten dan proyeksi 'deforestasi yang direncanakan', seperti perluasan tanaman perkebunan, pertambangan dan konversi lahan hutan yang ditetapkan secara hukum sebagai hutan konversi atau penggunaan lahan lainnya. Seperti dalam Amazon Fund di Brasil, proyeksi laju deforestasi akan ditinjau kembali setiap lima tahun. Bagi Indonesia, perhitungan RL nasional besar kemungkinan merupakan agregat dari data RL subnasional (Langkah 2).

Provinsi Sulawesi Tengah, yang merupakan studi percontohan UN-REDD Programme, telah melakukan studi rinci tentang penghitungan karbon, kompilasi data nasional inventarisasi hutan (NFI), dan mengumpulkan data lapangan tambahan dengan tujuan menerapkan metode Perubahan Stok untuk menghitung emisi karbon dalam waktu lima tahun (UN-REDD Programme 2011a). Selain itu, berdasarkan kesepakatan antara Pemerintah Indonesia dan Norwegia yang ditandatangani pada Mei 2010, Kalimantan Tengah terpilih sebagai provinsi percontohan berbagai pengukuran, pelaporan dan verifikasi REDD+ (MRV). Satuan Tugas REDD menyatukan instansi pemerintah dan baru-baru ini menyelesaikan pedoman strategi MRV. Lembaga yang terlibat termasuk Kementerian Kehutanan, Dewan Nasional Perubahan Iklim, Lembaga Penerbangan dan Antariksa Nasional, Kementerian Lingkungan Hidup, dan Badan Koordinasi Survei dan Pemetaan Nasional. REL diusulkan untuk dua lanskap hutan yang berbeda: hutan pada tanah mineral dan lahan gambut. Sementara aktivitas percontohan MRV ini harus selesai pada akhir 2012, faktor emisi yang paling mungkin untuk diprediksi berdasarkan kombinasi pendekatan Penambahan-Pengurangan dan Stok-Perbedaan.

Berdasarkan kesepakatan dengan Norwegia, tahap ketiga REDD+ (lihat Kotak 16.3) akan diperkenalkan mulai tahun 2014. Diharapkan posisi Indonesia adalah untuk "menerima "kontribusi tahunan untuk pengurangan emisi nasional yang diverifikasi secara independen dibandingkan dengan tingkat acuan UNFCCC (atau tingkat acuan yang ditetapkan oleh Indonesia dan para mitranya berdasarkan janji pengurangan emisi Indonesia dan panduan metodologis UNFCCC (4/CP 15), sesuai keputusan yang relevan dari Konferensi Para Pihak, jika tidak ada tingkat acuan UNFCCC yang ditetapkan untuk Indonesia)." 


\subsection{Mengaitkan ketidakpastian dalam RL bertahap dan basis insentif keuangan}

Pendekatan bertahap menyediakan pilihan bagi proses penghitungan RL, mulai dari pendekatan berdasarkan data yang sederhana dengan (kemungkinan) ketidakpastian yang tinggi (Langkah 1) hingga pilihan menggunakan data yang lebih akurat dan analisis ketidakpastian yang lebih kompleks (Langkah 3). Adalah wajar bahwa tingkat kepastian yang lebih tinggi harus dihargai dengan kompensasi yang lebih tinggi. Hal ini merupakan insentif yang penting untuk membantu strategi pendekatan bertahap agar dapat berjalan sekaligus mendorong negara-negara untuk bergerak ke tahap yang lebih tinggi dalam rangka menghitung RL menggunakan data yang lebih baik. RL Langkah 1 pada umumnya dianggap memiliki ketidakpastian yang tinggi untuk digunakan sebagai dasar pembayaran REDD+. Strategi pendekatan bertahap harus memperhitungkan faktor ketidakpastian untuk alasan keefektifan, efisiensi, dan untuk 'pembagian risiko yang adil' antara para pihak yang terlibat dalam kesepakatan. Beberapa pilihan telah diusulkan untuk menangani ketidakpastian, yang dirangkum dalam Tabel 16.2.

Salah satu usulan adalah membolehkan penyesuaian setelah RL, yang awalnya disebut dengan istilah 'Compensated Successful Efforts' (Combes Motel dkk. 2009). Tekanan deforestasi, misalnya di Amazon Brasil, terkait erat dengan tingkat keuntungan ternak dan produksi kedelai dan memungkinkan penyesuaian RL berdasarkan harga komoditas ini akan lebih baik mencerminkan skenario BAU yang benar. Karena itu memungkinkan pengukuran pengurangan emisi nyata yang lebih baik.

Pendekatan koridor, yang diajukan oleh Schlamadinger dkk. (2005), menyatakan adanya ketidakpastian pada setiap titik estimasi tingkat acuan. Karena itu diusulkan untuk memasukkan sebuah faktor penyesuai yang dapat membuat jumlah pengurangan emisi karbon yang lebih untuk mendapatkan faktor diskon semakin rendah (dengan kata lain, harga per $\mathrm{tCO}_{2}$ menjadi lebih tinggi). Pendekatan ini mendefinisikan interval (koridor) di sekitar titik estimasi RL, dengan faktor diskon meningkat dari 0 ke 1 (pembayaran nol sampai penuh) dalam interval ini. Dengan demikian, negara-negara REDD+ akan mendapatkan pembayaran, bahkan jika laju deforestasi di negara tersebut relatif tinggi, sebagai dampak dari kebijakan yang kurang berhasil dalam mengurangi laju deforestasi. Di sisi lain, negara donor tidak perlu membayar penuh apabila deforestasi berkurang namun ada alasan lain selain keberhasilan kebijakan REDD+. Sejauh yang kami ketahui, pendekatan koridor ini belum diterapkan secara riil, meskipun perjanjian antara 


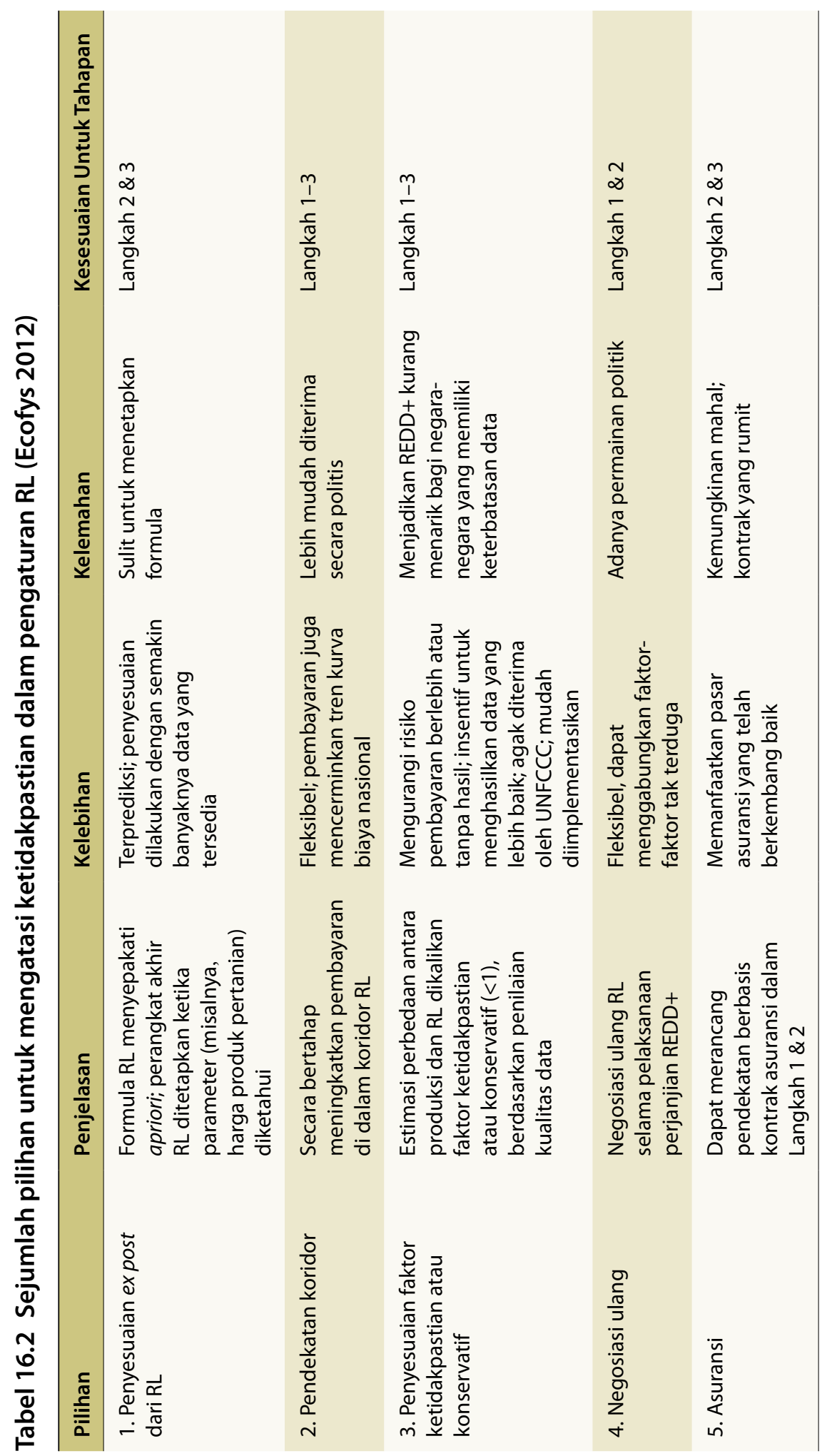


Pemerintah Guyana dan Norwegia sebenarnya mencakup beberapa elemen penting dari pendekatan ini. ${ }^{2}$

Pendekatan lain adalah dengan menggunakan ketidakpastian data atau penyesuaian konservatif. Dalam konteks ini, penyesuaian RL bisa mencerminkan tingkat ketidakpastian, sehingga negara-negara dengan kualitas data yang kurang akurat dapat menerapkan diskon berlipat ganda berdasarkan tingkat ketidakpastian data, misalnya dalam bentuk harga yang lebih rendah per $\mathrm{tCO}_{2}$. Pendekatan ini mengatasi salah satu masalah ketidakpastian, yaitu risiko pembayaran berlebih dan kredit REDD+ yang tidak dibenarkan. Penggunaan asumsi konservatif tercermin dalam keputusan terbaru UNFCCC (UNFCCC 2011c) mengenai kemungkinan menghilangkan sumber karbon nonsignifikan atau aktivitas REDD+ tertentu dalam mengembangkan RL. Pendekatan ini pada prinsipnya sudah digunakan oleh UNFCCC dan dapat memberikan pilihan sederhana yang paling cocok untuk menetapkan pembayaran pada kondisi RL yang tidak pasti (Grassi dkk. 2008) dan memungkinkan partisipasi menyeluruh dalam REDD+ sambil mengembangkan sistem inventarisasi yang lebih baik.

Pilihan lain untuk menangani ketidakpastian adalah perundingan ulang kontrak atau asuransi, tetapi hal ini belum dieksplorasi dalam konteks RL REDD+. Pertanyaan mengenai asuransi dalam kaitannya dengan isu ketetapan telah dibahas oleh Dutschke dan Angelsen (2008) di mana pilihan yang diulas juga relevan untuk perhitungan RL.

Tabel 16.2 mencakup kolom pada keterterapan berbagai penyesuaian pada setiap langkah dalam perhitungan RL. Karena pada umumnya negara akan mulai dengan pendekatan Langkah 1 atau 2, penyesuaian konservatif menjadi solusi yang paling sederhana. Perundingan ulang secara berkala juga merupakan pilihan, tetapi rentan terhadap bias politis. Pendekatan koridor memiliki beberapa ciri menarik dan dapat dianggap sebagai satu varian dari pendekatan penyesuaian konservatif (dengan tingkat penyesuaian progresif).

\subsection{Kesimpulan}

Menetapkan tingkat acuan hutan bagi negara-negara berkembang merupakan salah satu tugas yang paling mendesak dan menantang dalam pelaksanaan REDD+. Meskipun sudah ada beberapa pedoman umum dari UNFCCC mengenai perhitungan tingkat acuan hutan (UNFCCC 2011c), hal ini

2 Tingkat acuan yang direvisi dalam kemitraan Guyana-Norwegia mengikuti konsep pendekatan koridor yang di dalamnya setiap peningkatan deforestasi dari tingkat yang sangat rendah saat ini akan diberi penalti (dengan pengurangan pembayaran) dan di atas tingkat cut-off tertentu, pembayaran sepenuhnya akan menghilang (Kementerian Lingkungan Hidup Norwegia 2011). 
tidak mengurangi tantangan signifikan yang disebabkan oleh berbagai hal. Negara-negara diminta untuk memilih pendekatan yang sesuai untuk menetapkan RL, walaupun perlu disadari banyak negara yang berjuang keras karena kurangnya ketersediaan data yang berkualitas, ketidakpastian tentang laju deforestasi dan degradasi di masa depan, dan adanya potensi insentif apabila terjadi bias pada hasil estimasi RL, khususnya ketika tingkat acuan dikaitkan dengan skema dan tingkat pembayaran. Oleh karena itu, kami menyoroti dua arti dan penggunaan RL: yakni sebagai tolok ukur efek atau dampak kebijakan dan tindakan REDD+ serta RL yang digunakan sebagai basis untuk menghitung pembayaran sebagai kompensasi atas pengurangan emisi yang dilakukan oleh suatu negara, unit subnasional, atau proyek.

Strategi pendekatan bertahap dalam penghitungan RL hutan dapat membantu mengatasi tantangan akibat keterbatasan data, faktor ketidakpastian, dan persaingan kepentingan, guna mendorong partisipasi yang lebih luas dari setiap negara untuk berpartisipasi dalam mekanisme REDD+. Strategi pendekatan bertahap merupakan pendekatan berbasis data; sehingga ketersediaan data yang lebih banyak dan lebih berkualitas akan meningkatkan kualitas RL dari waktu ke waktu. Walaupun perhitungan RL dilakukan dengan mengambil pendekatan Langkah 1 yang lebih sederhana dan memberikan hasil dengan tingkat ketidakpastian yang tinggi, paling tidak hal ini memungkinkan negara-negara untuk memulai aktivitas perhitungan RL guna memberikan tolok ukur dalam menilai tren dan kinerja sementara. Langkah 2 memungkinkan penyertaan kondisi nasional yang lebih luas dengan menghubungkan RL dengan faktor penyebab deforestasi dan degradasi yang relevan sebagai sarana untuk menyesuaikan tingkat perubahan penggunaan lahan, termasuk wilayah hutan di masa lalu. Langkah 3 dari pendekatan bertahap ini diharapkan dapat mengaplikasikan data spasial terpilah yang lebih terinci serta mengetahui secara lebih pasti jumlah dan lokasi pemicu serta faktor penyebab terjadinya deforestasi. Langkah 3 dapat diterapkan, misalnya, melalui penggunaan model simulasi spasial yang juga memungkinkan untuk melakukan proyeksi laju deforestasi di masa mendatang.

Strategi Pendekatan bertahap secara alami akan menghasilkan RL pada berbagai tingkat ketidakpastian dan hal ini harus diperhitungkan dalam setiap cara pembayaran. Ketika ketidakpastian bervariasi (misalnya, antara satu negara dengan negara lainnya), basis insentif keuangan (FIB) yang mengubah kondisi awal BAU merupakan sarana untuk menghargai upaya mengurangi ketidakpastian dan berpindah ke tahapan RL yang lebih tinggi dari waktu ke waktu. Ada beberapa pendekatan untuk menangani ketidakpastian RL; faktor penyesuaian konservatif saat ini menjadi pilihan yang paling cocok. Pendekatan ini, setidaknya pada prinsipnya, sudah dibahas dan dipertimbangkan oleh UNFCCC (Grassi dkk. 2008; UNFCCC 2011c). 



\section{Bab}

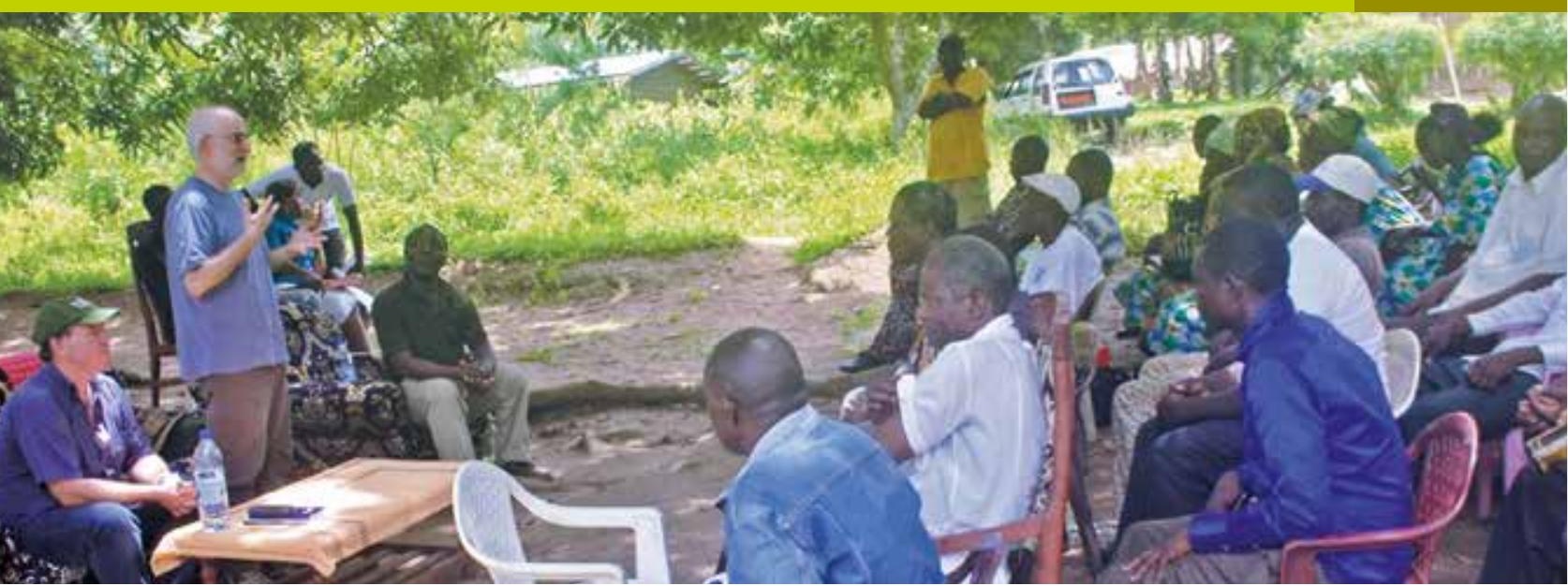

\section{Pengamanan REDD+ dalam wacana kebijakan nasional dan proyek-proyek percontohan}

Pamela Jagger, Kathleen Lawlor, Maria Brockhaus, Maria Fernanda Gebara, Denis Jean Sonwa dan Ida Aju Pradnja Resosudarmo

- Adopsi dini berbagai standar sosial dan lingkungan di tingkat nasional dan tingkat proyek menunjukkan bahwa para perumus kebijakan, personel proyek, dan investor REDD+ menghargai pengamanan bagi REDD+.

- Untuk memperoleh waktu tunggu tingkat nasional untuk pengamanan REDD+, kedaulatan nasional harus diakui dan kebijakan-kebijakan pengamanan yang simpang siur harus diselaraskan.

- Dialog seputar pengamanan REDD+ perlu bergerak dari diskusi internasional tingkat tinggi ke arah tindakan. Dialog ini mencakup mengenalkan panduan, strategi biaya rendah dan pengembangan kapasitas untuk mendukung interpretasi, implementasi, pemantauan, dan pelaporan pengamanan.

\subsection{Tantangan utama}

Pengamanan REDD+ adalah kebijakan dan langkah yang menangani dampak langsung dan tidak langsung REDD+ bagi masyarakat dan ekosistem. Pengamanan ini dilakukan dengan mengidentifikasi, menganalisis, dan mengelola risiko dan peluang (Murphy, 2011). Perjanjian Cancun yang ditandatangani dalam Konferensi Para Pihak ke-16 (COP16) UNFCCC mengajak pihak-pihak untuk memajukan, 
mendukung, dan melaporkan implementasi tujuh pengamanan sosial dan lingkungan untuk REDD+ (lihat Kotak 17.1). Bentuknya meliputi tata kelola yang transparan; penghormatan pada hak-hak penduduk asli dan masyarakat setempat, serta partisipasi penuh mereka dalam kegiatan-kegiatan REDD+; serta tindakan-tindakan yang mengurangi risiko kehilangan keanekaragaman hayati, kelanggengan dan pengalihan emisi (kebocoran) (UNFCCC 2011a).

Penetapan berbagai standar sosial dan lingkungan yang diakui secara internasional untuk memandu kebijakan dan rancangan proyek REDD+ sangat penting untuk mencapai hasil sosial dan lingkungan yang efektif, efisien, dan setara. Para perumus kebijakan REDD+ menghadapi tantangan besar dalam menetapkan rangkaian kebijakan pengamanan yang dapat diterapkan, dipantau, dan ditegakkan dengan biaya yang relatif murah, serta yang menarik bagi para investor karbon. Di banyak negara REDD+, diskusi seputar pengamanan masih sangat baru dan mewakili sebagian kecil dari

\section{Kotak 17.1 Pengamanan United Nations Framework Convention on Climate Change (UNFCCC) yang diartikulasikan dalam Perjanjian Cancun}

1. Tindakan yang melengkapi atau konsisten dengan tujuan program hutan nasional serta konvensi dan perjanjian internasional yang relevan.

2. Struktur tata kelola hutan nasional yang transparan dan efektif, dengan mempertimbangkan undang-undang dan kedaulatan nasional.

3. Penghormatan atas pengetahuan dan hak penduduk asli dan masyarakat setempat, dengan mempertimbangkan kewajiban internasional yang relevan, kondisi nasional, dan hukum, serta memperhatikan bahwa Majelis Umum PBB telah mengadopsi Deklarasi PBB tentang Hak Penduduk Asli.

4. Partisipasi penuh dan efektif dari para pemangku kepentingan yang terkait, khususnya penduduk asli dan masyarakat setempat, dalam tindakan yang dirujuk pada paragraf 70 dan 72 dari keputusan ini.

5. Tindakan konsisten dengan pelestarian hutan alam dan keanekaragaman hayati, dengan memastikan bahwa tindakan yang dirujuk pada paragraf 70 dari keputusan ini tidak digunakan untuk konversi hutan alam, melainkan digunakan untuk merangsang perlindungan dan pelestarian hutan alam dan pelayanan ekosistemnya, serta untuk memperbesar manfaat sosial lainnya.

6. Tindakan untuk mengatasi risiko kemunduran.

7. Tindakan untuk mengurangi pengalihan emisi.

Sumber: UNFCCC (2011a) 
dialog kebijakan REDD+ secara keseluruhan. Prakarsa kesiapan REDD+ terutama memfokuskan pada pemantauan karbon, pelaporan dan verifikasi (MRV), dan tidak banyak memberi perhatian pada hal-hal penting lainnya yang terkait dengan pengamanan.

Bab ini membahas kondisi saat ini seputar pengamanan sosial dan lingkungan di tingkat internasional, nasional, dan proyek untuk mitigasi iklim berbasiskan hutan. Berdasarkan kerangka '4I' yang diuraikan dalam Bab 2, bab ini mengulas analisis pengamanan REDD+ pada berbagai skala. Bagian 17.3, 17.4, dan 17.5 menampilkan analisis tentang dialog internasional saat ini mengenai pengamanan $\mathrm{REDD}+$, perspektif tingkat nasional dan proyek, serta pengalaman dengan pengamanan REDD+. Bagian terakhir mengidentifikasi tantangan dan peluang utama untuk melangkah maju.

\subsection{Pengamanan dilihat dari lensa ekonomi politik}

Kerangka 4I (Bab 2) mengaitkan kelembagaan, kepentingan, gagasan, dan informasi untuk membangun dasar bagi analisis tentang pengamanan REDD+. Kerangka ini menggunakan lensa ekonomi politik, yang dapat membantu menjelaskan bagaimana kebijakan pengamanan dirancang, mengapa pengamanan diadopsi, dan peranannya dalam mencapai tujuan REDD+ secara keseluruhan. Pengamanan REDD+ adalah norma-norma atau lembaga-lembaga (North 1990) yang memfokuskan pada pencapaian berbagai standar sosial dan lingkungan minimum, memperhitungkan insentif untuk permintaan dan penawaran kredit karbon yang dihasilkan sesuai dengan standar internasional yang diakui, serta mencakup diskusi-diskusi seputar peran informasi dan gagasan dalam penetapan kebijakan pengamanan REDD+.

Pengamanan REDD+ yang dirumuskan saat ini merupakan serangkaian norma atau lembaga yang memandu harapan seputar hasil sosial dan lingkungan yang terkait pengurangan emisi karbon di negara-negara berkembang. Berbeda dengan peraturan yang memberlakukan sanksi terkait ketidakpatuhan, pengamanan $\mathrm{REDD}+$ menyediakan serangkaian prinsip pemandu yang menggambarkan penawaran untuk, dan permintaan akan, pengurangan emisi. Apakah pengamanan REDD+ akan mencakup bahasa yang menaikkannya ke tingkat peraturan masih belum pasti. Sekalipun pengamanan bersifat tidak terikat atau sukarela, para investor memiliki kemampuan untuk memberi sanksi secara informal kepada penghasil karbon dengan menunjukkan preferensi untuk karbon yang dipasok sesuai dengan standar pengamanan.

Implementasi, pemantauan, dan pelaporan seputar pengamanan REDD+ melibatkan biaya transaksi yang signifikan. Karena itu, ketaatan pada kebijakan pengamanan membawa keuntungan nyata yang lebih besar dibandingkan biayanya. Karena ketidakpastian mengenai artikulasi akhir 
mengenai pengamanan $\mathrm{REDD}+$ dan sifat serta volume pasar karbon, pemerintah nasional dan pemrakarsa proyek berkepentingan menempatkan diri mereka sedemikian rupa sehingga karbon yang mereka pasok setidaknya akan memenuhi pengamanan minimum karena tidak berbahaya. Banyak prakarsa REDD+ juga berupaya untuk memberikan keuntungan sampingan kepada para pengguna sumberdaya lokal. Selain insentif pasar, organisasi pendukung, para donor, dan pemerintah nasional bisa terdorong oleh kewajiban sosial dan lingkungan yang sudah ada untuk menaati pengamanan sosial dan lingkungan atau oleh harapan bahwa REDD+ hanya bisa efektif jika berbagai tujuan sosial dan normanya diindahkan.

Norma juga memengaruhi berbagai harapan dari sisi permintaan. Donor atau pembeli karbon dari sektor swasta mungkin lebih menyukai karbon yang dihasilkan sesuai dengan pengamanan (misalnya, perusahaan yang mewujudkan tanggung jawab sosial perusahaan atau donor yang mencapai tujuan lingkungan dan pembangunan). Selain itu, kepentingan para investor dalam pengamanan sepertinya digerakkan oleh keinginan untuk mengurangi risiko kerusakan reputasi mereka.

Gagasan dan ideologi memainkan peranan penting dalam dukungan untuk pengamanan, berdasarkan pendekatan berbasiskan hak yang menekankan hak asasi penduduk pribumi untuk mengabulkan atau menahan persetujuan sukarela setelah pemberitahuan sebelumnya (free, prior and informed consent-FPIC) untuk kegiatan-kegiatan yang memengaruhi tanah yang sudah lama mereka huni dan/atau kelola (Indigenous People's Summit on Climate Change 2009). Sebagian pendukung berpendapat bahwa semua masyarakat yang terkena dampak (bukan hanya kelompok masyarakat pribumi) harus diminta mengabulkan FPIC mereka untuk REDD+. ${ }^{1}$ Mereka yang berargumentasi normatif juga mendesak agar REDD+ memberikan manfaat eksplisit (bukan sekedar menghindari bahaya) kepada masyarakat setempat.

Gagasan atau prinsip kedaulatan nasional juga menjadi masalah besar dalam perdebatan seputar penetapan rangkaian pengamanan REDD+ secara internasional. Pemerintah nasional ingin mempertahankan otonomi mereka dalam kebijakan sosial dan lingkungan, yang membuat implementasi pengamanan dengan mandat internasional menjadi menantang.

Implementasi kebijakan pengamanan REDD+ yang efektif adalah tugas yang kompleks. Para pemangku kepentingan di berbagai tingkatan memiliki kepentingan sendiri untuk memastikan bahwa pengamanan sosial dan lingkungan terawasi, sehingga menyiratkan adanya mekanisme untuk

1 Lihat Lawlor dan Huberman (2009) untuk kajian tentang Deklarasi dan Perjanjian PBB tentang Hak Asasi yang paling relevan untuk mengartikulasikan pendekatan berbasis hak kepada REDD+, berdasarkan norma-norma internasional yang sudah mapan ini. 
arus informasi. Karena itu, pemerintah nasional perlu mengumpulkan dan melaporkan segala informasi tentang indikator-indikator sosial dan lingkungan untuk menunjukkan bahwa pengamanan telah terpenuhi. Negara-negara berkembang telah mengungkapkan rasa frustrasi mereka karena para donor memberlakukan syarat yang rumit dan mahal, yang bervariasi dari lembaga yang satu ke lembaga lainnya, khususnya pada saat dana yang mengalir untuk REDD+ lambat (Kovacevic 2011).

\subsection{Wacana internasional seputar pengamanan REDD+}

Pengamanan REDD+ dari UNFCCC saat ini paling tepat digambarkan sebagai 'prinsip-prinsip' yang tidak mengikat, dan bukannya kebijakan atau aturan yang sesungguhnya. Kesepakatan dan panduan yang digalakkan di UNFCCC seputar sistem informasi pengamanan bertujuan mencari keseimbangan antara aturan-aturan yang preskriptif, kedaulatan nasional, dan biaya transaksi. Di satu sisi, tujuannya adalah memberi panduan terperinci kepada negara-negara REDD+ supaya mereka bisa mengidentifikasi dampak negatif dan memungkinkan para pemangku kepentingan untuk menilai sebaik apa pengamanan tengah diimplementasikan. Di sisi lain, diakui bahwa kapasitas negara-negara dalam menerapkan dan melaporkan pengamanan beragam, dan bahwa banyak sistem pengamanan sudah ada, yang seharusnya menjadi dasar pengembangan dan bukannya diduplikasi (UNFCCC 2011c). Para pemangku kepentingan sedang menantikan klarifikasi lebih lanjut dari Subsidiary Body for Scientific and Technological Advice (SBSTA) tentang definisi ini serta persyaratan MRV untuk pengamanan sosial dan lingkungan dari REDD+. Sementara itu, lembaga-lembaga internasional lainnya, termasuk Convention on Biological Diversity (CBD), United Nations Declaration on the Rights of Indigenous Peoples (UN DRIP), dan Universal Declaration on Human Rights, sedang mengevaluasi apakah kebijakan pengamanan sosial dan lingkungan mereka selaras dengan kebijakan REDD+ (Hite 2010) (Kotak 17.2).

Di luar UNFCCC, beberapa organisasi internasional dan nirlaba telah mengartikulasikan standar pengamanan untuk kebijakan REDD+ di tingkat nasional. Komitmen 'tidak membahayakan' ini tercermin dalam kebijakan perlindungan sosial yang tengah diterapkan oleh Forest Carbon Partnership Facilities (FCPF), termasuk Strategic Environmental and Social Assessment (SESA) dan Environmental and Social Management Framework (ESMF) (FCPF 2011). FCPF bekerja sama dengan berbagai negara untuk membangun kapasitas kelembagaan mereka untuk merancang dan menerapkan REDD+. Sebagai contoh, FCPF terlibat dalam konsultasi partisipasi dengan pemangku kepentingan untuk mengidentifikasi dan mengelola potensi risiko bagi penduduk pribumi dan masyarakat yang hidupnya bergantung pada hutan (Rapp 2011). Prakarsa Standar Sosial dan Lingkungan REDD+ (REDD+ SES), yang dipimpin oleh Climate, Community and Biodiversity Alliance (CCBA) dan 


\section{Kotak 17.2 Mengaitkan Konvensi Mengenai Keanekaragaman Hayati (Convention on Biological Diversity/CBD) dan pengamanan keanekaragaman hayati oleh REDD+: Pengalaman dari Afrika subSahara}

Upaya untuk menghindari deforestasi dan degradasi hutan seharusnya meningkatkan pelestarian keanekaragaman hayati (Harvey dkk. 2010a; CBD 2011), dan peningkatan kemampuan ekosistem hutan untuk pulih memberi peluang bagi stabilitas karbon hutan (Thompson dkk. 2011). Namun demikian, fokus REDD+yang kuat pada pemeliharaan cadangan karbon telah menimbulkan kekhawatiran bahwa keanekaragaman hayati bisa terancam jika tidak mendapat perhatian sebagaimana mestinya (CBD 2010). Karena itu diperlukan dialog antara CBD dan UNFCCC untuk mengatasi kekhawatiran ini. COP10 CBD di Nagoya, Jepang, memberi perhatian pada kaitan antara sasaran keanekaragaman hayati dan pengamanan UNFCCC REDD+ dengan mengartikulasikan 20 sasaran keanekaragaman hayati (Sasaran Keanekaragaman Hayati Aichi 5, 7, 11 and 15) yang langsung terkait dengan REDD+.

Sesudah dialog global tersebut, sejumlah kegiatan konsultasi dan peningkatan kapasitas sudah berlangsung di tingkat regional. Tahun 2011, sebuah lokakarya gabungan CBD-UNFCCC membahas kaitan antara sasaran keanekaragaman hayati dan REDD+ di Afrika subSahara. Lokakarya ini, yang diadakan di Cape Town, Afrika Selatan, mempertemukan para anggota kunci dari CBD dan UNFCCC dengan mitra-mitra lainnya, termasuk sejumlah perwakilan dari penduduk asli dan masyarakat setempat. Kerangka pengamanan yang sudah ada dalam Program UN-REDD, Forest Carbon Partnership Facility (FCPF), dan Climate, Community and Biodiversity Alliance (CCBA) membantu memandu diskusi. Para peserta membahas penerapan kebijakan pengamanan REDD+ tentang keanekaragaman hayati, mengidentifikasi indikator untuk memahami REDD+ dalam lingkup tujuan CBD, dan menyoroti tantangan yang menghadang implementasi pengamanan keanekaragaman hayati di kawasan Afrika. Anggota Collaborative Partnership on Forests (CPF) memberikan informasi tentang pengalaman mereka dengan formulasi dan implementasi REDD+ di tingkat nasional dan tingkat proyek.

Kesimpulan dan rekomendasi yang terpenting adalah:

1. Pengamanan keanekaragaman hayati harus ditangani sedini mungkin dalam proses REDD+.

2. Kekurangan dalam proses zonasi lahan harus diatasi.

3. Tidak ada pengamanan khusus untuk mengatasi risiko pembukaan lahan untuk dijadikan hutan di kawasan yang keanekaragaman hayatinya tinggi.

4. Kurangnya perhatian pada kemungkinan untuk memindahkan tekanan deforestasi dan degradasi hutan ke kawasan bernilai karbon rendah dan keanekaragaman hayatinya tinggi.

5. Kurangnya perhatian pada potensi hilangnya pengetahuan ekologi tradisional. 
Hasil lokakarya digunakan untuk memberi informasi kepada Pihak-pihak sebelum COP11 CBD, dan untuk memfasilitasi penyelarasan lebih lanjut bagi kebijakan pengamanan keanekaragaman hayati antara CBD dan UNFCCC. Di Afrika subSahara, peningkatan kapasitas masih menjadi tantangan besar dan perlu lebih banyak penelitian untuk memahami kaitan antara REDD+ dan hasil keanekaragaman hayati. Di tingkat regional dan nasional, data tentang simpanan dan aliran karbon serta korelasinya dengan indikator keanekaragaman hayati perlu disediakan. Pengumpulan dan pemrosesan data jenis ini membutuhkan kapasitas dalam negeri untuk mengaitkan hasil karbon dan keanekaragaman hayati, dan untuk menganalisis penyebab dasar dari perimbangan dan sinergi karbon-keanekaragaman hayati.

a CPF adalah perjanjian sukarela informal dari 14 organisasi dan sekretariat internasional dengan program yang substansial tentang hutan.

CARE International, merangkul masyarakat madani bersama sektor swasta dan lembaga-lembaga pemerintah di negara-negara berkembang. Fokus mereka adalah untuk membangun indikator spesifik negara untuk melacak kepatuhan terhadap program-program REDD+ yang dipimpin oleh pemerintah dengan delapan prinsip prakarsa tersebut serta 34 kriteria pendukung (CCBA dan CARE 2010). ${ }^{2}$ Prinsip-prinsip ini meliputi komitmen untuk meningkatkan kesejahteraan masyarakat setempat dan memberi kontribusi pada tata kelola yang baik (REDD+SES 2010). Program UN-REDD juga terlibat dalam proses paralel untuk membangun prinsip dan kriteria sosial dan lingkungan yang mencerminkan pengamanan dalam Perjanjian Cancun, dan ini akan berlaku bagi negara-negara yang menerima dukungan finansial untuk REDD+. Program tersebut juga telah mengembangkan prinsip dan kriteria yang mendukung potensi REDD+ untuk membawa manfaat sosial (Program UN-REDD 2011c). Meskipun demikian, prinsip dan kriteria Program UN-REDD tidak membuat rujukan spesifik ke masalah utama seperti penguasaan lahan. Di samping itu, berbeda dengan Bank Dunia, yang mempunyai mekanisme inspeksi formal, Program UN-REDD tidak memiliki mekanisme akuntabilitas.

Ada beberapa standar sertifikasi sukarela untuk memperhitungkan dampak sosial dan lingkungan di tingkat proyek. Contoh yang paling menonjol adalah Climate, Community and Biodiversity (CCB) Standard, yang sudah diadopsi oleh sekitar 64\% dari seluruh proyek karbon hutan (EcoSecurities 2010). ${ }^{3}$ Hampir 60\% dari kredit karbon hutan yang dijual di pasar sukarela tahun 2010 berasal dari proyek-proyek bersertifikasi CCB (Diaz dkk. 2011). Penyerapan

2 Versi 2 dari standar ini masih dalam bentuk draft dan sedang menjalani periode komentar publik untuk direvisi. Versi 2 memiliki 7 prinsip dan jumlah kriteria lebih sedikit.

3 Plan Vivo adalah standar sertifikasi lainnya yang sudah mapan, yang mengharuskan proyek menghasilkan keuntungan bagi iklim dan pencaharian (Plan Vivo 2008). 
CCB Standard yang menyebar luas dan sukarela oleh proyek merupakan contoh dari apa yang dirujuk oleh Cashore (2002) sebagai "tata kelola yang digerakkan oleh pasar bukan negara”, yang mencerminkan gagasan dan kepentingan para pelaku dari sisi permintaan (investor, konsumen) maupun sisi penawaran (pemrakarsa proyek) REDD+.

Pengamanan REDD+ mengalami perkembangan di banyak arena politik dan pasar. Pengamanan diterapkan dalam berbagai skala tata kelola, termasuk tingkat proyek dan subnasional, tingkat nasional, dan di ranah kebijakan internasional. Selain perlunya keharmonisan di berbagai skala, ada sejumlah pertanyaan penting yang terkait dengan cara menyelaraskan pengamanan REDD+ dengan perjanjian internasional tentang lingkungan (seperti CBD) dan sejumlah kebijakan sosial dan lingkungan mereka.

\subsection{Wacana nasional kebijakan pengamanan REDD+}

Bagian ini beranjak dari data yang diambil dari Studi Komparatif Global CIFOR tentang REDD+ (lihat Lampiran) dan mengeksplorasi dialog media REDD+ nasional serta kapasitas nasional yang difokuskan pada pengamanan REDD+. Pendekatan studi kasus komparatif digunakan untuk menganalisis komunikasi media nasional di empat negara REDD+ dalam upaya untuk memahami substansi dialog kebijakan seputar pengamanan REDD+. Data dari profil negara membantu menjelaskan bagaimana aktivitas, struktur lembaga, dan keputusan kebijakan REDD+ bisa mengarah kepada hasil yang efektif, efisien, dan berkesetaraan. Profil negara juga memberikan indikator yang dapat digunakan untuk mengukur kapasitas nasional untuk menerapkan, memantau, dan melaporkan pengamanan.

\subsubsection{Analisis tentang wacana media}

GCS melaksanakan analisis wacana media secara menyeluruh di beberapa negara, termasuk Brasil, Kamerun, Indonesia, dan Vietnam, ${ }^{4}$ untuk memperhitungkan liputan koran seputar perumusan dan implementasi kebijakan REDD+. ${ }^{5}$ Para peneliti melakukan analisis liputan media cetak nasional dan mewawancarai sejumlah wartawan. ${ }^{6}$ Media dipandang sebagai jendela ke diskusi kebijakan informal dan formal (Boykoff 2008). Analisis yang dilakukan di sini mengidentifikasi rujukan-rujukan spesifik ke elemen-elemen

4 Media cetak di Vietnam dikendalikan oleh pemerintah pusat.

5 Meskipun Peru dan Tanzania termasuk di dalam Studi Komparatif Global CIFOR tentang REDD+, analisis media untuk negara-negara ini belum tersedia.

6 Data terutama berasal dari tahun 2005-2009 tetapi data yang dimutakhirkan sampai 2011 untuk Brasil dan Indonesia digunakan untuk melakukan analisis pendahuluan dan mengidentifikasi tren. Data diambil dari politik REDD+ dalam studi kasus media (Cronin and Santoso 2010; Kengoum 2011; May dkk. 2011a; Pham 2011). 
terpenting dari kebijakan pengamanan REDD+, termasuk tata kelola dan pengamanan, kesejahteraan sosial, keanekaragaman hayati, dan MRV.

Analisis tersebut mengungkapkan bahwa masalah-masalah utama yang terkait dengan tata kelola dan pengamanan tidak diliput dengan baik oleh media nasional. Namun yang paling memprihatinkan adalah korupsi di lembaga-lembaga kehutanan nasional dan kemungkinan dampak bertambahnya aliran dana dari REDD+ bagi sejumlah lembaga yang sudah ada, khususnya dalam membuka peluang baru untuk mencari rente di kalangan pejabat publik. Media di Indonesia menyuarakan keprihatinan tentang kontradiksi antara kebijakan umum REDD+ dan kebijakan di sektor lain, tapi tidak ada rujukan spesifik yang dibuat untuk kebijakan pengamanan. Ada liputan yang signifikan seputar isu-isu terkait hak masyarakat asli dan hak asasi di Brasil dan Indonesia, tapi tidak demikian halnya di Kamerun dan Vietnam. Hak kepemilikan dan penguasaan lahan dan karbon juga mendapat perhatian dan termasuk dalam diskusi tentang hilangnya akses ke hutan, serta keprihatinan seputar distribusi keuntungan di bawah REDD+. Secara keseluruhan, terbatasnya liputan seputar hak masyarakat asli, hak asasi, dan hak kepemilikan menunjukkan sedikitnya perhatian pada masalah pengamanan dalam dialog kebijakan nasional.

Keanekaragaman hayati secara konsisten dikaitkan dengan pelestarian, yang diidentifikasi sebagai pilihan terbaik untuk mempertahankan hutan asli di Brasil dan Kamerun. Media Vietnam menampilkan pelestarian keanekaragaman hayati sebagai potensi keuntungan tambahan dari REDD+. Di negara-negara dengan sistem MRV yang relatif maju, media membahas kebocoran dan kelestarian sebagai masalah penting dalam mencapai REDD+, tapi masalah ini tidak diliput di negara-negara dengan kapasitas MRV yang rendah. Kurangnya rujukan eksplisit untuk 'pengamanan' memang sudah diduga; istilah ini memang belum digunakan secara luas oleh media di banyak negara sebelum COP Cancun tahun 2010. Meskipun demikian, media Brasil membahas pengamanan secara eksplisit dalam pelaporan mereka seputar hasil negosiasi internasional yang tengah berlangsung tentang REDD+.

Media di Brasil dan Indonesia tampaknya paling sadar akan pengamanan. Meskipun mereka tidak meliput semua aspek, ada diskusi eksplisit tentang masalah-masalah utama, termasuk lembaga kehutanan yang korup, kedaulatan, hak-hak masyarakat asli, kebocoran, dan kelestarian. Kenyataan bahwa Brasil telah menunjukkan kepemimpinan yang mantap dalam menetapkan kebijakan pengamanan REDD+ (lihat Kotak 17.3) dan bahwa Indonesia sudah sampai pada proses kebijakan tingkat lanjut membantu menjelaskan temuan ini. 


\section{Kotak 17.3 Kebijakan pengamanan REDD+ nasional di Brasil}

Brasil adalah pemimpin dunia dalam hal pengembangan kebijakan nasional untuk pengamanan sosial dan lingkungan. Prosesnya dimulai tahun 2009 saat beberapa organisasi masyarakat madani mulai mengembangkan prinsip dan kriteria sosial dan lingkungan untuk program dan proyek REDD+. Prakarsa ini bertujuan untuk: i) memperkuat tata kelola hutan dan pengelolaan sumberdaya alam oleh penduduk asli dan masyarakat setempat; ii) mendorong partisipasi publik dalam perumusan kebijakan; iii) mengkoordinasikan tindakan di kalangan pemangku kepentingan; iv) meningkatkan transparansi informasi; dan v) membangkitkan penghormatan pada, serta kesadaran dan pengakuan akan hak-hak penduduk asli dan masyarakat setempat atas wilayah, tanah, sumberdaya alam, dan mata pencaharian serta budaya tradisional mereka (Gomes dkk. 2010).

The Institute for Agriculture and Forest Management Certification (IMAFLORA) memimpin proses konsultasi, yang terbuka bagi semua pemangku kepentingan utama. Empat lokakarya regional memastikan penduduk asli, masyarakat setempat, dan pemilik tanah skala kecil tercakup. ${ }^{a}$ Para pemangku kepentingan ini diuntungkan oleh penambahan kapasitas sebelum lokakarya untuk memastikan mereka benar-benar memahami dokumen pengamanan dan implikasinya. Tim tersebut juga mengundang kelompok-kelompok dari sektor swasta untuk menyumbangkan pendapat mereka. Menjelang Mei 2010, dokumen akhir yang menggambarkan prinsip dan kriteria Brasil untuk REDD+ sudah siap dan direkomendasikan kepada para perumus kebijakan di tingkat nasional dan negara. ${ }^{\text {b }}$ Prinsip dan kriteria yang dicantumkan di dalam dokumen itu menjadi dasar bagi pengamanan nasional Brasil dan strategi REDD+ sesuai permintaan dalam Perjanjian Cancun.

Tahun 2011, Kementerian Lingkungan menyelenggarakan dua pertemuan untuk menginformasikan perkembangan strategi nasional REDD+ Brasil (MMA 2011). Para peserta diambil dari berbagai sektor masyarakat madani dan pemerintahan. Mereka bekerja bersama untuk mengevaluasi apakah usulan kerangka pengamanan akan mencakup ancaman utama bagi keanekaragaman hayati dan penduduk asli/masyarakat setempat, serta untuk mengidentifikasi tantangan-tantangan utama dalam penerapannya.

Dalam pertemuan kedua, para peserta menelaah berbagai pendekatan dan definisi pengamanan. Sesudah pembahasan ini, Kementerian Lingkungan mengemukakan sebuah daftar pengamanan untuk dipertimbangkan dalam pengembangan strategi nasional REDD+ Brasil.

1. Peraturan hukum

2. Jaminan hak

3. Keberlanjutan ekonomi dan pengurangan kemiskinan

4. Pelestarian dan pemulihan keanekaragaman hayati 
5. Tata kelola

6. Pembagian keuntungan

7. Pemantauan dan transparansi

8. Kepastian dan kebocoran

9. Partisipasi.

Pertemuan-pertemuan tersebut sukses mendorong berlangsungnya proses terbuka ke arah pengembangan strategi pengamanan nasional. Mereka juga menyoroti persyaratan utama untuk keberhasilan implementasi; i) tata kelola dan partisipasi yang baik, yang mencakup kepastian kemauan politik, dialog, dan koordinasi; ii) informasi dan peningkatan kapasitas; iii) partisipasi pemangku kepentingan, pemantauan dan penyelesaian konflik; iv) pembagian keuntungan; dan v) koordinasi kebijakan-kebijakan sektoral, misalnya, peraturan hutan (MMA 2011). Kendala utama dalam implementasi yang efektif dari kebijakan pengamanan di Brazil adalah kurangnya data dan kriteria yang jelas yang dapat digunakan untuk kepentingan pemantauan.

Meskipun perhatiannya terpusat pada masalah-masalah pengamanan, Brasil juga mengambil posisi 'menghadang' di arena internasional sesudah COP17 di Durban tahun 2011. Selama pertemuan SBSTA, Brasil menentang pelaporan internasional mengenai cara menangani dan menyikapi pengamanan REDD+. Sebagian pihak menganggap posisi ini egois, karena menghambat kemajuan negosiasi REDD+ dan bisa merusak kredibilitas REDD+ di mata investor internasional. Setiap tindakan yang menghambat pendanaan akan membahayakan negara-negara yang tidak memiliki strategi pengamanan yang memadai.

a Lokakarya ini menghasilkan 379 komentar seputar 8 prinsip dan 27 kriteria. Secara keseluruhan, proses konsultasi menghasilkan 559 pertimbangan, komentar, dan saran, yang semuanya tersedia online.

b Untuk dokumen lengkap lihat: http://www.observatoriodoredd.org.br/site/pdf/ DevelopingREDD.pdf

\subsubsection{Kapasitas nasional untuk implementasi pengamanan REDD+}

Kalau pemerintah mau terlibat dalam kebijakan pengamanan, mereka harus mampu menilai hasil sosial dan lingkungan di tingkat nasional. ${ }^{7}$ Selain itu, saat membuat komitmen tingkat nasional untuk pengamanan internasional, negara harus memberikan indikator perubahan yang setara pada bidang-bidang utama, sebagaimana diartikulasikan oleh UNFCCC. Saat ini, sebagian besar negara REDD+ mengalami kesulitan dengan persyaratan minimum:

7 Sumber-sumber untuk bagian ini termasuk Dkamela (2011), May dkk. (2011b), DAR dan CIFOR (2012), Indrarto dkk. (2012), REPOA and CIFOR (2012). 
memperlihatkan bahwa deforestasi dan degradasi hutan berkurang. Kedua pengamanan ini baru bisa dipantau dengan baik bila mereka menambah kapasitas untuk MRV, yang mencakup masalah kebocoran dan kelestarian. Namun demikian, tantangan untuk melakukan perhitungan tingkat nasional tentang dampak sosial dan manfaat tambahan keanekaragaman hayati tidak banyak mendapat perhatian di sebagian besar negara REDD+. Data yang dikumpulkan oleh GCS memberikan profil untuk lima negara REDD+ (Brasil, Kamerun, Indonesia, Tanzania, dan Vietnam), yang meliputi perhitungan tingkat kapasitas mereka untuk implementasi, pemantauan, dan pelaporan seputar bidang-bidang tematik utama pengamanan REDD+ (kesejahteraan sosial, keanekaragaman hayati, kelestarian, dan kebocoran).

Negara-negara yang dikaji sepertinya memiliki kapasitas rendah untuk memantau dampak sosial dan keanekaragaman hayati. Kecuali Tanzania, perjanjian pembagian keuntungan masih belum diartikulasikan, sehingga sulit untuk mengevaluasi hasil kesejahteraan yang terkait dengan REDD+. Di samping itu, sebagian besar negara mengalami kesulitan menafsirkan FPIC. Di Indonesia, FPIC adalah suatu prakondisi untuk keterlibatan masyarakat dalam REDD+; namun, FPIC perlu didefinisikan dulu untuk menilai apakah FPIC sudah tercapai atau belum. Sebagai catatan positif, ada bukti partisipasi aktif dalam kebijakan REDD+ di tingkat nasional. Brasil, Indonesia, dan Tanzania telah mencapai keterlibatan yang berarti dari pemangku kepentingan dalam diskusi kebijakan terkait keuntungan bersama di bidang sosial dan keanekaragaman hayati, meskipun diskusi seputar pemantauan dampak keanekaragaman hayati dari REDD+ masih dalam tahap perencanaan. Sebagai contoh, Strategi REDD+ Indonesia menghendaki pembangunan sistem MRV nonkarbon yang mencakup keanekaragaman hayati.

Brasil, Indonesia, dan Tanzania telah mengembangkan kapasitas untuk memantau perubahan penggunaan lahan, dan mereka berada pada tahap-tahap yang berbeda terkait penetapan tingkat rujukan dan pemberlakuan sistem nasional untuk mengidentifikasi kebocoran. Negara-negara ini adalah di antara yang paling maju dalam urusan MRV karbon dan sudah siap memantau dan melaporkan kebocoran dan kelestarian. Namun demikian, mereka masih menghadapi kendala yang harus diatasi, yang meliputi keputusan tentang frekuensi pemantauan, bagaimana mendapatkan informasi real-time tentang perubahan penggunaan lahan, dan menggunakan data yang spesifik lokasi untuk mempersempit dan mengonfirmasi kebocoran dan kepastian. Negara-negara lain (misalnya, Kamerun dan Peru) masih tertinggal dan belum mampu memantau kebocoran dan kepastian. Di samping itu, semua laporan negara mencatat adanya ambiguitas terkait kepemilikan. Kalau hak kepemilikan atas tanah, pepohonan, dan karbon tidak jelas, pengurangan deforestasi hutan secara permanen tidak mungkin dicapai (lihat Bab 6, 8, dan 9). 
Membangun kapasitas untuk menerapkan, memantau, dan menegakkan pengamanan REDD+ adalah masalah yang sangat penting, dan negara-negara dengan infrastruktur REDD+ paling maju bisa menangani kebocoran dan kepastian. Meskipun demikian, sebagian besar masih belum bisa memantau kebocoran sosial atau mengevaluasi batasan dan integritas proses perizinan dan keikutsertaan (lihat Bab 6).

\subsection{Belajar dari pengalaman proyek}

Meskipun masih pada tahap awal, banyak proyek REDD+ sudah menerapkan tujuh pengamanan UNFCCC. Bagian ini mengulas motivasi dan pengalaman proyek dengan pengamanan kesejahteraan masyarakat setempat dan keanekaragaman hayati. Tim GCS mewawancarai personel proyek untuk mengetahui sejauh mana proyek mereka memenuhi sasaran-sasaran berikut: i) menghormati hak penduduk asli dan masyarakat setempat (pengamanan UNFCCC 3); ii) memfasilitasi partisipasi penuh dan efektif dari pemangku kepentingan setempat (pengamanan UNFCCC 4); dan iii) memastikan konsistensi dengan tujuan-tujuan pelestarian dan keanekaragaman hayati (pengamanan UNFCCC 5). Data dikumpulkan dari 19 proyek di Brasil (4), Kamerun (2), Indonesia (6), Tanzania (6), dan Vietnam (1). Semuanya, kecuali empat proyek, melaporkan bahwa mereka sudah punya rencana untuk mendapatkan sertifikasi CCB.

\subsubsection{Mendapatkan persetujuan sukarela setelah pemberitahuan sebelumnya (FPIC)}

Meskipun FPIC tidak muncul dalam pengamanan UNFCCC, secara implisit hal ini dirujuk dalam pengamanan nomor 3: ajakan kepada para pihak untuk menghormati hak-hak penduduk asli, sesuai kerangka UN DRIP. Berdasarkan keputusan ini, negara-negara anggota harus mendapatkan FPIC untuk kegiatan-kegiatan yang memengaruhi lahan hak milik adat, yang dihuni dan/ atau digunakan oleh penduduk asli. Standar CCB mengharuskan proyek mendapatkan FPIC dari seluruh masyarakat setempat (asli atau bukan). Saat ditanya seputar perolehan FPIC, kebanyakan tim proyek sudah mendapatkan atau merencanakan untuk mendapatkan FPIC (50 dari 59 desa dalam sampel GCS). Sembilan proyek memberikan informasi seputar jenis persetujuan yang diperoleh (atau direncanakan), sebagian besar mendapat persetujuan melalui perjanjian lisan dan hanya dua secara tertulis. Lima dari sembilan proyek berkonsultasi dengan subkelompok sebagai bagian dari proses FPIC.

Skala proyek sepertinya memengaruhi besarnya perhatian pada FPIC, khususnya definisi orang atau kelompok yang memberikan persetujuan serta penyebaran informasi tentang suatu proyek. Tim untuk proyek yang lebih besar, yang sebagian di antaranya meliputi seluruh provinsi atau beberapa kabupaten atau kota administratif, berusaha mendapatkan izin dari pemerintah di tingkat 
negara dan kabupaten, termasuk dari lembaga pemerintah, masyarakat, dan sektor industri. Proyek berskala lebih kecil (kelurahan atau kota) biasanya meminta persetujuan dari lembaga di tingkat desa atau dari masyarakat sendiri melalui rapat desa. Satu proyek menyewa pengacara untuk masyarakat dan mendorong mereka untuk mencari nasihat independen sebelum bertindak. Proyek yang lebih besar cenderung memberitahu masyarakat melalui lokakarya dengan para pemangku kepentingan, sementara proyek yang lebih kecil menggunakan media lokal (terutama radio), serta penyebaran poster dan selebaran serta sesi tanya jawab.

Motivasi untuk menjalankan FPIC dibagi menjadi tiga kategori: i) menegakkan hak asasi manusia; ii) mematuhi aturan atau lembaga formal seperti standar sukarela (misalnya, CCB) atau hukum nasional (misalnya, UU Tanah Tanzania); dan iii) mengurangi deforestasi dan degradasi hutan. Sebagaimana ditunjukkan dalam Gambar 17.1, pencapaian tujuan karbon hutan (keberhasilan) dan penegakan hak asasi manusia adalah motivasi utama. Sejalan dengan penekanan pada hak (gagasan, lembaga formal) dan keefektifan (kepentingan), beberapa perwakilan proyek menyatakan bahwa FPIC tidak pernah bisa sepenuhnya diperoleh karena FPIC adalah "sebuah proses dan bukan peristiwa" dan "menurut definisinya persetujuan ini tidak pernah berakhir".

Persyaratan pengungkapan informasi dan biaya transaksi terkait FPIC bisa menimbulkan masalah. Staf proyek mengalami kesulitan untuk mendapatkan orang dalam jumlah yang memadai untuk menghadiri rapat penyuluhan. Mereka juga mengalami kesulitan untuk mendapatkan sumberdaya keuangan dan waktu untuk proses partisipasi, terutama untuk memastikan bahwa informasi proyek sampai ke tiap rumah tangga secara tepat waktu. Seorang perwakilan proyek mencatat bahwa, meskipun sudah menandatangani perjanjian dan membangun kepercayaan yang cukup besar, "FPIC adalah sebuah mimpi yang mustahil" dan "sesungguhnya sangat sulit dipenuhi". REDD+ yang baru lahir ini menjadi tantangan yang lebih besar karena FPIC meminta orang untuk menyetujui sesuatu yang masih terus berubah dan masih menyimpan sejumlah pertanyaan terkait kompensasi atas perubahan pemanfaatan lahan.

\subsubsection{Keterlibatan masyarakat dalam rancangan proyek}

Sebagian besar proyek (16 dari 18) melibatkan masyarakat setempat dalam rancangan dan implementasinya. Misalnya, dalam mengidentifikasi pemicu deforestasi dan degradasi hutan, pengembangan skenario dasar, dan pengambilan keputusan tentang intervensi yang tepat serta kegiatan mata pencaharian alternatif. Di salah satu proyek, masyarakat setempat membantu penyusunan kata-kata dalam kontrak. Pertemuan pemangku kepentingan 


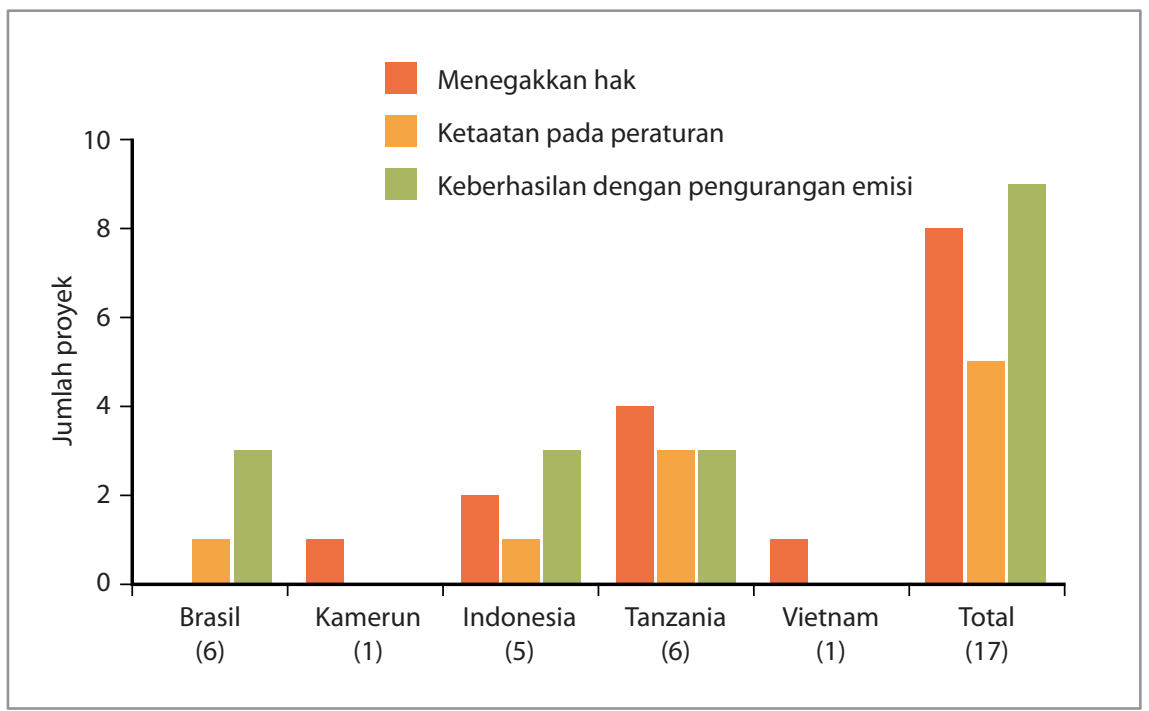

\section{Gambar 17.1 Motivasi proyek untuk mendapatkan FPIC: Hak, peraturan, dan keberhasilan}

Catatan:Tidak ada data untuk satu proyek di Kamerun dan satu proyek di Indonesia. Jumlah proyek di dalam tanda kurung.

yang diselenggarakan oleh proyek Acre di Brasil menyebabkan rancangan proyek dibongkar total, proyek yang spesifik lokasi diganti dengan program yang lebih menyeluruh, mencakup negara bagian dan mengubah penekanan dari pembayaran menjadi insentif untuk berbagai jasa lingkungan. Tantangan utamanya adalah: mengidentifikasi para pemimpin yang benar-benar mewakili masyarakat/sektor; memastikan masyarakat setempat punya suara yang berarti dalam pengambilan keputusan; dan mendapatkan sumberdaya finansial yang diperlukan untuk partisipasi penuh, terutama dalam upaya menjangkau penduduk yang nomaden.

\subsubsection{Tujuan keanekaragaman hayati dan pelestarian alam}

Sebagian dari data survei menjelaskan bagaimana proyek-proyek REDD+ menangani masalah-masalah terkait keanekaragaman hayati dan pelestarian alam. Sepuluh proyek - Brasil (1), Kamerun (2), Indonesia (2), Tanzania (4), dan Vietnam (1) - melaporkan bahwa lokasi mereka dipilih untuk mempertimbangkan masalah-masalah keanekaragaman hayati dan pelestarian alam. Meskipun demikian, hanya lima - Indonesia (1), Tanzania (3), dan Vietnam (1) - merencanakan untuk mencapai sasaran pengelolaan hutan dengan sasaran pelestarian atau regenerasi spesies tertentu. 


\subsection{Sejumlah tantangan dan pilihan untuk pengamanan REDD+}

Analisis ini menyoroti beberapa tantangan dan pilihan untuk keberhasilan implementasi pengamanan REDD+. Masyarakat kebijakan hutan global saat ini tengah menantikan penyelesaian pengamanan REDD+ oleh UNFCCC dan standar lainnya yang diakui secara internasional serta panduan yang terkait dengan pemantauan dan pelaporan kemajuan ke arah pencapaiannya.

\subsubsection{Tantangan}

Analisis kami menunjukkan sejumlah tantangan bagi pengamanan REDD+ saat diformalkan dan diintegrasikan dengan kebijakan REDD+ nasional.

Penyelarasan horizontal: Kebijakan pengamanan REDD+ harus diselaraskan dengan kebijakan pengamanan internasional lainnya (misalnya, CBD). Namun demikian, proses penyelarasan pengamanan lintas sektor dan ranah kebijakan menambah biaya transaksi untuk pengembangan dan implementasinya.

Penyelarasan vertikal: Ada tumpang tindih antara pengamanan dan standar REDD+ di tingkat internasional, nasional, dan proyek. Hal ini perlu dieksplorasi dengan cara yang produktif sehingga meminimalkan biaya transaksi dan menggunakan data dan indikator yang sudah ada seefektif mungkin.

Kedaulatan: Memutuskan sejauh mana suatu negara harus memiliki otonomi atas kebijakan sosial dan lingkungan.

Kapasitas: Ada heterogenitas yang cukup tinggi dalam hal kapasitas untuk memantau dan melaporkan pengamanan pada skala nasional. Meskipun pengembangan kapasitas untuk memantau dan melaporkan kebocoran dan kepastian menunjukkan kemajuan, sistem pemantauan tingkat nasional yang menunjukkan bagaimana REDD+ memengaruhi pengamanan tata kelola, kesejahteraan, dan keanekaragaman hayati masih tertinggal.

Biaya: Biaya tinggi diperlukan untuk menerapkan pengamanan sosial dan keanekaragaman hayati, termasuk FPIC, membina keikutsertaan, dan memantau keanekaragaman hayati. Karena itu kalau terlalu tinggi, biayanya bisa menjadikan REDD+ tidak layak lagi.

Masalah yang diabaikan: Beberapa masalah besar - terutama hak lahan, pepohonan, dan karbon (Bab 8) - tidak ditangani dengan memadai. Kurangnya perhatian pada kebijakan pengamanan internasional bisa berimplikasi pada hasil sosial dan lingkungan. Diperlukan kejelasan, khususnya mengenai apa yang sedang diamankan (hutan, pepohonan, karbon, mata pencaharian, atau keanekaragaman hayati) dan untuk siapa. 


\subsubsection{Pilihan}

Terlepas dari semua tantangan besar tersebut, ada peluang bagi keberhasilan pengamanan REDD+. Dengan menggunakan kerangka 4I, jalur-jalur pendekatan berikut ini diusulkan untuk langkah kebijakan.

Membina pengamanan sebagai norma yang universal: Sekalipun pemantauan dan pelaporan pengamanan internasional dan nasional bersifat sukarela, sebagian besar negara tidak akan menyimpang terlalu jauh dari normal bagaimana pun kondisi nasional mereka. Jika pasar karbon sukarela lepas landas, norma ini akan semakin dijunjung tinggi.

Menyeimbangkan kepentingan berbagai pelaku: Pelaksana proyek dan pemerintah nasional ingin menghasilkan karbon yang tidak membahayakan atau yang membawa manfaat sosial dan lingkungan. Para investor yang melindungi reputasi mereka, dan pihak-pihak yang berkepentingan dengan kesejahteraan atau pelestarian, mendukung kebijakan pengamanan. Kedua kelompok ini ingin meminimalkan biaya dan memaksimalkan keuntungan. Sinergi yang nyata ini harus dipantau dalam waktu dekat dan difasilitasi untuk mempertahankan insentif yang mendukung pengamanan sosial dan lingkungan.

Dari gagasan normatif ke praktik kebijakan: Masalah pengamanan dan implementasinya mendapat perhatian di sejumlah negara REDD+, di mana berbagai forum diskusi membantu menyampaikan informasi tentang proses kebijakan. Wacana tingkat nasional tentang pengamanan harus didorong dan didukung. Brasil telah mencapai kemajuan besar, tapi pengalaman ini masih belum berpengaruh di arena global.

Meningkatkan informasi: Masih banyak yang harus dipelajari dari pengalaman proyek, dialog tingkat nasional, dan sumberdaya alam serta prakarsa lainnya terkait iklim. Namun informasi tentang cara mengembangkan, menerapkan, memantau, dan melaporkan pengamanan perlu dibagikan. Standar REDD+ sukarela pada skala nasional dan skala proyek tengah diadopsi secara luas. Standar ini juga menetapkan etos untuk manfaat bersama dalam hal kesejahteraan dan keanekaragaman hayati serta persyaratan untuk mengumpulkan informasi seputar status pengamanan di seluruh siklus proyek. 



\section{Bab 18}

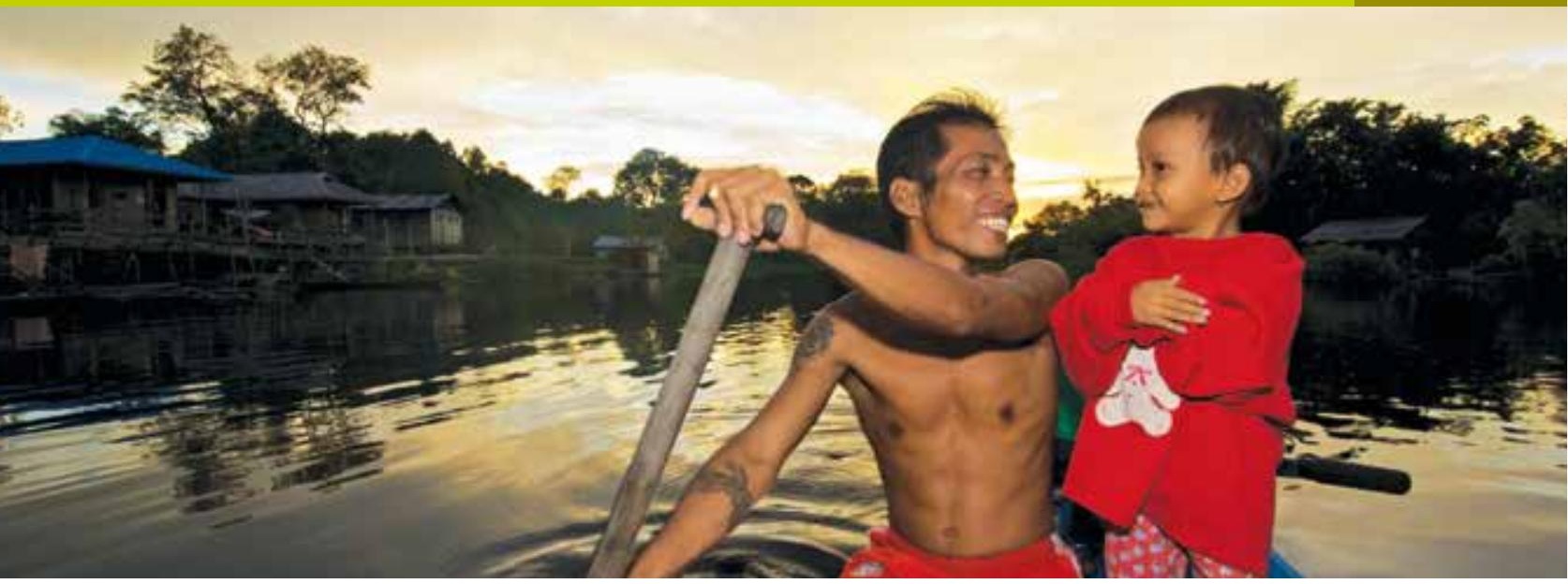

\section{Ringkasan dan kesimpulan REDD+ tanpa penyesalan}

Frances Seymour dan Arild Angelsen

- Berbagai perubahan dalam REDD+ selama lima tahun terakhir telah mengarah ke pergeseran yang penting dalam hal ukuran dan komposisi pendanaan dan perkiraan kecepatan dan biaya implementasinya, serta pencabangan minat di kalangan semua pelaku dan berbagai tingkatan. Tantangan yang berasal dari perubahan ini termasuk bertambahnya pendanaan dari anggaran bantuan internasional (bukan dari pasar karbon), masalah penahapan yang dihadapi para pemrakarsa proyek dan ketidakpastian imbalan dari upaya REDD+ oleh negara-negara dan berbagai komunitas berhutan.

- Berbagai pelajaran yang didapat dari generasi awal inisiatif REDD+ mencakup pentingnya skala yurisdiksi di antara tingkat nasional dan tingkat lokal dalam hal pengambilan keputusan penggunaan lahan, kebutuhan koordinasi lintas skala untuk menangani isu-isu seperti penguasaan lahan, pembagian keuntungan dan pemantauan, serta ketahanan minat dan lembaga-lembaga yang terkait dengan kegiatan bisnis seperti biasa.

- Untuk melangkah maju, berbagai sasaran REDD+ harus diperjelas dan strateginya dikembangkan untuk menjembatani kesenjangan pendanaan yang muncul karena kurangnya kesepakatan iklim internasional baru. 
Sambil menanti kepastian yang lebih besar bagi masa depan prioritas REDD+, reformasi kebijakan "tanpa penyesalan" yang diinginkan harus mendapat prioritas, tanpa memedulikan sasaran iklim. Demikian pula dengan pengembangan konstituensi dan kapasitas yang pada akhirnya sangat penting bagi keberhasilan REDD+.

\subsection{Pengantar}

Bab-bab sebelumnya telah menyajikan pandangan sekilas mengenai keadaan REDD+ sekarang dan meringkaskan temuan awal Studi Komparatif Global (GCS) CIFOR mengenai REDD+ dari arena kebijakan nasional terpilih dan berbagai lokasi proyek. Bab ini menyajikan ringkasan dan sintesis tema-tema utama yang muncul dari bab-bab sebelumnya dan mengembangkannya untuk menghadapi berbagai tantangan dan pilihan yang dihadapi para perumus kebijakan, praktisi dan peneliti REDD+.

REDD+, dan konteks di mana REDD+ beroperasi, telah mengalami banyak perubahan penting sejak resmi menjadi bagian agenda perubahan iklim internasional dalam COP11 tahun 2005. Namun yang terpenting, kesepakatan internasional mengenai iklim belum tercapai (Bagian 18.2). Konteks yang berubah ini memiliki implikasi besar bagaimana REDD+ akan berkembang selama tahun-tahun mendatang (Bagian 18.3). Sebagai tambahan, beberapa pelajaran dapat ditarik dari generasi pertama proyek-proyek dan reformasi kebijakan REDD+ (Bagian 18.4). Ketidakpastian mengenai masa depan REDD+ ini mungkin menyebabkan tidak adanya tindakan, tetapi kami mendebat bahwa sejumlah besar reformasi kebijakan REDD+ "tanpa penyesalan" akan berarti, bagaimanapun masa depan REDD+ dan harus diimplementasikan untuk mencapai berbagai sasaran yang lebih dari hanya mitigasi iklim (Bagian 18.5). Akhirnya, kami menyajikan beberapa pikiran yang merupakan kesimpulan mengenai REDD+ (Bagian 18.6).

\subsection{Berbagai perubahan pada konteks REDD+}

Gagasan mengenai menghindari deforestasi sebagai sebuah strategi mitigasi perubahan iklim diajukan dan ditolak dalam negosiasi UNFCCC terkait dengan Protokol Kyoto tahun 1997. Sebagai akibatnya, berbagai kegiatan terkait hutan yang termasuk dalam Mekanisme Pembangunan Bersih (CDM) terbatas pada aforestasi dan reforestasi. Satu dekade kemudian, sejumlah perubahan memungkinkannya untuk memasukkan apa yang kemudian dikenal sebagai REDD+ dalam Peta Jalan Bali di COP13 tahun 2007. Perubahan-perubahan ini mencakup:

- Perubahan dalam kerangka politik ketika reduksi emisi sekali lagi diajukan dalam negosiasi COP11 tahun 2005, hal ini dilakukan demikian oleh negara-negara berkembang dan dalam konteks aksi nasional, dengan demikian menjembatani pemisah Utara-Selatan. 
- Suatu perasaan mendesak dan pentingnya untuk memasukkan deforestasi dan degradasi hutan, setelah Laporan Penilaian Keempat oleh IPCC (IPCC 2007c) pencerahan mengenai kepentingan emisi dari perubahan penggunaan lahan.

- Publikasi analisis menekankan biaya rendah dalam pengurangan emisi dibandingkan berbagai pilihan mitigasi lainnya.

- Peningkatan dalam teknologi, yang menjadikan metodologi tersedia untuk mengukur perubahan dalam emisi dari deforestasi dan, setidaknya secara potensial, dari degradasi hutan.

Jadi, gagasan mengenai REDD + mulai terbentuk sebagai sebuah strategi mitigasi perubahan iklim yang dapat dipromosikan sebagai efektif, efisien dan setara.

Dalam putaran awal menuju COP15 di Kopenhagen tahun 2009, ketika sebuah kesepakatan baru mengenai iklim internasional pasca-2012 masih memungkinkan, ada pandangan bahwa REDD+ merupakan salah satu dari isu yang jarang, yang menawarkan sesuatu untuk semua orang: pengurangan emisi secara menyeluruh untuk tingkat pembiayaan global untuk mitigasi, offset efisiensi biaya untuk negara-negara industri, aliran dana baru yang signifikan untuk negara-negara berkembang dan, bila dirancang dengan benar, manfaat tambahan berupa konservasi keanekaragaman hayati dan pengurangan kemiskinan. Secara luas ada harapan bahwa penyejajaran kepentingan pada tingkat global ini akan mengarahkan pada pengikatan kesepakatan pasca-2012, termasuk pendanaan REDD+ berbasiskan kinerja. Dana yang akan mengalir menciptakan insentif bagi kebijakan REDD + nasional dan proyek-proyek lokal dengan dua tahap (tier), imbalan jasa lingkungan untuk model-model serupa PES (Angelsen dan Wertz-Kanounnikoff 2008).

Tiga tahun kemudian, pandangan terhadap REDD+ menjadi sangat berbeda.

Harapan sebelum Kopenhagen mengenai bagaimana REDD+ akan terlaksana belum tercapai. Sebagiannya, hal ini merupakan akibat kegagalan komunitas global untuk mencapai kesepakatan iklim menyeluruh di COP15 untuk mengganti Protokol Kyoto, dan sekarang tidak akan melakukan hal ini, setidaknya sebelum tahun 2015 (Bab 3). Prospek pendanaan REDD+ yang signifikan dihasilkan oleh pasar karbon di bawah kesepakatan semacam itu secara berpadanan telah ditolak. Sementara berbagai negosiasi terus membuat riap kemajuan pada arsitektur global REDD+, kepentingan relatif UNFCCC sebagai pendorong top-down dari pendanaan dan peraturan yang diperlukan telah berkurang secara signifikan. Sebagai akibatnya, sekarang ada banyak arena kebijakan REDD+ yang diisi oleh lembaga-lembaga bantuan, LSM internasional berskala besar dan berbagai pelaku domestik. Para pelaku di arena tersebut sering bersaing untuk pendanaan, kepemimpinan dalam penetapan standar dan pengaruh atas wacana mengenai pendefinisian REDD+. 
Seperangkat perubahan lain timbul dari fakta bahwa REDD+ muncul tepat pada saat dunia memasuki suatu periode gejolak ekonomi dan keuangan. Pada pertengahan tahun 2000-an, ekonomi global mengalami ledakan harga komoditas, ketika harga-harga untuk pangan, bahan bakar dan logam mencapai tingkat yang belum pernah terjadi. Harga yang tinggi untuk berbagai komoditas ini - dan ketakutan mengenai ketidakamanan pangan dan energi - mengarah pada serbuan global untuk mengamankan akses atas lahan untuk pertanian dan pengembangan pertambangan mineral (Bab 4). Persaingan yang meningkat untuk lahan berhutan mungkin akan menaikkan biaya-biaya REDD+ dan melampaui kecepatan perbaikan perencanaan tata guna lahan yang diperlukan untuk REDD+ agar dapat dianggap sebagai pilihan. Kemudian, krisis keuangan global yang menghantam pada tahun 2008 mengalihkan perhatian dari perubahan iklim; tekanan atas anggaran nasional mungkin menjadi kendala bagi ukuran dana bantuan yang tersedia untuk menjembatani kesenjangan pendanaan REDD+ karena kesepakatan internasional mengenai perubahan iklim belum tercapai.

\subsection{Implikasi konteks yang berubah}

Perubahan konteks REDD+ telah melambatkan laju implementasi dan mengundang tingkat ketidakpastian yang lebih tinggi mengenai mekanisme realisasi gagasan semula.

\subsubsection{Proses peralihan pendanaan dari pasar karbon menjadi dana bantuan REDD+}

Karena prospek pendanaan berskala besar berbasiskan pasar untuk REDD+ sampai sekurangnya tahun 2020 tertunda, dominasi berbagai lembaga dan sumber-sumber pendanaan saat ini yang terkait dengan bantuan pembangunan tradisional tampaknya akan berlanjut untuk beberapa tahun ke depan. Kondisi ini memiliki sejumlah implikasi bagi REDD+, termasuk berbagai sasarannya yang meluas, dan jenis-jenis intervensi dan kriteria kinerja (Bab 13). Selain itu ada risiko pengulangan berbagai kesalahan di masa lalu yang terkait dengan bantuan pembangunan (Bab 7). Sementara sudah ada beberapa percobaan baru dengan model bantuan pembayaran di tempat, kebijakan dan prosedur lembaga bantuan - dan dalam kasus tertentu masalah politik dan prosedur penganggaran bantuan pendanaan pembangunan di negara-negara donor - mungkin tidak cocok lagi dengan sistem pembayaran berbasiskan hasil yang dibayangkan untuk REDD+.

Peran pendanaan REDD+ telah terbukti menimbulkan ketidaknyamanan bagi lembaga-lembaga donor, misalnya dalam kasus peran Bank Dunia sebagai saluran dana Norwegia untuk Guyana. Sebagaimana diuraikan dalam Bab 13, kebutuhan akan indikator kinerja belum lama ini mendapat perhatian, khususnya untuk dua fase pertama implementasi REDD+ nasional. Dalam fase ini ruang lingkup ketidaksepakatan mengenai standar 
yang layak dan proses untuk mengukur pencapaiannya juga meluas. Risiko bahwa kemitraan yang baik lebih dihargai daripada kinerja yang aktual mengancam keefektifan dan efisiensi REDD+.

Kebergantungan pada dana bantuan pembangunan untuk REDD+ juga menciptakan lingkup yang lebih luas, mencakup berbagai sasaran pembangunan, yang mengarah pada pengurangan penekanan pada perlindungan iklim melalui reduksi emisi dan peningkatan penekanan manfaat tambahan, khususnya pengentasan kemiskinan. Dari segi politik, REDD+ dalam kerangka donor-penerima bantuan - bukannya sebagai transaksi antara para mitra yang setara dalam konteks suatu kesepakatan internasional - menciptakan dinamika politis domestik yang tidak menguntungkan di negara-negara penerima dan membangkitkan kekhawatiran mengenai kedaulatan.

Bila faktor-faktor tersebut disatukan, peralihan pendanaan dari pasar karbon menjadi dana bantuan pembangunan untuk REDD+ semakin lama semakin mengarah pada pemisahan pendanaan REDD+ dari pembayaran berbasiskan kinerja untuk pengurangan emisi, yang merupakan inti gagasan semula. Pembayaran berbasiskan kinerja untuk manfaat tambahan terikat erat dengan sasaran REDD+ - misalnya memperkuat hak penguasaan masyarakat atas lahan - menawarkan satu jalur yang mungkin untuk mempertahankan kaitan tersebut. Berbagai kebijakan dan proyek REDD+ akan semakin beragam, seperti bantuan pembangunan itu sendiri, dan hanya dapat dipersatukan dengan menempatkan pengurangan emisi sebagai salah satu dari beberapa sasaran.

\subsubsection{Masalah penahapan}

Sejumlah besar pemrakarsa proyek publik, swasta dan LSM mematuhi ajakan Rencana Aksi Bali 2007 untuk Para Pihak agar menjalankan kegiatan-kegiatan percontohan REDD+. Lebih dari 200 proyek REDD+ sekarang sedang berjalan di sekitar 34 negara (Bab 12). Para pemrakarsa proyek bersemangat untuk melangkah maju secepat mungkin, agar dapat menempatkan inisiatif mereka untuk memanfaatkan pendanaan REDD+ yang diharapkan sesudah COP15 tahun 2009.

Kegagalan untuk menandatangani kesepakatan iklim yang menyeluruh dan pengembangan kebijakan REDD+ tingkat nasional yang relatif lambat telah membuat posisi proyek-proyek ini genting dalam banyak hal. Sebagaimana diuraikan dalam Bab 10, ketidakpastian pendanaan REDD+ membuat sejumlah pemrakarsa proyek mengurangi risiko untuk melakukan kesalahan dengan menggeser fokus upaya mereka ke kegiatan proyek konservasi dan pembangunan terpadu tradisional (ICDP). Pendekatan semacam ini berisiko memisahkan REDD+ dari PES berbasiskan kinerja dan mengulangi keberhasilan ICDP sebelumnya yang terbatas. 
Mereka juga berisiko melampaui negosiasi internasional yang berkepanjangan mengenai aturan-aturan untuk pengukuran, pelaporan dan verifikasi (MRV) dan pengamanan. Suatu penilaian atas proyek-proyek awal REDD+ menunjukkan bahwa sebagian besar metode MRV yang digunakan tidak memenuhi standar VCS (Standar Karbon Sukarela), yang dapat menjadi modal untuk standar yang akan dinegosiasikan di masa depan (Bab 14). Selain itu, ketidakpastian mendorong beberapa pemrakarsa proyek untuk menahan diri dan tidak mengungkapkan informasi sepenuhnya mengenai aliran keuangan potensial yang mungkin direalisasikan melalui REDD+. Tindakan ini berisiko untuk gagal mematuhi sepenuhnya prinsip persetujuan sukarela, yang didahului dan berlandaskan informasi lengkap. Prinsip ini mungkin dimasukkan dalam rezim pengamanan di masa depan.

Proyek-proyek perintis REDD+ awal juga menghadapi risiko karena perkembangan yang lambat dari kerangka kerja legal dan pengaturan pada tingkat nasional. Kepastian hukum mengenai siapa yang memiliki hak karbon hutan, dan kepastian pengaturan mengenai pembagian biaya dan manfaat REDD+ kepada semua tingkat dan pemangku kepentingan, tetap tidak jelas (Bab 8). Meskipun penguasaan lahan muncul sebagai isu utama di banyak lokasi proyek, ada bukti terbatas mengenai perhatian nasional yang serius, yang diperlukan untuk menyelesaikan ketidakamanan dan konflik atas lahan. Meskipun beberapa intervensi dapat diterapkan dalam kondisi sistem penguasaan lahan yang ada, dalam ketiadaan reformasi, intervensi semacam itu terbatas ruang lingkup, keefektifan dan efisiensinya, dan mungkin juga mengakibatkan distribusi hasil yang tidak setara.

\subsubsection{Berbagai negara dan komunitas dibiarkan menghadapi risiko}

Semakin tingginya ketidakpastian yang terkait dengan pengaturan waktu dan ukuran aliran dana REDD+ internasional, ditambah perubahan ekonomi yang memicu meningkatnya persaingan akan lahan berhutan, telah menggeser perhitungan risiko dan imbalan REDD+ di tingkat nasional dan lokal. Kredibilitas janji sama-sama-menang dari REDD+ (yaitu biaya-biaya pengurangan deforestasi dan degradasi hutan akan mendapat kompensasi) berada dalam bahaya akan mengalami kemerosotan.

Agar REDD+ berhasil di tingkat nasional, konstituensi ke arah perubahan transformatif harus didahulukan daripada kepentingan bisnis seperti biasa (Bab 2). Lambatnya kemajuan dalam negosiasi UNFCCC telah melemahkan tangan konstituen (prospek pendanaan internasional berskala besar dalam jangka panjang menjadi tertunda), sementara perubahan ekonomi telah memperkuat tangan pihak yang berkepentingan dengan bisnis seperti biasa (biaya kesempatan dari perlindungan hutan semakin meningkat). Ketika kondisi REDD+ memerlukan tindakan yang melampaui strategi pengembangan tanpa 
penyesalan, pemerintah yang bergerak melewati fase kesiapan menuju penentuan kebijakan dan langkah-langkah yang mengurangi deforestasi dan degradasi hutan memerlukan sumber dana yang dapat diandalkan dari pendanaan internasional jangka panjang. Namun dana ini tidak dapat disediakan oleh bantuan pembangunan pada skala yang diperlukan (Bab 7).

Sejumlah perubahan dalam konteks untuk REDD+ juga telah memengaruhi perhitungan risiko di tingkat lokal. Para pemrakarsa REDD+ telah mulai memosisikan ulang proyek-proyek mereka untuk kemungkinan aliran dana yang diharapkan tidak terwujud (Bab 10). Kekhawatiran yang dikemukakan oleh para penduduk desa di Indonesia - bahwa proyek-proyek REDD+ tidak akan mampu menghalangi perusahaan-perusahaan besar untuk mengubah hutan lokal untuk kegunaan lain - konsisten dengan pemahaman kami mengenai kekuatan-kekuatan ekonomi yang lebih luas. Pemahaman ini mengatakan bahwa para penduduk desa yang disurvei memahami proyek-proyek REDD+ adalah untuk perlindungan hutan, dengan harapan dan kekhawatiran mereka terfokus pada dampak potensialnya bagi pendapatan mereka (Bab 11). Temuan ini menunjukkan bahwa mereka tidak yakin mengenai kaitan positiflangsung antara perlindungan hutan dan mata pencaharian dalam berbagai program REDD+ yang diajukan.

\subsection{Pelajaran dari inisiatif REDD+ generasi pertama}

Berbagai perubahan dalam konteks inisiatif REDD+ generasi kedua tidak terbatas pada perubahan yang dihasilkan dari kondisi status negosiasi UNFCCC dan ekonomi global. Selain itu, pengetahuan baru (atau yang diakui sebagai baru) dan pemahaman yang berasal dari inisiatif REDD+ generasi pertama juga sedang bermunculan.

\subsubsection{REDD+ menelan biaya lebih banyak dan memakai lebih banyak waktu daripada yang diharapkan}

Implementasi berbagai inisiatif REDD+ menelan biaya lebih banyak dan waktu lebih panjang daripada yang semula diharapkan. Mungkin tidak mengejutkan bagi mereka yang berpengalaman dengan sistem kelembagaan dan tata kelola yang khas di sektor kehutanan negara berkembang, banyak target dan garis waktu REDD+ yang diumumkan pada tahun 2007 terbukti tidak realistis. Khususnya, waktu yang diperlukan untuk konsultasi dan pembangunan konsensus pemangku kepentingan tampaknya sering dianggap ringan (Bab 7).

Forest Carbon Partnership Facility (FCPF) pada mulanya menawarkan hibah sebesar AS \$3,6 juta per negara untuk kegiatan kesiapan REDD+, berdasarkan perkiraan awal biaya untuk mengembangkan strategi dan sistem pemantauan REDD+. Perkiraan ini kontras dengan berbagai proposal negara 
yang kemudian meminta rata-rata AS \$15-20 juta, mencerminkan kisaran kegiatan yang meluas dan mendalamnya pemahaman berbagai negara mengenai persyaratan REDD+, seperti perhatian yang lebih besar untuk penataan kelembagaan untuk mengelola dana REDD+, pengamanan sosial dan lingkungan hidup dan konsultasi pemangku kepentingan (komunikasi pribadi, Ken Andrasko, Bank Dunia FCPF).

Sebelumnya kami telah mengenali dilema bahwa "REDD+ bersifat mendesak... tetapi tidak bisa diburu-buru" (Seymour dan Angelsen 2009). Kebutuhan akan kepemilikan nasional (Bab 5) mengharuskan REDD+ didasarkan pada proses politik domestik yang sah. Berdasarkan kondisi ketidakpastian yang terus berlangsung dalam kaitannya dengan kontur rezim internasional, perubahan transformatif di tingkat nasional tampaknya tidak akan berlangsung cepat dan mudah. Karena itu, komunitas REDD+ dihadapkan dengan ironi bahwa, meskipun pendanaan jangka panjang merupakan masalah penting, para donor menghadapi kesulitan untuk membelanjakan uang dengan cepat pada awalnya (Bab 7). Adanya tekanan internal dan eksternal bagi lembaga-lembaga donor untuk menggerakkan uang dapat ditafsirkan sebagai tanda positif bahwa keterkaitan dana REDD+ dengan kinerja dianggap serius.

Selain kerangka waktu yang lebih lama dari yang diharapkan untuk proses pengambilan keputusan REDD+, berbagai kesenjangan ketersediaan data dan kapasitas untuk mendukung persyaratan teknis REDD+ ternyata lebih besar dari yang semula dipikirkan. Meskipun ada kemajuan teknologi yang membantu menggerakkan deforestasi di negara-negara berkembang kembali ke meja negosiasi UNFCCC antara Para Pihak di Kyoto dan Bali, dan fokus investasi kesiapan REDD+ dalam MRV, berbagai kesenjangan tetap bertahan (Bab 14). Sebagian besar negara berhutan belum memiliki data, kapasitas, atau kemauan politik (misalnya, membagi dan mengungkap data) yang mereka perlukan untuk sepenuhnya mendukung sistem imbalan berbasiskan kinerja.

Saat ini sudah ada kemajuan dalam penerapan teknologi penginderaan jauh untuk mendeteksi deforestasi dan degradasi hutan. Namun data yang diperlukan untuk menghitung faktor-faktor emisi yang diperlukan untuk menerjemahkan perubahan kondisi hutan menjadi perubahan emisi kesemuanya masih belum ada untuk wilayah-wilayah hutan luas di dunia (Bab 15). Sudah ada kemajuan konseptual menuju penetapan tingkat emisi acuan yang kuat (REL), tetapi kemajuan dalam berbagai negara berjalan lambat, karena kurangnya data dan ketidakpastian bawaan dalam memperkirakan skenario emisi bisnis seperti biasa (Bab 16). Meskipun ada investasi dalam kegiatan kesiapan, sejauh ini baru ada sedikit peningkatan kapasitas teknis lembaga yang bertanggung jawab untuk MRV.

Derap yang lebih lambat dari yang diharapkan dan biaya yang lebih tinggi dari yang diperkirakan juga memiliki implikasi bagi politik REDD+ di tingkat nasional, baik di negara donor maupun di negara REDD+, yang 
membuat para pemrakarsa proyek bersikap defensif. Pemerintah Norwegia dan Indonesia menghadapi kritikan yang tidak nyaman ketika tenggat akhir tahun 2010 tiba dan berlalu untuk mengeluarkan moratorium konsesi hutan baru, dan baru ada pengumuman pada bulan Mei 2011. Pada awal tahun 2012, Pemerintah Australia menghadapi kritikan dari kalangan akademisi (Obrei dan Howes 2012) dan media (Hamann 2012) mengenai keterbatasan kemajuan nyata yang dicapai sebuah proyek REDD+ berprofil tinggi di Kalimantan yang didanai oleh AusAID.

\subsubsection{Kegigihan lembaga-lembaga kepentingan dan gagasan yang menganut 'bisnis seperti biasa'}

Seperangkat pelajaran lain yang ditimba dari inisiatif REDD+ generasi pertama - meskipun tidak sepenuhnya tidak diharapkan - menyangkut kesulitan yang menantang para pelaku yang kepentingan khusus untuk bertahan dengan bisnis seperti biasa, kerumitan untuk mereformasi lembaga yang sudah ada untuk tujuan-tujuan baru - atau menciptakan lembaga baru - dan upaya yang diperlukan untuk mencabut berbagai gagasan yang sudah mapan tentang bagaimana mengelola hutan dan oleh siapa.

Sebagaimana ditunjukkan oleh analisis media yang dilaksanakan untuk GCS, wacana mengenai REDD+ di tingkat nasional telah didominasi oleh para pelaku negara, yang mungkin menyuarakan kepentingan dari sektor bisnis (Bab 5). Proposal untuk melemahkan Forest Code di Brazil, dan lingkup yang sempit dalam moratorium di Indonesia (Kotak 2.1), dapat dipahami sebagai desakan untuk mundur yang efektif dari mereka yang melihat kepentingannya terancam. Kurangnya penekanan dalam diskusi strategi REDD+ nasional mengenai kebutuhan untuk memperjelas hak penguasaan hutan dan hak-hak karbon menunjukkan penghindaran untuk melakukan perubahan yang mungkin mengancam kondisi status quo.

Kami sebelumnya telah mengamati dilema bahwa REDD+ "harus baru... tetapi dibangun di atas apa yang telah ada sebelumnya" (Seymour dan Angelsen 2009). Dilema ini khususnya gawat ketika harus memilih lembaga untuk fungsi-fungsi baru REDD+. Ketika lembaga-lembaga yang ada berperan memimpin, mereka cenderung untuk mengulang pola-pola sebelumnya dalam menangani berbagai tantangan baru REDD+. Hal ini sungguh terjadi bukan hanya di tingkat internasional (misalnya, bagaimana lembaga donor multilateral telah memprogramkan dana REDD+) dan tingkat nasional (misalnya, bagaimana berbagai kementerian kehutanan telah mengadaptasi REDD+ dengan paradigma pengelolaan hutan mereka), tetapi juga di tingkat proyek, di mana berbagai LSM berorientasi konservasi telah memilih berbagai lokasi sesuai dengan sasaran-sasaran terkait keanekaragaman hayati (Bab 12), dan sedang melaksanakan berbagai kegiatan serupa ICDP (Bab 10). Bagi banyak pelaku, REDD+ telah menjadi sumber pendanaan baru untuk berbagai kegiatan yang telah ada sebelumnya, dengan sedikit perubahan label untuk menyesuaikan dengan agenda iklim. 
Namun mendirikan lembaga-lembaga baru untuk REDD+ juga sukar. Badan-badan REDD+ baru menghadapi tantangan dalam hal otoritas dan keabsahan mereka, dan proses menetapkan mekanisme keuangan REDD+ baru selama ini disertai dengan penundaan dan frustrasi (Bab 7). Pada waktu yang sama, hasil REDD+ yang positif di banyak negara ialah membuka dialog mengenai pengelolaan hutan di luar kementerian yang secara langsung bertanggung jawab, dengan satuan tugas REDD+ bertumbuh untuk melibatkan kementerian keuangan dan perencanaan, kementerian lainnya dan masyarakat madani.

\subsubsection{Sejumlah isu lintas skala}

Rangkaian pelajaran ketiga yang muncul dari inisiatif REDD+ generasi pertama terkait dengan pentingnya koordinasi lintas skala yang diperlukan untuk mencapai sasaran keefektifan, efisiensi dan kesetaraan. Penggunaan lembaga "polisentris" dalam tata kelola hutan (Ostrom 2010) dan 'pendekatan terintegrasi' untuk implementasi REDD+ (Pedroni dkk. 2007) telah lama dikenali. Pengalaman terbaru lebih jauh menerangi isu-isu dan tantangan spesifik yang memerlukan keterkaitan lintas skala, kepentingan relatif masing-masing tingkatan dalam berbagai tingkatan tata kelola untuk fungsi-fungsi yang berbeda dan keragaman di semua tingkatan ini.

Kajian atas inisiatif REDD+ generasi pertama menunjukkan bahwa banyak kesempatan yang hilang untuk saling berbagi pengalaman antara tingkat nasional dan lokal. Dalam beberapa kasus para pemrakarsa proyek tampaknya sengaja menghindari keterlibatan dengan kebijakan dan kelembagaan REDD+ tingkat nasional yang samar-samar; dengan demikian mereka kehilangan kesempatan untuk terlibat membentuknya. Di sisi lain, para perumus kebijakan REDD+ tingkat nasional tidak secara konsisten memandang pengalaman proyek tingkat lokal sebagai sumber wawasan yang terkait dengan kenyataan di lapangan.

Dengan demikian analisis yang disajikan dalam buku ini menunjukkan adanya kebutuhan untuk meningkatkan integrasi vertikal REDD+ dan upaya yang lebih baik oleh para perintis REDD+ untuk bekerja lintas skala. Bab 6 memberikan contoh-contoh rintangan yang dihadapi oleh MRV lintas skala dan upaya pengendalian kebocoran di Brasil, Indonesia dan Vietnam, tetapi juga beberapa pendekatan yang menjanjikan untuk mengatasi berbagai rintangan tersebut. Menangani berbagai kendala penguasaan hutan dalam REDD + (Bab 9) dan memastikan kepatuhan dengan pengamanan (Bab 17) akan memerlukan koordinasi yang lebih baik antara tingkat nasional dan lokal untuk menjamin bahwa kerangka kerja kebijakan didasarkan pada realitas lokal dan bahwa berbagai sasaran kebijakan-kebijakan tersebut direalisasikan di tingkat lokal.

Pembagian biaya dan manfaat mungkin merupakan ujian terbesar dalam menghadapi keefektifan tata kelola di berbagai tingkatan konteks REDD+. 
Berbagai pertanyaan mendasar terkait siapa yang seharusnya mendapat manfaat dari aliran dana REDD+ - dan atas dasar apa dan melalui bentuk kompensasi yang bagaimana - masih belum terjawab dan berbagai pemangku kepentingan yang berlainan di berbagai tingkat yang berbeda memiliki pandangan yang berbeda pula mengenai jawaban yang benar (Bab 8). Sebagaimana dibahas dalam Bab 3, kekuatan REDD+ sebagai gagasan, sebagiannya berasal dari kemampuan setiap pemangku kepentingan untuk mencanangkan visinya mengenai arti REDD+ dalam praktiknya. Mewujudkan pembagian manfaat secara spesifik akan menjadi ujian berat bagi ketangguhan gagasan ini. Karena itu memerinci pilihan dan implikasi mekanisme pembagian manfaat alternatif merupakan salah satu prioritas tertinggi untuk penelitian dan eksperimen REDD+ lebih jauh. Dan, karena tidak ada rumus sederhana atau disetujui untuk digunakan dalam mekanisme pembagian keuntungan, keabsahan prosesnya menjadi penting.

Akhirnya, pengalaman awal REDD+ telah menyoroti kepentingan skala yurisdiksi, yaitu tingkat subnasional di antara berbagai kebijakan nasional dan proyek-proyek lokal. Justru pada skala yurisdiksi tingkat menengah ini terjadi banyak pengambilan keputusan dan di mana beberapa inisiatif REDD+ yang lebih menjanjikan - seperti yang terjadi di Brasil - sedang terbentuk.

\subsection{Mencari arah masa depan REDD+ yang tidak pasti}

Ketidakpastian mengenai masa depan REDD+, sedikitnya karena kelambanan negosiasi UNFCCC secara menyeluruh dan perubahan kondisi ekonomi global, berarti bahwa REDD+ harus memiliki dasar yang semakin kuat atas kontribusinya yang menjanjikan bagi banyak sasaran di berbagai tingkatan, dan bukan hanya mitigasi perubahan iklim global. Di masa depan REDD+ juga tidak dapat bergantung pada aliran insentif dari atas untuk mendatangkan perubahan. Karena itu para pendukungnya harus menginvestasikan lebih banyak strategi dari bawah ke atas untuk membangun konstituensi ke arah perubahan yang tidak bergantung pada kesepakatan global yang mengikat atau dana yang signifikan dalam jangka waktu dekat.

Kalangan tertentu mungkin menanggapi ketidakpastian ini dengan pendekatan tunggu-dan-lihat. Kami percaya bahwa pendekatan yang lebih baik adalah mengajukan tiga pertanyaan: i) apa yang dapat dilakukan untuk membangun dukungan politik yang luas bagi REDD+? ii) apa saja tindakan dengan prioritas tertinggi untuk membangun dasar bagi keberhasilan REDD+? dan iii) tindakan-tindakan apa yang akhirnya akan tetap berguna kalau diterapkan, apa pun skenario yang akan terwujud dalam pendanaan REDD+ internasional dan perkembangan ekonomi global?

Kami membahas tiga pertanyaan tersebut dalam bagian selanjutnya. Tabel 1 menyediakan ringkasan dari prioritas tindakan, disusun menurut tingkatnya. 


\subsubsection{Membangun dukungan politik yang luas untuk REDD+}

Menata ulang kerangka REDD+ sebagai sebuah sasaran dan bukannya sebagai program kehutanan. Salah satu keberhasilan REDD+ sejauh ini adalah tingkat kesadaran yang tinggi yang diciptakannya - melampaui lingkaran kebijakan iklim dan hutan yang sempit - mengenai kepentingan emisi yang terkait hutan. Konsensus internasional bahwa emisi semacam itu harus dikurangi tetap ada, dengan atau tanpa mekanisme pendanaan spesifik di bawah UNFCCC. Karena itu sasaran ini tetap sah untuk dicakup dalam kebijakan publik di semua sektor dan tingkat. Secara khusus, pergeseran politik Utara-Selatan dalam negosiasi iklim - di mana negara-negara berpendapatan menengah diharapkan untuk menanggung lebih banyak biaya mitigasi - berarti bahwa berbagai tindakan untuk mengurangi emisi dari hutan di negara-negara tersebut tidak dapat mengharapkan kompensasi internasional penuh (Bab 3 dan 7).

Jadi, daripada membiarkan gagasan REDD+ didefinisikan sebagai program-program dalam sektor tertentu, sering terbatas di sektor kehutanan, para pendukungnya perlu menata ulang kerangka emisi dari hutan sebagai sebuah sasaran untuk dicapai dalam konteks yang lebih luas. Pendekatan semacam itu sepenuhnya konsisten dengan teks-teks UNFCCC, dan juga dengan istilah-istilah populernya yang telah memikat dana dalam konteks Rio+20 (termasuk 'pembangunan rendah karbon', 'ekonomi hijau', dan 'pertanian yang cerdas-iklim') dan pendekatan pembangunan berkelanjutan yang diwakilinya. Membebaskan REDD+ dari kungkungan sektor kehutanan - dan dari definisi yang terbatas pada pembayaran untuk pengurangan emisi terverifikasi - juga merupakan prasyarat untuk penanganan berbagai pemicu deforestasi yang bersumber dari luar suatu sektor.

Investasi untuk keabsahan politik. Meskipun ada konsensus internasional mengenai urgensi pengurangan emisi dari hutan, kemajuan negosiasi UNFCCC yang berlangsung lambat, keyakinan bahwa perlindungan hutan berlawanan dengan pembangunan, serangan-serangan yang lebih luas terhadap ilmu iklim dan kebergantungan REDD+ yang semakin meningkat pada bantuan pembangunan, semuanya mengancam keabsahan politiknya di negara-negara donor maupun penerima. Supaya keabsahannya bertahan, REDD+ perlu bergerak maju terus, dan melakukannya dengan cara-cara yang memperkuat, bukannya menganggap rendah keyakinan atas integritas dan keadilannya, baik di dalam dan di antara berbagai negara.

Di tingkat global, untuk mencapai keabsahan akan memerlukan kemajuan ke arah pengurangan emisi yang nyata, yang berarti harus menangani berbagai tantangan yang terus menghadang dalam hal kepenambahan, kebocoran dan kelestarian. Aturan-aturan yang diterima secara global mengenai acuan 
tingkat emisi dan MRV perlu didasarkan pada ilmu pengetahuan yang kokoh dan, sampai tahap yang memungkinkan, tidak dicemari oleh politik, bahkan bila penyesuaian aturan-aturannya perlu mengikutsertakan kondisi nasional untuk alasan keadilan.

Di tingkat nasional, keabsahan politis memerlukan konstituensi REDD+ yang cukup luas dan dalam agar tahan menghadapi sejumlah kemunduran yang tidak terduga ketika berbagai kebijakan REDD+ mulai menantang kepentingan bisnis seperti biasa dan skandal-skandal yang dapat terjadi - misalnya penyalahgunaan dana REDD+ - yang tidak terhindari akan menyertai tindakan di lapangan. Karena itu pengamanannya perlu mendapat perhatian serius, untuk menghindari malapetaka dan juga rusaknya reputasi REDD+. Keabsahan juga akan bergantung pada integritas mengenai proses untuk menetapkan dan melaksanakan mekanisme pembagian manfaat REDD+.

Membangun konstituensi yang lebih luas untuk REDD+. Realitas politik mengharuskan pelibatan berbagai sasaran pembangunan ekonomi dalam agenda iklim, sehingga REDD+ dapat menikmati dukungan luas dan berkelanjutan. REDD+ telah menjadi gagasan yang kuat, sebagian karena janjinya untuk mencapai sejumlah sasaran. Manfaat tambahan yang sering disebutkan mencakup keanekaragaman hayati, konservasi, pengentasan kemiskinan dan tata kelola yang lebih baik, tetapi mobilisasi konstituensi untuk sasaran-sasaran ini arena kebijakan REDD+ tidak seimbang. Bahkan, konstituensi tertentu sudah menanti untuk menentang REDD+ dengan alasan REDD+ akan mengurangi hak dan kepemilikan lahan hutan oleh masyarakat. Beberapa contoh yang jelas dari inisiatif REDD+ yang mendorong hak dan kepemilikan lahan lebih kuat, ditambah perhatian serius terhadap pengamanan, dapat membangun kepercayaan bahwa REDD+ lebih merupakan janji daripada ancaman.

Selain itu, dan konsisten dengan penataan ulang kerangka REDD+ yang dikemukakan di atas, manfaat untuk mempertahankan hutan pada skala lanskap lebih banyak mendapat perhatian. Wacana mengenai keamanan pangan terus memandang hutan sebagai rintangan bagi peningkatan produksi pertanian melalui ekstensifikasi. Karena itu diperlukan upaya yang lebih besar untuk membagikan pengetahuan yang ada dan menghasilkan pengetahuan baru mengenai layanan ekosistem dari hutan demi mendukung produktivitas pertanian. Peran hutan dalam menyangga kepentingan ekonomi dari dampak perubahan iklim - sebuah komponen utama dalam strategi untuk adaptasi - masih tetap kurang dihargai. Karena itu, menunjukkan kontribusi REDD+ bagi produktivitas pertanian dan ketahanan iklim dapat membantu melawan tuduhan yang terus berjalan bahwa perlindungan hutan itu bertentangan dengan pembangunan. 


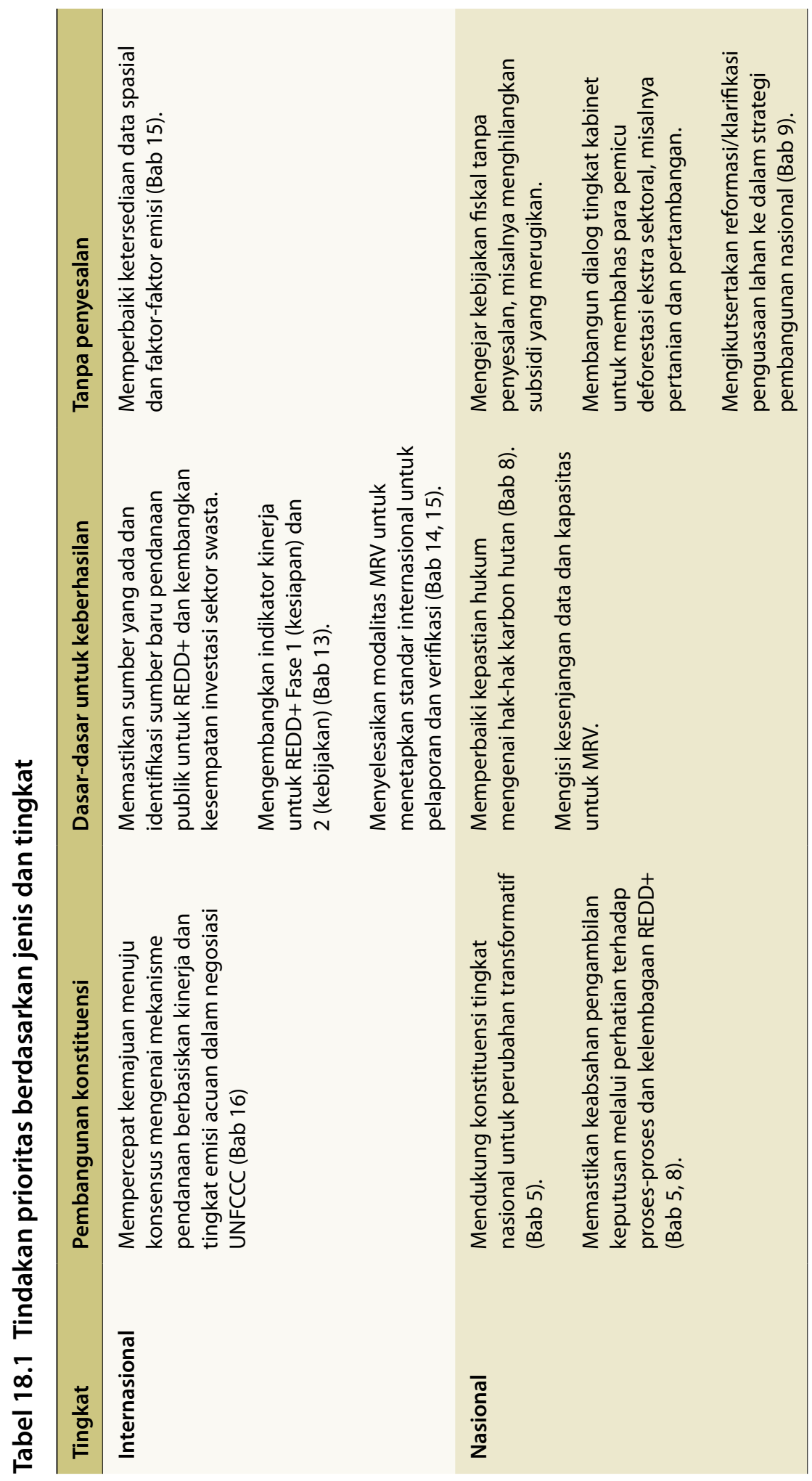




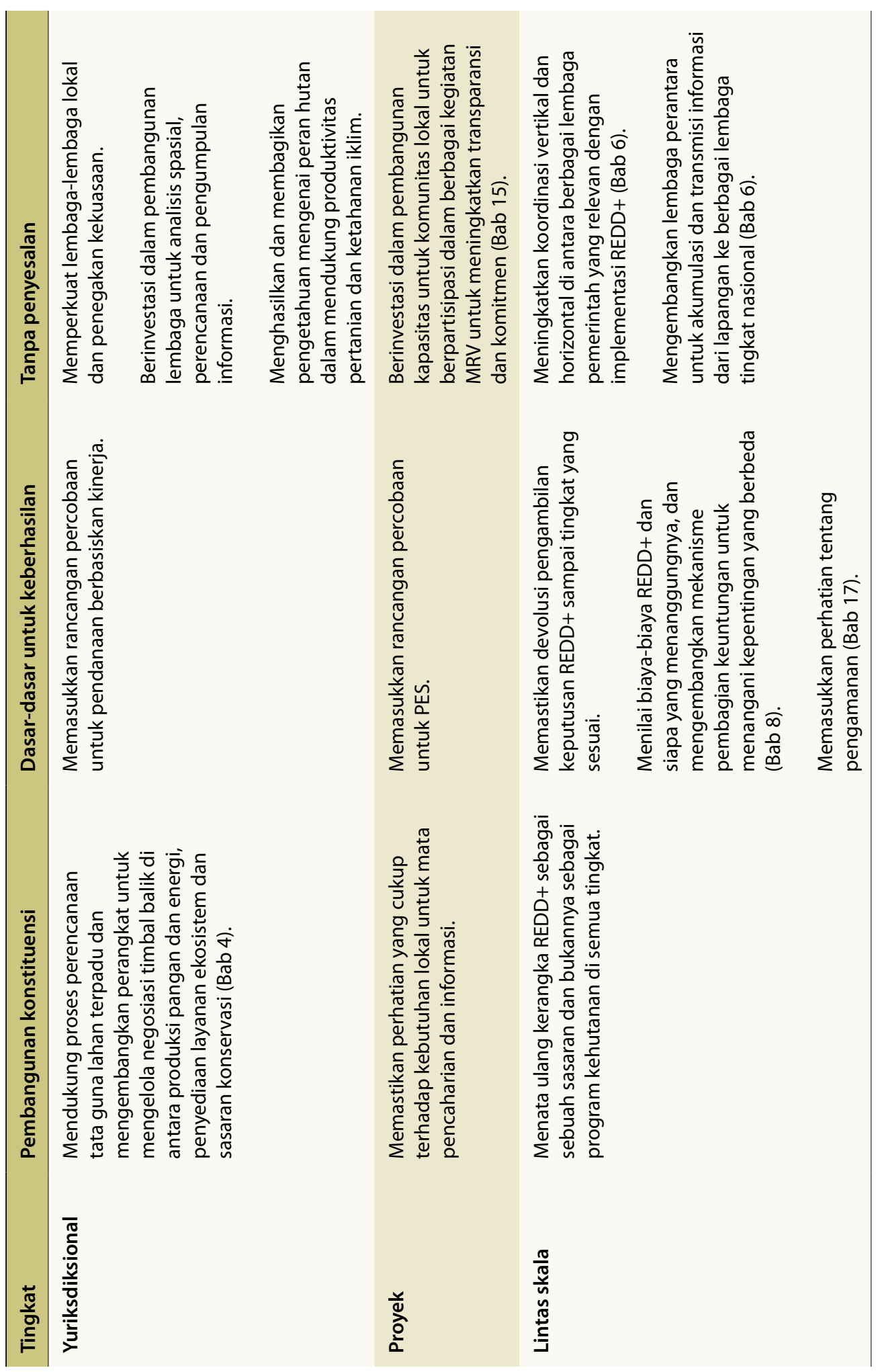




\subsubsection{Sejumlah tindakan prioritas untuk membangun dasar untuk mencapai keberhasilan}

Mempertahankan kaitan dengan PES, tetapi juga kaitan erat dengan sarana lainnya. Ada banyak alasan untuk merasa takut bahwa pelemahan pembayaran atas kinerja sebagai sifat utama REDD+ akan mengurangi keefektifannya, membuatnya tidak berbeda dengan intervensi sektor kehutanan sebelumnya (seperti ICDP) yang keberhasilan terbatas. Jadi, penting sekali untuk merangkaikan berbagai sumber dana - termasuk pasar karbon sukarela, keuangan domestik dan bantuan pembangunan - untuk menjembatani kesenjangan dalam kepatuhan pasar global yang diantisipasi untuk kredit karbon hutan dan untuk mulai mewujudkan pembayaran atas kinerja pada skala internasional/nasional dan nasional/subnasional.

Namun adanya kemungkinan pendanaan yang lebih sedikit dari yang diharapkan, setidaknya dalam jangka pendek, dan meningkatnya harga-harga komoditas yang bersaing untuk lahan yang sama, membuat REDD+ tidak dapat bergantung pada aliran dana dan instrumen PES saja. Mempertahankan tutupan hutan optimal pada tingkat lanskap - dari sudut pandang sasaran mitigasi iklim global dan konservasi keanekaragaman hayati, dan juga sasaran penghidupan lokal yang lebih banyak serta layanan ekosistem - akan memerlukan integrasi yang kokoh atas berbagai instrumen, termasuk perintah dan kendali tradisional, pendekatan penegakan hukum, insentif fiskal dan pengembangan infrastruktur yang lebih cerdas dan perencanaan tata guna lahan.

Fokus pada kemacetan utama yang menghambat kemajuan. Jumlah persoalan yang harus diselesaikan agar dapat mencapai hasil REDD+ yang efektif, efisien dan setara dapat melemahkan semangat. Karenanya, penting sekali untuk menargetkan investasi untuk menghilangkan kemacetan utama di tingkat kebijakan dan mengisi kesenjangan-kesenjangan utama dalam hal pengetahuan dan kapasitas yang dibutuhkan untuk implementasi REDD+.

Di tingkat global, para juru runding harus memberikan prioritas pada percepatan kemajuan untuk mekanisme pendanaan dan modalitas implementasi lainnya. Di tingkat nasional, para pendukung REDD+ harus berfokus pada pembangunan konstituensi ke arah perubahan kebijakan transformatif, termasuk penjangkauan bagi sektor bisnis yang sedang maju, yang sampai hari ini relatif terabaikan, dan juga terhadap konstituensi untuk reformasi penguasaan hutan. Investasi berkelanjutan dibutuhkan lintas skala, untuk merangkaikan semua komponen sistem MRV, termasuk mengisi kesenjangan saat ini dalam hal data dan kapasitas.

Menggeser penekanan relatif lintas skala dan berbagai upaya tingkat yurisdiksional. Inisiatif REDD+ generasi pertama (dan penelitian terkait) 
cenderung berfokus pada proses-proses kebijakan tingkat nasional dan proyek perintisan tingkat lokal, mungkin dengan penekanan berlebihan pada proyek-proyek dan tingkat interaksi suboptimal di antara keduanya. Ke depan, skala yurisdiksional perlu mendapat perhatian yang lebih besar, khususnya sebagai fokus proses perencanaan tata guna lahan yang penting dan ruang di mana transparansi yang lebih baik dan partisipasi publik tetap diinginkan meskipun tanpa kehadiran REDD+. Terlebih lagi, investasi lebih besar dalam berbagai mekanisme untuk memfasilitasi keterkaitan lintas skala juga diperlukan, bukan hanya dalam rancangan kebijakan dan lembaga untuk pembagian manfaat REDD+.

\subsubsection{Reformasi kebijakan tanpa penyesalan}

Ada sejumlah reformasi terkait hutan dan reformasi lainnya yang akan mewakili kebijakan publik yang baik, bahkan bila mereka tidak menghasilkan pengurangan emisi hutan sebagai manfaat tambahan. Selain itu, informasi, lembaga dan kapasitas yang diperlukan untuk REDD+ juga perlu untuk melayani sasaran-sasaran kemasyarakatan lainnya.

Memperjelas hak penguasaan lahan. Memperjelas hak ini akan mengarah pada tata guna lahan yang lebih efisien, merangsang investasi untuk meningkatkan produktivitas pertanian dan berkontribusi bagi pembangunan ekonomi. Penyelesaian konflik-konflik mengenai lahan juga akan menyingkirkan suatu sumber utama kekerasan di daerah-daerah pedesaan.

Menghapuskan subsidi yang merugikan. Para pelaku deforestasi sering merupakan penerima kredit murah, infrastruktur, pembebasan pajak dan insentif lain yang disediakan oleh negara. Penghapusan subsidi semacam ini akan mengarah ke alokasi sumberdaya yang lebih efisien dan menciptakan ruang fiskal dalam anggaran pemerintah, sambil membangun konstituensi untuk pengelolaan hutan yang lebih baik di kementerian keuangan.

Memperkuat supremasi hukum. Mengurangi peluang bagi kejahatan terkait hutan, termasuk korupsi, merupakan cara lain untuk menciptakan ruang fiskal dengan memastikan bahwa rente dari eksploitasi sumberdaya hutan diterima oleh negara. Menghentikan konversi hutan berskala besar yang ilegal melalui penegakan hukum yang ditargetkan juga membantu sasaran konservasi keanekaragaman hayati.

Meningkatkan ketersediaan data terkait hutan. Sistem data dan pengelolaan informasi yang lebih baik penting untuk perencanaan yang terinformasi, pemberian dan pemantauan izin dan tugas pengelolaan hutan lainnya.

Memperkuat kapasitas kelembagaan. Kompetensi dalam fungsi-fungsi seperti pengelolaan keuangan yang transparan, perencanaan tata guna lahan inklusif 
dan koordinasi lintas sektor dan tingkat diperlukan untuk perencanaan dan implementasi sebagian besar kegiatan pembangunan di semua tingkat.

Memperbaiki tata kelola hutan. Perbaikan tata kelola hutan secara lebih umum - termasuk transparansi, proses pengambilan keputusan inklusif dan mekanisme akuntabilitas - membantu memberdayakan konstituensi untuk kepentingan publik. Perbaikan semacam itu juga menyediakan saran untuk melindungi hak-hak dan penghidupan masyarakat hutan yang mungkin terancam oleh agen-agen konversi hutan dari luar.

\subsection{Pikiran penutup}

\subsubsection{Ciri-ciri utama REDD+ yang harus dilindungi}

Sementara gagasan mengenai REDD+ terus berubah cepat, dan ekspresi konkretnya beragam, ada manfaatnya untuk berhenti sejenak merenungkan unsur-unsur utama yang menjadikan REDD+ layak untuk dikejar dan apa saja kemungkinan risikonya. Pertama, tentu saja, adalah sasaran yang dideskripsikan oleh namanya, mengurangi emisi dari deforestasi dan degradasi hutan. Bukti yang terus bertambah bahwa planet Bumi sedang menuju perubahan iklim yang secara potensial membawa bencana menjadikan pengejaran sasaran ini sebagai sebuah keterdesakan moral.

Berikutnya adalah keterkaitan REDD+ dengan perubahan transformatif. Mencapai tujuan REDD+ bukanlah menjalani bisnis seperti biasa dalam kerja sama kehutanan internasional: intervensi teknis sedikit demi sedikit, dari penebangan dengan dampak tereduksi sampai kompor masak yang lebih baik. Sebaliknya, REDD+ mengharuskan pergeseran transformatif pada ekonomi politis hutan, menantang perusakan hutan untuk keuntungan kepentingan kelompok terbatas dengan mengorbankan kepentingan publik yang lebih luas dan komunitas hutan. REDD+ adalah menyangkut pengubahan ekonomi hutan melalui insentif baru untuk melestarikan layanan ekosistem yang penting secara global dan juga mengenai mengubah politik hutan dengan mengakui hak-hak dan norma-norma baru dalam pengambilan keputusan.

Karena itu, ciri-ciri REDD+ yang membedakannya dari berbagai upaya di masa lalu untuk mengubah tata kelola dan pengelolaan hutan adalah penting. Salah satunya adalah keterkaitan dengan kinerja: menggeser fokus dari asupan dan keluaran menjadi keluaran dan hasil adalah penting untuk keefektifan REDD+ dan keabsahannya. Hal lainnya adalah implementasinya pada skala nasional dan yurisdiksional. Bagaimana pun inovatifnya atau taat-pada-standarnya, bahkan jika ratusan proyek perintisan ditambahkan, tidak mungkin akan menghasilkan perubahan transformatif bila tidak ada kebijakan tingkat nasional dan pengembangan kelembagaan dan perbaikan dalam perencanaan tata guna lahan subnasional. 


\subsubsection{Berbagai risiko REDD+ dan kerugiannya}

Ketika Studi Komparatif Global REDD+ digagas, ada asumsi umum bahwa REDD+ diperkirakan akan cepat meluncur. Bagi para pembela masyarakat hutan, memulai REDD+ dengan cepat adalah menakutkan, karena kekhawatiran bahwa program apa pun untuk menjadikan hutan lebih bernilai akan menjadikan keadaan masyarakat hutan lebih buruk, mengingat kondisi tata kelola umumnya di berbagai negara berhutan.

Bagi masyarakat hutan, REDD+ yang berlangsung lebih lambat dalam beberapa sisi merupakan hal yang baik, karena menyediakan lebih banyak waktu agar suara mereka diikutsertakan dalam proses kebijakan REDD+ di semua tingkat dan lebih banyak perhatian terhadap hak-hak mereka, isu-isu mata pencaharian dan pengamanan yang penting bagi mereka. Pada waktu yang sama, berbagai masalah yang diantisipasi oleh beberapa orang mungkin merupakan "masalah yang baik yang terjadi”, karena bila masalah-masalah ini timbul, setidaknya akan mengindikasikan bahwa REDD+ mewujudkan realitas di lapangan, dana REDD + mengalir dan kebijakan REDD+ mulai menantang kepentingan-kepentingan tertentu.

Bila REDD + tidak mendapatkan perhatian, kita tidak perlu khawatir tentang risikonya. Namun risikonya menjadi lebih besar bila REDD+ sebagai sebuah visi gagal bersaing dengan bisnis seperti biasa. Berbagai manfaat lokal dari mempertahankan hutan begitu penting: rata-rata, rumah tangga yang berlokasi di dalam dan sekeliling hutan mendapatkan lebih dari seperlima pendapatan mereka dari sumberdaya hutan, menurut temuan oleh Poverty and Environment Network (PEN) CIFOR. ${ }^{1}$ Karena itu, akan ironis, bahkan tragis, bila penggunaan lahan yang relatif jinak berasal REDD+ (dari segi dampak sosial dan lingkungan hidup) kemudian kalah dengan konversi hutan - dan sering disertai pencabutan hak milik masyarakat - yang terkait dengan agribisnis skala komersial dan pertambangan karena REDD+ dipandang sebagai terlalu berisiko.

\subsubsection{Berbagai alasan untuk bersikap optimis}

Serangkaian masalah yang dihadapi oleh inisiatif REDD+ generasi pertama dapat menjadikan penafsiran yang melemahkan semangat. Namun adanya berbagai perubahan dalam konteks yang lebih luas, dan berbagai pelajaran keras yang ditimba dari pengalaman awal, potensi REDD+ terus memukau imajinasi dan menarik investasi berkesinambungan di semua tingkat karena fakta-fakta bahwa: i) ada konsensus luas bahwa tidak akan mungkin mempertahankan target pemanasan global di bawah $2^{\circ} \mathrm{C}$ tanpa upaya serempak untuk mengurangi emisi dari perubahan tata guna lahan; ii) para

1 http://www.cifor.org/pen. 
perunding UNFCCC terus bergerak, meskipun lambat, menuju kesepakatan mengenai pendanaan, pengamanan dan REL/MRV, dan komitmen pendanaan dari para donor bilateral dan multilateral belum memperlihatkan tanda-tanda akan berkurang; iii) pemerintah nasional dan konstituensi yang mendukung REDD+ terus mengembangkan berbagai kebijakan dan strategi REDD+, dalam banyak kasus dengan dukungan eksplisit dari para kepala negara, iv) para pelaku subnasional (misalnya, mereka yang terkait dengan Satuan Tugas Iklim dan Hutan Pemerintah) telah muncul untuk melengkapi ratusan inisiatif tingkat proyek.

Selain itu, beberapa kemajuan positif baru-baru ini dan secara prospektif dapat dijadikan alasan bahwa REDD+ akan berguna, apa pun yang terjadi pada REDD+ sebagai sebuah mekanisme global, strategi nasional atau kumpulan proyek-proyek lokal. Kemajuan positif ini mencakup kesadaran global yang lebih besar mengenai pentingnya hutan dalam perlindungan iklim, meningkatnya transparansi informasi terkait hutan dan pengambilan keputusan di sejumlah negara dan perhatian yang baru terhadap isu-isu penguasaan hutan. REDD+ sebagai sebuah sasaran yang layak masih sangat hidup. 


\section{Lampiran}

\section{Studi Komparatif Global (GCS) CIFOR tentang REDD+}

Louis V. Verchot, Maria Brockhaus, William D. Sunderlin, dan Arild Angelsen

CIFOR tengah menerapkan strategi penelitian dan berbagi pengetahuan tentang Pengurangan Emisi dari Deforestasi dan Degradasi Hutan (REDD+). Tujuannya adalah untuk menyediakan analisis, informasi, dan alat yang dibutuhkan oleh para perumus kebijakan REDD dan komunitas praktisi untuk memastikan pengurangan emisi karbon secara efektif dan efisien dan memberikan dampak yang setara serta memberikan manfaat tambahan - termasuk pengurangan kemiskinan, perlindungan mata pencaharian lokal, hak dan penguasaan lahan, serta peningkatan layanan ekosistem nonkarbon. Kami menyebutnya kerangka 3E+. Kerangka ini diuraikan dalam buku sebelumnya 'Mewujudkan REDD+' (Angelsen dkk. 2009).

Strategi ini diterapkan melalui tiga komponen penelitian:

1. Inisiatif REDD+ nasional

2. Proyek subnasional

3. Pemantauan dan tingkat acuan 
Tujuan khusus komponen pertama adalah mendukung pencapaian hasil $3 \mathrm{E}+$ oleh strategi dan kebijakan REDD+ nasional. Tujuan ini diwujudkan dengan menghasilkan informasi, analisis, dan perangkat yang mempertimbangkan beragam kepentingan pemangku kepentingan dan dirancang untuk menginformasikan strategi dan kebijakan nasional REDD+ (Bab 5, 8, 9, dan 17 dalam buku ini). Selain itu, visi kami adalah agar generasi kedua inisiatif REDD+ nasional memasukkan praktik terbaik yang berasal dari penilaian rinci yang bersumber dari strategi dan kebijakan generasi pertama.

Tujuan khusus komponen kedua adalah menginformasikan proyek REDD+ subnasional generasi pertama dengan menganalisis rancangan dan implementasinya. Hasil analisis dan perangkat yang sedang kami kembangkan akan meningkatkan pembelajaran tentang cara mencapai hasil 3E+ dari proyek-proyek REDD+. Pelajaran dan praktik terbaik yang diperoleh dari penilaian rinci aktivitas percontohan REDD+ generasi pertama juga akan menginformasikan dan meningkatkan aktivitas percontohan REDD+ generasi kedua.

Tujuan khusus komponen ketiga adalah mendukung sistem pengukuran, pelaporan, dan verifikasi (MRV) yang lebih baik dan lebih hemat biaya untuk proyek REDD+ dan skema REDD+ nasional. Kami sedang mengembangkan

\section{Tabel A1 Negara-negara yang termasuk dalam penelitian GCS}

\begin{tabular}{lccc}
\hline Negara & Komponen 1 & Komponen 2 & Komponen 3 \\
\hline Brasil & $\mathrm{X}$ & $\mathrm{X}$ & \\
Peru & $\mathrm{X}$ & $\mathrm{X}$ & $\mathrm{X}$ \\
Kamerun & $\mathrm{X}$ & $\mathrm{X}$ & $\mathrm{X}$ \\
Tanzania & $\mathrm{X}$ & $\mathrm{X}$ & $\mathrm{X}$ \\
Indonesia & $\mathrm{X}$ & $\mathrm{X}$ & $\mathrm{X}$ \\
Vietnam & $\mathrm{X}$ & $\mathrm{X}$ & $\mathrm{X}$ \\
Bolivia & $\mathrm{X}$ & & \\
Republik Demokratik & $\mathrm{X}$ & & \\
Kongo (RDK) & & & \\
Nepal & $\mathrm{X}$ & & \\
Burkina Faso & $\mathrm{X}$ & & \\
Mozambik & $\mathrm{X}$ & & \\
Papua Nugini (PNG) & $\mathrm{X}$ & & \\
\hline
\end{tabular}

Catatan: tiga kategori ini (dalam warna yang berbeda) menunjukkan jumlah pekerjaan (dalam urutan menurun) yang dilakukan oleh GCS 


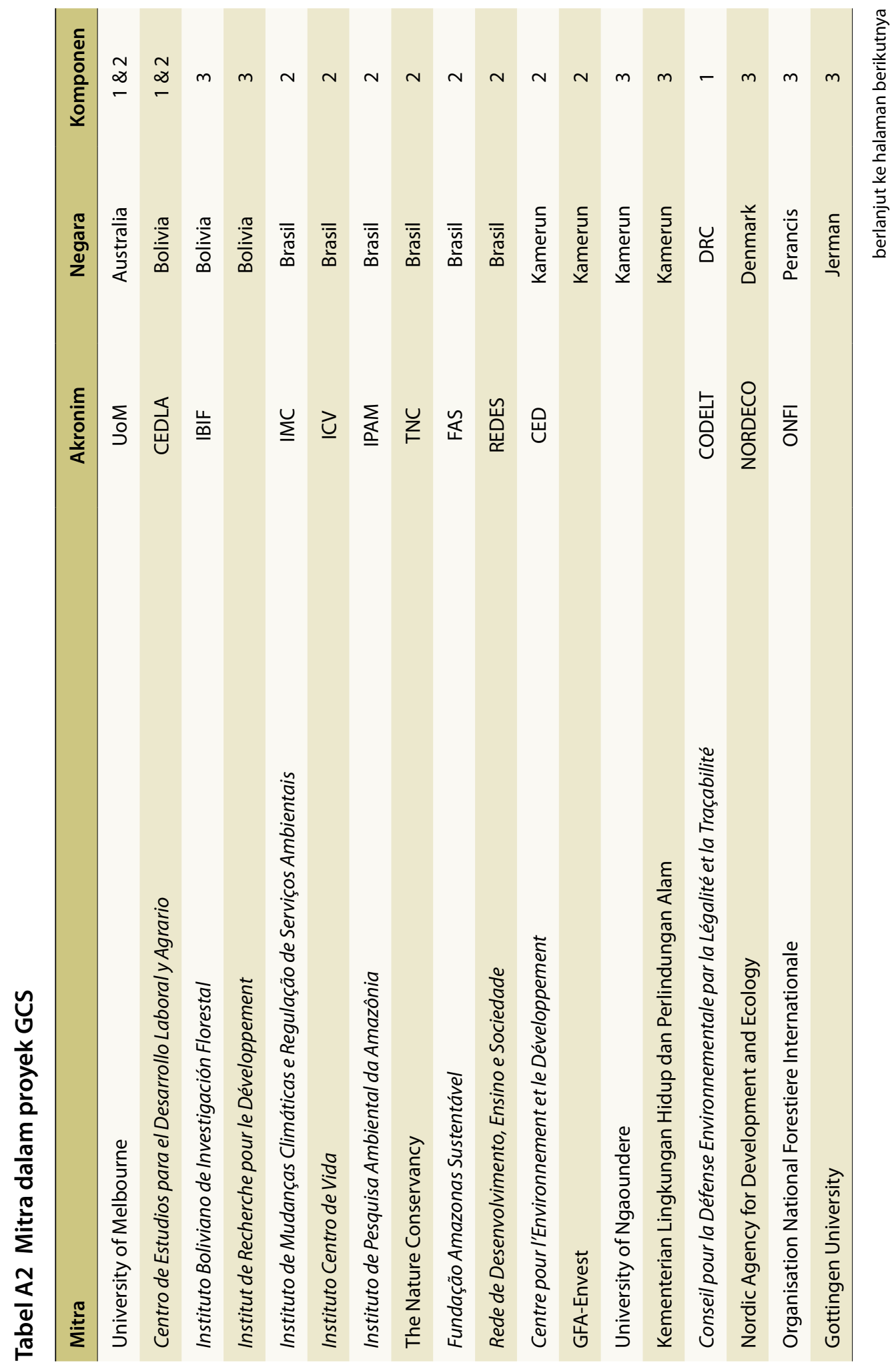




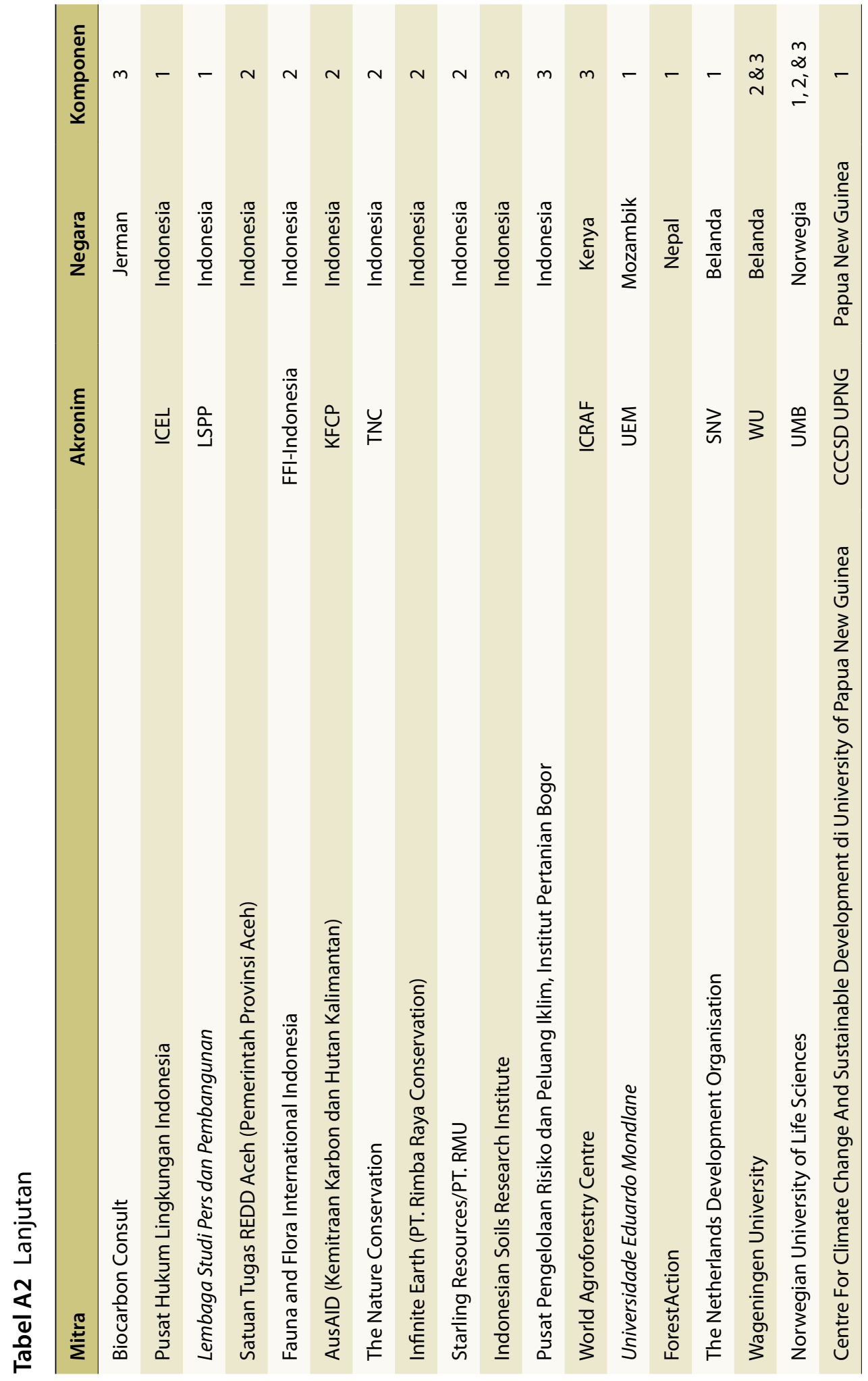




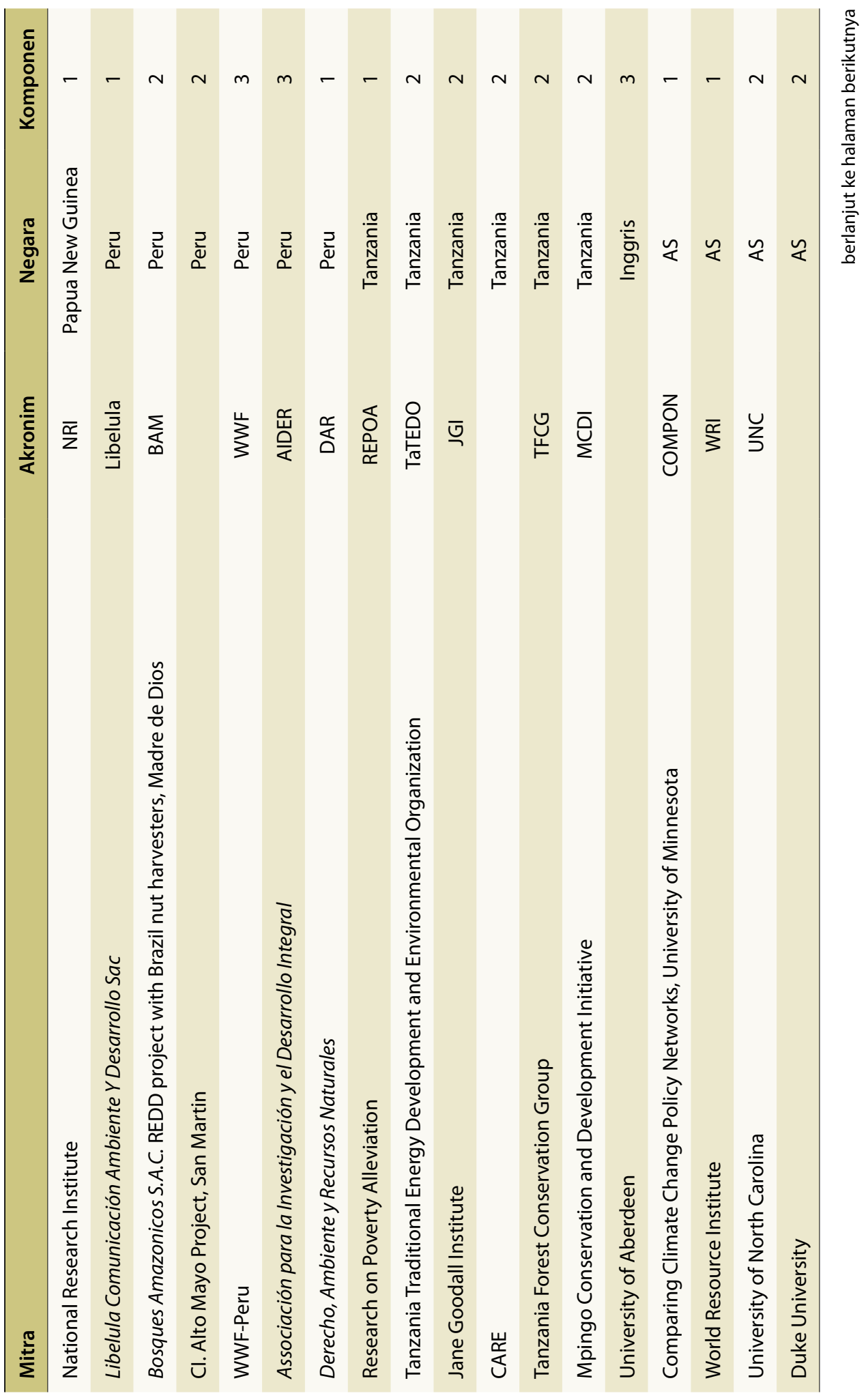




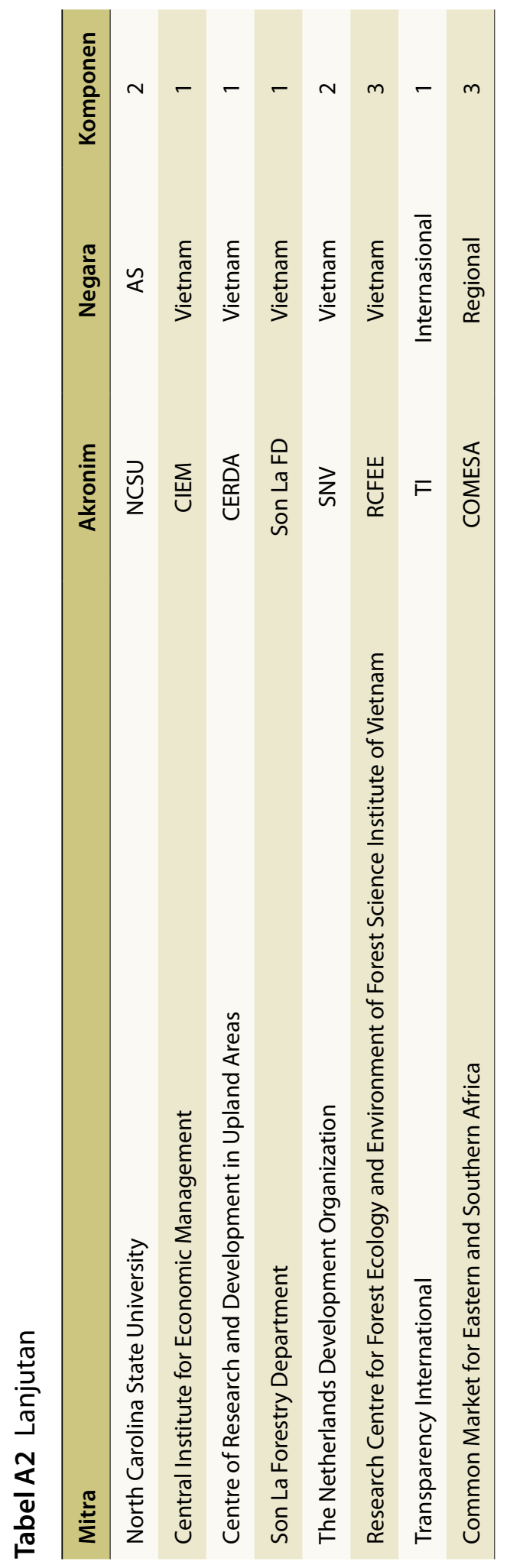


pengetahuan baru di empat bidang: Kapasitas lembaga dan kelembagaan MRV; pendekatan untuk menilai tingkat emisi acuan nasional dan subnasional (REL/RL); faktor emisi untuk implementasi yang lebih baik dari metode inventarisasi Tingkat 2 IPCC (untuk definisi, lihat Bab 15 dan Kotak 16.3); dan partisipasi masyarakat dalam MRV. Saat ini sebagian besar negara berkembang menggunakan metode Tingkat 1 dalam inventarisasi gas rumah kaca (GRK) nasional. Kami bertujuan untuk mengembangkan pengetahuan yang lebih baik tentang rancangan pengambilan sampel dan penilaian stok karbon dalam rangka memfasilitasi implementasi pendekatan Tingkat 2 IPCC untuk inventarisasi karbon. Kemajuan ini akan memastikan estimasi pengurangan emisi yang lebih akurat dan tepat.

Komponen keempat dalam proyek ini bertujuan untuk menyebarluaskan pengetahuan yang dihasilkan dalam tiga komponen penelitian kepada para perumus kebijakan dan praktisi REDD+ di semua tingkatan. Komponen ini terutama didasarkan pada sistem berbasiskan web, tetapi informasinya juga disebarluaskan melalui sarana yang lebih tradisional, seperti buku ini.

Saat ini kami bekerja di 12 negara REDD+, masing-masing memiliki fokus dan cakupan yang berbeda dari tiga komponen penelitian.

Proyek ini melibatkan banyak sekali mitra. Kemitraan nasional mencakup lembaga pemerintah, seperti Pemerintah Provinsi Aceh dan Kementerian Kehutanan di Kamerun, dan organisasi lembaga swadaya masyarakat seperti Rede de Desenvolvimento Ensino e Sociedade (REDES) dan Indonesian Center for Environmental Law (ICEL). Di tingkat internasional, proyek ini bekerja sama dengan mitra PBB (misalnya FAO, UNDP, UNEP, UNFCCC) dan LSM internasional berskala besar (seperti CARE, The Nature Conservancy, WWF). Selain itu, ada beberapa kemitraan dengan perusahaan swasta (misalnya, Starling Resources) dan beberapa universitas di negara-negara maju (seperti North Carolina State University, Norwegian University of Life Sciences, University of Melbourne).

\section{Komponen 1: Proses REDD+ nasional}

Komponen 1 menganalisis proses kebijakan yang mengarah ke perumusan dan implementasi strategi REDD+ nasional. Penelitian ini sedang berlangsung di sembilan negara (Bolivia, Brasil, Kamerun, Republik Demokratik Kongo (RDK), Indonesia, Nepal, Peru, Tanzania, dan Vietnam) dan analisis parsial sedang dilakukan di tiga negara tambahan (Burkina Faso, Mozambik, dan PNG). Analisis wacana berbasis media sedang berlangsung di Norwegia.

Tujuan penelitian ini adalah untuk memberi informasi kepada para perumus kebijakan nasional bahwa kendala perumusan kebijakan yang efektif dapat diatasi melalui rancangan kebijakan yang memadai. Fokus khusus diberikan 
pada penyediaan pilihan berbasiskan bukti untuk mencapai strategi kebijakan REDD+ yang efisien, efektif, dan setara. Rekomendasi kebijakan akan mencakup aspek rancangan kelembagaan sesuai konteks negara tertentu.

Penelitian ini menyelidiki bagaimana hasil 3E+ strategi nasional REDD+, serta perumusan dan penerapannya, bergantung pada kondisi tata kelola yang ada, termasuk para pelaku yang terlibat dalam proses kebijakan, mekanisme, dan struktur. Lebih luas lagi, penelitian ini menganalisis bagaimana konteks kelembagaan, praktik-praktik yang berbasiskan wacana dan kondisi ekonomi makro suatu negara memengaruhi kebijakan nasional. Tingkat komitmen politik, dinamika kekuatan internal dan adanya mekanisme untuk belajar kebijakan dianalisis untuk menjelaskan tingkat keberhasilan rancangan kebijakan dan implementasinya. Selain itu, penelitian ini menyelidiki bagaimana keterbatasan mekanisme kelembagaan yang tepat membatasi keefektifan penargetan insentif keuangan untuk mengurangi deforestasi dan mencapai manfaat tambahan yang lebih luas, serta kemungkinan pilihan-pilihan untuk mengatasi hambatan tersebut.

Analisis komparatif melengkapi penelitian studi kasus tunggal yang mendalam dan menilai faktor-faktor sosial, politik-ekonomi dan kelembagaan yang menjelaskan berbagai hasil 3E+ dari strategi REDD+ nasional.

Para peneliti CIFOR telah mengembangkan lima modul kerja untuk menganalisis strategi REDD+ nasional: profil negara, analisis media, analisis jaringan kebijakan, analisis susbtansi kebijakan REDD+, dan modul yang lentur untuk studi kebijakan spesifik yang menanggapi kebutuhan penelitian setiap negara. Modul ini dijelaskan lebih lanjut dalam Tabel A3 dan Gambar A1.

\section{Komponen 2: Proyek subnasional}

Komponen 2 bertujuan untuk memberikan landasan empiris yang kuat untuk menjawab pertanyaan penelitian menyeluruh berikut ini: Bagaimana proyek REDD+ harus dirancang sedemikian rupa agar hasilnya memenuhi kriteria manfaat 3E+? Tujuan lainnya adalah untuk menjawab pertanyaan turunan berikut ini: Apakah proyek REDD+ memenuhi kriteria manfaat tambahan 3E+? Jika ya, bagaimana? Jika tidak, kenapa tidak? Berdasarkan pengetahuan ini, bagaimana kita menyempurnakan rancangan dan pelaksanaan proyek-proyek saat ini dan masa depan?

Komponen 2 bertujuan untuk menjawab pertanyaan-pertanyaan ini melalui pendekatan kontrafaktual yang disebut 'before-after/control-intervention' (BACI, sebelum-sesudah/kontrol-intervensi). Data lapangan sosial ekonomi dan biofisik dikumpulkan sebelum dan sesudah insentif REDD+ 


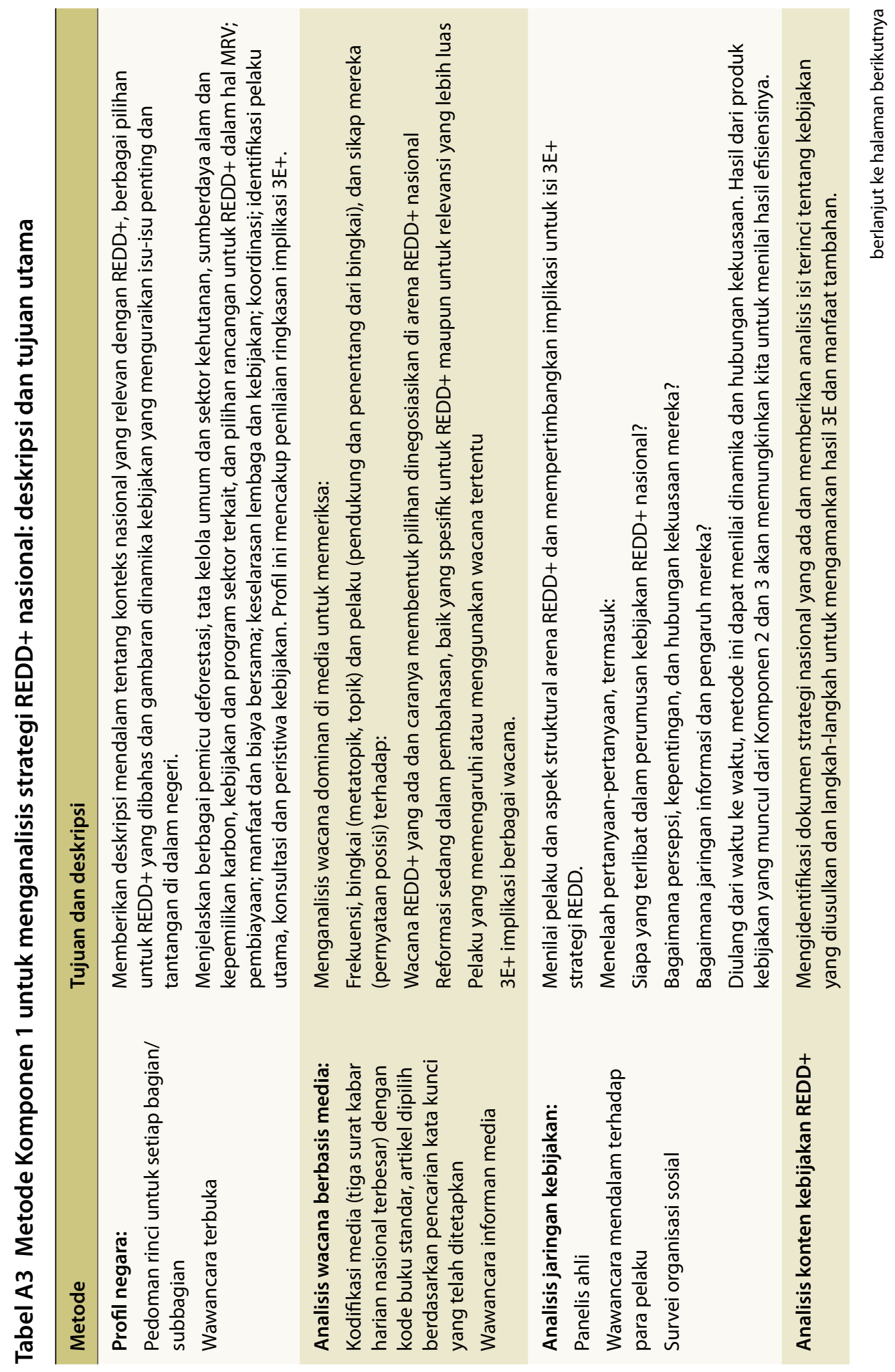




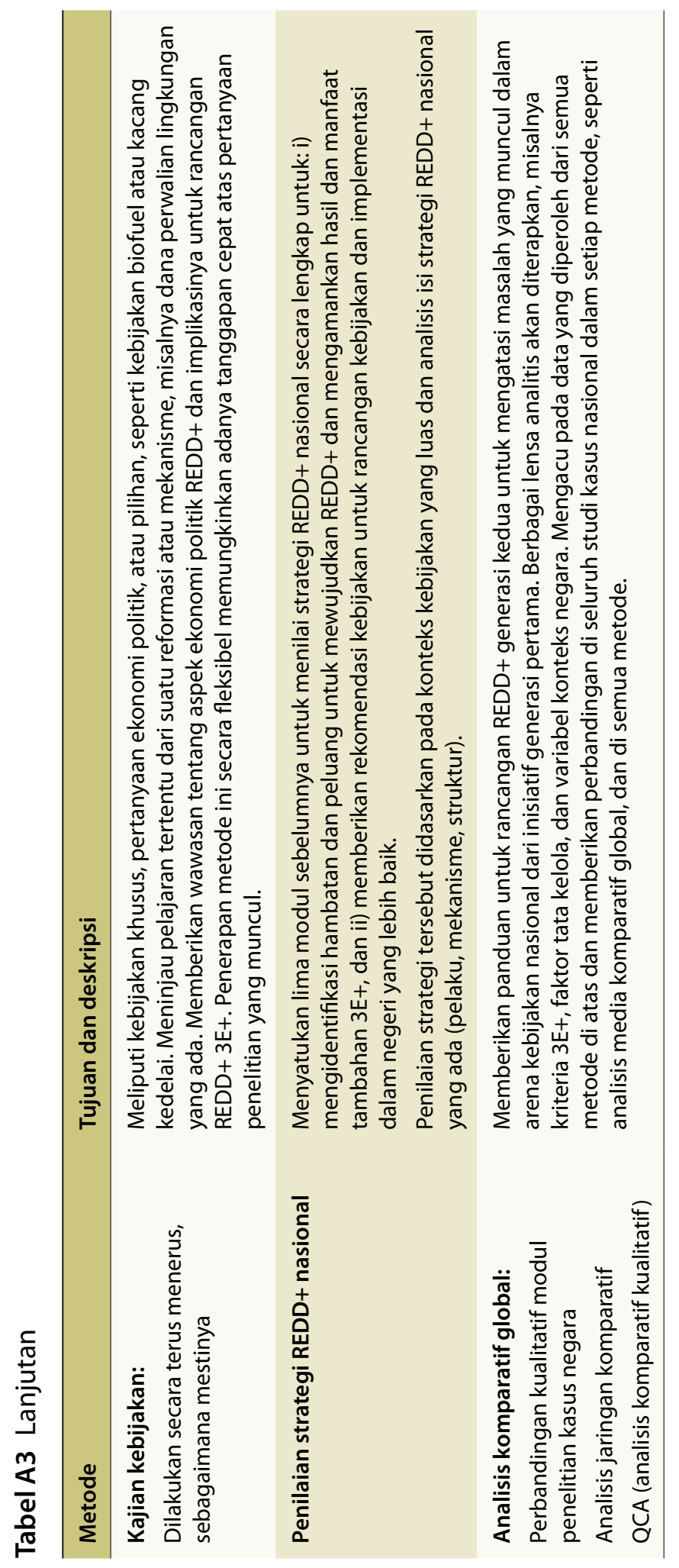




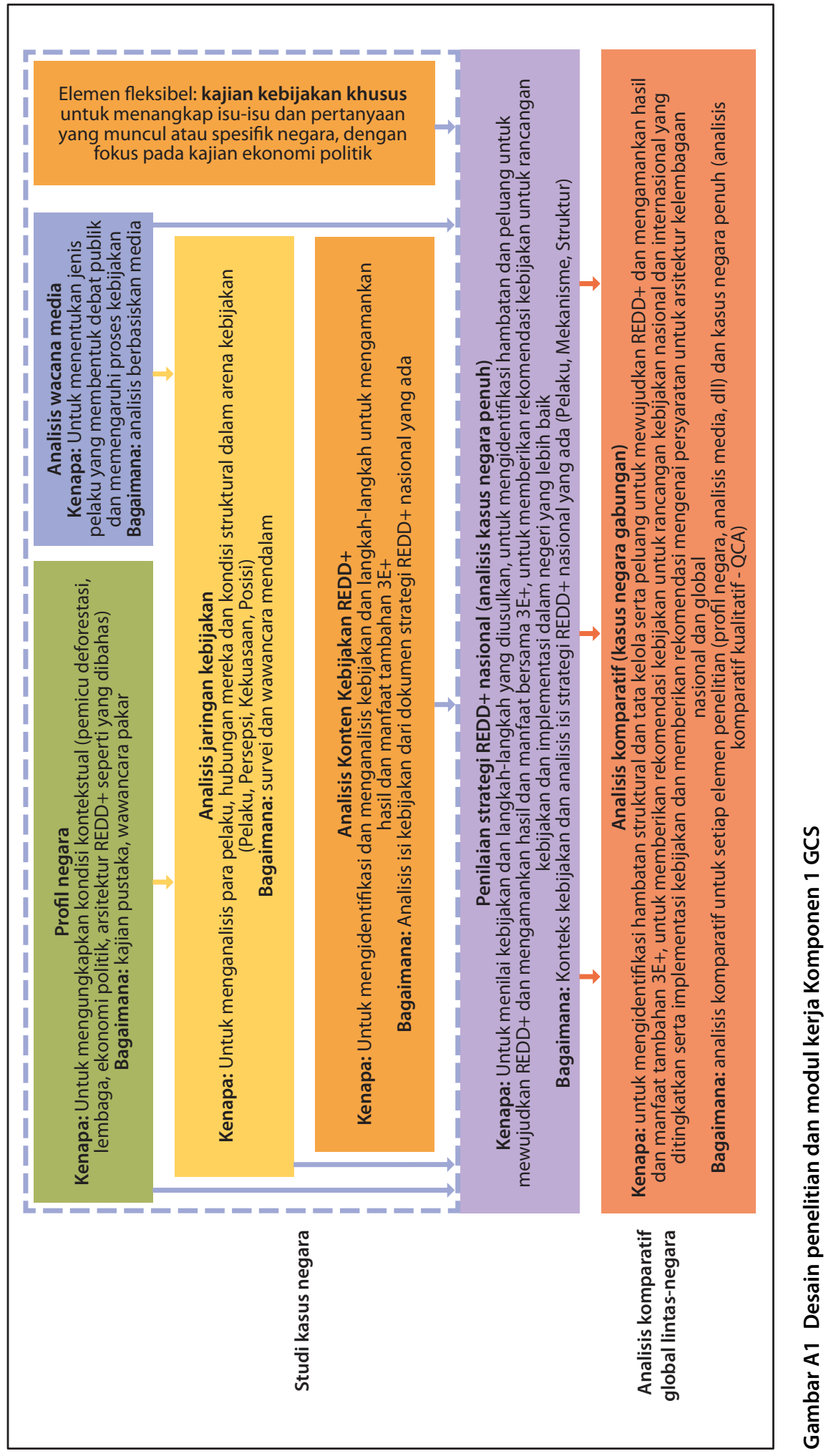


bersyarat dan berbasiskan kinerja (pembayaran untuk layanan lingkungan, disingkat PES) diperkenalkan - bagian BA dari BACI. Data dikumpulkan di desa-desa yang di luar (kontrol) dan di dalam (intervensi) batas-batas proyek REDD+ - bagian CI. Jagger dkk. (2010) menjelaskan pendekatan BACI secara rinci dan Sunderlin dkk. (2010) menyajikan pedoman teknis implementasi Komponen 2.

Data berfungsi sebagai kondisi awal untuk memprediksi bagaimana proyek akan tampil nantinya (pendekatan ex ante) dan, dalam hubungannya dengan putaran kedua data yang dikumpulkan sesudah pengenalan intervensi REDD+, membantu untuk secara retrospektif mengukur dampak REDD+ (pendekatan expost).

Penelitian lapangan Komponen 2 akan dilakukan di 24 lokasi proyek di enam negara GCS inti: Brasil (7), Peru (2), Kamerun (2), Tanzania (6), Indonesia (6), dan Vietnam (1). Tabel A4 memuat daftar 22 lokasi proyek yang sudah dipilih dan yang sudah memulai pekerjaan lapangan. ${ }^{1}$ Semua proyek menggunakan pendekatan BACI kecuali Bolsa Floresta di Brasil; insentif REDD+ bersyarat diperkenalkan di sini sebelum Komponen 2 dimulai, sehingga pendekatan BACI itu tidak mungkin dilakukan.

Unit analisisnya adalah: lokasi proyek; desa di dalam batas proyek; dan rumah tangga di dalam desa (analisis rumah tangga tidak dilakukan di semua lokasi

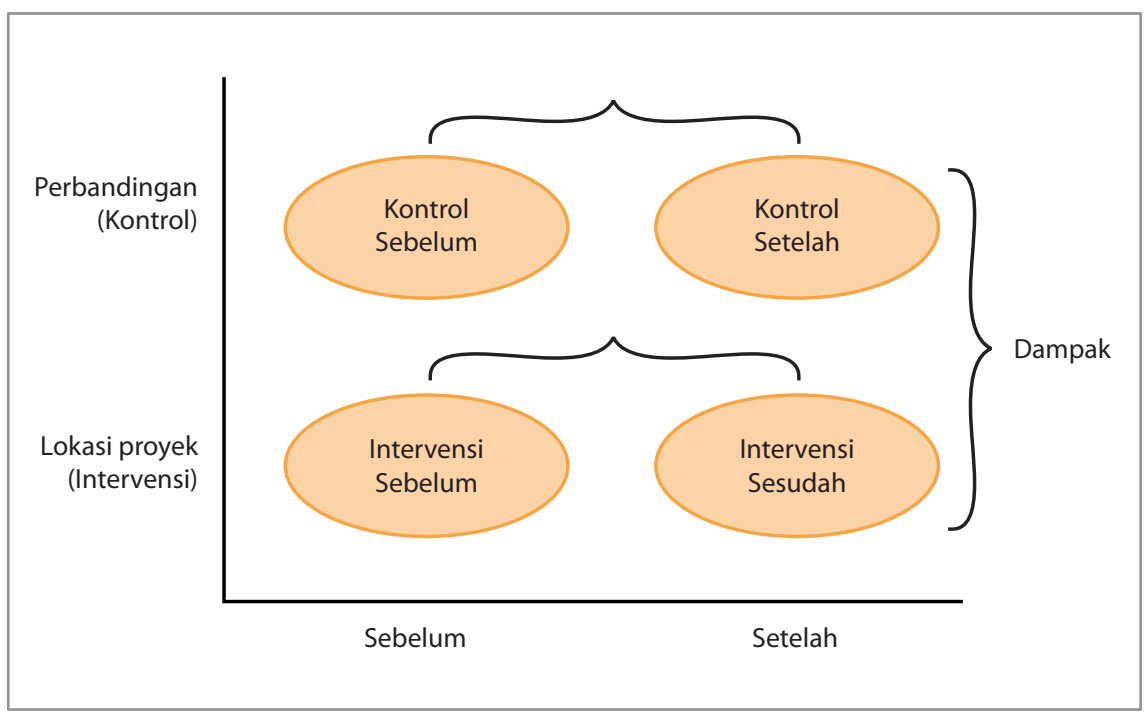

Gambar A2 Metode BACI Komponen 2

1 Dua lokasi proyek yang harus dipilih di Brasil. 


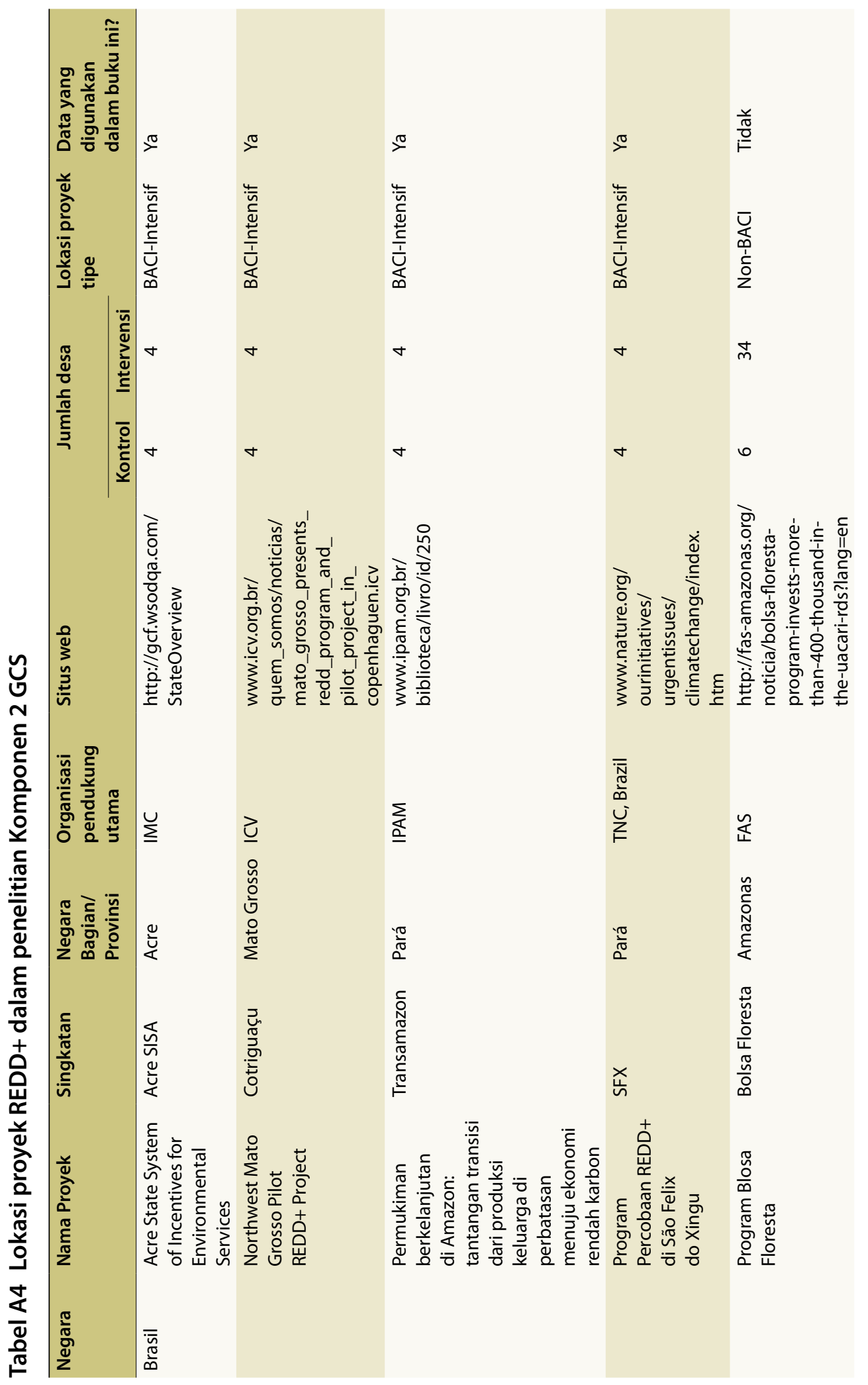




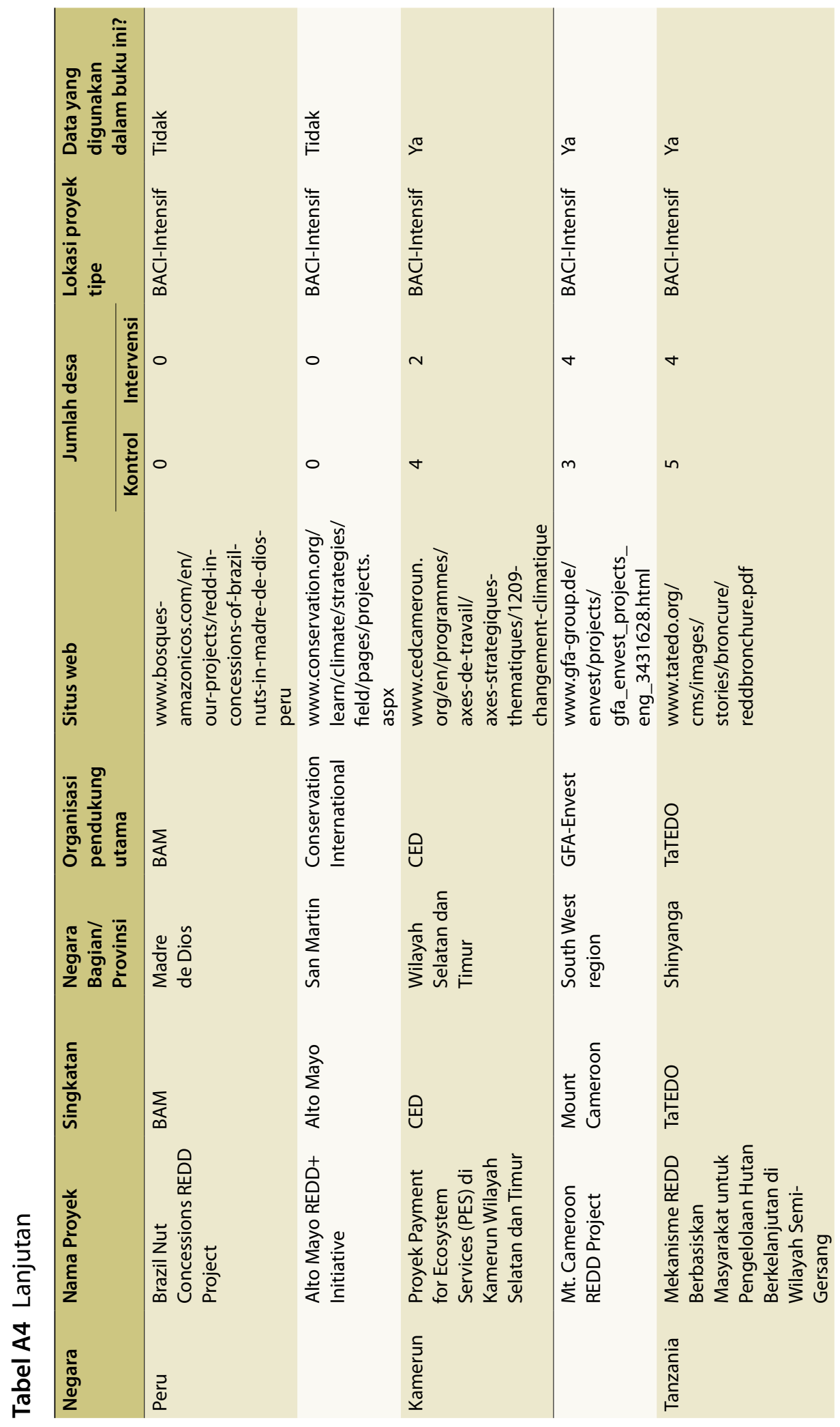




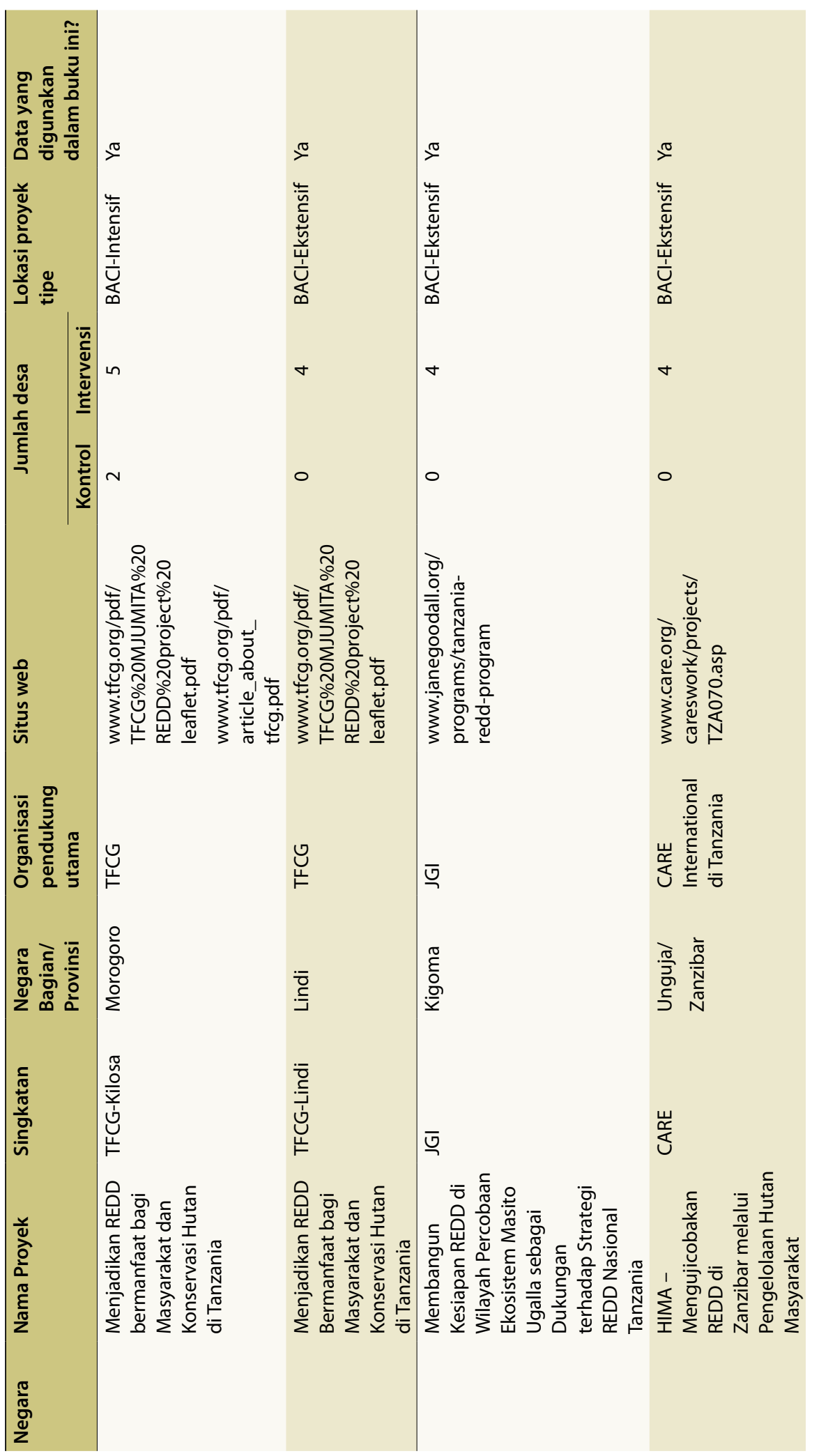

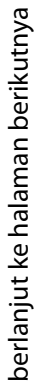




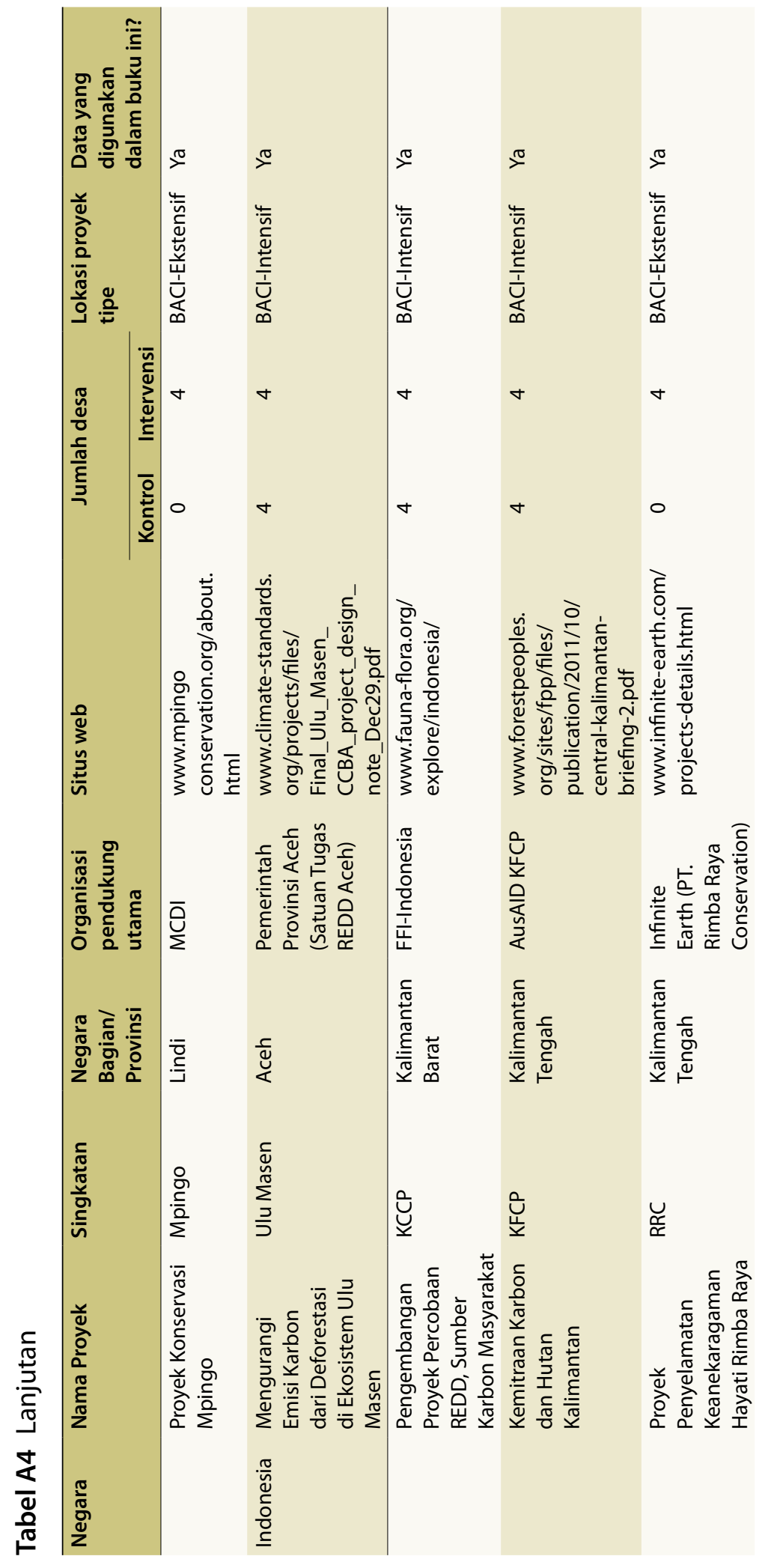




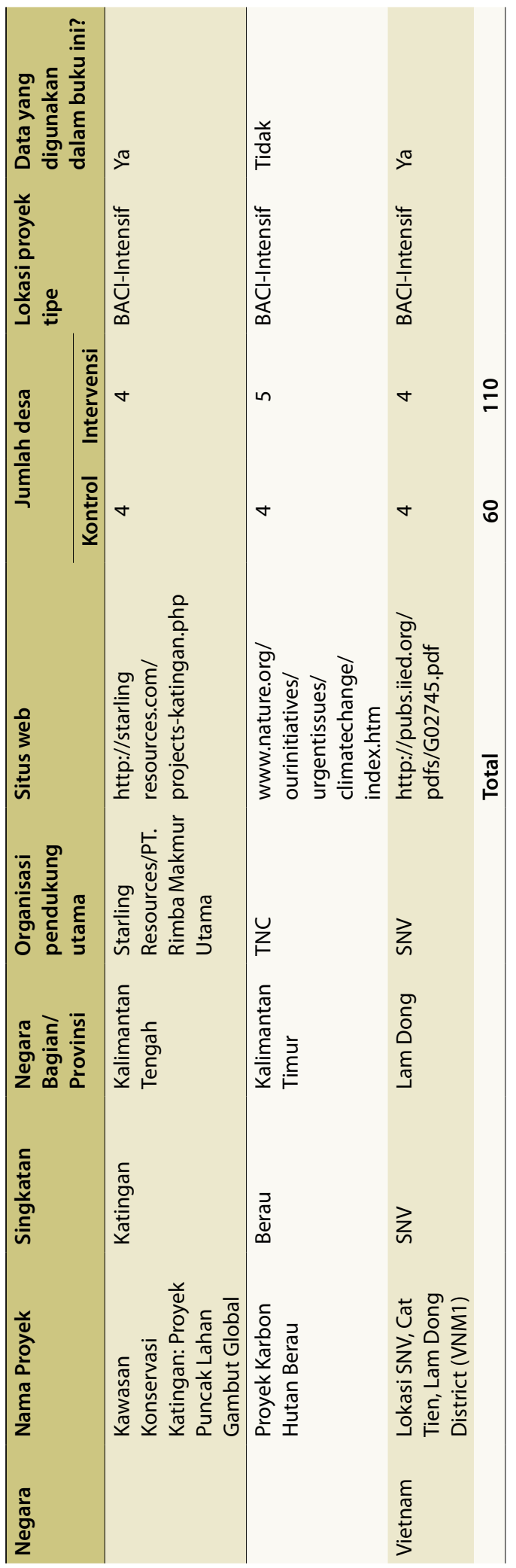


proyek). Di 16 lokasi proyek 'intensif', kami menganalisis proyek secara keseluruhan: sekitar delapan desa (empat di kelompok kontrol dan empat di kelompok intervensi) dan sekitar 240 rumah tangga (30 di setiap desa). Di lima lokasi proyek 'ekstensif', kami menganalisis proyek dan empat desa intervensi, namun tanpa desa kontrol dan rumah tangga. Pada saat penulisan (Mei 2012), data telah dikumpulkan di 20 lokasi proyek (19 BACI dan satu nonBACI), 170 desa, dan 3905 rumah tangga (lihat Tabel A5).

Rencana awalnya adalah melakukan penelitian ex ante dan expost dalam periode GCS pertama (2009-2013). Karena keterlambatan dalam pengenalan insentif REDD+ bersyarat di hampir semua lokasi (lihat Bab 10), rencana ini mustahil dilakukan. Sebaliknya, selama periode GCS pertama, fokus Komponen 2 telah hampir seluruhnya pada kompilasi data kondisi awal - mengantisipasi bahwa data 'sesudah' akan dikumpulkan setelah 2013 - dan melakukan analisis ex ante mengenai proses dan hasil awal persiapan proyek REDD+.

Penelitian Komponen 2 menggunakan berbagai macam instrumen penelitian, bergantung pada tujuan, unit analisis, dan populasi sasarannya. Tabel A6 mengelompokkan instrumen penelitian ke dalam kategori tujuan dan menjelaskan kegunaannya. Beberapa instrumen dapat diakses dari situs web GCS: www.cifor.org/nc/online-library/browse/view-publication/ publication/3286.html

\section{Komponen 3: Pemantauan dan tingkat acuan}

Komponen 3 penelitian ini menyediakan informasi dan perangkat yang berguna bagi para perumus kebijakan dan praktisi untuk inventarisasi GRK yang lebih baik dan metode untuk menetapkan tingkat acuan nasional dan subnasional. Penelitian ini sedang dilakukan di Peru, Kamerun, Indonesia, dan Vietnam. Analisis parsial telah dilakukan di Bolivia dan Kenya. Penelitian ini menyelidiki bagaimana REDD+ dapat diterapkan secara efektif dan efisien. Hasil penelitian ini berkontribusi untuk menjawab pertanyaan kesetaraan melalui peningkatan penjelasan dampak (siapa telah melakukan apa) dan presisinya. Kesetaraan dibahas sebagai salah satu pertimbangan dalam menetapkan tingkat acuan. Kami juga menyertakan analisis beberapa standar karbon berorientasi sosial dan lingkungan, seperti Aliansi Iklim, Komunitas, dan Keanekaragaman Hayati (CCBA) dalam analisis. Tabel A7 merangkum berbagai metode penelitian.

Penelitian ini menyelidiki keefektifan dan efisiensi MRV di tingkat kelembagaan dengan menyelidiki kapasitas dan mengidentifikasi kesenjangan kapasitas. Negara-negara harus mampu mengukur perubahan luas hutan dan 


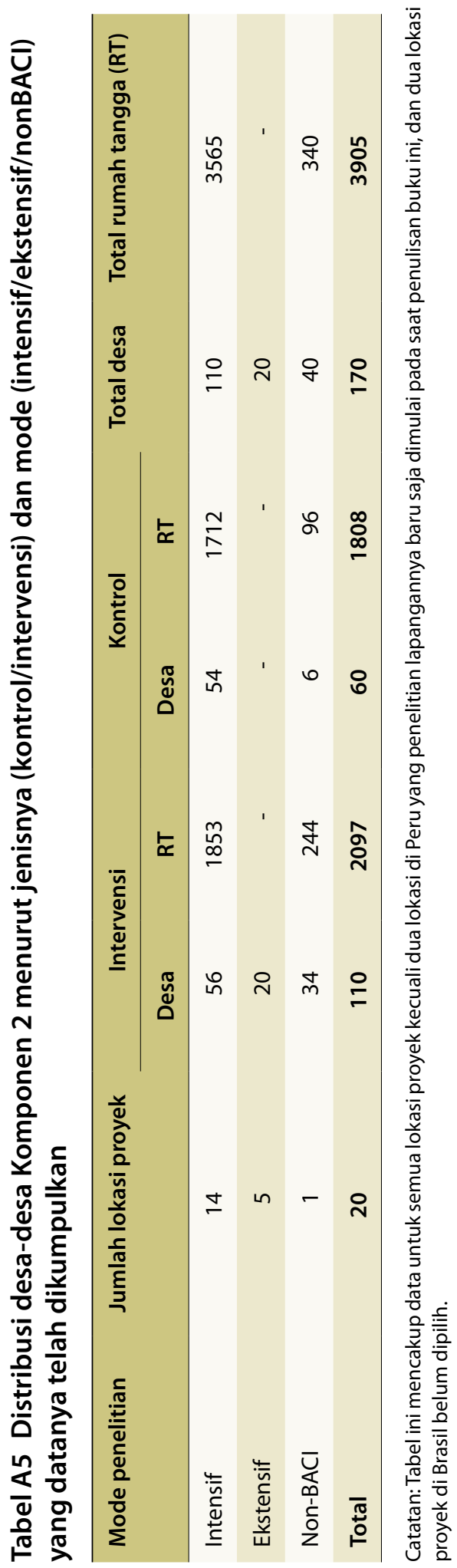




\section{Tabel A6 Instrumen penelitian Komponen 2 GCS}

\begin{tabular}{|c|c|c|}
\hline $\begin{array}{l}\text { Kategori } \\
\text { instrumen }\end{array}$ & Instrumen & Tujuan \\
\hline \multirow[t]{3}{*}{$\begin{array}{l}\text { Penjajakan/ } \\
\text { persiapan }\end{array}$} & Penilaian desa & $\begin{array}{l}\text { Menyusun data untuk pencocokan statistik desa kontrol } \\
\text { dan desa intervensi }\end{array}$ \\
\hline & $\begin{array}{l}\text { Penilaian } \\
\text { pendukung }\end{array}$ & $\begin{array}{l}\text { Informasi tentang maksud proyek, tujuan, ruang } \\
\text { lingkup, atribut, pencapaian sampai saat ini }\end{array}$ \\
\hline & Narasi lokasi & $\begin{array}{l}\text { Penilaian konsistensi antara strategi pendukung dan } \\
\text { pendorong deforestasi lokal }\end{array}$ \\
\hline \multirow{4}{*}{$\begin{array}{l}\text { Survei } \\
\text { lapangan } \\
\text { tentang } \\
\text { pemangku } \\
\text { kepentingan } \\
\text { setempat }\end{array}$} & $\begin{array}{l}\text { Survei rumah } \\
\text { tangga }\end{array}$ & $\begin{array}{l}\text { Data mengenai komposisi rumah tangga, aset, } \\
\text { kepemilikan, pendapatan, perubahan tutupan hutan, } \\
\text { pandangan tentang perubahan kesejahteraan, } \\
\text { pandangan tentang REDD+ }\end{array}$ \\
\hline & Survei desa & $\begin{array}{l}\text { Informasi dasar tentang desa, kepemilikan, mata } \\
\text { pencaharian, praktik dan aturan pengelolaan lahan, } \\
\text { pandangan tentang perubahan kesejahteraan, } \\
\text { tantangan, pandangan tentang REDD+ }\end{array}$ \\
\hline & Survei perempuan & $\begin{array}{l}\text { Informasi tentang kehidupan perempuan, kegiatan } \\
\text { spesifik gender, pengelolaan hutan, pengambilan } \\
\text { keputusan, pandangan tentang perubahan } \\
\text { kesejahteraan, pandangan tentang REDD+ }\end{array}$ \\
\hline & $\begin{array}{l}\text { Survei pemilik } \\
\text { lahan menengah } \\
\text { dan luas }\end{array}$ & $\begin{array}{l}\text { Data mengenai komposisi rumah tangga, aset, } \\
\text { kepemilikan, pendapatan, pengelolaan/perizinan } \\
\text { penggunaan lahan, perubahan tutupan hutan, } \\
\text { pandangan tentang perubahan kesejahteraan, } \\
\text { pandangan tentang REDD+ }\end{array}$ \\
\hline \multirow{5}{*}{$\begin{array}{l}\text { Survei tentang } \\
\text { implementasi } \\
\text { proyek }\end{array}$} & $\begin{array}{l}\text { Kronologi kegiatan } \\
\text { desa }\end{array}$ & $\begin{array}{l}\text { Mengenali dan mencatat rincian implementasi proyek } \\
\text { di setiap desa sampai saat ini }\end{array}$ \\
\hline & $\begin{array}{l}\text { Daftar pemangku } \\
\text { kepentingan }\end{array}$ & $\begin{array}{l}\text { Mengidentifikasi biaya implementasi dan peluang } \\
\text { yang dikeluarkan oleh pemangku kepentingan dan } \\
\text { menentukan kelompok pemangku kepentingan yang } \\
\text { paling signifikan }\end{array}$ \\
\hline & $\begin{array}{l}\text { Biaya peluang dan } \\
\text { implementasi }\end{array}$ & $\begin{array}{l}\text { Menilai persepsi pendukung biaya peluang dan kerja } \\
\text { terkait yang direncanakan atau yang telah dilakukan; } \\
\text { mendapatkan perkiraan total biaya implementasi } \\
\text { hingga saat ini }\end{array}$ \\
\hline & $\begin{array}{l}\text { Survei opini } \\
\text { mengenai persepsi } \\
\text { dan politik }\end{array}$ & $\begin{array}{l}\text { Menilai persepsi tentang REDD+ dan proyek, } \\
\text { mengidentifikasi manfaat atau biaya tak terduga }\end{array}$ \\
\hline & $\begin{array}{l}\text { Daftar periksa } \\
\text { proyek }\end{array}$ & $\begin{array}{l}\text { Memahami proyek dalam konteks yang lebih luas, } \\
\text { termasuk interaksi dengan tingkat nasional dan rencana } \\
\text { terkait dengan pendanaan karbon dan pembagian } \\
\text { keuntungan }\end{array}$ \\
\hline
\end{tabular}


Tabel A6 Lanjutan

\begin{tabular}{lll}
\hline $\begin{array}{l}\text { Kategori } \\
\text { instrumen }\end{array}$ & Instrumen & Tujuan \\
\hline MRV & $\begin{array}{l}\text { Latihan penjajakan } \\
\text { biaya }\end{array}$ & $\begin{array}{l}\text { Jajaki kesediaan pendukung untuk berkolaborasi dalam } \\
\text { analisis mendalam biaya proyek }\end{array}$ \\
\hline Survei tentang & $\begin{array}{l}\text { Informasi tentang penginderaan jauh dan ketersediaan } \\
\text { data GIS, teknik yang digunakan, estimasi REL, dan } \\
\text { rencana pemantauan }\end{array}$ \\
\hline Lain-lain & $\begin{array}{l}\text { Pembaruan } \\
\text { penentuan waktu } \\
\text { Intervensi REDD+ }\end{array}$ & $\begin{array}{l}\text { Mengetahui penentuan waktu intervensi seperti } \\
\text { pembatasan akses hutan, mata pencaharian } \\
\text { alternatif, PES }\end{array}$ \\
& $\begin{array}{l}\text { Survei tambahan } \\
\text { tentang partisipasi } \\
\text { dan kepemilikan }\end{array}$ & $\begin{array}{l}\text { Informasi mendalam mengenai keterlibatan pendukung } \\
\text { masyarakat dalam membangun dan melaksanakan } \\
\text { proyek, dan perhatian terhadap isu-isu kepemilikan }\end{array}$ \\
\hline
\end{tabular}

Catatan: Seperti dijelaskan sebelumnya dalam Lampiran ini, lokasi proyek Bolsa Floresta di Brasil sudah memperkenalkan insentif bersyarat REDD+ dan karena itu bukan bagian dari metode penelitian $\mathrm{BACl}$. Untuk proyek ini, instrumen survei dari dua kategori pertama dalam tabel ini diadaptasi untuk mengukur pelaksanaan proyek yang sedang berlangsung.

\section{Tabel A7 Metode analisis strategi REDD+ nasional: deskripsi dan tujuan utama}

\begin{tabular}{ll} 
Metode & Tujuan dan deskripsi \\
\hline Kapasitas & Menentukan tingkat kapasitas awal di semua 99 negara nonAneks I \\
kelembagaan & $\begin{array}{l}\text { Mengembangkan studi kasus negara tentang penilaian kapasitas untuk } \\
\text { memahami mengapa kapasitas masih rendah dan apa yang dapat dilakukan } \\
\text { tentang hal itu. }\end{array}$
\end{tabular}

Tingkat acuan emisi

Mengembangkan dan menguji pendekatan bertahap dengan menggunakan model regresi berganda

Mengembangkan studi kasus negara menggunakan model statistik untuk memprediksi tren masa depan dalam emisi GRK.

Faktor emisi

Pemantauan karbon hutan berbasis masyarakat
Penilaian nasional sumber data untuk laporan UNFCCC mengenai emisi GRK. Pembuatan pustaka ilmiah untuk faktor emisi yang meningkat untuk lahan basah tropis dan untuk GRK nonCO $\mathrm{CO}_{2}$

Pekerjaan lapangan untuk mengembangkan faktor emisi baru dengan mitra negara tuan rumah dalam layanan teknis.

Uji lapangan perbandingan inventarisasi hutan oleh masyarakat vs oleh rimbawan profesional, untuk menilai pengorbanan biaya-akurasi

Rancangan partisipatif pemantauan hutan untuk kebutuhan masyarakat, meliputi pengukuran yang diperlukan untuk pemantauan karbon.

Penelitian sosiologis mengenai sikap dan perubahan sikap terkait dengan pemantauan hutan berbasiskan masyarakat. 
menilai perubahan stok karbon untuk menerapkan sistem MRV nasional. Mengingat kondisi biofisik yang berbeda di tiap negara, maka tantangan MRV juga bervariasi; analisis kami membandingkan tantangan dalam hal kapasitas untuk mengidentifikasi berbagai kesenjangan yang ada. Kami menggunakan dua latihan pelaporan internasional terbaru dalam Penilaian Sumberdaya Kehutanan untuk memeriksa kemajuan dalam pembangunan kapasitas.

Dengan fondasi penelitian CIFOR selama bertahun-tahun tentang berbagai pemicu ekonomi bagi deforestasi, kami mengembangkan pendekatan bertahap untuk pengaturan REL/RL (lihat Bab 16). Sejumlah keputusan dalam UNFCCC meningkatkan pentingnya penggunaan pendekatan yang didorong oleh data dalam penyusunan REL/RL, khususnya mengenai penggunaan data historis, disesuaikan dengan kondisi nasional dan transparansi tentang sumber karbon dan gas yang telah disertakan atau dihilangkan. Kualitas data yang tersedia dan data yang akan dikumpulkan oleh negara merupakan isu utama yang mendukung penyusunan REL/RL hutan. Kami menggunakan data subnasional dengan berbagai tingkat agregasi untuk menguji pendekatan kami, yang menggunakan kerangka pemodelan regresi. Cara ini memungkinkan suatu negara untuk membuat model deforestasi masa depan dan menganalisis skenario emisi masa depan yang masuk akal. Perangkat analisis ini akan membantu negara-negara menentukan kemungkinan rentang emisi di masa depan dengan asumsi transparan tentang berbagai pemicu deforestasi yang dikenali.

Ketersediaan faktor-faktor emisi untuk menerapkan metode IPCC dalam penghitungan GRK nasional terus menjadi kendala utama penerapan MRV di banyak negara berkembang. Tim kami telah menilai status pengetahuan terkini tentang faktor-faktor ini di negara-negara sasaran dan ekosistem hutan yang penting, dan menetapkan prioritas untuk mengumpulkan data tambahan. Mereka sekarang bekerja dengan berbagai lembaga layanan teknis di berbagai negara guna mengumpulkan data yang diperlukan untuk meningkatkan inventarisasi. Fokus kami adalah pada perubahan penggunaan lahan di lahan basah tropis dan hutan Afrika, yang datanya sangat kurang. Kami telah menghasilkan persamaan biomassa baru dan menggali sistem akar untuk mengestimasi rasio akar:batang. Kami juga telah mengambil banyak pengukuran fluks untuk menilai pengaruh perubahan penggunaan lahan terhadap respirasi tanah dan pada fluks $\mathrm{N}_{2} \mathrm{O}$ dan $\mathrm{CH}_{4}$, menggunakan teknik ruang. Kami juga mengukur pengaruh pupuk pada dekomposisi gambut. Dengan berpartisipasi dalam pekerjaan ini, peneliti lokal di Afrika, Asia, dan Amerika Latin mengembangkan keterampilan mereka dalam metode kuantitatif empiris. 
Terakhir, penelitian tentang pengembangan metode pengukuran yang dilakukan masyarakat yang sesuai untuk memfasilitasi partisipasi pemangku kepentingan lokal dalam proses ini baru dimulai. Masyarakat dapat memberikan aliran data yang sah ke sistem MRV nasional dan kami bekerja di beberapa lokasi untuk merancang dan menguji berbagai pendekatan. Kami membandingkan akurasi dan biaya inventarisasi hutan yang dilakukan oleh masyarakat dengan yang dilakukan oleh petugas kehutanan profesional. Kami harap partisipasi masyarakat akan meningkatkan transparansi studi REDD+ dan meningkatkan kepemilikan masyarakat atas kegiatan REDD+. Kami akan menguji asumsi ini secara empiris melalui penelitian sosiologis.

\section{Integrasi}

Buku ini merupakan sintesis pertama dari hasil penelitian Studi Komparatif Global CIFOR. Tidak seperti buku-buku kami sebelumnya tentang REDD+, buku ini menyajikan temuan penelitian baru dari program yang dirancang khusus untuk mendukung pengembangan dan penerapan kebijakan REDD+. Ketiga komponen penelitian GCS memberikan sudut yang berbeda sehingga dapat mengamati perkembangan REDD+ di negara-negara generasi pertama. Dua komponen pertama skala analisisnya berbeda, tetapi dalam kenyataannya kedua skala ini saling terkait di berbagai negara. Demikian juga di GCS, skalanya tersebut saling terkait dan beberapa penelitian interdisipliner yang lebih menarik sedang dikembangkan antarmuka antara komponen-komponennya. MRV meliputi beberapa skala dan membentuk saluran yang melaluinya informasi dikumpulkan dan bergerak di seluruh skala dan tingkat. MRV ini berfungsi sebagai dasar untuk penilaian kesetaraan karena menentukan siapa yang telah melakukan apa dalam pengurangan emisi. Interaksi ketiga komponen program penelitian ini, dan antarmuka antara berbagai disiplin ilmu, merupakan esensi dari proses pembelajaran penting yang berlangsung. Menghubungkan penelitian di berbagai skala dan tingkat dan interdisipliner diperlukan untuk penelitian yang kokoh dan komprehensif, serta merupakan tantangan tersendiri.

Kami menghadapi tantangan tambahan dari fakta bahwa REDD+ adalah target bergerak, tetapi bergerak lebih lambat dari yang diharapkan. Ketika melaksanakan berbagai proyek percontohan, kami juga menghadapi tantangan kerahasiaan dan kepekaan dalam berbagi dan menggunakan data. Penelitian tentang REDD+ menghadapi sejumlah masalah, tidak terkecuali penelitian REDD+ oleh GCS. Kotak A1 merangkum sebagian dari tantangan ini.

REDD+ merupakan mekanisme yang agak rumit untuk memastikan integritas lingkungan dan pengurangan emisi secara nyata, dan akan diterapkan di negara-negara dengan kapasitas terbatas. Kami percaya bahwa agar REDD+ 


\title{
Kotak A1 Sejumlah tantangan penelitian REDD+
}

\author{
Frances Seymour
}

REDD+ menghadirkan sejumlah tantangan bagi peneliti. Gagasan dan ruang lingkup REDD+ berkembang pesat. Karena gagasan untuk memasukkan deforestasi di negara berkembang diajukan dalam COP11 UNFCCC tahun 2005, Pengurangan Emisi dari Deforestasi (RED) telah menambahkan ' $D$ ' kedua untuk degradasi hutan, dan kemudian satu ' + ' untuk konservasi stok karbon hutan, pengelolaan hutan yang berkelanjutan dan peningkatan stok karbon hutan. Seperti dijelaskan dalam Bab 3, konsep REDD+ awalnya digagas sebagai PES dari global ke nasional ke lokal. Seiring waktu, pemikiran ini meluas untuk menggabungkan manfaat lainnya, seperti konservasi keanekaragaman hayati dan pengurangan kemiskinan, dan semakin menjauh dari pembayaran berbasiskan kinerja. Istilah 'REDD+' dapat dipahami dengan berbagai cara sebagai tujuan, mekanisme yang diusulkan di bawah UNFCCC, atau seperangkat kebijakan, program, dan proyek berskala luas yang bergerak maju sesuai namanya. Karena itu, para peneliti terus ditantang untuk menentukan ruang lingkup terbatas untuk mempelajari REDD+.

Praktik REDD+ perlahan semakin maju. Setelah dimasukkan dalam Rencana Aksi Bali dalam COP13 di Bali dan pengumuman komitmen pendanaan yang signifikan, banyak yang berharap implementasi REDD+ dapat bergerak maju dengan cepat. Antara lain karena kegagalan mencapai kesepakatan global mengenai perubahan iklim dalam COP15 tahun 2010, dan penurunan terkait janji jangka pendek penyediaan dana berbasiskan pasar, laju perkembangan melambat di semua tingkatan. Para peneliti yang menggunakan metode yang membandingkan kondisi sebelum dan sesudah intervensi REDD+ dibiarkan menunggu intervensi ini berlangsung, setelah mengumpulkan data kondisi awal. Banyak analisis tentang kondisi yang diperlukan dan cukup agar REDD+ efektif, efisien, dan setara masih bersifat spekulatif. Contohnya, empat kondisi yang dijelaskan dalam Bab 5 yang diperlukan untuk perumusan kebijakan tingkat nasional yang efektif belum diamati di negara penelitian mana pun.

REDD+ semakin multiskala. Seperti telah dikupas dalam buku ini, upaya REDD+ di tiap tingkatan terkait erat dengan kemajuan REDD+ pada skala lainnya. Rancangan penelitian asli dari GCS tentang REDD+ kurang memberikan perhatian yang cukup untuk skala (atau yurisdiksi) subnasional, yang kemudian muncul sebagai tingkat penting untuk perencanaan penggunaan lahan, implementasi program, dan pengembangan kebijakan (misalnya, dalam kasus Satuan Tugas Gubernur untuk Hutan dan Iklim).

REDD+ kontroversial. REDD+ adalah ide yang diperdebatkan; para pendukung dan penentangnya beradu argumen di berbagai forum mulai dari negosiasi internasional hingga media nasional dan jurnal akademis. Peneliti harus melalui medan yang penuh beban ideologis untuk menghindari bias fakta dan penampilan. 
Beberapa aspek REDD+ sensitif. Data yang relevan dengan REDD+ dapat mencakup informasi sensitif dari rencana bisnis eksklusif, peta yang menunjukkan konversi lahan ilegal, dan kesaksian mengenai konflik kekerasan atas kepemilikan lahan. Para peneliti yang mengumpulkan data tentang REDD+ sering mengalami kesulitan dalam meraih kepercayaan dari informan penting dan harus memberikan perhatian khusus untuk menghormati komitmen pada kerahasiaan.

Pekerjaan lapangan sulit. Pengumpulan data di daerah terpencil, dengan hutan yang masih utuh, memiliki bahaya tersendiri. Tim lapangan GCS menjumpai pemburu harimau, kerusakan kendaraan, kondisi jalan yang buruk, serangan lebah, akomodasi seadanya, kebakaran, asap, dan tantangan lain yang terkait dengan pekerjaan lapangan tropis. Di kebanyakan tempat, fasilitas medis sangat sederhana dan tidak ada organisasi penyelamatan.

bisa efektif, realitas di lapangan di negara-negara ini harus dipertimbangkan. REDD+ berpotensi untuk menjadi program transformatif bagi hutan tropis, tetapi keberhasilannya tidak dijamin. Melalui upaya penelitian kami yang berkelanjutan di GCS, kami bercita-cita untuk memberikan pelajaran awal yang memadai untuk menghindari perangkap dan kesalahan besar yang bisa menggagalkan seluruh proses. Mengutip Albert Einstein, REDD+ harus sesederhana mungkin, tetapi bukan disederhanakan!

\section{Ucapan Terima Kasih}

\section{Komponen 1}

Metode dan pedoman yang digunakan dalam komponen penelitian ini dirancang oleh Maria Brockhaus, Monica Di Gregorio, dan Sheila Wertz-Kanounnikoff. Metode yang diterapkan untuk analisis media dan analisis jaringan kebijakan dikembangkan berdasarkan penelitian yang dilakukan di COMPON, ${ }^{2}$ dipimpin oleh Jeffrey Broadbent dan dananya didukung oleh National Science Foundation. Monica Di Gregorio dan Maria Brockhaus mengadaptasi 'Protocol for Media Analysis' (Protokol untuk Analisis Media) dan 'Protocol for Policy Network Analysis' (Protokol untuk Analisis Jaringan Kebijakan) COMPON. Banyak orang memberikan kontribusi bagi studi kasus negara, termasuk analisis media, analisis jaringan kebijakan dan profil negara, dan telah memberikan data, analisis, dan dukungan.

Tanpa upaya pembinaan dan koordinasi ilmiah dari pemimpin kasus negara di negara masing-masing, pekerjaan komparatif ini tidak mungkin terlaksana: Peter Cronkleton (Bolivia); Sven Wunder dan Peter May 
(Brasil); Suwadu Sakho-Jimbira (Burkina Faso); Samuel Assembe dan Jolien Schure (Kamerun); Samuel Assembe (Kongo); Daju Resosudarmo dan Moira Moeliono (Indonesia); Sheila Wertz-Kanounnikoff (Mozambik); Thuy Thu Pham (Nepal); Arild Angelsen (Norwegia); Andrea Babon (PNG); Mary Menton (Peru); Salla Rantala (Tanzania); Thuy Thu Pham dan Moira Moeliono (Vietnam).

Organisasi mitra nasional dan tim mereka di negara-negara penelitian melakukan pengumpulan data dan analisis, bersama para pemimpin kasus negara. Secara khusus, kami ingin mengucapkan terima kasih kepada: Walter Arteaga, Bernado Peredo, Jesinka Pastor (Bolivia); Maria Fernanda Gebara, Brent Millikan, Bruno Calixto, Shaozeng Zhang (Brasil); Mathurin Zida, Michael Balinga, Houria Djoudi (Burkina Faso); Guy Patrice Dkamela, Felicien Kengoum (Kamerun); Felicien Kabamba, Augustin Mpoyi, Angelique Mbelu (Kongo); Levania Santoso, Tim Cronin, Giorgio Indrarto, Prayekti Murharjanti, Josi Khatarina, Irvan Pulungan, Feby Ivalerina, Justitia Rahman, Muhar Nala Prana (Indonesia); Almeida Sitoe, Alda Salomão (Mozambik); Dil Badhur, Bryan Bushley, Rahul Karki, Naya Sharma Paudel (Nepal); Laila Borge (Norway); Daniel McIntyre, Gae Gowae, Nidatha Martin, Nalau Bingeding, Ronald Sofe, Abel Simon (PNG); Hugo Piu, Javier Perla, Daniela Freundt, Eduardo Burga Barrantes, Talía Postigo Takahashi (Peru); RehemaTukai, GeorgeJambiya, Riziki Shemdoe, Demetrius Kweka, Therese Dokken (Tanzania); Nguyen Thi Hien, Nguyen Huu Tho, Vu Thi Hien, Bui Thi Minh Nguyet, Nguyen Tuan Viet dan Huynh Thu Ba (Vietnam); dan banyak lagi yang mendukung tim negara.

Efrian Muharrom, Sofi Mardiah, Christine Wairata, dan Ria Widjaja-Adhi memberikan dukungan dan bantuan penelitian yang sangat berharga.

Kami juga ingin mengucapkan terima kasih kepada Jan Börner, Martin Herold, Markku Kanninen, Kaisa Korhonen-Kurki, Anne Larson, Cecilia Luttrell, Pablo Pacheco, Elena Petkova, Frances Seymour, dan banyak lagi atas masukan dan dukungan mereka.

\section{Komponen 2}

Versi yang dipublikasikan dari panduan metode Komponen $2^{3}$ ditulis oleh Pamela Jagger, Erin Sills, Kathleen Lawlor, William Sunderlin dan petunjuk teknis $^{4}$ ditulis oleh William Sunderlin, Anne Larson, Amy Duchelle, Erin Sills, Cecilia Luttrell, Pamela Jagger, Subhrendu Pattanayak, Peter Cronkleton, dan Andini Desita Ekaputri. Penghargaan juga patut diberikan kepada orang-orang yang memberikan komentar dan kritik mendalam selama

3 www.cifor.org/nc/online-library/browse/view-publication/publication/3283.html.

4 www.cifor.org/publications/pdf_files/Books/BSunderlin1001.pdf. 
proses perancangan dan prapengujian instrumen survei pada tahun 2009, dan mereka yang berpartisipasi dalam pertemuan untuk menyelesaikan rancangan penelitian pada Januari 2010: Arild Angelsen, Andre Aquino, Stibniati Atmadja, Abdon Awono, Huynh Thu Ba, Riyong Kim Bakkegaard, Simone Bauch, Rizaldi Boer, Jan Börner, Miguel Calmon, Mariano Cenamo, Peter Cronkleton, Therese Dokken, Paul Ferraro, Maria Fernanda Gebara, Raissa Guerra, Dian Intarini, Markus Kaiser, Alain Karsenty, Anirudh Krishna, Erin Myers Madeira, Peter May, Steve Panfil, Ida Aju Pradnja Resosudarmo, Mustofa Agung Sardjono, Galia Selaya, Frances Seymour, Denis Sonwa, Satyawan Sunito, Peter Vaughan, dan Sven Wunder.

Pekerjaan lapangan Komponen 2 dilakukan di 22 lokasi proyek (lihat Tabel A4). Kami sangat berutang budi kepada organisasi yang terkait dengan lokasi proyek atas kolaborasi mereka yang sangat mendukung dan kesabarannya dalam memenuhi segala permintaan kami.

Anggota tim penelitian lapangan di enam negara penelitian terdiri dari:

Brasil: Amy Duchelle (perwakilan negara); Riyong Kim Bakkegaard, Marina Cromberg, Maria Fernanda Gebara, Raissa Guerra, Tadeu Melo (pembimbing penelitian lapangan); Carolle Utrera Alarcon, Marileide Gonçalves,Leonela Guimarães, Thiago Machado Greco, Giselle Monteiro, José Roberio Rodrigues, Kaline Rossi (enkoder).

Kamerun: Abdon Awono (perwakilan negara dan pembimbing penelitian lapangan); Henri Owona (enkoder).

Indonesia: Ida Aju Pradnja Resosudarmo (perwakilan negara); Pangestuti Astri, Stibniati Atmadja, Yayan Indriatmoko, Dian Intarini, Augusta Mindry (pembimbing penelitian lapangan); Merlinta Anggilia, Mella Komalasari, Jhon Roy Sirait, Tina Taufiqoh (enkoder).

Peru: Amy Duchelle, Peter Cronkleton (perwakilan negara); Mary Menton (rekan penelitian), Valerie Garrish, Galia Selaya (pembimbing penelitian lapangan).

Tanzania: Therese Dokken (perwakilan negara dan pembimbing penelitian lapangan); Eliakimu Zahabu (mantan perwakilan negara); Demetrius Kweka, Susan Caplow (pembimbing penelitian lapangan); Johannes Dill (enkoder).

Vietnam: Huynh Thu Ba (perwakilan negara dan pembimbing penelitian lapangan); Nguyen Tien Dat (enkoder).

Lebih dari 80 petugas lapangan melakukan sebagian besar wawancara dan pengumpulan data. 
Staf di kantor pusat CIFOR di Bogor, Indonesia, berikut ini berperan penting dalam melakukan penelitian Komponen 2: Made Agustavia (administrator database); Made Dwi Astuti (sekretaris); Andini Desita Ekaputri (petugas penelitian); Tini Gumartini (asisten penelitian); Shijo Joseph (rekan penelitian pascadoktoral); Mrigesh Kshatriya (analis data); Oktarita Satria (asisten proyek); Ida Aju Pradnja Resosudarmo (perwakilan negara Indonesia); William D. Sunderlin (pemimpin komponen); Ria Widjaja-Adhi (asisten proyek).

Kami menghargai kontribusi Josil Murray, mahasiswa program S3 yang melakukan penelitian tentang REDD+ dan keanekaragaman hayati di Peru dan Indonesia.

\section{Komponen 3}

Metode dan pedoman yang digunakan dalam komponen penelitian ini dirancang oleh Louis V. Verchot, Arild Angelsen, Martin Herold, Markku Kanninen, Kristell Hergoualc'h, dan Daniel Murdiyarso. Metode lapangan yang diterapkan untuk penelitian faktor emisi dirancang oleh mahasiswa MSc dan PhD kami: Jenny Farmer, Fitri Aini, Sebastian Persch, dan Margaret Thiong'o, dan mendapat dukungan dana di antaranya dari Global Environment Facility. Mereka didukung oleh pembimbing akademik Jo Smith (University of Aberdeen), Robin Matthews (McCauley Land Use Research Institute) dan Dirk Hölscher (Georg August University of Göttingen). Metode penelitian tentang kebocoran dirancang oleh Stibniati Atmadja dan Peter Vayda. Metode untuk tingkat acuan (termasuk tingkat emisi acuan) dikembangkan oleh Arild Angelsen, Simone Bauch, John Herbert Ainembabazi, Martin Herold, dan Arief Widjaya. Metode untuk penilaian kapasitas kelembagaan dikembangkan oleh Martin Herold dan Erika Romijn. Metode penilaian MRV tingkat proyek dikembangkan oleh Shijo Joseph, William D. Sunderlin, dan Louis V. Verchot.

Banyak pihak yang memberikan kontribusi dalam studi kasus negara: Zulma Villegas dan Bonifacio Mostacedo (Bolivia); Denis Sonwa, Pascal Cuny, Maden Le Crom, dan Adeline Giraud (Kamerun); Rizaldi Boer, Titiek Setyawati, Tania June, dan Doddy Yuli Irawan (Indonesia); Vu Tan Phuong, Vu Tien Dien, Pham Manh Cuong, Nguyen Thuy My Linh, Nguyen Viet Xuan, dan Vo Dai Hai (Vietnam). Data lapangan negara dikumpulkan oleh Margaret Thiong'o, Edith Anyango, Paul Mutuo, Sheila Abwanda, Denis Sonwa, dan Victor Kemeuze (Kenya). Oktarita Satria dan Levania Santoso memberikan dukungan dan bantuan penelitian yang sangat berharga. 


\section{Komponen 4}

Komponen berbagi pengetahuan diawasi oleh John Colmey dan Daniel Cooney. Ucapan terima kasih kami sampaikan kepada Sandra McGuire, yang menulis proposal komunikasi awal untuk Komponen 4, tetapi meninggalkan CIFOR sebelum diluncurkan. Komponen ini telah bekerja dengan sejumlah mitra, termasuk Climate Change Media Partnership, Internews, Masyarakat Jurnalis Lingkungan Indonesia, Green Ink, PANOS London, Transparency International, Uni Internasional untuk Konservasi Alam, Badan Penelitian dan Pengembangan Kehutanan Indonesia, dan pemerintah Denmark, Indonesia, Meksiko, Polandia, dan Afrika Selatan. Tim staf dan konsultan komunikasi yang penuh talenta (bekerja paruh waktu dan penuh waktu) meliputi: Leony Aurora, James Maiden, Michelle Kovacevic, Catriona Moss, Karin Holzknecht, Gabriela Ramirez, Kamal Prawiranegara, Gugi Ginanjar, Andrea Booth, Kate Evans, Mokhamad Edliadi, Aris Sanjaya, Budhy Kristanty, Nia Sabarniati, Mohammad Agus Salim, Atie Puntodewo, Yahya Sampurna, Gusdiyanto, Dodi Iriyanto, Wigid Triyadi, Gideon Suharyanto, Eko Prianto, Catur Wahyu, Vidya Fitrian, Erisa, Sufiet Erlita, Yuan Oktafian, RizkaTaranita, Wiwit Siswarini, Sekar Palupi, Dina Satrio, Santi Darmokusumo, Widya Sutiyo, Imogen Badgery Parker, dan Romy Serfaty. Mantan staf, konsultan, dan mitra meliputi Nita Murjani, Edith Abilogo, James Clarke, Neil Palmer, Tim Cronin, Edith Johnson, Angela Dewan, Jeff Walker, Ramadian Bachtiar, dan Yani Saloh.

\section{Dukungan proyek GCS}

Dukungan administratif yang sangat berharga diberikan oleh Rosita Go, Ria Widjaja-Adhi, Rina, Made Dwi Astuti, Christine Wairata, Anna Luntungan, Susan Kabiling, Anastasia Elisa, Feby Litamahuputty, dan Oktarita Satria.

\section{Donor}

Kami berterima kasih atas dukungan keuangan dari pemerintah Australia, Finlandia, Norwegia, Inggris, dan Komisi Eropa. 


\section{Daftar istilah dan singkatan}

2BSvs

$3 \mathrm{E}$

4Is

AAU

ACR

$\mathrm{AD}$

$\mathrm{ADg}$

$\mathrm{ADM}$

AF

$\mathrm{AF}$

AFOLU

AfD
Biomass biofuels sustainability voluntary scheme (skema keberlanjutan biomassa bahan bakar hayati sukarela)

Effectiveness, efficiency and equity (keefektifan, efisiensi dan kesetaraan)

Institutions, interests, ideas and information (Lembaga, kepentingan, gagasan dan informasi)

Assigned amount unit (unit penurunan emisi gas rumah kaca)

American Carbon Registry (Pencatatan Karbon Amerika)

Avoided deforestation (Deforestasi yang dihindari)

Avoided degradation (Degradasi yang dihindari)

Archer Daniels Midland

Amazon Fund (Dana Perwalian Amazon)

Afforestation (Aforestasi)

Agriculture, forest and other land uses (Pertanian, kehutanan dan penggunaan lahan lain)

Agence Française du Développement (French Development Agency/Lembaga Pembangunan Perancis) 
AG

AIDER

ANSAB

APD

AR

AR4

ARR

AUDD

AWG-LCA

BAM

BAM

BAU

BINGO

BG

BNDES

$\mathrm{BRIC}(\mathrm{S})$

BSM

$\mathrm{C}$

CAIT
Aboveground biomass (Biomassa di atas tanah)

Associación para la Investigación y el Desarrollo Integral (Association for Integral Research and Development, Perul Asosiasi untuk Penelitian Pembangunan Integral, Peru) Asia Network for Sustainable Agriculture and Bioresources (Jaringan Pertanian Berkelanjutan dan Sumberdaya Hayati di Asia)

Avoiding planned deforestation (Menghindari deforestasi yang direncanakan)

Afforestation and reforestation (Aforestasi dan reforestasi)

Fourth Assessment Report of the United Nations Intergovernmental Panel on Climate Change (Laporan Penilaian Keempat oleh Panel Antarpemerintah PBB mengenai Perubahan Iklim)

Afforestation, reforestation and revegetation (Aforestasi, reforestasi dan revegetasi)

Avoiding unplanned deforestation and/or degradation (Menghindari deforestasi dan/atau degradasi yang direncanakan)

Ad Hoc Working Group on Long-term Cooperative Action of the United Nations Framework Convention on Climate Change (Kelompok Kerja Ad Hoc Aksi Kerjasama Jangka Panjang dari Konvensi Kerangka Kerja PBB mengenai Perubahan Iklim

Bosques Amazonicos

Border adjustment measure (Ukuran penyesuaian perbatasan)

Business as usual (Bisnis seperti biasa)

Biginternationalnongovernmentalorganisation (Organisasi nonpemerintah internasional berskala besar)

Below ground biomass (Biomassa di bawah tanah)

Banco Nacional de Desenvolvimento Econômico e Social (National Bank for Economic and Social Development, Brazil/Bank Nasional untuk Pembangunan Ekonomi dan Sosial, Brasil)

Brazil, Russia, India, China, (South Africa) (Brasil, Rusia, India, China, (Afrika Selatan)

Benefit sharing mechanism (Mekanisme pembagian manfaat)

Carbon (Karbon)

Climate analysis indicators tool (Perangkat indikator analisis iklim) 
CAT

CBD

CBFF

CBFM

$\mathrm{CBO}$

CC

CCBA

$\mathrm{CCB}(\mathrm{S})$

CCCSD UPNG

CCDS

CDM

CED

CEDLA

CER

CERDA

CFM

CGIAR

$\mathrm{CH}_{4}$

CI

CIEM
Cap and trade (Pembatasan emisi dan proses jual beli izin pembatasan)

Convention on Biological Diversity (Konvensi Keanekaragaman Hayati)

Congo Basin Forest Fund (Dana Hutan Kawasan Kongo)

Community-based forest management (Pengelolaan hutan oleh masyarakat)

Community-based organisation (Organisasi berbasiskan masyarakat)

Climate change (perubahan iklilm)

Climate, Community and Biodiversity Alliance (Aliansi Iklim, Komunitas dan Keanekaragaman hayati)

Climate, Community and Biodiversity (Standards) ((Standar) Iklim, Komunitas dan Keanekaragaman hayati)

Centre for Climate Change and Sustainable Development, University of Papua New Guinea (Pusat Perubahan Iklim dan Pembangunan Berkelanjutan, Universitas Papua Nugini)

Climate change development strategy (Strategi pembangunan perubahan iklim)

Clean Development Mechanism (Mekanisme Pembangunan Bersih)

Centre pour l'Environnement et le Développement (Centre for Environment and Development, Cameroon/Pusat Lingkungan Hidup dan Pembangunan, Kamerun)

Centre for Latin American Research and Documentation, the Netherlands (Pusat untuk Penelitian Amerika Latin dan Dokumentasi, Belanda)

Certified emission reduction (Reduksi emisi bersertifikasi)

Centre of Research and Development in Upland Areas, Vietnam (Pusat Penelitian dan Pembangunan di Dataran Tinggi, Vietnam)

Community forest management (Pengelolaan hutan kemasyarakatan)

CGIAR adalah kemitraan penelitian global untuk masa depan dengan keamanan pangan

Methane (Metana)

Conservation International (nama organisasi konservasi berbasis di Amerika Serikat )

Central Institute for Economic Management, Vietnam (Lembaga Sentral Pengelolaan Ekonomi, Vietnam) 
CIFOR

CODELT

$\mathrm{CO}_{2}$

COBA

COMESA

COMIFAC

COMPON

COMTRADE

COP

$\mathrm{CPO}$

CRBM

CSO

CSR

CT-REDD

DAC

DAR

$\mathrm{dbh}$

DD

DMA

DNPI

DoF

DRC
Center for International Forestry Research (Pusat Penelitian Kehutanan Internasional)

Conseil pour la Défense Environnementale par la Légalité et la Traçabilité (Council for Environmental Defense through Legality and Traceability, Democratic Republic of Congo, Dewan Pertahanan Lingkungan melalui Legalitas dan Keterlacakan, Republik Demokratik Kongo)

Carbon dioxide (Karbon dioksida)

Communauté de Base (local forest management associations, Madagascarl asosiasi pengelolaan hutan lokal Madagaskar) Common Market for Eastern and Southern Africa (Pasaran Bersama untuk Afrika Timur dan Selatan)

Central Africa Forest Commission (Komisi Hutan Afrika Tengah)

Comparing Climate Change Policy Networks (Jaringan Perbandingan Kebijakan Perubahan Iklim)

United Nations Commodity Trade Statistics Database (Basis Data Statistik Perdagangan Komoditi PBB)

Conference of the Parties (Konferensi Para Pihak)

Crude palm oil (Minyak kelapa sawit mentah)

Campagna per la Riforma della Banca Mondiale (Campaign for the Reform of the World Bank, Italy/Kampanye untuk Reformasi Bank Dunia, Italia)

Civil society organisation (Organisasi masyarakat madani) Corporate social responsibility (Tanggung jawab sosial perusahaan)

Comité Technique REDD

Development Assistance Committee of the OECD (Komite Bantuan Pembangunan OECD)

Derecho, Ambiente y Recursos Naturales (Law, Environment and Natural Resources, Peru/Undang-undang, Lingkungan Hidup dan Sumberdaya Alam, Peru)

Diameter at breast height (diameter setinggi dada)

Deforestation and (forest) degradation (Deforestasi dan degradasi (hutan))

Defense Mapping Agency, USA (Lembaga Pemetaan Pertahanan AS)

Dewan Nasional Perubahan Iklim Indonesia)

Department of Forestry (Departemen Kehutanan)

Democratic Republic of the Congo (Republik Demokrasi Kongo)

DW Dead wood (Kayu mati) 
EC

ECG

$\mathrm{EF}$

EIU

EMBRAPA

ENGO

ER

ES

ETM

ETS

EU-RED

FAO

FAOSTAT

FAS

FCPF

FDI

FFI

FIP

FLA

FLEGT

FONAM

FOEI

FPIC
European Commission (Komisi Eropa)

Expert Consultation Group (Kelompok Konsultasi Ahli)

Emission factor (Faktor emisi/FE)

Economist Intelligence Unit (Unit Intelejensi Ekonomi)

Empresa Brasileira de Pesquisa Agropecuária (Brazilian

Enterprise for Agricultural Research/Lembaga Penelitian Pertanian Brasil)

Environmental nongovernmental organisation (Organisasi nonpemerintah di bidang lingkungan hidup)

Emission reduction (reduksi atau pengurangan emisi)

Environmental services (jasa/layanan lingkungan)

Enhanced thematic mapper (Pemetaan tematik yang ditingkatkan)

Emissions trading scheme (European Union) (Skema Perdagangan Emisi (Uni Eropa))

European Union Renewable Energy Directive (Rancangan Energi Terbarukan Uni Eropa)

Food and Agriculture Organization of the United Nations (Organisasi Pangan dan Pertanian Perserikatan Bangsa-Bangsa)

Food and Agriculture Organization of the United Nations Statistical Database (Basis Data Statistik Organisasi Pangan dan Pertanian Perserikatan Bangsa-Bangsa)

Fundação Amazonas Sustentável (Amazonas Sustainable Foundation, Brazill Yayasan Amazonas Berkelanjutan, Brasil)

Forest Carbon Partnership Facility (Fasilitas Kemitraan Karbon Hutan)

Foreign direct investment (Investasi langsung luar negeri)

Fauna and Flora International

Forest Investment Programme (Program Investasi Hutan)

Forest land allocation (Alokasi lahan hutan)

Forest Law Enforcement, Governance and Trade (European Union) (Penegakan Hukum Kehutanan, Tata kelola dan Perdagangan (Uni Eropa))

El Fondo Nacional del Ambiente (National Fund for Environment, Peru) (Dana Nasional untuk Lingkungan Hidup, Peru)

Friends of the Earth International

Free, prior and informed consent (Persetujuan sukarela setelah mendapat informasi sebelumnya) 
FRA

FSC

G-20

GCF

GCS

GDP

GEF

GEO

GFA - Envest

GHG

GIS

GOFC-GOLD

GPG

GRIF

GSO

$\mathrm{Gt}$

ha

HCVF

HIMA

HLPE

IBGE

IBIF

ICV

ICDP
Forest resource assessment (UN Food and Agriculture Organization) (Penilaian sumberdaya hutan (Organisasi Pangan dan Pertanian PBB))

Forest Stewardship Council (Dewan Penatalayanan Hutan)

The Group of Twenty Finance Ministers and Central Bank Governors (Kelompok Dua Puluh Menteri Keuangan dan Gubernur Bank Sentral)

Governors' Climate and Forests Task Force (Satuan Tugas Iklim dan Hutan dari Gubernur)

Global Comparative Study on REDD+ (Studi Komparatif Global REDD+)

Gross domestic product (Produk domestik bruto (PDB))

Global Environment Facility (Fasilitas Lingkungan Hidup Global)

Group on Earth Observations (Kelompok Observasi Bumi)

Sebuah perusahaan konsultan di Kamerun

Greenhouse gas (Gas rumah kaca (GRK))

Geographic Information System (Sistem informasi geografis)

Global Observation of Forest and Land Cover Dynamics (Observasi Global atas Hutan dan Dinamika Tutupan Lahan)

Good practice guidance (Panduan Praktik yang Baik)

Guyana REDD+ Investment Fund (Dana Investasi REDD+ Guyana)

General Statistics Office (Organisasi Statistik Umum)

Gigatonne (gigaton)

Hectare (hektar)

High conservation value forests (hutan bernilai konservasi tinggi)

Hifadhi ya Misitu ya Asili (Merintis REDD di Zanzibar melalui Pengelolaan Hutan Kemasyarakatan, Tanzania)

High Level Panel of Experts on Food Security and Nutrition of the Committee on World Food Security (Panel Tingkat Tinggi Ahli dalam Keamanan Pangan Komite Keamanan Pangan Dunia)

Instituto Brasileiro de Geografia e Estatistica (Lembaga Geografi dan Statistik Brasil)

Instituto Boliviano de Investigación Florestal (Lembaga Penelitian Kehutanan Bolivia)

Instituto Centro de Vida (Institut Pusat Kehidupan, Brasil) Integrated conservation and development project (Proyek Konservasi dan pembangunan terpadu) 
ICEL Indonesian Center for Environmental Law (Yayasan Pengembangan Hukum Lingkungan Indonesia)

IDB Inter-American Development Bank

IDESAM Institute for the Conservation and Sustainable Development of Amazonas (Lembaga Konservasi dan Pembangunan Berkelanjutan Amazon)

IE

Infinite Earth

IEA

IFM

International Energy Agency (Lembaga Energi Internasional)

Improved forest management (Pengelolaan hutan yang lebih baik)

IGES Institute for Global Environmental Strategies (Lembaga Strategi Lingkungan Hidup Global)

ILUC Indirect land use change (Perubahan penggunaan lahan secara tidak langsung)

IMAFLORA Instituto de Manejo e Certificação Florestal e Agrícola (Lembaga untuk Sertifikasi Pertanian dan Pengelolaan Hutan, Brasil)

IMC

Instituto de Mudanças Climáticas e Regulação de Serviços Ambientais (Institute of Climate Change and Ecosystem Services Regulation, Brazil/Lembaga Perubahan Iklim dan Pengaturan Layanan Lingkungan, Brasil)

INCAS Indonesian national carbon accounting system (Sistem neraca karbon Indonesia)

INCRA Instituto Nacional de Colonização e Reforma Agrária (National Institute for Colonization and Agrarian Reform, Brazil)/ Lembaga Nasional untuk Kolonisasi dan Reformasi Agraria, Brasil)

INGO International nongovernmental organisation (Organisasi lingkungan hidup non pemerintah internasional)

INPE Instituto Nacional de Pesquisas Espaciais (National Institute for Space Research, Brazil) Lembaga Nasional Penelitian Ruang Angkasa, Brasil

Inpres Instruksi Presiden (Indonesia)

Int International (Internasiona)

IPAM Instituto de Pesquisa Ambiental da Amazônia (Amazon Environmental Research Institute, Brazil) Lembaga Penelitian Lingkungan Hidup Amazon, Brasil

IPCC Intergovernmental Panel on Climate Change (Panel Antarpemerintah mengenai Perubahan Iklim)

ISCC International Sustainability \& Carbon Certification (Sertifikasi Keberlanjutan dan Karbon Internasional) 
ISO

IUCN

IWGFF

IWG-IFR

JCN

JFM

JGI

$\mathrm{KCCP}$

KFCP

KfW

LCDS

LiDAR

LoI

LSPP

LU

LUC

LULUCF

MCDI

MDG

MfDR

MIFEE

MINEP

MLG

MMA
International Organization for Standardization (Organisasi standarisasi internasional)

International Union for the Conservation of Nature (Perserikatan Konservasi Alam Internasional)

Indonesian Working Group on Forest Finance (Kelompok Kerja Indonesia tentang Pendanaan Hutan)

Informal Working Group - Interim Finance for REDD+ (Kelompok Kerja Informal - Pendanaan Interim untuk REDD+)

Joint concept note (Catatan konsep bersama)

Joint forest management (Pengelolaan hutan bersama)

Jane Goodall Institute

Ketapang Community Carbon Pool, Indonesia (Tampungan

Karbon Komunitas Ketapang, Indonesia)

Kalimantan Forest Carbon Partnership, Indonesia (Kemitraan Karbon Hutan Kalimantan, Indonesia)

Kreditanstalt fuer Wiederaufbau (Reconstruction Credit Institute, Germanyl Lembaga Rekonstruksi Kredit, Jerman)

Low carbon development strategy (Strategi pembangunan rendah karbon)

Light detection and ranging (Deteksi cahaya dan penjarakan)

Letter of intent (Surat pernyataan kehendak)

Lembaga Studi Pers dan Pembangunan (Indonesia)

Land use (penggunaan lahan)

Land use change (Perubahan penggunaan lahan)

Land use, land use change and forestry (Penggunaan lahan, perubahan penggunaan lahan dan kehutanan)

Mpingo Conservation \& Development Initiative, Tanzania (Inisiatif Konservasi \& Pembangunan, Tanzania)

Millennium Development Goals (Sasaran Pembangunan Milenium)

Managing for development results (Pengelolaan untuk hasil-hasil pembangunan)

Merauke Integrated Food and Energy Estate, Indonesia (Estat Pangan dan Energi Terpadu Merauke, Indonesia)

Ministry of Environment and Nature Protection, Cameroon (Kementerian Lingkungan Hidup dan Perlindungan Alam, Kamerun)

Multilevel governance (tata kelola multilevel)

Ministério do Meio Ambiente (Ministry of Environment, Brazil/ Kementerian Kehutanan, Brasil) 


MoU
MRV
/a
$\mathrm{N}_{2} \mathrm{O}$
NAFORMA
NAMA
NASA
Nat
NCSU
NEC
NGGIP
NGO
NOK
NORDECO

$\mathrm{NOx}$

NPCC

NRI-PNG

NRS

NTF

OAR

OCCD

ODA

OECD

ONACC
Memorandum of understanding (Nota Kkesepahaman)

Measurement/Monitoring, reporting and verification (Pengukuran/Pemantauan, pelaporan dan verifikasi) Not applicable or not answered (tidak dapat diterapkan atau tidak dijawab)

Nitrous oxide (Dinitro oksida)

National Forest Resource Assessment, Tanzania

Nationally appropriate mitigation actions (Tindakan mitigasi yang sesuai secara nasional)

National Aeronautics and Space Administration (Lembaga Antariksa dan Ruang Angkasa AS)

National (Nasional)

North Carolina State University, USA

National Executive Council, UK (Dewan Pelaksana Nasional, Inggris)

National Greenhouse Gas Inventory Programme (Program Inventarisasi Gas Rumah Kaca Nasional)

Nongovernmental organisations (Lembaga swadaya masyarakat)

Norwegian Kroner (Kroner, mata uang Norwegia)

Nordic Agency for Development and Ecology (Badan Pembangunan dan Ekologi Nordik)

Nitrogen oxide (Nitrogen oksida)

National Policy on Climate Change (Kebijakan Nasional mengenai Perubahan Iklim)

National Research Institute, Papua New Guinea (Lembaga Penelitian Nasional, Papua Nugini)

National REDD+ Steering Committee (Komite Pengarah REDD+ Nasional)

National Trust Fund, Tanzania (Dana Perwalian Nasional, Tanzania)

Option assessment report (Laporan pilihan penilaian)

Office of Climate Change and Development, Papua New Guinea (Departemen Perubahan Iklim dan Pembangunan, Papua Nugini)

Official development assistance (aliran bantuan pembangunan resmi ke negara-negara berkembang)

Organisation for Economic Cooperation and Development (Organisasi untuk Kerjasama Ekonomi dan Pembangunan)

Observatoire National sur les Changements Climatiques (National Observatory on Climate Change, Cameroon/ Observatori Nasional Perubahan Iklim, Kamerun) 
ONFI

PAM

PES

PFM

PNGFA

PWC

$\mathrm{RaCSA}$

RCFEE

RED

REDD

REDD DA

REDD+

REDD-MF

REDES

REL

REPAR

RFF

REPOA
Organisation Nationale Forestière Internationale

Policies and measures (Kebijakan dan tindakan)

Payments for environmental services (Imbalan jasa lingkungan)

Participatory forest management (Pengelolaan hutan partisipatif)

Papua New Guinea Forestry Authority (Otoritas Kehutanan Papua Nugini)

PricewaterhouseCoopers

Rapid carbon stock appraisal (Cara cepat dan terpadu untuk menilai stok karbon)

Research Centre for Forest Ecology and Environment, Forest Science Institute of Vietnam (Pusat Penelitian Ekologi Hutan dan Lingkungan Hidup, Institut Ilmu Pengetahuan Kehutanan Vietnam)

Reducing emissions from deforestation (Reduksi emisi dari deforestasi)

Reducing emissions from deforestation and forest degradation (Pengurangan Emisi dari Deforestasi dan Degradasi hutan)

Reduced emission from deforestation and forest degradation - demonstration activity (Pengurangan Emisi dari Deforestasi dan Degradasi hutan-kegiatan percontohan)

Reducing emissions from deforestation and forest degradation and enhancing forest carbon stocks (Pengurangan Emisi dari Deforestasi dan Degradasi dan meningkatkan stok karbon hutan)

REDD methodology modules (Modul metodologi REDD) Rede de Desenvolvimento, Ensino e Sociedade (Network for Development, Education and Society, BrazillJejaring untuk Pembangunan, Pendidikan dan Kemasyarakatan, Brasil)

Reference emission level (Tingkat emisi acuan)

Réseau des Parlementaires pour la Gestion Durable des Écosystèmes Forestières d'Afrique Centrale (Network of Parliamentarians for Sustainable Management of Forest Ecosystems in Central Africa)/Jejaring Parlemen untuk Pengelolaan Berkelanjutan Ekosistem Hutan di Afrika Tengah)

Resources for the Future (Sumberdaya untuk masa depan)

Research on Poverty Alleviation, Tanzania (Penelitian tentang Pengentasan Kemiskinan, Tanzania)

RL

Reference level (Tingkat acuan) 


\begin{tabular}{|c|c|}
\hline R-PIN & $\begin{array}{l}\text { Readiness Plan Idea Notes (Catatan Gagasan } \\
\text { Rencana Kesiapan) }\end{array}$ \\
\hline RPP & $\begin{array}{l}\text { Readiness Preparation } \quad \text { Proposal } \\
\text { Rencana Kesiapan) }\end{array}$ \\
\hline RRI & $\begin{array}{l}\text { Rights and Resources Initiative (Inisiatif } \mathrm{Hak} \text { dan } \\
\text { Sumberdaya) }\end{array}$ \\
\hline RS & Restoration (Restorasi) \\
\hline RSB & $\begin{array}{l}\text { Roundtable on Sustainable Biofuels (Perundingan } \\
\text { mengenai Bahan Bakar Hayati Berkelanjutan) }\end{array}$ \\
\hline RSBA & $\begin{array}{l}\text { RED Bioenergy Sustainability Assurance (Jaminan } \\
\text { Keberlanjutan Bioenergi RED) }\end{array}$ \\
\hline SABLs & $\begin{array}{l}\text { Special agriculture and business leases (Izin khusus } \\
\text { pertanian dan bisnis) }\end{array}$ \\
\hline SBSTA & $\begin{array}{l}\text { Subsidiary Body for Scientific and Technological Advice of the } \\
\text { United Nations Framework Convention on Climate Change } \\
\text { (Badan Pendukung UNFCCC yang menangani masalah } \\
\text { teknis dan ilmiah) }\end{array}$ \\
\hline SES & $\begin{array}{l}\text { Social and environmental standards (Standar sosial dan } \\
\text { lingkungan hidup) }\end{array}$ \\
\hline SESA & $\begin{array}{l}\text { Strategic environmental and social assessment (Prosedur } \\
\text { untuk penilaian lingkungan dan sosial) }\end{array}$ \\
\hline SFEs & State forest enterprises (Perusahaan hutan negara) \\
\hline SIA & Social impact assessment (Penilaian dampak sosial) \\
\hline SIGSIF & $\begin{array}{l}\text { Registrados no Sistema de Informaçôes Gerenciais do Serviço } \\
\text { de Inspeção Federal (Management Information System of } \\
\text { the Federal Inspection System, Brazil-Sistem Pengelolaan } \\
\text { Informasi dari Sistem Inspeksi Federal-Brasil) }\end{array}$ \\
\hline SIF & $\begin{array}{l}\text { Serviço de Inspeção Federal (Federal Inspection Service, } \\
\text { Brazil-Layanan Inspeksi Federal, Brasil) }\end{array}$ \\
\hline SISA & $\begin{array}{l}\text { System of incentives for environmental services (Sistem } \\
\text { insentif untuk jasa lingkungan) }\end{array}$ \\
\hline SMART & $\begin{array}{l}\text { Specific, measurable, achievable, relevant and time } \\
\text { bound (Spesifik, terukur, dapat dicapai, relevan dan } \\
\text { terikat waktu) }\end{array}$ \\
\hline SNV & $\begin{array}{l}\text { Netherlands Development Organisation } \\
\text { Pembangunan Belanda) }\end{array}$ \\
\hline Son La FD & $\begin{array}{l}\text { Son La Forestry Department, Vietnam (Departemen } \\
\text { Kehutanan Son La, Vietnam) }\end{array}$ \\
\hline SOC & Soil organic carbon (Karbon organik tanah) \\
\hline SSA & Sub-Saharan Africa (Sub-Sahara Afrika) \\
\hline
\end{tabular}

TaTEDO Tanzania Traditional Energy Development and Environmental Organization (Organisasi Pembangunan Energi Tradisional dan Lingkungan Hidup Tanzania) 
TDERM

TFCG

TFWG

TI

TM

TNC

UEM

UKP4

UMB

UNC

UNCTAD

UN-DESA

UNDRIP

UNDP

UNEP

UNFCCC

UNORCID

UN-REDD
Tropical deforestation emissions reduction mechanism (Mekanisme pengurangan emisi dari deforestasi hutan tropis)

Tanzania Forest Conservation Group (Kelompok Konservasi Hutan Tanzania)

Tanzania Forestry Working Group (Kelompok kerja Kehutanan Tanzania)

Transparency International

Thematic mapper (Pemeta Tematik)

The Nature Conservancy

Universidade Eduardo Mondlane (Eduardo Mondlane

University, Mozambiquel Universitas Eduardo Mondlane, Mozambik)

Unit Kerja Presiden Pengawasan dan Pengendalian Pembangunan (The President's Unit for Development Control and Monitoring, Indonesia)

Universitetet for miljø- og biovitenskap (Norwegian University of Life Sciences/ Universitas Ilmu Hayati Norwegia)

University of North Carolina, USA

United Nations Conference on Trade and Development (Konferensi PBB mengenai Perdagangan dan Pembangunan)

United Nations Department of Economic and Social Affairs (Departemen Urusan Ekonomi dan Sosial Perserikatan Bangsa-Bangsa)

United Nations Declaration on the Rights of Indigenous Peoples (Deklarasi PBB tentang Hak-hak Penduduk Asli)

United Nations Development Programme (Program Pembangunan PBB)

United Nations Environment Programme (Program Lingkungan Hidup PBB)

United Nations Framework Convention on Climate Change (Konvensi Kerangka Kerja PBB tentang Perubahan Iklim) United Nations Office for REDD+ Coordination in Indonesia (Kantor PBB untuk Koordinasi REDD+ di Indonesia)

United Nations Collaborative Programme on Reducing Emissions from Deforestation and Forest Degradation in Developing Countries (Program Bersama Perserikatan Bangsa-Bangsa mengenai Pengurangan Emisi dari Deforestasi dan Degradasi Hutan di Negara berkembang) 
UoM University of Melbourne, Australia

VCS Verified carbon standard (formerly known as voluntary carbon standard); standar karbon terverifikasi, sebelumnya dikenal sebagai standar karbon sukarela)

VCU Verified carbon unit (Unit karbon terverifikasi)

VER Certified emission reduction (Pengurangan emisi terverifikasi)

VPA Voluntary partnership agreement (Kesepakatan kemitraan sukarela)

VRO Vietnam REDD+ Office (Kantor REDD+ Vietnam)

WCED World Commission on Environment and Development (Komisi Dunia untuk Lingkungan Hidup dan Pembangunan)

WGIII Working Group III of the IPCC (Kelompok Kerja III IPCC)

WRI World Resources Institute (Lembaga Sumberdaya Dunia)

WU Wageningen University, the Netherlands (Universitas Wageningen, Negeri Belanda)

WWF World Wildlife Fund/Worldwide Fund for Nature (Organsisasi konservasi alam dunia) 


\section{Daftar istilah}

4I

Adalah singkatan dari Institutions (Lembaga, yaitu aturan, alur kebergantungan atau keterlekatan), Interests (Kepentingan: manfaat materi potensial), Ideas (Gagasan: wacana kebijakan, ideologi yang mendasari, kepercayaan) dan Information (Informasi: pembentukan data dan ilmu pengetahuan dan kegunaannya).

\section{Additionality}

Kepenambahan ialah syarat sebuah kegiatan atau proyek REDD+ yang harus menghasilkan manfaat, seperti pengurangan emisi atau peningkatan penyerapan, yang tidak akan terjadi tanpa suatu kegiatan (yaitu skenario bisnis seperti biasa).

\section{AFOLU}

Singkatan dari Agriculture, Forestry and Other Land Use (Pertanian, Kehutanan dan Penggunaan Lahan Lainnya). Istilah ini dikemukakan dalam Panduan Inventarisasi Gas Rumah Kaca Nasional Panel Antarpemerintah mengenai Perubahan Iklim (IPCC,GL) (2006) untuk memperluas Panduan tahun 1996, yang hanya mencakup pertanian dan kehutanan. 


\section{Aforestasi}

Aforestasi ialah kegiatan manusia yang mengubah lahan yang selama sedikitnya 50 tahun tidak berupa hutan sehingga menjadi hutan, melalui penanaman, pembenihan dan atau pembenihan alami.

\section{Alur kebergantungan}

Alur kebergantungan menjelaskan ruang lingkup berbagai keputusan kebijakan saat ini terbatas oleh berbagai keputusan yang diambil di masa lalu, meskipun kondisi masa lalu mungkin sekarang sudah tidak relevan lagi (misalnya, 'masalah-masalah historis').

\section{Bahan bakar hayati}

Bahan bakar yang berasal dari materi organik, seperti kayu, tumbuh-tumbuhan, tanaman pangan dan limbah.

\section{Biaya implementasi}

Biaya untuk menyiapkan suatu sistem dan menempatkan kebijakan dan tindakan yang diperlukan untuk mencapai REDD+.

\section{Biaya peluang}

Dalam REDD+ hal ini mengacu pada keuntungan yang hilang dari penggunaan lahan alternatif terbaik.

\section{Biaya transaksi}

Biaya yang timbul ketika melakukan pertukaran ekonomi. Biaya ini mencakup biaya yang terkait pencarian dan informasi, penegakan, implementasi dan pemantauan. Biaya transaksi biasanya digunakan terkait dengan sistem PRS, tetapi kadang juga digunakan melebihi arti semulanya, untuk mencakup biaya REDD+ apa pun, kecuali biaya peluang.

\section{Biomassa}

Total massa kering materi organik hidup.

\section{Bisnis seperti biasa}

Rujukan kebijakan netral untuk emisi atau penyerapan di masa depan, diestimasi dengan menggunakan proyeksi emisi atau penyerapan di masa depan tanpa adanya kegiatan REDD+. Istilah ini juga digunakan dalam pengertian ekonomi politis dengan makna keberlangsungan kebijakan dan praktik konsisten dengan status quo dalam ekonomi politik praREDD+ di suatu negara.

\section{Dana multilateral}

Pendanaan yang menerima kontribusi dari lebih dari satu negara donor dan kebanyakan dilaksanakan oleh organisasi internasional. 


\section{Data aktivitas}

Data mengenai besarnya kegiatan manusia yang memicu emisi atau penyerapan karbon. Untuk REDD+, data ini biasanya merujuk ke luas lahan dalam suatu sistem pengelolaan, deforestasi atau degradasi, tetapi juga bisa merujuk ke hal-hal lain, seperti jumlah asupan, misalnya pupuk.

\section{Deforestasi}

Konversi lahan dari hutan menjadi bukan hutan yang bersifat permanen. Dalam Perjanjian Marrakesh, deforestasi didefinisikan sebagai 'konversi dari lahan berhutan menjadi lahan tidak berhutan yang langsung disebabkan oleh manusia.' FAO mendefinisikan deforestasi sebagai 'konversi hutan menjadi penggunaan lahan lain atau pengurangan dalam jangka panjang atas tutupan kanopi pohon di bawah ambang minimum 10\%'.

\section{Degradasi}

Degradasi mengacu pada perubahan dalam suatu hutan yang secara negatif memengaruhi struktur atau fungsi tegakan atau lahan hutan, dan dengan demikian menurunkan kapasitasnya untuk memasok berbagai barang dan jasa. Dalam lingkup REDD+, degradasi hutan dapat diukur melalui pengurangan stok karbon dalam hutan yang tetap tinggal sebagai hutan. Belum ada definisi formal degradasi yang diadopsi, karena banyak stok karbon hutan berfluktuasi akibat siklus alami atau praktik-praktik pengelolaan.

\section{Eksternalitas}

Biaya atau manfaat yang ditanggung para pelaku selain dari pelaku yang melakukan suatu kegiatan. Juga disebut sebagai limpahan atau efek samping.

\section{Faktor emisi}

Sebuah faktor yang menguantifikasi emisi atau penyerapan GRK per unit data kegiatan, misalnya, deforestasi per hektar.

Fase

Fase mengacu pada tahap-tahap implementasi REDD+ di berbagai negara:

Fase 1: Pemantapan kerangka kerja, strategi, kebijakan REDD+ dan kerangka kerja pertanggungjawaban (kesiapan REDD+)

Fase 2: Implementasi berbagai kebijakan dan tindakan REDD+, dan kemungkinan pembayaran berdasarkan implementasinya.

Fase 3: Pembayaran berbasiskan hasil untuk REDD+ (yaitu untuk emisi dan penyerapan). 
G-20

Kelompok dari Dua Puluh Menteri Keuangan dan Gubernur Bank Sentral. Kelompok ini mencakup 19 negara anggota dan Uni Eropa. Sasaran G-20 mencakup koordinasi kebijakan untuk mencapai kestabilan ekonomi global, mendorong peraturan keuangan yang mengurangi risiko dan mencegah krisis keuangan di masa depan serta menciptakan arsitektur keuangan internasional yang baru.

\section{Hutan}

FAO mendefinisikan hutan sebagai lahan yang memiliki tutupan kanopi minimum 10\%, ketinggian tegakan pohon minimum in situ $5 \mathrm{~m}$, luas minimum 0,5 hektar, dan pertanian bukan merupakan penggunaan lahan dominan. Konvensi PBB mengenai Kerangka Kerja Perubahan Iklim (UNFCCC) mengizinkan definisi hutan yang lebih luwes, yaitu: tutupan kanopi minimum 10-30\%, ketinggian pohon minimum 2-5 meter, dan luas minimum 0,1 hektar. Setiap negara mempunyai definisi sendiri.

\section{Imbalan untuk jasa ekosistem/lingkungan}

Pembeli yang menilai jasa lingkungan membayar kepada pemasok atau pengelola penggunaan lahan yang memberikan jasa lingkungan jika dan hanya jika, penjual benar-benar memberikan jasa lingkungan. Dalam REDD+, PES merupakan sistem berbasiskan hasil; pembayaran imbalan didasarkan atas pengurangan emisi atau peningkatan cadangan karbon dibandingkan dengan tingkat acuan yang disepakati.

\section{Insentif yang merugikan}

Suatu kebijakan yang menciptakan insentif tetapi memberikan hasil tidak dimaksudkan dan tidak dikehendaki.

\section{Kebijakan dan tindakan (PAM)}

Dalam REDD+, PAM merupakan kebijakan dan tindakan yang diberlakukan secara nasional sehingga setiap negara melaksanakan pengurangan emisi atau peningkatan penyerapan karbon.

\section{Kebocoran}

Dalam kaitannya dengan perubahan iklim, kebocoran karbon terjadi ketika kegiatan pengurangan emisi di suatu wilayah (subnasional atau nasional) menyebabkan peningkatan emisi di kawasan lain. Istilah resmi UNFCCC ialah "pengalihan emisi”.

\section{Kesiapan}

Kegiatan REDD+ di setiap negara, termasuk pembangunan kapasitas, perumusan kebijakan, konsultasi dan pengambilan kesepakatan, serta pengujian dan penilaian strategi REDD+ nasional, sebelum pelaksanaan REDD+ secara keseluruhan. 


\section{Kondisi awal}

Istilah ini digunakan dalam cara-cara berbeda, tetapi biasanya untuk menunjukkan skenario bisnis seperti biasa. Dalam REDD+, kondisi awal ini mewakili perubahan dalam stok karbon hutan akibat kegiatan manusia, yang diproyeksikan akan muncul dalam keadaan tanpa kegiatan proyek yang diusulkan atau intervensi kebijakan. Lihat juga tingkat acuan. Dalam evaluasi proyek, 'kondisi awal' juga dapat mengacu pada kondisi praproyek (misalnya, 'studi kondisi awal' melibatkan pengumpulan data sosio-ekonomi dan ekologis sebelum sebuah proyek dimulai, secara implisit mengasumsikan bahwa perubahan apa pun yang terjadi adalah karena adanya proyek tersebut).

Konferensi Para Pihak (COP) dari UNFCCC

Badan pengatur Konvensi Kerangka Kerja Perubahan Iklim PBB (UNFCCC). Badan ini bertemu setahun sekali.

\section{LULUCF}

Merupakan singkatan dari "penggunaan lahan, perubahan penggunaan lahan dan kehutanan" Kegiatan LULUCF dijelaskan dalam Pasal 3 (ayat 3 dan 4) dan Pasal 6 dan 12 Protokol Kyoto.

\section{Manfaat tambahan}

Manfaat yang berasal dari REDD+ selain manfaat mitigasi iklim, misalnya pengayaan keanekaragaman hayati, peningkatan adaptasi terhadap perubahan iklim, pengurangan kemiskinan, perbaikan mata pencaharian masyarakat lokal, perbaikan tata kelola hutan dan perlindungan hak masyarakat.

\section{Mekanisme pasar langsung}

Mekanisme yang menghasilkan pendanaan dari penjualan langsung pengurangan emisi terverifikasi atau bersertifikasi dalam pasar karbon sukarela atau pasar kepatuhan.

\section{Mekanisme pasar tidak langsung}

Suatu mekanisme yang menghasilkan pendanaan untuk REDD+ melalui menautkan konservasi hutan dengan transaksi di pasar nonkarbon, misalnya untuk komoditas atau jasa terkait dengan pemicu deforestasi.

\section{Mekanisme pembangunan bersih (CDM)}

Sebuah mekanisme pengimbangan karbon di bawah Pasal 12 Protokol Kyoto yang dirancang untuk membantu negara-negara Aneks I dalam memenuhi target pengurangan emisi mereka, dan untuk membantu negara-negara nonAneks I untuk mencapai pembangunan berkelanjutan. CDM memungkinkan negara-negara Aneks I untuk mendanai dan melaksanakan proyek-proyek yang mengurangi emisi di 
negara-negara nonAneks I sehingga mereka dapat memperoleh kredit (pengurangan emisi bersertifikasi) untuk memenuhi target pengurangan emisi mereka sendiri.

\section{Negara-negara Aneks I dan NonAneks I}

Di bawah Konvensi Kerangka Kerja mengenai Perubahan Iklim PBB (UNFCCC), negara-negara terbagi menjadi dua kategori: negara-negara maju (negara-negara Aneks I) dan negara-negara berkembang (negara-negara nonAneks I) Menurut prinsip "tanggung jawab bersama, tetapi dibedakan", negara-negara dalam Aneks I bertanggung jawab lebih besar untuk menjalankan kebijakan dan melaporkan dibandingkan dengan negara-negara nonAneks I. Sebagian besar negara Aneks I telah berjanji untuk mengurangi emisi berdasarkan Protokol Kyoto.

\section{Offset atau pengimbangan karbon}

Pengurangan emisi atau peningkatan penyerapan yang terjadi untuk mengompensasi emisi yang terjadi di tempat lain. Offset karbon diukur dalam ton metrik $\mathrm{CO}_{2}$-setara.

\section{Otonomi negara}

Derajat di mana negara dapat mengambil keputusan kebijakan secara independen dari kelompok-kelompok sosial.

\section{Panduan IPCC 2006 (IPCC GL)}

Panel Antarpemerintah mengenai Perubahan Iklim (IPCCC) menerbitkan laporan metodologis ini pada tahun 2006. Laporan ini menyediakan panduan untuk inventarisasi GRK nasional.

\section{Pasar karbon}

Pasar untuk perdagangan pengurangan emisi karbon, biasanya dalam bentuk kredit karbon (pengurangan emisi terverifikasi atau tereduksi). Pasar karbon berbentuk: i) pasar sukarela (target pengurangan emisi tidak diatur); atau ii) pasar wajib (kredit karbon dijual untuk memenuhi target pengurangan emisi yang diatur). Pasar karbon terbesar saat ini adalah Sistem Perdagangan Emisi (ETS) Uni Eropa.

\section{Pasar sukarela}

Pasar karbon sukarela berfungsi selain pasar wajib. Pembelinya ialah perusahaan, pemerintah, LSM dan perorangan yang secara sukarela berupaya mengganti rugi emisi mereka dengan membeli pengurangan emisi yang dapat dibuktikan.

\section{Pasar wajib}

Pasar wajib diciptakan dan diatur oleh pihak yang berwenang dalam urusan iklim nasional atau internasional yang bersifat wajib. Pasar ini 
menetapkan atau melelang pembatasan (kuota atau batas-atas) emisi GRK kepada negara-negara atau pihak-pihak subnasional (misalnya, perusahaan) dan mengizinkan mereka membeli kredit karbon untuk memenuhi batas-atas mereka, atau menjual kredit karbon jika mereka mengeluarkan gas kurang daripada batas atas mereka (yaitu perdagangan, sehingga juga disebut sebagai "batas-atas dan perdagangan").

\section{Pasar wajib/kepatuhan/keharusan}

Pasar yang diciptakan oleh sistem legal internasional, nasional atau regional untuk membatasi emisi GRK.

\section{Pembagian manfaat}

Distribusi perolehan bersih secara langsung maupun tidak langsung (manfaat berupa uang maupun bukan uang) dari implementasi REDD+.

\section{Pendanaan berbasiskan pasar}

Menggalang dana dari pasar karbon wajib atau sukarela untuk REDD+ dengan menjual pengurangan emisi terverifikasi atau tersertifikasi. Para pembelinya perorangan, perusahaan swasta atau badan pemerintah. Pendanaan berbasiskan pasar dapat juga mengacu pada menggalang uang dari pasar nonkarbon, misalnya pajak penerbangan yang disisihkan untuk mitigasi dan adaptasi iklim.

\section{Pendanaan nonpasar}

Bentuk-bentuk pendanaan tradisional, seperti bantuan pembangunan resmi dan pengeluaran domestik pemerintah.

\section{Pendekatan (mengacu pada data kegiatan)}

Ada tiga pendekatan dalam pengumpulan data kegiatan untuk inventarisasi GRK, menurut IPCCGL:

Pendekatan 1 Total luas penggunaan lahan, tanpa adanya konversi data di antara penggunaan lahan.

Pendekatan 2 Total luas penggunaan lahan, termasuk berbagai perubahan antarkategori

Pendekatan 3 Data konversi penggunaan lahan eksplisit secara spasial.

\section{Pendekatan berbasiskan dana}

Pendekatan yang memobilisasi pendanaan untuk REDD+ melalui kontribusi anggaran belanja dan menyalurkan pendanaan berdasarkan syarat dan kriteria yang disepakati.

\section{Penduduk asli}

Tidak ada definisi yang disepakati secara universal mengenai penduduk asli, meskipun beberapa instrumen legal internasional memberikan berbagai definisi. Menurut PBB, daripada mendefinisikan penduduk asli, 
pendekatan yang paling berguna adalah mengenali diri sesuai dengan hak asasi untuk menentukan nasib sendiri sesuai yang tercantum dalam deklarasi hak asasi manusia.

\section{Penyerapan}

Mengacu pada penyerapan $\mathrm{CO}_{2}$ atau GRK lain dari atmosfer dan penyimpanannya dalam tampungan karbon, seperti yang ditemukan di hutan. Lihat juga sekuestrasi karbon.

\section{Penyerapan karbon}

Penyerapan karbon dari atmosfer ke penyimpanan jangka panjang dalam rosot melalui proses fisika atau biologi, seperti fotosintesis.

\section{Perladangan berpindah}

Sebuah sistem pertanian di mana plot-plot lahan ditanami selama beberapa tahun, kemudian ditinggalkan ketika tanah sudah tidak subur lagi atau gulma mendominasi. Plot lahan itu kemudian ditinggalkan untuk ditumbuhi kembali oleh vegetasi alami.

\section{Persamaan alometrik}

Persamaan ini menyatakan hubungan kuantitatif antara ukuran sebuah pohon dan biomassanya. Persamaan ini digunakan untuk memperkirakan biomassa pepohonan berdasarkan ukuran yang mudah, seperti tinggi pohon atau diameter setinggi dada (dbh).

\section{Persetujuan sukarela setelah mendapat informasi sebelumnya (FPIC)}

Deklarasi PBB tentang Hak-hak Penduduk Asli (2007) mendukung hak-hak penduduk asli untuk menghibahkan atau menahan persetujuan sukarela mereka untuk: kegiatan yang memengaruhi lahan yang secara tradisional mereka miliki, mereka tinggali, atau mereka gunakan; pengajuan relokasi manapun dan setiap tindakan legal atau administratif yang memberi berdampak bagi mereka. Artinya, FPIC menegaskan bahwa persetujuan telah diperoleh tanpa pemaksaan sebelum proyek disetujui dan dimulai, dan bahwa pihak-pihak yang terpengaruh sepenuhnya memahami lingkup, jangka waktu dan dampak potensial dari berbagai kegiatan yang dilakukan.

\section{Pertanian perladangan}

Praktik pertanian yang melibatkan penebangan dan pembakaran hutan atau lahan berhutan untuk menciptakan ladang, biasanya merupakan bagian dari sistem perladangan berpindah (juga dikenal sebagai pertanian tebas-dan-bakar).

\section{Pertanian tebas-dan-bakar}

Praktik pertanian yang melibatkan penebangan dan pembakaran hutan atau lahan berhutan untuk menciptakan ladang, biasanya merupakan bagian dari sistem perladangan berpindah. 


\section{Perubahan penggunaan lahan secara tidak langsung}

Konsekuensi yang tidak diharapkan atau efek samping suatu bentuk penggunaan lahan (dan emisi) yang muncul dari implementasi proyek atau kebijakan, misalnya, menanam bahan baku bahan bakar hayati di tanah pertanian mungkin menyebabkan lahan di tempat lain dialokasikan untuk produksi pangan.

\section{Perubahan transformatif}

Perubahan sikap, wacana, hubungan kekuasaan dan tindakan yang disengaja, yang diperlukan untuk menghasilkan perumusan kebijakan dan implementasi yang tidak seperti pendekatan kebijakan bisnis seperti biasa.

\section{Program REDD-PBB}

Program Bersama Perserikatan Bangsa-Bangsa untuk pengurangan emisi dari deforestasi dan degradasi hutan di negara berkembang. Program ini merupakan gabungan dari FAO, UNDP dan UNEP yang membentuk dana perwalian multidonor pada bulan Juli 2008 dan merupakan kumpulan kegiatan program sumberdaya dan dana. Program ini memberikan dukungan bagi berbagai negara untuk kegiatan kesiapan dan pengembangan kebijakan dan implementasi.

\section{Protokol Kyoto}

Perjanjian tahun 1997 dalam Konvensi PBB mengenai Kerangka Kerja Perubahan Iklim (UNFCCC). Negara-negara Aneks-Iyang meratifikasi Protokol ini bertekad untuk mengurangi emisi karbondioksida dan lima jenis GRK lain mereka sebesar rata-rata 5,2\% antara tahun 2008 dan 2012 dibandingkan dengan tingkat emisi tahun 1990. Saat ini, Protokol Kyoto mencakup 191 negara di seluruh dunia, tetapi kurang dari 64\% sumber emisi GRK dunia. Terhitung sejak April 2012, Amerika Serikat merupakan satu-satunya negara yang turut menandatangani, tetapi belum meratifikasi Protokol ini dan Kanada melepaskan Protokol ini pada bulan Desember 2011. Jangka waktu perjanjian pertama Protokol Kyoto berakhir tanggal 31 Desember 2012.

\section{Rasio akar:batang}

Ukuran perbandingan antara biomassa pada akar dan biomassa batang. Rasio ini sering digunakan untuk mengestimasi unsur di bawah tanah dari biomassa tampungan karbon berdasarkan pengukuran biomassa di atas tanah.

Reduksi Emisi dari Deforestasi dan Degradasi dan meningkatkan stok karbon hutan di negara-negara berkembang (REDD+)

Istilah 'REDD' digunakan dalam banyak cara. Definisi umum, didasarkan pada terminologi resmi COP13, menyatakan bahwa REDD+ terdiri atas tindakan lokal, subnasional, nasional dan global yang tujuan utamanya adalah untuk mengurangi emisi dari deforestasi dan degradasi hutan 
dan meningkatkan stok karbon hutan (meningkatkan penyerapan) di negara-negara berkembang. Namun definisi yang lebih sempit ialah bahwa REDD+ juga mencakup imbalan/pembayaran berbasiskan hasil atau bersyarat, yang merupakan gagasan inti ketika REDD+ pertama diluncurkan.

Dari sudut pandang lain, REDD+ mungkin bukan hanya mengacu pada tindakan, tetapi juga pada gagasan, sasaran keseluruhan untuk mengurangi emisi dan meningkatkan penyerapan, perangkat kebijakan atau tindakan yang diperlukan untuk mencapai sasaran tersebut, hasilnya yang diukur berupa pengurangan emisi dan peningkatan penyerapan atau proses yang melibatkan ke semua unsur tersebut. REDD (tanpa tanda plus) digunakan untuk mengacu hanya pada deforestasi dan degradasi hutan, dan tidak termasuk peningkatan stok karbon hutan.

\section{Reforestasi}

Reforestasi adalah konversi lahan nonhutan menjadi lahan hutan sebagai akibat langsung kegiatan manusia, melalui kegiatan penanaman, pembenihan dan/atau mendukung penyebaran sumber benih alami, di atas lahan yang sebelumnya berhutan, namun telah dikonversi menjadi lahan bukan hutan.

\section{Rosot karbon}

Sebuah penampungan (cadangan) yang menyerap karbon dari bagian aktif siklus karbon.

\section{Sarana Kemitraan Karbon Hutan (FCPF)}

Sebuah program Bank Dunia untuk membantu negara-negara berkembang mengurangi emisi dari deforestasi dan degradasi hutan. Tujuannya antara lain untuk pembangunan kapasitas dalam REDD+ dan menguji program imbalan berbasis kinerja di negara rintisan.

\section{Stok Karbon}

Jumlah karbon yang terkandung dalam sebuah tampungan karbon.

\section{Tampungan karbon}

Suatu penampungan yang mengakumulasi atau melepaskan karbon. Perjanjian Marrakesh mengakui lima tampungan karbon utama di hutan: biomassa di atas tanah, biomassa di bawah tanah, kayu mati, materi serasah dan bahan organik tanah.

\section{Tingkat (Tier)}

Tingkat dalam Panduan Praktik yang Baik dari IPCC ialah tingkatan kerumitan metodologis untuk mengukur emisi GRK.

Tingkat 1 merupakan yang paling dasar dan menggunakan nilai standar global untuk stok karbon. 
Tingkat 2 merupakan tahap menengah dan menggunakan nilai nasional. Tingkat 3 merupakan yang paling ketat dalam pemahaman kerumitan dan kebutuhan data, menggunakan nilai-nilai stok karbon yang khusus untuk suatu lokasi.

\section{Tingkat acuan}

RL memiliki dua makna dan penggunaan yang dapat dibedakan. Pertama, RL digunakan untuk skenario bisnis seperti biasa atau kondisi awal untuk mengetahui perubahan stok karbon, yang digunakan sebagai tolok ukur untuk menilai dampak kebijakan dan tindakan REDD+ dan untuk menetapkan pengurangan emisi. Dalam pengertian ini, tingkat acuan dapat mengacu pada tingkat emisi kotor dari deforestasi dan degradasi hutan (RL) dan tingkat emisi bersih dari semua emisi dan penyerapan dari deforestasi, degradasi hutan, konservasi, pengelolaan hutan berkelanjutan dan peningkatan stok karbon hutan (REL).

Kedua, dalam sistem berbasiskan hasil, tingkat acuan digunakan sebagai tolok ukur untuk mengestimasi pembayaran kepada berbagai negara, unit subnasional atau proyek atas pengurangan emisi. Dalam buku ini, kami mengacu pada penggunaan ini sebagai Tolok Ukur Insentif Finansial (FIB). 


\section{Referensi}

Achard, F., Eva, H.D., Stibig, H.-J., Mayaux, P., Gallego, J., Richards, T. dan Malingreau, J.P. 2002 Determination of deforestation rates of the world's humid tropical forests. Science 297(5583): 999-1002.

Adam, C.S. dan Gunning, J.W. 2002 Redesigning the aid contract: donors' use of performance indicators in Uganda. World Development 30(12): 2045-2056.

Agrawal, A., Nepstad, D. dan Chhatre, A. 2011 Reducing emissions from deforestation and forest degradation. Annual Review of Environment and Resources 36(1): 373-396.

Alencar, A., Asner, G.P., Knapp, D. dan Zarin, D. 2011 Temporal variability of forest fires in eastern Amazonia. Ecological Applications 21(7): 2397-2412.

Amazon Fund 2009 The Amazon Fund's annual report. The Brazilian development bank. http://www.amazonfund.gov.br/FundoAmazonia/ export/sites/default/site_en/Galerias/Arquivos/Boletins/Rafa_2009_ versxo_final_inglxs.pdf (24 Mei 2012). $111 \mathrm{hlm}$.

An, N.T., Brofeldt, S., Budiman, A., Burgess, N.D., Caizhen, L., Chang, F.R., Danielsen, F., Jensen, A.E., Kurniawan, Y. dan Mingxu, Z. 2011 Theoretical 
framework for community-based forest monitoring. Deliverable 4.1. I-REDD+. http://i-redd.eu/taxonomy/term/21 (26 April 2012).

Andreae, M.O. dan Merlet, P. 2001 Emission of trace gases and aerosols from biomass burning. Global Biogeochemical Cycles 15(4): 955-966.

Angelsen, A. 2007 Forest cover change in space and time: combining the von Thunen and forest transition theories. Policy research working paper WPS 4117. The World Bank, Washington, DC. $43 \mathrm{hlm}$.

Angelsen, A. 2008a How do we set the reference levels? Dalam: Angelsen, A. (ed.) Moving ahead with REDD: issues, options and implications, 53-63. CIFOR, Bogor, Indonesia.

Angelsen, A. (ed.) 2008b Moving ahead with REDD: issues, options and implications. CIFOR, Bogor, Indonesia. $156 \mathrm{hlm}$.

Angelsen, A. 2009a Introduction. Dalam: Angelsen, A., with Brockhaus, M., Kanninen, M., Sills, E., Sunderlin, W.D. dan Wertz-Kanounnikoff, S. (ed.) Realising REDD+: National strategy and policy options, 1-9. CIFOR, Bogor, Indonesia.

Angelsen, A. 2009b Policy options to reduce deforestation. Dalam: Angelsen, A., with Brockhaus, M., Kanninen, M., Sills, E., Sunderlin, W.D. dan Wertz-Kanounnikoff, S. (ed.) Realising REDD+: national strategy and policy options, 125-138. CIFOR, Bogor, Indonesia.

Angelsen, A. 2010a The 3 REDD 'I's. Journal of Forest Economics 16(4): 253-256.

Angelsen, A. 2010b Policies for reduced deforestation and their impact on agricultural production. Proceedings of the National Academy of Sciences 107(46): 19639-19644.

Angelsen, A. dan Wertz-Kanounnikoff, S. 2008 What are the key design issues for REDD and the criteria for assessing options? Dalam: Angelsen, A. (ed.) Moving ahead with REDD: issues, options and implications, 11-21. CIFOR, Bogor, Indonesia.

Angelsen, A., with Brockhaus, M., Kanninen, M., Sills, E., Sunderlin, W.D. dan Wertz-Kanounnikoff, S. (ed.) 2009 Realising REDD+: national strategy and policy options. CIFOR, Bogor, Indonesia. $361 \mathrm{hlm}$.

Angelsen, A., Gierløff, C.W., Beltrán, A.M. dan den Elzen, M. 2012 REDD credits in a global carbon market: Options and impacts. The Nordic Working Group on Global Climate Negotiations, the Nordic Council, Helsinki, Finland. 69 hlm.

Anseeuw, W., Alden Wily, L., Cotula, L. dan Taylor, M. 2012 Land rights and the rush for land: findings from the Global Commercial Pressures on Land Research Project. International Land Coalition, Rome.

Arima, E.Y., Richards, P., Walker, R. dan Caldas, M.M. 2011 Statistical confirmation of indirect land use change in the Brazilian Amazon. Environmental Research Letters 6(2): 024010. 
Armitage, D. 2008 Governance and the commons in a multi-level world. International Journal of the Commons 2(1): 7-32.

Arriagada, R.A., Ferraro, P.J., Sills, E.O., Pattanayak, S.K. dan CorderoSancho, S. 2012 Do payments for environmental services affect forest cover? A farm-level evaluation from Costa Rica. Land Economics 88(2): 382-399.

Arts, B. dan Buizer, M. 2009 Forests, discourses, institutions: a discursiveinstitutional analysis of global forest governance. Forest Policy and Economics 11(5-6): 340-347.

Asner, G.P., Powell, G.V.N., Mascaro, J., Knapp, D.E., Clark, J.K., Jacobson, J., Kennedy-Bowdoin, T., Balaji, A., Paez-Acosta, G., Victoria, E. dkk. 2010 High-resolution forest carbon stocks and emissions in the Amazon. Proceedings of the National Academy of Sciences 107(38): 16738-16742.

Assunção, C.J. dan Gandour, R.R. 2012 Deforestation slowdown in the legal Amazon: prices or policies? CPI working paper. Climate Policy Initiative, Rio de Janeiro, Brazil.

Atmadja, S. dan Verchot, L. 2012 A review of the state of research, policies and strategies in addressing leakage from reducing emissions from deforestation and forest degradation (REDD+). Mitigation and Adaptation Strategies for Global Change 17(3): 311-336.

Awono, A. 2011 Insights from REDD+ project sites in Cameroon. CIFOR, Tidak diterbitkan.

Baccini, A., Goetz, S.J., Walker, W.S., Laporte, N.T., Sun, M., SullaManashe, D., Hackler, J., Beck, P.S.A., Dubayah, R., Friedl, M.A. dkk. 2012 Estimated carbon dioxide emissions from tropical deforestation improved by carbon density maps. Nature Climate Change 2: 182-185.

Bahroeny, J.J. 2009 Palm oil as an economic pillar of Indonesia. The Jakarta Post, 2 Desember 2009. http://www.thejakartapost.com/ news/2009/12/02/palm-oil-economic-pillar-indonesia.html (30 Mei 2012).

Baker, M.M. 2004 Soy monoculture in the Americas: globalization ruins food economy. EIR 19 November 2004.

Ball, J.B. 2001 Global forest resources: history and dynamics. Dalam: Evans, J. (ed.) The Forests Handbook, 3-22. Blackwell Science, Oxford, UK.

Barona, E., Ramankutty, N., Hyman, G. dan Coomes, O.T. 2010 The role of pasture and soybean in deforestation of the Brazilian Amazon. Environmental Research Letters 5(2): 024002.

Basuno, E. dan Weinberger, K. (ed.) 2011 Forecasting food security under El Nino in Asia and the Pacific, CAPSA Working Paper No. 105. Centre for Alleviation of Poverty through Sustainable Agriculture and Economic and Sustainable Commission for Asia and the Pacific. Bogor, Indonesia. 
Baumgartner, F.R., Jones, B.D. dan Wilkerson, J. 2011 Comparative studies of policy dynamics. Comparative Political Studies 44(8): 947-972.

Behn, R.D. 2003 Why measure performance? Different purposes require different measures. Public Administration Review 63(5): 586-606.

Benford, R.D. dan Snow, D.A. 2000 Framing processes and social movements: an overview and assessment. Annual Review of Sociology 26: 611-639.

Binnendijk, A. 2001 Results-based management in the development cooperation agencies: a review experience. Organisation for Economic Co-operation and Development - Development Assistance Committee, Paris. 158 hlm.

Bishaw, B. 2001 Deforestation and land degradation in the Ethiopian highlands: strategy for physical recovery. Journal of Northeast African Studies (8): 7-26.

Blaser, J. dan Robledo, C. 2007 Initial analysis of the mitigation potential in the forestry sector. Prepared for the United Nations Framework Convention on Climate Change Secretariat. Intercooperation, Bern, Switzerland.

Blom, B., Sunderland, T. dan Murdiyarso, D. 2010 Getting REDD to work locally: lessons learned from integrated conservation and development projects. Environmental Science \& Policy 13(2): 164-172.

Blomley, T., Lukumbuzya, K. dan Brodning, G. 2011 Participatory forest management and REDD+ in Tanzania. World Bank. Washington DC.

Bond, I., Grieg-Gran, M., Wertz-Kanounnikoff, S., Hazlewood, P., Wunder, S. dan Angelsen, A. 2009 Incentives to sustain forest ecosystem services: a review and lessons for REDD. Natural Resources Issues No 16. International Institute for Environment and Development, London with CIFOR, Bogor, Indonesia dan World Resources Institute, Washington, DC. $47 \mathrm{hlm}$.

Boucher, D. 2009 Money for nothing? Principles and rules for REDD and their implications for protected areas. Prepared for the workshop "Connecting protected areas and indigenous lands to REDD frameworks." School of Earth Sciences, Stanford University, Palo Alto, CA, USA. 11-12 Februari 2009.

Boucher, D., Elias, P., Lininger, K., May-Tobin, C., Roquemore, S. dan Saxon, E. 2011 The root of the problem: what's driving tropical deforestation today? The Union of Concerned Scientists, Cambridge, MA, USA.

Boykoff, M.T. 2008 The cultural politics of climate change discourse in UK tabloids. Political Geography 27(5): 549-569.

Brack, D. 2005 Controlling illegal logging and the trade in illegally harvested timber: the EU's forest law enforcement, governance and trade initiative. Review of European community \& international environmental law 14(1): 28-38. 
Brandon, K. dan Wells, M. 2009 Lessons for REDD+ from protected areas and integrated conservation and development projects. Dalam: Angelsen, A., with Brockhaus, M., Kanninen, M., Sills, E., Sunderlin, W.D. dan Wertz-Kanounnikoff, S. (ed.) Realising REDD+: national strategy and policy options, 225-236. CIFOR, Bogor, Indonesia.

Brockhaus, M., Obidzinski, K., Dermawan, A., Laumonier, Y. dan Luttrell, C. 2012 An overview of forest and land allocation policies in Indonesia: is the current framework sufficient to meet the needs of REDD+? Forest policy and economics 18: 30-37.

Brooks, J.S., Franzen, M.A., Holmes, C.M., Grote, M.Ndan Mulder, M.B. 2006 Testing hypotheses for the success of different conservation strategies. Conservation Biology 20(5): 1528-1538.

Brown, S. 2002 Measuring carbon in forests: current status and future challenges. Environmental Pollution 116(3): 363-372.

Brown, S. dan Lugo, A.E. 1992 Aboveground biomass estimates for tropical moist forests of the Brazilian Amazon. Interciencia 17(1): 8-18.

Brown, S., Gillespie, A.J.R. dan Lugo, A.E. 1989 Biomass estimation methods for tropical forests with applications to forest inventory data. Forest Science 35(4): 881-902.

Brown, W.A., Pinchuk, R. dan Cooper, D.G. 1997 Determining biomass from differential total organic carbon. Biotechnology Techniques 11(3): 213-216.

Brown, D., Seymour, F. dan Peskett, L. 2008 How do we achieve REDD co-benefits and avoid doing harm? Dalam: Angelsen, A. (ed.) Moving ahead with REDD: issues, options and implications, 107-118. CIFOR, Bogor, Indonesia.

Bucki, M., Cuypers, D., Mayaux, P., Achard, F., Estreguil, C. dan Grassi, G. 2012 Assessing REDD+ performance of countries with low monitoring capacities: the matrix approach. Environmental Research Letters 7(1): 014031.

Busch, J., Lubowski, R.N., Godoy, F., Steininger, M., Yusuf, A.A., Austin, K., Hewson, J., Juhn, D., Farid, M. dan Boltz, F. 2012 Structuring economic incentives to reduce emissions from deforestation within Indonesia. Proceedings of the National Academy of Sciences 109(4): 1062-1067.

Butler, R.A., Koh, L.P. dan Ghazoul, J. 2009 REDD in the red: palm oil could undermine carbon payment schemes. Conservation Letters 2(2): 67-73.

Börner, J. dan Wunder, S. 2008 Paying for avoided deforestation in the Brazilian Amazon: from cost assessment to scheme design. International Forestry Review 10(3): 496-511.

Börner, J., Wunder, S., Wertz-Kanounnikoff, S., Hyman, G. dan Nascimento, N. 2011 REDD sticks and carrots in the Brazilian Amazon: assessing costs and livelihood implications. CCAFS Working Paper no. 8. Consultative 
Group on International Agricultural Research Research Program on Climate Change, Agriculture and Food Security, Kopenhagen, Denmark. 40 hlm.

Börner, J., Wunder, S., Wertz-Kanounnikoff, S., Tito, M.R., Pereira, L. dan Nascimento, N. 2010 Direct conservation payments in the Brazilian Amazon: scope and equity implications. Ecological Economics 69(6): 1272-1282.

C2 countryteamBrazil 2012 Presentation. GCSREDD+Component 2 meeting in Barcelona, 8-10 Februari 2012. CIFOR. Tidak diterbitkan.

C2 country team Cameroon 2012 Presentation. GCS REDD+ Component 2 meeting in Barcelona, 8-10 Februari 2012. CIFOR. Tidak diterbitkan.

C2 country team Indonesia 2012 Presentation. GCS REDD+ Component 2 meeting in Barcelona, 8-10 Februari 2012. CIFOR. Tidak diterbitkan.

C2 country team Peru 2012 Presentation. GCS REDD+Component 2 meeting in Barcelona, 8-10 Februari 2012. CIFOR. Tidak diterbitkan.

C2 country team Tanzania 2012 Presentation. GCS REDD+ Component 2 meeting in Barcelona, 8-10 Februari 2012. CIFOR. Tidak diterbitkan.

C2 country team Vietnam 2012 Presentation. GCS REDD+ Component 2 meeting in Barcelona, 8-10 Februari 2012. CIFOR. Tidak diterbitkan.

Cairns, M.A., Brown, S., Helmer, E.H. dan Baumgardner, G.A. 1997 Root biomass allocation in the world's upland forests. Oecologia 111(1): 1-11.

Calmel, M., Martinet, A., Grondard, N., Dufour, T., Rageade, M. dan FertéDevin, A. 2010 REDD+ at project scale: evaluation and development guide. Office National des Forêts International, Paris. $215 \mathrm{hlm}$.

Caplow, S., Jagger, P., Lawlor, K. dan Sills, E. 2011 Evaluating land use and livelihood impacts of early forest carbon projects: Lessons for learning about REDD+. Environmental Science \& Policy 14(2): 152-167.

CarboAfrica Quantification, understanding and prediction of carbon cycle and other GHG gases in Sub-Saharan Africa. http://www.carboafrica. net/index_en.asp (28 Februari 2012).

Cashore, B. 2002 Legitimacy and the privatization of environmental governance: how non-state market-driven (NSMD) governance systems gain rule-making authority. Governance 15(4): 503-529.

CBD 2010. Outcomes of the global expert workshop on biodiversity benefits of reducing emissions from deforestation and forest degradation in developing countries. UNEP/CBD/WS-REDD/1/3. 20-23 Sep. 2010. Nairobi, Kenya.

CBD 2011. Outcomes of the Africa regional consultation and capacitybuilding workshop on reducing emissions from deforestation and forest degradation in developing countries (REDD+), including on relevant biodiversity safeguards. UNEP/CBD/WS/CB/REDD/ AFR/1/2. 20-23 September 2011. Cape Town, Afrika Selatan. 
CCBA dan CARE 2010 REDD+ social \& environmental standards. Version 1. Jun 2010. Climate, Community \& Biodiversity Alliance and Care International, Washington, DC and Nairobi, Kenya. http://www. cbd.int/doc/meetings/for/wscbredd-afr-01/other/wscbredd-afr-01soc-env-en.pdf (28 April 2012).

CEDLA dan CIFOR 2011a The context of REDD+ in Bolivia: drivers, agents, and institutions. CIFOR, Bogor, Indonesia. Tidak diterbitkan.

CEDLA dan CIFOR 2011b REDD+ politics in the media: a case study from Bolivia. CIFOR, Bogor, Indonesia. Tidak diterbitkan.

Cerbu, G.A., Swallow, B.M. dan Thompson, D.Y. 2011 Locating REDD: a global survey and analysis of REDD readiness and demonstration activities. Environmental Science and Policy 14(2): 168-180.

Cerutti, P.O., Assembe-Mvondo, S., German, L. dan Putzel, L. 2011 Is China unique? Exploring the behaviour of Chinese and European firms in the Cameroonian logging sector. International Forestry Review 13(1): 23-34.

Chagas, T., Streck, C., O'Sullivan, R., Olander, J. dan Seifert-Granzin, J. 2011 Nested approaches to REDD+: an overview of issues and options. Forest Trends and Climate Focus, Washington, DC.

Chave, J., Andalo, C., Brown, S., Cairns, M., Chambers, J., Eamus, D., Fölster, H., Fromard, F., Higuchi, N., Kira, T. dkk. 2005 Tree allometry and improved estimation of carbon stocks and balance in tropical forests. Oecologia 145(1): 87-99.

Chave, J., Rieara, B. dan Marc-A., D. 2001 Estimation of biomass in a neotropical forest of French Guiana: spatial and temporal variability. Journal of Tropical Ecology 17: 79-96.

Chomitz, K.M., with Buys, P., De Luca, G., Thomas, T.S. dan WertzKanounnikoff, S. 2007 Overview at loggerheads? Agricultural expansion, poverty reduction, and environment in the tropical forests. The World Bank, Washington, DC.

Clapp, J. dan Dauvergne, P. 2005 Paths to a green world: the political economy of the global environment. MIT Press, Cambridge, MA, USA. $351 \mathrm{hlm}$.

Cleaver, F. 2002 Reinventing institutions: bricolage and the social embeddedness of natural resource management. The European Journal of Development Research 14(2): 11-30.

Climate Focus 2011 The handbook for programme of activities: practical guidance to successful implementation. Climate Focus, Amsterdam, the Netherlands. $79 \mathrm{hlm}$.

Climate Funds Update 2012 Types of funding. REDD. http://www. climatefundsupdate.org/themes/redd (15 April 2012).

Coen, D. 2004 Environmental and business lobbying alliances in Europe: learning from Washington? Dalam: Levy, D.L. dan Newell, P.J. (ed.) The 
business of global environmental governance, 197-222. The MIT Press, Cambridge, MA, USA.

Colchester, M. dan Chao, S. (ed.) 2011 Oil palm expansion in South East Asia: trends and implications for local communities and indigenous peoples. Forest Peoples Programme adn Perkumpulan Sawit Watch, Moreton-in-Marsh, UK dan Bogor, Indonesia.

Combes Motel, P., Pirard, R. dan Combes, J.L. 2009 A methodology to estimate impacts of domestic policies on deforestation: compensated successful efforts for "avoided deforestation" (REDD). Ecological Economics 68(3): 680-691.

COMTRADE 2012 Statistical database on world trade. http://www.intracen. org/marketanalysis/Default.aspx (6 Maret 2011).

Corbera, E. dan Schroeder, H. 2011 Governing and implementing REDD+. Environmental Science and Policy 14(2): 89-99.

Costenbader, J. 2011 REDD+ benefit sharing: a comparative assessment of three national policy approaches. Forest Carbon Partnership Facility and United Nations REDD Programme. http://www.unredd.net/index. php?option=com_docman $\&$ task=doc_details\&gid=5587\&Itemid=53 (21 Mei 2012).

Cotula, L. dan Mayers, J. 2009 Tenure in REDD - Start-point or afterthought? Natural Resource Issues No. 15. International Institute for Environment and Development, London.

Covington dan Baker\&McKenzie 2009 Background analysis of REDD regulatory frameworks. The Terrestial Carbon Group and the United Nations Collaborative Programme on REDD, New York.

Cronin, T. dan Santoso, L. 2010 REDD+ politics in the media: a case study from Indonesia. CIFOR Working Paper 49. CIFOR, Bogor, Indonesia. $28 \mathrm{hlm}$.

Crow, T.R. 1978 Biomass and production in three contiguous forests in Northern Wisconsin. Ecology 59(2): 265-273.

Cunia, T. 1987 The error of biomass estimates in forest inventories: its major components. Dalam: Wharton, E.H. dan Cunia, T. (ed.) Estimating tree biomass regressions and their error. Proceedings of the workshop on tree biomass regression functions and their contribution to the error Part B, 303. US Department of Agriculture, Forest Services, Newtown Square, PA, USA.

Dahal, G.R., Atkinson, J. dan Bampton, J. 2011 Forest tenure in Asia: status and trends. European Union Forest Law Enforcement Governance and Trade Facility, Kuala Lumpur, Malaysia. $37 \mathrm{hlm}$.

Daniels, A.E., Bagstad, K., Esposito, V., Moulaert, A. dan Rodriguez, C.M. 2010 Understanding the impacts of Costa Rica's PES: are we asking the right questions? Ecological Economics 69(11): 2116-2126. 
Danielsen, F., Burgess, N.D., Jensen, P.M. dan Pirhofer-Walzl, K. 2010 Environmental monitoring: the scale and speed of implementation varies according to the degree of peoples involvement. Journal of Applied Ecology 47(6): 1166-1168.

Danielsen, F., Skutsch, M., Burgess, N.D., Jensen, P.M., Andrianandrasana, H., Karky, B., Lewis, R., Lovett, J.C., Massao, J., Ngaga, Y. dkk. 2011 At the heart of REDD+: a role for local people in monitoring forests? Conservation Letters 4(2): 158-167.

DAR dan CIFOR 2012 The context of REDD+ in Peru: drivers, agents, and institutions. CIFOR, Bogor, Indonesia. Tidak diterbitkan.

Daviet, F. 2009 Beyond carbon financing: the role of sustainable development policies and measures in REDD. Climate and Forests Policy Series. World Resources Institute, Washington, DC. $16 \mathrm{hlm}$.

de Andrade, R.M.T. dan Miccolis, A. 2011 Policies and institutional and legal frameworks in the expansion of Brazilian biofuels. CIFOR, Bogor, Indonesia. $39 \mathrm{hlm}$.

de Veiga, J.B., Tourrand, J.F., Piketty, M.G., Poccard-Chapuis, R., Alves, A.M. dan Thales, M.C. 2004 Expansão e Trajetórias da Pecuária na Amazônia: Pará, Brasil. Editora Universidade de Brasília, Brasilia, Brasil.

Deininger, K. dan Byerlee, D. 2011 Rising global interest in farmland: can it yield sustainable and equitable benefits? World Bank, Washington, DC. $213 \mathrm{hlm}$.

Dermawan, A., Petkova, E., Sinaga, A.C., Muhajir, M. dan Indriatmoko, Y. 2011 Preventing the risks of corruption in REDD+ in Indonesia. CIFOR, Bogor, Indonesia. $72 \mathrm{hlm}$.

Deveny, A., Nackoney, J. dan Purvis, N. 2009 Forest carbon index: the geography of forests in climate solutions. Resources for the Future and Climate Advisers, Washington, DC. $77 \mathrm{hlm}$.

Di Gregorio, M. 2012 Networking in environmental movement organisation coalitions: interest, values or discourse? Environmental Politics 21(1): 1-25.

Diaz, D., Hamilton, K. dan Johnson, E. 2011 State of the forest carbon markets 2011: from canopy to currency. Forest Trends, Washington, DC. $70 \mathrm{hlm}$.

Direktorat Jenderal Perkebunan 2011 Luas Areal dan Produksi Kelapa Sawit Indonesia 1967-2010. Statistics table at the Directorate for Plantation Estates. http://arieyoedo.blogspot.com/2011/03/luasareal-danproduksi-kelapa-sawit.html (24 Mei 2012).

Dkamela, G.P. 2011 The context of REDD+ in Cameroon: drivers, agents and institutions. Occasional paper 57. CIFOR, Bogor, Indonesia. $63 \mathrm{hlm}$.

DMA 1992 Digital chart of the world. Defense Mapping Agency, Fairfax, VA, USA. 
Doan, D., Shanks, E. dan Nguyen, T.B. 2005 Situation analysis, needs assessment and recommendations of forestry research, education, training and extension (RETE) for the National Forestry Strategy 2006 to 2020. Helvetas International and Ministry of Agriculture and Rural Development, Hanoi, Vietnam. $63 \mathrm{hlm}$.

Dokken, T., Caplow, S., Sunderlin, W. dan Angelsen, A. 2011 Early lessons from REDD+ pilot projects in Tanzania: tenure insecurity and implications for deforestation and forest degradation. CIFOR, tidak diterbitkan.

Donovan, R.Z., Clarke, G. dan Sloth, C. 2010 Verification of progress related to enabling activities for the Guyana-Norway REDD+ agreement. Rainforest Alliance, Richmond, VT., USA. $40 \mathrm{hlm}$.

Droege, S. 2011 Using border measures to address carbon flows. Climate Policy 11(5): 1191-1201.

Dryzek, J.S. 1997 Politics of the earth: environmental discourses. Oxford University Press, New York.

Duchelle, A., Börner, J., Wunder, S., Araújo, E., Farias, R., Tezza, J., Toniolo, A., Cortez, R.G., de los Ríos, M., Gebara, M.F. dkk. 2011a Grounding the REDD+ debate: preliminary evidence from pilot initiatives in the Brazilian Amazon. Amazon Initiative Policy Brief 02, COP 16. CIFOR, Cancun, Meksiko.

Duchelle, A.E., Cromberg, M., Gebara, M.F., Guerra, R., Melo, T., Larson, A., Cronkleton, P., Borner, J., Sills, E., Bauch, S. dkk. 2011b. Land tenure and carbon rights in the Brazilian Amazon: learning from four incipient REDD+ initiatives. Paper to the workshop on land tenure and forest carbon management: lessons for more effective and equitable REDD investments. Land Tenure Center, Madison, WI, USA.

Dudley, N. 2010 Protected areas as tools for REDD: an issues paper for WWF. http://www.law.harvard.edu/programs/about/pifs/symposia/fcfs/2010fcfs-briefing-materials/dudley-final.pdf (14 April 2012).

Duffy, R. 2006 Non-governmental organisations and governance states: the impact of transnational environmental management networks in Madagascar. Environmental Politics 15(5): 731-749.

Dutschke, M. dan Angelsen, A. 2008 How do we ensure permanence and assign liability? Dalam: Angelsen, A. (ed.) Moving ahead with REDD: issues, options and implications, 77-85. CIFOR, Bogor, Indonesia.

Earle, J. 2011. Trustee receives second installment of GRIF amounting to US\$38M. Guyana Chronicle Online 24 Juli 2011. http://www. guyanachronicleonline.com/site/index.php?option=com_content\&vie $\mathrm{w}=$ article \&id=30906: trustee - receives - second - installment - of - grifamounting-to-us38m\&catid=4:top-story\&Itemid=8 (17 Maret 2012). 
EC 2003 Global land cover 2000 project database. European Commission, Joint Research Center. http://bioval.jrc.ec.europa.eu/products/glc2000/ glc2000.php (15 April 2012).

EC 2008 Addressing the challenges of deforestation and forest degradation to tackle climate change and biodiversity loss. Communication from the Commission to the European Parliament, the Council, the European Economic and Social Committee and the Committee of the Regions. European Commission, Brussels, Belgia. http://eur-lex.europa.eu/ LexUriServ/LexUriServ.do?uri=COM:2008:0645:FIN:EN:PDF (15 Mei 2012). $13 \mathrm{hlm}$.

EC 2009 Directive 2009/28/EC of the European Parliament and of the Council, of 23 April 2009, on the promotion of the use of energy from renewable sources and amending and subsequently repealing Directives 2001/77/EC and 2003/30/EC. European Commission, Brussels, Belgium.

ECG 2011 Payments for environmental services in Papua New Guinea: a proposed PES system in PNG. Expert Consultation Group. Draft concept note 2.0.

Ecofys 2012 Testing methodologies for REDD+: deforestation drivers, costs and reference levels. Technical report. UK Department of Energy and Climate Change. Dalam persiapan.

Economist Intelligence Unit 2011 Democracy index 2011: democracy under stress. A report from the Economist Intelligence Unit. http://www.eiu. com/Handlers/WhitepaperHandler.ashx?fi=Democracy_Index_Final_ Dec_2011.pdf\&mode=wp (7 Mei 2012).

Ecosecurities 2007 Policy brief: REDD policy scenarios and carbon markets. Ecosecurities, Oxford, UK. $9 \mathrm{hlm}$.

EcoSecurities 2010 Forest carbon offset reporting 2010. EcoSecurities Group, Dublin, Irlandia. $35 \mathrm{hlm}$.

Edwards, R., Mulligan, D. dan Marelli, L. 2010 Indirect land use change from increased biofuels demand - comparison of models and results for marginal biofuels production from different feedstocks. Joint Research Centre for the European Commission and Institute for Prospective Technological Studies, Luxembourg, Luksemburg.

Eliasch, J. 2008 Climate change: financing global forests. The Eliasch Review. Office of Climate Change, London.

EMPRAPA/INPE 2011 Levantamento de informaçôes de uso e cobertura da terra na Amazônia: summario executivo. Empresa Brasileira de Pesquisa Agropecuária, Instituto Nacional de Pesquisas Espaciais, Brasilia, Brasil. http://www.inpe.br/cra/projetos_pesquisas/sumario_executivo_ terraclass_2008.pdf (25 Februari 2012).

Espeland, W.N. dan Stevens, M.L. 2008 A sociology of quantification. European Journal of Sociology/Archives Européennes de Sociologie 49(03): 401-436. 
Estrada, M. 2011 Standards and methods available for estimating projectlevel REDD+ carbon benefits: reference guide for project developers. CIFOR, Bogor, Indonesia. $75 \mathrm{hlm}$.

EU 2010 Guide to statistics in European Commission development cooperation. Eurostat methodologies and working papers, version 1.0. European Union, Luxembourg, Luksemburg. $455 \mathrm{hlm}$.

Evans, P. 1995 Embedded autonomy: states and industrial transformation. Princeton University Press, Princeton, NJ, USA. $336 \mathrm{hlm}$.

Falkowski, M. 2011 Financialization of commodities. Contemporary Economics 5(4): 4-17.

FAO 2003 Forestry outlook study for Africa: subregional report - East Africa. African Development Bank, European Commission, Food and Agriculture Organization of the United Nations, Roma.

FAO 2006 Global forest resources assessment 2005: progress towards sustainable forest management. Food and Agriculture Organization of the United Nations, Roma. 320 hlm.

FAO 2007 GeoNetwork. Organic carbon pool $(\mathrm{kg} / \mathrm{m} 2 / \mathrm{m})$ - subsoil. Food and Agriculture Organization GeoNetwork. http://www.fao.org/ geonetwork/srv/en/main.home (17 April 2012).

FAO 2010 Global forest resources assessment 2010. Food and Agriculture Organization of the United Nations, Roma. $340 \mathrm{hlm}$.

FAO Statistics 2012 FAOSTAT - production - live animals. Food and Agricultural Organization of the United Nations. http://faostat.fao.org/ site/573/default.aspx\#ancor (25 Februari 2011).

FCPF 2011 Forest Carbon Partnership Facility (FCPF) readiness fund: common approach to environmental and social safeguards for multiple delivery partners. Final version. The World Bank, Washington, DC.

Fearnside, P.M. 1997 Greenhouse gases from deforestation in Brazilian Amazonia: net committed emissions. Climatic Change 35(3): 321-360.

Ferraro, P. dan Hanauer, M. 2011 Protecting ecosystems and alleviating poverty with parks and reserves: 'win-win' or tradeoffs? Environmental and Resource Economics 48(2): 269-286.

Fisher, B., Edwards, D.P., Giam, X. dan Wilcove, D.S. 2011 The high costs of conserving Southeast Asia's lowland rainforests. Frontiers in Ecology and the Environment 9(6): 329-334.

FOEI 2009Views on issues relating to indigenous peoples and local communities for the development and application of methodologies. Submission to SBSTA from Friends of the Earth International 15 February 2009. Friends of the Earth International. http://unfccc.int/resource/docs/2009/ smsn/ngo/105.pdf (1 April 2012).

Foellesdal, A. 1998 Survey article: subsidiarity. Journal of Political Philosophy 6(2): 190-218. 
Fogarty, D. 2011. Special report: how Indonesia hurt its climate change project. Reuters 16 Agustus 2011. http://www.reuters.com/article/2011/08/16/ us-indonesia-carbon-idUSTRE77F0IK20110816 (27 Mei 2012).

Fonseca, M.B., Burrell, A., Gay, H., Henseler, M., Kavallari, A., M’Barek, R., Pérez Domínguez, I. dan Tonini, A. 2010 Impacts of the EU biofuel target on agricultural markets and land use: a comparative modelling assessment. Joint Research Centre for the European Commission and Institute for Prospective Technological Studies, Luxembourg, Luksemburg.

Forest Action dan CIFOR 2011 The context of REDD+ in Nepal: drivers, agents, and institutions. CIFOR, Bogor, Indonesia. Tidak diterbitkan.

Forest Action and CIFOR 2012 REDD+ politics in the media: a case study from Nepal. CIFOR, Bogor, Indonesia. Tidak diterbitkan.

Forest Trends 2010 Timber markets and trade between Laos and Vietnam: a commodity chain analysis of Vietnamese-driven timber flows. Forest Trends Associations, Washington, DC.

Forsyth, T. 2003 Critical political ecology: the politics of environmental science. Routledge, New York. $320 \mathrm{hlm}$.

Forsyth, T. 2009 Multilevel, multiactor governance in REDD+. Dalam: Angelsen, A., with Brockhaus, M., Kanninen, M., Sills, E., Sunderlin, W.D. dan Wertz-Kanounnikoff, S. (ed.) Realising REDD+: national strategy and policy options, 113-122. CIFOR, Bogor, Indonesia.

Foucault, M. 1980 Power/Knowledge: selected interviews and other writings 1972-1977. Gordon, C. (ed) Harvester, London.

Fry, B.P. 2011 Community forest monitoring in REDD+: the 'M' in MRV? Environmental Science and Policy 14(2): 181-187.

Garnett, S.T., Sayer, J.A. dan Du Toit, J. 2007 Improving the effectiveness of interventions to balance conservation and development: a conceptual framework. Ecology and Society 12(1): 2.

Gebara, M.F. 2011 REDD+ institutions: a preliminary analysis. Dalam: Oliveira, C.C. dan Rocha Sampaio, R.S. (ed.) A economia do verde no contexto do desenvolvimento sustentável: a governança dos atores públicos e privados. Fundação Getulio Vargas, Rio de Janeiro, Brasil.

Gellert, P.K. 2005 The shifting natures of "development": growth, crisis, and recovery in Indonesia’s forests. World Development 33(8): 1345-1364.

Gibbs, H.K., Brown, S., Niles, J.O. dan Foley, J.A. 2007 Monitoring and estimating tropical forest carbon stocks: making REDD a reality. Environmental Research Letters 4(2): 045023.

Gibbs, H.K., Ruesch, A.S., Achard, F., Clayton, M.K., Holmgren, P., Ramankutty, N. dan Foley, J.A. 2010 Tropical forests were the primary sources of new agricultural land in the 1980s and 1990s. Proceedings of the National Academy of Sciences 107(38): 16732-16737. 
Gitlin, T. 1980 The whole world is watching: mass media in the making and unmaking of the New Left. University of California Press, Berkeley, CA, USA dan London. $327 \mathrm{hlm}$.

Global Witness, Forest Management Trust, Forest Peoples Programme and Rainforest Foundation 2011 Analysis of rainforest alliance report on the verification of progress related to enabling activities for the Guyana - Norway REDD+ agreement. Open letter to Hans Brattskar and Tensie Whelan. http://www.globalwitness.org/sites/default/files/Norway-Guyana_MoU_ analysis\%20of\%20RA\%20report\%20final.pdf (15 Februari 2012).

GOFC-GOLD 2008 Reducing greenhouse gas emissions from deforestation and degradation in developing countries: a sourcebook of methods and procedures for monitoring, measuring and reporting, GOFC-GOLD Report version COP13-2. Global Observations of Forest Cover and Land Dynamics Project Office, Natural Resources Canada, Alberta, Canada. http://www.gofcgold.wur.nl/redd/index.php (24 Mei 2012).

GOFC-GOLD 2010 A sourcebook of methods and procedures for monitoring and reporting anthropogenic greenhouse gas emissions and removals caused by deforestation, gains and losses of carbon stocks in forest remaining forests, and forestation. GOFC-GOLD Report version COP16-1. Global Observations of Forest Cover and Land Dynamics Project Office, Natural Resources Canada, Alberta, Canada. http:// www.gofc-gold.uni-jena.de/redd/sourcebook/Sourcebook_Version_ Nov_2010_cop16-1.pdf (24 Mei 2012). $203 \mathrm{hlm}$.

GOFC-GOLD 2011 A sourcebook of methods and procedures for monitoring and reporting anthropogenic greenhouse gas emissions and removals caused by deforestation, gains and losses of carbon stocks in forest remaining forests, and forestation. GOFC-GOLD Report version COP17-1. Global Observations of Forest Cover and Land Dynamics Project Office, Natural Resources Canada, Alberta, Canada. http:// www.gofc-gold.uni-jena.de/redd/sourcebook/Sourcebook_Version_ Nov_2011_cop17_1.pdf (24 Mei 2012). $203 \mathrm{hlm}$.

Gomes, R., Bone, S., Cunha, M., Nahur, A.C., Moreira, P.F., Meneses-Filho, L.C.L., Voivodic, M., Bonfante, T. dan Moutinho, P. 2010 Exploring the bottom-up generation of REDD+ policy by forest-dependent peoples. Policy Matters 17: 161-168.

Government of Acre 2010 Sistema de incentivo a serviços ambientais. Governo do Acre, Rio Branco, Brasil. 29 hlm.

Government of Norway 2010 Administration agreement (Guyana REDDplus investment fund) between Royal Norwegian Ministry of Foreign Affairs and International Development Association. Trust fund MTO no. 069017. http:/www.regjeringen.no/upload/MD/Vedlegg/Klima/ klima_skogprosjektet/Guyana/aa.pdf (19 Februari 2012). 
Government of the Democratic Republic of Congo 2010 Readiness preparation proposal (R-PP). Forest Carbon Partnership Facility, Washington, DC.

Grassi, G., Monni, S., Federici, S., Achard, F. dan Mollicone, D. 2008 Applying the conservativeness principle to REDD to deal with the uncertainties of the estimates. Environmental Research Letters 3(3): 035005.

Gregersen, H., Lakany, H.E., Karsenty, A. dan White, A. 2010 Does the opportunity cost approach indicate the real cost of REDD+? Rights and realities of paying for REDD+. Rights and Resources Initiative, Washington, DC. $24 \mathrm{hlm}$.

Grieg-Gran, M. 2008 The cost of avoiding deforestation: update of the report prepared for the Stern Review of the economics of climate change. International Institute for Environment and Development, London. $25 \mathrm{hlm}$.

Grindle, M.S. 1999 In quest of the political: the political economy of development policy making. CID Working Paper No. 17. Center for International Development at Harvard University, Cambridge, MA, USA.

GSO 2009 The year book of 2008. General Statistics Office, Hanoi, Vietnam.

Guizol, P. dan Atmadja, S. 2008 Appendix: overview of REDD proposals submitted to the UNFCCC. Dalam: Angelsen, A. (ed.) Moving ahead with REDD: issues, options and implications, 119-131. CIFOR, Bogor, Indonesia.

Gunning, J.W. 2006 Budget support, conditionality and impact evaluation. Dalam: Koeberle, S., Stavreski, Z. dan Walliser, J. (ed.) Budget support as more effective aid? Recent experiences and emerging lessons, 295-308. The World Bank, Washington, DC.

Gutman, P. dan Aguilar-Amuchastegui, N. 2012 Referencelevels and payments for REDD+: lessons from the recent Guyana-Norway agreement. World Wildlife Fund USA. http://assets.panda.org/downloads/rls_and_ payments_for_redd_lessons.pdf (24 Mei 2012). $16 \mathrm{hlm}$.

Guyana-Norway Joint Concept Note 2011. http://www.regjeringen.no/ upload/MD/2011/vedlegg/klima/klima_skogprosjektet/Guyana/ JointConceptNote_31mars2011.pdf (19 Februari 2012).

Guyana REDD+ Investment Fund 2012. www.guyanareddfund.org (20 Februari 2012).

Hajek, F., Ventresca, M.J., Scriven, J. dan Castro, A. 2011 Regime-building for REDD+: evidence from a cluster of local initiatives in south-eastern Peru. Environmental Science and Policy 14(2): 201-215.

Hajer, M.1995 The politics of environmental discourse: ecological modernization and the policy. Clarendon Press, Oxford, UK. $344 \mathrm{hlm}$.

Hajer, M. dan Versteeg, W. 2005 A decade of discourse analysis of environmental politics: achievements, challenges, perspectives. Journal of Environmental Policy \& Planning 7(3): 175-184. 
Hall, P.A. 1997 The role of interests, institutions and ideas in the comparative political economy of the industrialized nations. Dalam: Lichbach, M.I. dan Zuckerman, A.S. (ed.) Comparative politics: rationality, culture, and structure, 179-207. Cambridge University Press, Cambridge, UK.

Hamann, K. 2012. FEATURE: Carbon scheme bogged down. Australia network news, 20 April 2012. http://www.australianetworknews.com/ stories/201204/3482539.htm (2 Mei 2012).

Hansen, M.C., Stehman, S.V., Potapov, P.V.,Loveland, T.R., Townshend,J.R.G., DeFries, R.S., Pittman, K.W., Arunarwati, B., Stolle, F., Steininger, M.K. dkk. 2008 Humid tropical forest clearing from 2000 to 2005 quantified by using multitemporal and multiresolution remotely sensed data. Proceedings of the National Academy of Sciences 105(27): 9439-9444.

Hardcastle, P.D., Baird, D., Harden, V., Abbot, P.G., O’Hara, P., Palmer, J.R., Roby, A., Haüsler, T., Ambia, V., Branthomme, A. dkk. 2008 Capability and cost assessment of the major forest nations to measure and monitor their forest carbon: for Office of Climate Change. LTS International, Edinburgh, Skotlandia.

Harvey, C.A., Dickson, B. dan Kormos, C. 2010a Opportunities for achieving biodiversity conservation through REDD. Conservation Letters 3(1): 53-61.

Harvey, C.A., Zerbock, O., Papageorgiou, S. dan Parra, A. 2010b What is needed to make REDD+ work on the ground? Lessons learned from pilot forest carbon initiatives. Conservation International, Arlington, VA, USA. $121 \mathrm{hlm}$.

Heath, L.S. dan Chojnacky, D.C. 1995 Down dead wood statistics for Maine timberlands. USDA Forest Service, Northeastern Research Station, Newtown Square, PA, USA. http://www.treesearch.fs.fed.us/pubs/20935 (26 April 2012).

Hecht, S.B. 2012 From eco-catastrophe to zero deforestation? Interdisciplinarities, politics, environmentalisms and reduced clearing in Amazonia. Environmental Conservation 39(1): 4-19.

Heinzerling, L. dan Ackerman, F. 2002 Pricing the priceless: cost benefit analysis of environmental protection. Georgetown University, Washington, DC.

Helvetas Swiss Intercooperation, Ecole Supérieure des Sciences Agronomiques and Département des Eaux et Forêts Madagascar 2011 REDD+ from a bottom-up perspective: tools for implementing REDD+ with a mechanism for direct incentives. Swiss Agency for Development and Cooperation Bern, Swiss. 68 hlm.

Henry, M., Picard, N., Trotta, C., Manlay, R.J., Valentini, R., Bernoux, M. dan Saint-André, L. 2011 Estimating tree biomass of subSaharan African forests: a review of available allometric equations. Silva Fennica 45(3B): 477-569. 
Hergoualc'h, K. dan Verchot, L.V. 2011 Stocks and fluxes of carbon associated with land use change in Southeast Asian tropical peatlands: A review. Global Biogeochem. Cycles 25(2): GB2001.

Herold, M. 2009 An assessment of national forest monitoring capabilities in tropical non-Annex I countries: recommendations for capacity building. Report for the Prince's Rainforests Project and the Government of Norway. Friedrich-Schiller-Universität Jena and Global Observation of Forest and Land Cover Dynamics Land Cover Project Office, Jena, Jerman. $62 \mathrm{hlm}$.

Herold, M. dan Skutsch, M. 2009 Measurement, reporting and verification for REDD+: objectives, capacities and institutions. Dalam: Angelsen, A., with Brockhaus, M., Kanninen, M., Sills, E., Sunderlin, W.D. dan Wertz-Kanounnikoff, S. (ed.) Realising REDD+: national strategy and policy options, 85-100. CIFOR, Bogor, Indonesia.

Herold, M. dan Skutsch, M. 2011 Monitoring, reporting and verification for national REDD + programmes: two proposals. Environmental Research Letters 6(1): 014002.

Higuchi, N., Santos, J.d. dan Jardim, F.C.S. 1982 Tamaho da parcela amostral para inventários florestais. Acta Amazônica 12: 91-103.

Hiraldo, R. dan Tanner, T. 2011a Forest voices: competing narratives over REDD+. IDS bulletin 42(3): 42-51.

Hiraldo, R. dan Tanner, T. 2011b The global political economy of REDD+: engaging social dimensions in the emerging green economy. United Nations Research Institute for Social Development, Geneva, Swiss. $24 \mathrm{hlm}$.

Hite, K. 2010 Safeguards and REDD. Presentation published online. The Center for International Environmental Law. http://www. rightsandresources.org/documents/files/doc_1513.pdf (22 April 2012).

HLPE 2011 Land tenure and international investments in agriculture. The High Level Panel of Experts on Food Security and Nutrition of the Committee on World Food Security, Roma.

Hoang, M.H., Do, T.H., Van Noordwijk, M., Pham, T.T., Palm, M., To, X.P., Doan, D., Nguyen, T.X. dan Hoang, T.V.A. 2010 An assessment of options for reducing emissions from all land uses in Vietnam: ready for REDD. Final national report. ASB Partnership for the Tropical Forest Margins, Nairobi, Kenya. $85 \mathrm{hlm}$.

Houghton, R.A. 2009 Development and climate change: emissions of carbon from land management. Background note to the World Development Report. World Bank, Washington, DC.

Houghton, R.A., Lawrence, K.T., Hackler, J.L. dan Brown, S. 2001 The spatial distribution of forest biomass in the Brazilian Amazon: a comparison of estimates. Global Change Biology 7(7): 731-746. 
Houghton, R.A., Skole, D.L., Nobre, C.A., Hackler, J.L., Lawrence, K.T. dan Chomentowsk, W.H. 2000 Annual fluxes of carbon from deforestation and regrowth in the Brazilian Amazon. Nature 403: 301-304.

Huettner, M., Leemans, R., Kok, K. dan Ebeling, J. 2009 A comparison of baseline methodologies for 'reducing emissions from deforestation and degradation'. Carbon Balance and Management 4(1): 4.

IBGE 2011 Sistema IBGE de Recuperacao Automatica. Instituto Brasileiro de Geografia e Estatística. http://www.sidra.ibge.gov.br/bda/pesquisas/ ca/default.asp (28 Desember 2011).

IEA $2011 \mathrm{CO}_{2}$ emissions from fuel combustion. International Energy Agency, Paris.

Inamura, Y., Kimata, T., Kimura, T. dan Muto, T. 2011 Recent surge in global commodity prices: impact of financialization of commodities and globally accommodative monetary conditions. Bank of Japan Review, International Department, Tokyo, Jepang.

Indigenous Peoples' Global Summit on Climate Change 2009 The Anchorage Declaration. Anchorage, AK. http://unfccc.int/resource/docs/2009/ smsn/ngo/168.pdf (20 Mei 2012).

Indonesia-Norway Joint Concept Note 2010. http://www.norway.or.id/ PageFiles/434849/jcn_indonesia_norway_redd_partnership_2010.pdf (19 Februari 2012).

Indrarto, G.B., Muharjanti, P., Khatarina, J., Pulungan, I., Ivalerina, F., Rahman, J., Prana, M., N., Resosudarmo, I., A, P. dan Muharrom, E. 2012 The context of REDD+ in Indonesia: drivers, agents, and institutions. Indonesian Center for Environmental Law dan CIFOR, Jakarta dan Bogor, Indonesia. Tidak diterbitkan.

Ingram, J., Stevens, T., Clements, T., Hatchwell, M., Krueger, L., Victurine, R., Holmes, C. dan Wilkie, D. 2009 REDD project development guide. Wildlife Conservation Society. http://www.translinks.org/ ToolsandTrainingMaterials/tabid/2064/ctl/Login/Default.aspx?returnu $\mathrm{rl}=\% 2 \mathrm{f}+$ ToolsandTrainingMaterials $\% 2 \mathrm{ftabid} \% 2 \mathrm{f} 2064 \% 2$ flanguage $\% 2 \mathrm{f}$ en-US\%2fDefault.aspx (15 April 2012).

INPE 2011 Monitoramento da floresta Amazônica Brasileira por satélite. Instituto Nacional de Pesquisas Espaciais, São José dos Campos, Brasil. http://www.obt.inpe.br/prodes/prodes_1988_2010.htm (25 Februari 2012).

IPCC 2000 Good practice guidance and uncertainty management in national greenhouse gas inventories. Penman, J., Kruger, D., Galbally, I., Hiraishi, T., Nyenzi, B., Enmanuel, S., Buendia, L., Hoppaus, R., Martinsen, T., Meijer, J., $d k k$. (ed.) Intergovernmental Panel on Climate Change Hayama, Jepang. 
IPCC 2003 Good practice guidance for land use, land-use change and forestry. Penman, J., Gytarsky, M., Hiraishi, T., Krug, T., Kruger, D., Pipatti, R., Buendia, L., Miwa, K., Ngara, T., Tanabe, K., dkk. (ed.) Institute for Global Environmental Strategies, Hayama, Japan.

IPCC 20062006 IPCC guidelines for national greenhouse gas inventories. Eggleston, H.S., Buendia, L., Miwa, K., Ngara, T. dan Tanabe, K. (ed.) Institute for Global Environmental Strategies, Hayama, Jepang.

IPCC 2007a Climate change 2007: synthesis report. Contribution of Working Groups I, II and III to the fourth assessment report of the Intergovernmental Panel on Climate Change. Dalam: Pachauri, R.K. dan Reisinger, A. (ed.) Intergovernmental Panel on Climate Change, Geneva, Switzerland. $104 \mathrm{hlm}$.

IPCC 2007b IPCC fourth assessment report. Cambridge University Press, Cambridge, UK.

Irawan, S. dan Tacconi, L. 2009 Reducing emissions from deforestation and forest degradation (REDD) and decentralized forest management. International Forestry Review 11(4): 427-438.

IUCN 2009 REDD-plus and benefit sharing: experiences in forest conservation and other resource management sectors. International Union for Conservation of Nature, Washington, DC. $7 \mathrm{hlm}$.

IUCN dan UNEP 2010 The world database on protected areas. United Nations Environment Programme - World Conservation Monitoring Centre, Cambridge, UK. http://www.wdpa.org/ (20 Mei 2012).

IWG-IFR 2009 Report on the informal working group on interim finance for REDD+. Discussion document. Informal Working Group for Interim Finance for REDD. http:/www.regjeringen.no/upload/MD/ Vedlegg/Klima/klima_skogprosjektet/iwg/Report\%20of\%20the\%20 Informal\%20Working\%20Group\%20on\%20Interim\%20Finance\%20 for\%20REDD+\%20_IWG\%20IFR_Final.pdf (10 Mei 2012).

IWGFF 2010 Perkirakaan pengunaan sumber bahan baku industri pulp and paper. Indonesian Working Group on Forest Finance, Jakarta, Indonesia. $38 \mathrm{hlm}$.

Jagger, P., Sills, E., Lawlor, K. dan Sunderlin, W.D. 2010 A guide to learning about livelihood impacts of REDD+. CIFOR, Bogor, Indonesia. $93 \mathrm{hlm}$.

Jakarta Post 2010 Govt to open $2 \mathrm{~m}$ hectares of new farmlands. 20 Juni 2010. Jakarta, Indonesia. http://www.thejakartapost.com/news/2010/07/20/ govt-open-2m-hectares-new-farmlands.html (22 Mei 2012).

Jambiya, G., Riziki, S. dan Rehema, T. 2011 The context of REDD+ in Tanzania: drivers, agents and institutions. CIFOR, tidak diterbitkan.

Jasanoff, S. 2009 Governing innovation. Paper presented at Knowledge in Question - a synopsium on interrogating knowledge and questioning science\#597. Mei 2009. http://www.india-seminar.com/2009/597/597_ sheila_jasanoff.htm (16 April 2012). 
Jenkins, C.J. 1995 Social movements, political representation, and the state: an agenda and comparative framework. Dalam: Jenkins, C.J. dan Klandermans, B. (ed.) The politics of social protest: comparative perspectives on states and social movements, 7-16. UCL Press, London.

Johannsen, L. dan Pedersen, K.H. 2008 The responsive state: openness and inclusion in the policy process. Dalam: Dani, A.A. dan de Haan, A. (ed.) Inclusive states: social policy and structural inequalities, 73-95. The International Bank for Reconstruction and Development/The World Bank, Washington, DC.

Johnson, F.X., Pacini, H. dan Smeets, E. 2012 Transformations in EU biofuels markets under the Renewable Energy Directive and the implications for land use, trade and forests. CIFOR, Bogor, Indonesia.

Kaimowitz, D. 2008 The prospects for reduced emissions from deforestation and degradation (REDD) in Mesoamerica. International Forestry Review 10(3): 485-495.

Kaimowitz, D. dan Smith, J. 2001 Soybean technology and the loss of natural vegetation in Brazil and Bolivia. Dalam: Angelsen, A. dan Kaimowitz, D. (ed.) Agricultural technologies and tropical deforestation. $C A B$ International and CIFOR, Wallingford, UK dan Bogor, Indonesia.

Kaimowitz, D., Mertens, B., Wunder, S. dan Pacheco, P. 2004 Hamburger connection fuels Amazon destruction: cattle ranching and deforestation in Brazil's Amazon. CIFOR, Bogor, Indonesia.

Kanninen, M., Brockhaus, M. dan Murdiyarso, D. 2010 Harnessing forests for climate change mitigation through REDD+. Dalam: Mery, G., Katila, P., Galloway, G., Alfaro, R.I., Kanninen, M., Lobovikov, M. dan Varjo, J. (ed.) Forests and society - responding to global drivers of change. International Union of Forest Research Organizations, Vienna, Austria.

Kanninen, M., Murdiyarso, D., Seymour, F., Angelsen, A., Wunder, S. dan German, L. 2007 Do trees grow on money? The implications of deforestation research for policies to promote REDD. Forest Perspectives. CIFOR, Bogor, Indonesia. $61 \mathrm{hlm}$.

Karsenty, A. dan Assembe, S. 2011 Les régimes fonciers et la mise en oeuvre de la REDD+ en Afrique Centrale. Land Tenure Journal(2): 105-129.

Karsenty, A. dan Ongolo, S. 2012 Can "fragile states" decide to reduce their deforestation? The inappropriate use of the theory of incentives with respect to the REDD mechanism. Forest Policy and Economics 18: 38-45.

Kengoum, D.F. 2011 REDD+ politics in the media: a case study from Cameroon. Working Paper 51. CIFOR, Bogor, Indonesia. $28 \mathrm{hlm}$.

Ketterings, Q.M., Coe, R., van Noordwijk, M., Ambagau', Y. dan Palm, C.A. 2001 Reducing uncertainty in the use of allometric biomass equations for predicting above-ground tree biomass in mixed secondary forests. Forest Ecology and Management 146(1-3): 199-209. 
Khor, M. 2000 Globalization and the south: some critical issues. UNCTAD Discussion Papers No. 147. United Nations Conference on Trade and Development, Geneva, Swiss.

Killeen, T.J., Schroth, G., Turner, W., Harvey, C.A., Steininger, M.K., Dragisic, C. dan Mittermeier, R.A. 2011 Stabilizing the agricultural frontier: leveraging REDD with biofuels for sustainable development. Biomass and Bioenergy 35(12): 4815-4823.

Kindermann, G.E., Obersteiner, M., Rametsteiner, E. dan McCallum, I. 2006 Predicting the deforestation-trend under different carbonprices. Carbon Balance and Management 1(15).

Kindermann, G.E., Obersteiner, M., Sohngen, B., Sathaye, J., Andrasko, K., Rametsteiner, E., Schlamadinger, B., Wunder, S. dan Beach, R. 2008 Global cost estimates of reducing carbon emissions through avoided deforestation. Proceedings of the National Academy of Sciences 105(30): 10302-10307.

Kissinger, G. 2011 Linking forests and food production in the REDD+ context. CCAFS Working Paper No. 1. Climate Change Agriculture and Food Security, Kopenhagen, Denmark.

Knight, J. dan Sened, I. (ed.) 1995 Explaining social institutions. University of Michigan Press, Ann Arbor, MI, USA. $238 \mathrm{hlm}$.

Knoepfel, I. 2011 Responsible investment in commodities: the issues at stake and a potential role for institutional investors. Values Investment Strategies and Research, Zurich, Swiss. $30 \mathrm{hlm}$.

Koeberle, S., Stavreski, Z. dan Walliser, J. 2006 Budget support as more effective aid? Recent experiences and emerging lessons. The World Bank, Washington, DC. 508 hlm.

Kongsager, R. dan Reenberg, A. 2012 Contemporary land-use transitions: the global oil palm expansion. GLP Report No. 4. The Global Land Project International Project Office, Kopenhagen, Denmark.

Koran Kaltim 2011. Investasi HTI Capai Rp 22,9 Triliun Koran Kaltim 8 Agustus 2011. http://m.korankaltim.co.id/read/m/14008/

Kovacevic, M. 2011 Durban talks both good and bad for REDD+, says expert. 14 Desember 2011. CIFOR Forests blog. http://blog.cifor. org/6507/durban-talks-both-good-and-bad-for-redd-says-expert/ (28 April 2012).

Kshatriya, M., Sills, E.O. dan Lin, L. 2011 Global database of REDD+ and other forest carbon projects. Interactive map. http://www. forestsclimatechange.org/redd-map/ (15 April 2012).

Kurniatun, H., Sitompul, S.M., van Noordwijk, M. dan Palm, C. 2001 Methods for sampling carbon stocks above and below ground. ASB lecture note $4 \mathrm{~b}$. International Centre for Research in Agroforestry, Bogor, Indonesia. 
Lambin, E.F., Geist, H.J. dan Lepers, E. 2003 Dynamics of land-use and land-cover change in tropical regions. Annual Review of Environment and Resources 28(1): 205-241.

Lambin, E.F., Turner, B.L., Geist, H.J., Agbola, S.B., Angelsen, A., Bruce, J.W., Coomes, O.T., Dirzo, R., Fischer, G., Folke, C. dkk. 2001 The causes of land-use and land-cover change: moving beyond the myths. Global Environmental Change 11(4): 261-269.

Lang, C. 2011a Eight problems with Norway's REDD support to Guyana: open letter to Erik Solheim. REDD-Monitor 25 Maret 2011. http://www. redd-monitor.org/2011/03/25/eight-problems-with-norways-reddsupport-to-guyana-open-letter-to-erik-solheim/ (15 Februari 2012).

Lang, C. 201 b Erik Solheim's reply to the Open Letter outlining eight problems with Norway's REDD support to Guyana: "It will not be possible to go into the details of your letter here." REDD-Monitor 19 Mei 2011. http:// www.redd-monitor.org/2011/05/19/erik-solheims-reply-to-theopen-letter-outlining-eight-problems-with-norway\%E2\%80\%99sredd - support- to - guyana-it - will- not-be- possibleto-go-into-the-details-of-your-letter-here/ (15 Februari 2012).

Lang, G. dan Chan, C.H.W. 2006 China's impact on forests in Southeast Asia. Journal of Contemporary Asia 36(2): 167-194.

Lapola, D.M., Schaldach, R., Alcamo, J., Bondeau, A., Koch, J., Koelking, C. dan Priess, J.A. 2010 Indirect land-use changes can overcome carbon savings from biofuels in Brazil. Proceedings of the National Academy of Sciences 107(8): 3388-3393.

Larson, A.M. 2011 Forest tenure reform in the age of climate change: lessons for REDD+. Global Environmental Change 21(2): 540-549.

Larson, A.M. dan Petkova, E. 2011 An introduction to forest governance, people and REDD+ in Latin America: obstacles and opportunities. Forests 2(1): 86-111.

Larson, A.M. dan Ribot, J.C. 2009 Lessons from forestry decentralisation. Realising REDD+: national strategy and policy options. Center for International Forestry Research (CIFOR), Bogor, Indonesia.

Larson, A.M., Barry, D. dan Ram Dahal, G. 2010 New rights for forestbased communities? Understanding processes of forest tenure reform. International Forestry Review 12(1): 78-96.

Laumann, E.O. dan Knoke, D. 1987 The organizational state: social choice in national policy domains. University of Wisconsin Press, Madison, WI, USA dan London. $539 \mathrm{hlm}$.

Laurance, W.F. 2008 The need to cut China's illegal timber imports. Science 319: 1184. 
Lawlor, K. dan Huberman, D. 2009 Reduced emissions from deforestation and degradation (REDD) and human rights. Dalam: Campese, J., Sunderland, T., Greiber, T. dan Oviedo, G. (ed.) Rights-based approaches: exploring issues and opportunities for conservation, 269-286. CIFOR dan International Union for Conservation of Nature, Bogor, Indonesia.

Leach, M., Scoones, I. dan Stirling, A. 2010 Governing epidemics in an age of complexity: narratives, politics and pathways to sustainability. Global Environmental Change 20(3): 369-377.

Lee, K.N. 1993 Compass and gyroscope: integrating science and politics for the environment. Island Press, Washington, DC.

Libelula dan CIFOR 2012 REDD+ politics in the media: a case study from Peru. CIFOR, Bogor, Indonesia. Tidak diterbitkan.

Lima, M., Skutsch, M. dan de Medeiros Costa, G. 2011 Deforestation and the social impacts of soy for biodiesel: perspectives of farmers in the south Brazilian Amazon. Ecology and Society 16(4): 4.

Lin, L. Forthcoming Geography of REDD+ at multiple scales: country participation and project location. Tidak diterbitkan. North Carolina State University, Raleigh, NC. http://repository.lib.ncsu.edu/ir/ handle/1840.16/1 (20 Mei 2012).

Lin, L., Sills, E., Pattanayak, S., Atmadja, S. dan Streck, J. 2012 Sub-national geography of REDD+ projects. The Yale Chapter of the International Society of Tropical Foresters, 26-28 Januari 2012, New Haven, CT, USA.

Lindhjem, H., Aronsen, I., Bråten, K.G. dan Gleinsvik, A. 2010 Experiences with benefit sharing: issues and options for REDD-plus. Econ Pöyry Oslo, Norway. $116 \mathrm{hlm}$.

Liu, J. dan Diamond, J. 2005 China's environment in a globalizing world. Nature 435(7046): 1179-1186.

Lohmann, L. 2012 Financialization, commodification and carbon: the contradictions of neoliberal climate policy. Socialist Register. http:// thecornerhouse.org.uk/sites/thecornerhouse.org.uk/files/Socialist $\% 20$ Register\%20Neoliberal\%20Climate\%20Policy\%20Contradictions.pdf (23 Mei 2012).

Louman, B., Cifuentes, M. dan Chacón, M. 2011 REDD+, RFM, development, and carbon markets. Forests 2(1): 357-372.

Lubowski, R.N. 2008 The role of REDD in stabilising greenhouse gas concentration: lessons from economic models. CIFOR Info Brief no. 18. CIFOR, Bogor, Indonesia.

Macedo, M.N., DeFries, R.S., Morton, D.C., Stickler, C.M., Galford, G.L. dan Shimabukuro, Y.E. 2012 Decoupling of deforestation and soy production in the southern Amazon during the late 2000s. Proceedings of the National Academy of Sciences 109(4): 1341-1346. 
MacKenzie, C. 2006 Forest governance in Zambesia, Mozambique: Chinese takeaway! Forum das Organização Não-Governamental da Zambézia, Zambézia, Mozambique.

Managing for Development Results 2011 Emerging good practice in managing for development results. Sourcebook, $3^{\text {rd }}$ edition. Managing for Development Results, Washington, DC. $99 \mathrm{hlm}$.

Maniatis, D. dan Mollicone, D. 2010 Options for sampling and stratification for national forest inventories to implement REDD+ under the UNFCCC. Carbon Balance and Management 5(1): 1-14.

March, J.G. dan Olsen, J.P. 1998 The institutional dynamics of international political orders. International Organization 52(04): 943-969.

Margulis, S. 2004 Causes of deforestation of the Brazilian Amazon. Report No. 22. The World Bank, Washington, DC.

Marklund, L. dan Schoene, D. 2006 Global assessment of growing stock, biomass and carbon stock. Global Forest Resources Assessment 2005. FRA working paper 106/4. Food and Agriculture Organization of the United Nations, Roma. $55 \mathrm{hlm}$.

Marsh, D. dan Smith, M. 2000 Understanding policy networks: towards a dialectical approach. Political Studies 48(1): 4-21.

Martinet, A., Megevand, C. dan Streck, C. 2009 REDD reference levels and drivers of deforestation in Congo Basin countries. World Bank. http:// climatefocus.com/downloads/technical-note-on-redd-referencelevels-and-drivers-of-deforestation-in-congo-basin-countries.pdf (24 Mei 2012). $18 \mathrm{hlm}$.

Mather, A.S., Fairbairn, J. dan Needle, C.L. 1999 The course and drivers of the forest transition: the case of France. Journal of Rural Studies 15(1): 65-90.

Mather, A.S. dan Needle, C.L. 1998 The forest transition: a theoretical basis. Area 30(2): 117-124.

May, P.H., Boyd, E., Veiga, F. dan Chang, M. 2004 Local sustainable development effects of forest carbon projects in Brazil and Bolivia: a view from the field. International Institute for Environment and Development, London. $21 \mathrm{hlm}$.

May, P.H., Calixto, B. dan Gebara, M.F. 2011a REDD+ politics in the media: a case study from Brazil. Working Paper 55. CIFOR, Bogor, Indonesia. $28 \mathrm{hlm}$.

May, P.H., Millikan, B. dan Gebara, M.F. 2011 b The context of REDD+ in Brazil: drivers, agents, and institutions. CIFOR, Bogor, Indonesia. 69 hlm.

Mayer, A.L., Kauppi, P.E., Angelstam, P.K., Zhang, Y. dan Tikka, P.M. 2005 Importing timber, exporting ecological impact. Science 308(5720): 359-360. 
McCarthy, J.F. 2010 Processes of inclusion and adverse incorporation: oil palm and agrarian change in Sumatra, Indonesia. Journal of Peasant Studies 37(4): 821-850.

McKinsey dan Company 2009 Pathways to a low-carbon economy: version 2 of the global greenhouse gas abatement cost curve. McKinsey \& Company. http://www.worldwildlife.org/climate/WWFBinaryitem1 1334.pdf (24 April 2012). $190 \mathrm{hlm}$.

McNeill, D. 2006 The diffusion of ideas in development theory and policy. Global Social Policy 6(3): 334-354.

McShane, T.O., Hirsch, P.D., Trung, T.C., Songorwa, A.N., Kinzig, A., Monteferri, B., Mutekanga, D., Thang, H.V., Dammert, J.L., Pulgar-Vidal, M. dkk. 2011 Hard choices: making trade-offs between biodiversity conservation and human well-being. Biological Conservation 144(3): 966-972.

Merger, E., Dutschke, M. dan Verchot, L. 2011 Options for REDD+ voluntary certification to ensure net GHG benefits, poverty alleviation, sustainable management of forests and biodiversity conservation. Forests 2(2): 550-577.

Merian Research dan CRBM 2010 The vultures of land grabbing: the involvement of European financial companies in large-scale land acquisition abroad. Regulate Finance for Development, London. http://farmlandgrab.org/wp-content/uploads/2010/11/VULTUREScompleto.pdf (22 Mei 2012). $44 \mathrm{hlm}$.

Meridian Institute 2009 Reducing emissions from deforestation and forest degradation: an options assessment report. Prepared for the Government of Norway, by A. Angelsen, S. Brown, C. Loisel, L. Peskett, C. Streck, and D. Zarin. http://www.REDD-OAR.org.

Meridian Institute 2011a Guidelines for REDD+ reference levels: principles and recommendations. Dipersiapkan untuk Pemerintah Norwegia oleh Arild Angelsen, Doug Boucher, Sandra Brown, Valérie Merckx, Charlotte Streck, and Daniel Zarin. www.REDD-OAR.org.

Meridian Institute 2011b Modalities for REDD+ reference levels: technical and procedural issues. Disiapkan untuk Pemerintah Norwegia oleh Arild Angelsen, Doug Boucher, Sandra Brown, Valérie Merckx, Charlotte Streck, and Daniel Zarin. www.REDD-OAR.org.

Meyfroidt, P. dan Lambin, E.F. 2008 The causes of the reforestation in Vietnam. Land Use Policy 25(2): 182-197.

Meyfroidt, P. dan Lambin, E.F. 2009 Forest transition in Vietnam and displacement of deforestation abroad. Proceedings of the National Academy of Sciences 106(38): 16139-16144.

Meyfroidt, P., Rudel, T.K. dan Lambin, E.F. 2010 Forest transitions, trade, and the global displacement of land use. Proceedings of the National Academy of Sciences 107(49): 20917-20922. 
Michaelowa, A. 2011 Failures of global carbon markets and CDM? Climate Policy 11(1): 839-841.

Miettinen, J., Shi, C. dan Liew, S.C. 2011 Deforestation rates in insular Southeast Asia between 2000 and 2010. Global Change Biology 17: 2261-2270.

Milledge, S., Gelvas, I.K. dan Ahrends, A. 2007 Forestry, governance and national development: lessons learned from a logging boom in Southern Tanzania. TRAFFIC East/Southern Africa, Dar Es Salaam, Tanzania.

Ministry of Energy and Mineral Resources 2010 Refleksi kinerja sektor energi dan sumber daya mineral tahun 2010. Press release 73/HUMAS KESDM/2010, 31 Desember 2010. Ministry of Energy and Mineral Resources, Jakarta, Indonesia.

Ministry of Finance 2009 Ministry of Finance green paper: economic and fiscal policy strategies for climate change mitigation in Indonesia. Ministry of Finance and Australia-Indonesia Partnership, Jakarta, Indonesia.

MMA 2011 Relatório da Oficina: Implementação das Salvaguardas Sociais e Ambientais na Estratégia Nacional de REDD+, realizada. Ministério do Meio Ambiente (Ministry of the Environment), Brasília, Brasil.

MMA 2012 REDD+: Relatório do Painel Técnico do MMA sobre financiamento, benefícios e co-benefícios. Gebara, M.F. (ed.) Secretaria de Mudanças Climáticas, Ministério do Meio Ambiente (Ministry of the Environment), Brasília, Brasil.

Mokany, K., Raison, R.J. dan Prokushkin, A.S. 2006 Critical analysis of root:shoot ratios in terrestrial biomes. Global Change Biology 12(1): 84-96.

Mollicone, D., Freibauer, A., Schulze, E.D., Braatz, S., Grassi, G. dan Federici, S. 2007 Elements for the expected mechanisms on 'reduced emissions from deforestation and degradation, REDD' under UNFCCC. Environmental Research Letters 2(4): 045024.

Mortimer, N.D. 2011 Life-cycle assessment of refined vegetable oil and biodiesel from jatropha grown in Dakatcha Woodlands of Kenya. http://www.actionaid.org.uk/doc_lib/kenyan_jatropha_final_report.pdf (30 Mei 2012).

Morton, D.C., DeFries, R.S., Shimabukuro, Y.E., Anderson, L.O., Arai, E., del Bon Espirito-Santo, F., Freitas, R. dan Morisette, J. 2006 Cropland expansion changes deforestation dynamics in the southern Brazilian Amazon. Proceedings of the National Academy of Sciences 103(39): 14637-14641.

Moutinho, P., Stella, O., Lima, A., Christovam, M., Castro, I. dan Nepstad, D. 2011 REDD no Brasil: um enfoque amazônico: fundamentos, critérios e estruturas institucionais para um regime nacional de redução de emissóes por desmatamento e degradação florestal - REDD. Centro de Gestão e Estudos Estratégicos, Brasilia, Brasil. 
Mumssen, Y., Johannes, L. dan Kumar, G. 2010 Output-based aid: lessons learned and best practices. The World Bank, Washington, DC. $175 \mathrm{hlm}$.

Murdiyarso, D., Dewi, S., Lawrence, D. dan Seymour, F. 2011 Indonesia's forest moratorium: a stepping stone to better forest governance? Working Paper 76. CIFOR, Bogor, Indonesia.

Murphy, D. 2011 Safeguards and multiple benefits in a REDD+ mechanism. International Institute for Sustainable Development, Winnipeg, Kanada. $37 \mathrm{hlm}$.

Murray, B.C. dan Olander, L. 2008 A core participation requirement for creation of a REDD market. Nicholas Institute for Environmental Policy Solutions. Durham, NC, USA.

Murray, B.C., Lubowski, R. dan Sohngen, B. 2009 Including international forest carbon incentives in climate policy: understanding the economics. Nicholas Institute for Environmental Policy Solutions, Duke University, Durham, NC, USA. $63 \mathrm{hlm}$.

Naidoo, R. dan Iwamura, T. 2007 Global-scale mapping of economic benefits from agricultural lands: Implications for conservation priorities. Biological Conservation 140(1-2): 40-49.

Nakhooda, S., Caravani, A. dan Schalatek, L. 2011 Climate finance fundamentals. Brief 5. Overseas Development Institute and Heinrich Boell Foundation, Amerika Utara, Washington, DC.

Naylor, R. 2011 Expanding the boundaries of agricultural development. Food Security 3(2): 233-251.

Nepstad, D.C., Soares-Filho, B., Merry, F., Moutinho, P., Rodrigues, H.O., Bowman, S., Schwartzman, S., Almeida, O. dan Rivero, S. 2007 The costs and benefits of reducing carbon emissions from deforestation and forest degradation in the Brazilian Amazon. The Woods Hole Research Center, Falmouth, MA, USA. 26 hlm.

Nepstad, D.C., Stickler, C.M. dan Almeida, O.T. 2006 Globalization of the Amazon soy and beef industries: opportunities for conservation. Conservation Biology 20(6): 1595-1603.

Newell, P. dan Wheeler, J. 2006 Rights, resources and the politics of accountability: an introduction Dalam: Newell, P. dan Wheeler, J. (ed.) Rights, resources and the politics of accountability, 1-36. Zed Books, London.

NORDECO 2011 First program evaluation for the Forest Carbon Partnership Facility (FCPF): evaluation report commissioned by the Participants Committee of the FCFP. Nordic Agency for Development and Ecology, Helsinki, Finlandia. $156 \mathrm{hlm}$.

North, D.C. 1990 Institutions, institutional change and economic performance. Cambridge University Press, Cambridge, UK. $152 \mathrm{hlm}$. 
Norton Rose 2010 Forest carbon rights in REDD+ countries: a snapshot of Africa. Norton Rose LLP. http://www.nortonrose.com/files/forestcarbon-rights-in- redd-countries-a-snapshot-of-africa-pdf- $994-$ kb-32479.pdf (21 Mei 2012). $40 \mathrm{hlm}$.

Norwegian Ministry of Environment 2011 Joint idea note and technical note on payments to Guyana. Guyana-Norway partnership on climate and forests. http://www.regjeringen.no/en/dep/md/Selectedtopics/climate/the-government-of-norways-international- / guyananorwaypartnership.html?id=592318 (24 Mei 2012).

Obersteiner, M., Huettner, M., Kraxner, F., McCallum, I., Aoki, K., Bottcher, H., Fritz, S., Gusti, M., Havlik, P., Kindermann, G. dkk. 2009 On fair, effective and efficient REDD mechanism design. Carbon Balance and Management 4(1): 11.

Obidzinski, K. dan Dermawan, A. 2010 Smallholder timber plantation development in Indonesia: what is preventing progress? International Forestry Review 12(4): 339-348.

OECD 2002 Glossary of key terms in evaluation and results based management. Organisation for Economic Co-operation and Development, Paris. $37 \mathrm{hlm}$.

OECD 2005 Paris Declaration on aid effectiveness. Organisation for Economic Co-operation and Development, Development Assistance Committee, Paris, Perancis. http://www.oecd.org/dataoecd/11/41/34428351.pdf (15 Februari 2012). $21 \mathrm{hlm}$.

OECD 2008 Evaluating development co-operation: summary of key norms and standards. Organisation for Economic Co-operation and Development, Paris.

OECD 2010 How to manage for results: some reflections on the use of common indicators. Organisation for Economic Co-operation and Development, Paris. $23 \mathrm{hlm}$.

OECD 2012 Climate change expert group global forum on the new UNFCCC marketmechanismand trackingclimatefinance(March2012).Organisation for Economic Co-operation and Development. http://www.oecd.org/ document/38/0,3746,en_2649_34361_49998630_1_1_1_1,00.html (17 Maret 2012).

Olbrei, E. dan Howes, S. 2012 A very real and practical contribution? Lessons from the Kalimantan Forests and Climate Partnership. Development Policy Centre Discussion Paper 16. Crawford School of Economics and Government, the Australian National University, Canberra, Australia.

Olsen, N. dan Bishop, J. 2009 The financial costs of REDD: evidence from Brazil and Indonesia. International Union for Conservation of Nature, Gland, Switzerland. $64 \mathrm{hlm}$. 
Olson, J.M., Misana, S., Campbell, D.J., Mbonile, M. dan Mugisha, S. 2004 The spatial patterns and root causes of land-use change in East Africa. LUCID Project Working Paper 47. International Livestock Research Institute, Nairobi, Kenya.

ONFI 2008 Reducing emissions from deforestation and forest degradation (REDD). Analysis of 7 outstanding issues for the inclusion of tropical forests in the International Climate Governance. Office National de Forets International, Paris, Perancis. $51 \mathrm{hlm}$.

Ostrom, E. 2010 Polycentric systems for coping with collective action and global environmental change. Global Environmental Change 20(4): 550-557.

Ostrom, E. dan Nagendra, H. 2006 Insights on linking forests, trees, and people from the air, on the ground, and in the laboratory. Proceedings of the National Academy of Sciences 103(51): 19224-19231.

Ostrom, V. dan Ostrom, E. 1977 Public goods and public choices. Dalam: Savas, E.S. (ed.) Alternatives for delivering public services: towards improved performance, hlm. 7-49. Westview Press, Boulder, CO, USA.

Oyono, P.R. 2004 One step forward, two steps back? Paradoxes of natural resources management decentralisation in Cameroon. The Journal of Modern African Studies 42(01): 91-111.

Pacheco, P. dan Poccard-Chapuis, R. 2012 The complex evolution of cattle ranching development amid market integration and policy shifts in the Brazilian Amazon. Annals of the Association of American Geographers In press.

Pacheco, P., Aguilar-Støen, M., Börner, J., Etter, A., Putzel, L. dan Diaz, M.d.C.V. 2010 Landscape transformation in tropical Latin America: assessing trends and policy implications for REDD+. Forests 2(1): 1-29.

Pagiola, S. 2008 Payments for environmental services in Costa Rica. Ecological Economics 65(4): 712-724.

Pagiola, S. dan Bosquet, B. 2009 Estimating the costs of REDD at the country level. World Bank. http:/www.forestcarbonpartnership.org/fcp/sites/ forestcarbonpartnership.org/files/Documents/PDF/REDD-Costs-22. pdf (21 Mei 2012), Washington, DC. $22 \mathrm{hlm}$.

Pahl-Wostl, C. 2009 A conceptual framework for analysing adaptive capacity and multi-level learning processes in resource governance regimes. Global Environmental Change 19(3): 354-365.

Palace, M., Keller, M., Hurtt, G. dan Frolking, S. 2012 A review of above ground necromass in tropical forests. Dalam: Sudarshana, P., NageswaraRao, M. dan Soneji, J.R. (ed.) Tropical forests, 215-252. InTech, Rijeka, Kroasia.

Pandey, K.D., Buys, P., Chomitz, K. dan Wheeler, D. 2008 Biodiversity conservation indicators: new tools for priority setting at the global environment facility. Global Environment Facility, Washington, DC. 
Parker, C., Brown, J., Pickering, J., Roynestad, E., Mardas, N. dan Mitchell, A.W. 2009a The little climate finance book. Global Canopy Foundation, Oxford, UK. 177 hlm.

Parker, C., Cranford, M., Oakes, N. dan Leggett, M. 2012 The little biodiversity finance book. 3rd edition. Global Canopy Foundation, Oxford, UK. $211 \mathrm{hlm}$.

Parker, C., Mitchell, A., Trivedi, M. dan Mardas, M. 2009b The little REDD+ book: a guide to governmental and non-governmental proposals for reducing emissions from deforestation and forest degradation. Global Canopy Programme, Oxford, UK.

Pearson, T., Walker, S. dan Brown, S. 2005 Sourcebook for land use, land use change and forestry projects. Winrock International. http://www. winrock.org/ecosystems/files/winrockbiocarbon_fund_sourcebookcompressed.pdf (26 April 2012).

Pedroni, L., Streck, C., Estrada, M. dan Dutschke, M. 2007 The "nested approach.” A flexible mechanism to reduce emissions from deforestation. Centro Agronómico Tropical de Investigación y Enseñanza, Turrialba, Kosta Rika.

Persson, U.M. dan Azar, C. 2009 Preserving the world's tropical forests - a price on carbon may not do. Environmental Science \& Technology 44(1): 210-215.

Peskett, L. 2011a Benefit sharing in REDD+: exploring the implications for poor and vulnerable people. The World Bank and REDD-net, Washington, DC.

Peskett, L. 2011b REDD+ benefit sharing in Indonesia. World Bank and REDD-net, Washington, DC. http://redd-net.org/files/WB_ CSBEnefitIndonesia.pdf (21 Mei 2011). $5 \mathrm{hlm}$.

Peskett, L. dan Brockhaus, M. 2009 When REDD+ goes national: a review of realities, opportunities and challenges. Dalam: Angelsen, A., Brockhaus, M., Kanninen, M., Kanounnikoff, S.W., Sills, E. dan Sunderlin, W. (ed.) National REDD architecture and policies, 25-43. CIFOR, Bogor, Indonesia.

Peskett, L. dan Brodnig, G. 2011 Carbon rights in REDD+: exploring the implications for poor and vulnerable people. The World Bank and REDD-net, Washington, DC.

Peters-Stanley, M., Hamilton, K., Marcello, T. dan Sjardin, M. 2011 Back to the future: state of the voluntary carbon market 2011. Ecosystem Marketplace and Bloomberg New Energy Finance, Washington, DC dan New York. $78 \mathrm{hlm}$.

Pfaff, A. dan Walker, R. 2010 Regional interdependence and forest "transitions": substitute deforestation limits the relevance of local reversals. Land Use Policy 27(2): 119-129. 
Pham, C.M. dan Kei, S. 2011 Development of REL in Vietnam: interim results and lessons learned. Presentation at UNFCCC SBSTA workshop on REL and RL, November 2011. United Nations Framework Convention on Climate Change, Bonn, Jerman. http://unfccc.int/files/ methods_science/redd/application/pdf/sbsta_rel_vn_and_jp_rev3.pdf (24 Mei 2012).

Pham, T.T. 2011 REDD+ politics in the media: a case study from Vietnam. Working Paper 53. CIFOR, Bogor, Indonesia.

Pham, T.T., Campbell, B.M., Garnett, S., Aslin, H. dan Hoang, M.H. 2010 Importance and impacts of intermediary boundary organisations in facilitating payment for environmental services in Vietnam. Environmental Conservation 37(1): 64-72.

Pham, T.T., Moeliono, M., Nguyen, T.H., Nguyen, H.T. dan Vu, T.H. 2012 The context of REDD+ in Vietnam: drivers, agents and institutions. CIFOR, Bogor, Indonesia. $79 \mathrm{hlm}$.

Phelps, J., Friess, D.A. dan Webb, E.L. Win-win REDD+ approaches belie carbon-biodiversity trade-offs. Biological Conservation. In press.

Phelps, J., Guerrero, M.C., Dalabajan, D.A., Young, B. dan Webb, E.L. 2010a What makes a 'REDD' country? Global Environmental Change 20(2): 322-332.

Phelps, J., Webb, E.L. dan Agrawal, A. 2010b Does REDD+ threaten to recentralize forest governance? Science 328(5976): 312-313.

Picard, N., Henry, M., Mortier, F., Trotta, C. dan Saint-André, L. 2012 Using Bayesian model averaging to predict tree aboveground biomass in tropical moist forests. Forest Science 58(1): 15-23.

Pielke, R.A. 2010 The climate fix: what scientists and politicians won't tell you about global warming. Basic Books, New York. $288 \mathrm{hlm}$.

Plan Vivo 2008 The Plan Vivo standards. Plan Vivo Foundation, Edinburgh, Scotland. http://www.planvivo.org (20 Mei 2012).

Pratihast, A.K. dan Herold, M. 2011 Community based monitoring and potential links with national REDD+ MRV. Input paper No. 1 for the FCPF workshop "Linking community monitoring with national MRV for REDD+," 12-14 September 2011. The World Bank dan Universidad Nacional Autónoma de México, Mexico City, Mexico.

ProForest 2009 Joint FLEGT Vietnam scoping study - main report prepared for the European Forest Institute (EFI) final report. ProForest, Oxford, UK. 39 hlm.

Putzel, L. 2010 The tree that held up the forest: Shihuahuaco (Dipteryx spp.) and the Chinese timber trade. City University of New York, New York. $288 \mathrm{hlm}$.

PWC 2011 Funding for forests: UK government support for REDD+. Report prepared for the Secretary of State for International 
Development at the UK Department for International Development. PricewaterhouseCoopers LLP, Climate Focus, International Union for Conservation of Nature, Winrock International. http://www.decc.gov. uk/assets/decc/internationalclimatechange/1832-funding-for-forestsuk-government-support-for-red.pdf (24 April 2012). $130 \mathrm{hlm}$.

Qureshi, A., Pariva, Badola, R. dan Hussain, S.A. 2012 A review of protocols used for assessment of carbon stock in forested landscapes. Environmental Science and Policy 16: 81-89.

Rapp, K.W. 2011 World Bank safeguards as the basis for environmental and social risk management for the Forest Carbon Partnership Facility (FCPF). Presentasi pertemuan ahli SBSTA pada acara "Guidance on systems for providing information on how safeguards for REDD-plus activities are addressed and respected," 8-9 Oktober 2011. Panama City, Panama. http://unfccc.int/files/methods_science/redd/application/pdf/ fcpf_sesa+esmf_presentation_8oct2011.pdf (20 Mei 2012).

REDD+ Partnership 2010 A voluntary, non-legally binding framework for the interim REDD+ Partnership. 27 May 2010. http://www.oslocfc2010. no/pop.cfm?FuseAction=Doc\&pAction=View\&pDocumentId=25019 (15 Februari 2012). 5 hlm.

REDD+ SES 2010 The REDD+ Social and Environmental Standards. Version 1 Juni 2010. http://www.redd-standards.org/files/pdf/lang/ english/REDD_Social_Environmental_Standards_06_01_10_finalEnglish.pdf (20 Mei 2012).

Repetto, R. dan Gillis, M. (ed.) 1998 Public policies and the misuse of forest resources. World Resources Institute, Washington, DC.

REPOA and CIFOR 2012 The context of REDD+ in Tanzania: drivers, agents, and institutions. CIFOR, Bogor, Indonesia. Tidak diterbitkan.

Republic of Guyana 2008 Creating incentives to avoid deforestation. The Office of the President, Republic of Guyana, Georgetown, Guyana.

Resosudarmo, I.A.P., Atmadja, S., Astri, P., Ekaputri, A.D., Intarini, D.Y. dan Indriatmoko, Y. 2011 Can the existing tenure system foster effective REDD+ implementation? Reflections from five emerging $\mathrm{REDD}+$ projects in Indonesia. Workshop on land tenure and forest carbon management: lessons for more effective and equitable REDD investments, Land Tenure Center. Madison, WI, USA.

Ribot, J.C. 2003 Democratic decentralisation of natural resources: institutional choice and discretionary power transfers in sub-Saharan Africa. Public Administration and Development 23(1): 53-65.

Richards, P.D., Myers, R.J., Swinton, S.M. dan Walker, R.T. 2012 Exchange rates, soybean supply response, and deforestation in South America. Global Environmental Change 22(2): 454-462. 
Roberts, D.G. 2008 Convergence of the fuel, food and fibre markets: a forest sector perspective. International Forestry Review 10(1): 81-94.

Romijn, E., Herold, M., Kooistra, L., Murdiyarso, D. dan Verchot, L. 2012 Assessing capacities of non-Annex I countries for national forest monitoring in the context of REDD+. Environmental Science and Policy 19-20: 33-48.

Ross, M.L. 2001 Timber booms and institutional breakdown in Southeast Asia. Cambridge University Press, Cambridge, UK.

Royal society 2012 People and the planet. The Royal Society, London. http:// royalsociety.org/uploadedFiles/Royal_Society_Content/policy/projects/ people-planet/2012-04-25-PeoplePlanet.pdf(22 Mei 2012). $133 \mathrm{hlm}$.

RRI 2012 Turning point: what future for forest peoples and resources in the emerging world order? Rights and Resources Initiative, Washington, DC. $33 \mathrm{hlm}$.

Rudel, T.K. 2007 Changing agents of deforestation: from state-initiated to enterprise driven processes, 1970-2000. Land use policy 24(1): 35-41.

Rudel, T.K., Defries, R., Asner, G.P. dan Laurance, W.F. 2009 Changing drivers of deforestation and new opportunities for conservation. Conservation Biology 23(6): 1396-1405.

Rudorff, B.F.T., Adami, M., Aguiar, D.A., Moreira, M.A., Mello, M.P., Fabiani, L., Amaral, D.F. dan Pires, B.M. 2011 The soy moratorium in the Amazon biome monitored by remote sensing images. Remote Sensing 3(1): 185-202.

Rusastra, I.W., Thompson, G., Bottema, J.W.T. dan Baldwin, R. 2008 Food security and poverty in the era of decentralization in Indonesia. CAPSA Working Paper No. 102. Centre for Alleviation of Poverty through Sustainable Agriculture, Bogor, Indonesia.

Saatchi, S.S., Harris, N.L., Brown, S., Lefsky, M., Mitchard, E.T.A., Salas, W., Zutta, B.R., Buermann, W., Lewis, S.L., Hagen, S.. 2011 Benchmark map of forest carbon stocks in tropical regions across three continents. Proceedings of the National Academy of Sciences 108(24): 9899-9904.

Sabatier, P.A. (ed.) 1999 Theories of the policy process: theoretical lenses on public policy. Westview Press, Boulder, CO, USA. $304 \mathrm{hlm}$.

Sabatier, P.A. dan Jenkins-Smith, H.C. 1999 The advocacy coalition framework: an assessment. Dalam: Sabatier, P.A. (ed.) Theories of the policy process: theoretical lenses on public policy, $304 \mathrm{hlm}$. Westview Press, Boulder, CO, USA.

Sama, N.J. dan Tawah, E.B. 2009 Case study: Cameroon. Dalam: Costenbader, J. (ed.) Legal frameworks for REDD: design and implementation at the national level, 139-150. International Union for Conservation of Nature, Gland, Swiss. 
Sánchez-Azofeifa, G.A., Pfaff, A., Robalino, J.A. dan Boomhower, J.P. 2007 Costa Rica's payment for environmental services program: intention, implementation, and impact. Conservation Biology 21(5): 1165-1173.

Santilli, M., Moutinho, P., Schwartzman, S., Nepstad, D., Curran, L. dan Nobre, C. 2005 Tropical deforestation and the Kyoto Protocol. Climatic Change 71(3): 267-276.

Scheyvens, H. (ed.) 2010 Developing national REDD-plus systems: progress challenges and ways forward. Studi Negara Indonesia dan Vietnam. Institute for Global Environmental Strategies, Hayama, Japan. $80 \mathrm{hlm}$.

Schlamadinger, B., Ciccarese, L., Dutschke, M., Fearnside, P.M., Brown, S. dan Murdiyarso, D. 2005 Should we include avoidance of deforestation in the international response to climate change? Dalam: Murdiyarso, D. dan Herawati, H. (ed.) Carbon forestry: who will benefit?: Prosiding hasil workshop "carbon sequestration and sustainable livelihoods", Bogor, 1617 Februari 2005. CIFOR, Bogor, Indonesia. $215 \mathrm{hlm}$.

Schoneveld, G. 2011 The anatomy of large-scale farmland acquisitions in sub-Saharan Africa. CIFOR, Bogor, Indonesia. $21 \mathrm{hlm}$.

Schroeder, H. dan Lovell, H. 2011 The role of non-nation-state actors and side events in the international climate negotiations. Climate Policy 12(1): 23-37.

Seymour, F. dan Angelsen, A. 2009 Summary and conclusions: REDD wine in old wineskins? Dalam: Angelsen, A., with Brockhaus, M., Kanninen, M., Sills, E., Sunderlin, W.D. dan Wertz-Kanounnikoff, S. (ed.) Realising REDD+: national strategy and policy options, 293-303. CIFOR, Bogor, Indonesia.

Sheil, D., Casson, A., Meijaard, E., van Noordwjik, M., Gaskell, J., Sunderland-Groves, J., Wertz, K. dan Kanninen, M. 2009 The impacts and opportunities of oil palm in Southeast Asia: what do we know and what do we need to know? CIFOR, Bogor, Indonesia. $67 \mathrm{hlm}$.

Shoch, D., Eaton, J. dan Settelmyer, S. 2011 Project developer's guidebook to VCS REDD methodologies. Version 1.0/November 2011. Conservation International. http://www.conservation.org/about/centers_programs/ carbon_fund/Documents/project_developers_guide_to_vcs_ redd_11282011FINAL.pdf (30 April 2012).

Sills, E., Madeira, E., Sunderlin, W. dan Wertz-Kanounnikoff, S. 2009 The evolving landscape of REDD+ projects. Dalam: Angelsen, A., with Brockhaus, M., Kanninen, M., Sills, E., Sunderlin, W.D. dan WertzKanounnikoff, S. (ed.) Realising REDD+: national strategy and policy options, 265-280. CIFOR, Bogor, Indonesia. 
Silva, R.P. 2007 Alometria, estoque e dinâmica da biomassa de florestas primárias e ecundárias na região de Manaus (AM). PhD Thesis. Federal University of Amazonas and National Institute of Amazon Research, Manaus, Brasil. $152 \mathrm{hlm}$.

Simula, M. 2010 Analysis of REDD+ financing gaps and overlaps. Final draft. The REDD+ Partnership. http://reddpluspartnership.org/25159-09eb3 78a8444ec149e8ab32e2f5671b11.pdf (10 Mei 2012).

Skutsch, M. (ed.) 2010 Community forest monitoring for the carbon market: opportunities under REDD. Earthscan, London. $188 \mathrm{hlm}$.

Skutsch, M. dan Van Laake, P.E. 2008 REDD as multilevel governance inthe-making. Energy and Environment 19(6): 831-844.

Slette, J. dan Wiyono, I.E. 2011 Indonesia: oilseeds and products update. GAIN Report Number ID1139. Global Agricultural Information Network, Jakarta, Indonesia.

Smeraldi, R. dan May, P. 2009 A hora da conta: pecuária, Amazônia e conjuntura. Amigos da Terra - Amazônia Brasileira, São Paulo, Brasil.

Smith, A., Stirling, A. dan Berkhout, F. 2004 Governing sustainable industrial transformation under different transition contexts. Dalam: Jacob, K., Binder, M. dan Wieczorek, A. (ed.) Governance for industrial transformation. Proceedings of the 2003 Berlin Conference on the human dimensions of global environmental change. Environmental Policy Research Centre, Berlin, Jerman. 113-132.

Soares-Filho, B.S., Nepstad, D.C., Curran, L.M., Cerqueira, G.C., Garcia, R.A., Ramos, C.A., Voll, E., McDonald, A., Lefebvre, P. dan Schlesinger, P. 2006 Modelling conservation in the Amazon Basin. Nature 440(7083): 520-523.

Sohngen, B. 2009 An analysis of forestry carbon sequestration as a response to climate change. Copenhagen Consesnus Center, Fredriksberg, Denmark. $28 \mathrm{hlm}$.

Sparovek, G., Berndes, G., Barretto, A.G.d.O.P. dan Klug, I.L.F. 2012 The revision of the Brazilian Forest Act: increased deforestation or a historic step towards balancing agricultural development and nature conservation? Environmental Science and Policy 16: 65-72.

Stern, N. 2006 The Stern Review: the economics of climate change. Cambridge University Press, Cambridge, UK.

Strassburg, B.B.N., Kelly, A., Balmford, A., Davies, R.G., Gibbs, H.K., Lovett, A., Miles, L., Orme, C.D.L., Price, J., Turner, R.K. $d k k$. 2010 Global congruence of carbon storage and biodiversity in terrestrial ecosystems. Conservation Letters 3(2): 98-105.

Streck, C. 2009 Rights and REDD+: legal and regulatory considerations. Dalam: Angelsen, A., with Brockhaus, M., Kanninen, M., Sills, E., Sunderlin, W.D. dan Wertz-Kanounnikoff, S. (ed.) Realising REDD+: national strategy and policy options, 151-162. CIFOR, Bogor, Indonesia. 
Streck, C. dan O'Sullivan, R. 2007 Legal tools for the ENCOFOR Programme. Joanneum, Austria. http:/www.joanneum.at/encofor/tools/ doc/Encofor\%20Contracts\%20Manual.pdf (21 Mei 2012). $14 \mathrm{hlm}$.

Subedi, B.P., Pandey, S.S., Pandey, A., Rana, E.B., Bhattarai, S., Banskota, T.R., Charmakar, S. dan Tamrakar, R. 2010 Forest carbon stock measurement: guidelines for measuring carbon stocks in community-managed forests. Asia Network for Sustainable Agriculture and Bioresources, Federation of Community Forest Users, International Centre for Integrated Mountain Development, Kathmandu, Nepal. $69 \mathrm{hlm}$.

Sugardiman, R.A. 2011 Forest RELs and RL for implementation of REDD+ activities in Indonesia. Presentation at UNFCCC SBSTA workshop on REL and RL, November 2011. United Nations Framework Convention on Climate Change, Bonn, Germany. http://unfccc.int/files/methods_ science/redd/application/pdf/20111114_indonesia_forest_rel.pdf (30 Mei 2012).

Sunderland, T.C.H., Ehringhaus, C. dan Campbell, B.M. 2007 Conservation and development in tropical forest landscapes: a time to face the tradeoffs? Environmental Conservation 34(4): 276-279.

Sunderlin, W.D. 2011 The global forest tenure transition: background, substance and prospects. Dalam: Sikor, T. dan Stahl, J. (ed.) Forests and people. Earthscan, London.

Sunderlin, W.D. dan Atmadja, S. 2009 Is REDD+ and idea whose time has come, or gone? Dalam: Angelsen, A., with Brockhaus, M., Kanninen, M., Sills, E., Sunderlin, W.D. dan Wertz-Kanounnikoff, S. (ed.) Realising REDD+: national strategy and policy options, 45-53. CIFOR, Bogor, Indonesia.

Sunderlin, W.D., Hatcher, J. dan Liddle, M. 2008 From exclusion to ownership? Challenges and opportunities in advancing forest tenure reform. Rights and Resources Initiative, Washington, DC.

Sunderlin, W.D., Larson, A.M. dan Cronkleton, P. 2009 Forest tenure rights and REDD+. Dalam: Angelsen, A., with Brockhaus, M., Kanninen, M., Sills, E., Sunderlin, W.D. dan Wertz-Kanounnikoff, S. (ed.) Realising REDD+: national strategy and policy options, 139-150. CIFOR, Bogor, Indonesia.

Sunderlin, W.D., Larson, A., Duchelle, A.E., Resosudarmo, I.A.P., Huynh, T.B., Abdon, A. dan Dokken, T. 2011 Is it possible to resolve tenure insecurity at REDD+ project sites? Evidence from Brazil, Cameroon, Tanzania, Indonesia, and Vietnam. Tidak diterbitkan.

Sunderlin, W.D., Larson, A.M., Duchelle, A., Sills, E.O., Luttrell, C., Jagger, P., Pattanayak, S., Cronkleton, P. dan Ekaputri, A.D. 2010 Technical guidelines for research on REDD+ project sites. CIFOR, Bogor, Indonesia. $158 \mathrm{hlm}$. 
Suparno, R. dan Afrida, N. 2009. RI to expand oil palm estates amid environmental concerns. The Jakarta Post, 3 Desember 2009. http:// www. thejakartapost.com/news/2009/12/03/ri-expand-oil-palmestates-amid-environmental-concerns.html (3 Desember 2011).

Swidler, A. 1986 Culture in action: symbols and strategies. American Sociological Review 51(2): 273-286.

Tabor, K., Burgess, N.D., Mbilinyi, B.P., Kashaigili, J.J. dan Steininger, M.K. 2010 Forest and woodland cover and change in Coastal Tanzania and Kenya, 1990 to 2000. Journal of East African Natural History 99(1): 19-45.

Takacs, D. 2009 Forest carbon: law and property rights. Conservation International, Arlington, VA. $77 \mathrm{hlm}$.

Tauli-Corpuz, V., de Chavez, R., Baldo-Soriano, E., Magata, H., Golocan, C., Bugtong, M.V., Enkiwe-Abayao, L. dan Cariño, J. 2009 Guide on climate change and indigenous peoples. Second edition. Tebtebba Foundation, Baguio City, Filipina.

Tavoni, M., Sohngen, B. dan Bosetti, V. 2007 Forestry and the carbon market response to stabilize climate. Energy Policy 35(11): 5346-5353.

Terheggen, A. 2010 The new kid in the forest: the impact of China's resource demand on the tropical timber value chain in Gabon. Tidak diterbitkan. The Open University. http://mpra.ub.uni-muenchen.de/37982/1/ MPRA_paper_37982.pdf (22 Mei 2012). $264 \mathrm{hlm}$.

TFWG 2010 Options for REDD in Tanzania: key design issues for the national REDD strategy. Brief 2, September 2010. Tanzania Forestry Working Group, Arusha, Tanzania. http://www.tfcg.org/pdf/Brief\%20 2\%20Key\%20Design\%20Issues\%20for\%20REDD\%20Strategy.pdf (21 Mei 2012).

The Government of Australia and The Government of the Republic of Indonesia 2007 Subsidiary agreement between the Government of Australia and the Government of the Republic of Indonesia relating to a program of bilateral cooperation to reduce greenhouse gas emissions associated with deforestation in Indonesia under the global initiative on forest and climate. Tidak diterbitkan.

The Prince's Rainforest Project 2011 Emergency finance for tropical forests. Two years on: is interim REDD+ finance being delivered as needed? The Prince's Charities' International Sustainability Unit, London. $22 \mathrm{hlm}$.

The REDD+ Partnership 2011 The voluntary REDD+ database: making REDD+ finance information accessible. http://www.reddplusdatabase. org/ (2 Maret 2012).

Thompson, M.C., Baruah, M. dan Carr, E.R. 2011 Seeing REDD+ as a project of environmental governance. Environmental Science and Policy 14(2): 100-110. 
Tilman, D., Balzer, C., Hill, J. dan Befort, B.L. 2011 Global food demand and the sustainable intensification of agriculture. Proceedings of the National Academy of Sciences 108(50): 20260-20264.

Tipper, R. 2011 Real-time evaluation of Norway's international climate and forest initiative: contributions to a global REDD+ regime 20072010. Evaluation Report 12/2010. Norwegian Agency for Development Cooperation, Oslo, Norwegia.

Tragistina, O.V.N. 2011. Ekspor batu bara 2010 diperkirakan mencapai 230 juta ton. Kontan, 4 Januari 2011. http://industri.kontan. co.id/news/ekspor-batu-bara-2010-diperkirakan-mencapai-230juta-ton-1 (30 Mei 2012).

UN-REDD Programme 2010 Design of a REDD-compliant benefit distribution system for Viet Nam. The United Nations Collaborative Programme on Reducing Emissions from Deforestation and Forest Degradation in Developing Countries and the Vietnam Department of Forestry, Hanoi, Vietnam. $191 \mathrm{hlm}$.

UN-REDD Programme 2011a Tahun pertama UN-REDD Programme Indonesia: mempercepat kesiapan REDD+ nasional (The first year report of UN-REDD Programme Indonesia: acceleration of national REDD+ readiness). United Nations Collaborative Programme on Reducing Emissions from Deforestation and Forest Degradation in Developing Countries Indonesia, Jakarta, Indonesia. http://www.redd-indonesia. org/pdf/AnnRepUN-REDDFinalindo.pdf (24 Mei 2012). $15 \mathrm{hlm}$.

UN-REDD Programme 2011b Technical manual for participatory carbon monitoring. United Nations Collaborative Programme on Reducing Emissions from Deforestation and Forest Degradation in Developing Countries Viet Nam Programme, Hanoi, Vietnam. 24 hlm.

UN-REDD Programme 2011c UN-REDD Programme Social and Environmental Principles and Criteria. Version 3-draft for consultation. September 2011. The United Nations Collaborative Programme on Reducing Emissions from Deforestation and Forest Degradation in Developing Countries. http://www.un-redd.org/Multiple_Benefits_ SEPC/tabid/54130/Default.aspx (20 Mei 2012).

UN DESA 2004 Sustainable energy consumption in Africa. United Nations Department of Economic and Social Affairs New York.

UNCTAD 2009 The financialization of commodity markets. Dalam: Trade and development report, Chapter 2. United Nations Conference on Trade and Development, New Yord dan Geneva, Swiss.

UNDP 2011 Blending climate finance through national climate funds: a guidebook for the design and establishment of national funds to achieve climate change priorities. United Nations Development Programme, New York. $56 \mathrm{hlm}$. 
UNDP and The President of Ecuador 2011 Multi-partner trust fund office: Ecuador Yasuni ITT Trust Fund. United Nations Development Group. http://mptf.undp.org/yasuni (15 Mei 2012).

UNFCCC 1992 United Nations Framework Convention for Climate Change. FCCC/INFORMAL/84. United Nations Framework Convention on Climate Change. http://unfccc.int/resource/docs/convkp/conveng.pdf (23 Mei 2012).

UNFCCC 2003 Reporting on climate change: user manual for the guidelines on national communications from non-Annex I Parties. United Nations Framework Convention on Climate Change. http://unfccc.int/resource/ docs/publications/userman_nainc_en.pdf (24 Mei 2012).

UNFCCC 2005 Reducing emissions from deforestation in developing countries: approaches to stimulate action. Decision FCCC/CP/2005/L.2. United Nations Framework Convention on Climate Change, Bonn, Jerman. http://unfccc.int/resource/docs/2005/cop11/eng/102.pdf (23 Mei 2012).

UNFCCC 2007 Decision 2/CP.13: Reducing emissions from deforestation in developing countries: approaches to stimulate action. United Nations Framework Convention on Climate Change, Bonn, Jerman. http://unfccc.int/resource/docs/2007/cop13/eng/06a01.pdf\#page $=8$ (23 Mei 2012).

UNFCCC 2009a Cost of implementing methodologies and monitoring systems relating to estimates of emissions from deforestation and forest degradation, the assessment of carbon stocks and greenhouse gas emissions from changes in forest cover, and the enhancement of forest carbon stocks. FCCC/TP/2009/1. United Nations Framework Convention on Climate Change. http://unfccc.int/resource/docs/2009/ tp/01.pdf (24 Mei 2012).

UNFCCC 2009b Methodological guidance for activities relating to reducing emissions from deforestation and forest degradation and the role of conservation, sustainable management of forests and enhancement of forest carbon stocks in developing countries. Decision 4/CP.15. United Nations Framework Convention on Climate Change. http://unfccc.int/ resource/docs/2009/cop15/eng/1 1a01.pdf\#page=11 (18 April 2012).

UNFCCC 2010 Outcome of the work of the Ad Hoc Working Group on long-term cooperative action under the Convention. Draft decision -/ CP.16. United Nations Framework Convention on Climate Change. http://unfccc.int/files/meetings/cop_16/application/pdf/cop16_lca.pdf (24 Mei 2012).

UNFCCC 2011a The Cancun agreements: outcome of the work of the ad hoc working group on long-term cooperation under the Convention. Decision 1/CP.16. Laporan dari Konferensi para Pihak pada sesi 
keenam belas, Kankun, 29 November - 10 Desember 2010. FCC/ CP/2010/7 Add.1. Konvensi Kerangka Kerja PBB tentang Perubahan Iklim, Bonn, Jerman.

UNFCCC 2011b Clean development mechanism: CDM methodology booklet (up to EB 63). United Nations Framework Convention on Climate Change, Bonn, Jerman. $238 \mathrm{hlm}$.

UNFCCC 2011c Draft decision on guidance on systems for providing information on how safeguards are addressed and respected and modalities relating to forest reference emission levels and forest reference levels as referred to in decision 1/CP.16, appendix I. Draft decision -/ CP.17. United Nations Framework Convention on Climate Change. Advance unedited version.

UNCFFF 2011d Establishment of an Ad Hoc Working Group on the Durban Platform for Enhanced Action. Draft Keputusan -/CP.17. Konvensi Kerangka Kerja PBB tentang Perubahan Iklim. Bonn, Jerman. http:// unfccc.int/files/meetings/durban_nov_011/decisions/application/pdf/ cop17_durbanplatform.pdf (23 Mei 2012).

UNFCCC 2011e Report of the Conference of the Parties on its sixteenth session, held in Cancun from 29 November to 10 Desember 2010. Tambahan bagian kedua: tindakan yang diambil oleh Konferensi Para Pihak pada sesi keenam belas. FCCC/CP/2010/7/Add.1. Konvensi Kerangka Kerja PBB tentang Perubahan Iklim.

FCCC/CP/2010/7/Add.1. United Nations Framework Convention on Climate Change. http://unfccc.int/resource/docs/2010/cop16/ eng/07a01.pdf (19 April 2012). $31 \mathrm{hlm}$.

UNFCCC 2012 Report of the Conference of the Parties on its seventeenth session, held in Durban from 28 November to 11 Desember 2011. Tambahan bagian dua: Tindakan yang diambil oleh Konferensi Para Pihak pada sesi ketujuh belas. FCCC/CP/2011/9/Add.1Decision 2/CP17. Konvensi Kerangka Kerja PBB tentang Perubahan Iklim. http://unfccc. int/resource/docs/2011/cop17/eng/09a01.pdf (4 Mei 2012). 86 hlm.

United Republic of Tanzania 1998 National forest policy. Ministry of Natural Resources and Tourism, Dar Es Salaam, Tanzania.

United Republic of Tanzania 2009 National framework for REDD. United Republic of Tanzania, Dar Es Salaam, Tanzania.

United Republic of Tanzania 2010 National strategy for reduced emissions from deforestation and forest degradation (REDD+). Draft Desember 2010. Kantor Wakil Presiden dan Departemen Lingkungan Hidup, Dar Es Salaam, Tanzania.

van der Werf, G.R., Morton, D.C., DeFries, R.S., Olivier, J.G.J., Kasibhatla, P.S., Jackson, R.B., Collatz, G.J. dan Randerson, J.T. $2009 \mathrm{CO}_{2}$ emissions from forest loss. Nature Geosci 2(11): 737-738. 
Van Noordwijk, M. 2007 Rapid carbon stock appraisal (RaSCA). World Agroforestry Centre, Bogor, Indonesia.

Vatn, A. dan Angelsen, A. 2009 Options for a national REDD+ architecture. Dalam: Angelsen, A., with Brockhaus, M., Kanninen, M., Sills, E., Sunderlin, W.D. dan Wertz-Kanounnikoff, S. (ed.) Realising REDD+: national strategy and policy options, 57-74. CIFOR, Bogor, Indonesia.

Vatn, A. dan Vedeld, P. 2011 Getting ready! A study of national governance structures for REDD+. Noragric report no. 59. Aas, Norway, Department of International Environment and Development Studies at the Norwegian University of Life Sciences. $34 \mathrm{hlm}$.

VCS 2012 Methodologies webpage. Verified Carbon Standards. http:// www.v-c-s.org/methodologies/find (30 April 2012).

Verplanke, J.J. dan Zahabu, E. (ed.) 2009 A field guide for assessing and monitoring reduced forest degradation and carbon sequestration by local communities. Project team KYOTO: Think Global, Act Local, Enschede, Netherlands. $93 \mathrm{hlm}$.

Vhugen, D., Aguilar, S. dan Miner, J. 2011 REDD+ and carbon rights: lessons from the field. U.S. Agency for International Development Working Paper. United States Agency for International Development, Seattle, WA. $36 \mathrm{hlm}$.

Virgilio, N.R., Marshall, S., Zerbock, O. dan Holmes, C. 2010 Reducing emissions from deforestation and degradation (REDD): a casebook of on-the-ground experience. The Nature Conservancy, Conservation International and Wildlife Conservation Society, Arlington, VA, USA. $66 \mathrm{hlm}$.

Walker, R., Browder, J., Arima, E., Simmons, C., Pereira, R., Caldas, M., Shirota, R. dan Zen, S.d. 2009 Ranching and the new global range: Amazônia in the 21st century. Geoforum 40(5): 732-745.

Walker, W., Baccini, A., Nepstad, M., Horning, N., Knight, D., Braun, E. dan Bausch, A. 2011 Field guide for forest biomass and carbon estimation. Version 1.0. Woods Hole Research Center, Falmouth, MA, USA. 49 hlm.

Wang, G., Innes, J.L., Lei, J., Dai, S. dan Wu, S.W. 2007 China’s forestry reforms. Science 318(5856): 1556-1557.

WCED 1987 Our common future. Oxford University Press, Oxford, UK.

Wells, M. dan Brandon, K. 1992 People and parks: linking protected area management with local communities. The World Bank, Washington, DC. $116 \mathrm{hlm}$.

Wells, M., Guggenheim, S., Khan, A., Wardojo, W. dan Jepson, P. 1999 Investing in biodiversity. A review of Indonesia's integrated conservation and development projects. Directions in Development. The World Bank, Washington, DC. $136 \mathrm{hlm}$. 
Wertz-Kanounnikoff, S. dan Angelsen, A. 2009 Global and national REDD+ architecture: linking institutions and actions. Dalam: Angelsen, A., with Brockhaus, M., Kanninen, M., Sills, E., Sunderlin, W.D. dan WertzKanounnikoff, S. (ed.) Realising REDD+: national strategy and policy options, 13-24. CIFOR, Bogor, Indonesia.

Wertz-Kanounnikoff, S. dan Kongphan-apirak, M. 2009 Emerging REDD+: a preliminary survey of demonstration and readiness activities. CIFOR, Bogor, Indonesia.

White, A. dan Hatcher, J. 2012 The forest tenure challenge and a new initiative to leverage greater effort and funding. Presentasi untuk UN-REDD and FCPF, Paraguay, 27 Maret 2012. Rights and Resources Initiative. http://www.unredd.net/index.php?option=com_docman \&task=doc_ details\&gid $=$

7002\&Itemid=53 (7 Mei 2012).

White, D. dan Minang, P. (ed.) 2011 Estimating the opportunity costs of REDD+: a training manual. World Bank Institute, Washington, DC.

Williams, L.G., Larsen, G., Lupberger, S., Daviet, F. dan Davis, C. 2011 Getting ready with forest governance: a review of the World Bank Forest Carbon Partnership Facility Readiness Preparation Proposals and the UN-REDD National Programme Documents, v 1.6. World Resources Institute Working Paper. World Resources Institute, Washington, DC.

Winkel, G. 2012 Foucault in the forests-a review of the use of 'Foucauldian' concepts in forest policy analysis. Forest Policy and Economics 16: 81-92.

Wollenberg, E., Campbell, B.M., Holmgren, P., Seymour, F., Sibanda, L. dan von Braun, J. 2011 Actions needed to halt deforestation and promote climate-smart agriculture. Policy Brief No. 4. The Consultative Group on International Agricultural Research, Research Program on Climate Change, Agriculture and Food Security, Kopenhagen, Denmark.

World Bank 2010 Environmental, economic and social impacts of oil palm in Indonesia: a synthesis of opportunities and challenges. The World Bank, Jakarta, Indonesia.

World Bank 2011 Global development horizons 2011. Multipolarity: the new global economy. The World Bank, Washington, DC. $184 \mathrm{hlm}$.

WRI 2009 The governance of forests toolkit: a draft framework for assessing governance of the forest sector. World Resources Institute, Washington, DC. $67 \mathrm{hlm}$.

Wunder, S. 2005 Payments for environmental services: some nuts and bolts. CIFOR Occasional Paper no. 42. CIFOR, Bogor, Indonesia. $24 \mathrm{hlm}$.

Wunder, S. 2008 How do we deal with leakage? Dalam: Angelsen, A. (ed.) Moving ahead with REDD: issues, options and implications, 65-75. CIFOR, Bogor, Indonesia. 
Wunder, S., Campbell, B., Frost, P.G.H., Sayer, J.A., Iwan, R. dan Wollenberg, L. 2008 When donors get cold feet: the community conservation concession in Setulang (Kalimantan, Indonesia) that never happened. Ecology and Society 13(1): 12.

WWF 2009 Biofuel industry study in Tanzania: an assessment of the current situation. World Wide Fund for Nature Tanzania, Dar es Salaam, Tanzania.

Yokelson, R.J., Susott, R., Ward, D.E., Reardon, J. dan Griffith, D.W.T. 1997 Emissions from smoldering combustion of biomass measured by open path Fourier transform infrared spectroscopy. Journal of Geophysical Research 102(D15): 18865-18878.

Zanne, A.E., Lopez-Gonzalez, G., Coomes, D.A., Ilic, J., Jansen, S., Lewis, S.L., Miller, R.B., Swenson, N.G., Wiemann, M.C. dan Chave, J. 2009 Data from: towards a worldwide wood economics spectrum. Dyrad Digital Repository. http://datadryad.org/handle/10255/dryad.235 (26 April 2012). 

Sebagai sebuah gagasan, REDD+ adalah cerita sukses: sebuah pendekatan baru yang membangkitkan harapan bagi penggalangan dana berbasiskan hasil untuk menindaklanjuti kebutuhan mendesak dalam mitigasi perubahan iklim. Gagasan ini cukup luas untuk menjadi sebuah tajuk pohon, untuk memayungi sejumlah besar pelaku di bawahnya untuk menumbuhkan pohon mereka sendiri.

REDD+ menghadapi berbagai tantangan besar: Sejumlah kepentingan politik dan ekonomi yang kuat mendukung deforestasi dan degradasi yang berlanjut. Karena itu, implementasinya harus dikoordinasikan antara berbagai tingkat pemerintahan dan lembaga; manfaatnya harus disalurkan dengan menyeimbangkan keefektifan dan kesetaraan; ketidakpastian kepemilikan lahan (tenurial) dan jaringan pengamannya harus ditangani sungguh-sungguh; serta institusi yang transparan, pemantauan karbon yang dapat diandalkan dan tingkat acuan yang realistis, semuanya dibutuhkan untuk mendukung berbagai sistem berbasiskan hasil.

REDD+ membutuhkan - dan dapat menjadi katalisator - perubahan transformatif: Insentif ekonomi yang baru, informasi dan wacana yang baru, berbagai pelaku dan koalisi kebijakan yang baru berpotensi untuk menggeser kebijakan domestik agar menjauh dari jalur bisnis seperti biasa.

Proyek-proyek REDD+ bersifat gabungan di kawasan-kawasan yang tingkat deforestasinya tinggi: Para pengusul proyek mengusahakan strategi yang menggabungkan penegakan peraturan dan mendukung mata pencaharian alternatif (ICDP) dengan sejumlah insentif yang berbasiskan hasil (PES). Proyek-proyek cenderung berlokasi di kawasan-kawasan yang tingkat deforestasinya tinggi dan nilai karbonnya besar, sehingga menghasilkan nilai tambahan yang tinggi jika mereka berhasil.

Ada pilihan kebijakan 'tanpa penyesalan': Meskipun ada ketidakpastian tentang masa depan REDD+, para pemangku kepentingan perlu membangun dukungan dan koalisi politik untuk melakukan perubahan, melakukan investasi dalam sistem informasi yang memadai, serta melaksanakan kebijakan yang dapat mengurangi deforestasi dan degradasi hutan, yang semuanya tetap diinginkan terlepas dari tujuan-tujuan untuk mengatasi persoalan iklim.

\section{Disunting oleh Arild Angelsen}

Disunting bersama oleh Maria Brockhaus, William D. Sunderlin, Louis V. Verchot

Kata Pengantar oleh Tony La Viña

Kontributor John Herbert Ainembabazi, Arild Angelsen, Kamalakumari Anitha, André Aquino, Samuel Assembe-Mvondo, Stibniati Atmadja, Andrea Babon, Laila Borge, Maria Brockhaus, Neil D. Burgess, Bryan R. Bushley, Jan Börner, Marina Cromberg, Tim Cronin, Finn Danielsen, Ahmad Dermawan, Monica Di Gregorio, Rut Dini, Therese Dokken, Amy E. Duchelle, Andini Desita Ekaputri, Martin Enghoff, Manuel Estrada, Caleb Gallemore, Maria Fernanda Gebara, Kristell Hergoualc'h, Martin Herold, Rocio Hiraldo, Thu-Ba Huynh, Pamela Jagger, Francis X. Johnson, Shijo Joseph, Dil Bahadur Khatri, Kaisa Korhonen-Kurki, Mrigesh Kshatriya, Demetrius Kweka, Anne M. Larson, Kathleen Lawlor, Liwei Lin, Lasse Loft, Cecilia Luttrell, Daniel McIntyre, Desmond McNeill, Moira Moeliono, Efrian Muharrom, Krystof Obidzinski, Pablo Pacheco, Charlie Parker, Subhrendu K. Pattanayak, Pham Thu Thuy, Louis Putzel, Salla Rantala, Ida Aju Pradnja Resosudarmo, Erika Romijn, Emilia Runeberg, George Schoneveld, Frances Seymour, Erin O. Sills, Denis Jean Sonwa, Charlotte Streck, William D. Sunderlin, Thomas Tanner, Louis V. Verchot, Sheila Wertz-Kanounnikoff, Arief Wijaya, Sven Wunder.

Penelitian ini dilaksanakan oleh CIFOR sebagai bagian dari Program Penelitian CGIAR: Hutan, Pohon, dan Wanatani (Forests, Trees and Agroforestry). Program kolaboratif ini bertujuan untuk meningkatkan pengelolaan dan pemanfaatan hutan, wanatani, dan sumber daya genetis pohon yang mencakup lanskap dari hutan sampai ke lahan budidaya. CIFOR memimpin program kemitraan ini dengan bekerja bersama Biodiversity International, CIRAD, International Center for Tropical Agriculture dan World Agroforestry Centre

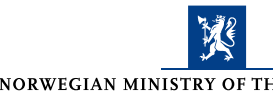

NORWEGIAN MINISTRY OF THE ENVIRONMENT NORWEGIAN MINISTRY OF FOREIGN AFFAIRS

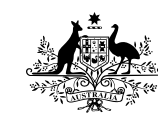

Australian Government

AusAID
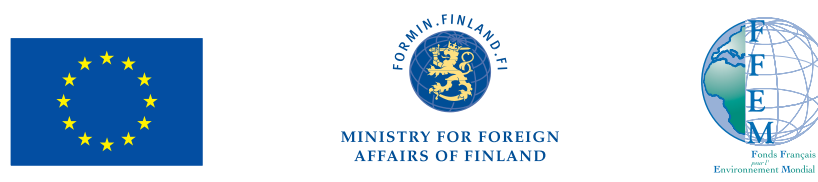